\section{PHYSICAL AND CHEMICAL IMPLICATIONS OF MID-WINTER PUMPING OF TUNDRA LAKES - NORTH SLOPE, ALASKA}

\section{FINAL DRAFT PHASE 1 TOPICAL REPORT}

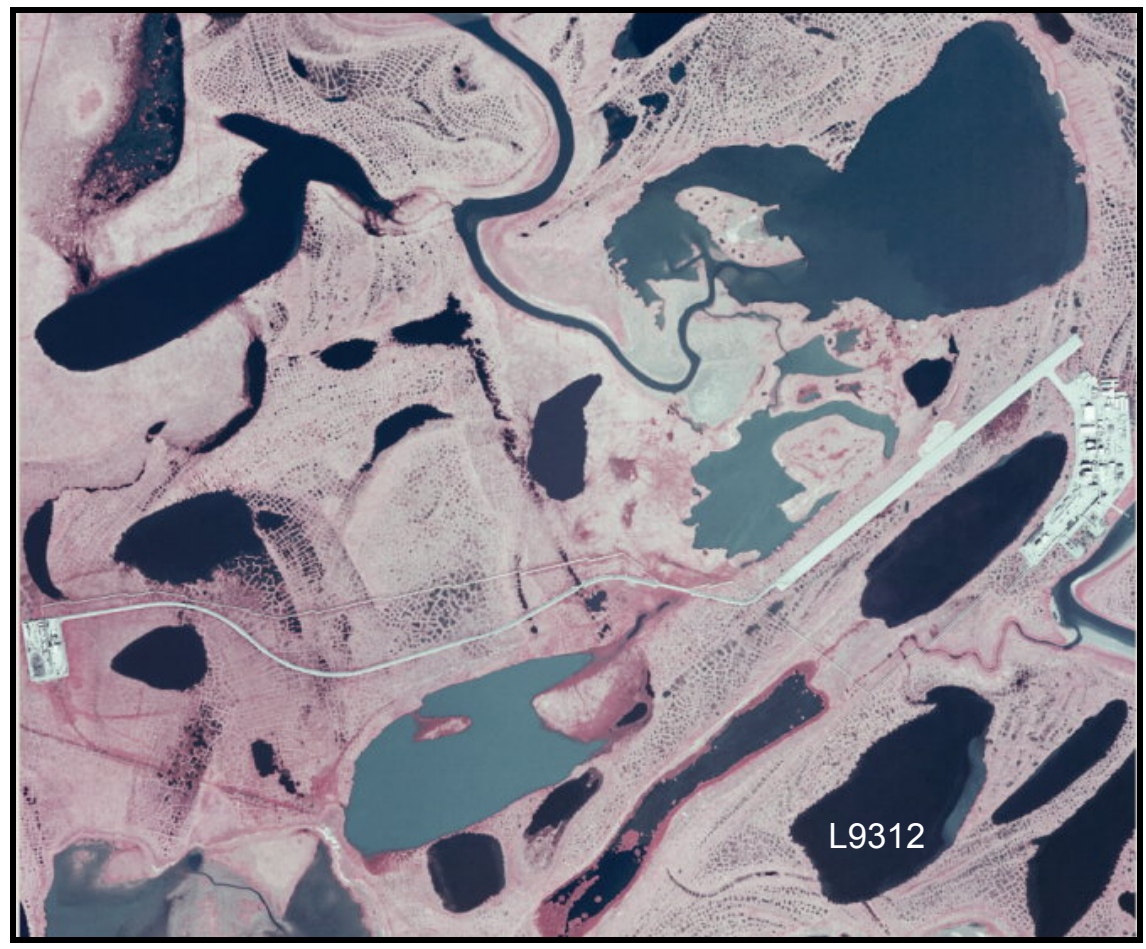

(Alpine Facility with water-supply lake L9312 in lower right, aerial photography provided by ConocoPhillips Alaska)

December 2006

North Slope Lakes Hydrologic Modeling Project Report No. INE/WERC 06.15
Water and Environmental Research Center
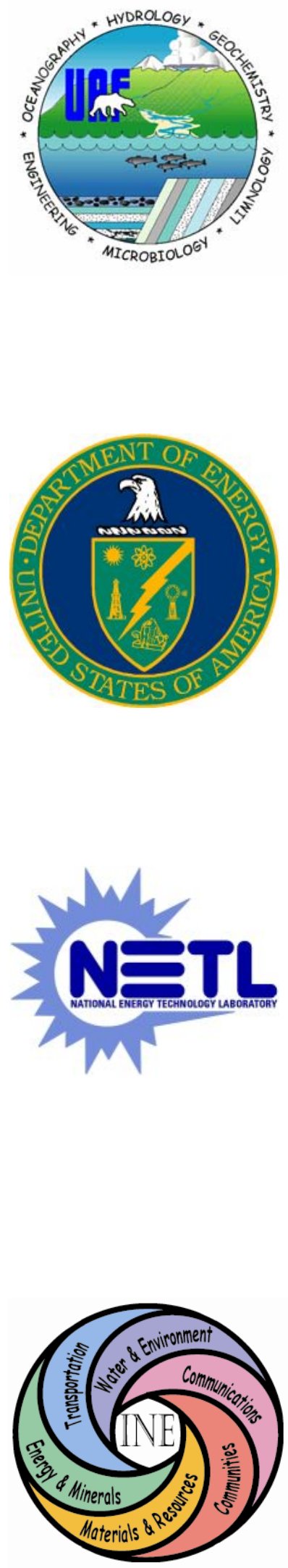


\title{
PHYSICAL AND CHEMICAL IMPLICATIONS OF MID-WINTER PUMPING OF TUNDRA LAKES - NORTH SLOPE, ALASKA
}

\author{
Topical Report \\ Reporting Period Start Date: July 1, 2001 \\ Reporting Period Ending Date: September 30, 2005
}

By Larry D.Hinzman ${ }^{1}$, Michael R. Lilly ${ }^{2}$, Douglas L. Kane ${ }^{1}$, D. Dan Miller ${ }^{1}$, Braden K. Galloway ${ }^{1}$, Kristie M. Hilton ${ }^{2}$, Daniel M. White ${ }^{1}$

${ }^{1}$ University of Alaska Fairbanks, Water and Environmental Research Center

${ }^{2}$ Geo-Watersheds Scientific

Submitted January 2007

DOE Award Number: DE FC26-01NT 41248

Submitted By:

Arctic Energy Technology Development Laboratory

University of Alaska Fairbanks

PO Box 755910, Fairbanks, AK 99775-5880

Prepared By:

Water and Environmental Research Center

University of Alaska Fairbanks

PO Box 755860, Fairbanks, AK 99775

Geo-Watersheds Scientific

PO Box 81538

Fairbanks, Alaska 99708

Prepared in Cooperation with:

BP Exploration (Alaska) Inc.

ConocoPhillips Alaska, Inc.

Alaska Department of Natural Resources Alaska Department of Fish and Game

U.S. Bureau of Land Management

Prepared For:

US Department of Energy, National Energy Technology Laboratory

626 Cochrans Mills Road, PO Box 10940

Pittsburgh, PA 15236-0940

\section{Recommended Citation:}

Hinzman, L.D., Lilly, M.R., Kane, D.L., Miller, D.D., Galloway, B.K., Hilton, K.M., and White, D.M. 2006.

Physical and chemical implications of Mid-Winter Pumping of Tundra Lakes - North Slope, Alaska.

December 2006, University of Alaska Fairbanks, Water and Environmental Research Center, Report

INE/WERC 06.15, Fairbanks, Alaska, 152 pp. plus appendices.

For additional information write to:

Publications

University of Alaska Fairbanks

Water and Environmental Research Center

PO Box 755860

Fairbanks, AK 99775 


\section{DISCLAIMER}

This report was prepared as an account of work sponsored by an agency of the United States Government. Neither the United States Government nor any agency thereof, nor any of their employees, makes any warranty, express or implied, or assumes any legal liability or responsibility for the accuracy, completeness, or usefulness of any information, apparatus, product, or process disclosed, or represents that its use would not infringe privately owned rights. Reference herein to any specific commercial product, process, or service by trade name, trademark, manufacturer, or otherwise does not necessarily constitute or imply its endorsement, recommendation, or favoring by the United States Government or any agency thereof. The views and opinions of authors expressed herein do not necessarily state or reflect those of the United States Government or any agency thereof.

The contents of this report reflect the views of the authors, who are responsible for the accuracy of the data presented herein. This research was funded by the U.S. Department of Energy (DOE), National Energy Technology Laboratory (NETL). Funding and support was also provided by the Bureau of Land Management (BLM), BP Exploration (Alaska) Inc. (BPX), ConocoPhillips Alaska, Inc. (CPA), and Geo-Watersheds Scientific (GWS). The contents of the report do not necessarily reflect the views of policies of the DOE, NETL, BLM, BPX, CPA, GWS, or any local sponsor. This work does not constitute a standard, specification, or regulation.

The use of trade and firm names in this document is for the purpose of identification only and does not imply endorsement by the University of Alaska Fairbanks, DOE, NETL, BLM, BP, CPA, GWS, or other project sponsors. 


\begin{abstract}
Tundra lakes on the North Slope, Alaska, are an important resource for energy development and petroleum field operations. A majority of exploration activities, pipeline maintenance, and restoration activities take place on winter ice roads that depend on water availability at key times of the winter operating season. These same lakes provide important fisheries and ecosystem functions. In particular, overwintering habitat for fish is one important management concern. This study focused on the evaluation of winter water use in the current field operating areas to provide a better understanding of the current water use practices. It found that under the current water use practices, there were no measurable negative effects of winter pumping on the lakes studied and current water use management practices were appropriately conservative. The study did find many areas where improvements in the understanding of tundra lake hydrology and water usage would benefit industry, management agencies, and the protection of fisheries and ecosystems.
\end{abstract}




\section{CONTENTS}

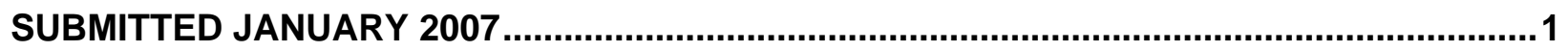

DOE AWARD NUMBER: DE FC26-01NT 41248 .......................................................

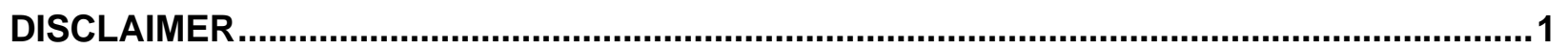

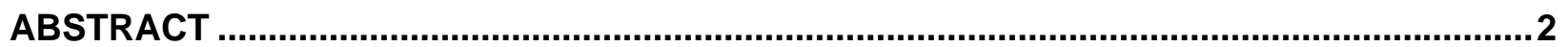

CONVERSION FACTORS, UNITS, WATER QUALITY UNITS, VERTICAL AND HORIZONTAL

DATUM, ABBREVIATIONS AND SYMBOLS .................................................................11

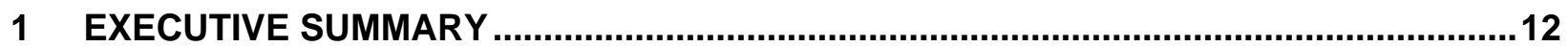

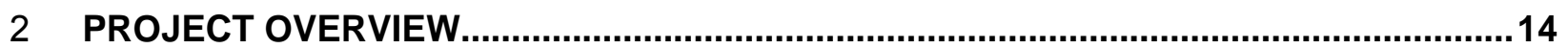

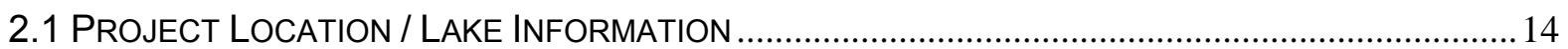

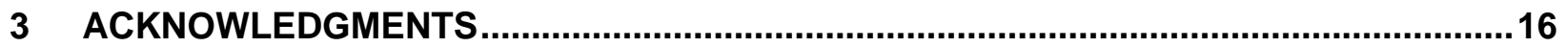

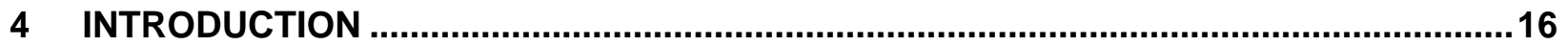

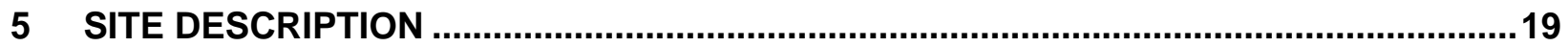

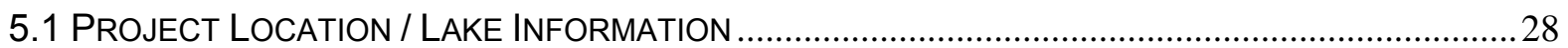

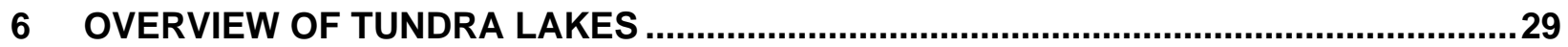

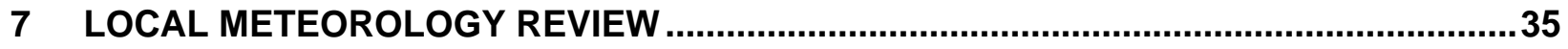

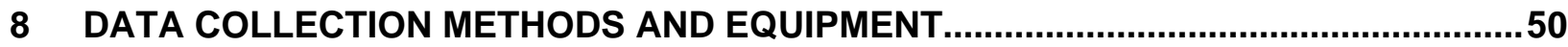

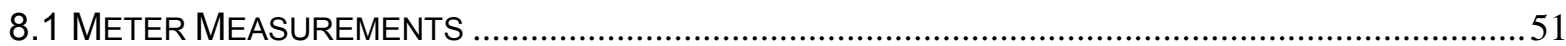

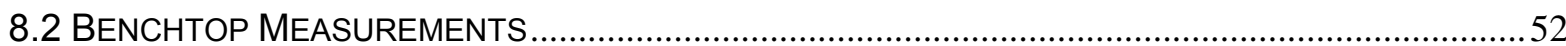

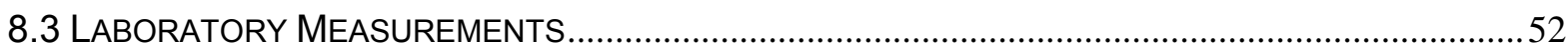

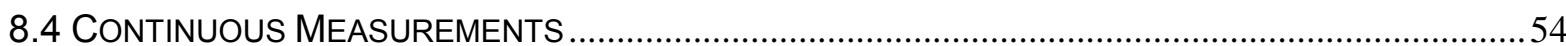

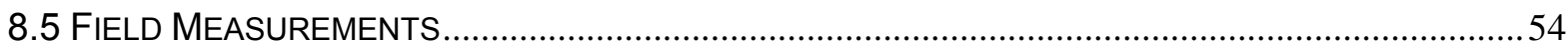

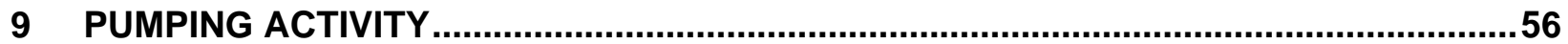

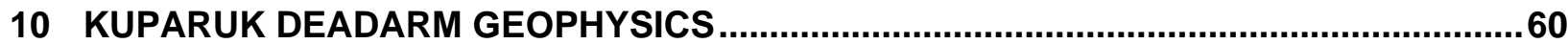

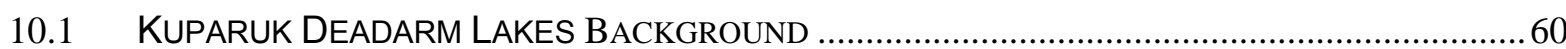

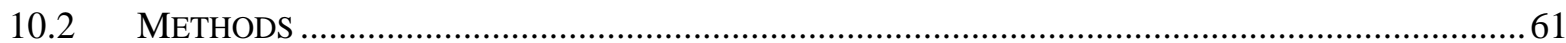

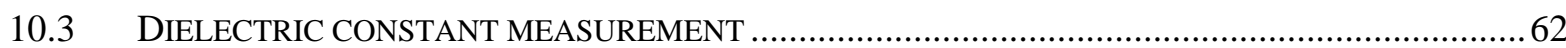

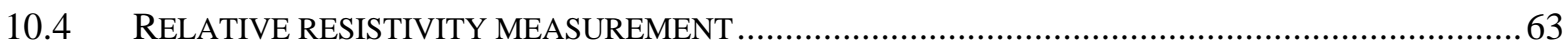

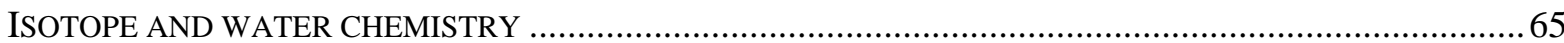

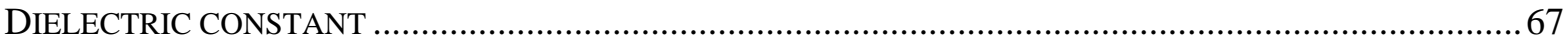

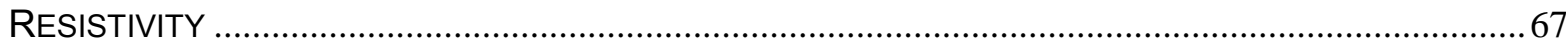

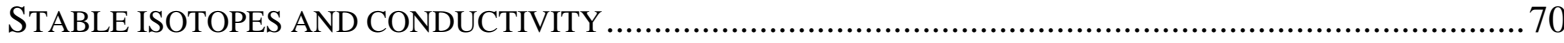

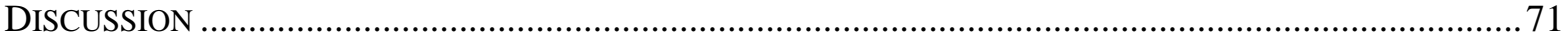




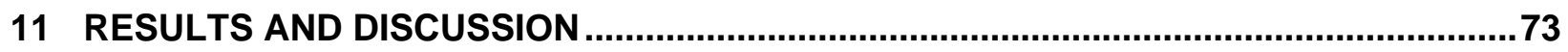

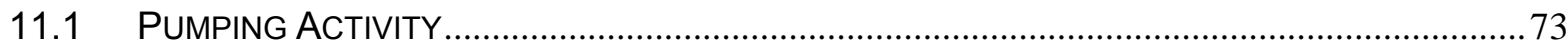

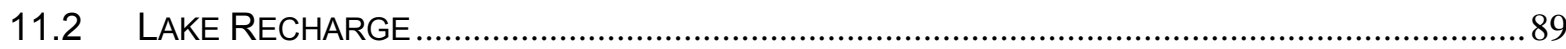

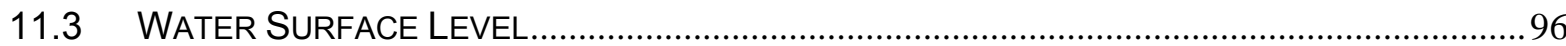

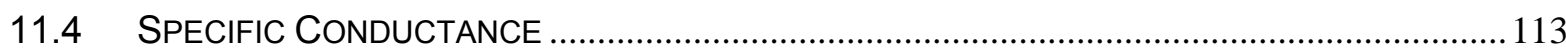

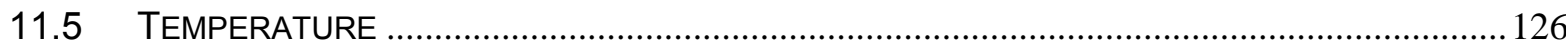

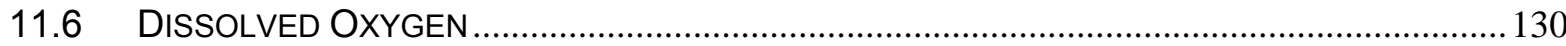

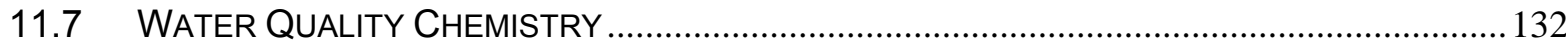

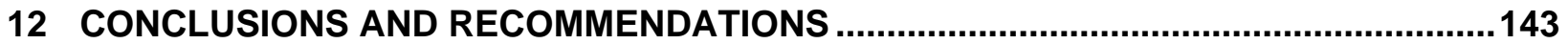

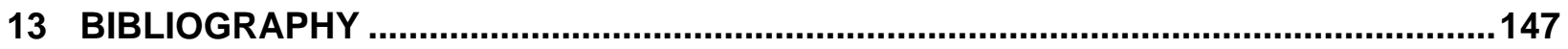

APPENDIX A: SCHEDULE OF METER USE AND CALIBRATION DATES...........................152

APPENDIX B: RECORD OF PRESSURE TRANSDUCER CALIBRATIONS AND WATER

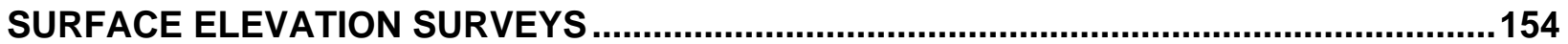

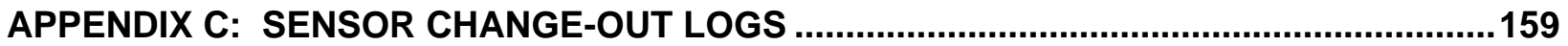

APPENDIX D: SELECTED WATER WITHDRAWAL RECORDS AND EXPECTED CHANGES IN WATER SURFACE LEVEL ...............................................................................161

APPENDIX E: STUDY LAKE INLET AND OUTLET COORDINATES AND SELECTED FIELD

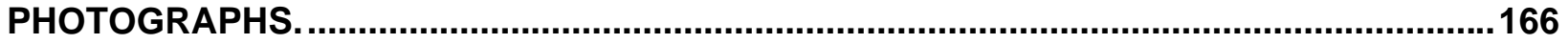

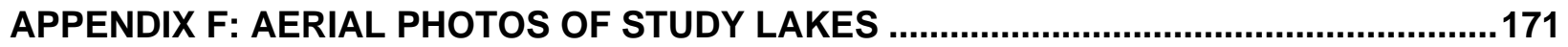

APPENDIX G: AVERAGE SNOW WATER EQUIVALENCE FOR STUDY LAKE BASINS AND

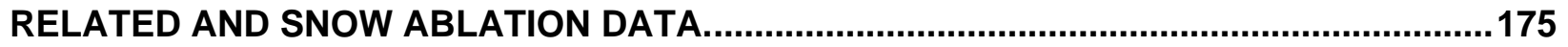

APPENDIX H: SNOW-WATER EQUIVALENCE DATA AND SNOW TRANSECT

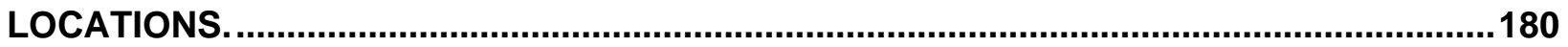

APPENDIX I: WATER QUALITY PARAMETERS AT STATION LOCATIONS.......................184

APPENDIX J: WINTER 2004 - 2005 WATER-QUALITY DATA ….......................................190

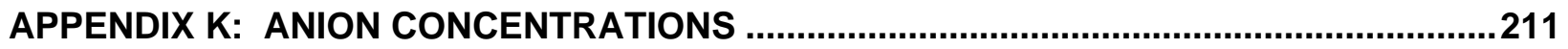

APPENDIX L: DISSOLVED AND TOTAL CARBON CONCENTRATIONS ............................215

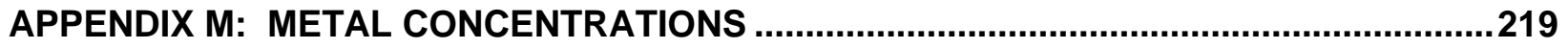

APPENDIX N：KUPARUK DEADARM ISOTOPE AND WATER CHEMISTRY......................224 


\section{LIST OF FIGURES}

FIGURE 1. MAP ILLUSTRATING LOCATION OF GENERAL STUDY SITE WITHIN THE ALASKA ARCTIC

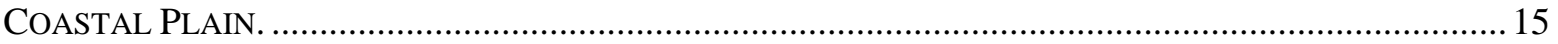

FIGURE 2. LOCATIONS OF STUDY LAKES IN KUPARUK AND ALPINE OILFIELDS, NORTH SLOPE, ALASKA. 15

FIGURE 3. A COMPLETED ICE ROAD LOOKING NORTHEAST TOWARD THE ALPINE OIL FIELD (PHOTO BY BILl MORRIS, ALASKA DEPARTMENT OF NATURAL RESOURCES) …............................................ 17

FIGURE 4. DISTRIBUTION OF MEAN MAXIMUM DEPTHS FOR ARCTIC COASTAL PLAIN LAKES (JOHNSON AND TRUETT, 2000). GEOGRAPHIC POINTS OF INTEREST HAVE BEEN ADDED. .......................................27

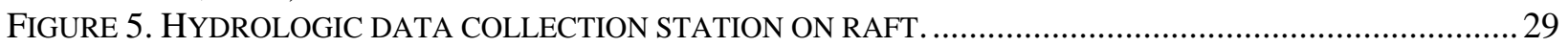

FIGURE 6. SEASONAL CHANGE IN THE CHEMICAL COMPOSITION OF IMIKPUK LAKE, LOCATED NEAR POINT BARROW. CHLORINE IS MEASURED AS TOTAL CHLORIDES IN NACL AND CALCIUM. MAGNESIUM AND ALKALINITY ARE MEASURED AS HARDNESS AS CACO3. NO IRON WAS DETECTED IN THE SAMPLES (REPRODUCED FROM BOYD 1959).

FIGURE 7. HISTORICAL (1983 - 2003) AVERAGE MAXIMUM AND MINIMUM DAILY AIR TEMPERATURES FROM KUPARUK AIRPORT METEOROLOGICAL TOWER (DATA TAKEN FROM WESTERN REGIONAL CLIMATE CENTER) COMPARED TO 10-DAY RUNNING AVERAGES FOR 2002 TO 2005 AT BETTY PINGO.

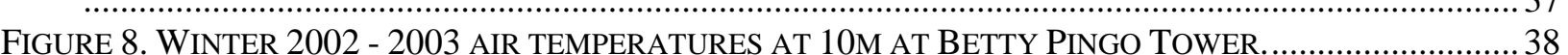

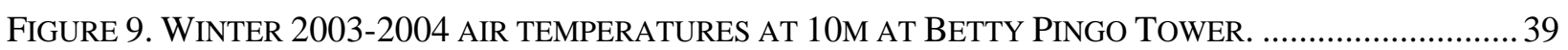

FIGURE 10. WINTER 2004-2005 AIR TEMPERATURES AT 10M AT BETTY PINGO TOWER. ......................... 40

FIGURE 11. STEFAN EQUATION ESTIMATE OF ICE THICKNESS DURING THE 2002-2003 WINTER PLOTTED WITH ONSITE ICE THICKNESS MEASUREMENTS AT THE KUPARUK STUDY LAKES.............................. 41

FIGURE 12. STEFAN ESTIMATE OF ICE THICKNESS DURING THE 2003-2004 WINTER PLOTTED WITH ONSITE

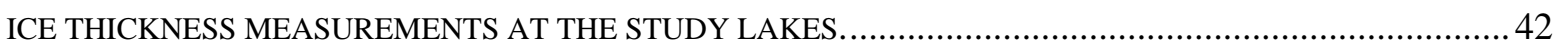

FIGURE 13. STEFAN ESTIMATE OF ICE THICKNESS DURING THE 2004-2005 WINTER PLOTTED WITH ONSITE

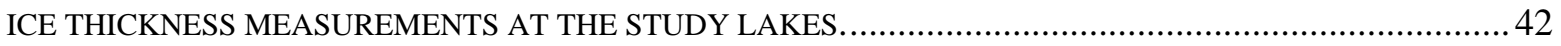

FIGURE 14. WINTER 2002 - 2003 RELATIVE HUMIDITY AT 10M AT BETTY PINGO TOWER. RELATIVE HUMIDITY READINGS HAVE A 100\% SATURATION UPPER THRESHOLD......................................... 43

FIGURE 15. WINTER 2003 - 2004 RELATIVE HUMIDITY AT 10M AT BETTY PINGO TOWER. RELATIVE HUMIDITY READINGS HAVE A 100\% SATURATION UPPER THRESHOLD............................................. 44

FIGURE 16. WINTER 2004-2005 RELATIVE HUMIDITY AT 3M AND 10M. RELATIVE HUMIDITY READINGS

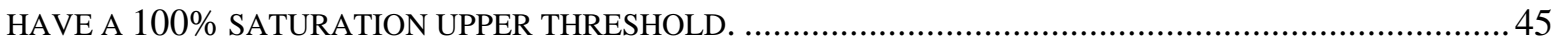

FIGURE 17. WINTER 2002-2003 WIND SPEED AT 1 M AND 10 M AT BETTY PINGO TOWER. ....................... 46

FIGURE 18. WINTER 2003-2004 WIND SPEED AT 1 M AND 10 M AT BETTY PINGO TOWER. RELATIVE HUMIDITY READINGS HAVE A 100\% SATURATION UPPER THRESHOLD. EXTENDED PERIODS OF ZERO WIND ARE PROBABLY CAUSED BY RIME ICE ON ANEMOMETER.

FIGURE 19. WINTER 2004-2005 WIND SPEED AT 1 M AND 10 M AT BETTY PINGO TOWER. RELATIVE HUMIDITY READINGS HAVE A 100\% SATURATION UPPER THRESHOLD. EXTENDED PERIODS OF ZERO WIND ARE PROBABLY CAUSED BY RIME ICE ON ANEMOMETER.

FIGURE 20. MEASURED DAILY WATER EQUIVALENT OF SNOW DURING 2003-2004 WINTER (DATA

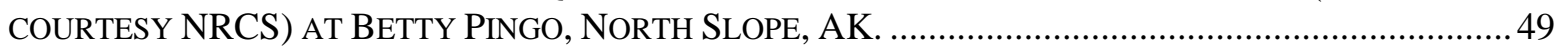

FIGURE 21. MEASURED DAILY WATER EQUIVALENT OF SNOW DURING 2004-2005 WINTER (DATA

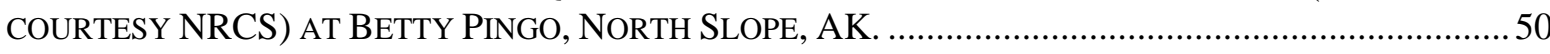

FIGURE 22. BOTH IN-SITU MEASUREMENTS OF WATER CHARACTERISTICS (DO, CONDUCTIVITY, TEMPERATURE, AND PH) AND WATER SAMPLES WERE COLLECTED AT THE LAKES AT SEVERAL TIMES

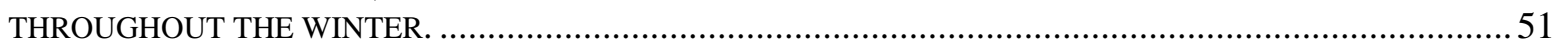

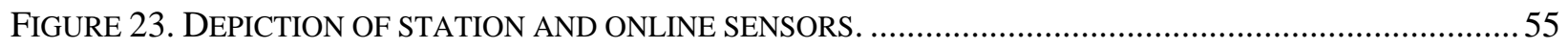

FIGURE 24. PUMPING ACTIVITY AT K209P DURING THE THREE WINTERS OF THE PROJECT. ......................56

FIGURE 25. PUMPING ACTIVITY AT K214P DURING THE THREE WINTERS OF THE PROJECT....................... 57

FIGURE 26. PUMPING ACTIVITY AT L9312P DURING THE THREE WINTERS OF THE PROJECT.......................58 
FIGURE 27. PUMPING ACTIVITY AT L9817P DURING THE THREE WINTERS OF THE PROJECT. 59

FIGURE 28. STUDY SITE AND SURVEY LINES. SECTION B-B'S ALSO IS USED TO HELP ILLUSTRATE A HYPOTHETICAL TALIK MODEL FOR THE AREA FROM THE KUPARUK RIVER EAST CHANNEL AND CELLS

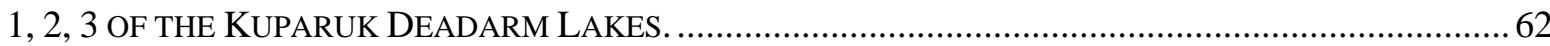

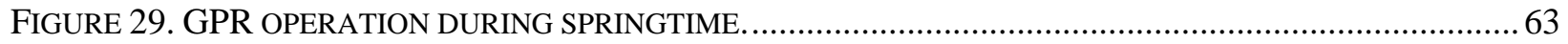

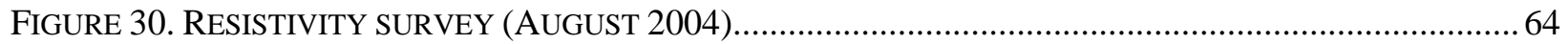

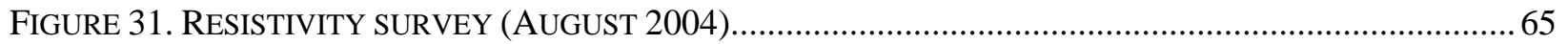

FIGURE 32. STRATIGRAPHIC SECTIONS OF KUPARUK RIVER INACTIVE FLOOD-PLAIN DEPOSITS AFTER

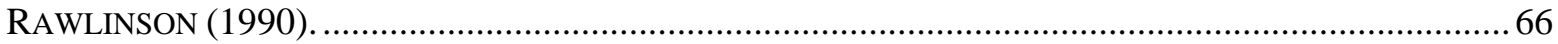

FIGURE 33. GPR OBTAINED IMAGES IN THE VICINITY OF THE KUPARUK RIVER, EAST CHANNEL, ADJACENT TO M PAD. THE DEPTH OF THE FIGURE SIGNAL IS APPROXIMATELY 7 METERS. ................................67

FIGURE 34. RESISTIVITY PROFILE AT A-A’ TRANSECT SOUTHWEST OF CELL 1 (RESERVOIR \#1)............... 68

FIGURE 35. PROFILES ACROSS SECTION A-A' SHOWING THE LOCATION OF THE RESISTIVITY SURVEY, AND A POTENTIAL TALIK CONFIGURATION BASED ON GEOPHYSICAL DATA AND TYPICAL TALIK DEVELOPMENT IN A RIVER CHANNEL SYSTEM.

FIGURE 36. TEMPERATURE PROFILES AT BARROW, ALASKA INDICATED ZERO ANNUAL AMPLITUDE 16M BELOW SURFACE.

FIGURE 37. THE RESISTIVITY VERSUS TEMPERATURE RELATIONSHIP OF NEARLY SATURATED CLAY AND SAND DEMONSTRATE DRAMATIC DIFFERENCES BETWEEN FROZEN AND UNFROZEN SOILS. ................69

FIGURE 38. STABLE ISOTOPE MEASUREMENTS OF SURFACE WATER BODIES TAKEN DURING SUMMER

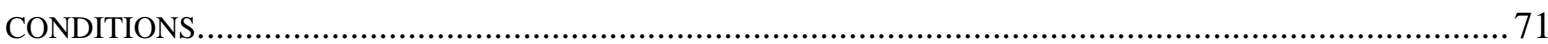

FIGURE 39. WATER ELEVATION SURVEYS (BPMSL) MEASURED DURING THE WINTER OF 2005-2006 FOR KUPARUK DEADARM LAKES, CELLS 1-3. DURING WINTER MONTHS, THIS IS THE WATER SURFACE IN

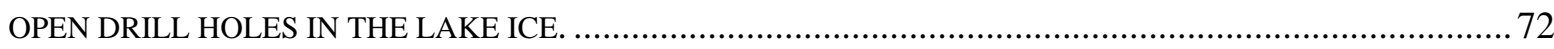

FIGURE 40. ILLUSTRATION OF PAN BATHYMETRY AND RESPONSE IN WATER SURFACE LEVEL CORRESPONDING TO AN EXAGGERATED VOLUME OF WATER WITHDRAWAL.................................... 74

FIGURE 41. ILLUSTRATION OF CONE BATHYMETRY AND RESPONSE IN WATER SURFACE LEVEL CORRESPONDING TO AN EXAGGERATED VOLUME OF WATER WITHDRAWAL.................................... 75

FIGURE 42. BATHYMETRIC TRANSECTS OF STUDY LAKE K209P (REPRODUCED FROM MOULTON 1998). . 75

FIGURE 43. BATHYMETRIC TRANSECTS OF LAKE L9121, A THAW LAKE EAST OF THE COLVILLE RIVER ABOUT 5 KM NORTHEAST OF K209P AND 7.5 KM WEST OF K214P (REPRODUCED FROM MOULTON 1998).

FIGURE 44. BATHYMETRIC TRANSECTS OF LAKE M9614, A THAW LAKE EAST OF THE COLVILLE RIVER BOUNDED BY THE COLVILLE AND KACHEMACH RIVERS (REPRODUCED FROM MOULTON 1998). M9614 IS ABOUT 11 KM WEST BY NORTHWEST OF K209P. 76

FIGURE 45. EXPECTED CUMULATIVE CHANGE IN WATER SURFACE LEVEL DUE TO PUMPING ACTIVITY

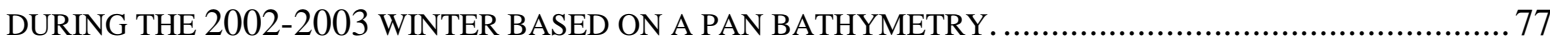

FIGURE 46. EXPECTED CUMULATIVE CHANGE IN WATER SURFACE LEVEL AS A RESULT OF PUMPING ACTIVITY DURING 2003-2004 WINTER BASED ON A PAN BATHYMETRY. .78

FIGURE 47. EXPECTED CUMULATIVE CHANGE IN WATER SURFACE LEVEL AS A RESULT OF PUMPING ACTIVITY DURING 2004-2005 WINTER BASED ON A PAN BATHYMETRY.

FIGURE 48. ILLUSTRATION OF PERCEIVED WATER LEVELS AT STUDY LAKES WHERE H IS EQUIVALENT TO THICKNESS AND S = SNOW, $\mathrm{I}=$ ICE, SWE $=$ SNOW WATER EQUIVALENCE, WI $=$ WHITE ICE, BI $=$ BLACK ICE AND W $=$ WATER. ILLUSTRATION IS CONCEPTUAL AND WITHOUT SCALE.

FIGURE 49. CHANGE IN PRESSURE TRANSDUCER 1 WATER SURFACE LEVEL AT LAKE K113C COMPARED TO MEASUREMENTS OF PRECIPITATION AS SNOW AT BETTY PINGO DURING THE 2003-2004 WINTER.

FIGURE 50. CHANGE IN PRESSURE TRANSDUCER 1 WATER SURFACE LEVEL AT LAKE K113C COMPARED TO MEASUREMENTS OF PRECIPITATION AS SNOW AT BETTY PINGO DURING THE 2004-2005 WINTER. 
FIGURE 51. CHANGE IN WATER SURFACE LEVEL AT LAKE K209P COMPARED TO WINTER PRECIPITATION AT BETTY PINGO DURING THE 2003-2004 WINTER. PRESSURE TRANSDUCERS DISCONNECTED IN LATE-FEBRUARY 2004.

FIGURE 52. CHANGE IN WATER SURFACE LEVEL AT LAKE K209P COMPARED TO WINTER PRECIPITATION AT BETTY PINGO DURING THE 2004-2005 WINTER.

FIGURE 53. CHANGE IN WATER SURFACE LEVEL AT LAKE K214P COMPARED TO WINTER PRECIPITATION

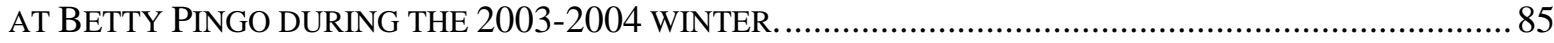

FIGURE 54. CHANGE IN WATER SURFACE LEVEL AT LAKE K214P COMPARED TO WINTER PRECIPITATION AT BETTY PINGO DURING THE 2004-2005 WINTER. 86

FIGURE 55. CHANGE IN WATER SURFACE LEVEL AT LAKE L9312 COMPARED TO WINTER PRECIPITATION AT BETTY PINGO DURING THE 2004-2005 WINTER.

FIGURE 56. CHANGE IN WATER SURFACE LEVEL AT LAKE L9817 COMPARED TO WINTER PRECIPITATION AT BETTY PINGO DURING THE 2004-2005 WINTER.

FIGURE 57. ILLUSTRATION OF FLOW FOLLOWING SPRING MELT AT CONTROL LAKE K113C...................91

FIGURE 58. ILLUSTRATION OF FLOW FOLLOWING SPRING MELT AT CONTROL LAKE K203C....................92

FIGURE 59. ILLUSTRATION OF FLOW FOLLOWING SPRING MELT AT PUMPED LAKE K214P...................... 93

FIGURE 60. ILLUSTRATION OF FLOW FOLLOWING SPRING MELT AT PUMPED LAKE K209P.......................94

FIGURE 61. ILLUSTRATION OF FLOW FOLLOWING SPRING MELT AT PUMPED LAKE L9312P. ....................95

FIGURE 62. ILLUSTRATION OF FLOW FOLLOWING SPRING MELT AT PUMPED LAKE L9817P. ....................96

FIGURE 63. CHANGE IN WATER SURFACE LEVEL AT CONTROL LAKE K113C THROUGHOUT 2003-2004 AND

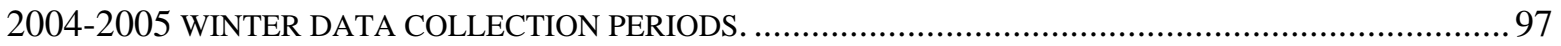

FIGURE 64. CHANGE IN WATER SURFACE LEVEL AT CONTROL LAKE K203C THROUGHOUT 2002-2003 AND 2003-3004 WINTER DATA COLLECTION PERIODS. 2003 DATA GAP DUE TO TEMPORARY LOSS OF

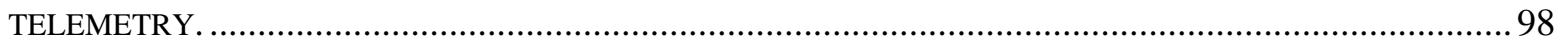

FIGURE 65. CHANGE IN WATER SURFACE LEVEL AT PUMPED LAKE K209P THROUGHOUT 2002-2003 AND 2003-2004 WINTER DATA COLLECTION PERIODS. THE PRESSURE TRANSDUCER AT K209P WAS

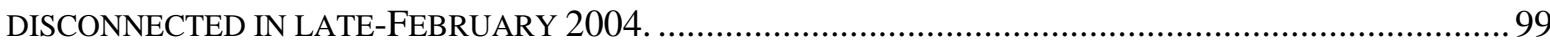

FIGURE 66. CHANGE IN WATER SURFACE LEVEL AT PUMPED LAKE K214P THROUGHOUT 2002-2003 AND 2003-2004 WINTER DATA COLLECTION PERIODS. ............................................................................ 100

FIGURE 67. WATER SURFACE HYDROGRAPH AT CONTROL LAKE K113C THROUGHOUT 2004-2005 WINTER DATA COLLECTION PERIODS 101

FIGURE 68. WATER SURFACE HYDROGRAPH AT CONTROL LAKE K209P THROUGHOUT 2004-2005 WINTER DATA COLLECTION PERIODS 102

FIGURE 69. WATER SURFACE HYDROGRAPH AT CONTROL LAKE K214P THROUGHOUT 2004-2005 WINTER DATA COLLECTION PERIODS

FIGURE 70. WATER SURFACE HYDROGRAPH AT CONTROL LAKE L9312P THROUGHOUT 2004-2005 WINTER DATA COLLECTION PERIODS 104

FIGURE 71. WATER SURFACE HYDROGRAPH AT CONTROL LAKE L9817P THROUGHOUT 2004-2005 WINTER DATA COLLECTION PERIODS 105

FIGURE 72. DETECTED CHANGE IN WSL AT K209P SHOWN WITH EXPECTED CUMULATIVE CHANGE IN WSL DUE TO PUMPING CALCULATED FROM IDEALIZED PAN AND CONE BATHYMETRIES. ...............106

FIGURE 73. DETECTED CHANGE IN WSL AT K214P SHOWN WITH EXPECTED CUMULATIVE CHANGE IN WSL DUE TO PUMPING CALCULATED FROM IDEALIZED PAN AND CONE BATHYMETRIES. ................107

FIGURE 74. WATER SURFACE LEVEL AT PUMPED LAKE K214P DURING PUMPING ACTIVITY DECEMBER 710, 2003 COMPARED TO WSL AT CONTROL LAKE K113C.

FIGURE 75. WATER SURFACE LEVEL AT LAKE K209P DURING PUMPING ACTIVITY DECEMBER 25-28, 2003 COMPARED TO WSL AT CONTROL LAKE K113C. DAILY PRECIPITATION VALUES ARE TAKEN FROM THE WYOMING SNOW GAUGE AT BETTY PINGO. 
FIGURE 76. WATER SURFACE LEVEL MEASUREMENTS AT PUMPED LAKE K209P DURING PUMPING ACTIVITY DECEMBER 30-31, 2003 COMPARED TO CONTROL LAKE K113C. DAILY PRECIPITATION VALUES ARE TAKEN FROM THE WYOMING SNOW GAUGE AT BETTY PINGO.

FIGURE 77. WATER SURFACE LEVEL MEASUREMENTS AT LAKE K209P DURING PUMPING ACTIVITY JANUARY 2-5, 2004 COMPARED TO CONTROL LAKE K113C JANUARY 2-5, 2004. DAILY PRECIPITATION VALUES ARE TAKEN FROM THE WYOMING SNOW GAUGE AT BETTY PINGO. ..........112

FIGURE 78. WATER SURFACE LEVEL MEASUREMENTS AT LAKE K209P DURING PUMPING ACTIVITY JANUARY 11-22, 2004 COMPARED TO CONTROL LAKE K113C JANUARY 11-22, 2004. THERE WAS NO

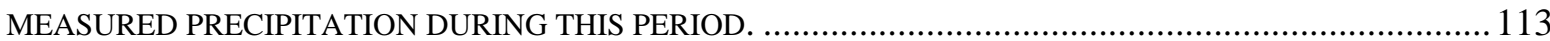

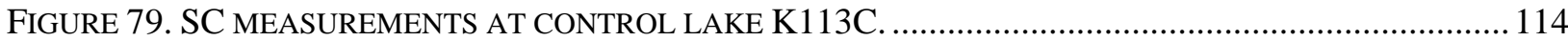

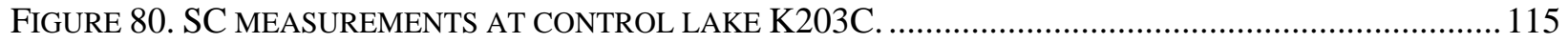

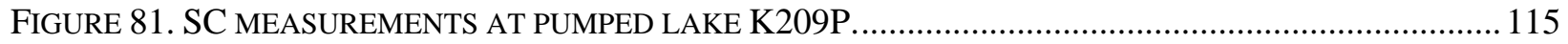

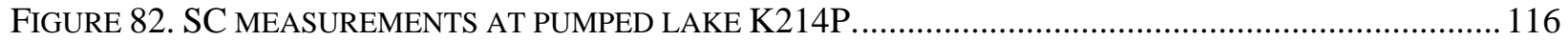

FIGURE 83. COMPARISON OF SC AT STUDY LAKES THROUGHOUT 2002-2003.................................... 116

FIGURE 84. COMPARISON OF SC AT STUDY LAKES THROUGHOUT WINTER 2003-2004 DATA COLLECTION PERIOD

FIGURE 85. SPRING 2005 CHEMISTRY AND SNOW WATER EQUIVALENT DURING ABLATION AT K113C. . 118

FIGURE 86. SPRING 2005 CHEMISTRY AND SNOW WATER EQUIVALENT DURING ABLATION AT L9312P. 119

FIGURE 87. SPRING 2005 CHEMISTRY AND SNOW WATER EQUIVALENT AT L9817P.............................120

FIGURE 88. SC MEASUREMENTS AT LAKE K214P DURING PUMPING ACTIVITY DECEMBER 7-10, 2003

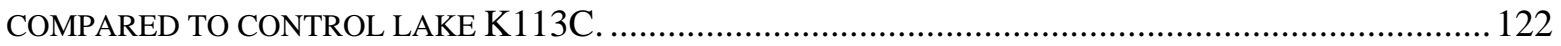

FIGURE 89. SC MEASUREMENTS AT LAKE K209P DURING PUMPING ACTIVITY DECEMBER 25-28, 2003

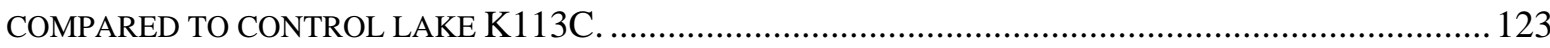

FIGURE 90. SC MEASUREMENTS AT LAKE K209P DURING PUMPING ACTIVITY DECEMBER 30-31, 2003

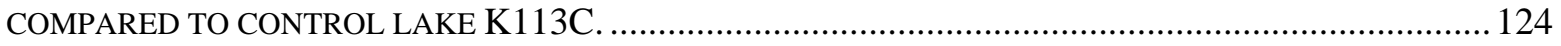

FIGURE 91. SC MEASUREMENTS AT LAKE K209P DURING PUMPING ACTIVITY JANUARY 2-5, 2004

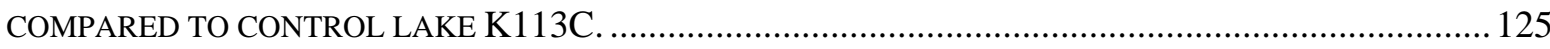

FIGURE 92. AVERAGED SC MEASUREMENTS AT LAKE K209P DURING PUMPING ACTIVITY JANUARY 11-

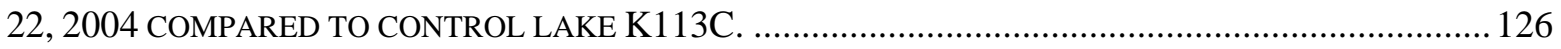

FIGURE 93. THERMAL PROFILES AT CONTROL LAKE K113C DURING THE WINTER 2002-2003 DATA

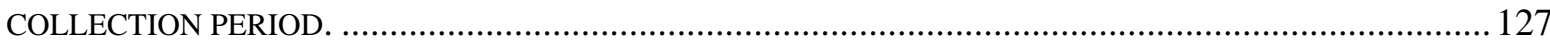

FIGURE 94. THERMAL PROFILES AT CONTROL LAKE K203C DURING THE WINTER 2002-2003 DATA

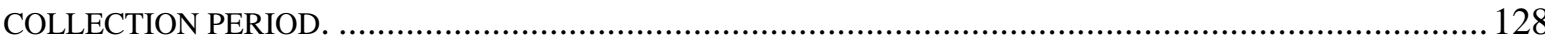

FIGURE 95. THERMAL PROFILES AT PUMPED LAKE K209P DURING THE WINTER 2002-2003 DATA

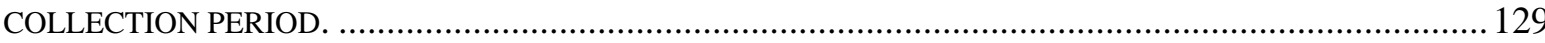

FIGURE 96. THERMAL PROFILES AT PUMPED LAKE K214P DURING THE WINTER 2002-2003 DATA

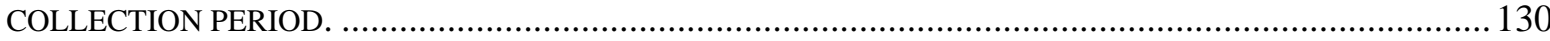

FIGURE 97. DISSOLVED OXYGEN AT CONTROL LAKE K113C DURING 2003-2004 WINTER DATA

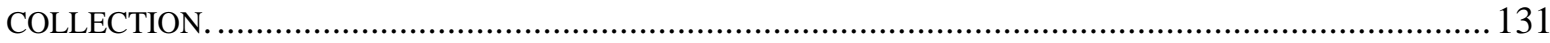

FIGURE 98. DISSOLVED OXYGEN AT CONTROL LAKE K203C DURING 2002-2003 WINTER DATA COLLECTION. GAP IN DATA DUE TO A LACK OF TELEMETRY WITH STATION. ................................ 132

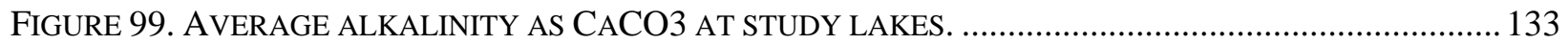

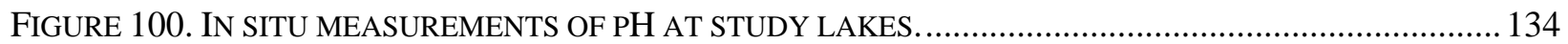

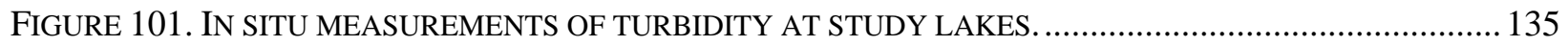

FIGURE 102. TOTAL ORGANIC CARBON CONCENTRATIONS AT THE STUDY LAKES................................136

FIGURE 103. DISSOLVED ORGANIC CARBON CONCENTRATIONS AT THE STUDY LAKES. ...........................137

FIGURE 104. NITROGEN AS NITRATE CONCENTRATIONS AT THE STUDY LAKES. ................................... 138

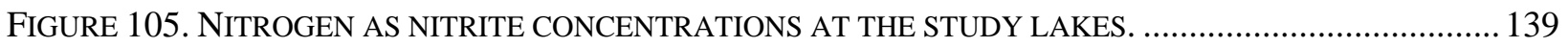

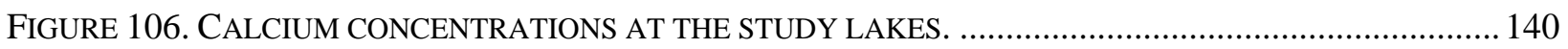

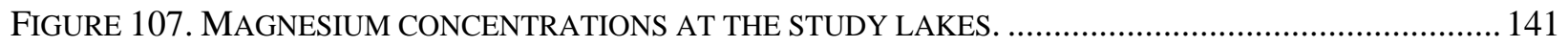




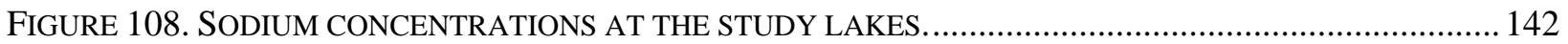

FIGURE 109. PHOSPHATE CONCENTRATIONS AT THE STUDY LAKES....................................................... 143 


\section{LIST OF TABLES}

TABLE 1. SUMMARY OF LAKE CHARACTERISTICS -- GEOGRAPHY AND OPERATIONS. 20

TABLE 2. SUMMARY OF LAKE CHARACTERISTICS -- GEOGRAPHY AND OPERATIONS -- CONTINUED. ......... 21

TABLE 3. SUMMARY OF LAKE CHARACTERISTICS -- HYDROLOGY AND BIOLOGY..................................22

TABLE 4. SUMMARY OF LAKE CHARACTERISTICS -- HYDROLOGY AND BIOLOGY -- CONTINUED................ 23

TABLE 5. SUMMARY OF LAKE CHARACTERISTICS -- HISTORY OF RESEARCH AND OPERATIONS. .................24

TABLE 6. SUMMARY OF LAKE CHARACTERISTICS - HISTORY OF RESEARCH AND OPERATIONS --

CONTINUED.

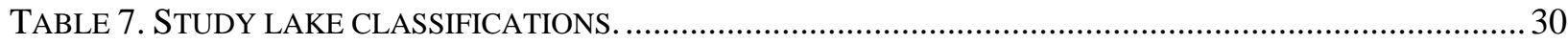

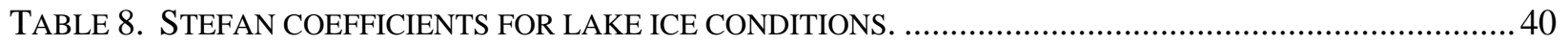

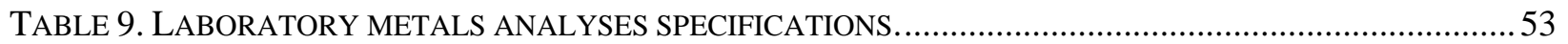

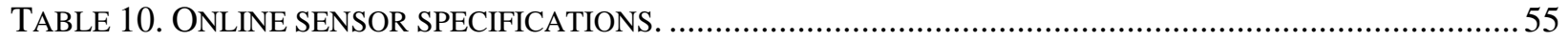

TABLE 11. OPERATING PERIOD FOR STUDY LAKES CONTINUOUS DATA-COLLECTION STATIONS................ 55

TABLE 12. WATER BALANCE AT STUDY LAKES FOR 2003-2004 WINTER INCLUDING DETECTED CHANGES IN WATER SURFACE LEVEL (WSL), EXPECTED CHANGE IN WS BASED ON PAN AND CONE

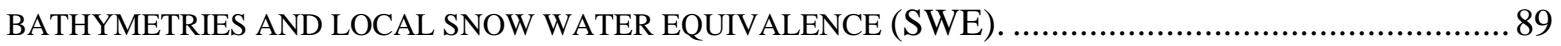

TABLE 13. SUMMARY OF RECHARGE SURVEYS. DATA NOT AVAILABLE FOR L9817 FOR 2005................. 90

TABLE 14. DEFINED PERIODS OF PUMPING ACTIVITY AT K209P AND WATER WITHDRAWAL VOLUME.... 108

TABLE 15. DEFINED PERIODS OF PUMPING ACTIVITY AT K214P AND WATER WITHDRAWAL VOLUME.... 108 


\begin{tabular}{|c|c|c|}
\hline Multiply & By & To obtain \\
\hline \multicolumn{3}{|c|}{ Length } \\
\hline inch (in.) & 25.4 & millimeter (mm) \\
\hline inch (in.) & 2.54 & centimeter (cm) \\
\hline foot $(\mathrm{ft})$ & 0.3048 & meter $(\mathrm{m})$ \\
\hline mile (mi) & 1.609 & kilometer (km) \\
\hline \multicolumn{3}{|c|}{ Area } \\
\hline Acre & 43559.999 & square feet $\left(\mathrm{ft}^{2}\right)$ \\
\hline Acre & 0.405 & hectare (ha) \\
\hline square foot $\left(\mathrm{ft}^{2}\right)$ & $3.587 e-8$ & square mile $\left(\mathrm{mi}^{2}\right)$ \\
\hline square mile $\left(\mathrm{mi}^{2}\right)$ & 2.590 & square kilometer $\left(\mathrm{km}^{2}\right)$ \\
\hline \multicolumn{3}{|c|}{ Volume } \\
\hline gallon (gal) & 3.785 & liter $(L)$ \\
\hline gallon (gal) & 3785.412 & milliliter (mL) \\
\hline cubic foot $\left(\mathrm{ft}^{3}\right)$ & 28.317 & liter $(\mathrm{L})$ \\
\hline Acre-ft & 1233 & cubic meter $\left(\mathrm{m}^{3}\right)$ \\
\hline \multicolumn{3}{|c|}{ Velocity and Discharge } \\
\hline foot per day (ft/d) & 0.3048 & meter per day $(\mathrm{m} / \mathrm{d})$ \\
\hline Square foot per day $\left(\mathrm{ft}^{2} / \mathrm{d}\right)$ & .0929 & square meter per day $\left(\mathrm{m}^{2} / \mathrm{d}\right)$ \\
\hline cubic foot per second $\left(\mathrm{ft}^{3} / \mathrm{s}\right)$ & 0.02832 & $\begin{array}{l}\text { cubic meter per second } \\
\left(\mathrm{m}^{3} / \mathrm{sec}\right)\end{array}$ \\
\hline \multicolumn{3}{|c|}{ Hydraulic Conductivity } \\
\hline foot per day (ft/d) & 0.3048 & meter per day $(\mathrm{m} / \mathrm{d})$ \\
\hline foot per day (ft/d) & 0.00035 & $\begin{array}{l}\text { centimeter per second } \\
(\mathrm{cm} / \mathrm{sec})\end{array}$ \\
\hline meter per day $(\mathrm{m} / \mathrm{d})$ & 0.00115 & $\begin{array}{l}\text { centimeter per second } \\
(\mathrm{cm} / \mathrm{sec})\end{array}$ \\
\hline \multicolumn{3}{|c|}{ Hydraulic Gradient } \\
\hline foot per foot (ft/ft) & 5280 & foot per mile (ft/mi) \\
\hline foot per mile (ft/mi) & 0.1894 & meter per kilometer $(\mathrm{m} / \mathrm{km})$ \\
\hline \multicolumn{3}{|c|}{ Pressure } \\
\hline pound per square inch (Ib/in $\left.{ }^{2}\right)$ & 6.895 & kilopascal (kPa) \\
\hline
\end{tabular}




\section{EXECUTIVE SUMMARY}

For many years, the oil industry and support services have withdrawn water from freshwater lakes on the North Slope of Alaska to build ice roads and pads for increased access to remote sites with decreased maintenance costs. This technique is quite important to industry in that it allows oil field development or maintenance while avoiding most of the environmental disturbance associated with construction of gravel roads and pads. Construction on ice-roads and pads begins in December or January when the tundra mat is adequately frozen to support construction traffic and continues through April (depending upon weather). Recently numerous questions were raised regarding the potential environmental consequences of water withdrawal. Possible effects of pumping include impacts to the water balance, direct impacts to aquatic organisms (including fish and invertebrates), and impacts to the lake-water chemistry (with subsequent effects on aquatic creatures). There may also be associated cumulative impacts as lakes are repeatedly pumped year after year. Questions have also been raised on pumping lakes and the consequent effects on neighboring (and potentially connected) unfrozen zones within frozen rivers that serve as over-winter fish habitat. This study includes continuous monitoring of water characteristics that may be affected by pumping activities and evaluation of the factors that impact biological populations and chemical concentrations. We also examined the inter-connectivity of lakes and channel networks in early spring to determine if pumping from one lake could impact a neighboring lake or river channel. This study focused on the evaluation of winter water use in the current field operating areas to provide a better understanding of the current water use practices. The identification of processes leading to cumulative impacts of water use was also an objective of the study.

Selected study lakes on the North Slope of Alaska were monitored between September 2002 and August 2005 to determine the effects of winter water withdrawals for ice road construction and facility or field operations. Physical and chemical parameters were measured for pumped and control lakes. Four lakes in the Kuparuk operations area were included in the study. Lakes K113C and K203C were unpumped control lakes, and lakes K209P and K214P were pumped lakes. An early winter storm in October 2003 overturned the data collection raft at K203C, and all raft components were recovered in January 2004. Instrumentation was not reinstalled at this site. In early 2004, two additional pumped lakes were added in the Alpine Field Area. Lake L9312 serves as one of the facility water-supply lakes for Alpine, and lake L9817 was used for ice road construction and maintenance. Lake recharge was monitored during spring snowmelt. Lakes K209P, K214P, and K113C all showed complete recharge during the snowmelt periods in 2003, 2004 and 2005 based on visual observations. Lake L9312 was completely recharged by the Colville River bank overflow during 2004 springmelt. In 2005, the Colville did not overflow its banks and recharge the lake. The contributions of snowmelt and summer precipitation runoff from the L9312 watershed brought the lake to near-full conditions by fall freeze-up. L9817 is more remote and not road accessible, thus leading to less frequent observations. During September 2005, its small outlet stream was flowing, indicating lake-full conditions going into winter. Lake water-level decreases in response to pumping were detected and matched reasonably well with calculated values of water-level changes. Snow loading atop lake ice affects lake water-level measurements, but was adequately quantified to give acceptable resolution compared to small changes in lake water levels due to pumping. Many lakes have less snow cover than adjacent tundra, due to wind erosion and redistribution of snow. This influences the assessment of snow loading on lakes from standard snowfall measurements.

Uniform reporting and archiving standards for lake water use data (monthly use volumes) will help with future evaluation of water use practices and future efforts to verify the presence or 
absence of cumulative effects. This will significantly contribute to the state of knowledge and understanding of tundra lakes and water use issues. This will help reduce risks associated with water use for both facility purposes and ecosystems. It will also help evaluate the potential effects of changing climate and baseline conditions.

The water-year (October to September) management approach corresponds better with the natural hydrologic cycle for tundra lakes on the North Slope. Adopting a uniform permitting period based on the water year, with a focus on appropriate recharge time periods would reduce risks to water users and simplify the water management process. We recommend separate reporting and permitting of land-fast ice removal from lakes. This is currently included in the permits and reports as under-ice pumped water. The primary management issue concerning land-fast ice removal is the determination of the equivalent water volume replacement during spring breakup. In addition, the removal of land-fast ice from grounded areas should not decrease the amount of under-ice water volume available for over-wintering fish habitat. The archiving of actual water volumes withdrawn from under lakes will help quantify the importance of spring snowmelt runoff for replacing removed lake ice and water.

Lakes and adjacent water bodies can be connected through taliks (unfrozen ground). The use of GPR methods is effective at identifying very shallow taliks. Resistivity methods are more effective at talik identification for larger lakes and river systems. Isotope analysis can also help identify water source information. Both of these methods can be used together, but should always be incorporated with standard water-level surveys coupled with analysis of soil properties from borings.

Lake chemistry changes during winter periods are dominated by ice-formation processes in shallow lakes. Specific conductance and ion concentrations were shown to increase throughout the winter due to solute exclusion processes. Measurements of specific conductance through spring breakup showed that the under-ice water is diluted by fresh, low specific-conductance meltwater, which essentially resets the lakes' chemistry going into summer. Temperatures in the water column were similar between pumped and control lakes and thermal profiles at pumped lakes were consistent with cold, shallow arctic lakes. Predominant wind-mixing in shallow lakes prevails over the typical lake turnover events due to temperature-density relationships. The gradual depletion of dissolved oxygen observed at the control lakes meets expectations of under-ice oxygen dynamics. Rigorous field measurements displayed vertical differences in DO concentration, with the highest levels found just below the ice and lowest just above lake bottoms. L9312 was observed to maintain high DO levels throughout winter months. The marked differences in vertical profiles clearly indicate that sampling technique is critically important in quantifying dissolved oxygen concentrations, and that different lakes may have different dissolved-oxygen consumption rates.

We found that under the current water use practices, there were no measurable negative effects of winter pumping on the lakes studied and current water use management practices were appropriately conservative. physical and chemical parameters were similar between pumped and control lakes for the range of water use observed during the 2002-2005 winter operational seasons. All lakes were completely recharged by spring snowmelt, with the exception of L9312 during the spring of 2005, though was partially recharged during spring snowmelt and summer 2005 precipitation. The study did find many areas where improvements in the understanding of tundra lake hydrology and water usage would benefit industry, management agencies, and the protection of fisheries and ecosystems resources. 


\section{PROJECT OVERVIEW}

For many years, the oil industry and support services have withdrawn water from freshwater lakes to build ice roads and pads for increased access to remote sites with decreased maintenance costs. This technique is important to the oil industry in that it allows oil field development or maintenance while avoiding the environmental disturbance associated with construction of gravel roads and pads. Construction on ice-roads and pads begins in December or January when the tundra mat is adequately frozen to support construction traffic and continues through April (depending upon weather). Recently numerous questions have been raised regarding the potential environmental consequences of water withdrawal. Possible effects of pumping include impacts to the water balance, direct impacts to aquatic organisms (including fish and invertebrates), and impacts to the pond water chemistry (with subsequent effects on aquatic creatures). There may also be associated cumulative impacts as ponds are repeatedly pumped year after year. Questions have also been raised on pumping ponds and the consequent effects on neighboring (and potentially connected) unfrozen zones within frozen rivers that serve as over-winter fish habitat. This study included continuous monitoring of water characteristics that may be affected by pumping activities and evaluation of the factors that impact biological populations and chemical concentrations. We also examined the interconnectivity of ponds and channel networks in mid-winter to determine if pumping from one lake can impact a neighboring lake or river channel.

Investigation of the physical and chemical effects of mid-winter pumping activity was conducted at six tundra lakes within the Alaska Arctic Coastal Plain during the 2002-2003, 2003-2004 and 2004-2005 winters. The purpose of the study was to determine the impact of using tundra lakes as a freshwater resource for the construction of ice roads and pads. Measurements of water surface level, specific conductance, temperature and dissolved oxygen were recorded in near real-time providing an opportunity to detect immediate and cumulative response from pumping activities. Water quality variables and recharge processes were also examined to further determine the impacts of mid-winter pumping activity.

Tundra lakes are a valuable freshwater resource on the Alaskan Arctic Coastal Plain and are of increasing relevance as the petroleum industry in Alaska continues to rely on the freshwater resource to support exploration and production activities. In examining and characterizing the effects of the water withdrawal, differences between pumped and control lakes were not statistically significant. We conclude there are no detectable adverse impacts at current levels of pumping.

\subsection{Project Location / Lake Information}

The study area is shown in Figure 1. The area is located on the North Slope of Alaska. The tundra lakes monitored are located within the Kuparuk and Alpine Oil Fields (Figure 2). These include lakes K214 and K209 in the Kuparuk field, which were pumped, lakes K203 and K113, (also in Kuparuk), which were not pumped and functioned as a basis of comparison and lakes L9312 and L9817, which were pumped in the Alpine field. Pumping occurred in December and January for lake K214 and January and February for lake K209. Lake L9312 is used for water supply for the Alpine facility and is periodically pumped throughout the year. Lake L9817 is used just for ice road construction and was typically pumped in early winter after tundra travel is permitted. Table 1 presents the coordinates, physical characteristics, and 2002-03 winter quantities of pumping for all lakes along with the location of the 2M Pad Repeater (Figure 3) 
used for telemetry on lake K209. Instruments were deployed on rafts positioned on the ice but left through springmelt (Figure 5). Dates and quantities of pumping activity are located in Table 2.

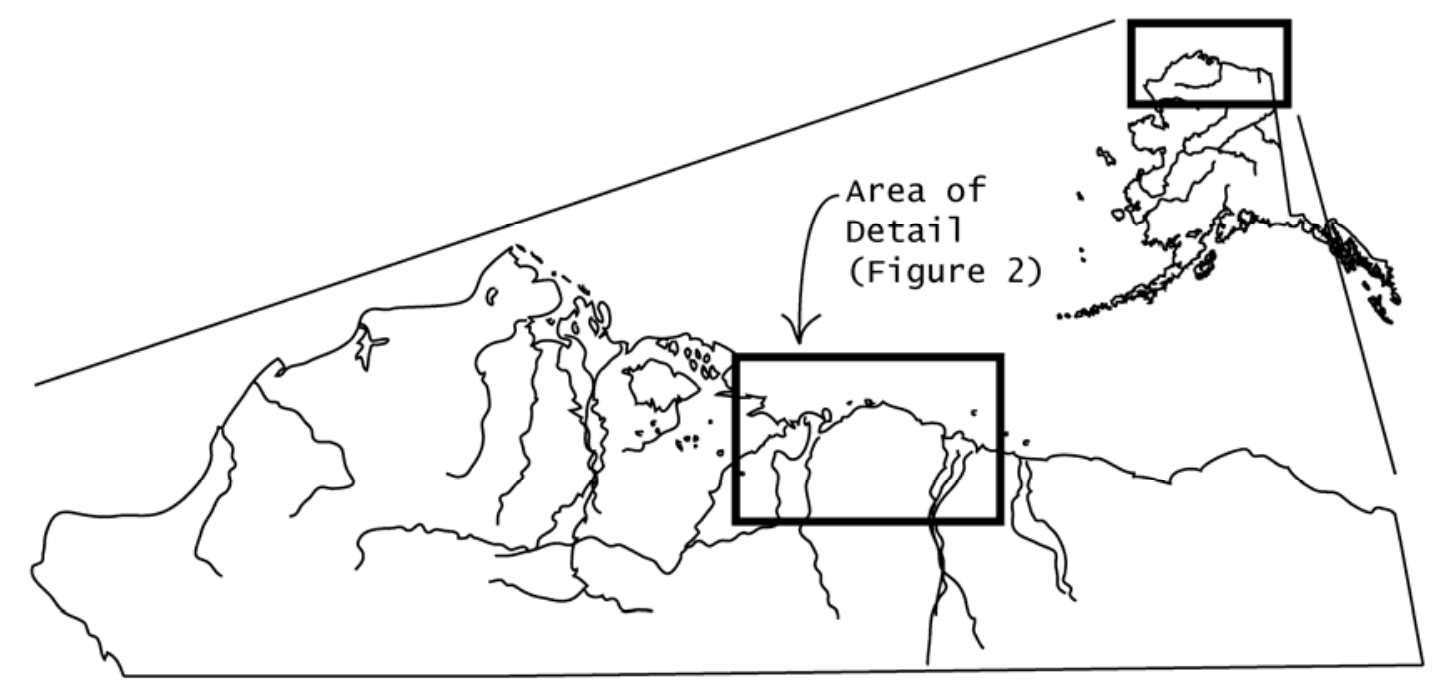

Figure 1. Map illustrating location of general study site within the Alaska Arctic Coastal Plain.

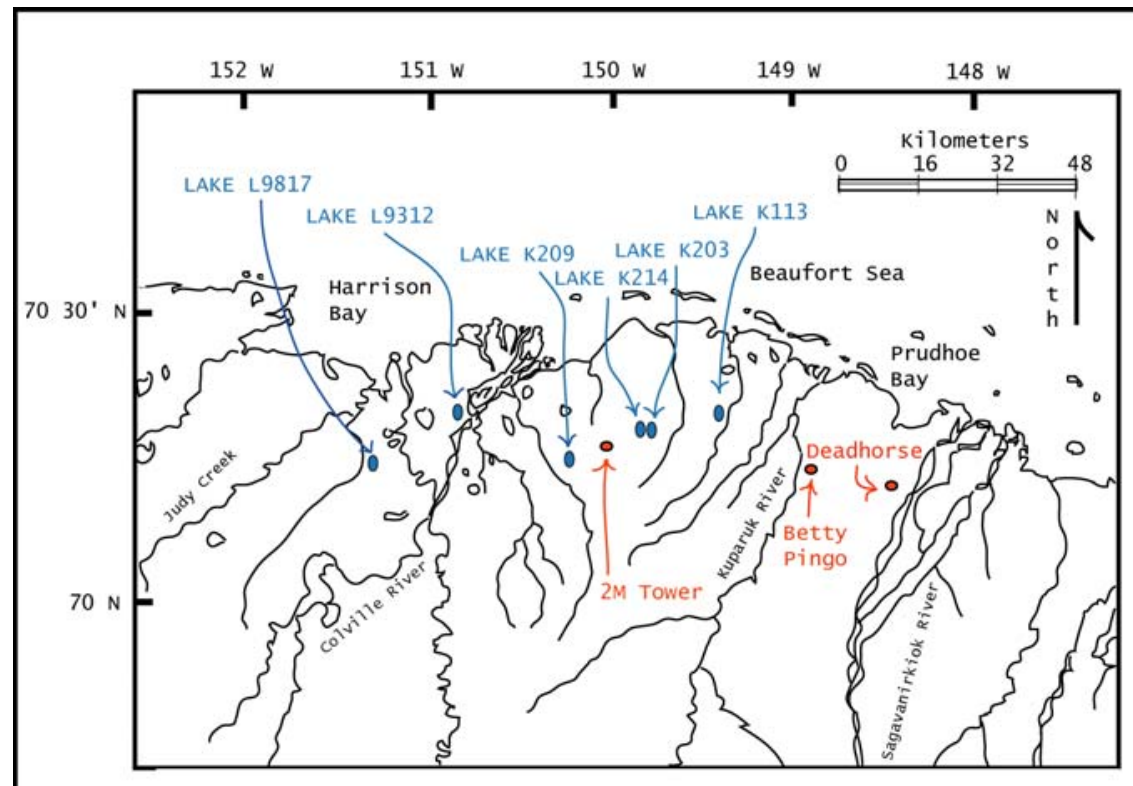

Figure 2. Locations of study lakes in Kuparuk and Alpine Oilfields, North Slope, Alaska. 


\section{ACKNOWLEDGMENTS}

Logistics of fieldwork and travel were facilitated by Jessica Adema and Justin Harth (ConocoPhillips Alaska, Inc.) and Wilson Cullor (BP Exploration (Alaska) Inc.). Field activities were further supported on-site by Alaska Clean Seas, the NSK Light Duty shop, the Sag River DOT crew and Lounsbury and LCMF surveyors. Richard Kemnitz and Matthew Whitman (US Bureau of Land Management) and Bill Morris (Alaska Department of Natural Resources) also supplied assistance. Funding of the project was provided through the Arctic Energy and Technology Development Laboratory under a grant from the U.S. Department of Energy. B. P. Exploration and ConocoPhillips, Alaska provided matching and logistical support. Caryn Rea (ConocoPhillips Alaska, Inc.) and Bill Streever (BP Exploration (Alaska) Inc.) also provided valuable technical input and support. BPX also provided financial support to fund a literature review of research conducted on North Slope lakes.

\section{INTRODUCTION}

Ice roads, pads and airstrips are an essential part of the winter Arctic transportation infrastructure on the North Slope of Alaska and in other cold regions. Trucking freight by ice roads allows for the timely delivery of materials and supplies at a fraction of the cost of traditional airfreight. Mobilizing exploration activities from ice pads also allows for minimal commitment while investigating the resource potentials of various sites. Moreover, the ice infrastructure has a minimum impact on the environment as it melts away seasonally, with some short-term affects on vegetation diversity but negligible long-term (> 20 years) environmental footprint on the sensitive Arctic terrain (Guyer and others, 2006).

The construction of ice roads was pioneered by John Denison in the 1950s in response to the existing inefficient system for hauling mining equipment and supplies throughout the gold-rich western Canadian provinces (Iglauer, 1974). Using experimental construction methods, Denison was able to build a transportation route linking lake to lake by ice roads and thereby make faster, more efficient long haul trips by taking shorter and more open routes through the terrain. The crowning achievement of Denison's methods was the completion of a $520 \mathrm{~km}$ ice road leading from a camp in Port Radium near Great Bear Lake to Yellowknife, NWT.

On the North Slope, where industrial transportation requirements are primarily defined by oil industry needs, ice road construction begins once the tundra is frozen and an adequate amount of snow cover exists to allow low-impact tundra travel vehicles access to the terrain. The available snow is consolidated by the vehicles for a base layer and then successive sprayings of water taken from nearby permitted lakes builds up an ice roadbed to a sufficient depth. Additionally, ice chips may be used to help supplement the available snow pack and rapidly build a thicker base. The spreading of ice chips can help build both a faster ice road, and one requiring less maintenance. Ice chips are removed from permitted lakes in areas where the water is frozen to the lake bed. Successive sprayings of water taken from nearby permitted lakes builds up an ice roadbed to a sufficient depth (Figure 3). Overall, the modern construction of ice roads is well planned and executed. However, concerns about the potential effects of withdrawing large volumes of water from the tundra lakes have arisen.

Concerns about the potential effects of withdrawing large volumes of water from the tundra lakes have arisen (National Research Council, 2003, p. 126-126, 153). The main concern is 
that pumping will negatively impact physical and chemical variables at the pumping lakes, which will in turn negatively affect the resident fish population. The hypothesis of this study is that discrete changes in physical and chemical variables of lakes subjected to winter pumping can be detected. The null hypothesis is that such changes cannot be detected. An example of potential impact from pumping activity is that pumped lakes might incur a water balance deficit due to water withdrawal volumes if not adequately recharged by spring meltwater. The deficit might be observed immediately in the following spring after winter pumping or potentially as a cumulative, long-term impact from continuous winter pumping activity at the same lake year after year. Alternatively, the possibility remains that impacts due to pumping may occur in variables not included in the study design.

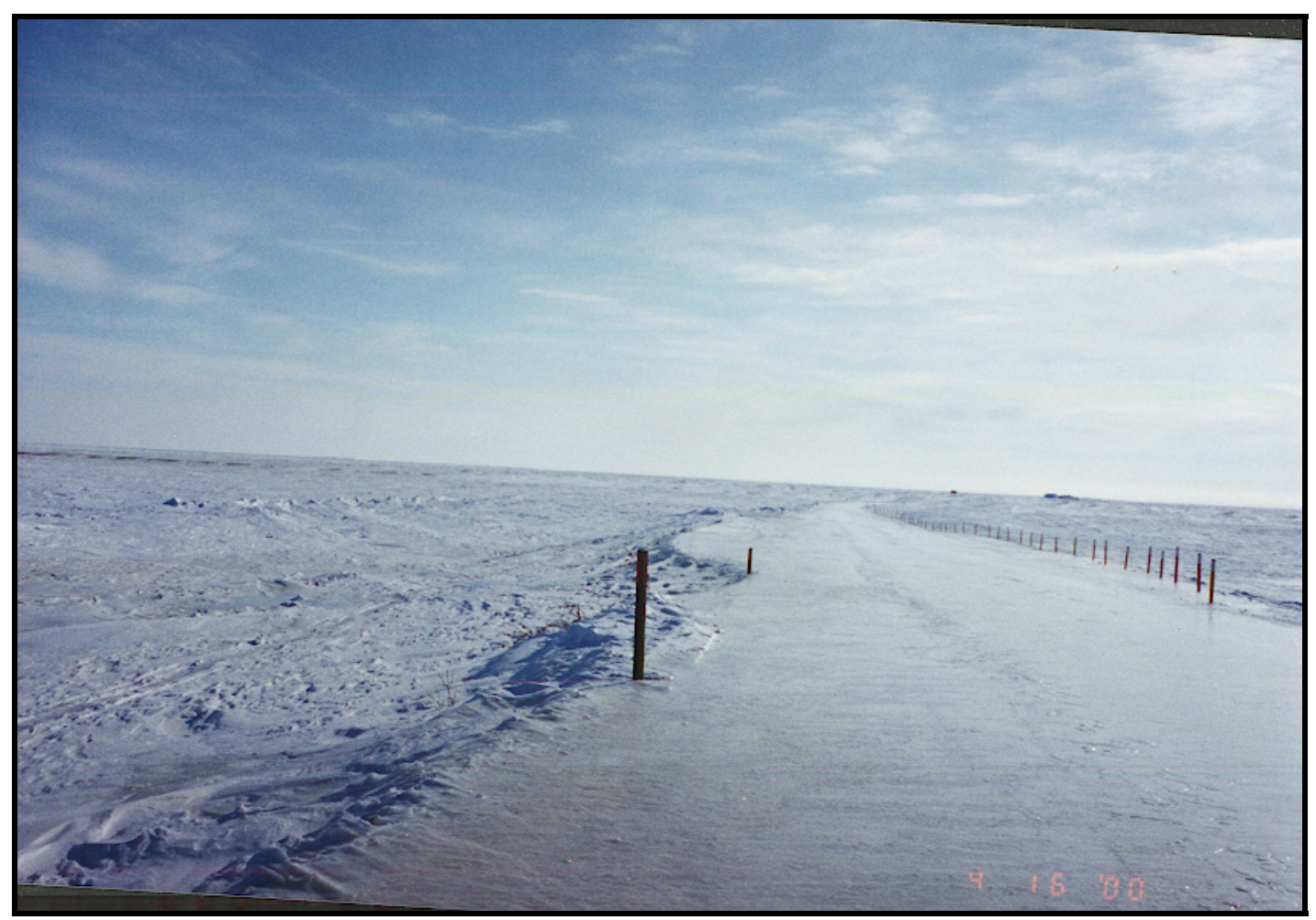

Figure 3. A completed ice road looking northeast toward the Alpine Oil Field (photo by Bill Morris, Alaska Department of Natural Resources).

This study examined and characterized lake recharge, water surface levels, specific conductance, temperature, dissolved oxygen and numerous water quality variables in order to analyze the impact of pumping activity. Various techniques of data collection were investigated and we noted a need for standardization of methods, especially for DO measurements. Extensive efforts were invested into Quality Assurance and Quality Control (QA/QC) but the rigors of working in extreme cold and persistent winds introduced problems not normally encountered in limnology studies in more temperate regions. These harsh conditions frequently created equipment problems, such as freezing probes. We were careful to confirm data quality; however, data collected under similar conditions in previous studies may not be directly comparable if adequate QA/QC protocols were not followed. In years one and two, to pumped lakes were compared to two non-pumped control lakes in the Kuparuk field to determine differences due to pumping. Two additional lakes in the Alpine area were added in year three. 
Our data collection system included continuous monitoring of several variables (including water temperature, water level and conductivity) using a raft mounted data logger system. This continuous monitoring enabled observation of changes that might occur in response to pumping events. The data logging system was connected via radio telemetry so the system could be observed in near real time. This presented some advantages in monitoring the functionality of the data logger and instruments. Unfortunately, it was nearly impossible to replace sensors that were beneath the lake ice but we were able to avoid some problems such as battery failure. Water surface levels were investigated in an attempt to observe pumping activity in near realtime at 15-minute intervals. Estimations based on idealized lake bathymetry projections were calculated and compared to detected changes in water surface levels. Detecting water surface level changes is a challenge because the expected change is minimal. The ability to accurately gauge water surface levels at the pumped lakes in near real-time would be a desirable tool for pumping operators, planners and regulators where water surface levels could be networked into an accessible database providing a proxy to a limiting water surface level at the permitted pumped lakes.

Specific conductance was measured both in continuous recording sensors and in periodic visits to the lakes. These measurements correlate very well with many chemical constituents of interest. Temperature is an important variable to qualify. Thermal disturbances due to pumping might occur that might affect the metabolic activity of lake biota. Any thermal differences between pumped and control lakes are important to detect and quantify.

Dissolved oxygen is a critical variable for fish. Due to low temperatures, resident fish maintain a low metabolism through the winter, thus requiring less oxygen. However, significant reductions in the low dissolved oxygen concentration would decrease their chances for overwinter survival. Determining any impact on dissolved oxygen resulting from pumping activity is important. In addition to $\mathrm{DO}$, other water quality variables including $\mathrm{pH}$, alkalinity, turbidity, nutrients and metals are specific indicators of lake health. Measuring water quality variables before and after pumping and comparing any changes among pumped and control lakes is a crucial determination in observing the effect of pumping activity.

Meteorological data were also collected at a site near the study lakes to better interpret relationships between environmental factors, such as precipitation as snow, and the data being measured at the lakes. Environmental influences on the measured lake variables are essential to characterize since the expected responses in the lakes are expected to be slight due to low pumping volumes as indicated from the results of previous studies.

This study examines the physical and chemical effects of the current water withdrawal volumes while examining the overall hydrology and chemistry of tundra lakes in the Alaskan Arctic. This study is limited to conditions encountered and different results might occur in a year with extremely low precipitation. No long-term studies have been conducted, so the range of variation of many variables is unknown. Determining the effects on tundra lakes from current pumping is essential as the oil industry continues to strive to minimize any anthropogenic impact to the environment they utilize. Results of this study should provide scientific data that can be used by resource agencies in their decision-making concerning water withdrawal and guide sustainable pumping activity. The limitations of this study must be acknowledged and these findings integrated with other scientific studies to present a complete understanding of natural dynamics and water use impacts.

Six lakes (four pumped, two control) on the North Slope of Alaska within the Kuparuk Oilfield Operating Unit and Alpine Oilfield Operating Unit have been examined. The lakes were 
monitored and sampled throughout the 2002-2003, 2003-2004 and 2004-2005 winters for numerous chemical and hydrological variables. Using online telemetry, dynamics of water surface elevation, specific conductance and dissolved oxygen of the under-ice water and profiles of lake temperature were observed in near real-time. Numerous water quality variables using in-situ, benchtop and laboratory techniques were also quantified. Investigation of lake recharge was also completed during the spring of 2003, 2004 and 2005.

\section{SITE DESCRIPTION}

The six primary study lakes (K113C, K203C, K209P, K214P, L9812P and L9817P) are in the arctic coastal plain of Alaska, an area approximately $70,900 \mathrm{~km}^{2}$ (Walker, 1973) bounded between the foothills of the Brooks Range to the south and the Arctic Ocean to the north. The study lakes are approximately $30-45 \mathrm{~km}$ south of the Arctic Ocean and located west of the lower Kuparuk River to an area approximately $25 \mathrm{~km}$ west of the Colville River (Figures 2 and 3 ).

Table 1- Table 6 summarize the geography, operations, hydrology, biology and research history of the lakes. All lakes were created by thaw or thermokarst processes and are generally uniform in morphology, although Kuparuk and Alpine lakes differ somewhat in terrain and geology. Although all lakes are permitted for pumping, lakes K113C (i.e. lake K113 Control) and K203C were not pumped during the 2002-2003 and 2003-2004 winter and provide a basis for comparison to the lakes that were pumped. K209P (i.e. K209 Pumped) and K214P. K113C has the least surface area of the Kuparuk lakes $\left(1,800,000 \mathrm{ft}^{2}, 166,000 \mathrm{~m}^{2}\right)$ and is relatively deep (2.3 m). Lake K214P, with the most surface area $\left(23,000,000 \mathrm{ft}^{2}\right)\left(2,100,000 \mathrm{~m}^{2}\right)$ also contains the most water of all lakes with $\left(317,999,000\right.$ gal) $1,203,757 \mathrm{~m}^{3}$. At Alpine, L9312P is the deepest at $4.3 \mathrm{~m}$ with surface area of $4,300,000 \mathrm{ft}^{2}$ or $400,000 \mathrm{~m}^{2}$. L9817P has a surface area of $3,200,000 \mathrm{ft}^{2}$ and $300,000 \mathrm{~m}^{2}$ and a depth of $2.9 \mathrm{~m}$.

The study lakes in the Kuparuk unit are comparable to relatively deep $(1.8-2.2 \mathrm{~m})$ thaw lakes within the arctic coastal plain that do not have significant interaction with the Arctic Ocean and do not support fish. NPRA and Colville Delta lakes may be deeper and more likely to support fish. Extrapolation is uncertain, as few formal investigations of similar tundra lakes have occurred in regions outside the Point Barrow area. Selection of lakes was difficult as instruments were installed prior to beginning of pumping activities. The top priority for lake selection was its probability of being pumped. Field contractors involved in ice road construction selected the lakes that were ultimately pumped based upon their convenience. Many dozens of lakes were permitted for water removal, but only a small fraction of those lakes were actually pumped in any single winter. 
Table 1. Summary of lake characteristics -- geography and operations.

\begin{tabular}{|c|c|c|c|c|c|}
\hline Parameter & Lake K113C & Lake K203C & Lake K209P & Lake K214P & Citation \\
\hline Latitude (NAD 27) & N 70 19' 11.6" & N 70 17' 07.2" & N 70 14'08.6" & N 70 17' $32.1^{\prime \prime}$ & - \\
\hline Longitude (NAD 27) & W 149 19' 08.0" & W 149 51' 34.7" & W 150 20' 54.1" & W 149 54' 52.8" & - \\
\hline $\begin{array}{c}\text { USGS Quadrangle } \\
\text { Map }\end{array}$ & $\begin{array}{l}\text { Beechey Point B-4: } \\
\text { T11N R11E, Sect } 10\end{array}$ & $\begin{array}{c}\text { Beechey Point B- } \\
\text { 5: T11N R9E, } \\
\text { Sect } 21\end{array}$ & $\begin{array}{c}\text { Harrison Bay A-1: } \\
\text { T10N R7E, Sect } \\
10,15\end{array}$ & $\begin{array}{l}\text { Beechey Point B-5: } \\
\text { T11N R9E, Sect } 20\end{array}$ & - \\
\hline Operating Field & Kuparuk & Kuparuk & Kuparuk & Kuparuk & - \\
\hline Nearest pad or facility & DS $1 M$ & CPF 2 & DS $2 \mathrm{~L}$ & CPF 2 & - \\
\hline $\begin{array}{l}\text { Permitted for winter } \\
\text { pumping activity? }\end{array}$ & Yes & Yes & Yes & Yes & Lauruhn, 2001 \\
\hline $\begin{array}{l}\text { Permit Volume } \mathrm{m}^{3} ; \\
\text { (gal) }\end{array}$ & $\begin{array}{c}12,507 \\
(3,300,000)\end{array}$ & $\begin{array}{c}103,732 \\
(27,370,000)\end{array}$ & $\begin{array}{c}635,947 \\
(167,796,091)\end{array}$ & $\begin{array}{c}143,237 \\
(37,793,380)\end{array}$ & $\begin{array}{c}\text { TWUP A2006-69, } \\
\text { TWUP A2006-73, } \\
\text { LAS 2762 } \\
\text { Bettis, } 2006\end{array}$ \\
\hline $\begin{array}{l}\text { Purpose of pumping } \\
\text { activity }\end{array}$ & $\begin{array}{l}\text { Control - No } \\
\text { Pumping }\end{array}$ & $\begin{array}{l}\text { Control - No } \\
\text { Pumping }\end{array}$ & Exploration & $\begin{array}{l}\text { Exploration / } \\
\text { Firewater }\end{array}$ & (- \\
\hline $\begin{array}{l}\text { Pumped in 2002-03 } \\
\text { winter? }\end{array}$ & No & No & Yes & Yes & CPAI, 2004 \\
\hline $\begin{array}{l}\text { Pumped in 2003-04 } \\
\text { winter? }\end{array}$ & No & No & Yes & Yes & CPAI, 2004 \\
\hline $\begin{array}{l}\text { Pumped in 2004-05 } \\
\text { winter? }\end{array}$ & No & No & Yes & Yes & CPAI, 2006 \\
\hline Other names & - & W27.1, M8104 & L9128, AA18.1 & W26.1, M8103 & ACS, 2001 \\
\hline
\end{tabular}


Table 2. Summary of lake characteristics -- geography and operations -- Continued.

\begin{tabular}{|c|c|c|c|}
\hline Parameter & Lake L9312P & Lake L9817P & Citation \\
\hline Latitude (NAD 27) & N $70199^{\prime} 58.0 "$ & N $7014 ' 17.4 "$ & -- \\
\hline Longitude(NAD 27) & W $150566^{\prime} 44.9 "$ & W 15120 ' 9.8” & -- \\
\hline $\begin{array}{l}\text { USGS Quadrangle } \\
\text { Map }\end{array}$ & Harrison Bay B-2: T11N R5E, Sect 5 & $\begin{array}{c}\text { Harrison Bay A3 T10N R3E, } \\
\text { Sect10 }\end{array}$ & -- \\
\hline Operating Field & Alpine & Alpine, NPRA & -- \\
\hline Nearest pad or facility & CD 1 & Ice Road & -- \\
\hline $\begin{array}{l}\text { Permitted for winter } \\
\text { pumping activity? }\end{array}$ & Yes & Yes & -- \\
\hline $\begin{array}{l}\text { Permit Volume } \mathrm{m}^{3} ; \\
\text { (gal) }\end{array}$ & $\begin{array}{c}113,676 ; \\
\text { (30 million gallons) }\end{array}$ & $\begin{array}{c}57,987 ; \\
\text { (15.3 million gallons) }\end{array}$ & $\begin{array}{c}\text { LAS 23889, } \\
\text { FG99-III-0051-6, } \\
\text { FH04-III-0310 }\end{array}$ \\
\hline $\begin{array}{c}\text { Purpose of pumping } \\
\text { activity }\end{array}$ & Drinking Water / Exploration & Exploration & -- \\
\hline $\begin{array}{l}\text { Pumped in 2002-03 } \\
\text { winter? }\end{array}$ & Yes & No & CPAI, 2006 \\
\hline $\begin{array}{l}\text { Pumped in 2003-04 } \\
\text { winter? }\end{array}$ & Yes & Yes & CPAI, 2006 \\
\hline $\begin{array}{l}\text { Pumped in 2004-05 } \\
\text { winter? }\end{array}$ & Yes & Yes & CPAI, 2006 \\
\hline Other names & U6.1 & & \\
\hline
\end{tabular}


Table 3. Summary of lake characteristics -- hydrology and biology.

\begin{tabular}{|c|c|c|c|c|c|}
\hline Parameter & Lake K113C & Lake K203C & Lake K209P & Lake K214P & Citation \\
\hline $\begin{array}{c}\text { Surface area } \mathrm{km}^{2} ; \\
\text { (acres) }\end{array}$ & $\begin{array}{l}0.1659 ; \\
(40.99)\end{array}$ & $\begin{array}{c}0.8417 ; \\
(207.99)\end{array}$ & $\begin{array}{c}1.404 ; \\
(346.94)\end{array}$ & $\begin{array}{c}2.104 ; \\
(519.91)\end{array}$ & Morris, 2003; Moulton, 1998 \\
\hline $\begin{array}{l}\text { Maximum water } \\
\text { depth, m; (ft.) }\end{array}$ & $2.29 ;(7.51)$ & $1.88 ;(6.17)$ & $1.86 ;(6.10)$ & $1.75 ;(5.74)$ & - \\
\hline $\begin{array}{l}\text { Total volume, } \mathrm{m}^{3} ; \\
\text { (gal) }\end{array}$ & $\begin{array}{c}125,070 \\
(33,000,000)\end{array}$ & $\begin{array}{c}1,037,360.9 \\
(273,710,000)\end{array}$ & $\begin{array}{c}1,272,265.1 \\
(335,690,000)\end{array}$ & $\begin{array}{c}2,686,086.7 \\
(708,730,000)\end{array}$ & $\begin{array}{l}\text { TWUP A2006-69, } \\
\text { TWUP A2006-73, } \\
\text { Bettis, } 2006\end{array}$ \\
\hline $\begin{array}{l}\text { Road dusting } \\
\text { potential }\end{array}$ & $\begin{array}{c}\text { High, lake } \\
\text { adjacent to high } \\
\text { traffic Spine Road }\end{array}$ & $\begin{array}{l}\text { Moderate, lake } \\
\text { near to CPF2 } \\
\text { facility }\end{array}$ & $\begin{array}{c}\text { Minimal, lake } 0.5 \\
\text { km away from } \\
\text { nearest pad }\end{array}$ & $\begin{array}{c}\text { Moderate, lake } \\
\text { near to CPF2 } \\
\text { facility }\end{array}$ & - \\
\hline $\begin{array}{c}\text { Subsurface } \\
\text { connection to nearby } \\
\text { streams }\end{array}$ & Unlikely & Unlikely & $\begin{array}{c}\text { Possible, bounded } \\
\text { between } \\
\text { Miluveah River } \\
\text { and Kachemach } \\
\text { River }\end{array}$ & Unlikely & - \\
\hline Fish species present & $\begin{array}{l}\text { Ninespine } \\
\text { Stickleback }\end{array}$ & $\begin{array}{c}\text { Ninespine } \\
\text { Stickleback }\end{array}$ & \begin{tabular}{|l|} 
Ninespine \\
Stickleback
\end{tabular} & $\begin{array}{c}\text { Ninespine } \\
\text { Stickleback }\end{array}$ & Moulton 1998 \\
\hline
\end{tabular}


Table 4. Summary of lake characteristics -- hydrology and biology -- Continued.

\begin{tabular}{|c|c|c|c|}
\hline Parameter & Lake L9312 & Lake L9817 & Citation \\
\hline $\begin{array}{c}\begin{array}{c}\text { Surface area } \mathrm{km}^{2} ; \\
\text { (acres) }\end{array} \\
\end{array}$ & $\begin{array}{c}0.4 \\
(98.84) \\
\end{array}$ & $\begin{array}{c}0.3 \\
(74.13)\end{array}$ & $\begin{array}{c}\text { Bill Morris, ADF\&G; Moulton } \\
1998 \text { and } 2003\end{array}$ \\
\hline $\begin{array}{c}\text { Maximum water depth, m; } \\
\text { (ft.) }\end{array}$ & $\begin{array}{c}4.3 \\
(14.11) \\
\end{array}$ & $\begin{array}{c}2.7 \\
(8.86) \\
\end{array}$ & 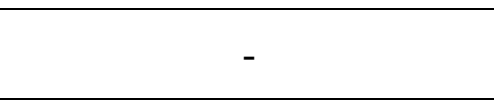 \\
\hline $\begin{array}{c}\text { Total volume, } \mathrm{m}^{3} ; \\
\text { (gal) }\end{array}$ & $\begin{array}{c}1,137,000 \\
(300,000,000)\end{array}$ & $\begin{array}{c}386,201 \\
(101,900,000)\end{array}$ & $\begin{array}{l}\text { FG99-III-0051-6, } \\
\text { FH04-III-0310 }\end{array}$ \\
\hline Road dusting potential & $\begin{array}{c}\text { Minimal, lake } 1 / 4 \text { mile away from } \\
\text { nearest pad }\end{array}$ & $\begin{array}{c}\text { Negligible, lake within exploration } \\
\text { area without gravel roads }\end{array}$ & - \\
\hline $\begin{array}{c}\text { Subsurface connection to } \\
\text { nearby streams }\end{array}$ & Unlikely & Unlikely & - \\
\hline Fish species present & $\begin{array}{c}\text { Ninespine Stickleback, Least } \\
\text { Cisco, Alaska Blackfish, Slimy } \\
\text { Sculpin }\end{array}$ & Ninespine Stickleback & Moulton 1998 \\
\hline
\end{tabular}


Table 5. Summary of lake characteristics -- history of research and operations.

\begin{tabular}{|c|c|c|c|c|c|}
\hline Parameter & Lake K113C & Lake K203C & Lake K209P & Lake K214P & Citation \\
\hline $\begin{array}{l}\text { Past hydrology } \\
\text { data or studies }\end{array}$ & - & MBJ in 2002 & - & MBJ in 2002 & MBJ, 2002 \\
\hline $\begin{array}{l}\text { Past chemistry } \\
\text { data or studies }\end{array}$ & - & MBJ in 2002 & $\begin{array}{c}\text { Moulton in } 1991 \\
\text { and } 1997\end{array}$ & MBJ in 2002 & $\begin{array}{c}\text { Moulton, 1998; } \\
\text { MBJ, } 2002\end{array}$ \\
\hline $\begin{array}{l}\text { Past biological } \\
\text { data or studies }\end{array}$ & Moulton, 1988 & Moulton 1981 & Moulton in 1996 & $\begin{array}{c}\text { Moulton } 1981 \text { and } \\
1982\end{array}$ & Moulton, 1998 \\
\hline $\begin{array}{l}\text { Years pumped } \\
\text { in winter }\end{array}$ & None & None & 2003-05 & 2003-05 & $\begin{array}{c}\text { CPAI, 2004, } \\
2006 \\
\end{array}$ \\
\hline $\begin{array}{l}\text { Permanent } \\
\text { pumping } \\
\text { installation }\end{array}$ & No & No & No & Yes & 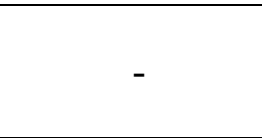 \\
\hline $\begin{array}{l}\text { Survey } \\
\text { benchmark } \\
\text { locations }\end{array}$ & $\begin{array}{l}\text { TBMs on } \\
\text { northern } \\
\text { product line } \\
\text { VSMs }\end{array}$ & $\begin{array}{c}\text { TBMs on VSMs } \\
\text { and } \\
\text { monuments } \\
\text { near NW } \\
\text { corner of lake }\end{array}$ & $\begin{array}{l}\text { VSMs on } \\
\text { pipeline to north } \\
\text { side near shore }\end{array}$ & $\begin{array}{l}\text { VSMs and } \\
\text { monuments along } \\
\text { east and west } \\
\text { sides of lake }\end{array}$ & $\begin{array}{c}\text { (TBM = } \\
\text { Temporary } \\
\text { Benchmark, } \\
\text { VSM = Vertica } \\
\text { Support } \\
\text { Member) }\end{array}$ \\
\hline
\end{tabular}


Table 6. Summary of lake characteristics - history of research and operations -- Continued.

\begin{tabular}{|c|c|c|c|}
\hline Parameter & Lake L9312 & Lake L9817 & Citation \\
\hline \hline $\begin{array}{c}\text { Past hydrology data } \\
\text { or studies }\end{array}$ & Baker & Baker & MBJ, 2002 \\
\hline $\begin{array}{c}\text { Past chemistry data } \\
\text { or studies }\end{array}$ & Moulton, Baker & Baker & MBJ, 2002 \\
\hline $\begin{array}{c}\text { Past biological data } \\
\text { or studies }\end{array}$ & Moulton & $2003-05$ & CPAI, 2006 \\
\hline $\begin{array}{c}\text { Years pumped in } \\
\text { winter }\end{array}$ & 2002-05 & No & - \\
\hline $\begin{array}{c}\text { Permanent pumping } \\
\text { installation }\end{array}$ & Yes & Surrounding SE lake perimeter & - \\
\hline $\begin{array}{c}\text { Survey benchmark } \\
\text { locations }\end{array}$ & At pump house intake structure & \\
\hline
\end{tabular}


Dominant landforms within the Alaskan arctic coastal plain include low and high centered polygons, strangmoor ridges and other nonpatterned ground (Everett and Parkinson, 1977). Pingos and dunes are also a common feature in many places on the coastal plain. Common vegetation includes grasses, sedges, mosses and lichens. Wet areas surrounding the lake perimeter contain mostly Carex and Eriophorum sedges with understories of moss (Hobbie, 1980). Surrounding soils are typically highly organic, highly acidic fibrous peat and approximately 8,000-10,000 years old (Jorgenson and others, 2002). Nearer to the coast, eolian sands and marine alluvium soils dominate. The dominant surface geological unit throughout the arctic coastal plain is late Quaternary unconsolidated sands and gravels (Black, 1964). Soils can be ice-rich or ice-poor. The topographic relief of the coastal plain is flat with an average surface slope between $0.1-0.2 \%$ (Rovansek and others, 1996); consequently, drainage is poor. Steeper scarps do exist within the vicinity of the lakes and are useful in delineating watersheds.

The Alaskan arctic coastal plain is rich in standing surface waters. Hussey and Michaelson (1966) estimate that $50-75 \%$ of the Alaskan arctic coastal plain is covered either by lakes and ponds or old thaw lake basins. According to Hall and others (1994) 83\% of the coastal plain is classified as wetlands, using the classification system reported by Cowardin and others, 1979. There are few precipitation stations on the North Slope. Benning and Yang (2005) report average wind-corrected precipitation data for Barrow as $185.1 \mathrm{~mm}$ (7.29 inches) for 1995-2001. Kane and others (2004) reported $376 \mathrm{~mm}$ ( 14.8 inches) for shielded annual precipitation for the period 1996-2002 in the upper Kuparuk River Watershed. However, evaporation typically exceeds precipitation through the summer and the area that is inundated with water gradually declines (Bowling and others, 2003). Active freshwater lakes and ponds may cover up to $40 \%$ of the surface (Hobbie, 1980) near the coast. However, most water bodies within the arctic coastal plain are shallow and have a maximum depth less than $2.0 \mathrm{~m}(\sim 6.6 \mathrm{ft})$ (Truett and Johnson, 2000). The occurrence of lakes decreases inland and eastward with the coast having the most surface water. However, the occurrence of deeper lakes also increases inland (Figure 4). 


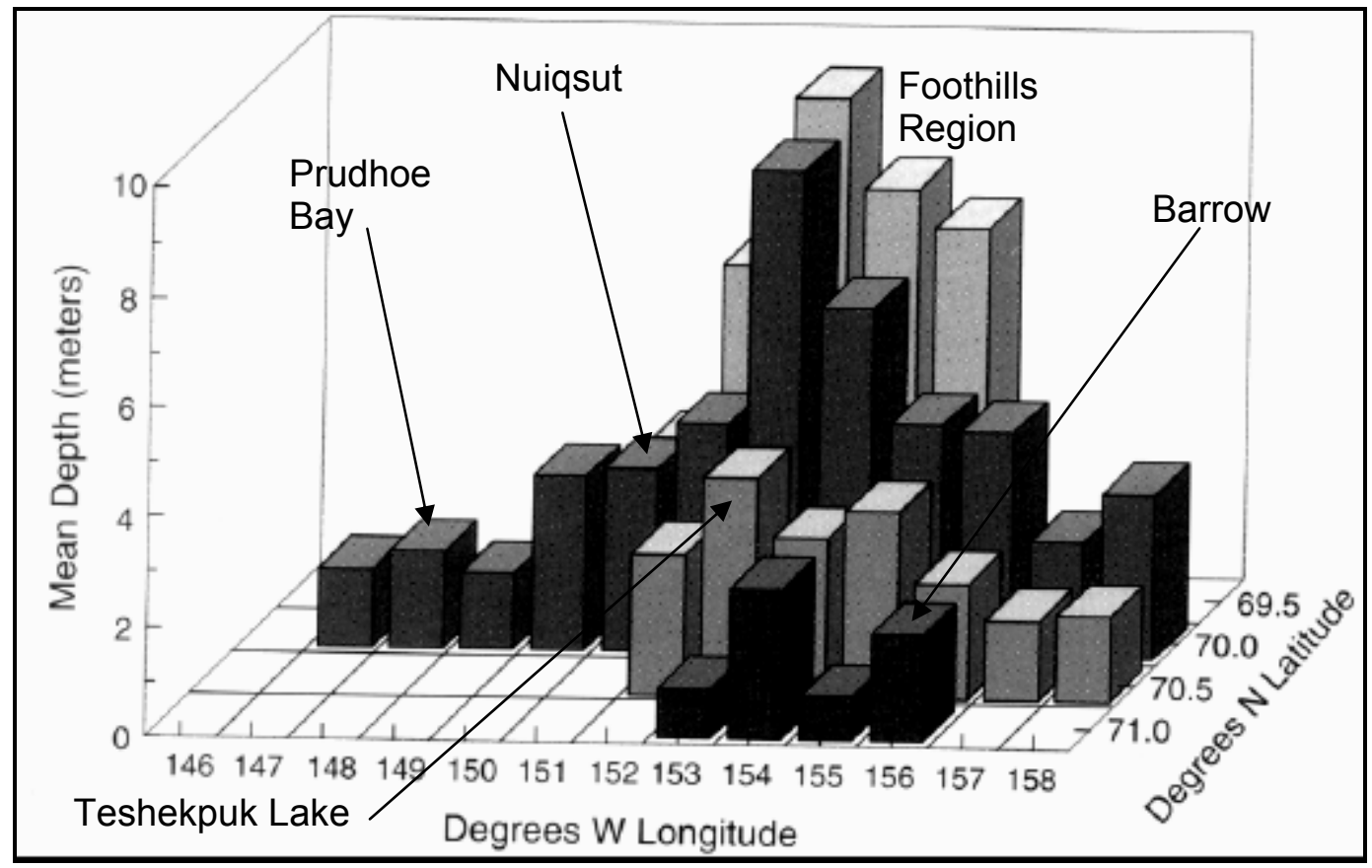

Figure 4. Distribution of mean maximum depths for arctic coastal plain lakes (Johnson and Truett, 2000). Geographic points of interest have been added.

Despite being abundant in surface water, the arctic coastal plain receives little annual precipitation. Precipitation is usually in the form of snow from mid-September to mid-May and in the form of rain during the summer months although snow can fall throughout the year. Precipitation as snow is about $40 \%$ of the total annual precipitation amount (Kane and others, 2000).

Snow is the most important water source for the lakes as meltwater is the primary recharge mechanism and the dominant input to the lakes annually. Any precipitation received later in the summer months is only received from direct precipitation to the lakes surface, as runoff is rare. The lack of summer runoff is a result of high summer evaporation drying the watershed and the consequent lack of hydraulic connections within the lake drainage network (Bowling and others, 2003). A 10-year data set at Betty Pingo site suggests the snow water equivalence (SWE) contributing to recharge ranges from $5.8-12.9 \mathrm{~cm}$ with an average of $8.9 \mathrm{~cm}$ (Kane and Hinzman, 2004). However, the grounded snow is subject to frequent redistribution by the constant strong winds and is highly variable in depth with respect to the local topography. Compacted snow on lake ice has both a lower snow water equivalent and less thermal resistance than the compacted snow on surrounding tundra (Sturm and Liston, 2003).

Snowmelt generally occurs in late May or early June, lasts 7-10 days and is the only appreciable annual stream runoff event. Runoff begins when the snowpack is mostly ablated and completely saturated with water. Maximum discharge usually occurs within 24 hours of saturation and in the next four days, $40-60 \%$ of the total runoff occurs (Hobbie, 1980). Because the active layer is nearly saturated and frozen at this time of the year, little infiltration occurs and most meltwater contributes to runoff.

Lakes remain ice covered well past snowmelt until late June or early July when the ice cover candles, moats and gradually melts. After snowmelt the lake water balance is dominated by 
evapotranspiration in the lower Put and Kuparuk River drainages (Rovansek and others, 1996). Evapotranspiration is high due to continuous solar radiation input from late-April to mid-August. Evaporation most often exceeds precipitation resulting in a net water loss, which must be replenished by next year's snowmelt runoff (Mendez and others, 1998; Bowling and others, 2003).

Mean annual air temperatures at $1 \mathrm{~m}$ (30-year average $=-11.56^{\circ} \mathrm{C}$ (Western Regional Climate Center, 2004)) are well below freezing throughout the arctic coastal plain so continuous permafrost exists throughout the area. Permafrost is a primary control on most hydrological processes in the area. Osterkamp and others (1985) reported an average permafrost depth of $680 \mathrm{~m}$ in the Prudhoe Bay region. The active layer (the layer of soil above the permafrost that thaws each summer and refreezes every winter), ranges from 25 to $100 \mathrm{~cm}$. Factors influencing thaw depth are vegetation type, ice content, topography, insulation by plant litter, and soil type (Hobbie, 1980). After spring snowmelt is complete, the contribution to the water balance from active layer flow is minimal (Rovansek and others, 1996).

Winds are persistent and strong throughout the year, with monthly mean wind speeds of 3.7 $5.6 \mathrm{~m} / \mathrm{s}$ and gusts reaching above $20 \mathrm{~m} / \mathrm{s}$. Summer winds are predominately from the northeast and southwest (Olsson and others, 2002).

\subsection{Project Location / Lake Information}

The study area (Figure 1) is located on the North Slope of Alaska. The tundra lakes monitored are located within the Kuparuk and Alpine Oil Fields and one lake in the National Petroleum Reserve Alaska (NPRA) (Figure 2). These include lakes K214P and K209P in the Kuparuk field, which were pumped, lakes K203C and K113C, (also in Kuparuk), which were not pumped and functioned as a basis of comparison and lakes L9312P in the Alpine Field and L9817P in NPRA, which were both pumped. Pumping occurred at various times for lakes K214 and K209. Lake L9312 is used as a permanent water supply for the Alpine facility and is periodically pumped throughout the year. Lake L9817 was used for ice-road construction and was pumped in January and February in 2004 and 2005. The lake was not used for ice chips. Table 1-6 presents the coordinates, physical characteristics, and winter quantities of pumping for all lakes. Instruments were deployed on rafts positioned on the ice but left through springmelt (Figure 5). 


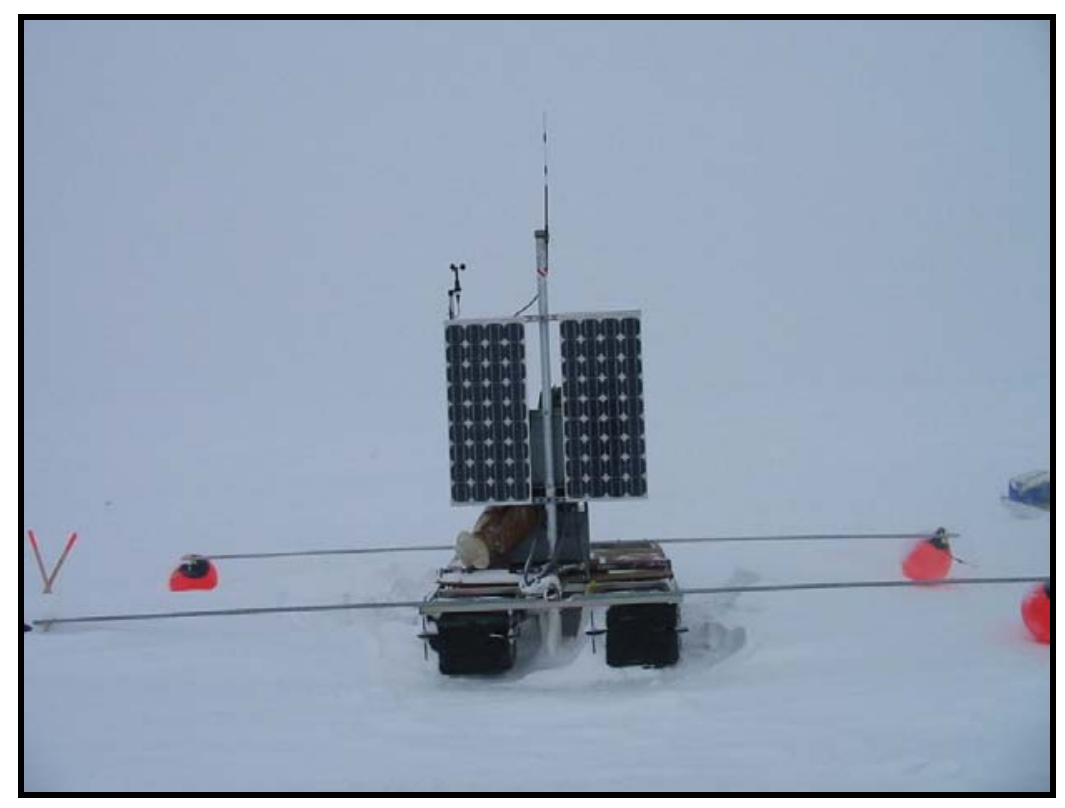

Figure 5. Hydrologic data collection station on raft.

\section{OVERVIEW OF TUNDRA LAKES}

Numerous classifications have been given to coastal plain lakes since the Alaskan arctic coastal plain gained further research relevance and accessibility with the discovery of oil in the Prudhoe Bay region in November 1968. Hablett (1979) discriminated lakes within the National Petroleum Reserve Alaska (NPRA) based on a lake's fishery potential: a $1.8 \mathrm{~m}$ threshold depth, an outlet in spring and adequate spawning substrate. Bendock and Burr (1985) categorized lakes of three types based on their natural history:

(1) Deflation Lakes - deepest depth, formed when dunes become revegetated and basin between dunes fills with water.

(2) Oxbow Lakes - intermediate depth, formed from abandoned river channels.

(3) Thaw Lakes - shallowest depth, formed as ground subsides and ice rich soils melt.

Moulton (1998) classified five types of lakes based on potential fish access from the Colville River delta and this naming convention is regularly used:

(1) Tapped Lakes - lakes with an active connection to a river channel during the summer.

(2) Low Perched Lakes - lakes having an obvious high-water channel that floods annually.

(3) High Perched Lakes - lakes without an obvious high-water channel that floods infrequently.

(4) Drainage Lakes - lakes with an active connection to creek(s). Typically a large thaw lake on a tundra stream.

(5) Tundra Lakes - lakes without a connection to a drainage network. 
Table 7. Study lake classifications.

\begin{tabular}{ccc} 
Lake Name & $\begin{array}{c}\text { Bendock and Burr (1985) } \\
\text { Classification }\end{array}$ & $\begin{array}{c}\text { Moulton (1998) } \\
\text { Classification }\end{array}$ \\
\hline K113C & Thaw Lake & Tundra Lake \\
K203C & Thaw Lake & Tundra Lake \\
K209P & Thaw Lake & Tundra Lake \\
K214P & Thaw Lake & Tundra Lake \\
L9312 & Thaw Lake & Low Perched Lake \\
L9817 & Thaw Lake & Tundra Lake
\end{tabular}

In this report, we will use the general term tundra lake to refer to the study lakes as a group. The term 'lake' is differentiated from 'pond' by Bendock's $1.8 \mathrm{~m}$ threshold maximum depth.

The origin of tundra lakes follows the thaw lake cycle as defined by Hopkins (1949) and others (Carson and Hussey, 1962; Britton, 1966; Billings and Peterson, 1980). The medium for the thaw lake cycle is the large quantities of ice in the upper layers of permafrost within the Alaska coastal plain. Sellmann and others (1975) reported up to $80 \%$ interstitially segregated ice in the top 3-4 $\mathrm{m}$ of permafrost so the upper layers of permafrost on the arctic coastal plain contain large quantities of ice. As this upper ice rich soil thaws due to a thermal disturbance, such as a change in vegetation or a large snow drift, small ponds begin to form. The ponded water eventually reaches a sufficient depth to have standing water over the permafrost, which results in greater heat transfer to the subsurface, melting of buried ice and subsidence of the surface. As the permafrost subsides, thermal erosion also occurs along the shore and small basins gradually form. These smaller basins eventually coalesce and form a larger basin. The newly formed basin continues to grow in dimension until it finally breaches a drainage divide. The lake basin then drains and the process begins anew.

The geomorphology of tundra lakes displays a distinct feature. Nearly all lakes are roughly elliptical with a prominent long northwest-southeast axis. The orientation of the lakes is a result of differential erosion from the wind-driven currents, which elongate the lakes normal to the prevailing northeast winds (Carson and Hussey, 1962). Sellman and others (1975) found that thaw lakes on the Alaskan arctic coastal plain have an average major axis of $1.21-2.30 \mathrm{~km}$ and an average minor axis of $0.68-1.10 \mathrm{~km}$.

Most of the lakes on the coastal plain are shallow. A study of the area inland from Barrow, Alaska, using a synthetic aperture radar technique, found $23 \%$ of lakes are more than $2.2 \mathrm{~m}$ deep, $10 \%$ are between $1.5 \mathrm{~m}$ and $2.2 \mathrm{~m}$ deep, $60 \%$ of lakes are between $1.4 \mathrm{~m}$ and $1.5 \mathrm{~m}$ deep and $7 \%$ are less than $1.4 \mathrm{~m}$ deep (Jeffries and others, 1996).

The thermal structure of the study lakes is cold monolithic (Wetzel, 2001) as the lakes are icecovered most of the year and do not have sufficient depth to stratify in the summer months. This category retains most arctic and some mountain lakes where circulation is limited to the summer months. Surface ice begins to form when the temperature of the water reaches $0{ }^{\circ} \mathrm{C}$. Surface ice forms best when significant surface heat loss is allowed such as a clear and cold night. After an ice cover has frozen, the lake is sealed off from the effects of wind and the lake inversely stratifies with the colder, less dense water neat the ice cover. Water that is near $4^{\circ} \mathrm{C}$ has a greater density and will be deepest. Heat input from solar radiation is minimal in the winter due to the low sun angle and the high albedo of any snow cover preventing radiation 
transmission through the ice and layers of white ice at the surface. Despite the isolated conditions, slight under-ice water currents may exist in lakes in closed basins without inflow and outflow. Small convective cells of density currents generated by the relatively large amount of sediment heat are responsible for the winter under-ice water movement (Welch and Bergmann, 1985). In the summer, water temperatures are more influenced by solar radiation than air temperature (Miller and others, 1980). Water column temperature differences are minimal in the summer due to winds circulating water and the temperature profile is regularly isothermal.

From November until mid-June, the lakes are typically covered by ice (Zhang and Jeffries, 2000). Two types of ice form over freshwater lakes: clear ice and white ice. Clear ice forms when ice gradually forms at the ice-water interface. Clear ice is notably more translucent than white ice. This is due to the gradual formation process of clear ice leading to an efficient exclusion of gases, ions and nutrients (Pounder, 1969). White ice forms as a result of the quick freezing of flooded snow on the ice surface. White ice usually forms early in the winter when the ice sheet is thin allowing the minimal snow loading to stress the ice sheet to failure and cause flooding. Using a heat-transfer model, Zhang and Jeffries (2000) found that the historical (50-year) annual maximum lake ice thickness has varied between $1.33 \mathrm{~m}$ and $2.47 \mathrm{~m}$. They report the historical mean maximum ice thickness was found to be $1.91+/-0.21 \mathrm{~m}$.

When maximum water depth exceeds the maximum ice thickness, a thaw bulb or talik gradually forms beneath the lake basin because the freezing front does not penetrate into the permafrost (Brewer, 1958). In shallow basins a thaw bulb may not develop if the winter ice cover freezes to the lake bottom early in the winter allowing adequate time for thawed sediments to freeze each winter (Lachenbruch, 1963).

The lake's ice cover begins to melt once the average daily air temperature is above $0{ }^{\circ} \mathrm{C}$ and usually is completely gone by mid-July (Hobbie, 1980). The rate of lake thaw is mainly determined by the thickness and albedo of the ice (Hobbie, 1973). In the process of thawing, the ice sheet candles, moats and eventually fragments into pieces, which are pushed to shore in the direction of local prevailing wind.

Tundra lakes are ecologically defined as oligotrophic, or low in nutrients and primary production, which has limiting effects throughout the food chain (Sierszen and others, 2003). This is a result of the cold arctic environment and a corresponding short ice-free season for normal productive processes to occur. However, arctic lakes are productive in the ice-free summer season and daily primary production is comparable to other ecosystems that are reasonably productive (Hobbie, 1980). Thus, there is an adequate food supply for habitation during the short ice-free period. Sierszen and others (2003) reported benthos as the basis for the artic lake food web because the oligotrophic conditions reduce phytoplankton resources in the lakes so the planktivorous fish must find alternatives.

Generally, the Arctic coastal plain is assumed to have a low diversity of plants and animals (Truett and Johnson, 2000). However, freshwater systems can support a wide variety of flora and fauna, including bacteria, protests, algae, and micro-invertebrates (Huntington, 2001). The micro-organisms of tundra lakes are remarkably similar to temperate lakes with bacteria being almost as abundant but with lower activity levels due to the colder temperature (Hobbie and others, 1980).

Common primary producers of the arctic tundra, which occupy various regions around the lake, include members of the sedge family (Cyperaceae) such as cottongrasses (Eriophorum angustifolium)), or tundra grasses such as Carex aqualtilis (Pielou, 1994 and Hobbie, 1980). 
Microalgae within the sediments, mostly diatoms and blue-green algae, are also important primary producers although they may be found in limited numbers. Algae and plants found within the water column can be grazed upon by zooplankton such as Daphnia (D. longiremis) and crustaceans such as fairy shrimp (Anostraca) which can occupy the base of the food web in lakes and ephemeral tundra pools. These organisms may then be fed upon by various predaceous zooplankton, birds, and fish (if in a system containing them). The ninespine stickleback, found in $91 \%$ of tundra lakes (Moulton, 1998) is one species that will directly feed on these smaller organisms and will serve as a food source themselves in any lake with larger piscivorous fish (Alexander and others, 1980).

Primary production in tundra and arctic lakes is limited by phosphorous, not nitrogen (Prentki and others, 1980). As such, adding phosphorous to a north Alaskan stream showed a shift in the photosynthetic community after several years of experimental treatment, followed by an accompanying increase in insect and fish populations (Huntington, 2001). Hamilton and others (2001) also found the lakes of the Canadian Arctic Archipelago to be phosphorous limited. Phosphorous levels are controlled primarily by interaction with the surface sediments, and because tundra lakes are shallow, the ratio of sediment surface area to water volume is high and allows for frequent interaction at the interface (Hinzman and others, 1998). Chemical interactions between sediment and water are further enhanced in the summer when wind and wave action can suspend the bottom sediment into the water column. The slow, limiting release of dissolved reactive phosphorous is controlled by its chemical equilibrium with the complex and the free water. Hobbie (1980) does indicate that during the short summer months, the productivity of tundra lakes does increase, however on an annual basis the lakes do not have a high rate of productivity due to the oligotrophic conditions.

The light, flocculant sediment covering the bottom of the study lakes is $80 \%$ organic (Prentki et al., 1980) and is a dark brown, unconsolidated material. Due to the high concentration of organic substrate, these sediments contain most of the living organisms within the tundra lake system. Comparing the average living organism density in one cross-sectional square meter of benthic sediment to a similar square meter of liquid water within the tundra pond, Hobbie et al. (1980) estimated 150 times greater concentration of living organisms within the sediment. In shallow lakes that completely freeze every winter, the sediment remains cold throughout the year but thaws $20-30 \mathrm{~cm}$ by the end of summer. In these shallow lakes, the sediment refreezes from the bottom up in the winter season due to the presence of cold permafrost near the lake bottom.

Although the Alaska arctic coastal plain contains an abundance of freshwater lakes and streams, fish habitat is limited because most water bodies are too shallow to support fish overwintering where ice depth can reach $2.0 \mathrm{~m}$ (Zhang and Jeffries 2000). Therefore, winter is considered the limiting period for freshwater fish because of restricting habitat. Despite the extremely limited habitat, 21 fish species have been identified in freshwaters within the Alaskan arctic coastal plain. The five most abundant freshwater fish species are ninespine stickleback, arctic grayling, least cisco, broad whitefish and round whitefish (Truett and Johnson, 2000). Ninespine sticklebacks are easily the most widespread in the region being found in $91 \%$ of lakes with sufficient overwintering habitat (Moulton, 1998).

Dissolved oxygen is essential to the metabolism of aquatic biota (Wetzel, 2001). In summer the wind currents distribute the oxygen derived from the atmosphere throughout the water column and dissolved oxygen levels are at saturation or super-saturation (oxygen is more soluble in water than in the nitrogen of the air). However, under ice, winds are eliminated and decreased levels of dissolved oxygen are expected. The oxygen content under snow and ice cover is a 
function of the amount of initial storage and the rate of depletion. Any photosynthetic oxygenation is suppressed since algae are unable to receive light through the snow cover over the ice. Consumption of dissolved oxygen is mostly due to bacterial respiration and chemical oxidation at the sediment/water interface and any fish in the water column only contribute minimally to the depletion (Ellis and Stefan, 1989). Pretenki and others (1980) suggested the high rates of benthic respiration to be the primary mechanism for dissolved oxygen depletion in shallow ponds near Point Barrow, Alaska.

The chemistry of tundra lakes water is determined by numerous and variable inputs. Rooted plants provide most of the organic carbon input by respiration and detritus (Pretenki and others, 1980). Most of the carbon is present as dissolved organic carbon, which is composed of high molecular weight compounds such as humic acids and smaller low molecular weight compounds such as simple carbohydrates and amino acids. High molecular weight compounds are broken down by incoming ultraviolet light or hydrolysis while low molecular weight compounds are used by bacteria.

Summer precipitation is an important chemical input to the lakes as the soils are thawed and chemicals can be leached from the soils. Runoff from rainfall contributes 60 to $80 \%$ of the total ion input, whereas snowmelt contributes 20 to $40 \%$. Snowmelt runoff is concentrated in the near surface organic mat, while runoff from summer rainfall events percolates through the thawed portion of the active layer, allowing greater interaction with soil chemistry. Pretenki and others (1980), studying tundra ponds near Point Barrow, found chloride to be the major anion and sodium to be the major cation.

Concentration of salts in the lakes is controlled by abiotic factors, namely the exclusion of solutes from growing lake ice into the water. The exclusion is a result of ice's crystalline structure, which rejects impurities, such as salts, during growth (Adams, 1981). Belzile and others (2002) found that small, less conjugated molecules are retained in the ice, whereas the larger, more conjugated molecules are preferentially excluded. During the winter, ions may be concentrated 30 -fold during freeze-up in the water column. In the spring, lake water following snowmelt may resemble distilled water (Pretenki and others, 1980). Dissolved organic matter is also excluded from the ice similar to the ions. Aside from concentrating ions and other dissolved matter, the ice exclusion processes also promotes under ice convection and affects the distribution of material and biota in the ecosystem by giving more availability for organic carbon substrates and nutrients for biota (Belzile and others, 2002). Another result of the ice exclusion process is the effect of salt concentration depressing the freezing point of the remaining free water.

The seasonal concentration trends of non-nutrient major cations $(\mathrm{Na}, \mathrm{Mg}, \mathrm{Ca})$ are similar year to year (Pretenki and others, 1980). Conductivity is a function of ion concentrations and the correlation is strong. Rodhe (1949) found that by knowing the initial concentrations of the major ions, the change in specific conductance could be used to estimate the proportional concentrations of the major cations with relatively small error.

Minor ions such as potassium and iron have concentrations that do not influence conductivity. Potassium reaches maximum concentrations after melt in response to leaching from plants and other organic materials during runoff. Iron reaches its maximum concentration later in July in response to precipitation input leaching iron from the surrounding soils or bottom sediments. Dissolved organic carbon is the largest pool of organic carbon and represents an important constituent of the biogeochemical carbon cycle (Belzile and others, 2002). Boyd (1959) 
regularly measured under-ice ion concentrations at Imikpuk Lake, near Point Barrow, and found good consistency in exclusion trends as seen in Figure 7.

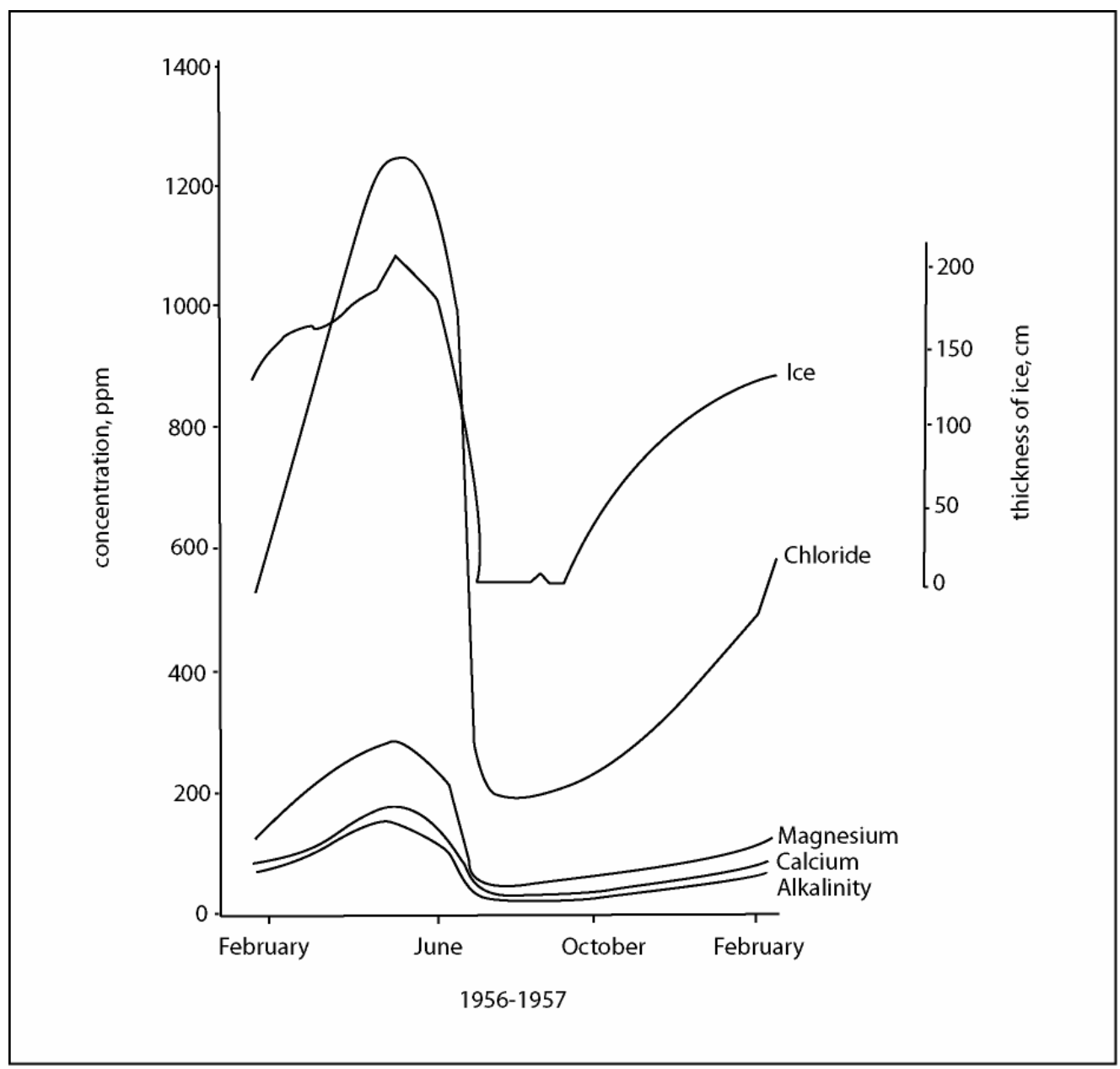

Figure 6. Seasonal change in the chemical composition of Imikpuk Lake, located near Point Barrow. Chlorine is measured as total chlorides in $\mathrm{NaCl}$ and calcium. Magnesium and alkalinity are measured as hardness as $\mathrm{CaCO} 3$. No iron was detected in the samples (reproduced from Boyd 1959).

As a summary, Hobbie (1980) lists eleven primary characteristics of arctic lakes and ponds:

(1) Most do not warm above $10^{\circ} \mathrm{C}$ and do not stratify. (authors' note, many lakes warm much beyond $10^{\circ} \mathrm{C}$ in recent years)

(2) Those shallower than $1.7-2.0 \mathrm{~m}(5.6-6.6 \mathrm{ft})$ freeze completely and therefore do not contain fish.

(3) The ice cover is usually $1.0-2.0 \mathrm{~m}(3.3-6.6 \mathrm{ft})$ and lasts 8 - 9 months.

(4) Lakes contain low amounts of available nutrients and low total dissolved salts, however the total inorganic ion concentration is different for drainage basins in different types of bedrock.

(5) Biota are subject to strong physiological stresses.

(6) They are oligotrophic.

(7) Fish are very slow-growing, but large fish may live for 40 years.

(8) With few exceptions, zooplankton has a dormant phase in its life cycle. 
(9) There are no benthic animals that graze on aquatic plants or animals that shred large organic particles or leaves. (authors' note, Large populations of migratory waterfowl such as geese and ducks do graze and shred water plants in these lakes.)

(10) The number of animal species is small.

(11) Decomposition rates are slow and large amounts of energy and nutrients are tied up in dead organic matter.

\section{LOCAL METEOROLOGY REVIEW}

Meteorological data were collected at Betty Pingo and 2M Repeater meteorological sites to help interpret relationships between environmental factors and the measurements reported at the lakes. Environmental influences on the data are important to characterize since the expected responses at the lakes are slight.

The 2M Repeater site was not fully functional and reporting until mid-winter 2004 and so the review makes use of the data at Betty Pingo site (Kane and Hinzman, 2004), which has been in consistent operation since 1994. Betty Pingo is located east of the lakes and is approximately $20 \mathrm{~km}$ from lake $\mathrm{K} 113 \mathrm{C}$ and $50 \mathrm{~km}$ from lake K209P. Despite the lack of close proximity, it is expected the meteorological data collected from Betty Pingo applies throughout the study area as there are no distinct topographic divides in the area and any weather system moving through likely affects the study area fairly uniformly over time.

The Betty meteorological station is situated at $148^{\circ} 53^{\prime} 44.5^{\prime \prime}$ west longitude and $70^{\circ} 16^{\prime}$ 46.9" north latitude. The dominant landforms in the wet low-lying areas are low centered polygons, strangmoor ridges, and small thaw ponds less than $1 \mathrm{~m}$ in depth. The slightly higher areas are better-drained upland tundra dominated by high-centered polygons and ice wedges. The vegetation is dominated by sedges, mainly Carex and Eriophorum species with an average height of $10-15 \mathrm{~cm}$. In the drier upland areas the sedges are intermixed with lichen, mosses, dwarf Salix and Betula species, and a variety of flowering herbaceous species (Walker and others 1980; Robinson 1995; Rovansek 1994).

The surface in this area is for the most part quite level or gently sloping, with most slopes from 0 to $5 \%$. This factor reduces runoff during most of the summer. During spring snowmelt, when soils are frozen and can only accept minimal snowmelt infiltration, melt water inundates large areas. Most of the snow melts by early June, but snowmelt can be initiated in early May. Roughly half of the snowpack exits the watersheds as runoff (Robinson 1995). The remainder either sublimates or goes into surface storage in ponds or subsurface storage to make up for water deficits from previous summer ET. The peak runoff time is during snowmelt in the beginning of the summer; afterwards the flow gradually decreases and completely ceases generally by mid-June.

Snow is an important source of water in this area. Approximately $50 \%$ of the annual precipitation in the basin falls as snow (Robinson 1995). In the summer, precipitation usually consists of rain, misty drizzle, and condensation. Most of the heavy rains come during the later part of the summer when sea ice cover is at a minimum. Measurements of snow and liquid precipitation (especially the light drizzle which is so common during the summer) at the site are usually 
affected by the nearly continuous winds in the area. Summer wind speeds can sometimes reach up to $16 \mathrm{~m} / \mathrm{s}$ with the predominant wind direction being from the east-northeast.

The average annual temperature at Prudhoe Bay is $-11.4{ }^{\circ} \mathrm{C}$ (NOAA 1986-1996). Usually temperatures remain below freezing from mid September to mid May. June is the first month with above freezing average temperatures. Average monthly temperatures can be approximately 3 to $9{ }^{\circ} \mathrm{C}$ above freezing from June until August, and during September they drop near freezing.

The summer usually ranges from June to early September. In the beginning of the summer and until solstice the days become progressively longer and the sun climbs higher in the arctic sky allowing more radiation to reach the surface. Part of the net radiation initiates melt of the thin layer of soil called the active layer which ranges in thickness between 30 and $100 \mathrm{~cm}$ depending on aspect, wetness, and soils (Walker and others 1980). Typical thaw depths in the study area are approximately $40 \mathrm{~cm}$. The maximum depth of soil thawed above the permafrost averaged $55 \mathrm{~cm}$ between 1993 and 1999 (Brown and Hinkel, 2000). Underneath ponds the thaw depth can reach up to $80 \mathrm{~cm}$ or more. Beneath this thin active layer lays a thick layer of permafrost that formed over thousands of years of long, cold winters. Osterkamp and others (1985) found the permafrost to be $680 \mathrm{~m}$ in thickness in Prudhoe Bay.

The soils of the site are mostly organic peat. A typical profile consists of approximately $10 \mathrm{~cm}$ fibrous peat intermixed with roots, underlain by a more decomposed peat layer which can be intermixed with silt, sand, and sometimes gravel (Rovansek and others 1996). The soils fall under the classification of Pergelic Cryosaprists and Pergelic Cryohemists (Ping and others 1994). Hydraulic conductivity of the soils is on the order of $10^{-4} \mathrm{~cm} / \mathrm{sec}$, and the specific yield is approximately 0.1 (Rovansek 1994).

The 2002-2003 winter was warmer than the 2003-2004 winter. The surface freezing index for 2002-2003 was $3815.3^{\circ} \mathrm{C}$ * $\mathrm{d}$ while the freezing index for $2003-2004$ was $4491.1^{\circ} \mathrm{C}$ * $\mathrm{d}$.

Similarly, the 2004-2005 winter was about the same as the $2003-2004$ winter with $4433^{\circ} \mathrm{C}{ }^{*} \mathrm{~d}$. The surface freezing index is defined as the annual summation of degree-days colder than $0{ }^{\circ} \mathrm{C}$. Overall, all three winters were noticeably warmer than the historical daily maximum temperature averages (Figure 7) collected at the Kuparuk airport's meteorological site. However, 10-day running average temperatures for the 2002-2003 through 2004-2005 winters are about $5{ }^{\circ} \mathrm{C}$ colder than the 11-day running average for 1994 to 1998 Olsson and others reported. Consequently, the 'deep cold' season of the three winters lasted longer, nearly into April, compared to the Olsson and others data.

Coldest temperatures occurred from January to April each winter. Cold temperature arrived later during the 2003-2004 winter compared to the 2002-2003 winter although the 2003-3004 cold period exhibited more persistence (Figure 8, Figure 9, and Figure 10). However, the lower limit of the air temperature sensor is $-40^{\circ} \mathrm{C}$ so temperatures may have been colder than the recorded $-40^{\circ} \mathrm{C}$. As a result, the calculated freezing indexes are slightly under-estimated. 


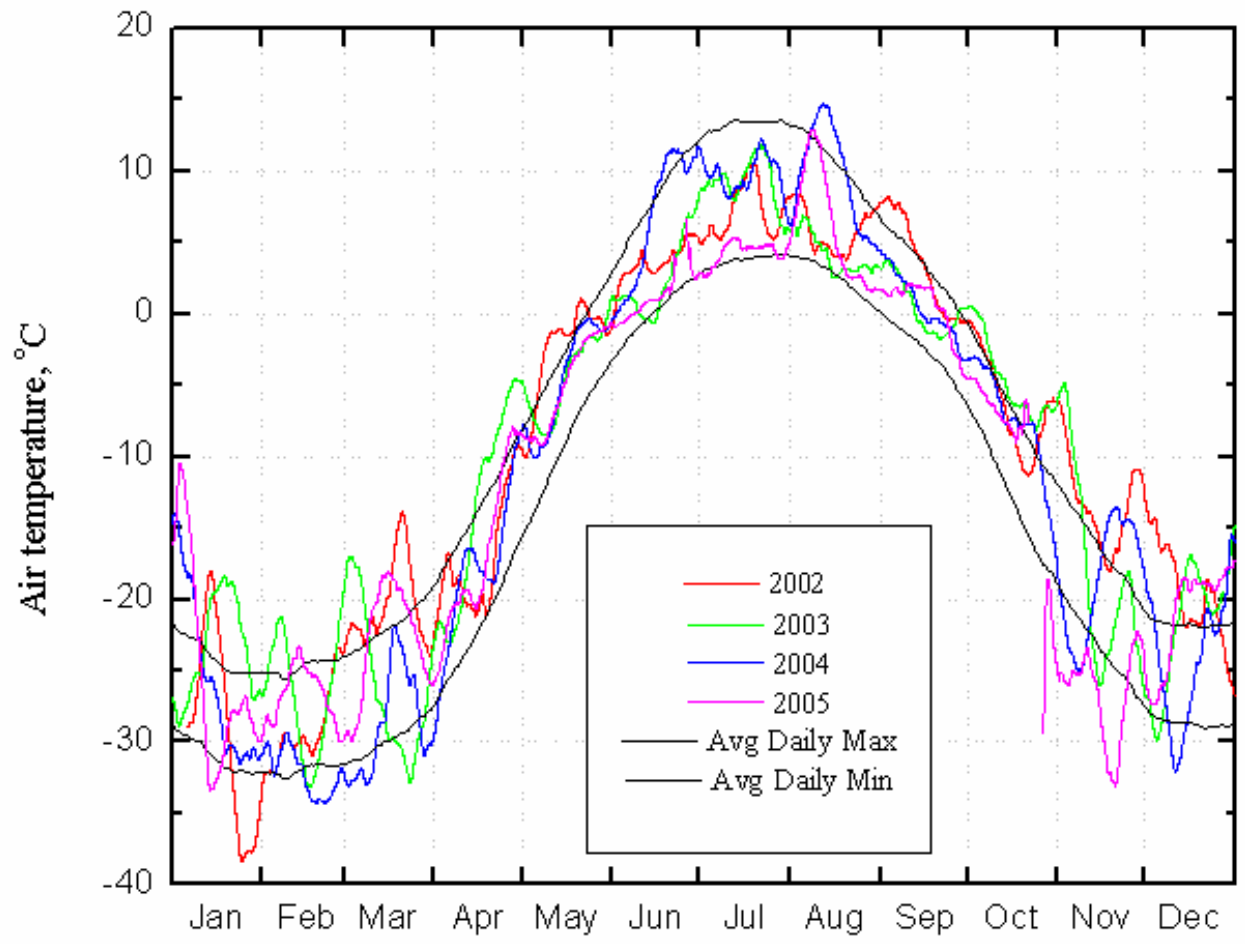

Figure 7. Historical (1983 - 2003) average maximum and minimum daily air temperatures from Kuparuk Airport Meteorological Tower (data taken from Western Regional Climate Center) compared to 10-day running averages for 2002 to 2005 at Betty Pingo. 


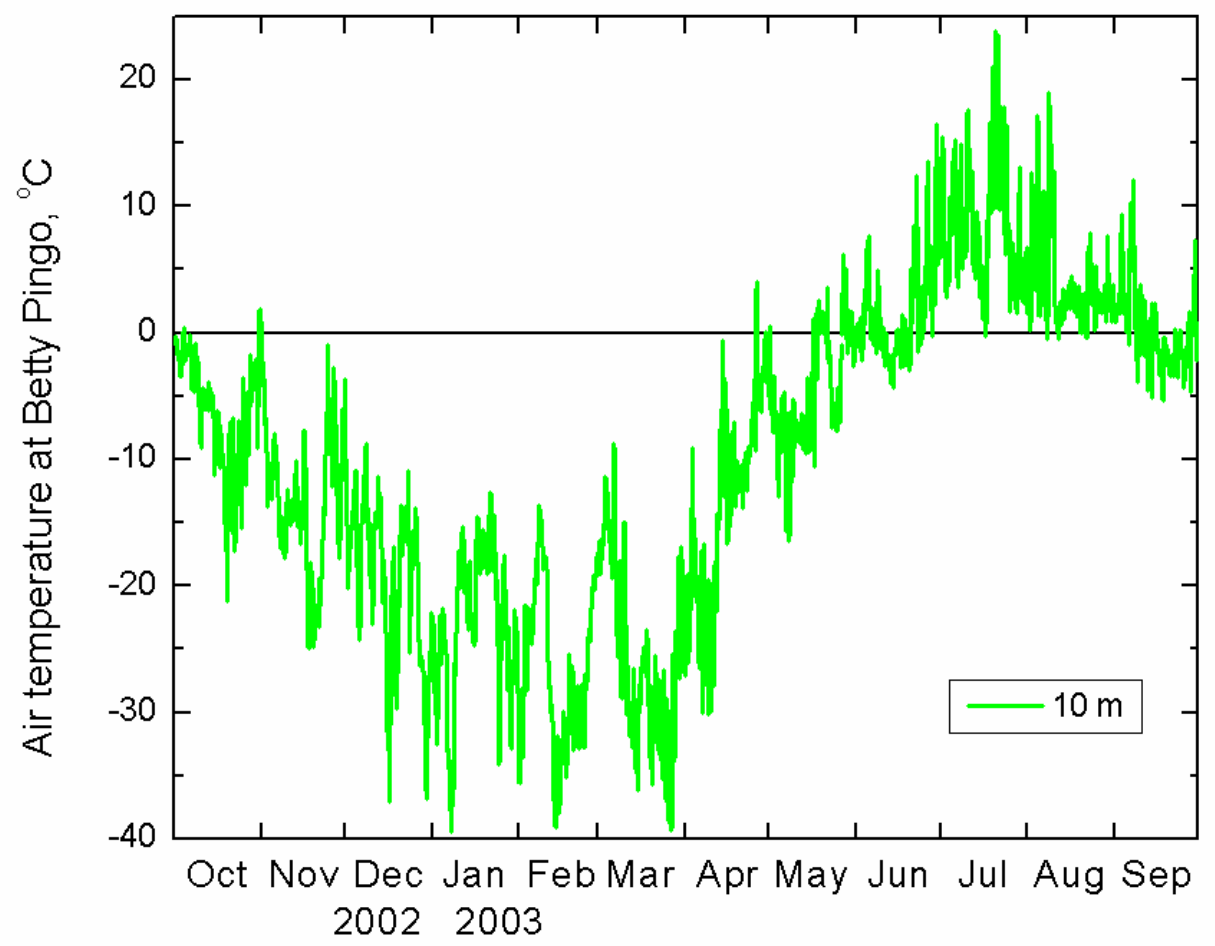

Figure 8. Winter $2002-2003$ air temperatures at 10m at Betty Pingo Tower. 


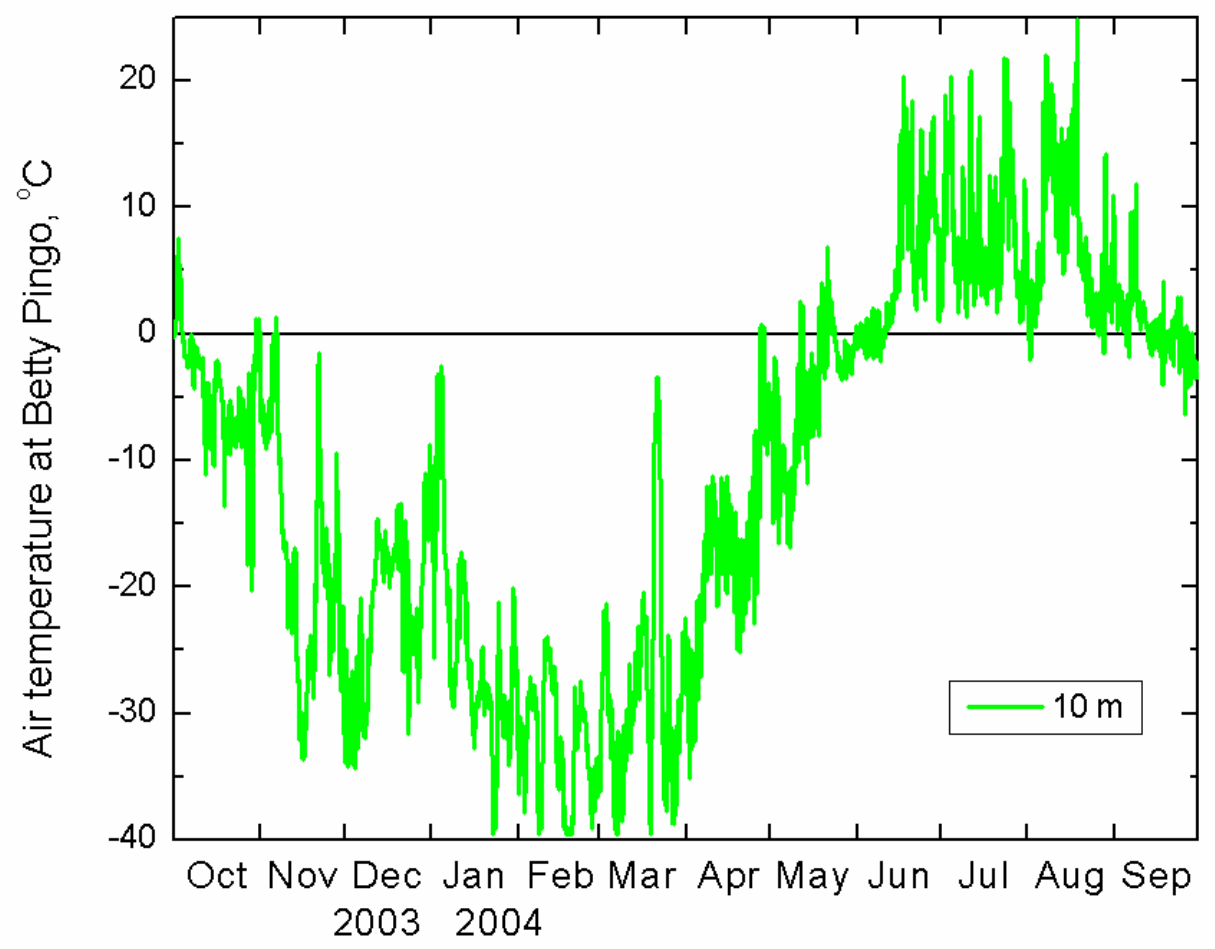

Figure 9. Winter 2003-2004 air temperatures at 10m at Betty Pingo Tower. 


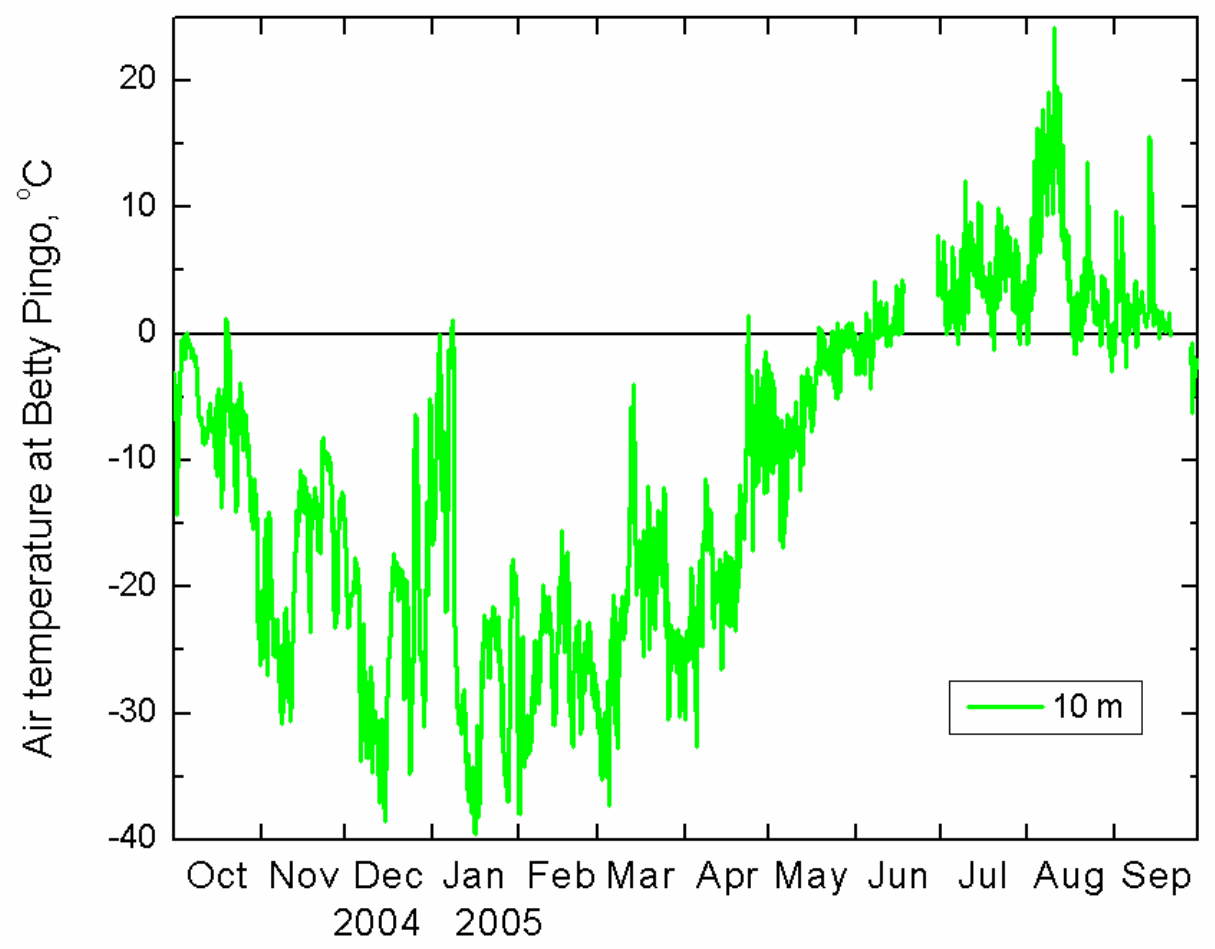

Figure 10. Winter 2004-2005 air temperatures at 10m at Betty Pingo Tower.

Initially, ice formation is rapid but gradually slow with the increased thermal insulation provided by the thickened ice and especially any snow atop the ice. Measurements of ice thickness are presented in Figure 11, Figure 12, and Figure 13 along with a predicted ice thickness estimate for the 2002-2003, 2003-2004, and 2004-2005 winters. The predicted ice thickness was modeled using the Stefan equation (Michel, 1971), which uses variables of surface cover and the calculated surface-freezing index. Four surface cover conditions are modeled with related empirically derived coefficients: no snow cover, light snow cover, moderate snow cover and heavy snow cover (see Table 8 for coefficients). The light snow cover coefficient most closely resembles the empirical data during the early part of the winter while moderate matches better in late winter. The Stefan equation somewhat overestimates the amount of ice generated by assuming the water is relatively pure and does not account for the lower freezing point of the brackish water that exists at winter's end in the shallower lakes due to the ice exclusion process, although the freezing point depression at these concentrations is not great.

Table 8. Stefan coefficients for lake ice conditions.

\begin{tabular}{|c|c|}
\hline Ice condition & Stefan coefficient \\
\hline \hline No snow & 0.80 \\
\hline Little snow & 0.70 \\
\hline Moderate snow & 0.50 \\
\hline Heavy snow & 0.40 \\
\hline
\end{tabular}




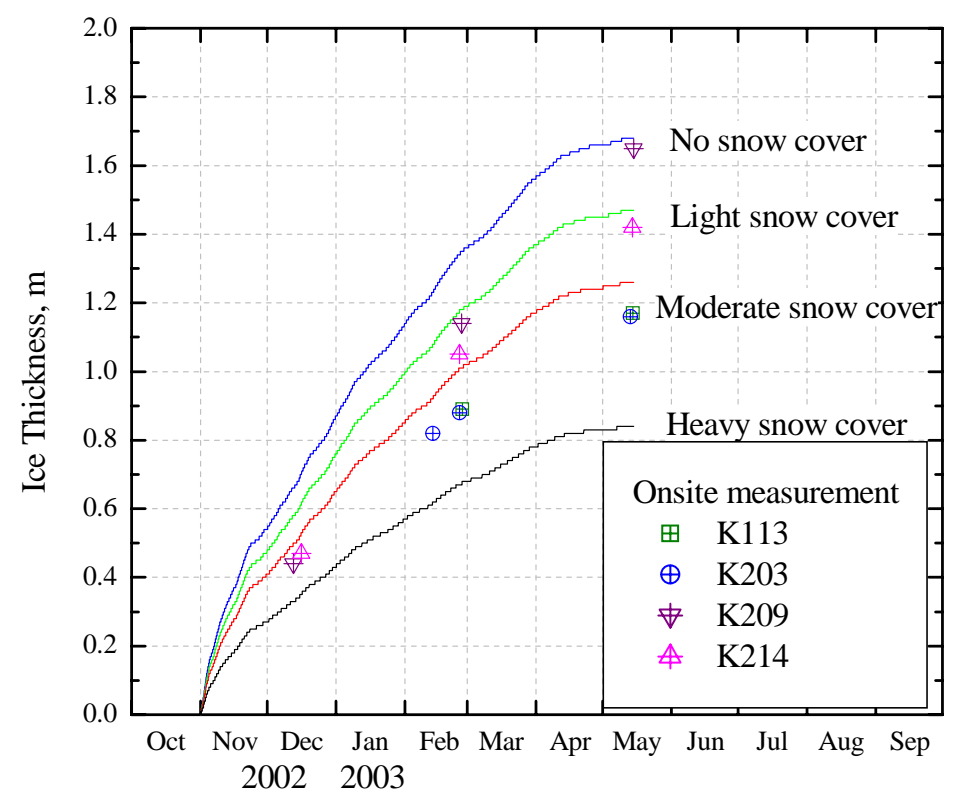

Figure 11. Stefan equation estimate of ice thickness during the 2002-2003 winter plotted with onsite ice thickness measurements at the Kuparuk study lakes. 


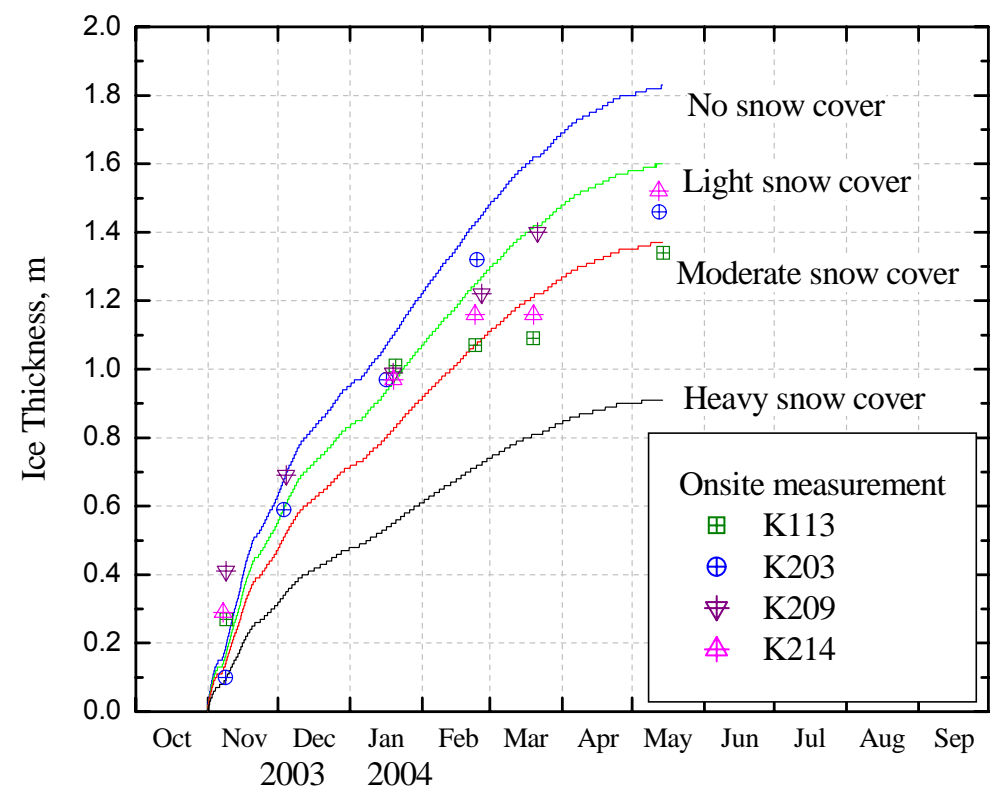

Figure 12. Stefan estimate of ice thickness during the 2003-2004 winter plotted with onsite ice thickness measurements at the study lakes.

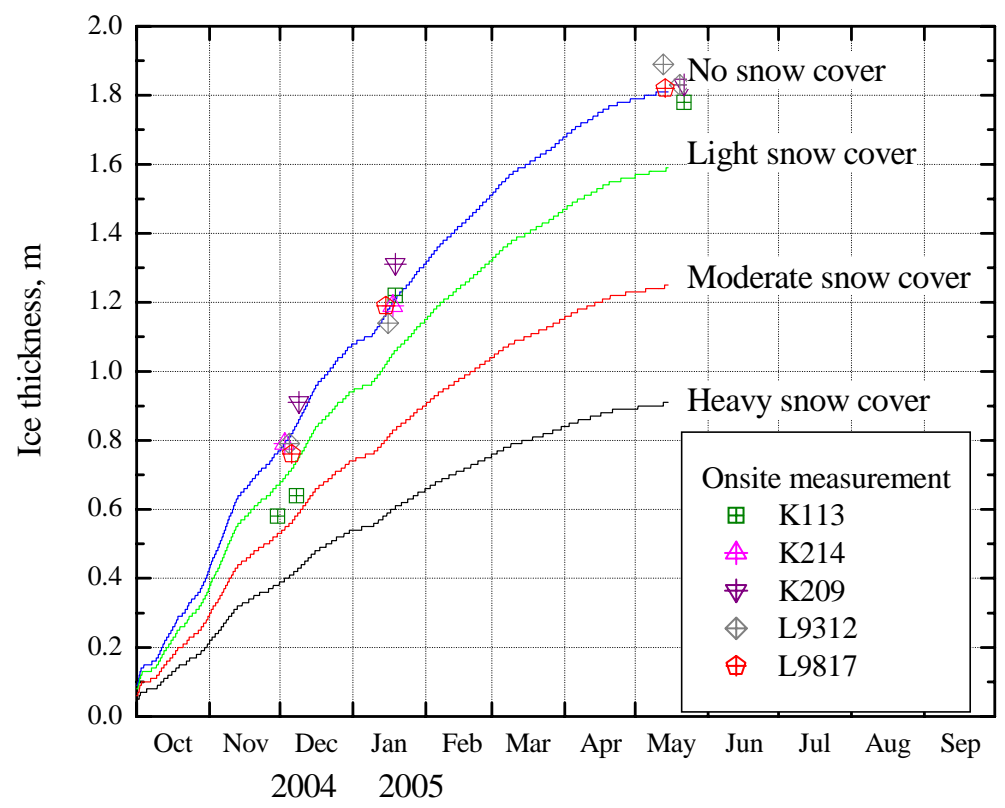

Figure 13. Stefan Estimate of ice thickness during the 2004-2005 winter plotted with onsite ice thickness measurements at the study lakes. 
Relative humidity during the 2002-2003, 2003-2004 and 2004-2005 winters is high as expected in a cold polar environment and often near $100 \%$ saturation (Figure 14, Figure 15, and Figure 16). This is a result of the close proximity of air temperature and dew point in the Arctic. In other words, low air temperature causes a similarly low dew point, and at a low dew point, the atmosphere is able to hold little moisture. Thus, despite the high relative humidity, the atmosphere throughout the arctic coastal plain holds little water vapor.

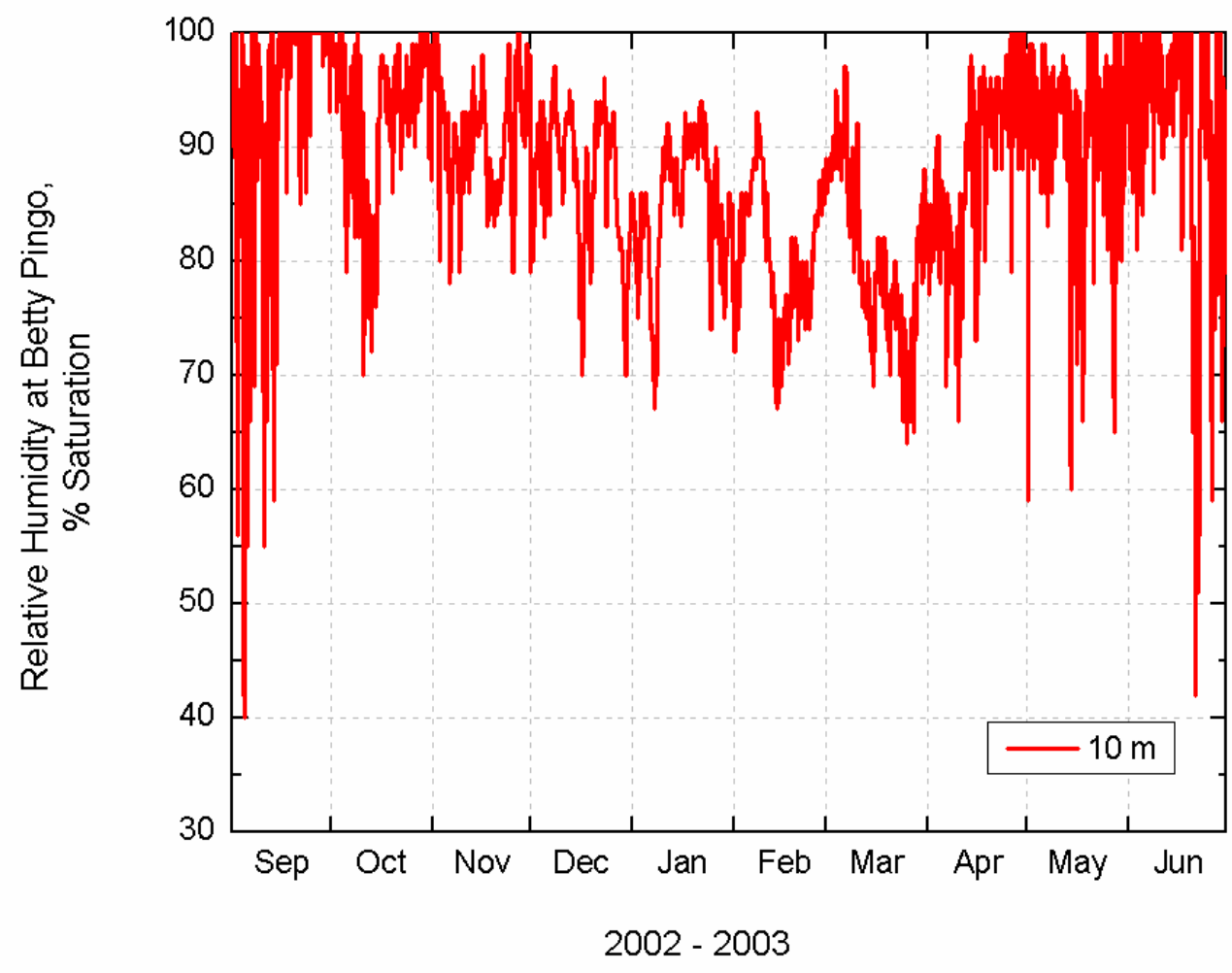

Figure 14. Winter $2002-2003$ relative humidity at $10 \mathrm{~m}$ at Betty Pingo Tower. Relative humidity readings have a $100 \%$ saturation upper threshold. 


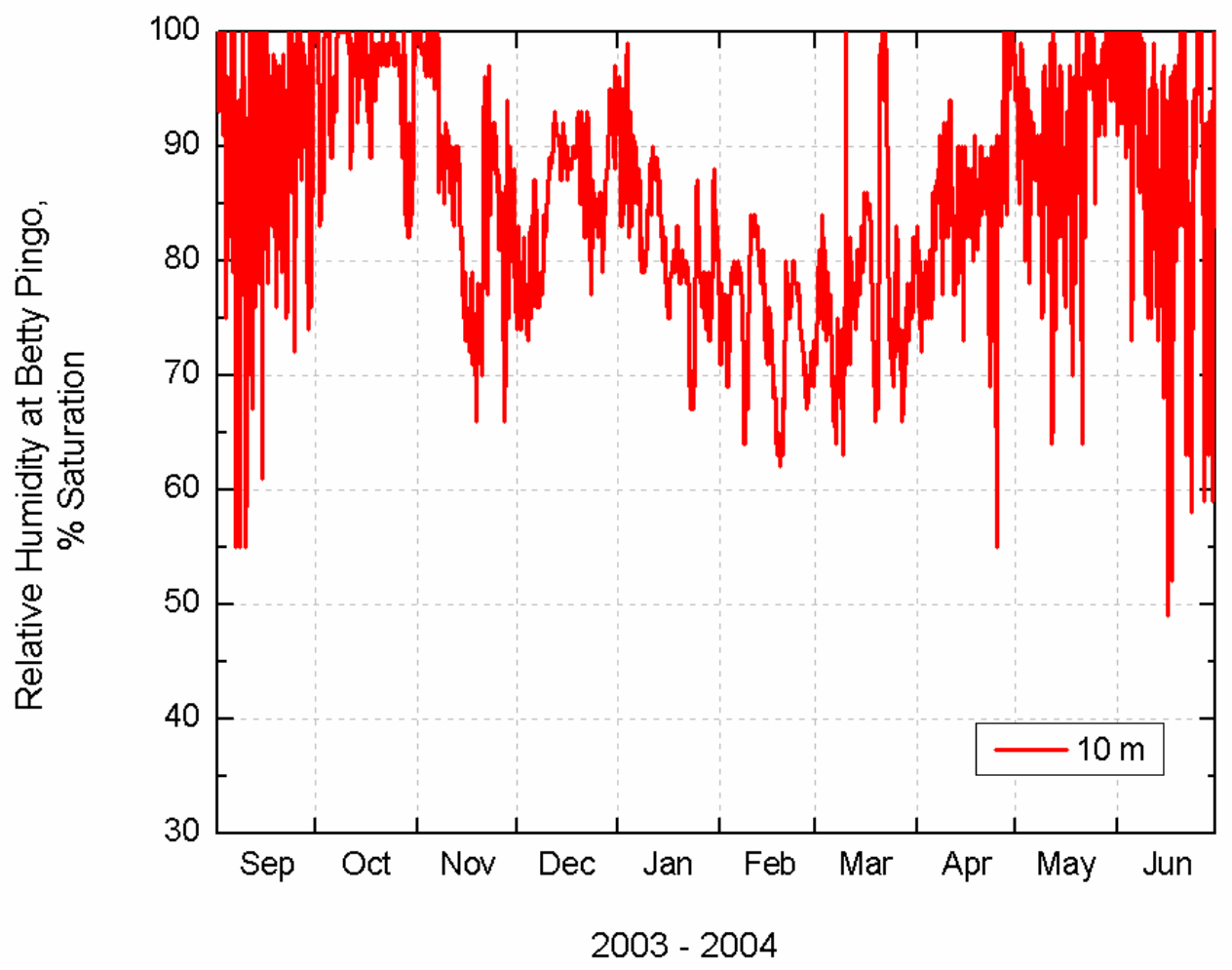

Figure 15. Winter 2003 - 2004 relative humidity at $10 \mathrm{~m}$ at Betty Pingo Tower. Relative humidity readings have a $100 \%$ saturation upper threshold. 


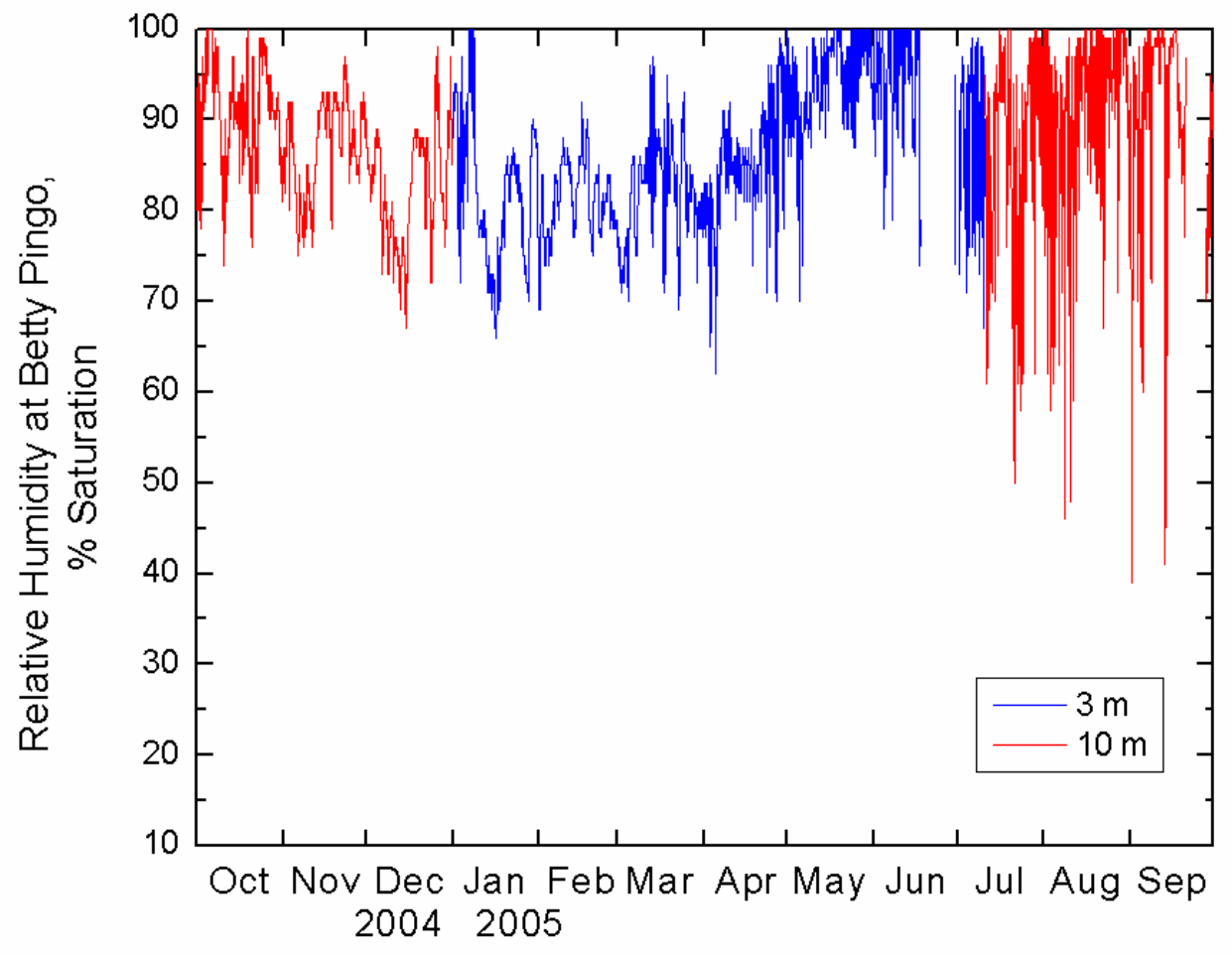

Figure 16. Winter 2004-2005 Relative Humidity at $3 \mathrm{~m}$ and $10 \mathrm{~m}$. Relative humidity readings have a $100 \%$ saturation upper threshold.

Winds in the area were consistent and strong (Figure 17, Figure 18, and Figure 19). Peak gusts above $15 \mathrm{~m} / \mathrm{s}$ were recorded both winters. Periods of inactivity such as January 2003 or February 2004 may be attributed to the challenge of gauging wind in the extreme arctic environment. It is likely the anemometer used to measure wind speed accumulated sufficient rime to prevent an accurate measurement at lower wind speeds $(<4 \mathrm{~m} / \mathrm{s})$ in these two instances. An eventual high wind event $(>8 \mathrm{~m} / \mathrm{s})$ freed the sensor. The anemometer has a lower threshold value of $0.4 \mathrm{~m} / \mathrm{s}$. 


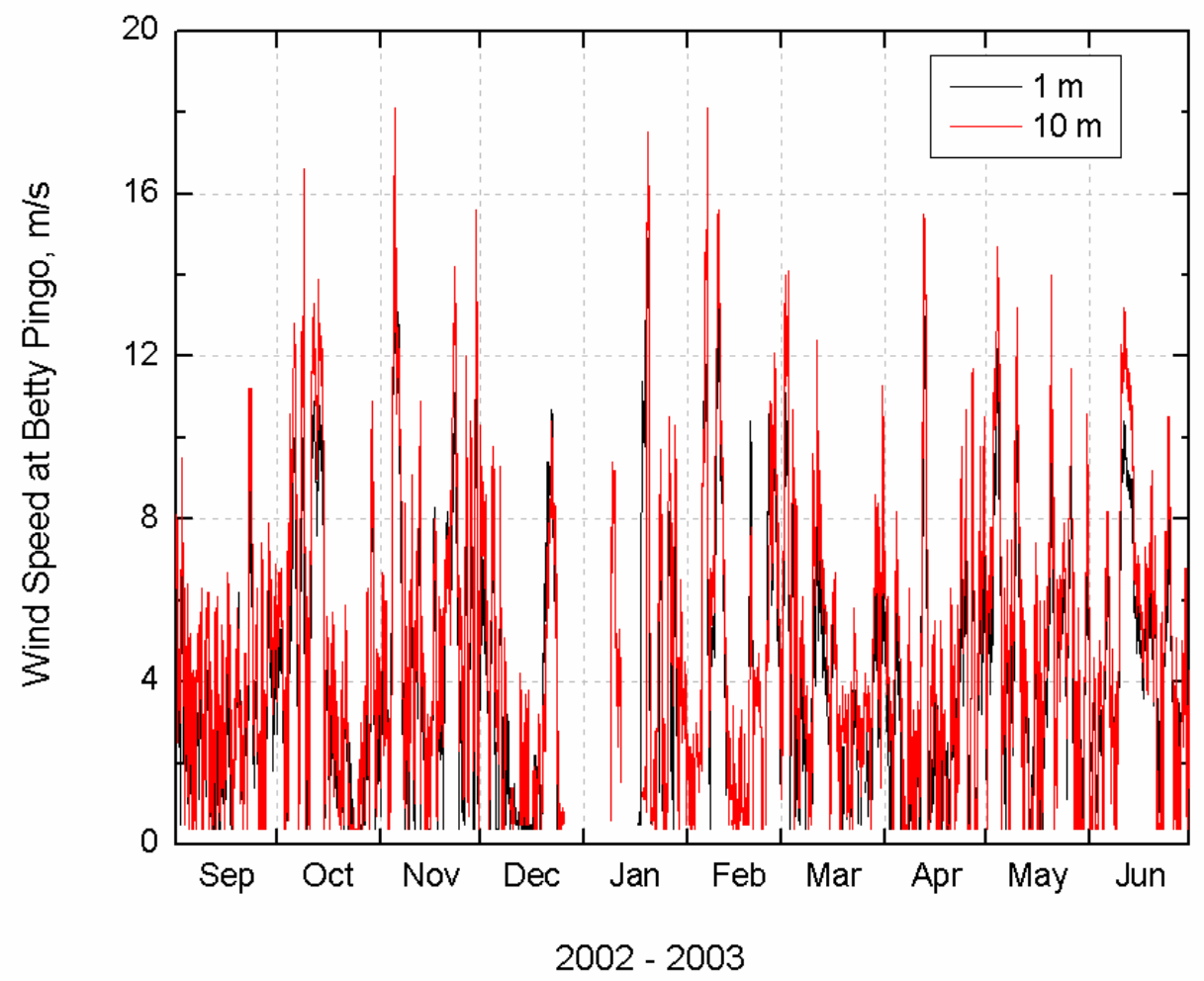

Figure 17. Winter 2002-2003 wind speed at $1 \mathrm{~m}$ and $10 \mathrm{~m}$ at Betty Pingo Tower. 


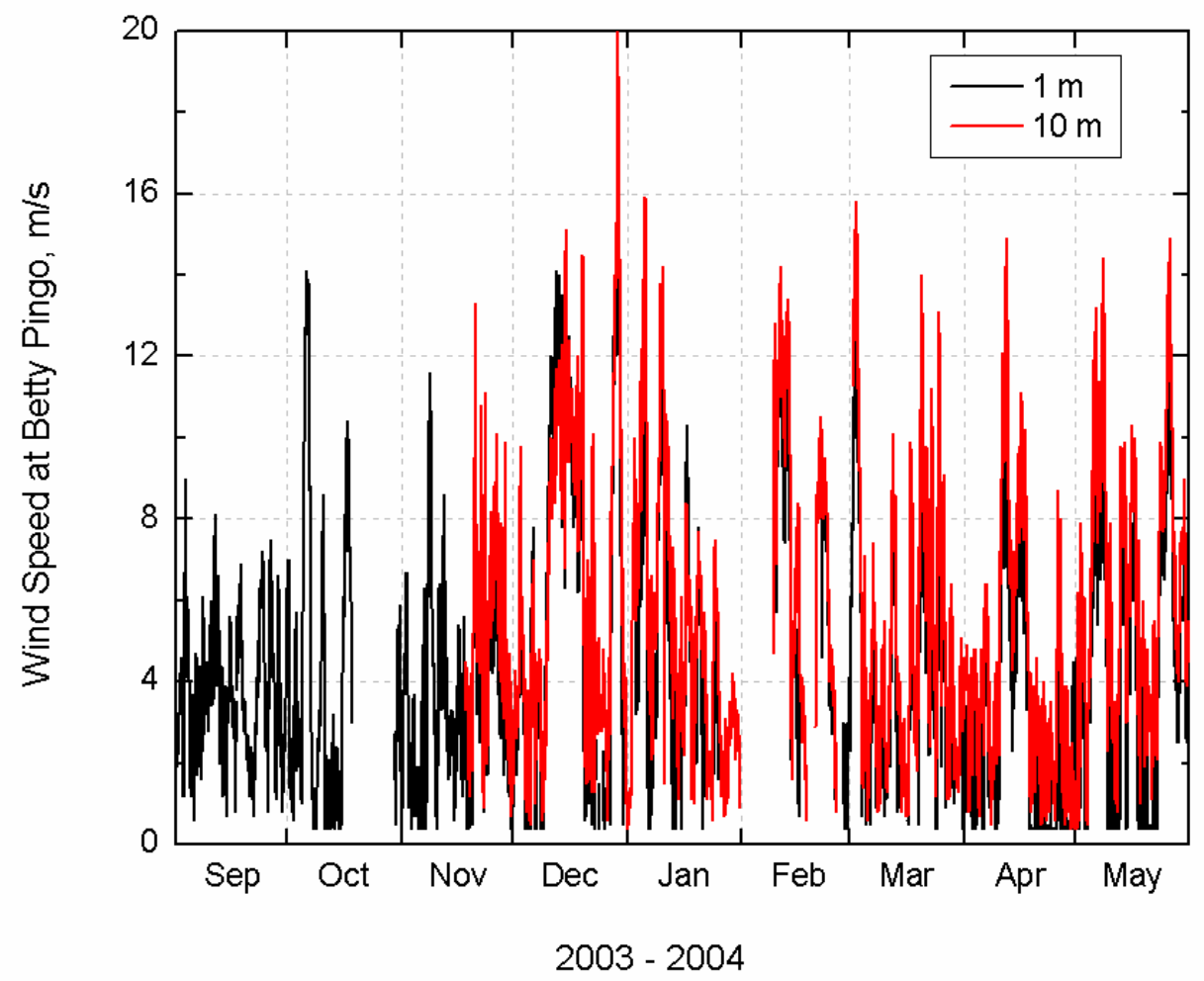

Figure 18. Winter 2003-2004 wind speed at $1 \mathrm{~m}$ and $10 \mathrm{~m}$ at Betty Pingo Tower. Relative humidity readings have a $100 \%$ saturation upper threshold. Extended periods of zero wind are probably caused by rime ice on anemometer. 


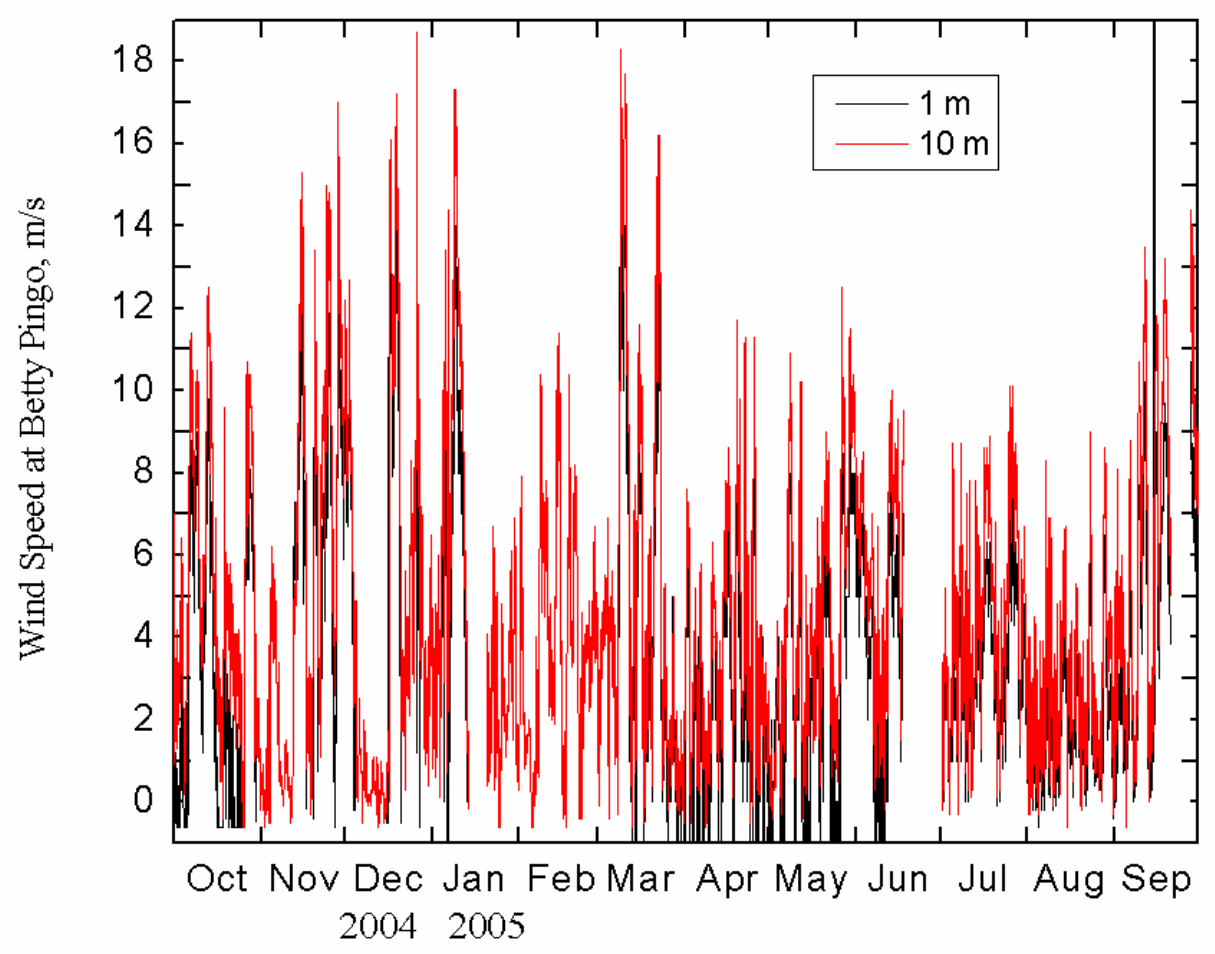

Figure 19. Winter 2004-2005 wind speed at $1 \mathrm{~m}$ and $10 \mathrm{~m}$ at Betty Pingo Tower. Relative humidity readings have a $100 \%$ saturation upper threshold. Extended periods of zero wind are probably caused by rime ice on anemometer.

Precipitation was recorded during winter to better understand the relationship of snowpack to the water surface levels being observed in the lakes. Precipitation was measured daily using an online pressure transducer installed in a Wyoming Snow Gauge adjacent to the Betty Pingo site (data courtesy NRCS). Wyoming snow gauges generally under report winter precipitation as snow. Figure 20 shows the record for the 2003-2004 winter assuming a zero beginning value November 1, 2003 and eliminating any recorded evaporation from the gauge. Figure 21 displays the same information for the 2004-2005 winter. Precipitation through the winter months is light and most precipitation throughout the year usually occurs during the relatively wet months of July and August. The proportion of precipitation as snow to precipitation as rain is distributed about 40 and $60 \%$ respectively. 


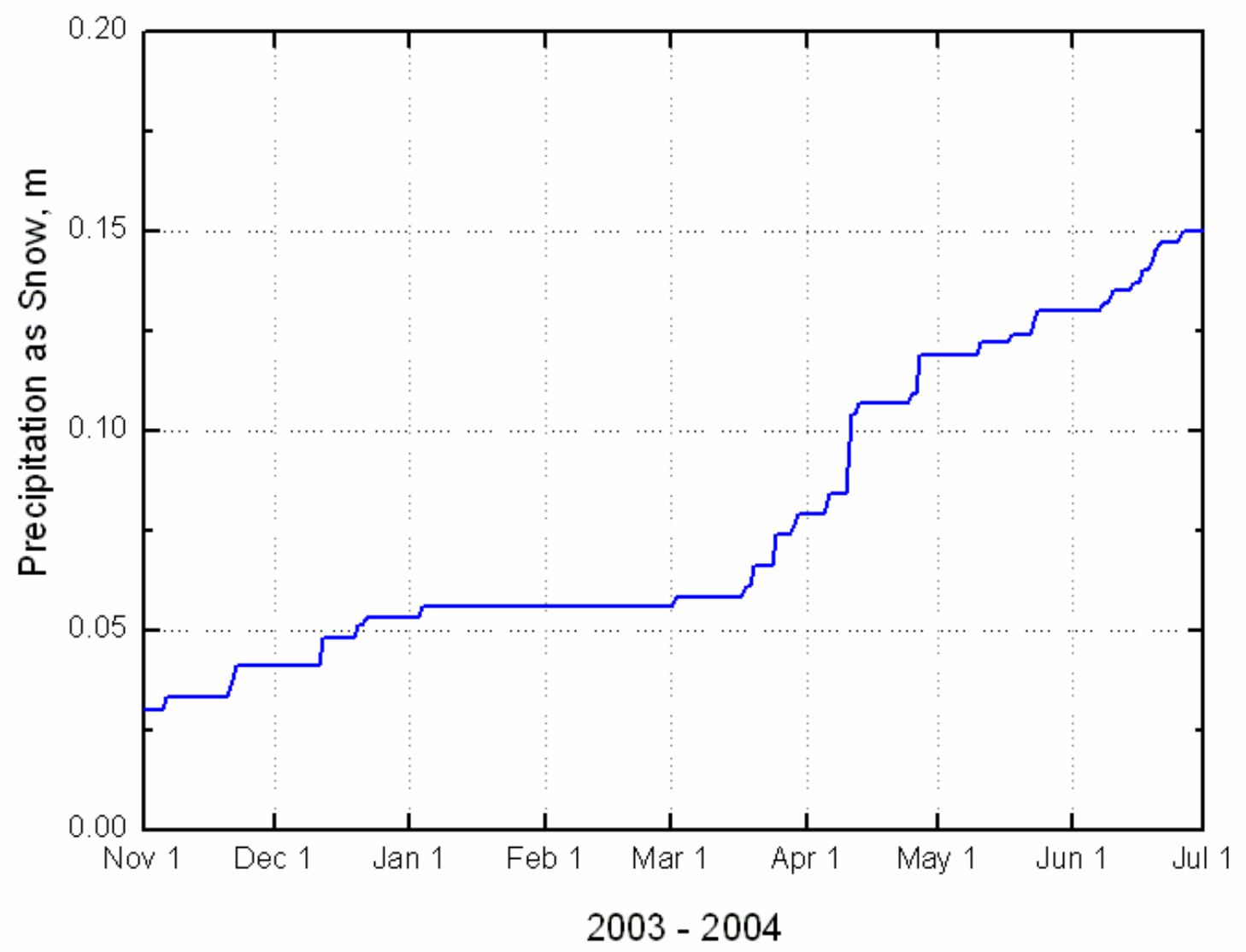

Figure 20. Measured daily water equivalent of snow during 2003-2004 winter (data courtesy NRCS) at Betty Pingo, North Slope, AK. 


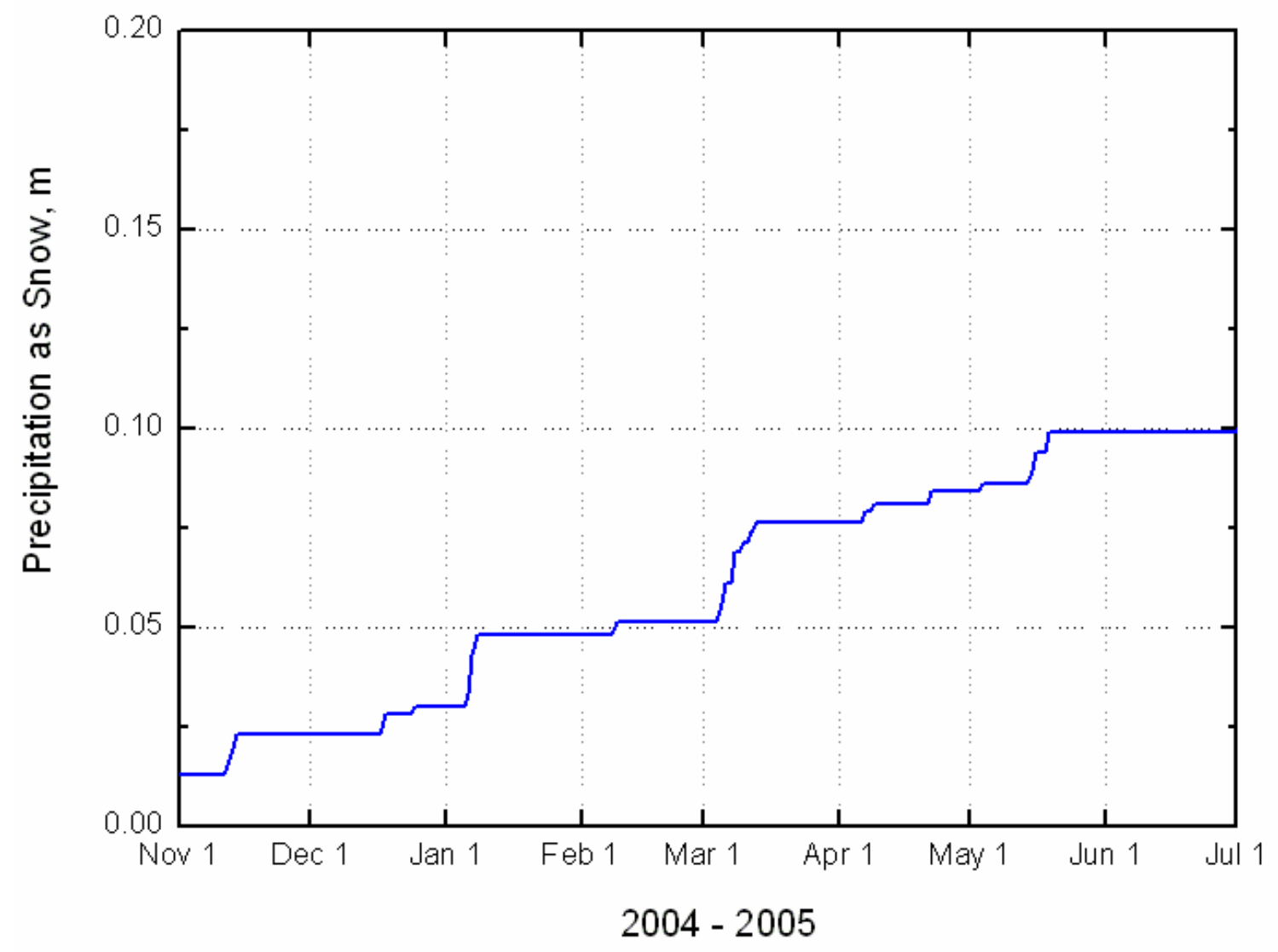

Figure 21. Measured daily water equivalent of snow during 2004-2005 winter (data courtesy NRCS) at Betty Pingo, North Slope, AK.

\section{DATA COLLECTION METHODS AND EQUIPMENT}

Water sampling occurred on-site using hand held water quality meters and off-site using portable devices and full-scale laboratory setups (Figure 22). All sampling devices and meters were calibrated before sampling efforts with NIST-traceable standards to ensure accurate measurements. Five sampling trips were accomplished during the first season of study (December 2002 - August 2003). Six sampling trips were accomplished in the second season of study (September 2003 - June 2004). Seven sampling trips were accomplished in the third season of study (September 2004 - June 2005). 


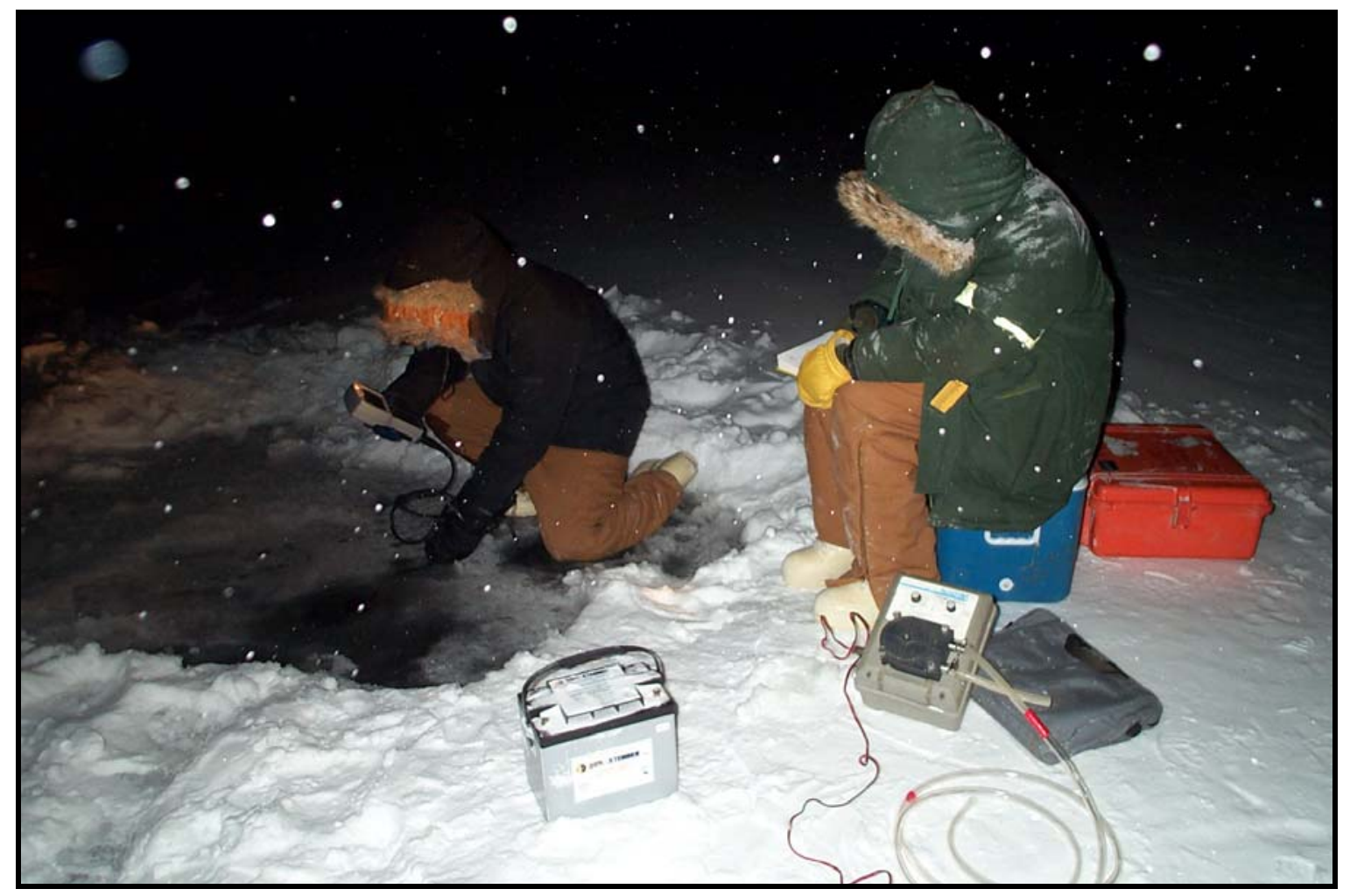

Figure 22. Both in-situ measurements of water characteristics (DO, conductivity, temperature, and $\mathrm{pH}$ ) and water samples were collected at the lakes at several times throughout the winter.

\subsection{Meter Measurements}

In-situ measurements of water temperature, $\mathrm{pH}$, dissolved oxygen, and specific conductivity were recorded using a variety of hand-held meters including Yellow Springs Instruments (YSI), Hydrolab, Hanna, Hach, and Lakewood meters. Table A-1 in the Appendix lists the sampling meters used for particular onsite sampling efforts along with lakes sampled and the sampling meters' calibration date.

In situ measurements were collected at a sampling hole augered through the ice in a location near the rafts. Typically only one hole was established for each sampling event. That site was marked and we attempted to return to the same location for each event during each winter. Insitu sampling meters recorded water quality variables (temperature, $\mathrm{pH}$, specific conductance, dissolved oxygen) at one-half the free water column depth. In other words, at a depth equivalent to half the distance between the lake bottom sediment interface and the bottom of ice (winter sampling) or the top of surface water (summer sampling). Readings on the meters were allowed to stabilize to attempt to minimize the aeration or sediment disruption caused by the necessity of augering a hole into the ice. Ice thickness was also measured onsite using a metered rod. 


\subsection{Benchtop Measurements}

Benchtop variables were those that required simple, non-laboratory analyses that could not practically be performed onsite due to harsh environmental conditions. Typically, the analyses were preformed at camp later in the day where instruments and reagents could remain warm and conditions were more conducive to careful measurement. Benchtop variables included alkalinity, turbidity, nitrate and nitrite.

Lake water for these measurements was taken using a peristaltic pump powered by a 12-volt non-spillable battery. The location of collection sample was at the standard one-half the free water column depth. As the samples were collected at only one depth during most sampling events, it was observed that the midpoint of the water column was most representative of the entire column characteristics. The depth of sampling was recorded along with other sampling notes. Lake water was allowed to run through the tubing for a sufficient period before collection to ensure an uncontaminated sample. About $300-450 \mathrm{~mL}$ of raw lake water was collected in $2-3$ $150-\mathrm{mL}$ plastic Nalgene bottles. The raw water was kept at $2-8{ }^{\circ} \mathrm{C}$ until analyses were possible. Benchtop analyses were typically preformed within a few hours after water collection to meet specific analyses holding times. Aliquots were taken from the raw water collection bottle for all analyses. All equipment was thoroughly rinsed by the lake's raw water before benchtop analyses and was cleansed in deionized water after analyses.

Alkalinity was measured by Hach portable titration method \#8203 with 0.16 or $1.6 \mathrm{~N}$ sulfuric acid as a titrant depending on the expected alkalinity. Turbidity was measured using a MicroTPI portable turbidimeter as well as a Hach 2100P portable turbidimeter. Turbidity analytical range was $0.002-1000$ Nephelometric Turbidity Units (NTU).

\subsection{Laboratory Measurements}

Variables analyzed in the University of Alaska Fairbanks (UAF) Water and Environmental Research Center (WERC) laboratory included: metals (sodium [Na], calcium [Ca], Magnesium $[\mathrm{Mg}]$, Iron [Fe] and potassium $[\mathrm{K}]$ ), nutrients (nitrate $\left[\mathrm{NO}_{3}\right]$, nitrite $\left[\mathrm{NO}_{2}\right]$ and ortho-phosphate [PO4]) and organic carbon (total organic carbon [TOC] and dissolved organic carbon [DOC]). Water samples for laboratory analytical testing were collected using a peristaltic pump powered off a 12-volt non-spillable battery. Lake water was allowed to run through the tubing for a sufficient period before collection to ensure a representative sample.

A single sampling set for laboratory analysis was made of two (one filtered and preserved, one unfiltered and preserved) 150-mL manufacturer-sterilized plastic Nalgene bottles. Duplicate and often triplicate sets were collected onsite for laboratory use. Filtered samples were preserved with $1 \mathrm{ml}$ of $6 \mathrm{~N}$ sulfuric acid added before collection while unfiltered samples were preserved with $1 \mathrm{ml}$ of $6 \mathrm{~N}$ nitric acid added before collection. This amount was enough to acidify the lake water to a $\mathrm{pH}$ near 2.0. Samples were filtered by an in-line AquaPrep 600, 0.45 um, capsule filter at the time of collection.

All samples were kept at the optimum temperature range of $2-8{ }^{\circ} \mathrm{C}$ during transportation back to UAF facilities for laboratory analyses. Samples were immediately ultra-acidified on arrival to a $\mathrm{pH}$ of less than 2 using phosphoric acid for further preservation. Storage at UAF laboratories 
was in a $5^{\circ} \mathrm{C}$ refrigerator until analysis was possible. The nutrient content (nitrate and nitrite) was analyzed within 12 hours to prevent bacterial consumption. 40-mL aliquots of filtered and unfiltered preserved water were transferred into manufacturer-sterilized glass vials with septa for TOC and DOC analyses.

Unfiltered bottled samples were analyzed for metals and total organic carbon. Filtered samples were analyzed for nutrients and dissolved organic carbon.

Analysis of metals was performed using a Perkin Elmer Analyst 300 atomic absorption spectrophotometer. The instrument was operated in flame mode using an air-acetylene flame for sample aspiration and burning. To perform the analysis, a subset was removed from the container and diluted to the appropriate analytical range (Table 4). The instrument was then calibrated using calibration standards and a calibration curve was derived. Deuterium background correction was used for all samples analyzed at wavelengths of less than $300 \mathrm{~nm}$ (Table 7).

Table 9. Laboratory metals analyses specifications.

\begin{tabular}{|ccccc|}
\hline Analyte & $\begin{array}{c}\text { Wavelength } \\
(\mathbf{n m})\end{array}$ & $\begin{array}{c}\text { Background } \\
\text { Correction }\end{array}$ & $\begin{array}{c}\text { Analytical } \\
\text { Range } \\
\text { (ppm) }\end{array}$ & $\begin{array}{c}\text { Standard } \\
\text { Lot Number }\end{array}$ \\
\hline \hline $\mathrm{Na}$ & 589 & No & $0-1.0$ & $\mathrm{~B} 1045104$ \\
$\mathrm{Ca}$ & 422.7 & No & $0-5.0$ & $\mathrm{~B} 2035080$ \\
$\mathrm{~K}$ & 766.5 & No & $0-2.0$ & $\mathrm{~B} 1055015$ \\
$\mathrm{Mg}$ & 285.2 & Yes & $0-0.5$ & $\mathrm{~B} 0035160$ \\
$\mathrm{Fe}$ & 248.3 & Yes & $0-6.0$ & $\mathrm{~B} 2025087$ \\
\hline
\end{tabular}

Organic carbon samples were analyzed using an Apollo 9000HS TOC analyzer. The analyzer was calibrated using a commercially available carbon standard. All samples were analyzed by sparging the samples for five minutes with clean air. The samples were then directly injected into the combustion chamber and analyzed.

Laboratory nitrate and nitrite analysis was performed using a colorimetric technique. Total (nitrate and nitrite) nitrogen was measured by first reducing all nitrate in the sample to nitrite using a commercially available cadmium reduction column. The sample was then diazotized using sulfanilamide and coupled with $\mathrm{N}$-(1-napthyl)-ethylenediamine dihydrochloride to form a highly colored dye. This solution was quantized using a Beckman DU520 UV-Visible spectrophotomer operating at $543 \mathrm{~nm}$. The instrument was calibrated using a standard prepared by dissolving sodium nitrate in water. Laboratory analysis of nitrate and nitrite has a lower detection limit of $5 \mathrm{ppb}$. 


\subsection{Continuous Measurements}

Continuous measurement of specific conductivity, water temperature, water level and dissolved oxygen during the 2002-2003, 2003-2004 and 2004-2005 winters was attempted with mixed success by continuously operating stations. Stations at lakes K113C, K203C, K214P and K209P were installed in February 2003 and recorded data until spring breakup in June. Stations at K113C, K214P and K209P were redeployed for the entire 2003-04 winter. Stations at lakes L9312 and L9817 were installed in December 2004 and recorded data until spring breakup in June 2005.

Variables of water level, specific conductance, temperature and dissolved oxygen were transmitted by radio to a base station connected to the Internet allowing near-real time (15-60 minute data intervals) data to be observed. Data sets were then reduced and Quality Assurance/Quality Control assessments conducted to detect data error. Two specific conductivity sensors and two dissolved oxygen sensors floated within the free water column approximately $0.35 \mathrm{~m}$ above the bottom sediments. Water level was recorded by two pressure transducer sensors anchored into the bottom sediment. Water temperature was typically recorded at $0.3 \mathrm{~m}$ intervals by a paired thermistor string throughout the water column with the bottom thermistor anchored in the bottom sediment.

Details of sensors utilized in the study are given in Table 8. Positioning of sensors in relation to the station itself is seen in Figure 23. Table 9 presents the time each station began reporting data. Record of pressure transducer calibrations is given in Appendix $B$ and a record of changes to field sensors is given in Appendix C.

\subsection{Field Measurements}

Measurements of snowpack water equivalent were conducted routinely in four locations around each lake and adjacent to each raft every May prior to the onset of snowmelt. This was conducted according to the procedure described in Rovansek et al., (1993). At each site, 10 cores were collected with an Adirondack snow tube. The depth and weight of the snow sample in the tube was recorded, allowing calculation of the snowpack water equivalent and density. Fifty additional depth measurements were also collected to clarify the representation of the measurements. 
Table 10. Online sensor specifications.

\begin{tabular}{|c|c|c|c|c|}
\hline Sensor & Make & Model & Resolution & $\begin{array}{c}\text { Sensor } \\
\text { Tolerance }\end{array}$ \\
\hline $\begin{array}{l}\text { Dissolved } \\
\text { Oxygen }\end{array}$ & $\begin{array}{c}\text { Greenspan } \\
\text { Technologies / } \\
\text { Steven Water } \\
\text { Monitoring }\end{array}$ & DO1200 & $\begin{array}{c}0.1 \% \\
\text { saturation }\end{array}$ & $+/-2.0 \%$ \\
\hline $\begin{array}{l}\text { Pressure } \\
\text { Transducer }\end{array}$ & $\begin{array}{c}\text { Honeywell / } \\
\text { GeoWatersheds } \\
\text { Scientific }\end{array}$ & $\begin{array}{l}\text { GWS5B - } 5 \\
\text { PSI range }\end{array}$ & $\begin{array}{l}0.001 \text { volts, } \\
0.01153 \mathrm{ft}, \\
0.00352 \mathrm{~m}\end{array}$ & $+/-0.1 \%$ \\
\hline Thermistor & $\begin{array}{l}\text { Yellow Springs } \\
\text { Instruments }\end{array}$ & YSI44000 & $0.01 \mathrm{C}$ & $+/-0.2 \mathrm{C}$ \\
\hline $\begin{array}{l}\text { Specific } \\
\text { Conductance }\end{array}$ & $\begin{array}{l}\text { Campbell } \\
\text { Scientific }\end{array}$ & CS547A & $0.001 \mathrm{mS} / \mathrm{cm}$ & $+/-5.0 \%$ \\
\hline
\end{tabular}

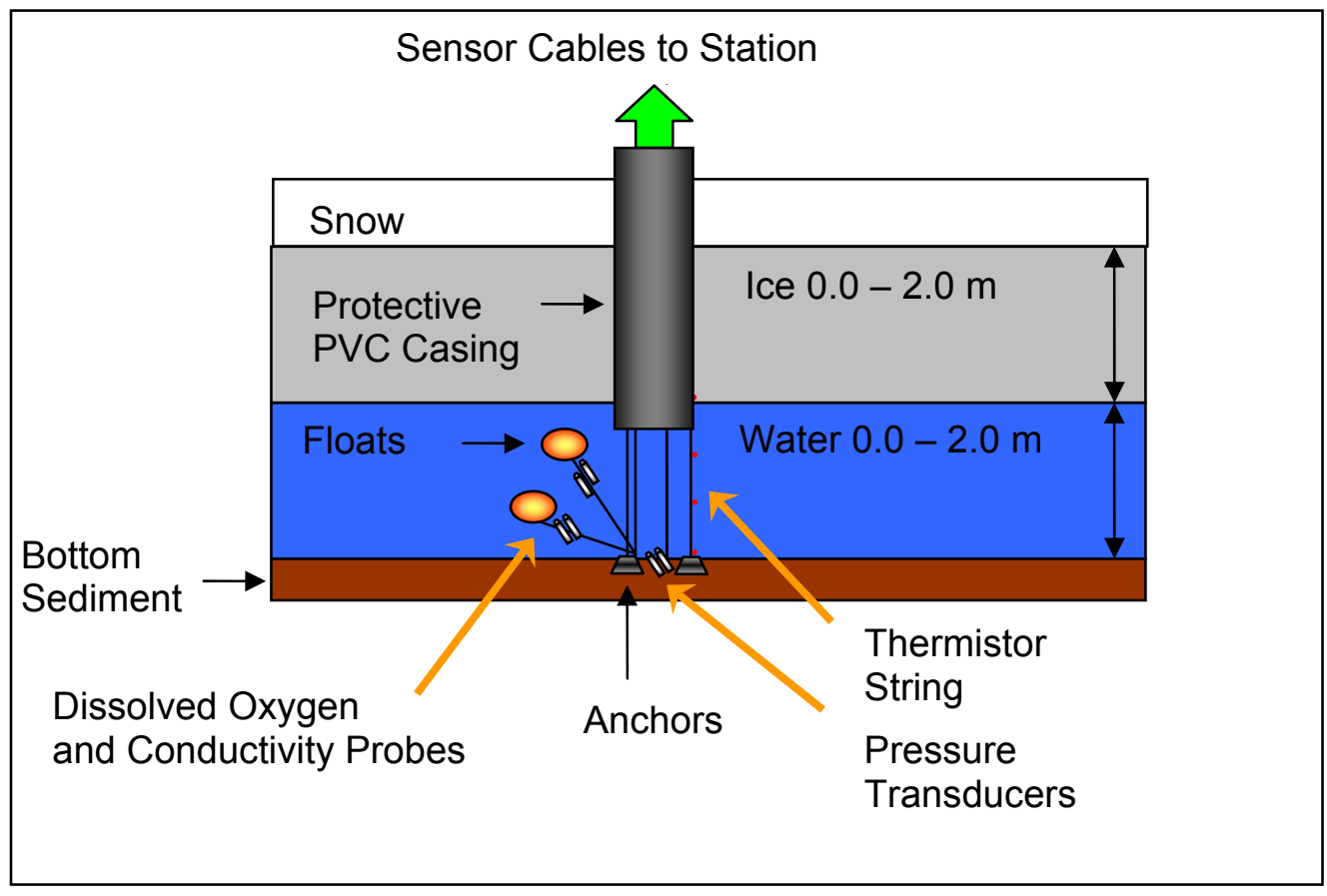

Figure 23. Depiction of station and online sensors.

Table 11. Operating period for study lakes continuous data-collection stations.

\begin{tabular}{|c|c|c|}
\hline Lake & Station Installed & Station End Date \\
\hline K113C & $2 / 15 / 03$ & $6 / 15 / 05$ \\
\hline K203C & $2 / 14 / 03$ & $4 / 15 / 03$ \\
\hline K209P & $2 / 13 / 03$ & $6 / 15 / 05$ \\
\hline K214P & $2 / 9 / 03$ & $6 / 15 / 05$ \\
\hline L9312P & $12 / 5 / 04$ & Currently Operating \\
\hline L9817P & $12 / 6 / 04$ & Currently Operating \\
\hline
\end{tabular}




\section{PUMPING ACTIVITY}

Water was withdrawn from the pumped lakes for a variety of uses during the winter periods throughout the study. The water was primarily used to create an ice infrastructure of roads for personnel and equipment transportation as well as operating pads and airstrips. Other potential uses of the pumped lakes' water during the winter included: potable water supply, firewater and drilling fluid. Overall, lake K209P was used as a resource more frequently and at higher volumes than K214P. This was due to lake K209P's proximity to the primary ice road leading across the Colville River to the Alpine satellite development. Lake K214P, more central in the Kuparuk operating unit, was not pumped as frequently or heavily.

Figure 24 to

Figure 27 summarize pumping activities at lakes K209P and K214P during the winters of 20022003 and 2003-2004. A more detailed record of pumping activity for the 2002-2005 winters is given in Appendix D. Note that there are several types of permits that are issued by DNR including LAS (water rights labeled under the land administration system), TWUP (temporary water use permit), and Habitat Permits (issued by DNR Habitat Division). Most of the TWUP and LAS permits operate on a calendar year basis, whereas the habitat permits are based on a water year (approximately Oct.1- May 1).

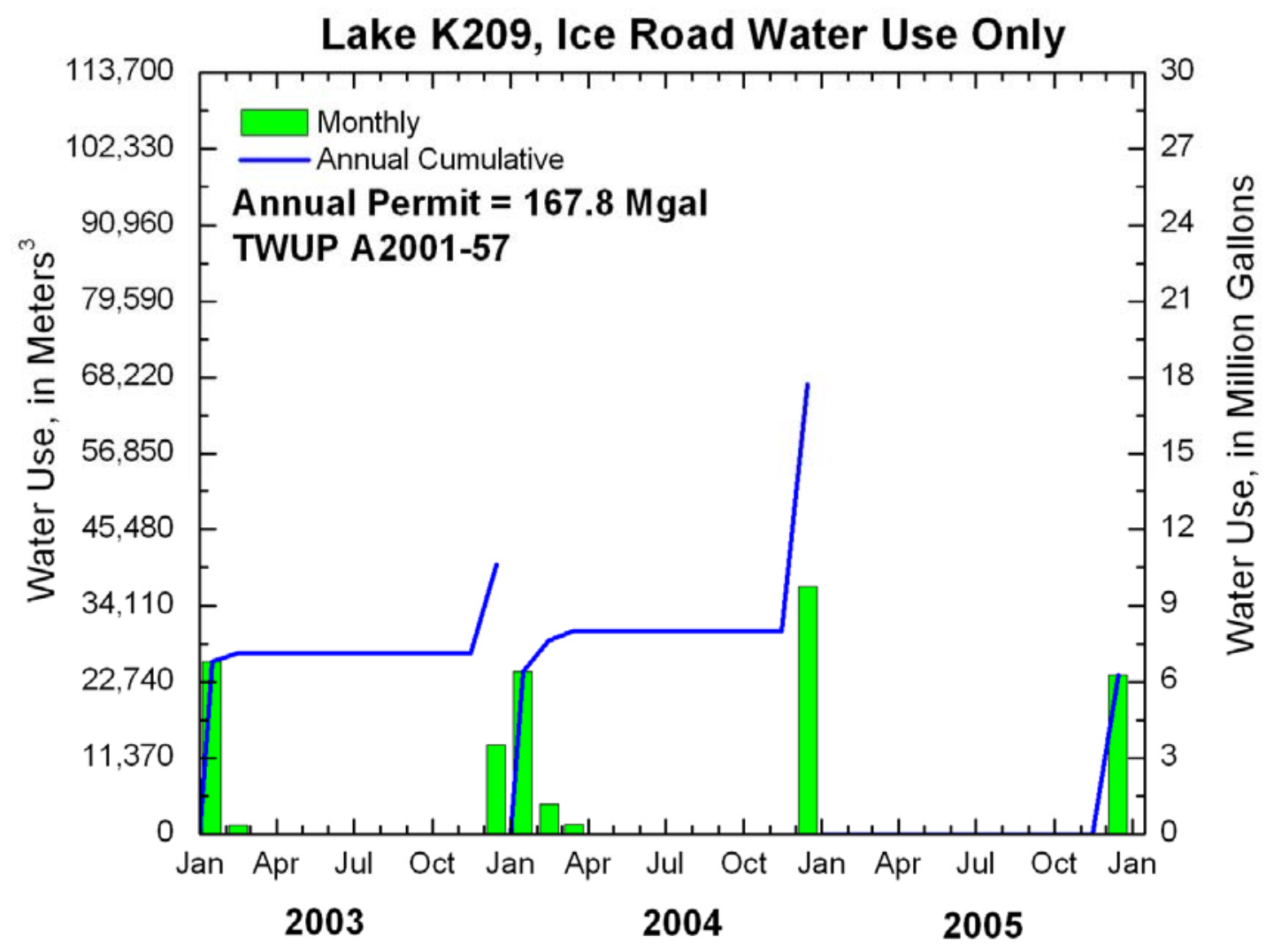

Figure 24. Pumping activity at K209P during the three winters of the project. 


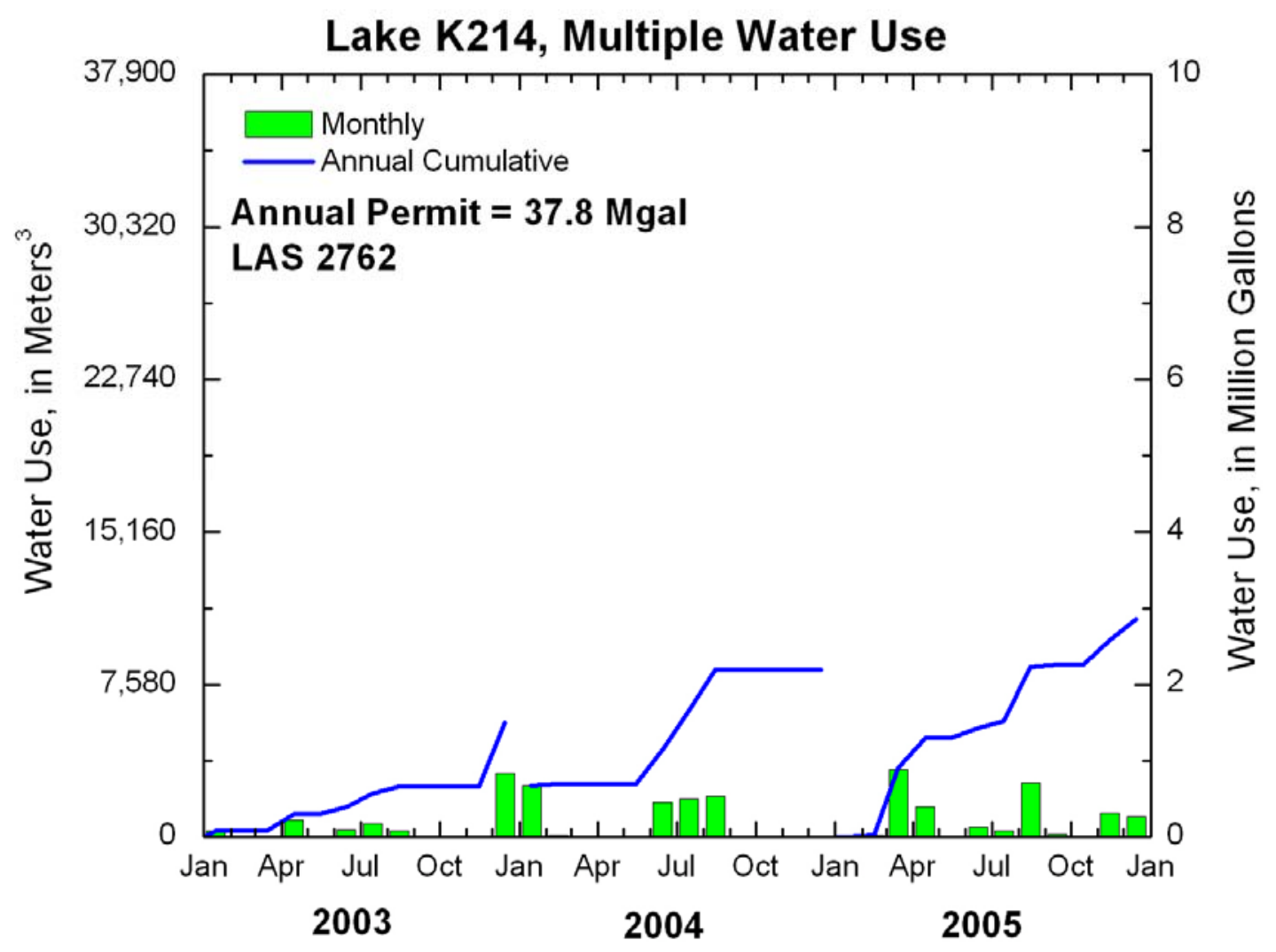

Figure 25. Pumping activity at K214P during the three winters of the project. 


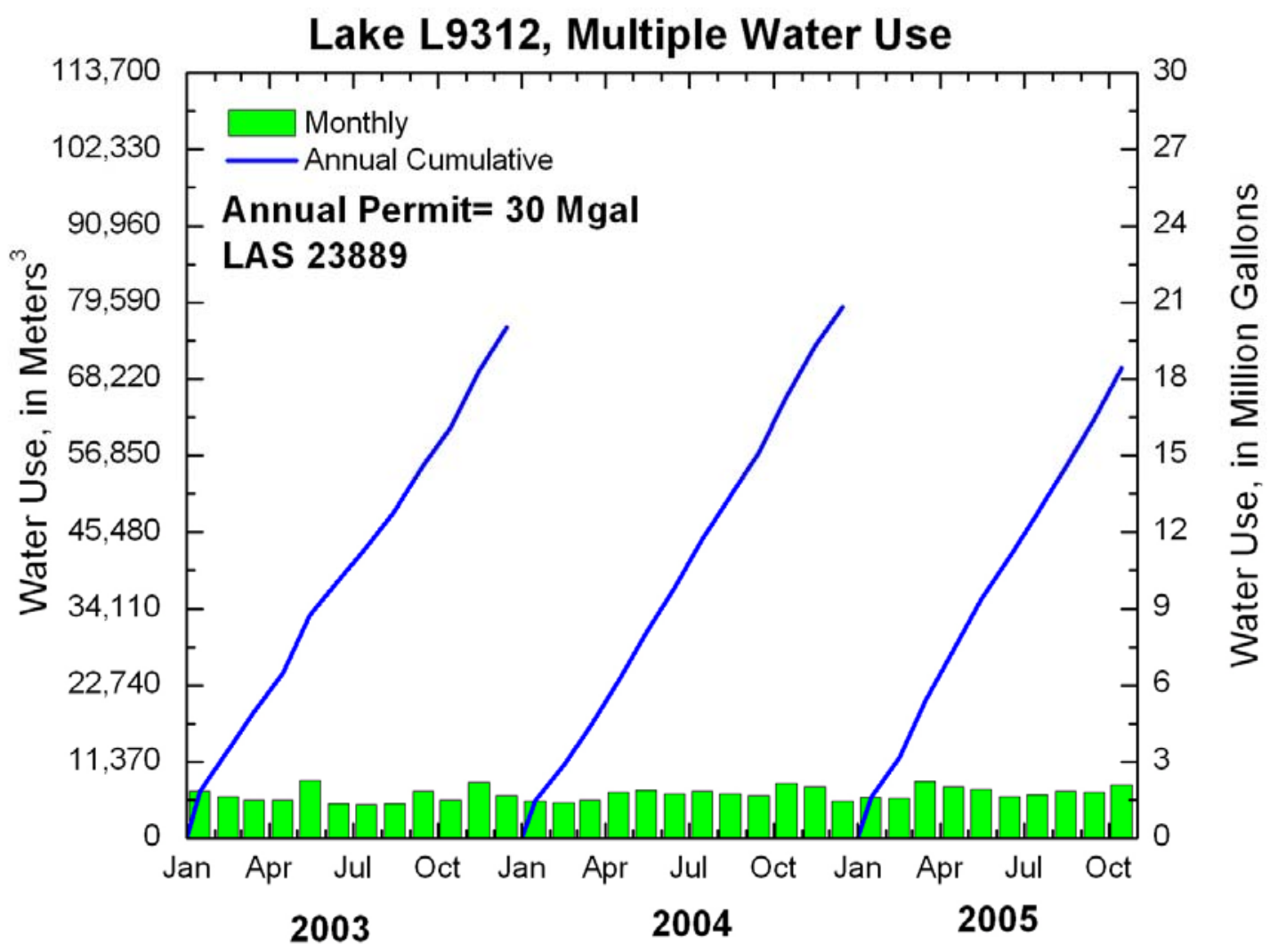

Figure 26. Pumping activity at L9312P during the three winters of the project. 


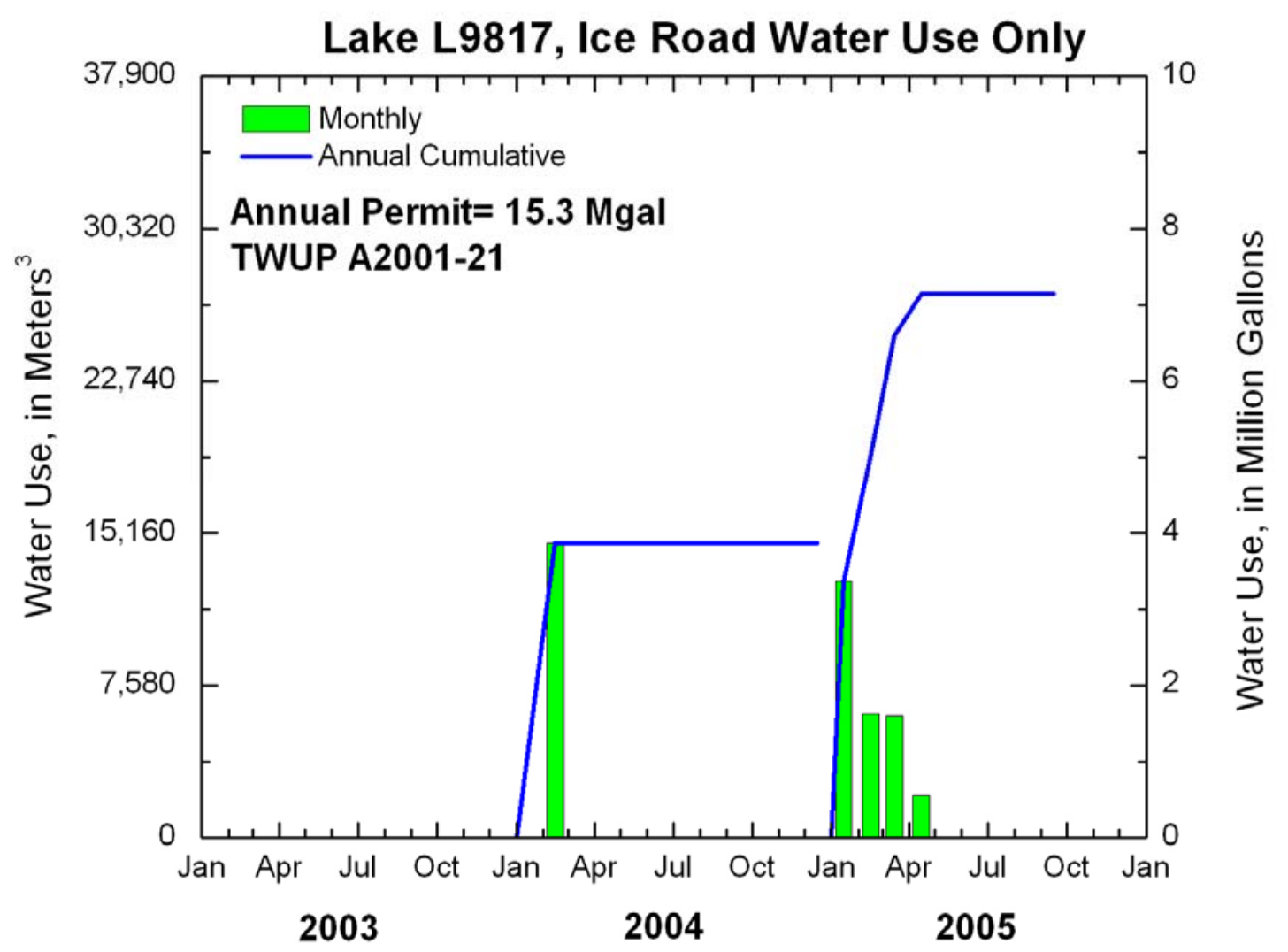

Figure 27. Pumping activity at L9817P during the three winters of the project. 


\section{KUPARUK DEADARM GEOPHYSICS}

The Kuparuk Dead Arm reservoir actually consists of seven major water reservoirs $\left(869,600 \mathrm{~m}^{2}\right)$ located on a paleo-flood plane adjacent to Kuparuk River in the Prudhoe Bay oilfields. The reservoir was originally developed as a gravel pit for road and pad construction, but has become an important water resource for oilfield activities. As a component of the investigation of water use from lakes on the coastal plain, questions also arose about the possibility of hydraulic connections between lakes and rivers. The essential question is, if water is removed from one lake, will that have an impact on adjacent lakes or river channels even though no apparent surface channel exists? The conventional wisdom was that sub-surface connections do not exist in regions of thick, ice-rich permafrost. However, our literature review and field studies do confirm that unfrozen hydraulic channels do exist under special circumstances; these include deep groundwater springs that can completely penetrate over $300 \mathrm{~m}$ of permafrost and taliks (or unfrozen zones within a permafrost area) that developed under lakes, stream or river channels. Depending upon the size of the talik, it can persist for decades or centuries after the lake has drained or a river has meandered to a new channel in a floodplain.

This study focused on potential talik connections between the Kuparuk River and Kuparuk Deadarm Lakes (reservoirs) as well as water movement from river to the reservoir during water removal by pumping. The reservoirs consist of a series of gravel extraction pits (cells) that having varying degrees of interconnected surface connections. A talik was discovered about 40 $-50 \mathrm{~m}$ below the ground surface in the area between cell \#1 on the southwest side (Section A-A', Figure 28). Its hydraulic conductivity was estimated to be about $10^{-4} \mathrm{~m} / \mathrm{s}$ based upon presumed material properties. Direct current resistivity tomography and ground penetrating radar surveys were conducted to obtain the subsurface fields of the dielectric constant and resistivity between the river and reservoirs. Stable isotope samples were obtained for input into a mixing model between river water and the reservoirs. Relative resistivity is an important and sensitive technique for deep talik detection. High frequency dielectric constant mapping (GPR survey) is an ideal second parameter for indication of soil type, water content and other physical properties for shallow taliks that are less than 10 meters in depth. Drill logs from borings near this area were obtained to support geophysical survey results. The combination of geophysical survey and isotope analysis are relatively economic and non-destructive methods to investigate subsurface hydrology in sensitive tundra ecosystems.

\subsection{Kuparuk Deadarm Lakes Background}

The methods of the field measurement of groundwater movement and aquifer permeability are technically well developed. However, most hydrologic surveys require ground disturbances such as slag or pump tests in wells or other surface disturbances that may impact sensitive tundra ecosystems. This study focused on detecting hydraulic connections between the surface water bodies of the Kuparuk River and adjacent reservoirs. Most of the surface water bodies (lakes) are considered as isolated by the impermeable cold permafrost (ca. -9 to $-12{ }^{\circ} \mathrm{C}$ ). However, freshwater taliks (an unfrozen layer in the permafrost) are known to be commonly located beneath deeper ponds $(>2 \mathrm{~m})$ or stream channels on the North Slope, Alaska. Brewer (1958a, 1958 b) reported that a sub lake bottom talik ("thaw bulb") reached $60 \mathrm{~m}$ deep beneath a lake in Barrow. Many of the closed system pingos and/or drained lakes in the Prudhoe Bay area maintain a fresh water talik similar to the Barrow lakes. The objective of this effort was to examine the thermal and hydraulic characteristics of the cold, continuous permafrost subsurface around the Kuparuk River and Dead Arm Lakes system using geophysical and water chemistry 
methods. The benefit of this approach was that it not only caused no disturbance to the tundra ecosystem, but it also efficiently and economically covered a wide area.

\section{$10.2 \quad$ Methods}

Geophysical surveys are conducted widely in permafrost regions. We used ground penetrating radar (GPR) and resistivity tomography surveys in this study (Figure 28). GPR determines the dielectric constant of the soil by measuring the travel time of the electromagnetic wave propagating through the frozen ground. DC resistivity survey is one of the traditional but perhaps most appropriate methods for studies in the permafrost region (Harada and Yoshikawa, 1996; Yoshikawa et al. 2004). The resistivity method measures variations in the ground's electrical resistivity by applying small electrical currents across arrays of electrodes inserted in the ground. The resistivity readings are processed to yield depth probes or sections of the thickness and resistivity of subsurface electrical layers. Results are correlated with real ground interfaces such as soil and rock layering or soil-bedrock interfaces to provide detailed information on subsurface structure. Four equally spaced electrodes are set out in a standard configuration (Wenner Array). A low frequency current is applied across the two outer electrodes and the voltage is measured across the inner electrodes. The voltage is converted into a resistivity value that represents the average ground resistivity between the electrodes. Models of vertical variations in ground resistivity are obtained using an expanding electrode array centered on a reference point. Depth penetration increases with electrode spacing. We conducted a GPR survey (April, 2004) (Figure 29) and Resistivity survey (August, 2004) (Figure 30and Figure 31) between the Kuparuk Dead Arm reservoirs and the Kuparuk River east channel. 


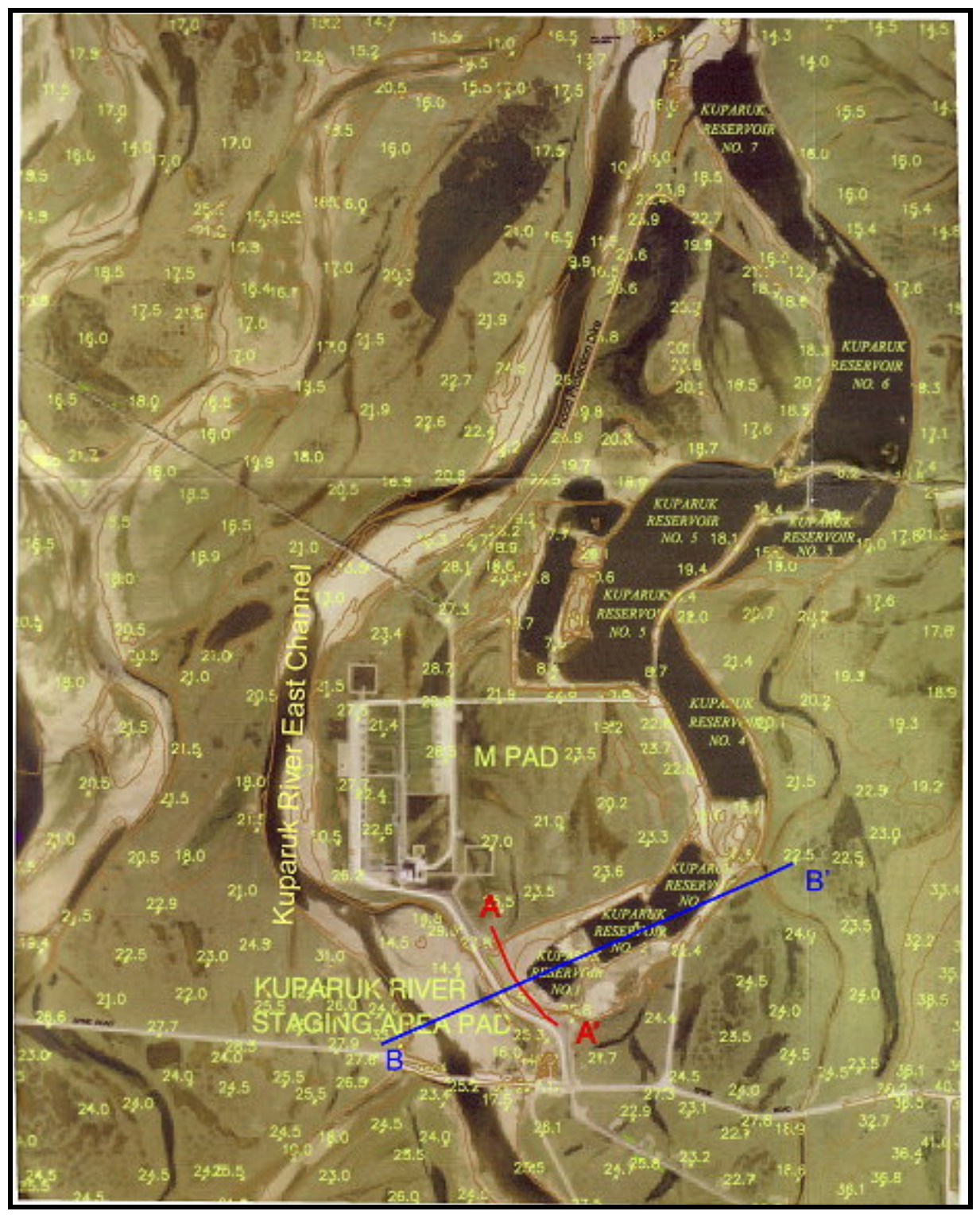

Figure 28. Study site and survey lines. Section B-B's also is used to help illustrate a hypothetical talik model for the area from the Kuparuk River east channel and cells 1, 2, 3 of the Kuparuk Deadarm Lakes.

\subsection{Dielectric constant measurement}

GPR surveys mainly focus on distinguishing the unfrozen layer in the upper $10 \mathrm{~m}$ of permafrost. The conditions during the GPR field surveys were ideal. The active layer was completely frozen and snowmelt had not yet initiated. A talik is relatively easy to find by GPR if liquid water is not present on the ground surface. We used a $200 \mathrm{MHz}$ radar antenna with a GSSI SIR-2000 system situated in a sled that was pulled by hand along the transects (Figure 29). The dielectric constant is calculated from velocity of wave propagation. The velocity (V) of electromagnetic wave is described as following: 


$$
V=c /(e)^{1 / 2}
$$

Eq.1

Where $c$ is the speed of light in vacuum $\left(c=3 \times 10^{8} \mathrm{~m} / \mathrm{s}=0.3 \mathrm{~m} / \mathrm{ns}\right)$, and $e$ is the dielectric constant.

The dielectric constant of the first (upper) layer was estimated using travel time (TT) of the echo and Equation 1. The travel time (TT) (ns) and velocity (V) are related through the following relationship:

$$
\mathrm{TT}=2 \mathrm{~d} / \mathrm{V} \quad \text { Eq.2 }
$$

Where $d(m)$ is distance to the reflector.

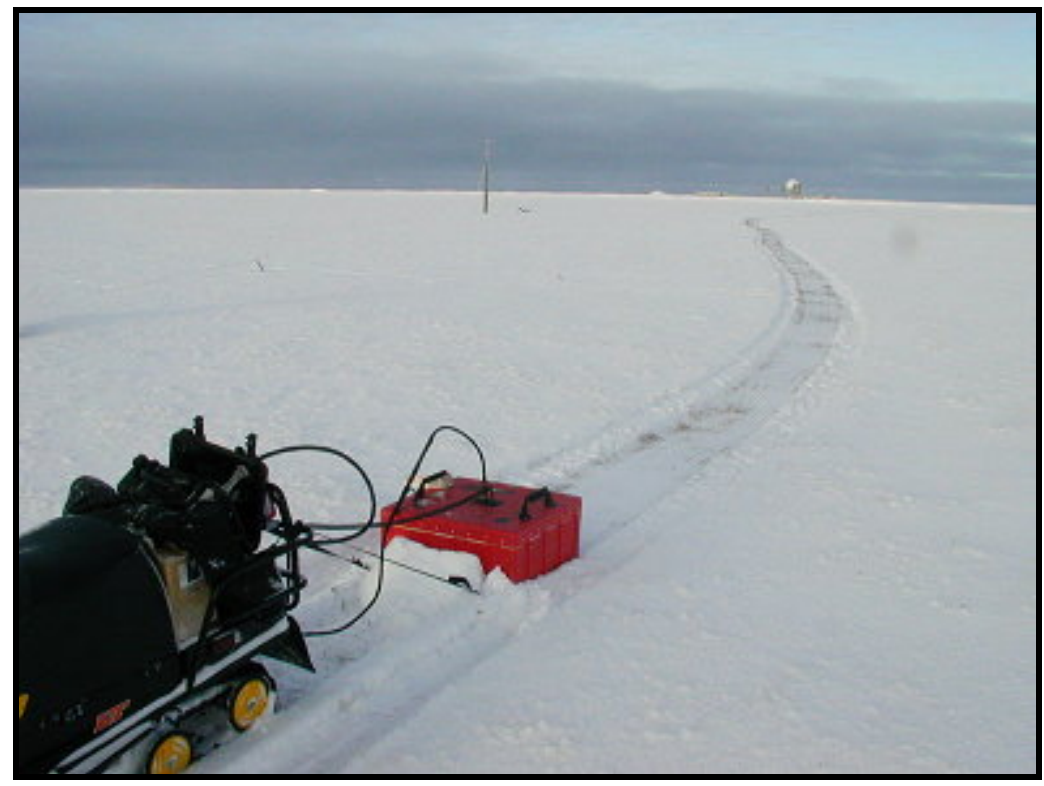

Figure 29. GPR operation during springtime.

\subsection{Relative resistivity measurement}

The electrical resistivity of soil depends on soil type, temperature, water content, porosity, and salinity. In general, apparent resistivity $\left(\rho_{\mathrm{a}}\right)$ values of frozen soil are 10-100 times greater than those of unfrozen soils (Harada and Yoshikawa, 1996). A resistivity survey was conducted at the end of the August 2004, because of the need for solid ground contact. For the measurements, a conventional resistivity-sounding meter (Syscal pro R1 72 channels switching system) was used to set up a Wenner electrode configuration (Figure 30 and Figure 31). A current (I) is delivered and received between the outer electrodes, and the resulting potential difference $(V)$ is measured between the inner electrodes. For this array on the ground surface, an apparent resistivity $\left(\rho_{\mathrm{a}}\right)$ is calculated from: 


$$
\rho_{a}=2 \pi a \mathrm{~V} / \mathrm{I}
$$

Where "a" is the distance separating the electrodes. An inversion analysis was performed with changing values of resistivity and layer thickness by using the linear filter method. An inversion program (RES2DINV at Geotomo software) was used for processing the resistivity imaging. Recent developments of the resistivity method have improved the resolution and quality of the data interpretation, providing a continuous 2-D model of resistivity along the section lines known as electrical imaging. The data processing procedures for the imaging method are more complicated and the rate of data acquisition is slower, making it most useful for investigating areas of complicated ground conditions. Resistivity imaging is particularly suitable for measuring the size of a talik or an aquifer in the permafrost regions where a detailed understanding of complex subsurface structure is important. We used 72 electrodes, placed in a line set at $5 \mathrm{~m}$ spacing (360m cross section), and connected to a computer controlled resistivity meter using a multicore cable. A switching unit takes a series of constant separation traverses along the array with increasing electrode spacing.

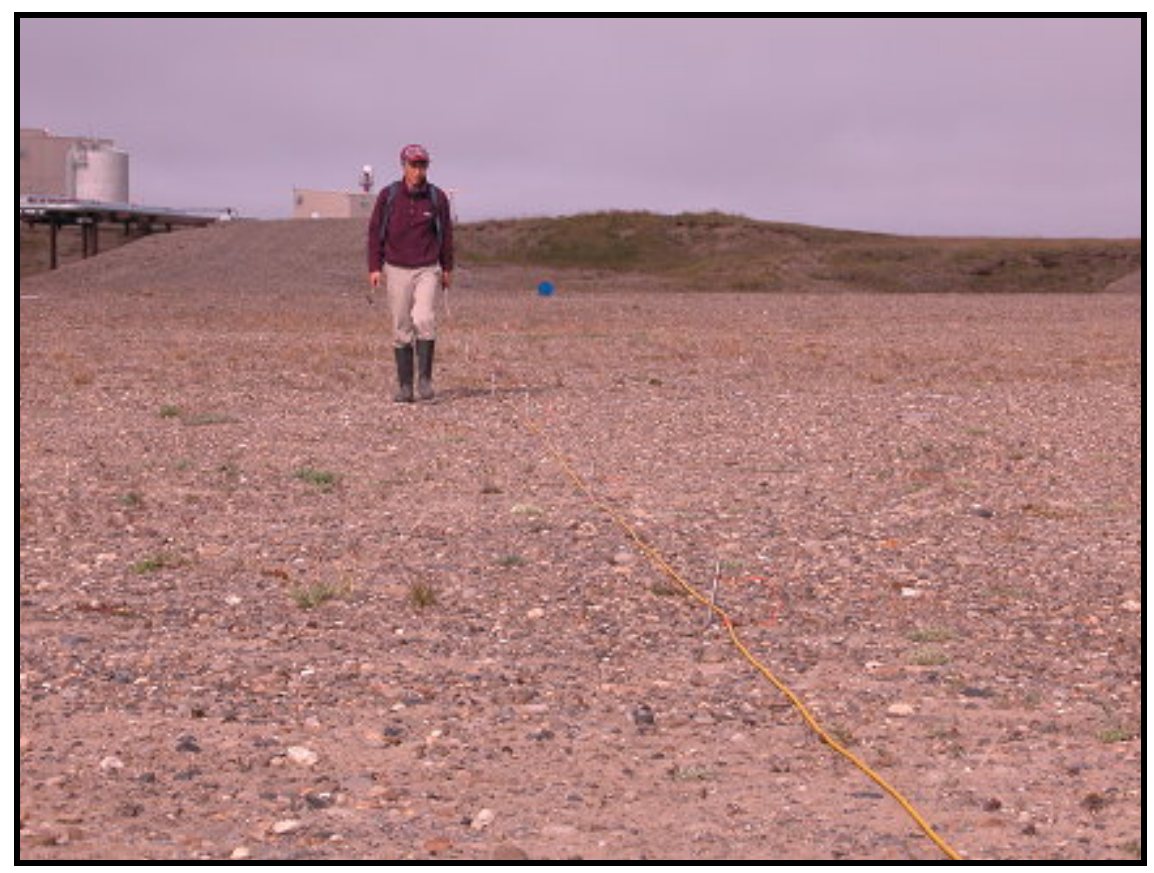

Figure 30. Resistivity survey (August 2004). 


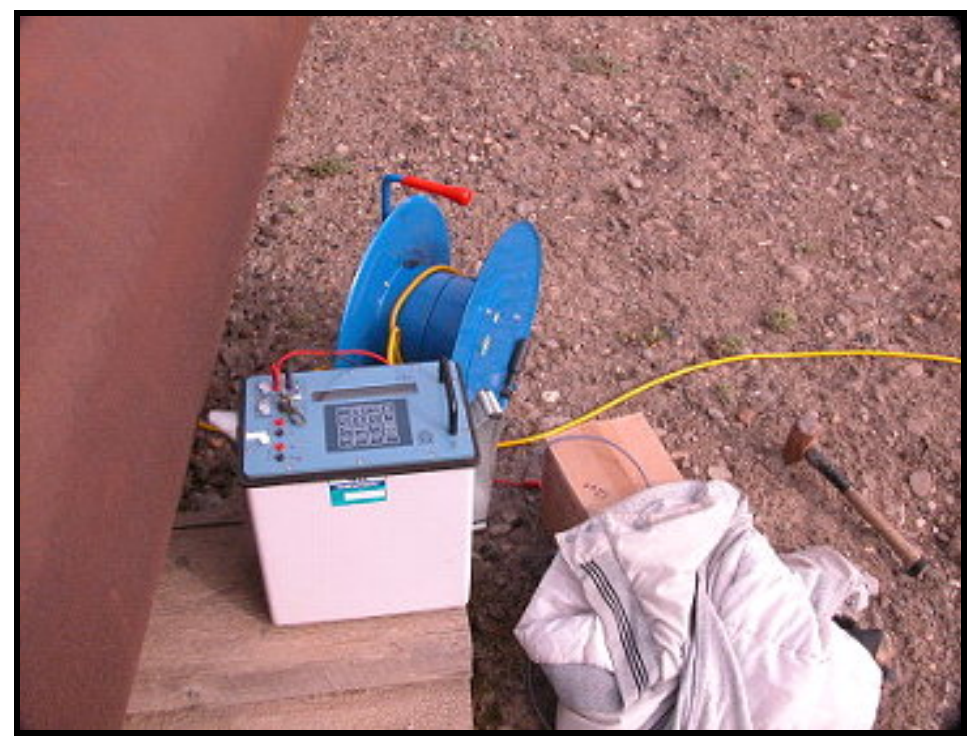

Figure 31. Resistivity survey (August 2004).

\section{Isotope and water chemistry}

Stable isotope $\left(\delta^{18} \mathrm{O}\right.$ and $\left.\delta^{2} \mathrm{H}\right)$ signals preserve many of the process trends necessary for reconstructing lake mixing, evaporation and condensation histories (Yoshikawa and Hinzman, 2003). Tundra ponds, river water and concurrent precipitation were sampled for stable isotope analysis at the Water and Environmental Research Center, University of Alaska Fairbanks. The samples were sealed until laboratory analysis. The instrument (Delta ${ }^{\text {plus }} \mathrm{XL}$ ), a ThermoQuest high temperature conversion elemental analyzer (TC/EA) is used in the analysis of liquid samples for oxygen and hydrogen stable isotopes. The TC/EA unit is interfaced to a mass spectrometer through the Conflo III system.

Water samples were obtained from Kuparuk Dead Arm reservoirs no.1, no. 2, no.3, no.4, no.5, no.6, the Kuparuk River east channel and adjacent small ponds. The climatic conditions of study site have been well-studied (Hinzman et al. 1988; Mendez et al., 1998) and are known from a near-by meteorological station. Estimation of evaporation from the lake surface was estimated based upon 2004 relative humidity measurements with comparisons to similar historic data of pan evaporation measurements (Hinzman et al. 1998). The sediments from the study site include sand and gravel to more than 60m depth by floodplain deposits (Rawlinson 1986, 1990) (Figure 32). 


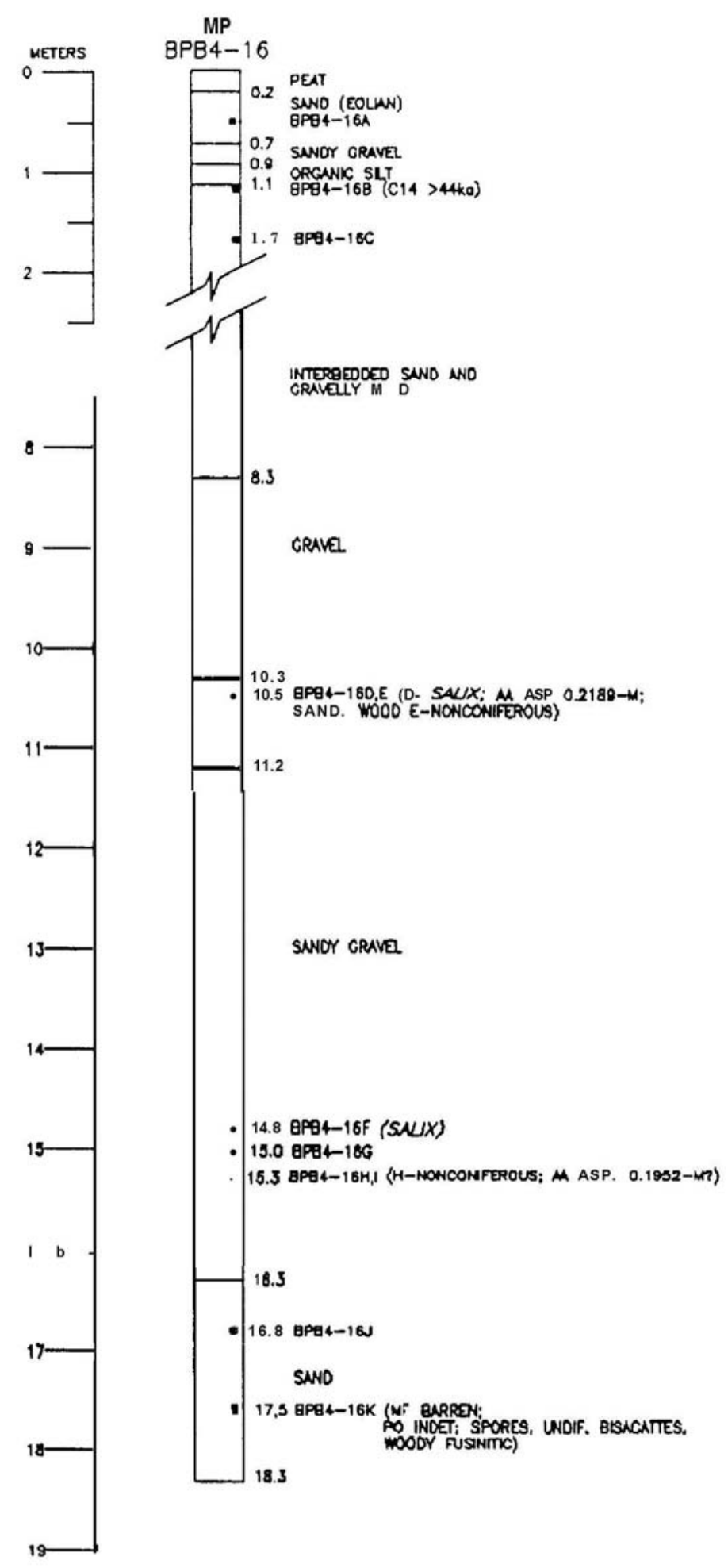

Figure 32. Stratigraphic sections of Kuparuk River inactive flood-plain deposits after Rawlinson (1990). 


\section{Dielectric constant}

Figure 33 displays the $200 \mathrm{MHz}$ radar signals at the Kuparuk River, east channel adjacent to $\mathrm{M}$ pad. The results indicate that the upper $10 \mathrm{~m}$ of the ground is completely frozen and none of the liquid brine pockets or high saline concentrations commonly observed in these coastal plain sediments were detected. Such results were typical of the entire study site. The GPR survey did not detect any shallow thawed ground or talik formations around the reservoir No 5, or in other areas that were surveyed in the area.

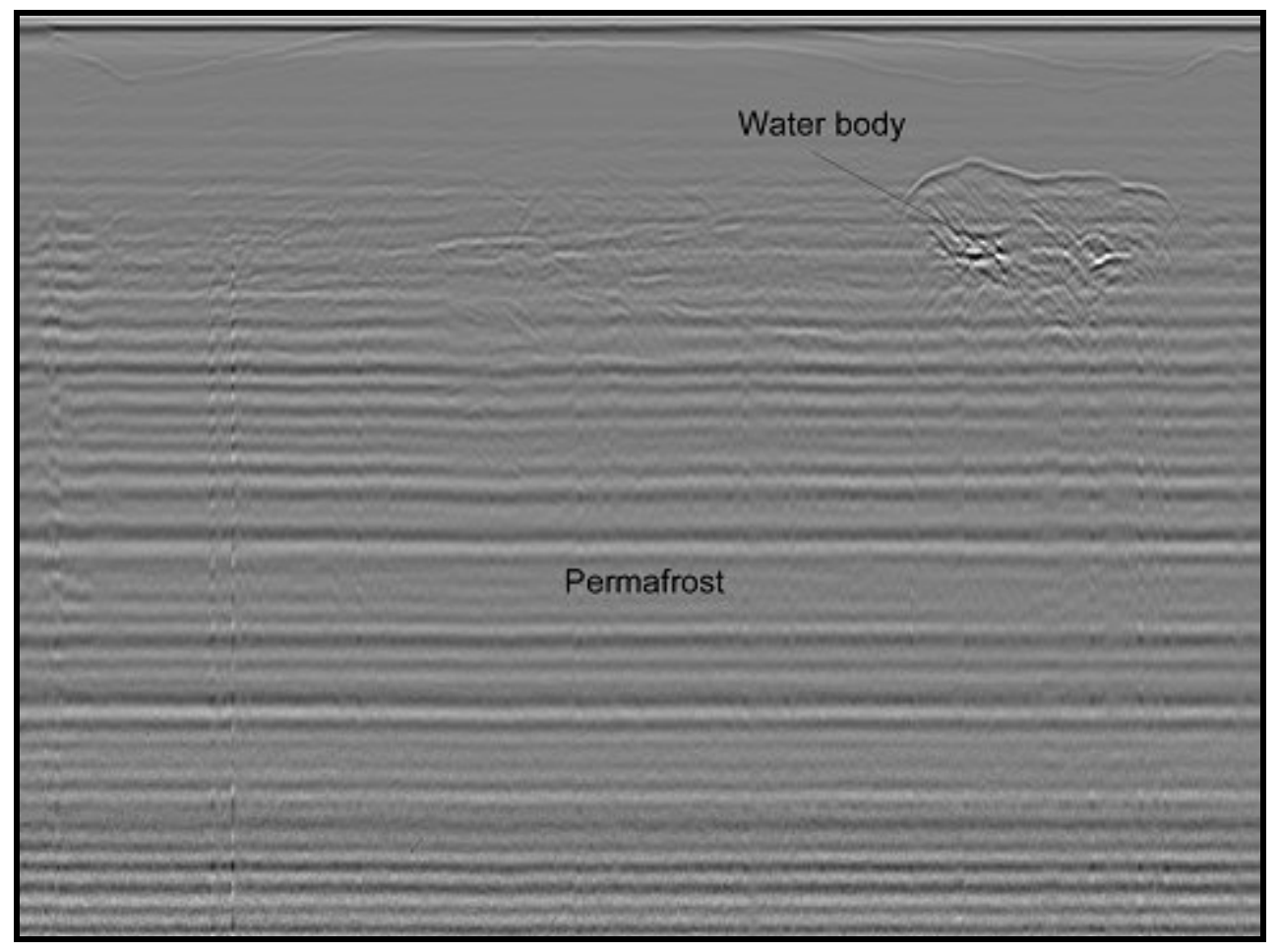

Figure 33. GPR obtained images in the vicinity of the Kuparuk River, east channel, adjacent to M pad. The depth of the figure signal is approximately 7 meters.

\section{Resistivity}

Figure 34 shows the apparent resistivity profiles obtained by field measurement in August 2004 and results of numerical (inversion) calculations. Between the Kuparuk River and reservoir no.1, three major layers of differing resistivity were detected. The first layer, with a value of $2000 \mathrm{ohm}-$ $\mathrm{m}$, had a thickness of $0.4 \mathrm{~m}$, which corresponds to the depth of the active layer measured with a thaw probe. The second layer had a resistivity value more than ten times higher, which corresponds to the depth of frozen sand, about $35 \mathrm{~m}$. The resistivity layer gradually decreased in the third layer. This layer's resistivity was significantly lower (50 to $200 \mathrm{ohm}-\mathrm{m}$ ). This low resistivity can be explained as a sandy talik (unfrozen) layer (Figure 34,

Figure 35). In this resistivity survey, we could not find the bottom of the talik, however, the depth of the talik should not exceed $60 \mathrm{~m}$ on the North Slope (Brewer, 1958a). Figure 35 shows a diagrammatic cross section of the study sites from our geophysical surveys. This diagram 
illustrates a potential talik configuration based on the resistivity survey at A-A' and the interpretation of past river channel effects on talik formations in the areas of cells 1-3. The annual amplitude of the permafrost temperature depends on thermal conductivity and water content. Usually the zero annual amplitude in tundra terrain is at about 16 to $20 \mathrm{~m}$ depth (Figure 36). The typical permafrost temperature at $35-60 \mathrm{~m}$ below ground surface is about $-9^{\circ} \mathrm{C}$ around the study site. Thus the resistivity value is typically $20,000 \mathrm{ohm}-\mathrm{m}$ for frozen sand and 5000 ohm-m for frozen clay (Figure 37). Therefore, the lower resistivity is most likely due to talik formations.

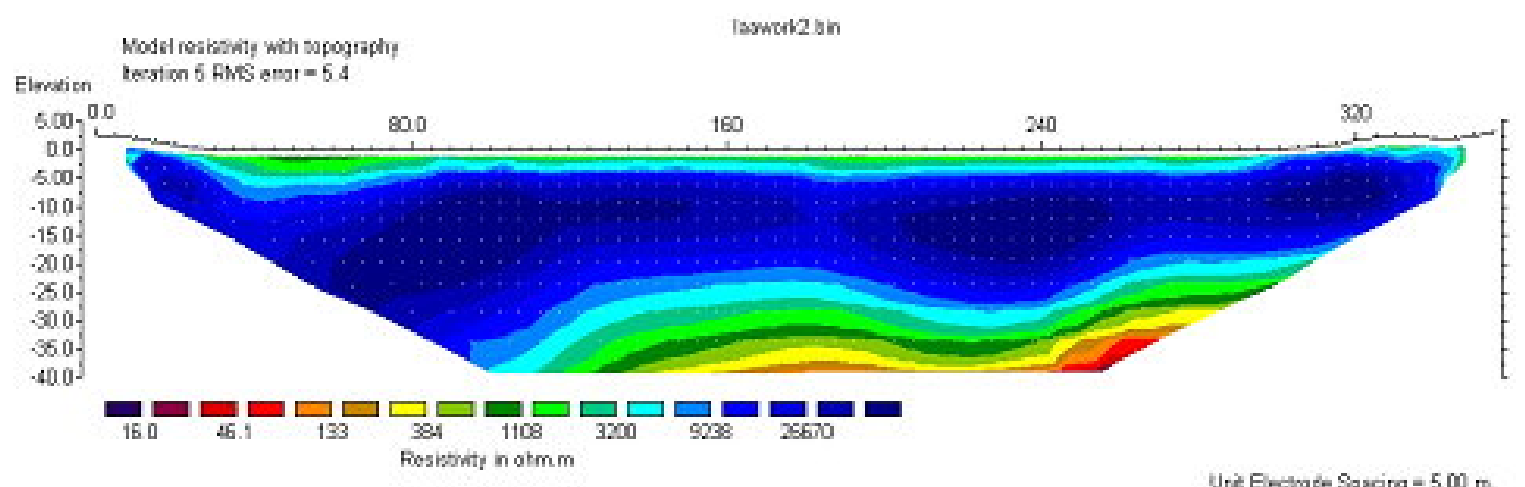

Herizental scala is 1328 pixels per srit spacing

Vertical ersgacreticn if modet actisn dsplay $=1.44$

First sactrode ia located at $0.0 \mathrm{~m}$.

Lend olbctode is bected at $355.0 \mathrm{~m}$

Figure 34. Resistivity profile at A-A' transect southwest of cell 1 (reservoir \#1).

B

B'

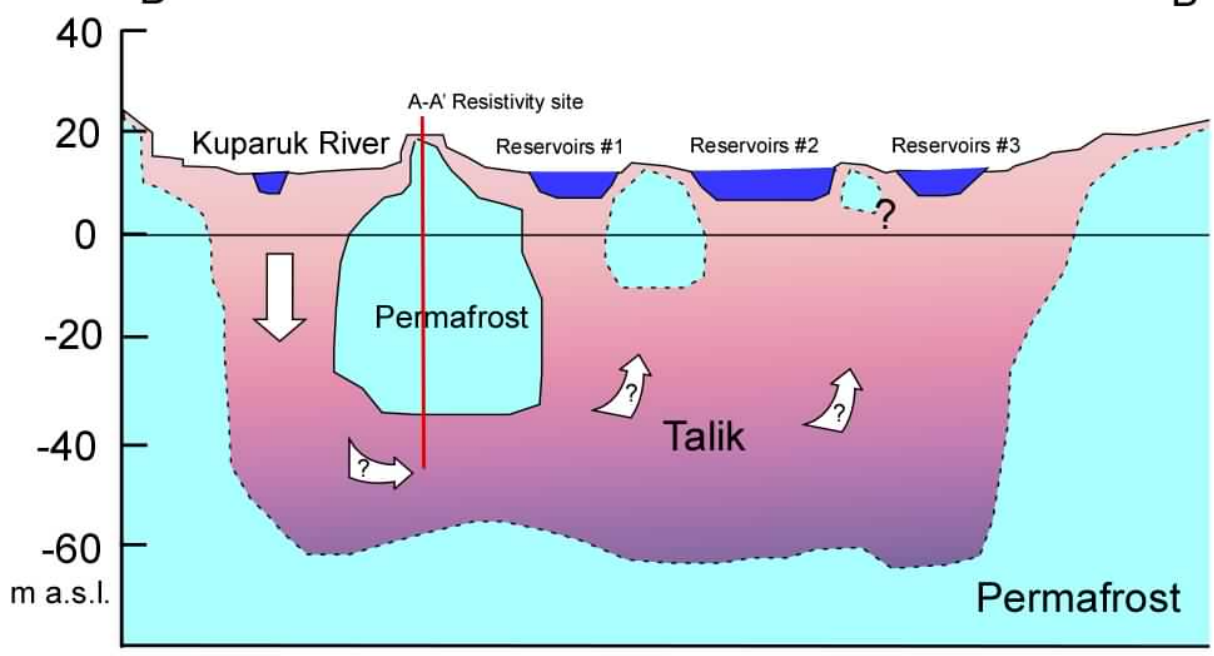

Figure 35. Profiles across section A-A' showing the location of the resistivity survey, and a potential talik configuration based on geophysical data and typical talik development in a river channel system. 


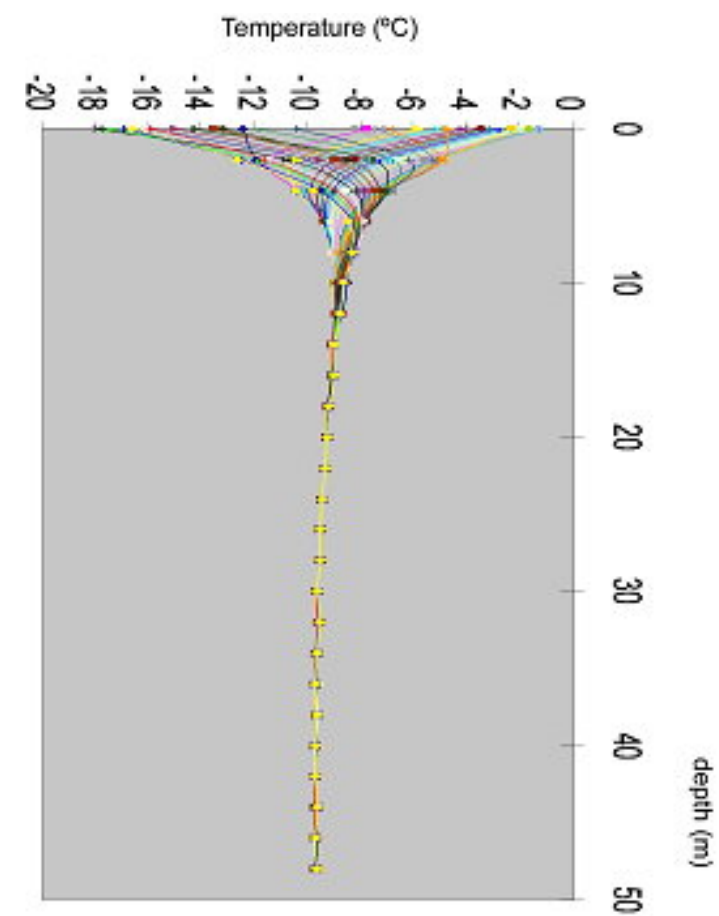

Figure 36. Temperature profiles at Barrow, Alaska indicated zero annual amplitude $16 \mathrm{~m}$ below surface.

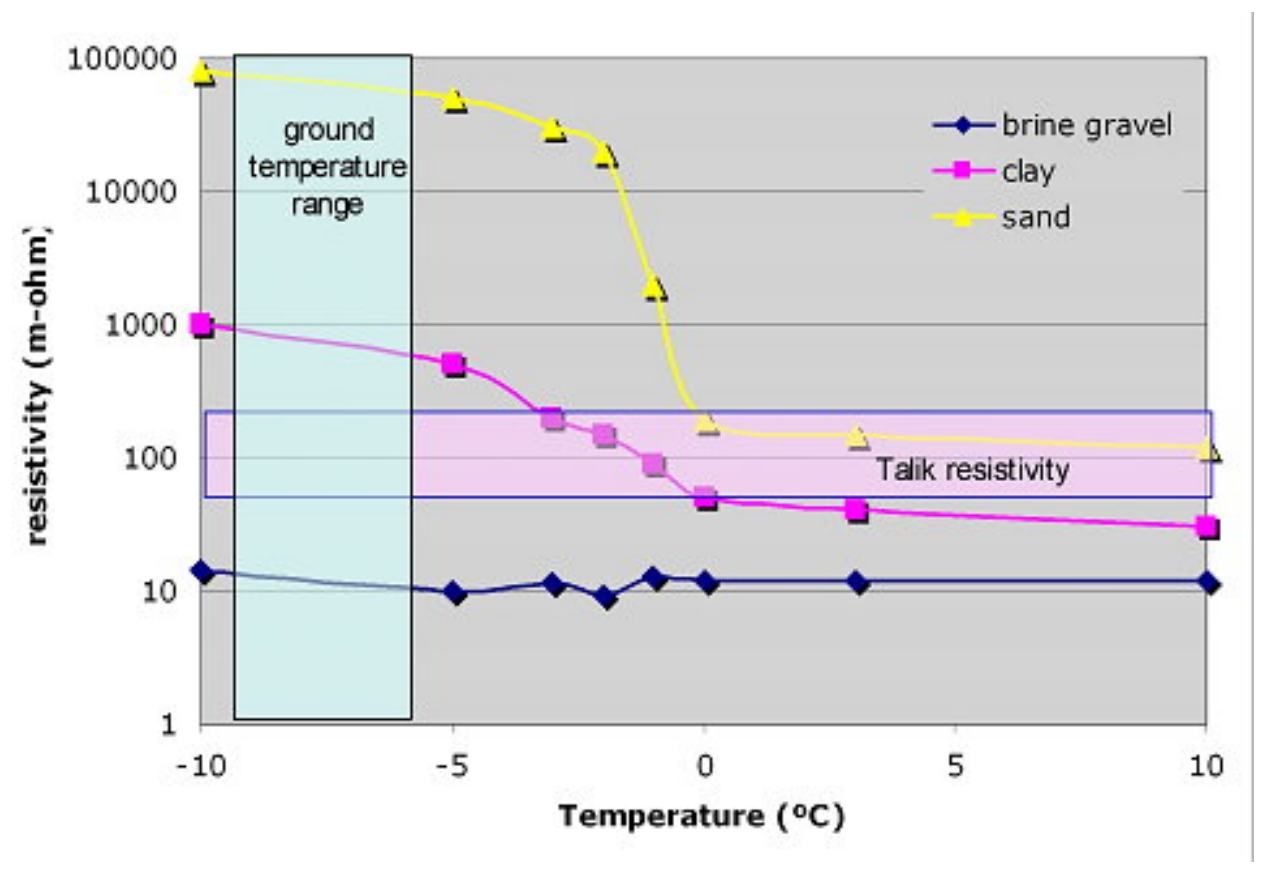

Figure 37. The resistivity versus temperature relationship of nearly saturated clay and sand demonstrate dramatic differences between frozen and unfrozen soils. 


\section{Stable isotopes and conductivity}

Electrical conductivity measurements of the surface water indicates that most of the reservoirs have hydraulic connections for groundwater recharge or direct flooding during spring breakup flooding; however, reservoirs nearer to the river had more mixing (Figure 38). The water in reservoir no. 5 had conductivity lower than $88 \mu \mathrm{S} / \mathrm{cm}$. The river and reservoir no. 1 frequently had conductivity over $110 \mu \mathrm{S} / \mathrm{cm}$. This result indicates the reservoirs may be connected with the Kuparuk River. Isotope analyses show the $\delta^{18} \mathrm{O} / \delta^{2} \mathrm{H}(\mathrm{O} / \mathrm{D})$ ratio in all of the reservoir water samples is aligned along the local meteorological line $\left(D=7.0927 \delta^{18} \mathrm{O}-2.8466\right)$. The summer of 2004 was very dry and evaporation was probably close to the maximum potential. The $\delta^{18} \mathrm{O}$ and $\delta^{2} \mathrm{H}$ ratio should be shifted, if the lakes are hydraulically separated (Yoshikawa and Hinzman, 2003). The slope of the evaporation line was 5.5 (equivalent to about $75-80 \%$ of relative humidity) from isolated pond water adjacent to the reservoirs. We can determine the kinetic fraction factors using Gonfiantini's equations as $\Delta e^{18} \mathrm{O}_{\mathrm{v}-\mathrm{bl}}=-7.1 \%$ and $\Delta e^{2} \mathrm{H}_{\mathrm{v}-\mathrm{bl}}=-6.3 \%$ (Gonfiantini, 1986). The overall enrichments for evaporation under these conditions, for the early summer average temperature of $5{ }^{\circ} \mathrm{C}$ is $11.1 \%$ for ${ }^{18} \mathrm{O}, 100 \%$ for ${ }^{2} \mathrm{H}$ (Majoube, 1971). The fractional water loss from evaporation can then be modeled according to Raleigh distillation. For $\delta^{18} \mathrm{O}$ evaporative, enrichment is up to $10 \%$ (Clark and Fritz, 1997).

$$
\delta^{18} \mathrm{O}_{\text {reservoir }}-\delta^{18} \mathrm{O}_{\text {pond }}=e^{18} \mathrm{O}_{\text {total }}{ }^{*} \operatorname{In} f=10 \% \text { Eq.4 }
$$

Yielding a residual water fraction $f$ of 0.4 at $10.2 \%$. This implies an average evaporative loss of $60 \%$ in the ponds adjacent to the reservoirs but not in the reservoirs. The $\delta^{18} \mathrm{O}$ value of the Kuparuk River water is around $-18.5 \%$. The groundwater mixing ratio from the river water and original reservoir water was distinguished using a two member mixing model (Rantz, et al. 1982).

$$
Q_{\text {in }}=Q_{\text {res }}\left(I_{\text {res }}-I_{\text {ori }}\right) /\left(I_{\text {river }}-I_{\text {ori }}\right) \quad \text { Eq.5 }
$$

Where $Q_{\text {res }}=$ current reservoir volume; $Q_{\text {in }}=$ infiltration volume of river water; $I_{\text {river }}=\delta^{18} \mathrm{O}$ value of the river water; $I_{\text {res }}=\delta^{18} \mathrm{O}$ value of the current reservoir; and $I_{\text {ori }}=\delta^{18} \mathrm{O}$ value of the original reservoir water. The reservoir and groundwater inflow had a nearly constant value of $\delta^{18} \mathrm{O}$ value between -19.5 and $-18.5 \%$, which indicates $70-90 \%$ of the reservoir water will be derived from river inflow, either from ground-water inflow, or surface flooding in the spring.

We did not detect any evaporation from these lakes with the isotope data but can distinguish evaporation from adjacent ponds and standing water bodies. In summer season, Mendez et al. (1998) measured an average relative humidity of $30 \%$ and $15 \mathrm{~cm} /$ year of evaporation. 

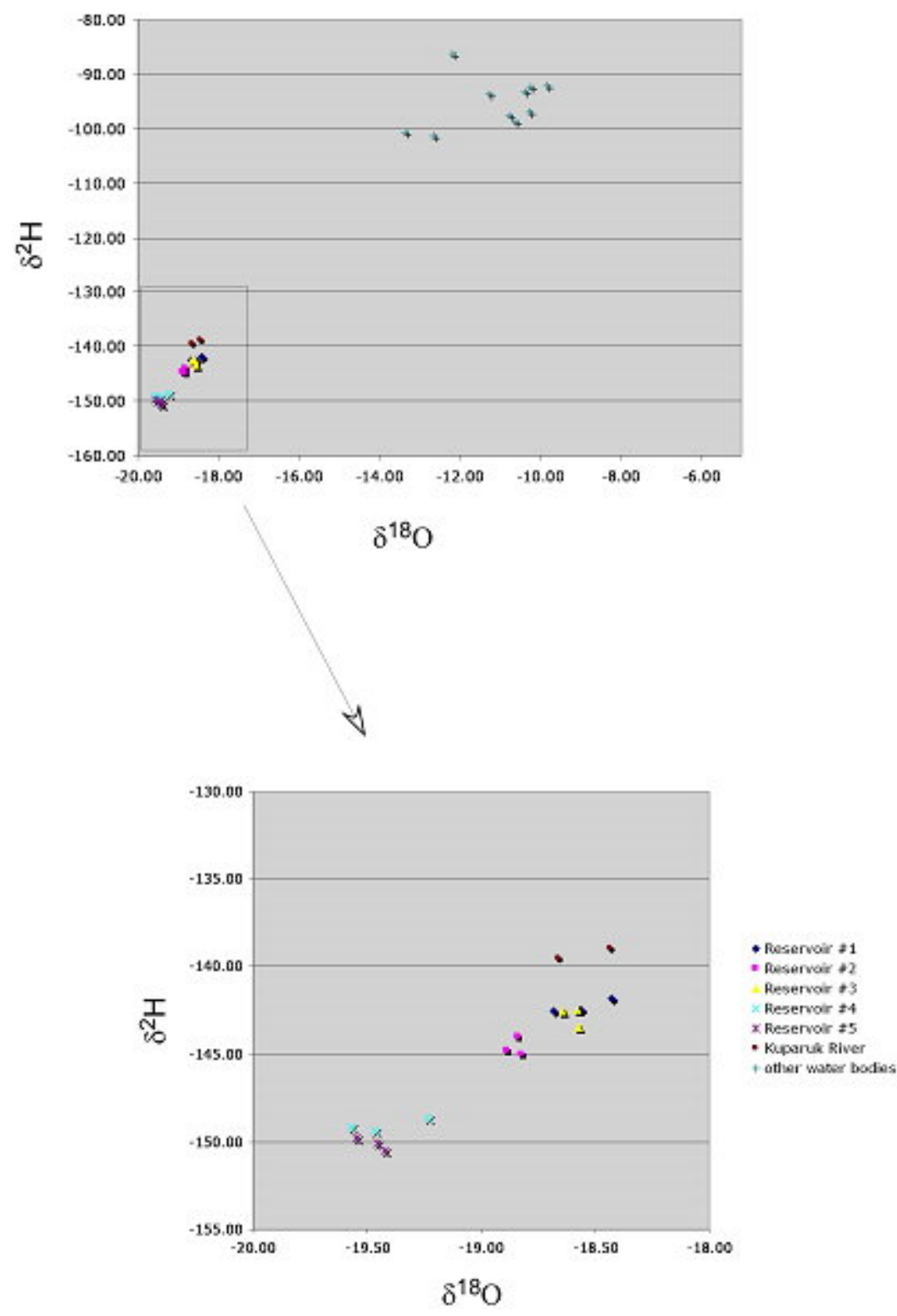

Figure 38. Stable isotope measurements of surface water bodies taken during summer conditions.

\section{Discussion}

The isotope and conductivity results indicate the reservoirs are hydraulically directly connected with Kuparuk River. The talik material was estimated to be homogeneous saturated sand, but no logs have been found to help verify there is not a low permeability (lithologic) layer of material that would serve as a flow boundary within a talik. To help better understand the results of the resistivity and isotope analysis, water elevation surveys were conducted during the winter months of 2005-2006. These surveys help show that, while there is evidence of a talik, there is probably no effective flow between cells 1-3. During this period, water was only pumped out of cell 2. Cell 1 has a shallow surface water connection that is dry by early freeze-up in the lakes. The channels between cell 2 and 3 appeared to be blocked by ice or frozen ground by January. 
The results of the elevation surveys indicate there is no measurable flow between the cells after surface-water channels are either dry, or blocked by lake ice formation (Figure 39).

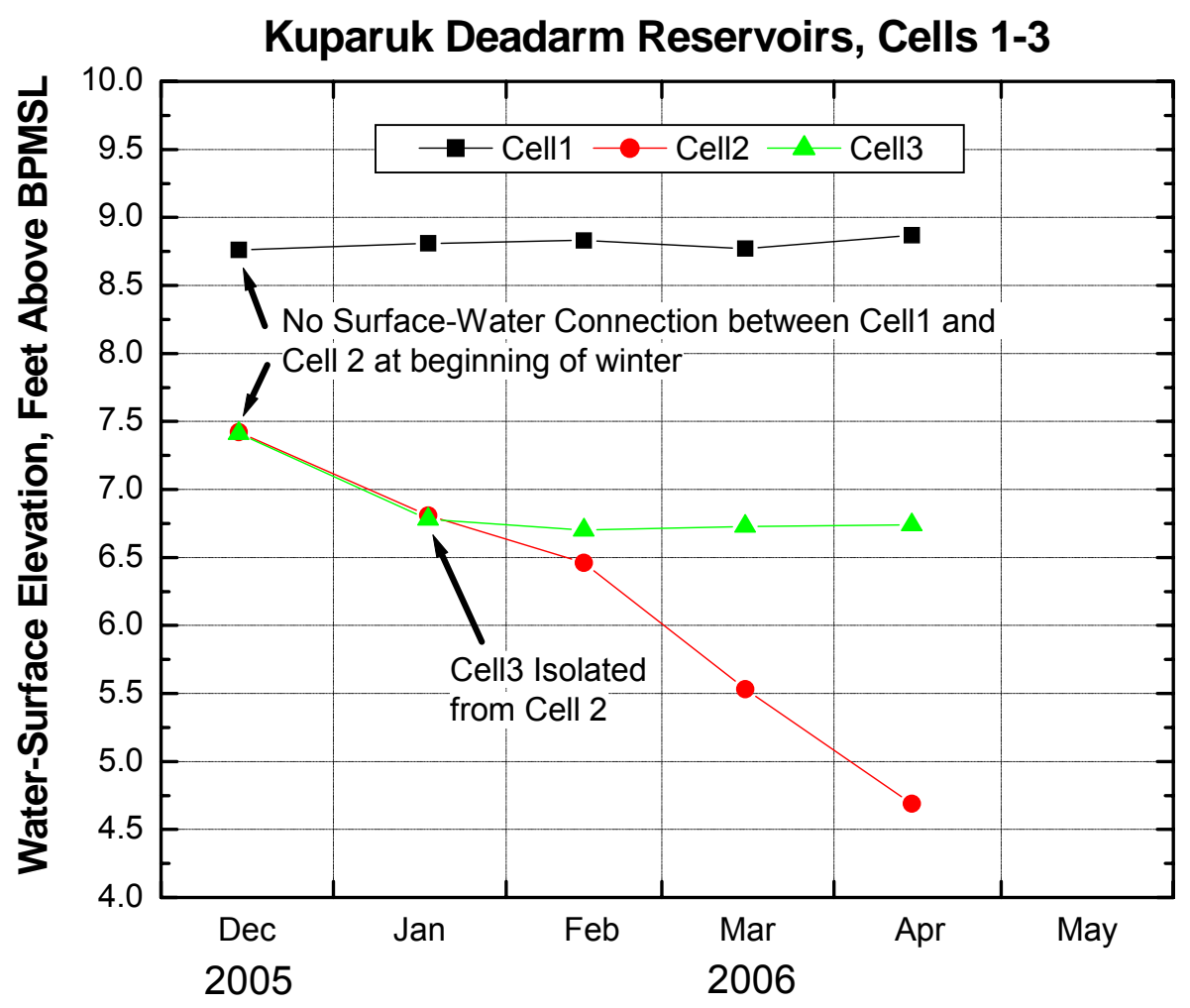

Figure 39. Water elevation surveys (BPMSL) measured during the winter of 2005-2006 for Kuparuk Deadarm Lakes, cells 1-3. During winter months, this is the water surface in open drill holes in the lake ice.

A resistivity survey is powerful and sensitive technique for talik detection. Stable isotope concentrations are ideal parameters to quantify the degree of water mixing. The combination of geophysical surveys, isotope analyses, and water elevation surveys allow us to better understand potential groundwater movement as well as permeability without any disturbance to the surface or subsurface conditions. Direct drilling of boreholes is expensive and requires surface disturbance. A combination of geophysical methods, geochemistry analysis, and elevation surveys can help define complex subsurface flow systems in taliks, and verify effective ground-water connections between lakes (reservoirs) and adjacent streams and rivers. 


\section{RESULTS AND DISCUSSION}

Water surface levels, specific conductance, dissolved oxygen, water temperature and water quality variables were examined to determine the effect of pumping activities. This discussion focuses on the 2003-2004 winter period since the instrumented stations were recording throughout the entire winter; however 2002-2003 and 2004-2005 winters displayed similar trends. Pumped lake measurements are compared to control lake measurements, which provide a baseline to detect and measure physical and chemical responses due to pumping activities. Where appropriate, volumes of water withdrawn from the pumped lakes are illustrated.

In the analyses, manual measurements by handheld meters during site visits are also presented to verify the continuous measurements. Continuous measurements were further verified by a paired redundant sensor for each variable. An investigation of the variations in water chemistry in vertical profiles and in a horizontal spatial array (data presented in Appendix I) demonstrates that the differences between manual and continuous measurements may be attributed to vertical sampling differences in the water column (for instance, the difference between a manual measurement at two feet above sediment compared to a continuous measurement one foot above sediment) as well as lateral change across the lake (for instance, the difference between a continuous measurement at the instrumented station compared to a manual measurement fifty feet north of the station).

\subsection{Pumping Activity}

Tundra lakes have been relied upon for large volumes of freshwater since the 1970s when oil activities began on the North Slope. The volumes of withdrawal depend mostly on the requirements of exploration and corresponding ice road requirements. Study lakes, K209P and K214P, were utilized during the 2002-2003, 2003-2004 and 2004-2005 winter ice road construction seasons (CPAI, 2004).

Pumping events were of different time duration and different withdrawal volume. Activity ranged from light pumping $\left(<500 \mathrm{~m}^{3} / \mathrm{d}\right)$ or $(<132086 \mathrm{gal} / \mathrm{d})$ to heavy pumping $\left(>2,000 \mathrm{~m}^{3} / \mathrm{d}\right)$ or $(528344$ $\mathrm{gal} / \mathrm{d}$ ). Industry pumping records were reported as an accumulated withdrawal volume over one day or an accumulated withdrawal volume over one month (CPA, 2004, 2006).

Changes in water surface level (WSL) due to water withdrawal volumes were estimated by two methods and these estimates are then used for comparison to the detected changes in WSL. One estimate is based on an assumption of pan or box lake bathymetry as seen in Figure 40. The expected change in WSL was calculated by dividing the volume of water withdrawal by the lake's surface area. The other estimate, using a conical projection as seen in Figure 41, takes into account a more gradual side contour reaching to the maximum depth of the lake. The expected change in WSL was calculated by dividing the volume of water withdrawal by the projected under-ice surface area of the water. The actual change in WSL detected by the sensor should fall between the ranges of these two extreme bathymetries. Figure 42, Figure 43, and Figure 44 present bathymetric transects of typical thaw lakes (including study lake K209P) near the Colville delta showing that actual thaw lake bathymetry falls between the idealized pan 
and cone projection (Moulton, 1998). Thus, the detected change in WSL by the instrumented station should fall between the expected change in WSL based on the pan and cone projection for lakes K209P and K214. We have also used a method that computes total volume based on measured bathymetry where such data exists; in principle, this approach should be better than the cone or pan methods.

Figure 45, Figure 46 and Figure 47 present expected cumulative change in water surface level resulting from discrete pumping events during the 2002-2003, 2003-2004 and 2004-2005 winters using the pan bathymetry method. Expected changes based on a cone bathymetry are shown in subsequent analyses. Appendix D also present expected change in WSL data numerically.

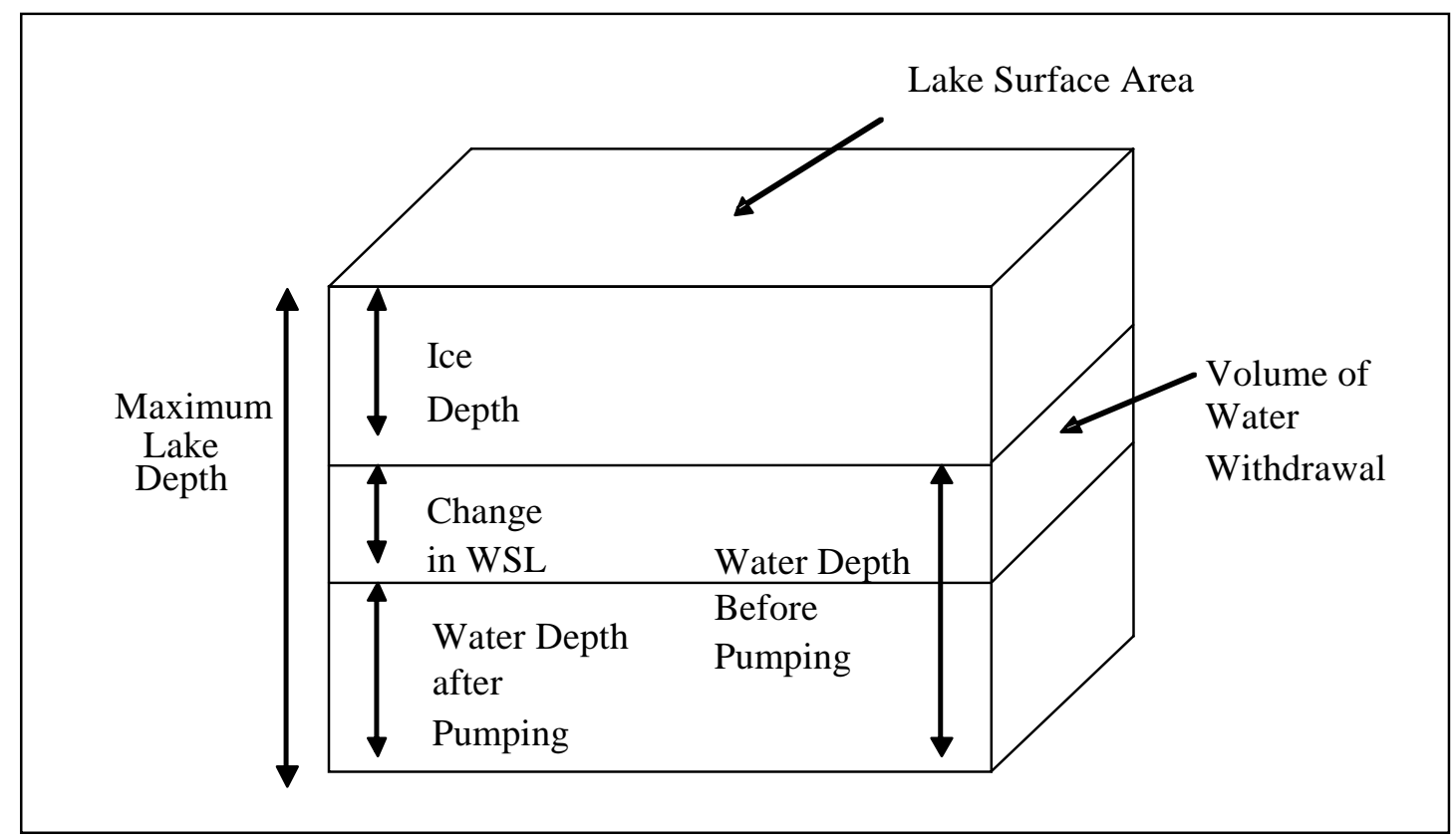

Figure 40. Illustration of pan bathymetry and response in water surface level corresponding to an exaggerated volume of water withdrawal. 


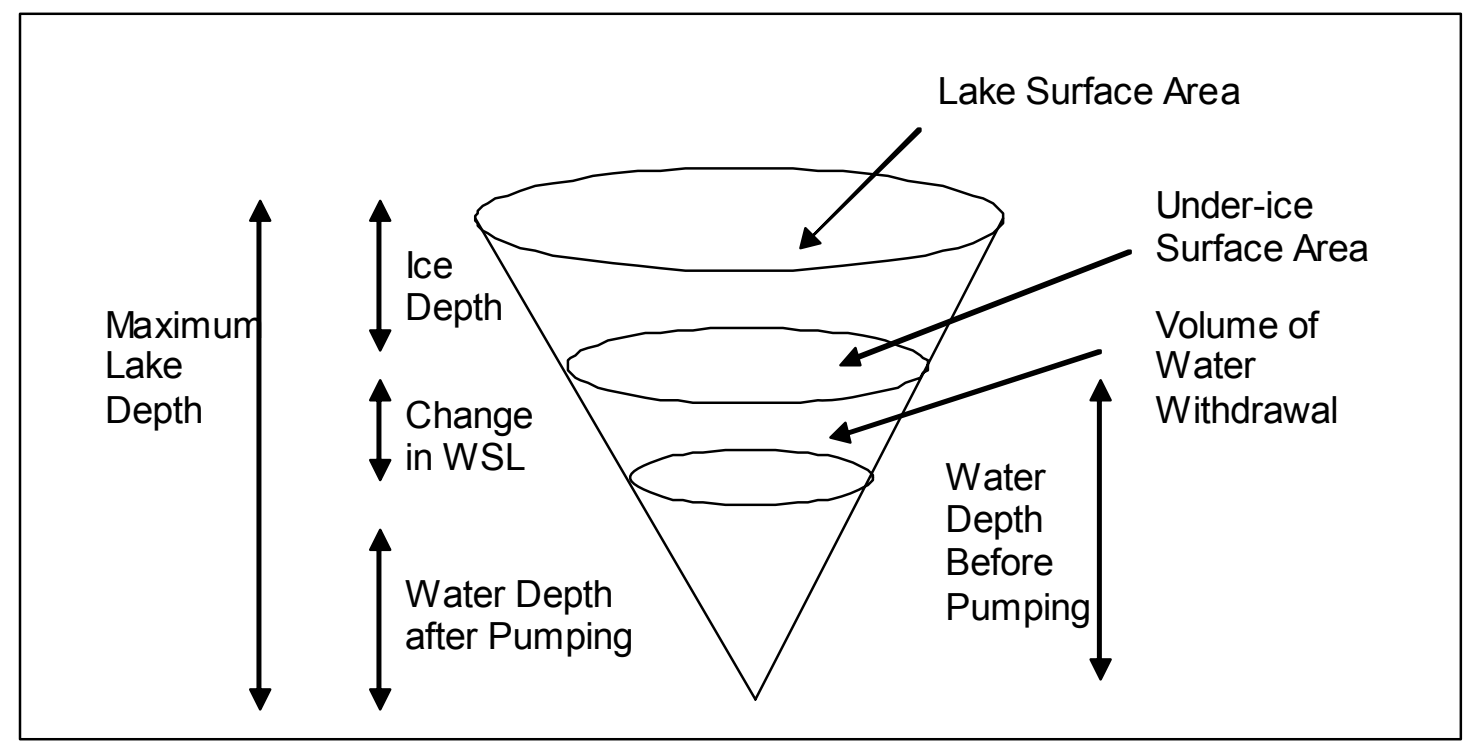

Figure 41. Illustration of cone bathymetry and response in water surface level corresponding to an exaggerated volume of water withdrawal.

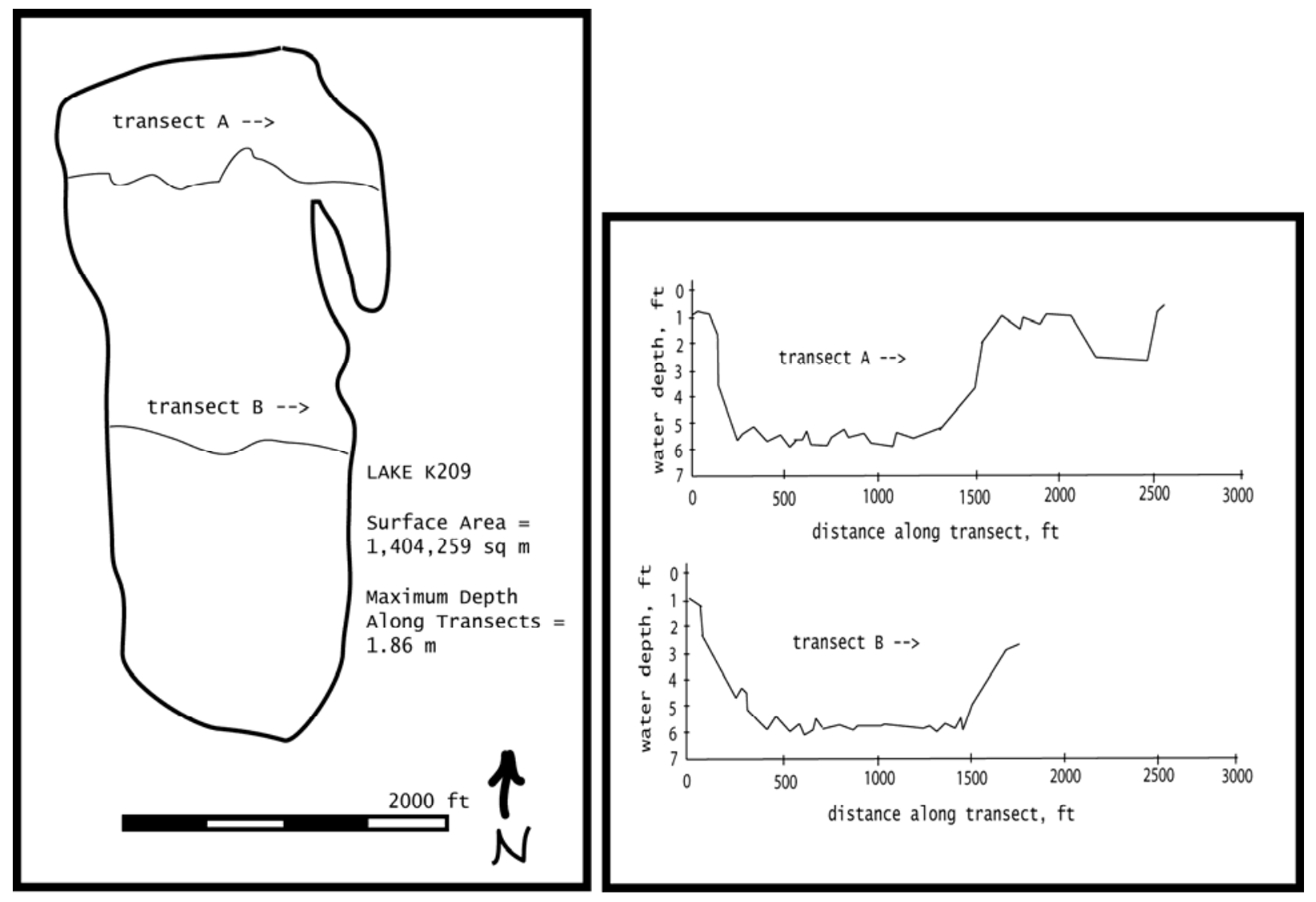

Figure 42. Bathymetric transects of study lake K209P (reproduced from Moulton 1998). 


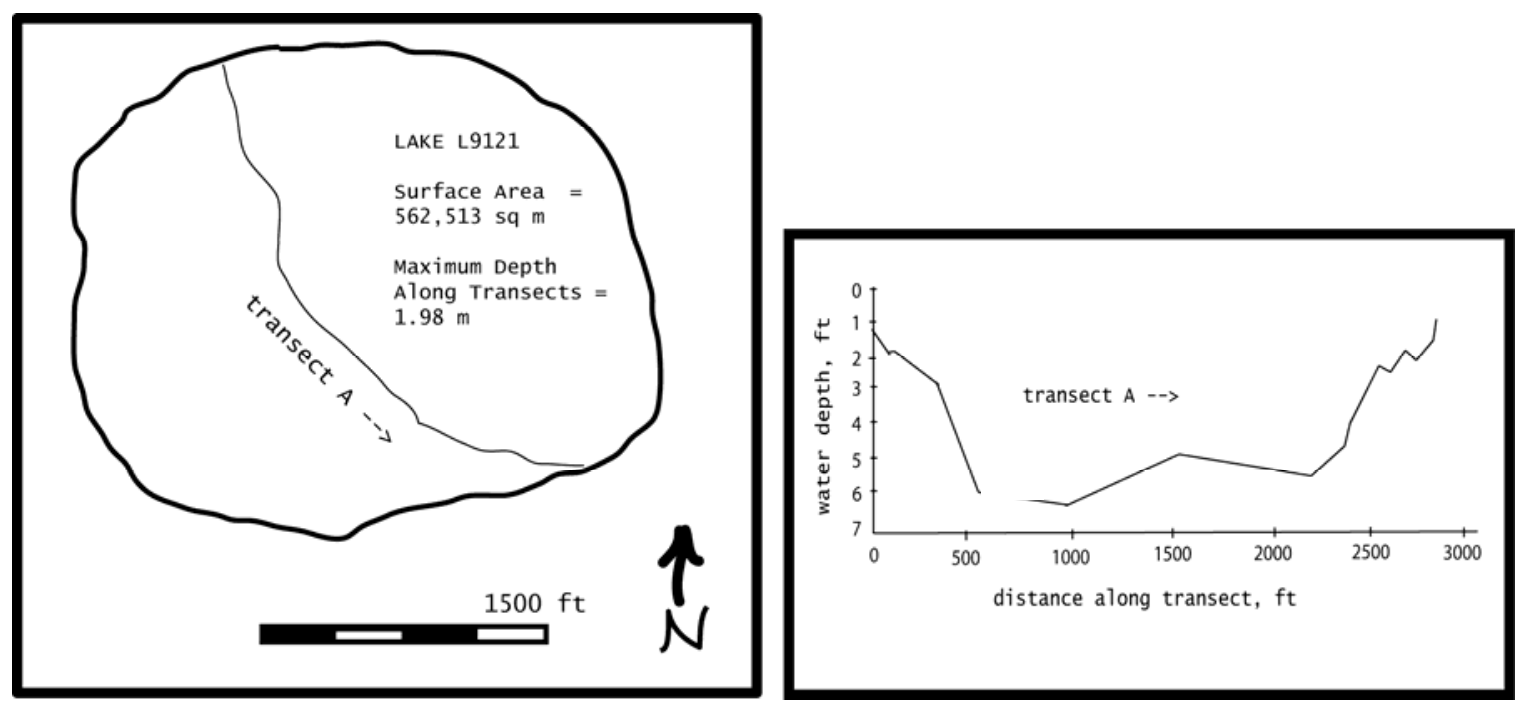

Figure 43. Bathymetric transects of lake L9121, a thaw lake east of the Colville River about $5 \mathrm{~km}$ northeast of K209P and $7.5 \mathrm{~km}$ west of K214P (reproduced from Moulton 1998).
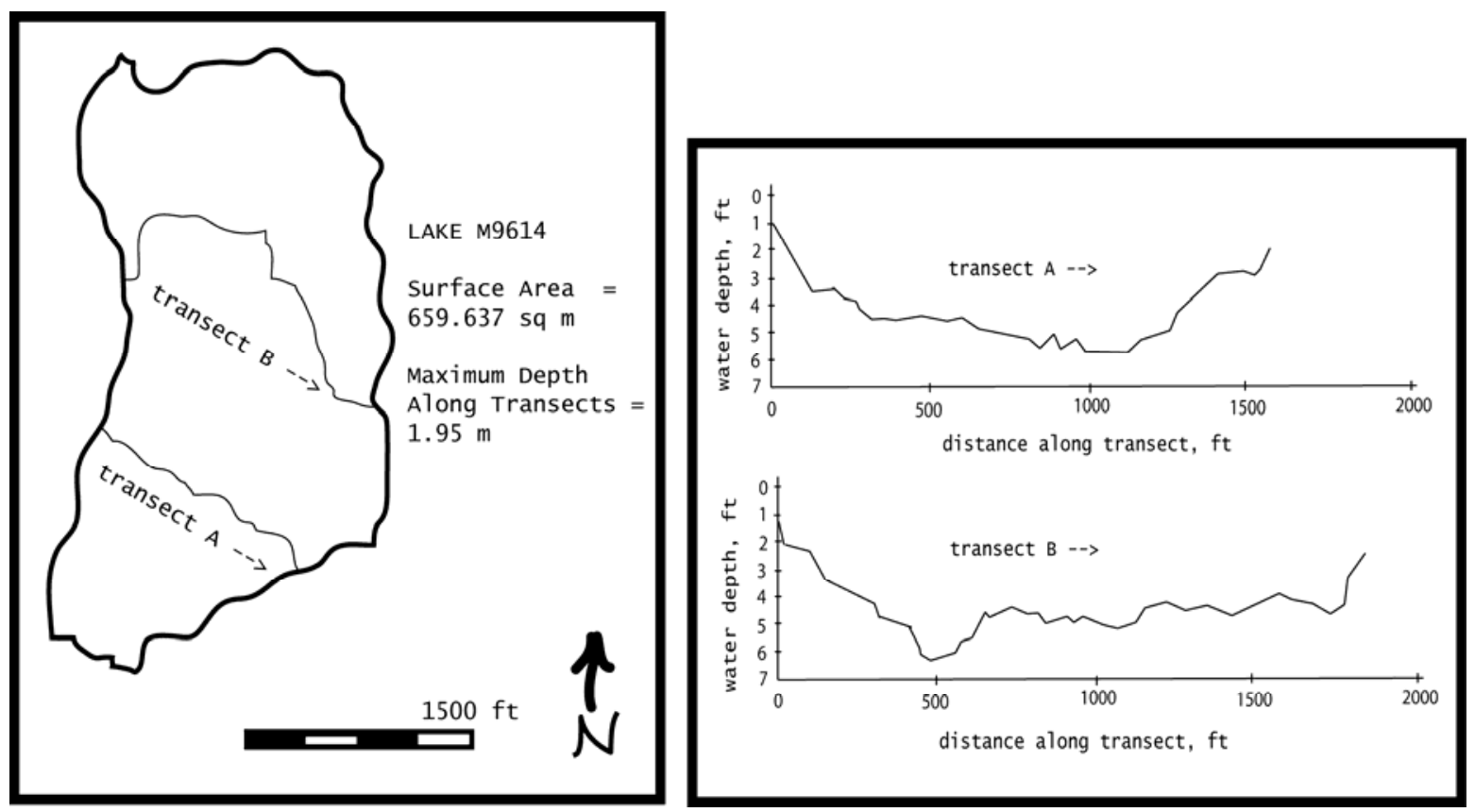

Figure 44. Bathymetric transects of lake M9614, a thaw lake east of the Colville River bounded by the Colville and Kachemach Rivers (reproduced from Moulton 1998). M9614 is about $11 \mathrm{~km}$ west by northwest of K209P. 


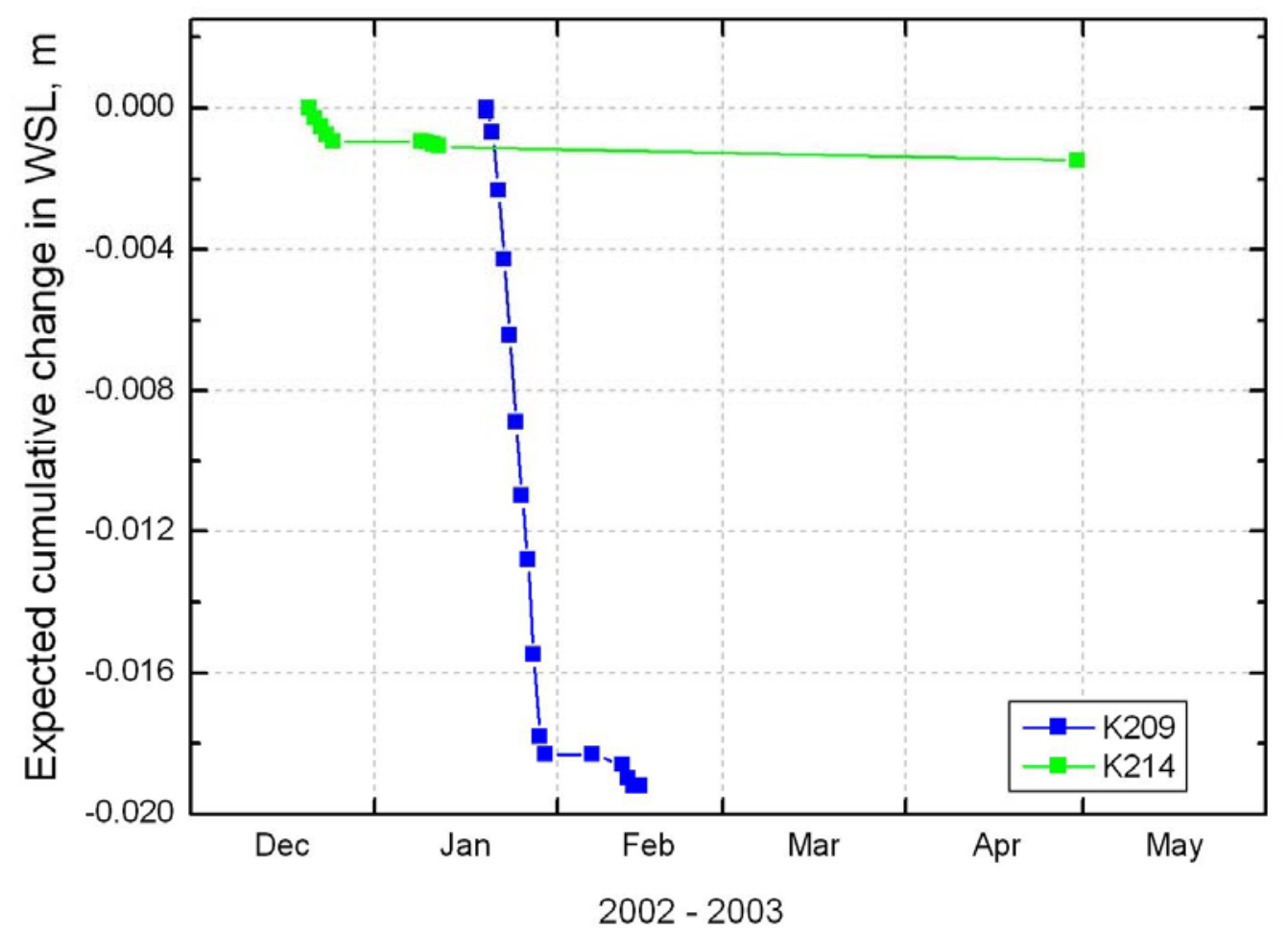

Figure 45. Expected cumulative change in water surface level due to pumping activity during the 20022003 winter based on a pan bathymetry. 


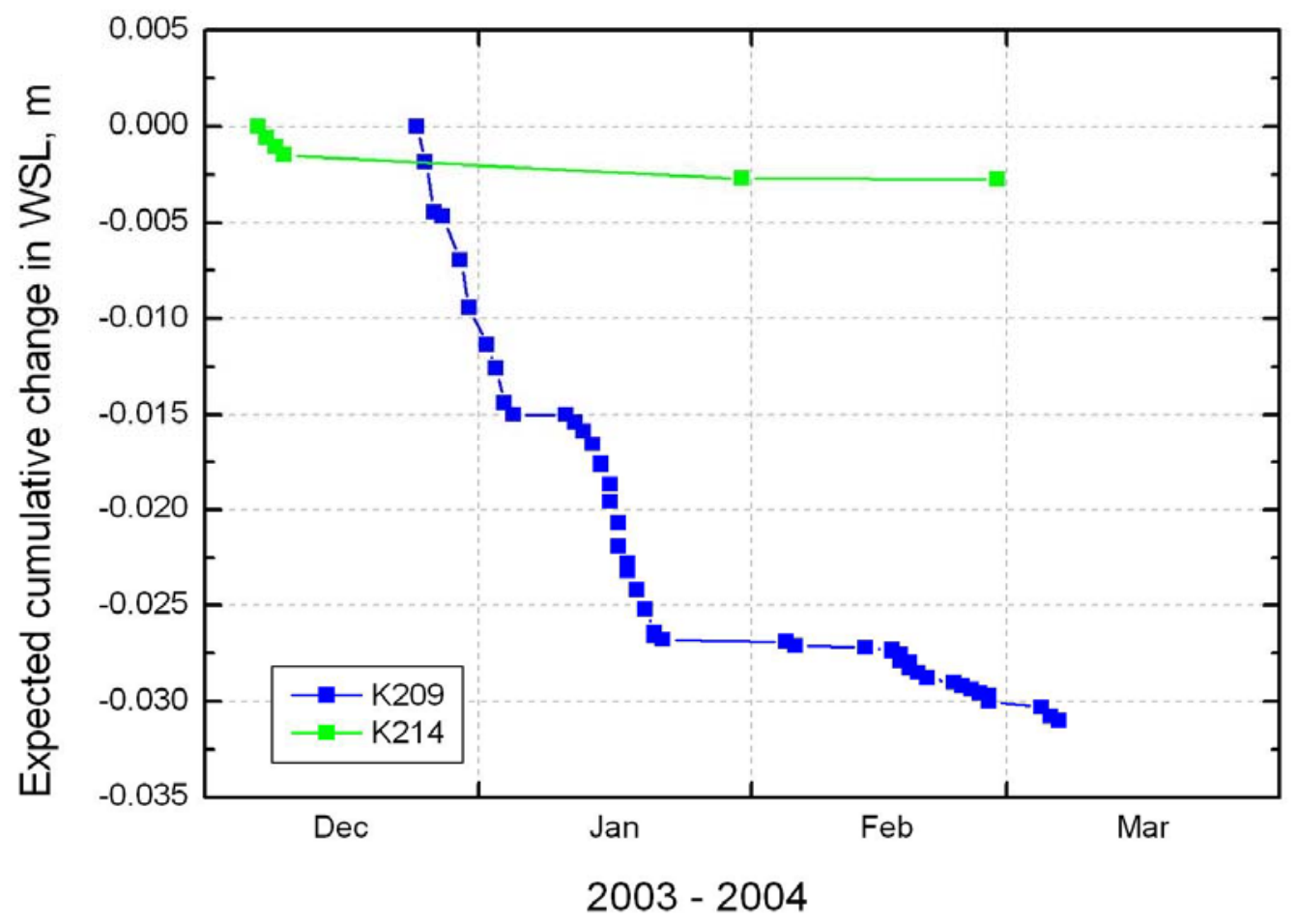

Figure 46. Expected cumulative change in water surface level as a result of pumping activity during 20032004 winter based on a pan bathymetry. 


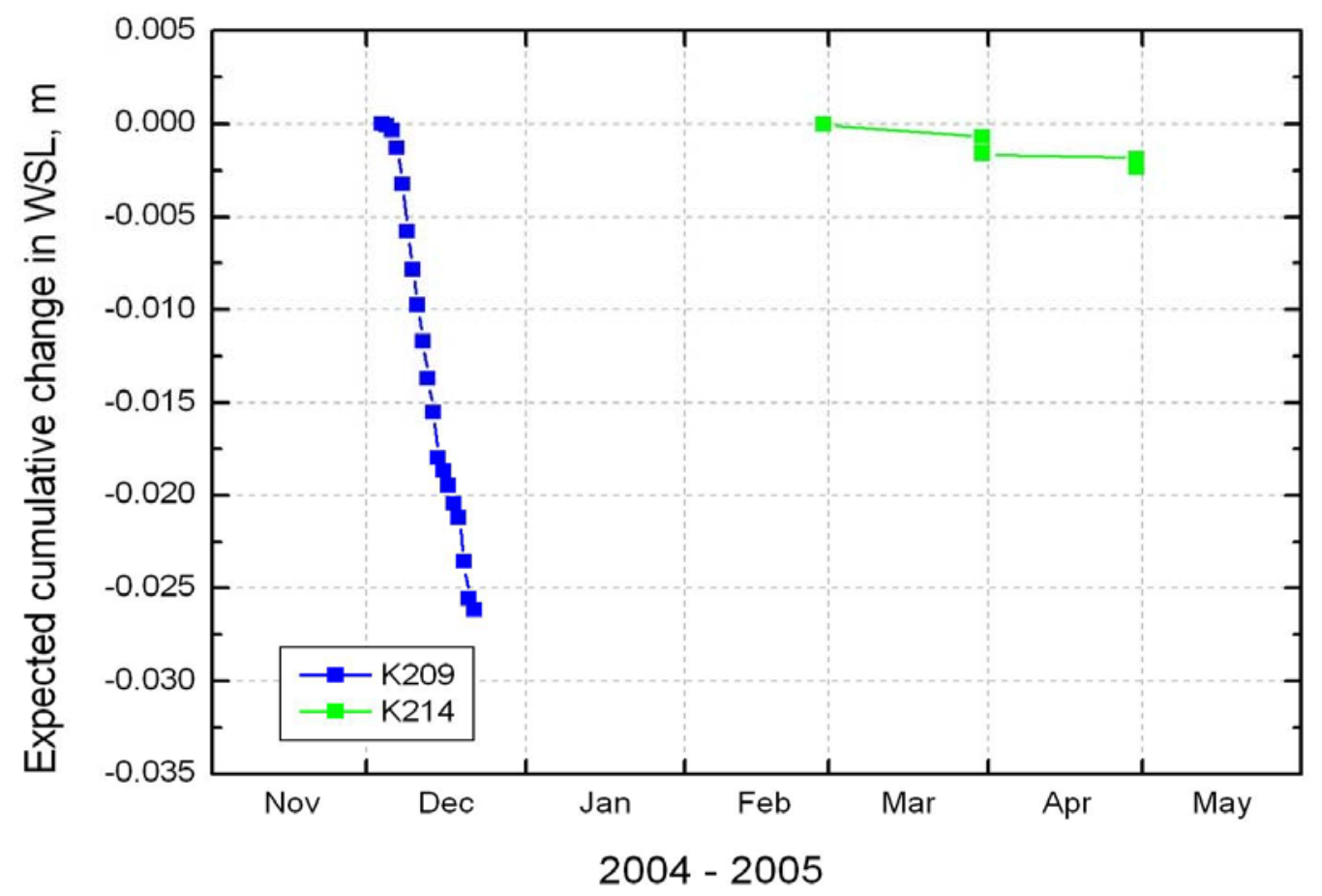

Figure 47. Expected cumulative change in water surface level as a result of pumping activity during 20042005 winter based on a pan bathymetry.

As apparent in Figure 45, Figure 46 and Figure 47, the expected water surface level change from winter pumping activity is small. For instance, expected drawdown of WSL at lake K214P from pumping activity does not cumulatively exceed the $0.005 \mathrm{~m}$ resolution of the pressure transducer sensor over the course of the 2002-2003, 2003-2004 or 2004-2005 winters. Lake K209P, with less surface area and higher volumes of water withdrawal, did display greater changes in WSL. Nevertheless, the expected changes at K209P are still very small and discrete time periods of substantial pumping activity must be integrated for any change of WSL with sensor resolution to be observed. Overall, cumulative pumping activities at K209P and K214P for winter 2002-2003, 2003-2004 and 2004-2005 ranged from 0.2 - 5.2 \% withdrawal of the total volume and $3.9-10.5 \%$ of the permitted volume.

The detection of WSL is further complicated by environmental factors; most significantly, snow loading atop the ice surface increases the perceived WSL. Although this is a correct measurement of the WSL, it interferes with the measurement of WSL of useable liquid water beneath the ice. Thus, it is essential to accurately quantify the snow load to correctly identify the small water surface level changes under the ice. An additional environmental factor that would influence perceived WSL is barometric pressure, but the pressure transducer, which measures WSL, is vented to the atmosphere, which eliminates the effect of barometric pressure changes. An important note is that snow loading on the lakes does not develop uniformly as snow distribution is formed by the constant strong winds. This has the effect of increasing snow 
loading at thaw lakes with older well-developed basins. Another impact to perceived WSL may be water trucks moving over the ice but this is difficult to quantify without knowing the exact time of the pumping activity when water trucks were on the lake ice.

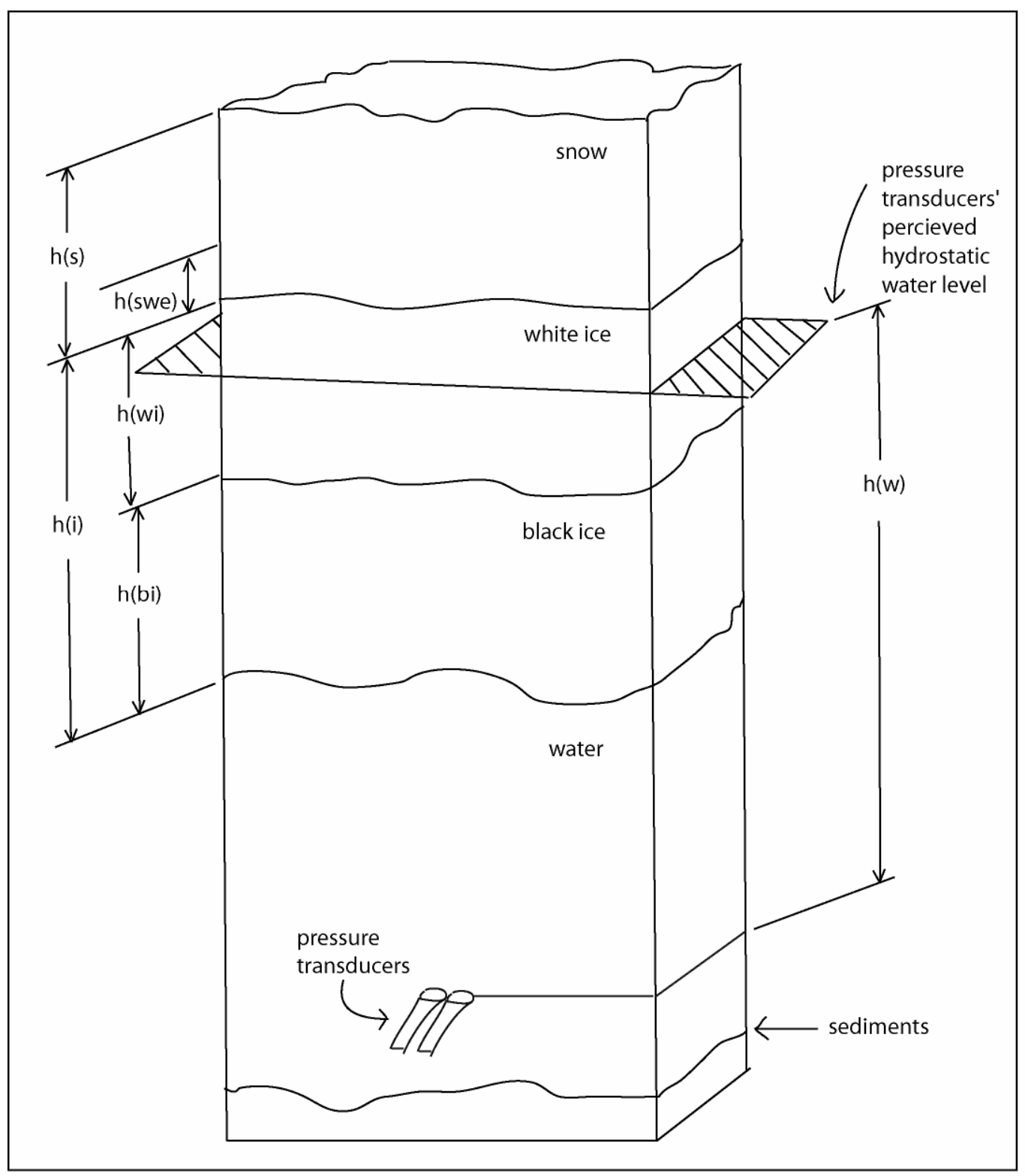

Figure 48. Illustration of perceived water levels at study lakes where $\mathrm{h}$ is equivalent to thickness and $\mathrm{s}=$ snow,$i=i c e$, swe $=$ snow water equivalence, $w i=$ white ice,$b i=$ black ice and $w=$ water. Illustration is conceptual and without scale. 
In attempting to filter out the primary environmental influence of snow loading on WSL, winter precipitation data were obtained from a Wyoming Snow Gauge at the Betty Pingo meteorological site. Trends in WSL at the lakes correlate well with the winter precipitation at Betty Pingo (Figure 49, Figure 50, Figure 51). Some scatter of the data is observed due to drifting of the snowpack but overall measurements of precipitation and measurements of WSL trend well. For example, the change in WSL at control lake $\mathrm{K} 113 \mathrm{C}(+8 \mathrm{~cm})$ is nearly equal to the cumulative snow water equivalent detected at the Betty Pingo meteorological site $(+9 \mathrm{~cm})$ from November 1, 2003 to May 1, 2004. This is expected since there is no winter water withdrawal at $\mathrm{K} 113 \mathrm{C}$. A similar trend of change in WSL following winter precipitation is observed at lake K214P since little pumping occurred and water surface level change from pumping activities was expected to be less than $0.005 \mathrm{~m}$. In contrast, heavily pumped lake K209P shows a slight response to pumping as WSL declines due to pumping (Figures 49-56).

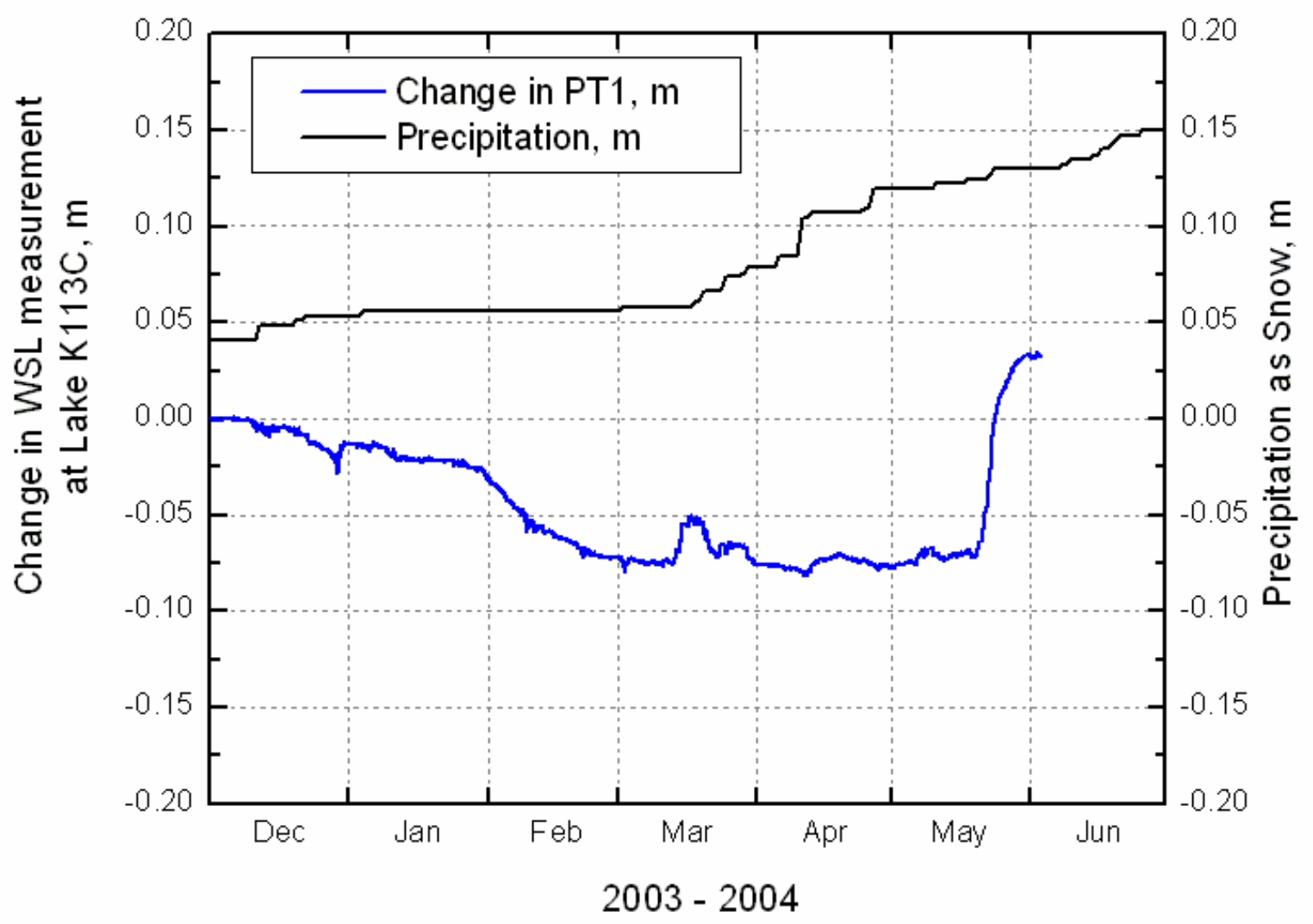

Figure 49. Change in pressure transducer 1 water surface level at lake $\mathrm{K} 113 \mathrm{C}$ compared to measurements of precipitation as snow at Betty Pingo during the 2003-2004 winter. 


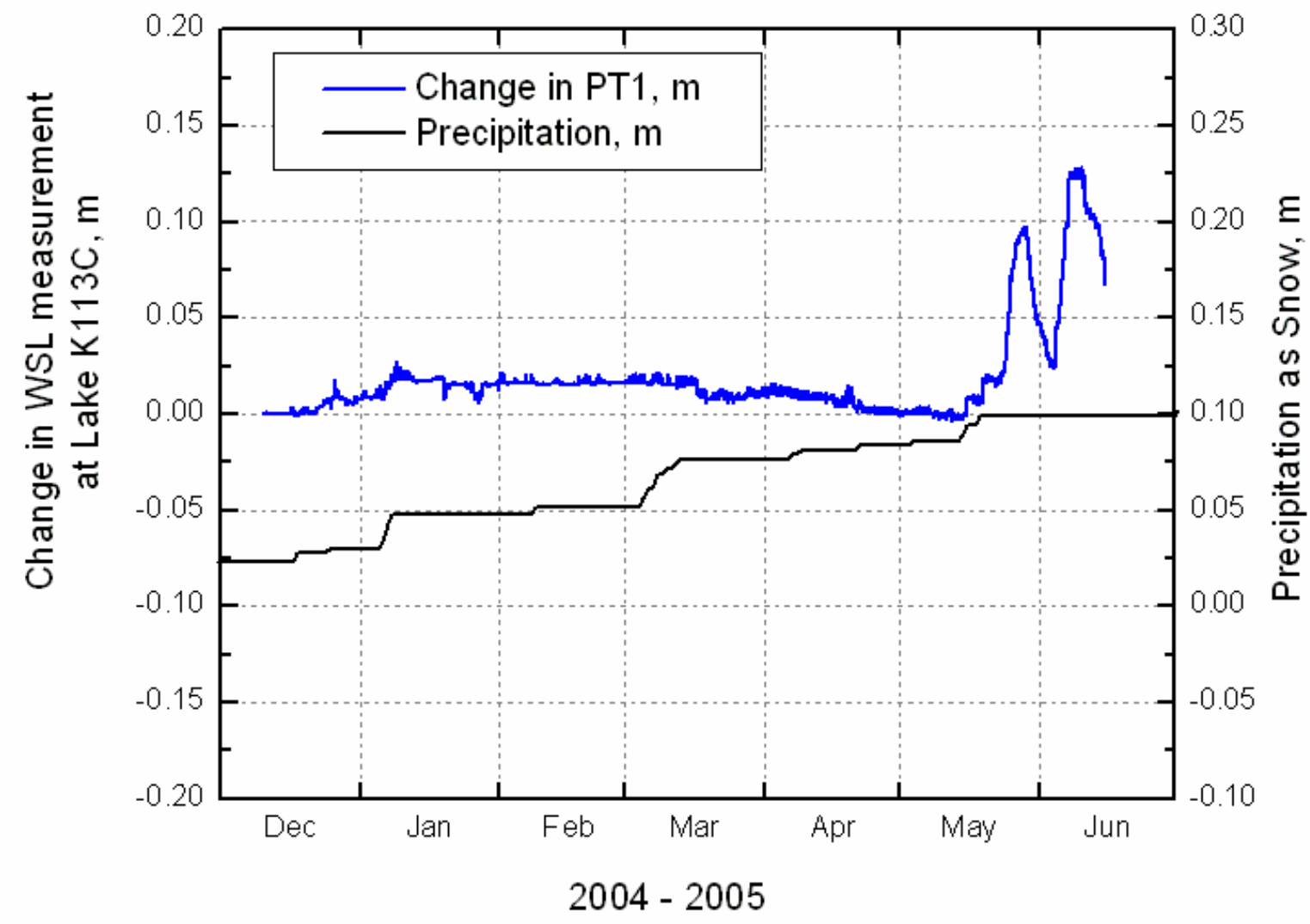

Figure 50. Change in pressure transducer 1 water surface level at lake $\mathrm{K} 113 \mathrm{C}$ compared to measurements of precipitation as snow at Betty Pingo during the 2004-2005 winter. 


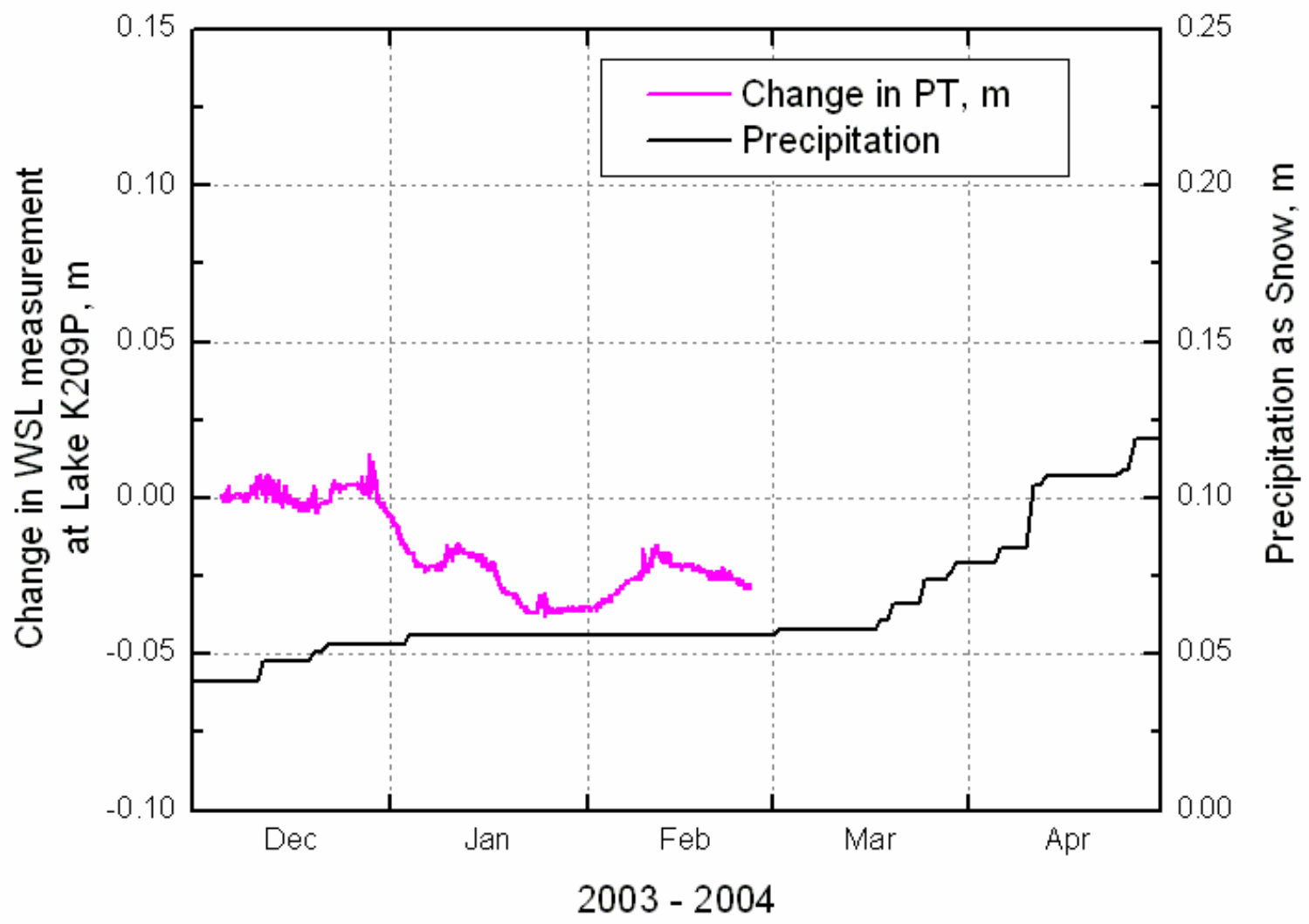

Figure 51. Change in water surface level at lake K209P compared to winter precipitation at Betty Pingo during the 2003-2004 winter. Pressure transducers disconnected in late-February 2004. 


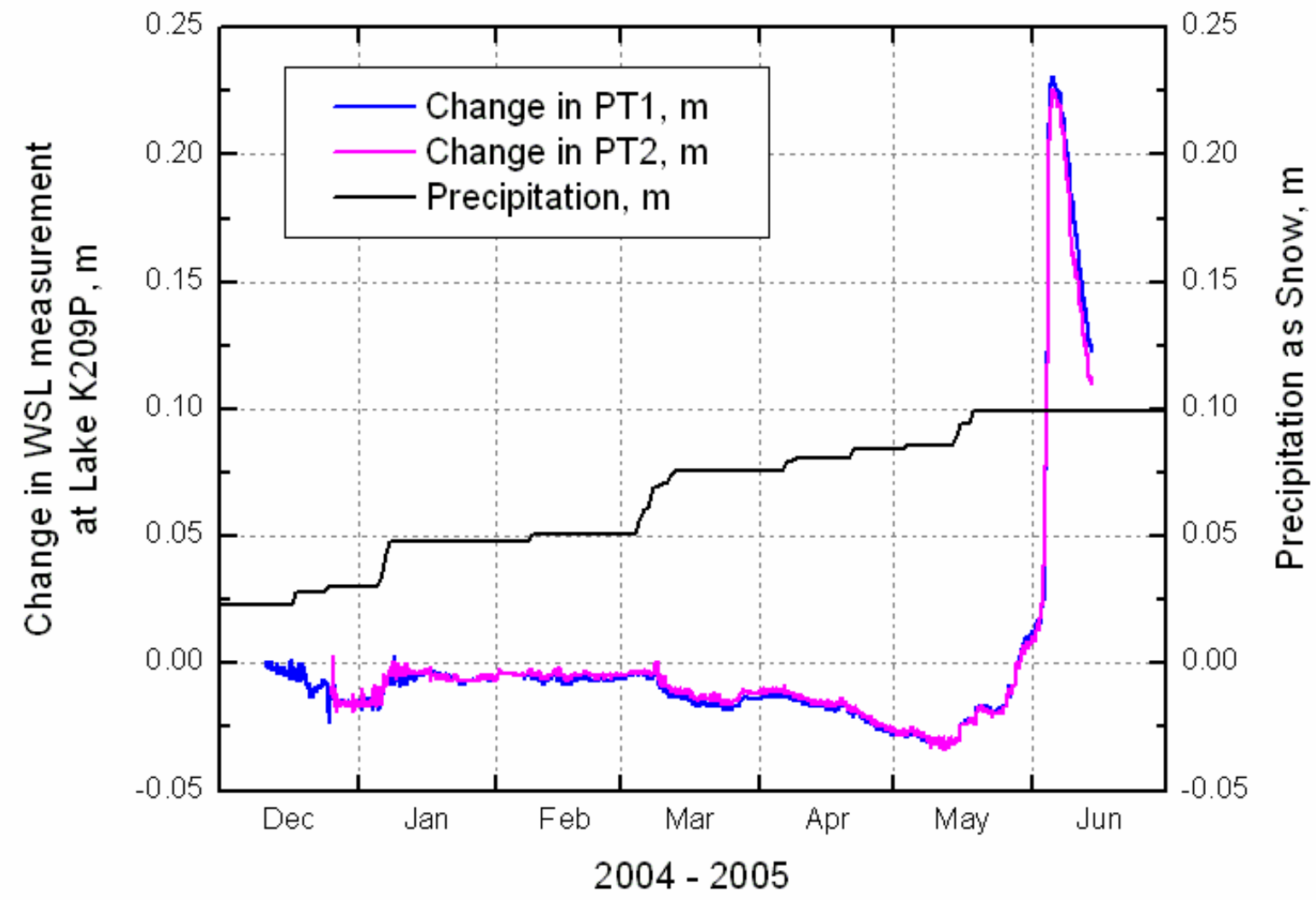

Figure 52. Change in water surface level at lake K209P compared to winter precipitation at Betty Pingo during the 2004-2005 winter. 


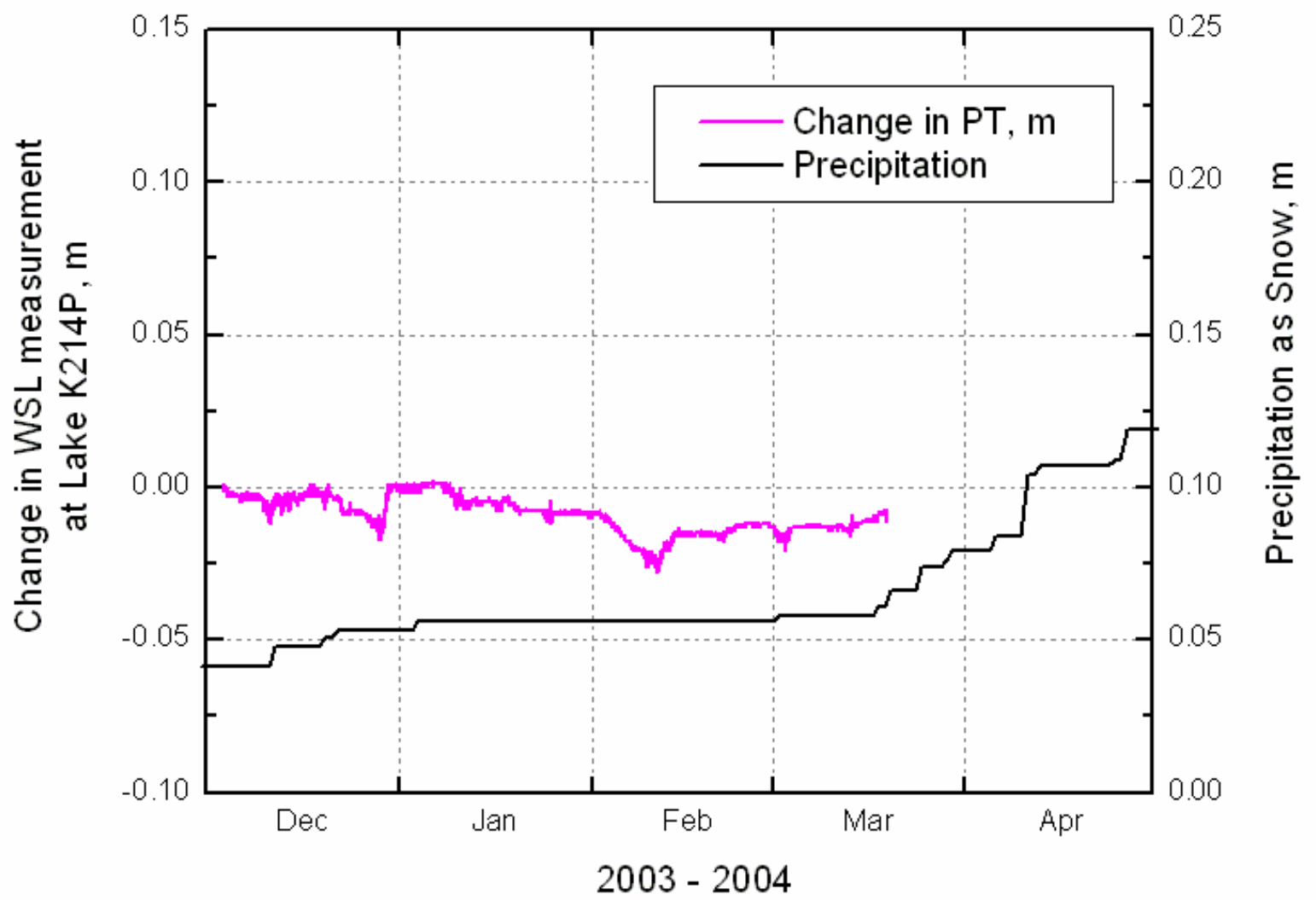

Figure 53. Change in water surface level at lake K214P compared to winter precipitation at Betty Pingo during the 2003-2004 winter. 


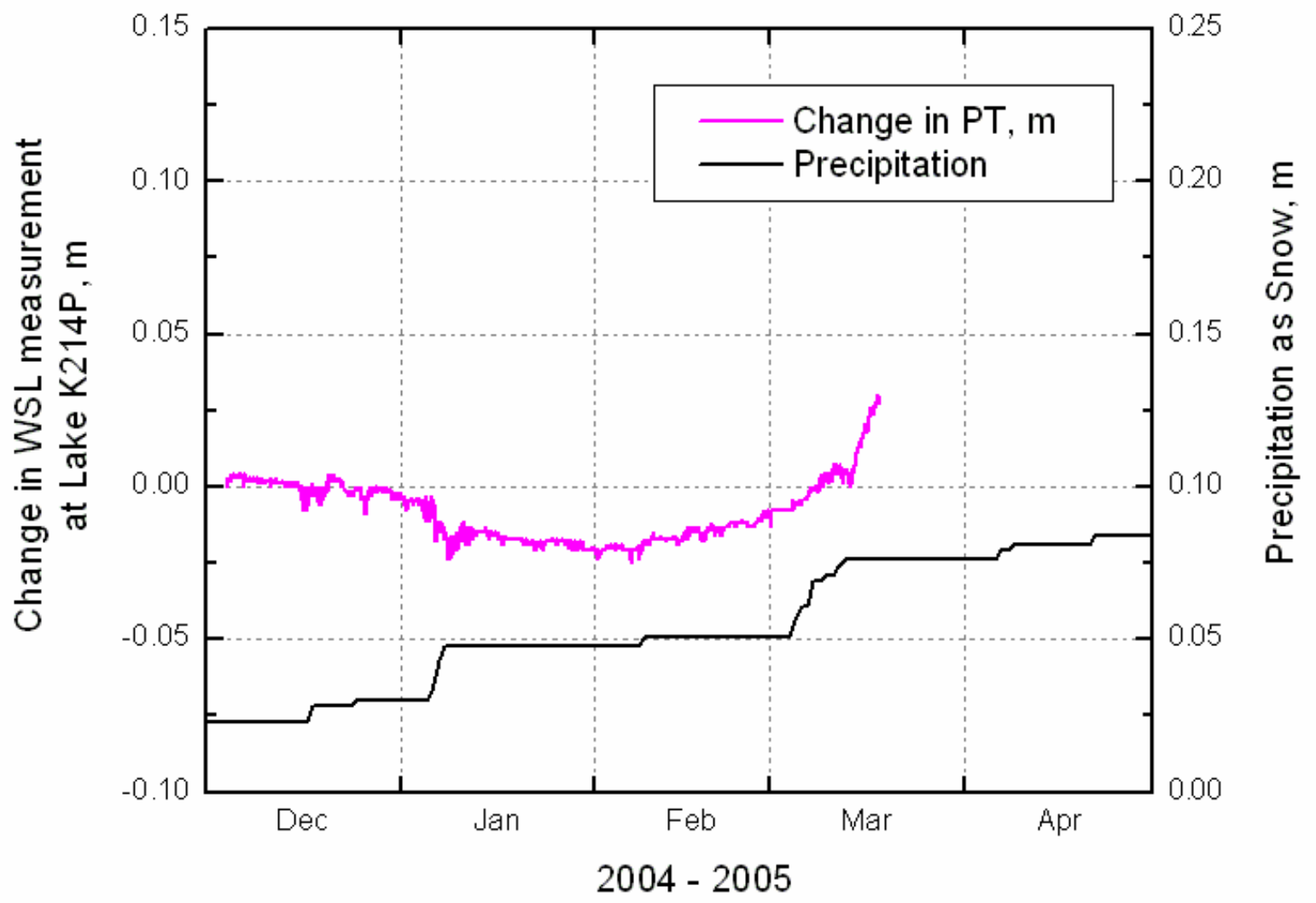

Figure 54. Change in water surface level at lake K214P compared to winter precipitation at Betty Pingo during the 2004-2005 winter. 


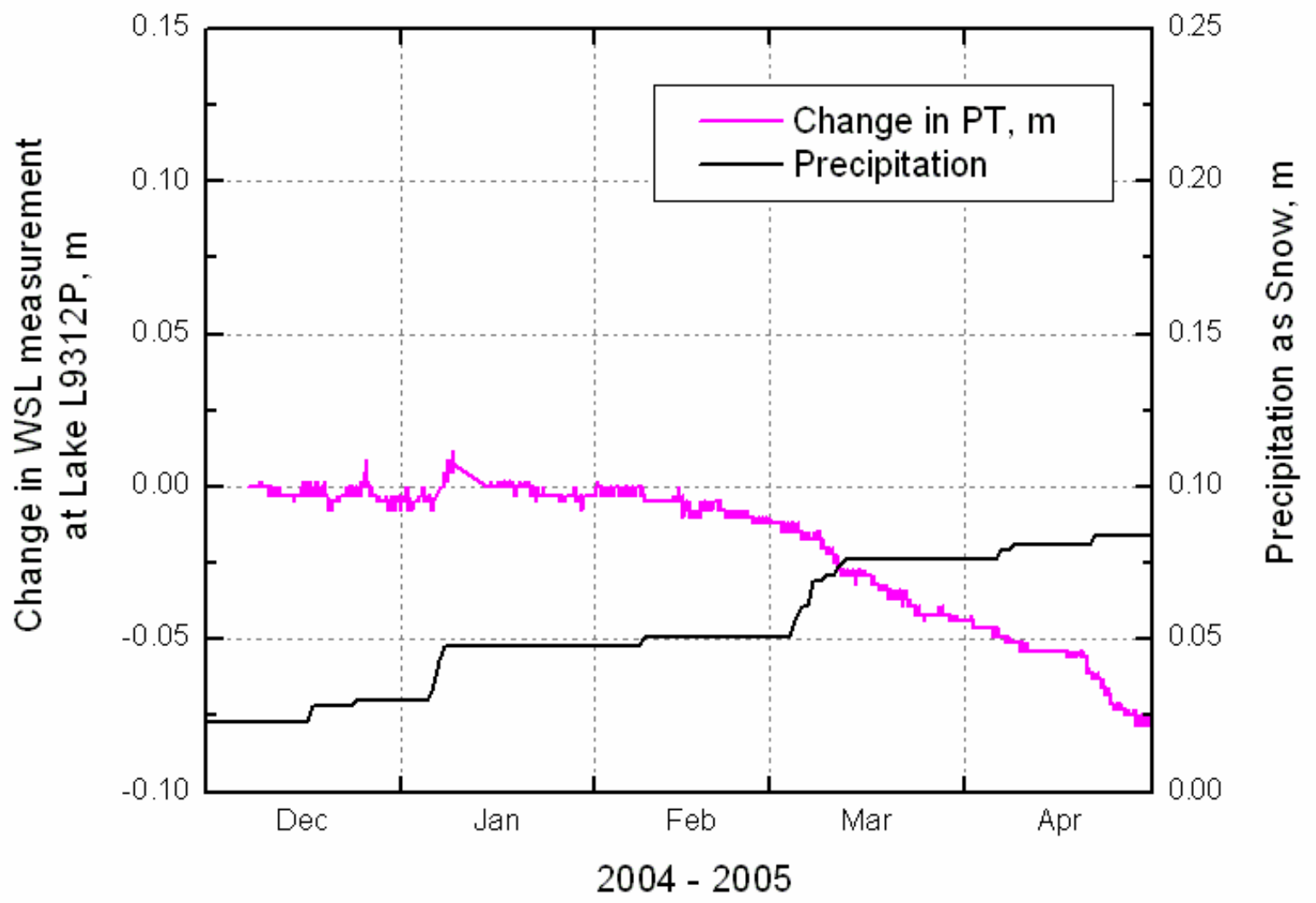

Figure 55. Change in water surface level at lake L9312 compared to winter precipitation at Betty Pingo during the 2004-2005 winter. 


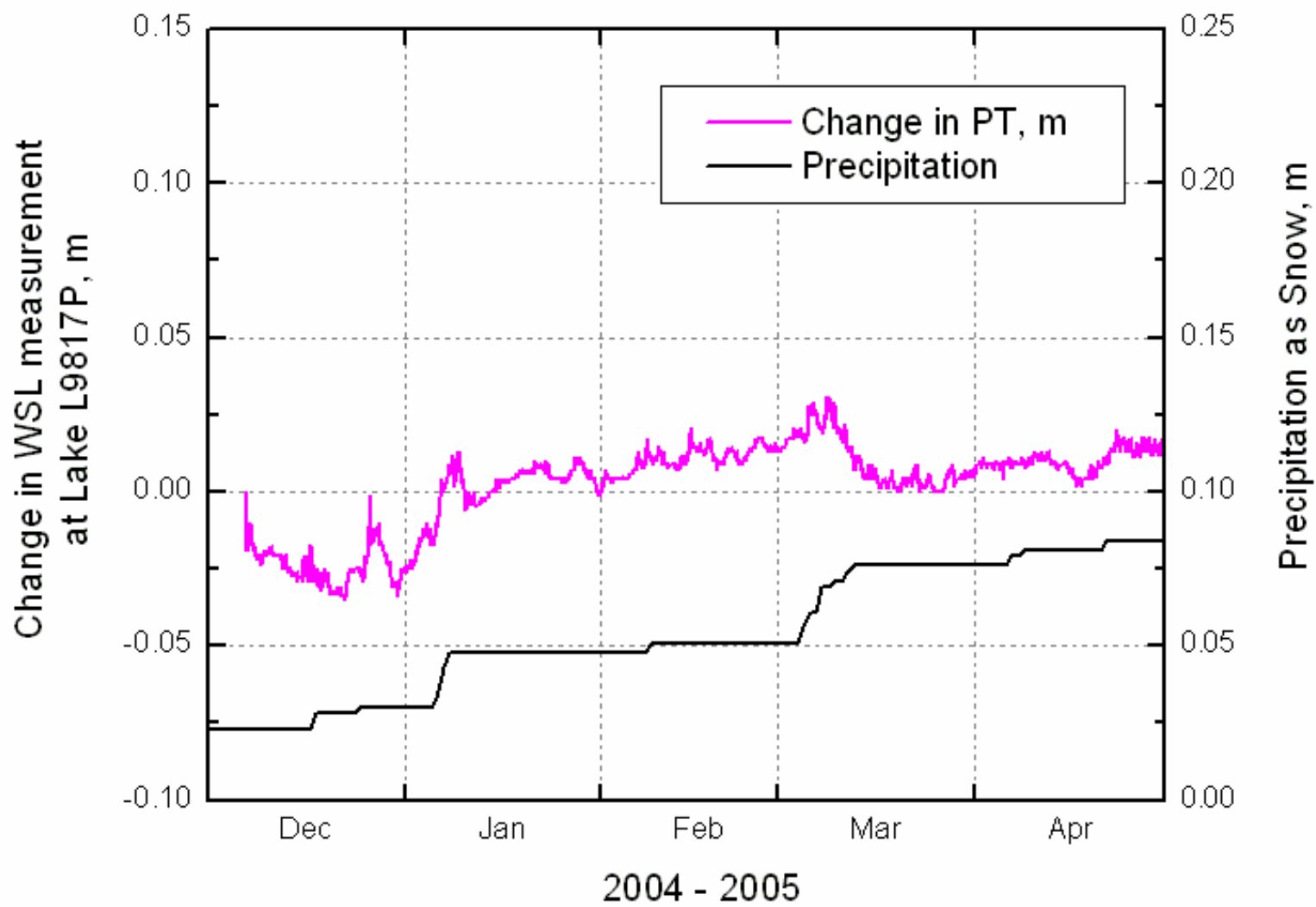

Figure 56. Change in water surface level at lake L9817 compared to winter precipitation at Betty Pingo during the 2004-2005 winter.

From a different perspective, looking at a water balance of the study lakes during the 2003-2004 winter, there was not always perfect agreement in expected and observed changes in the water surface levels (WSL). Theoretically, the observed change in measured WSL should equal the sum of the expected change (loss due to pumping) and the SWE (gain due to snowfall). The lack of a proper water balance may be due to using a single survey for pre-melt 2004 snow water equivalence at the lakes (although this consisted of about 240 point measurements of the snowpack around each lake). The more likely cause of the imbalance is the non-appropriate application of either the cone or pan bathymetry for lake volume calculations. 
Table 12. Water balance at study lakes for 2003-2004 winter including detected changes in water surface level (WSL), expected change in WS based on pan and cone bathymetries and local snow water equivalence (SWE).

\begin{tabular}{|c|c|c|c|c|}
\hline \multirow{2}{*}{ Lake } & $\begin{array}{c}\text { Average 2004 } \\
\text { SWE, cm }\end{array}$ & \multicolumn{2}{|c|}{$\begin{array}{c}\text { Expected change in 2003- } \\
\text { 2004 WSL, cm }\end{array}$} & $\begin{array}{c}\text { Measured Change in } \\
\text { 2003-2004 WSL, cm } \\
\text { (to nearest 0.5) }\end{array}$ \\
\cline { 3 - 4 } & & Pan & Cone & +8.0 \\
\hline \hline K113C & +7.1 & 0.0 & 0.0 & +8.0 \\
\hline K214P & +10.0 & -0.7 & -0.8 & +5.0 \\
\hline K209P & +11.3 & -3.1 & -12.8 & not operational \\
\hline K203C & \multicolumn{4}{|c|}{} \\
\hline
\end{tabular}

\subsection{Lake Recharge}

When investigating the effect of pumping on the study lakes, the primary question was, 'Are the pumped lakes completely recharged each year after pumping by snowmelt and/or rainfall'. To answer this important question, surveys of recharge were conducted May to June of 2003, 2004 and 2005 during spring snow melt - the dominant, if not exclusive, recharge mechanism for the lakes. Complete recharge was verified by surveys of outlet flow along the lake's perimeter during spring melt. If an active outlet was observed as the lake became flooded with meltwater, the lake was considered to be completely recharged.

Complete recharge is an important determination as pumped lakes might suffer from a deficit in their water volume due to water withdrawal if recharge is not of sufficient quantity and would point towards a non-sustainable pumping practice. All study lakes, both pumped and control, were determined to be completely recharged after the spring melt periods of 2003 and 2004 (Table 13). In Spring 2005, all lakes were completely recharged by the snowmelt runoff with the exception of L9312. This lake was recharged both by spring snowmelt and by summer rainfall. The definition of a full lake condition is best determined by its lowest outlet control elevation. As an example, L9312 was observed to have two outlets during early snowmelt in 2006. At the end of snowmelt, it was observed to have water flowing out of only one outlet. This indicates the lake was overfull and gradually declining. In September of 2006, water was still present in the marshy outlet, indicating the lake was still full or slightly overfull. Figure 57 to Figure 62 illustrate the approximate inlet and outlet locations at each lake observed during 2003 and 2004 spring melt. Specific coordinates of outlets and inlets, as well as photos of selected lakes, are given in Appendix E, and aerial photographs are shown in Appendix F. Also quantified in the appendices: the pre-melt snowpack leading to complete recharge is quantified, the ablation of the snowpack is presented, and other snow survey data and locations are given.

Pre-melt snow surveys were conducted May 13-18, 2003, May 20-22, 2004 and May 13-15, 2005 at the study lakes. Snowpack was quantified around the perimeter of each study lake at three or four locations and on the lake surface itself. The survey locations were approximately 
the same in all years. Ablation at K113C Index (referenced as 'K113C SS1' and located $500 \mathrm{~m}$ north of the lake K113C) and Betty Pingo was monitored daily until the snowpack was depleted.

Investigation of lake inlets and outlets occurred immediately after snowmelt runoff began. Inlet and outlet locations were logged using a Global Positioning System referenced to the WGS84 datum. 'Inlet' and 'outlet' refer to well-defined channel flow with water depth exceeding $0.15 \mathrm{~m}$. 'General inflow' and 'general outflow' refer to overland flow with maximum water depth not exceeding $0.15 \mathrm{~m}$. Inlet and outlet locations were at the same locations during all recharge surveys. 'Flooding' refers to an area of indeterminate general inflow and/or general outflow.

Table 13. Summary of recharge surveys. Data not available for L9817 for 2005.

\begin{tabular}{|c|c|c|c|c|c|}
\hline Lake & $\begin{array}{c}\text { Complete } \\
\text { Recharge? }\end{array}$ & $\begin{array}{c}\text { Recharge } \\
\text { Source }\end{array}$ & $\begin{array}{c}\text { Number } \\
\text { of } \\
\text { Outlets }\end{array}$ & $\begin{array}{c}\text { Number } \\
\text { of Inlets }\end{array}$ & Years surveyed \\
\hline \hline K113C & Yes & meltwater & 2 & 3 & $2003,2004,2005$ \\
\hline K203C & Yes & meltwater & 1 & 3 & 2003 \\
\hline K214P & Yes & meltwater & 3 & 1 & $2003,2004,2005$ \\
\hline K209P & Yes & meltwater & 3 & 3 & $2003,2004,2005$ \\
\hline L9312P & Yes & rainfall & 3 & 1 & 2005 \\
\hline L9817P & Yes & meltwater & na & na & 2005 \\
\hline
\end{tabular}




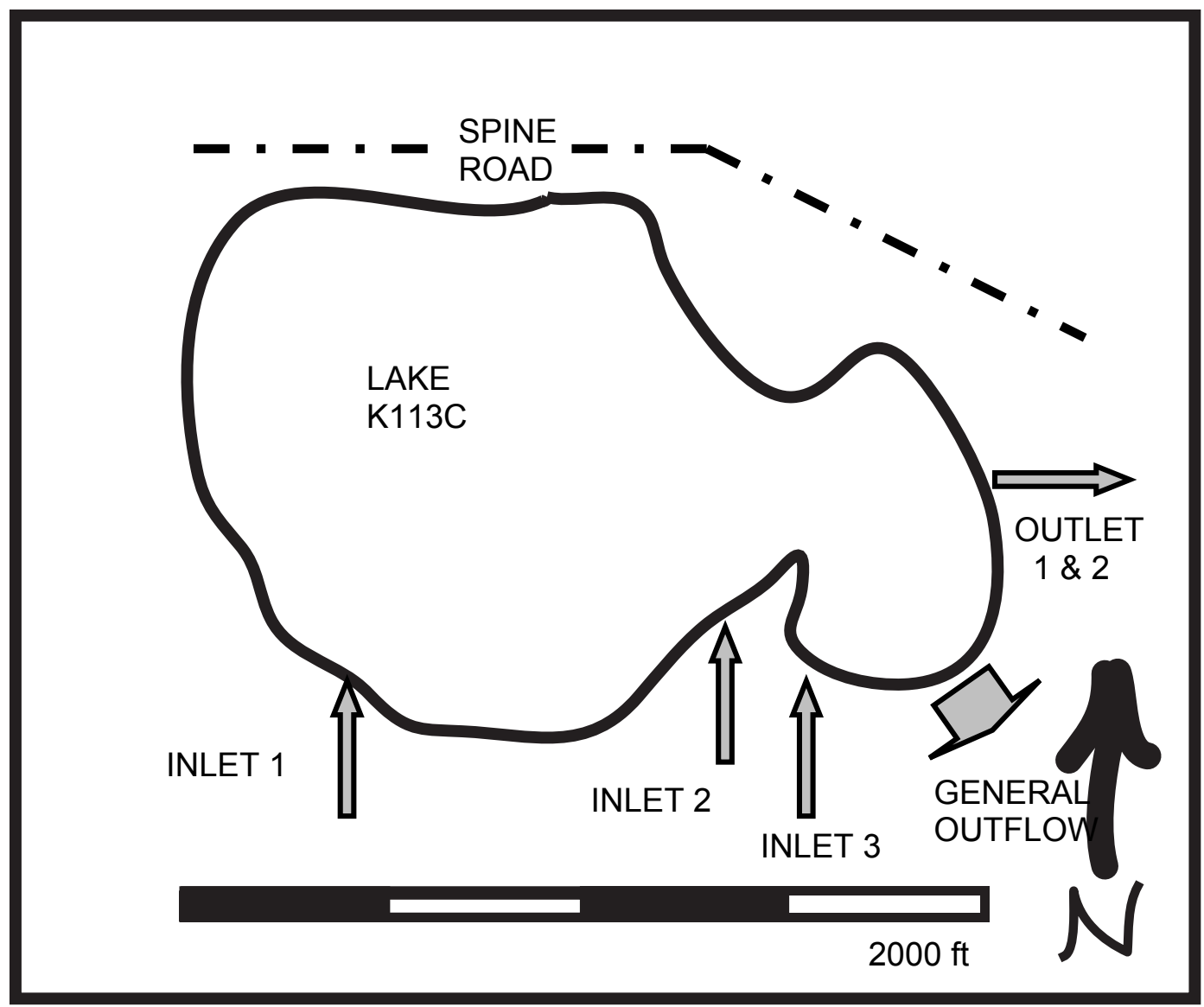

Figure 57. Illustration of flow following spring melt at control lake K113C. 


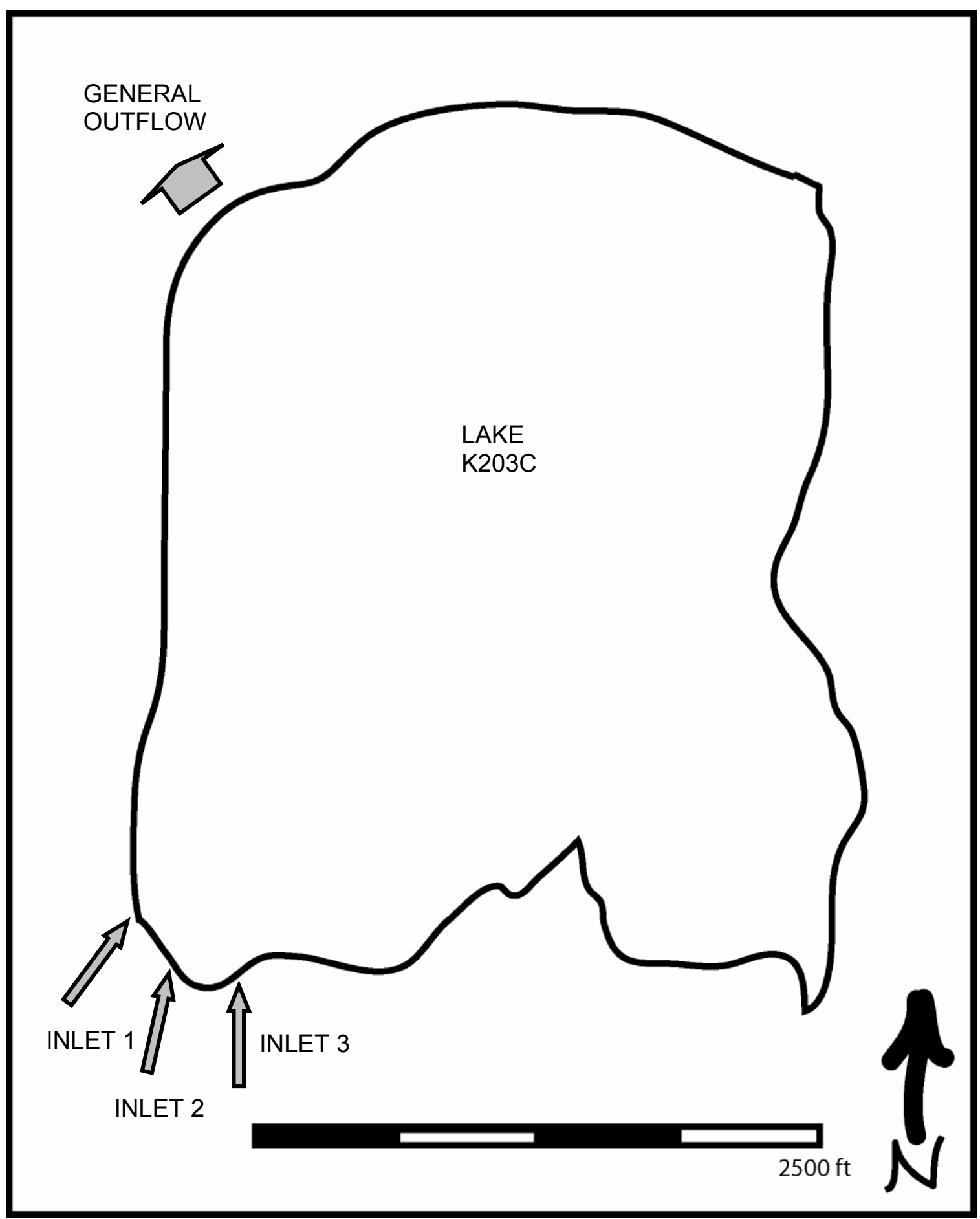

Figure 58. Illustration of flow following spring melt at control lake K203C. 


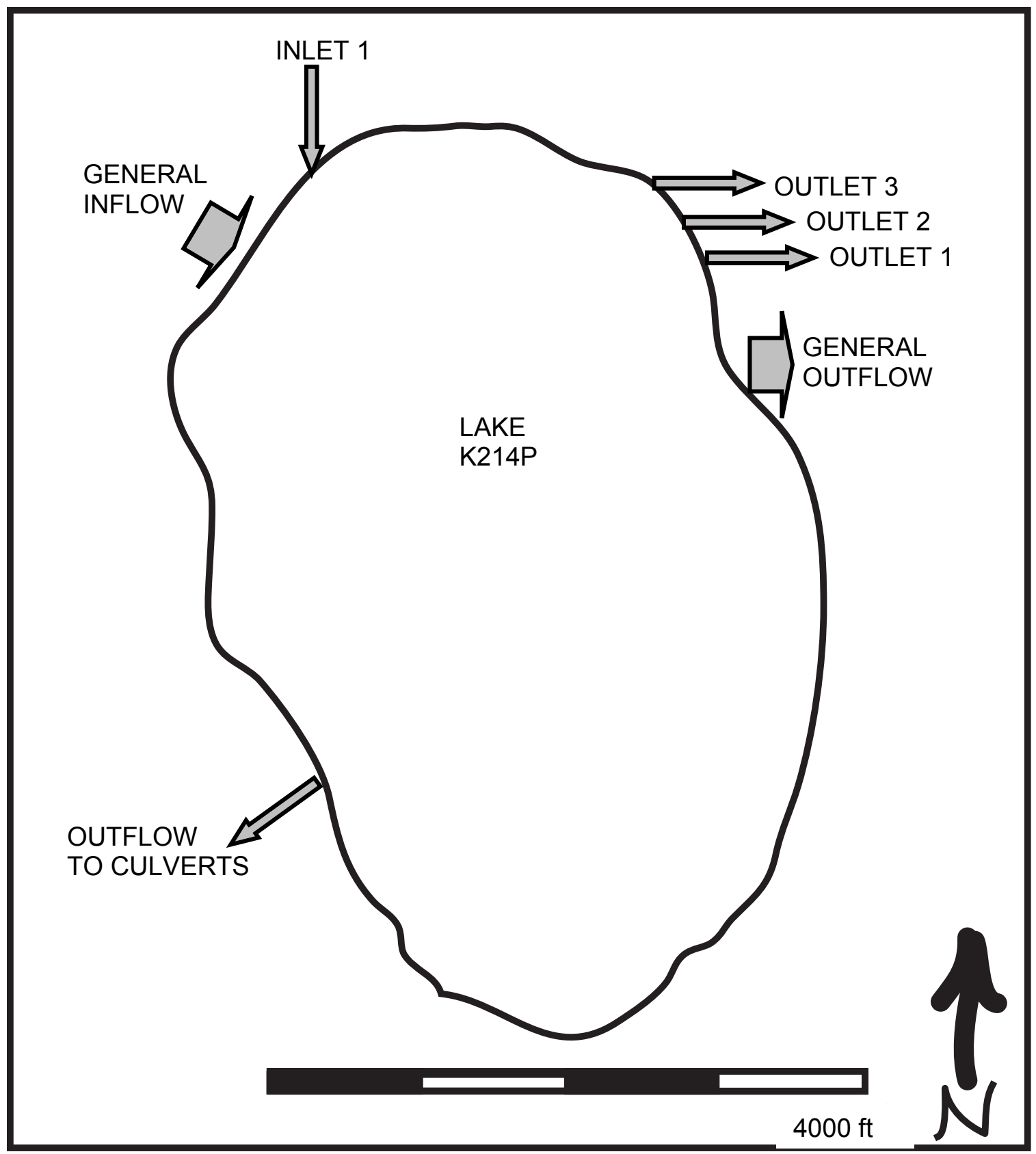

Figure 59. Illustration of flow following spring melt at pumped lake K214P. 


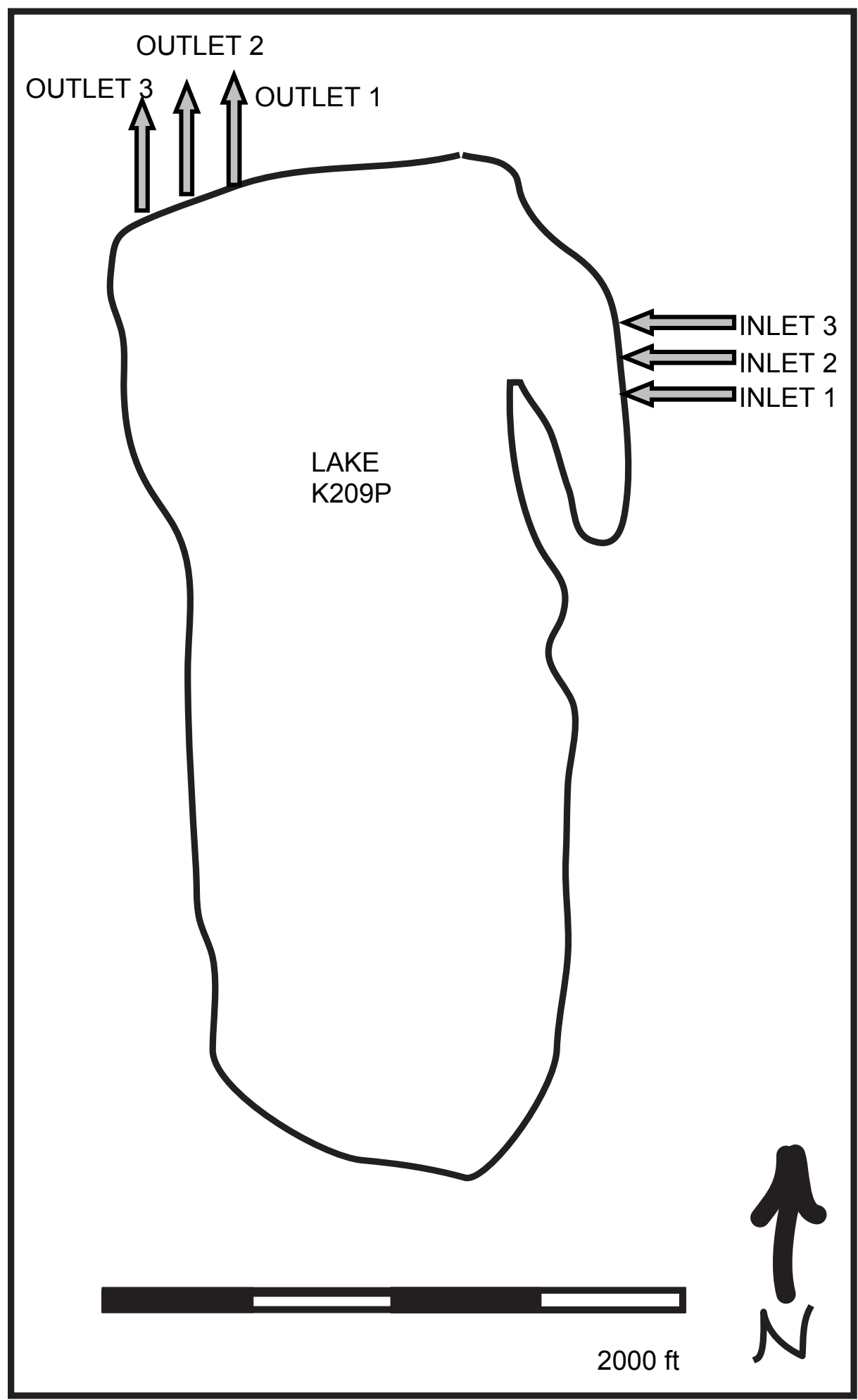

Figure 60. Illustration of flow following spring melt at pumped lake K209P. 


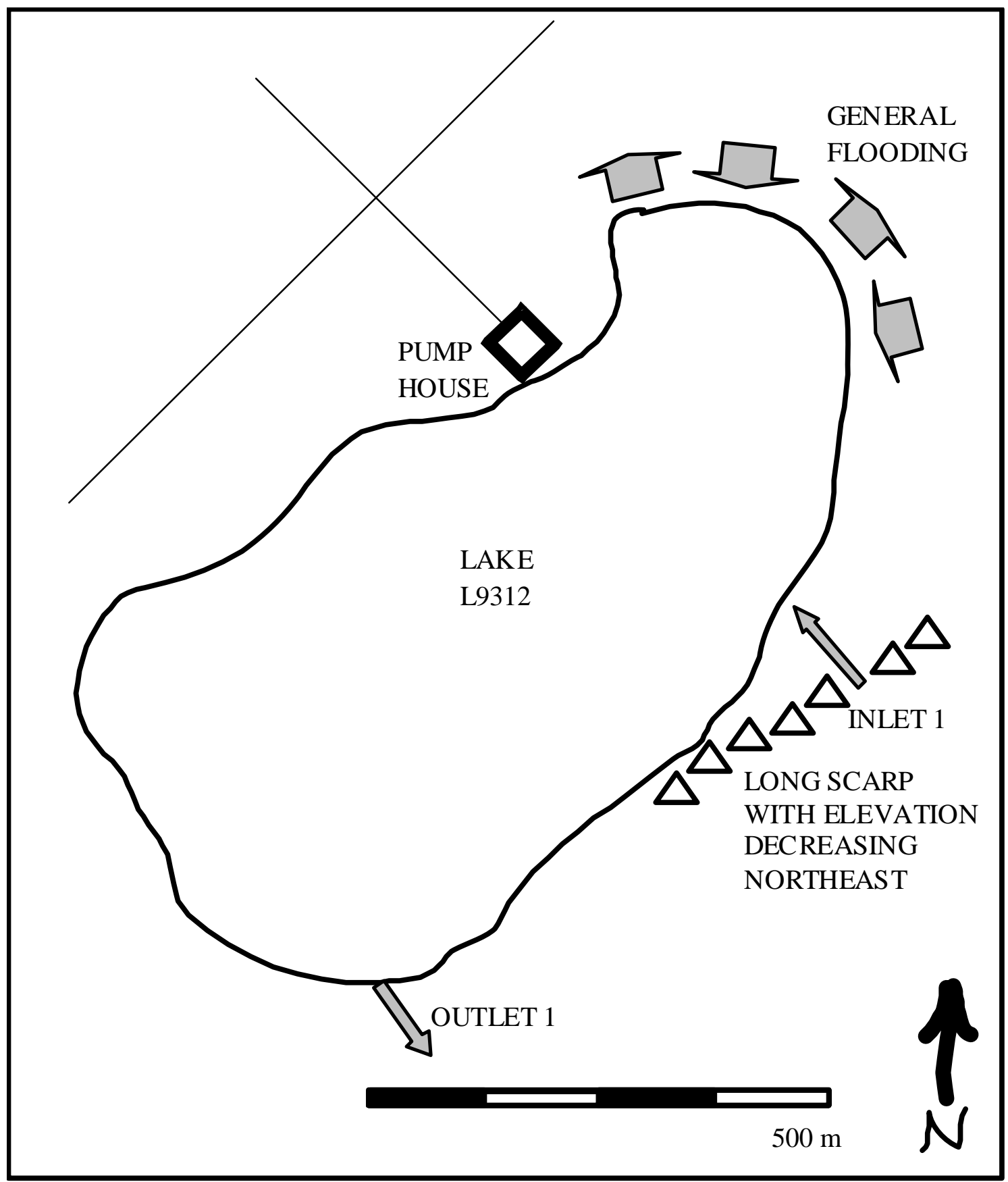

Figure 61. Illustration of flow following spring melt at pumped lake L9312P. 


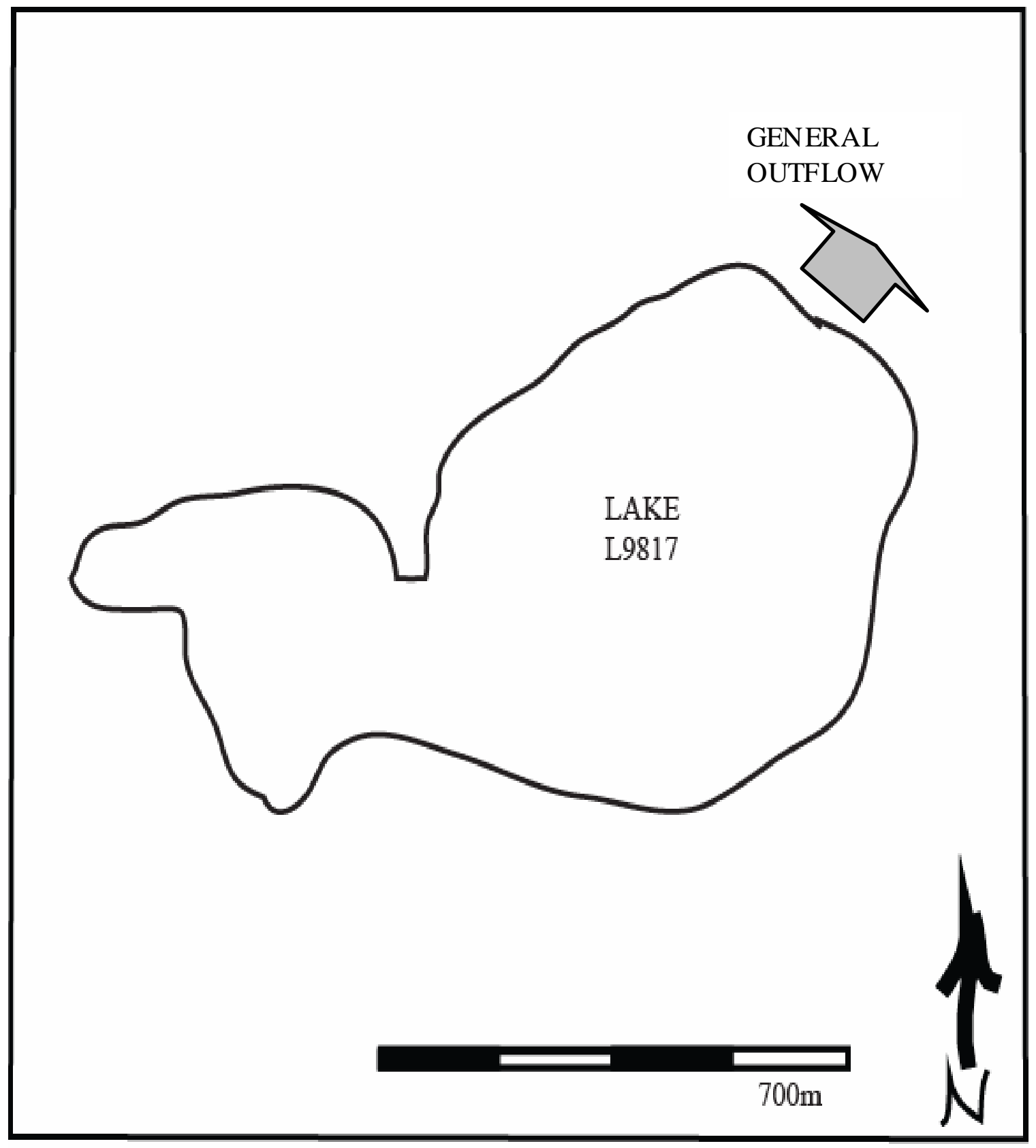

Figure 62. Illustration of flow following spring melt at pumped lake L9817P.

\subsection{Water Surface Level}

In some plots, WSL is reduced to an elevation change in the pressure transducer measurement. The zero value when reducing the data was taken as the initial value after the sensor had stabilized. Utilizing measurements of the relative change in WSL elevation rather than WSL referenced to sea level eliminates some survey error and gives more confidence when determining the effects of water withdrawal on WSL at pumped lakes. The method also has the 
advantage of allowing for finer resolution of WSL in comparison plots, which helps when attempting to detect small changes between pumped and control lakes.

Figure 63 to Figure 66 show the change in WSL at study lakes for the 2002-2003, 2003-2004, and 2004-2005 winters. The zero WSL value is taken to be 24 hours after station installation for the 2002-2003 winter and 0:00 AM November 1, 2003 for the 2003-2004 and 2004-2005 winters. Values of WSL change were processed to remain consistent when sensors were replaced in mid-winter.

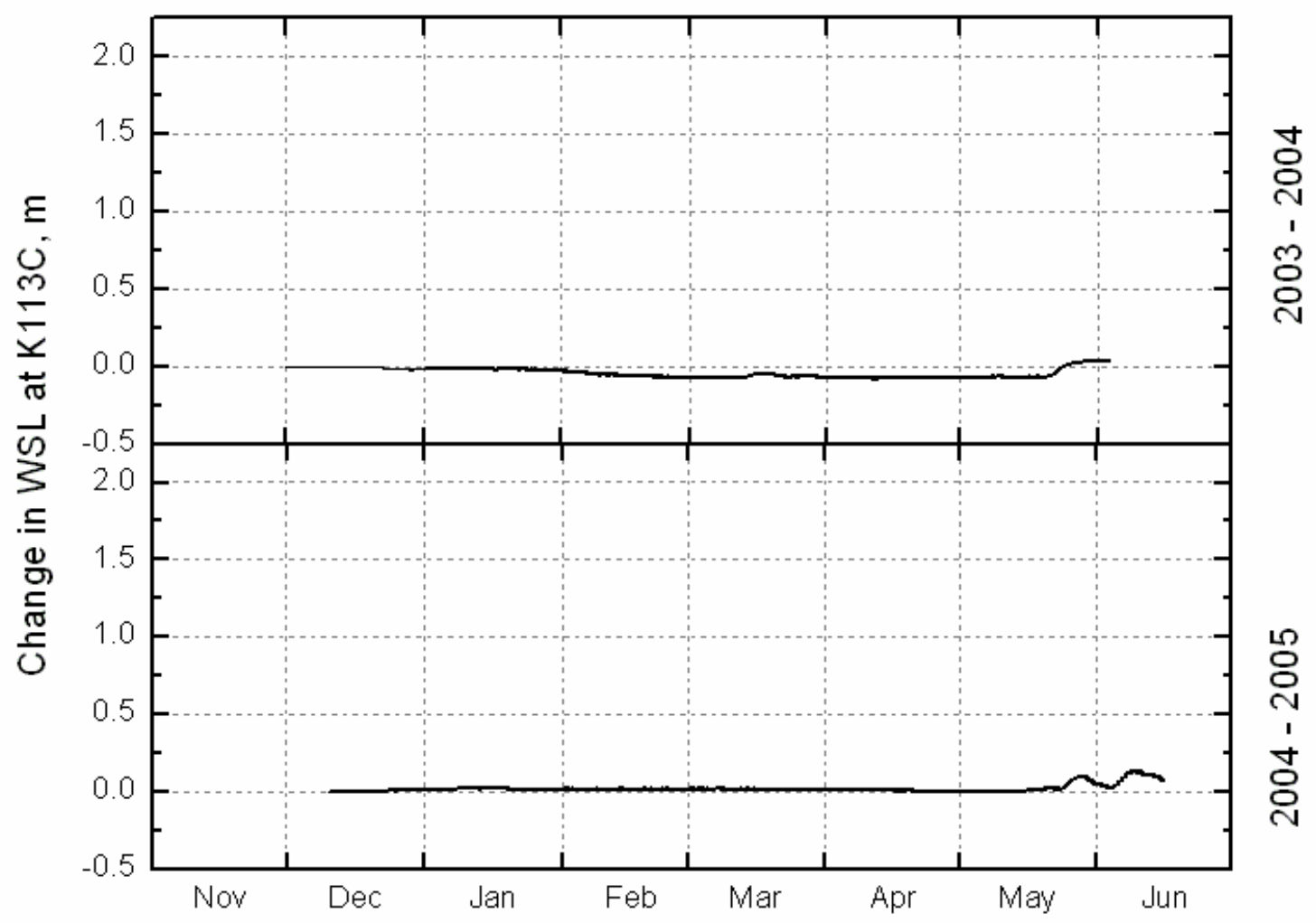

Figure 63. Change in water surface level at control lake K113C throughout 2003-2004 and 2004-2005 winter data collection periods. 


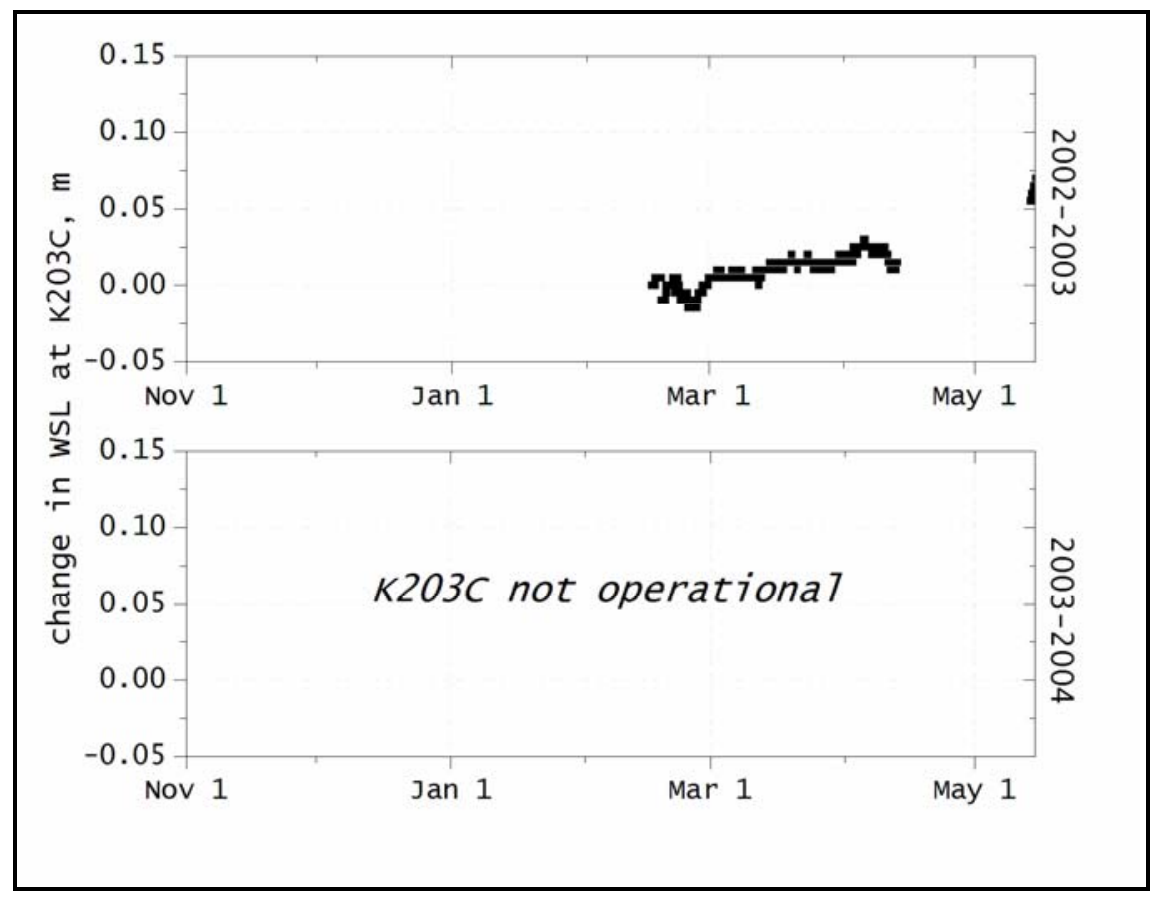

Figure 64. Change in water surface level at control lake K203C throughout 2002-2003 and 2003-3004 winter data collection periods. 2003 data gap due to temporary loss of telemetry. 


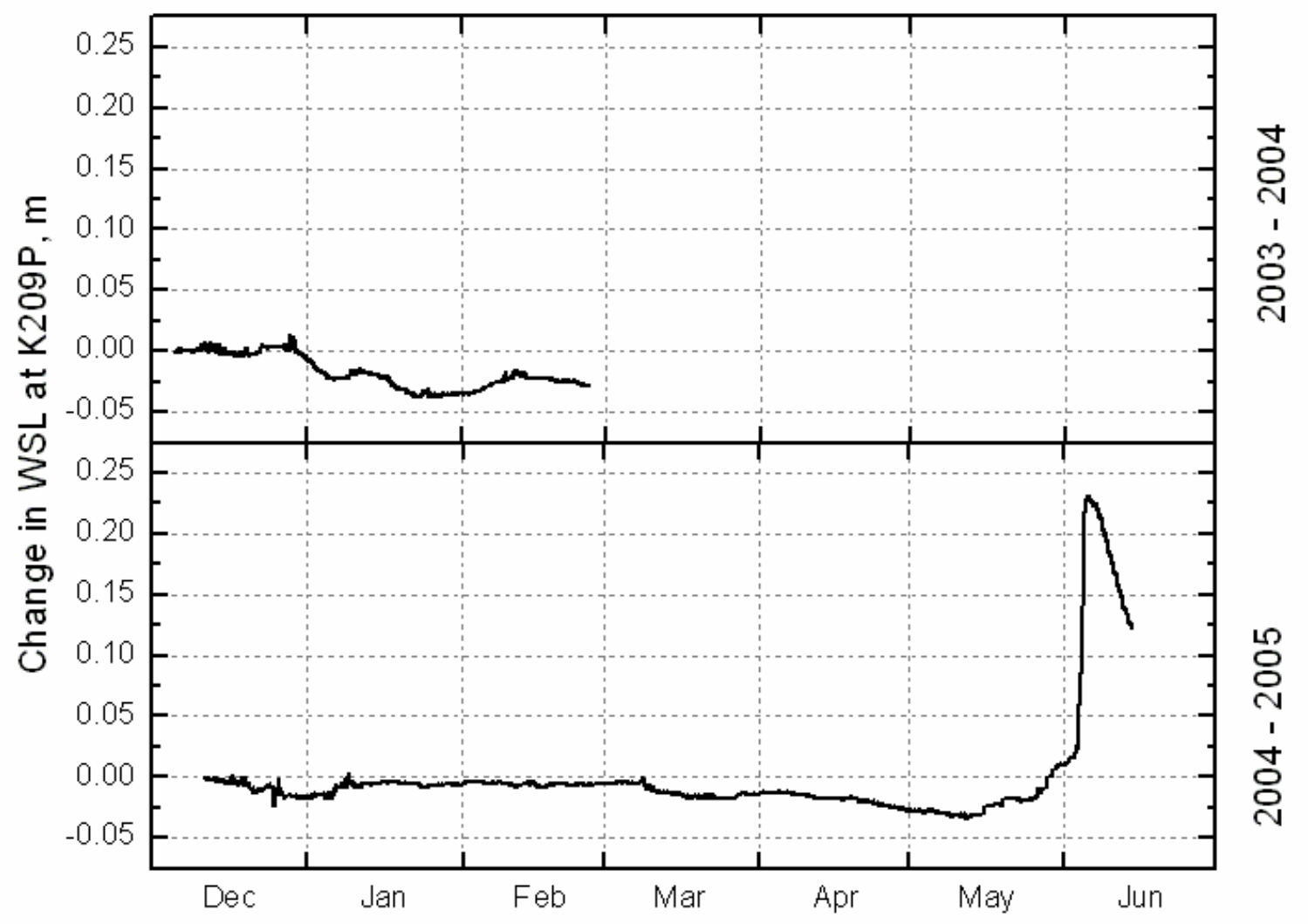

Figure 65. Change in water surface level at pumped lake K209P throughout 2002-2003 and 2003-2004 winter data collection periods. The pressure transducer at K209P was disconnected in late-February 2004. 


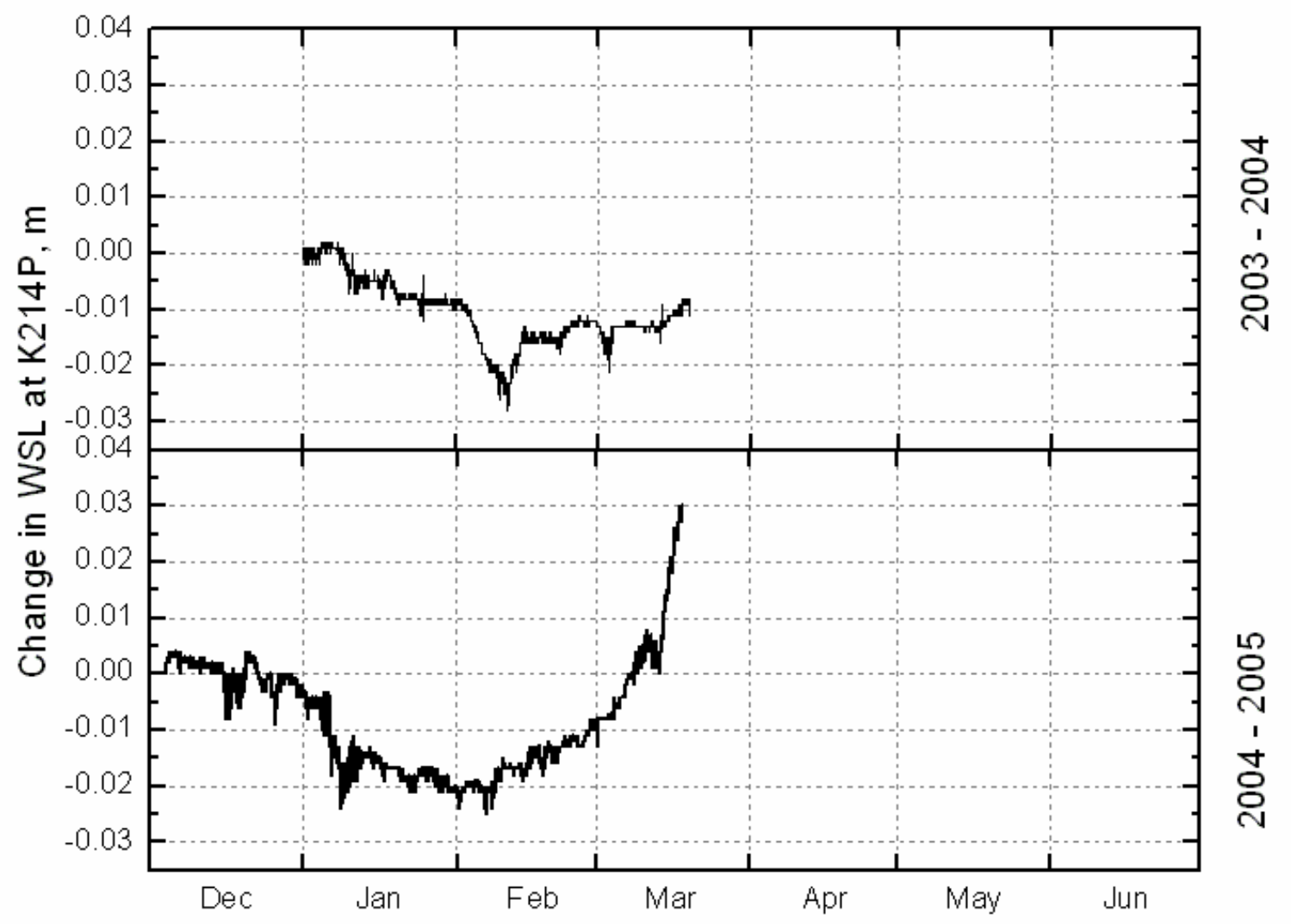

Figure 66. Change in water surface level at pumped lake K214P throughout 2002-2003 and 2003-2004 winter data collection periods. 


\section{Lake K113 Water Surface Elevation Above BPMSL}

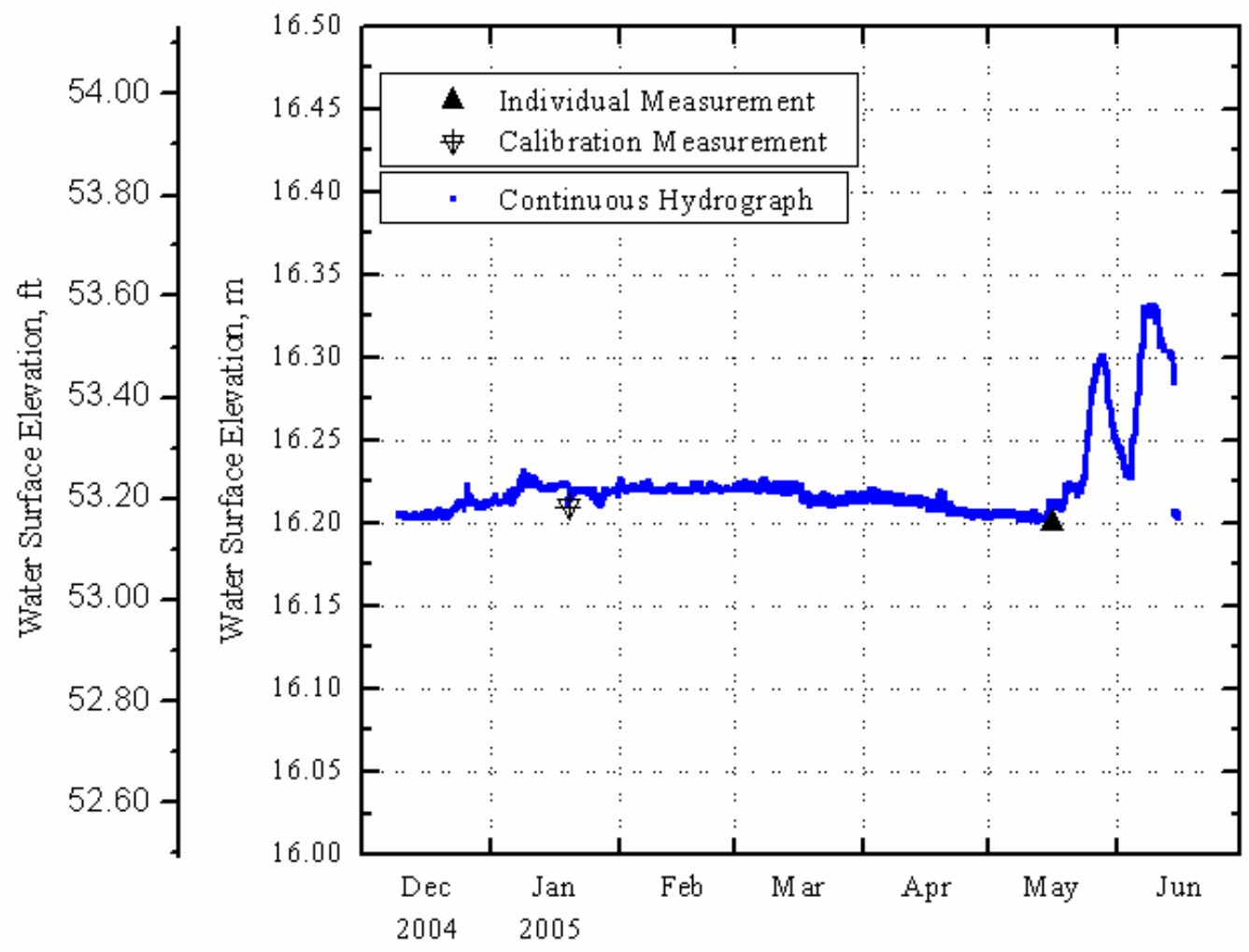

Figure 67. Water surface hydrograph at control lake K113C throughout 2004-2005 winter data collection periods. 
Lake K209 Water Surface Elevation Above BPMSL

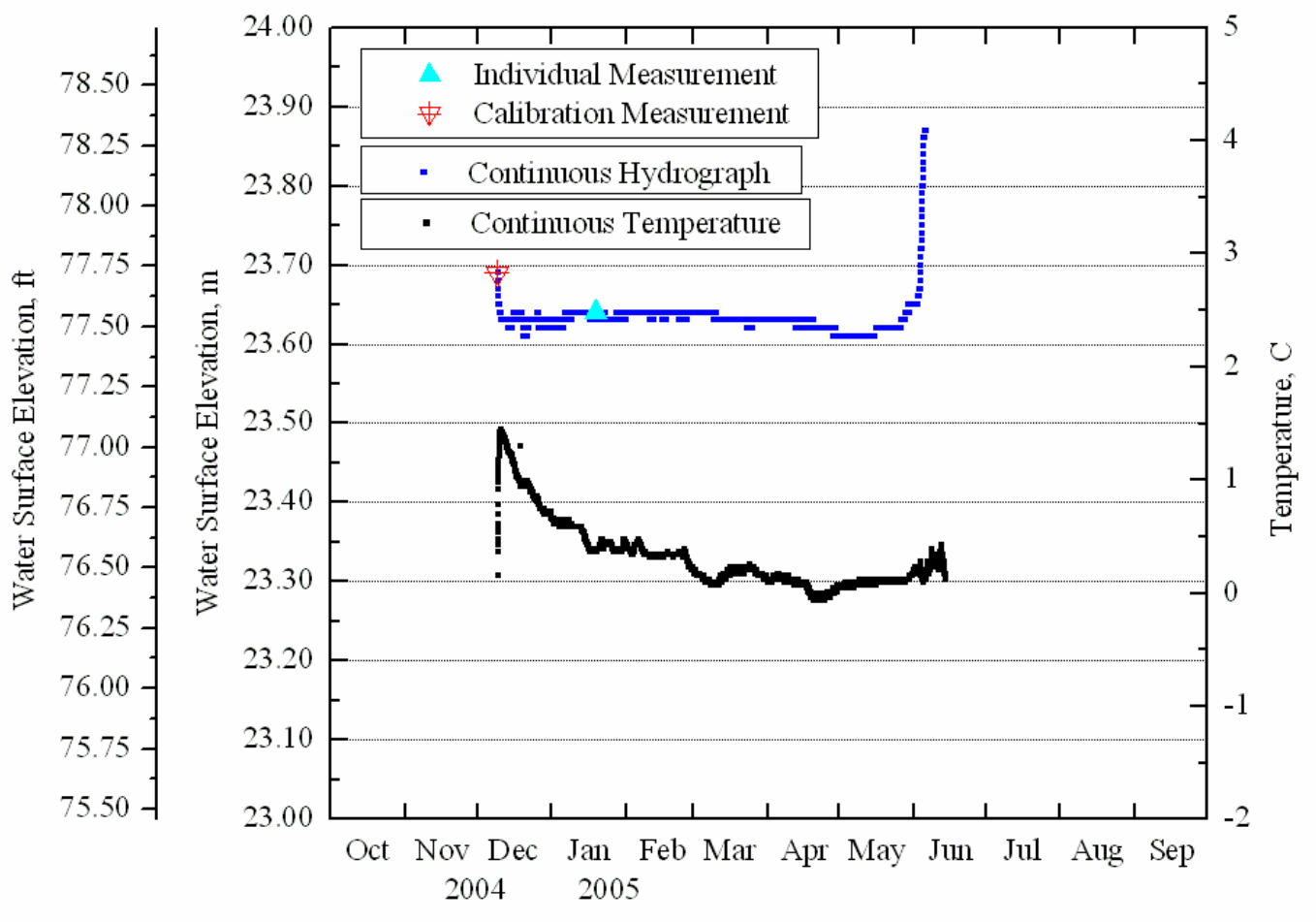

Figure 68. Water surface hydrograph at control lake K209P throughout 2004-2005 winter data collection periods. 
Lake K214 Water Surface Elevation Above BPMSL

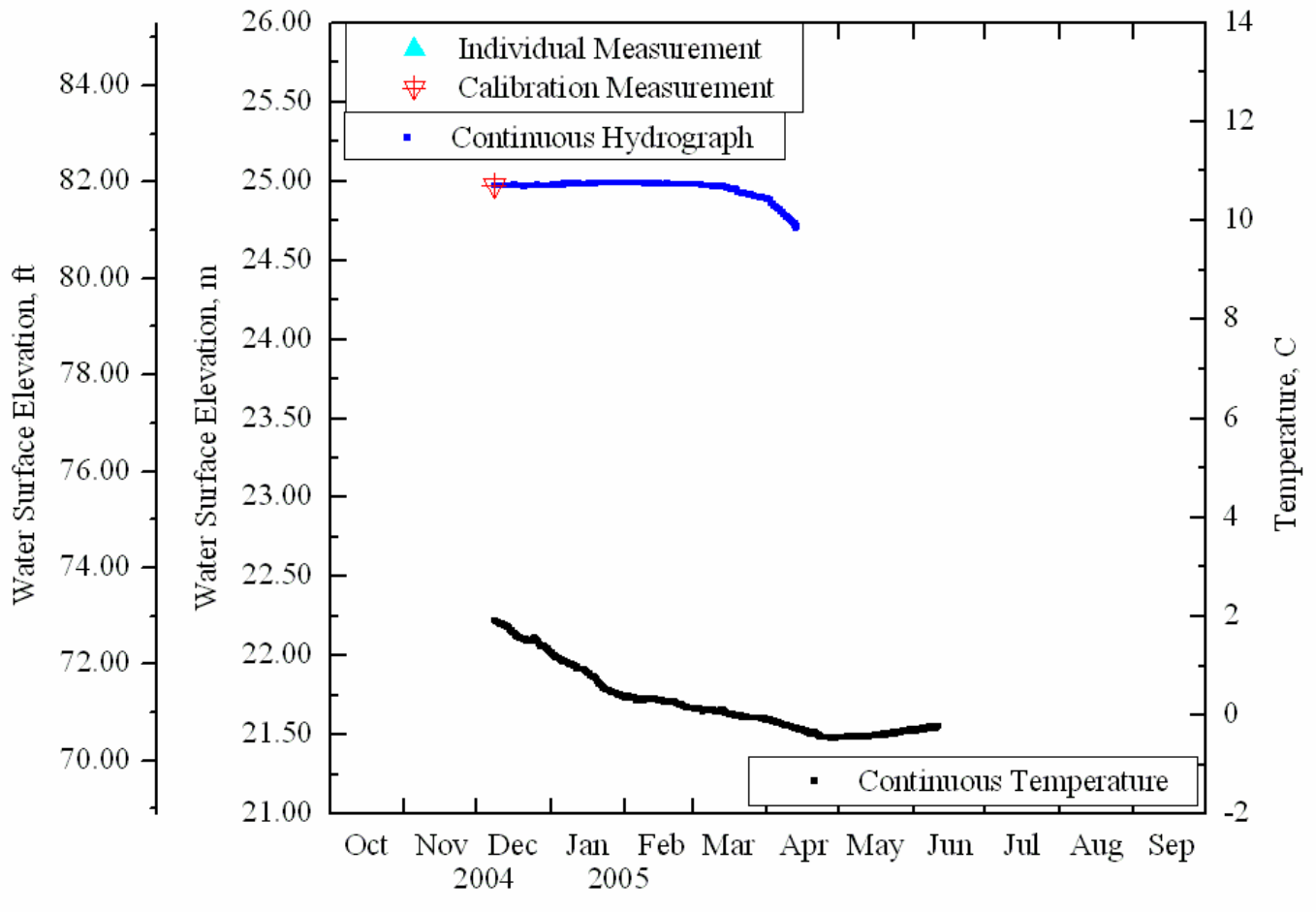

Figure 69. Water surface hydrograph at control lake K214P throughout 2004-2005 winter data collection periods. 
Lake L9312 Water Surface Elevation Above BPMSL
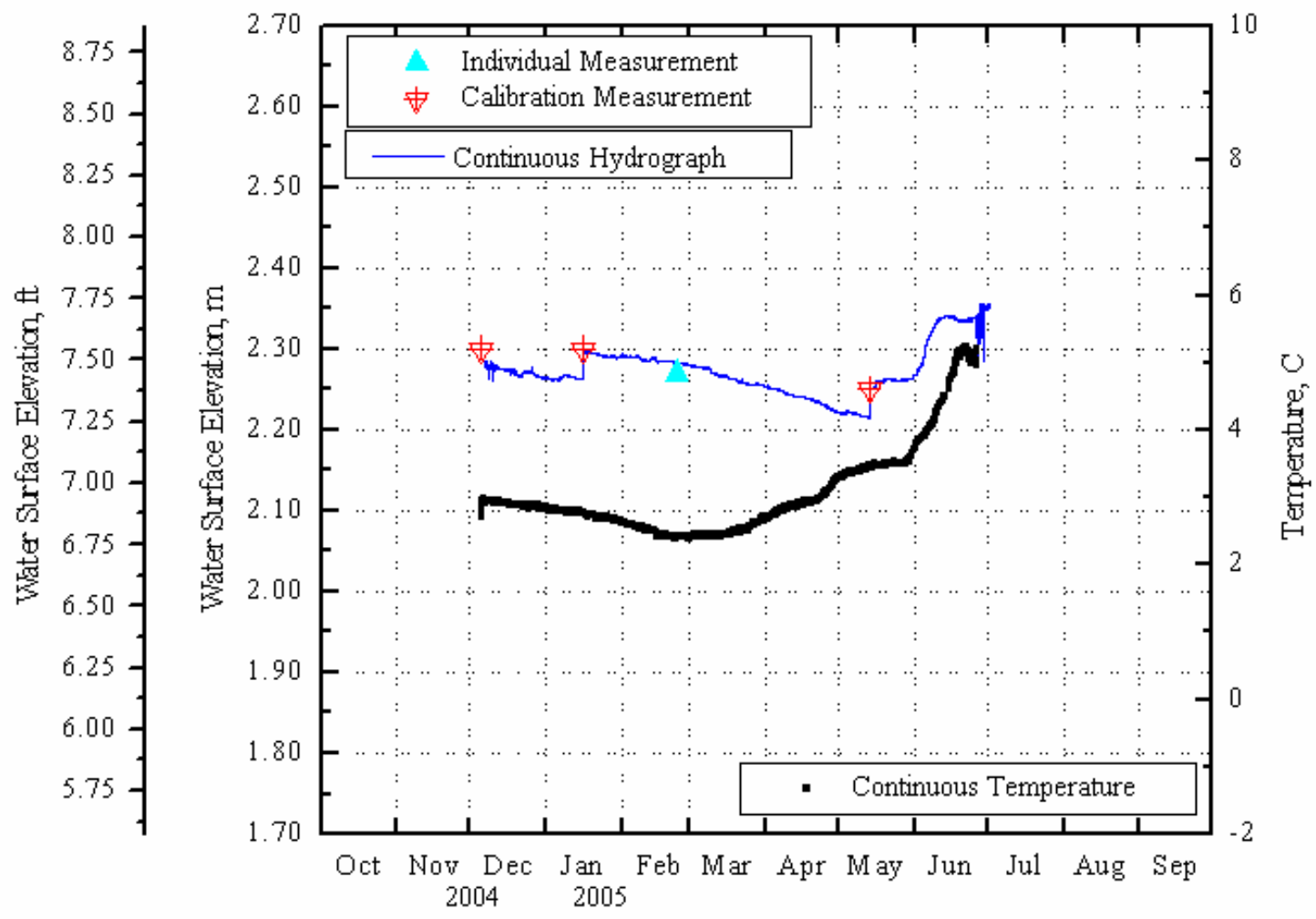

Figure 70. Water surface hydrograph at control lake L9312P throughout 2004-2005 winter data collection periods. 


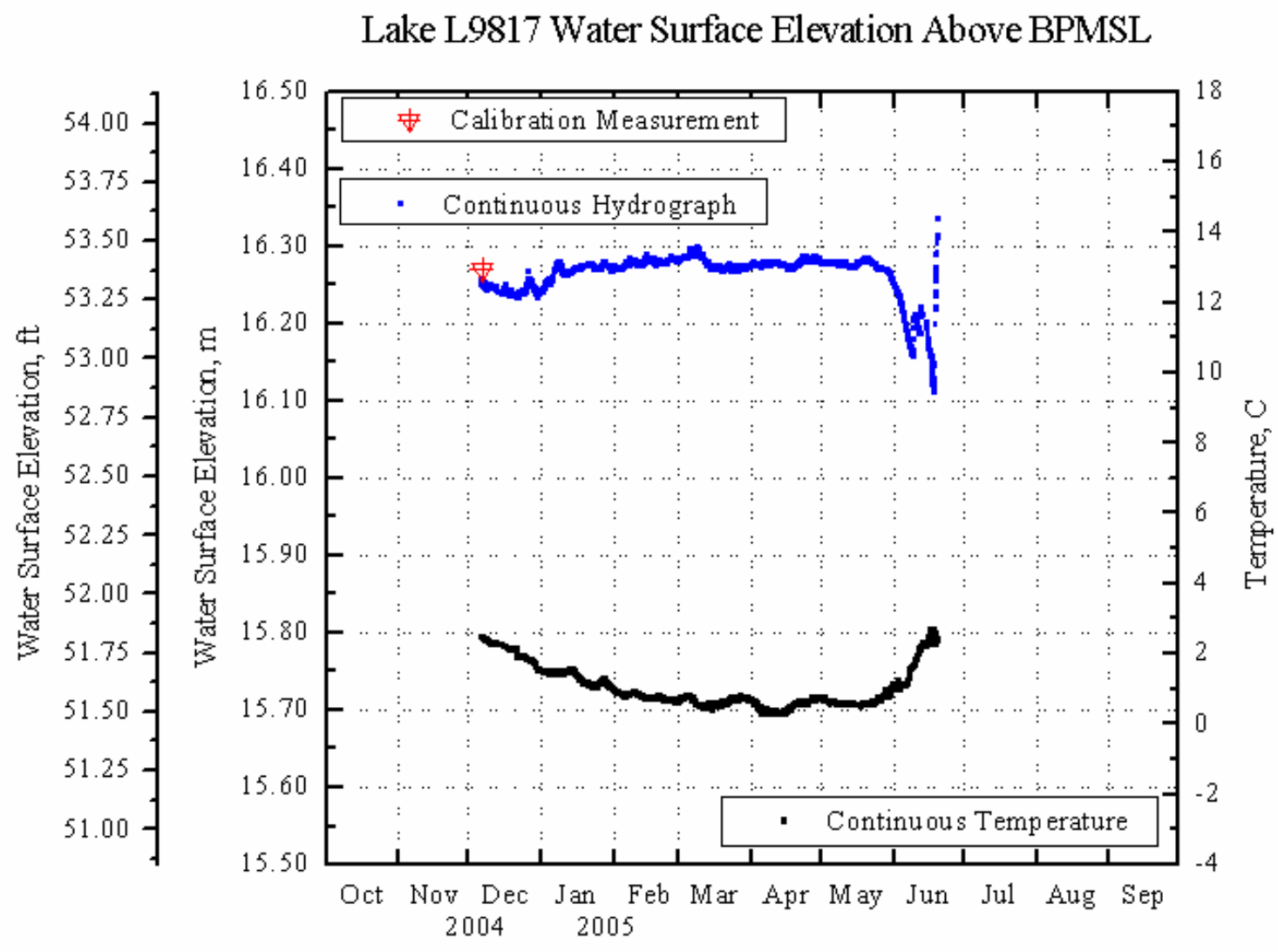

Figure 71. Water surface hydrograph at control lake L9817P throughout 2004-2005 winter data collection periods.

An increasing trend occurs in the WSL measurements at K113C, K203C, K214P, L9817 and L9312 P. The trend follows precipitation as snow collecting on top the lake ice sheet. Although K209P does indeed receive a similar load of snow, it was heavily pumped as a freshwater resource in 2004, so K209P does not see the same response to snow loading as the other lakes, which were not pumped or only in a very limited capacity (i.e. K214P in Figure 66). K209P shows a cumulative change in WSL due to pumping. This is a detected change due to significant pumping activity at lake K209P. Further, the detected WSL change at K209P is between the pan and cone bathymetry estimations of WSL change as expected (Figure 72). 


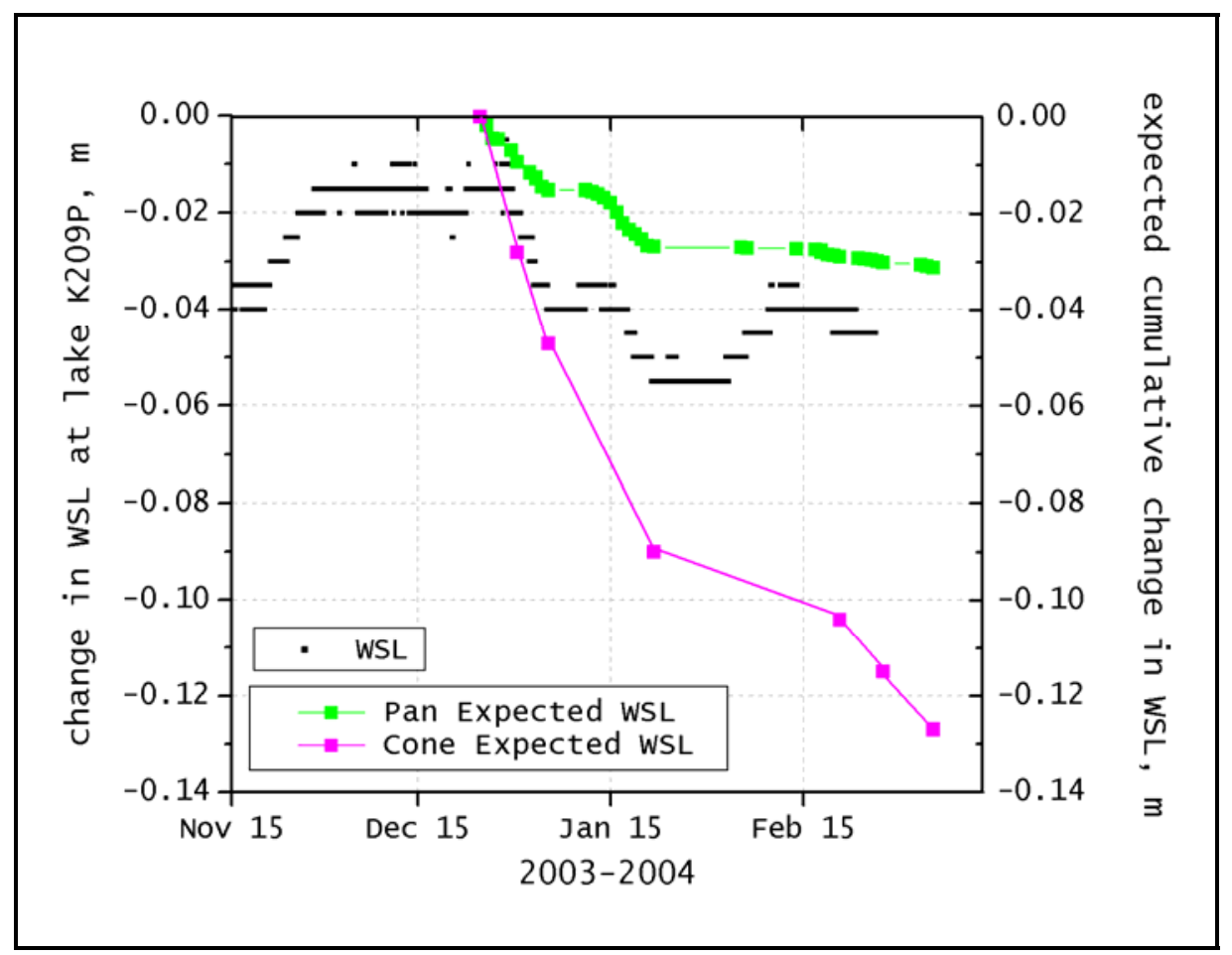

Figure 72. Detected change in WSL at K209P shown with expected cumulative change in WSL due to pumping calculated from idealized pan and cone bathymetries. 


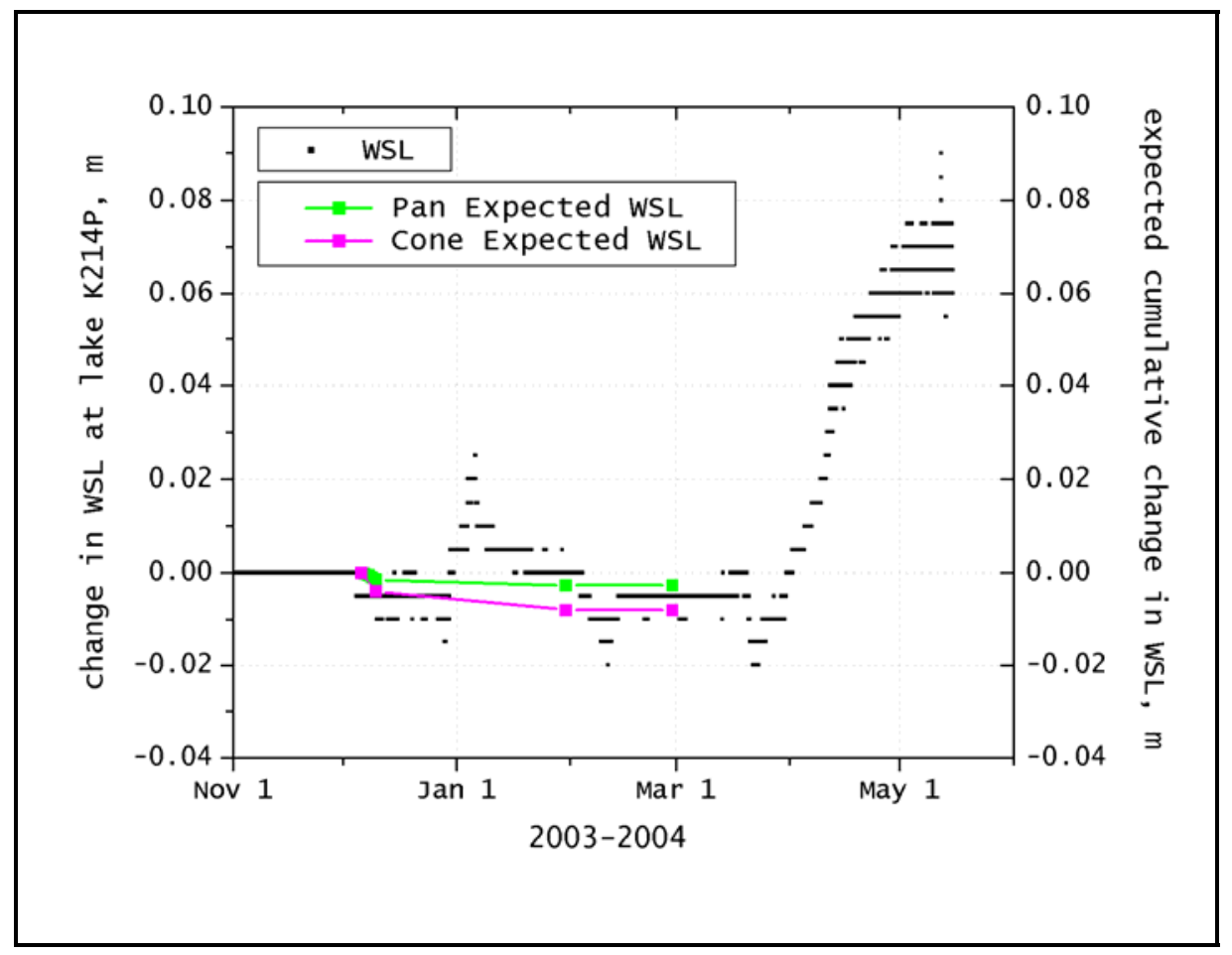

Figure 73. Detected change in WSL at K214P shown with expected cumulative change in WSL due to pumping calculated from idealized pan and cone bathymetries.

Water surface levels at pumped lakes are compared with control lakes in Figures 49 to 53 . The lakes are examined at periods of heavier pumping activity. Attention is given to K209P in the 2003-2004 winter since it experienced more frequent and voluminous pumping activity than K214P (Table 15). Daily pumping volumes as well as recorded precipitation as snow measurements are also shown in the figures. All water surface levels are referenced to British Petroleum Mean Sea Level (BPMSL). 
Table 14. Defined periods of pumping activity at K209P and water withdrawal volume.

\begin{tabular}{|c|c|c|}
\hline \multicolumn{3}{|c|}{ LAKE K209P } \\
\hline Time Period & Water withdrawal volume, $\mathbf{~ m}^{\mathbf{3}}$ & Water withdrawal volume, gal \\
\hline \hline $2 / 13 / 2003-2 / 15 / 2003$ & 796 & 210,202 \\
\hline $12 / 25 / 2003-12 / 28 / 2003$ & 6,587 & $1,740,181$ \\
\hline $12 / 30 / 2003-12 / 31 / 2003$ & 6,669 & $1,761,737$ \\
\hline $1 / 2 / 2004-1 / 5 / 2004$ & 7,731 & $2,042,420$ \\
\hline $1 / 11 / 2004-1 / 22 / 2004$ & 16,588 & $4,382,139$ \\
\hline $2 / 17 / 2004-2 / 21 / 2004$ & 2,409 & 636,285 \\
\hline $2 / 24 / 2004-2 / 28 / 2004$ & 1,669 & 441,009 \\
\hline $3 / 5 / 2004-3 / 7 / 2004$ & 1,419 & 374,860 \\
\hline
\end{tabular}

Table 15. Defined periods of pumping activity at K214P and water withdrawal volume.

\begin{tabular}{|c|c|c|}
\hline \multicolumn{3}{|c|}{ LAKE K214P } \\
\hline Time Period & Water withdrawal volume, $\mathbf{m}^{\mathbf{3}}$ & Water withdrawal volume, gal \\
\hline \hline $4 / 1 / 2003-4 / 30 / 2003$ & 843 & 222,697 \\
\hline $12 / 7 / 2003-12 / 10 / 2003$ & 3,156 & 833,727 \\
\hline $1 / 1 / 2004-1 / 31 / 2004$ & 2,540 & 670,997 \\
\hline $2 / 1 / 20042 / 29 / 2004$ & 78 & 20,605 \\
\hline
\end{tabular}

Notable in the plots is the most active pumping period of the past two winters for any lake; 16,588 cubic meters of water were removed from lake K209P from January 11-22, 2004. The expected drop in WSL for this event is $-0.012 \mathrm{~m}$, a conservative estimate based on ideal pan bathymetry. K209P shows a detected response of $-0.02 \mathrm{~m}$ in WSL for the event while control lake K113C shows a response of $+0.005 \mathrm{~m}$ Figure 75

Response in WSL due to pumping can be analyzed in two ways: (1) From a water balance perspective where detected change in WSL should equal the expected change in WSL summed with the change in precipitation, or (2) in direct comparison to the control lake WSLs. In the following analyses both alternatives are examined, however some preference should be given to Alternative 2 later in the winter since the projected bathymetry of the remaining water with significant ice depth is difficult to quantify due to highly variable bottom contours without detailed bathymetry across the lakes.

Figure 73 illustrates the WSL response to pumping activity at K214P from December 7-10, 2003. Cumulatively, $3155.9 \mathrm{~m}^{3}$ of water was withdrawn from lake K214P during the time period, 
corresponding to an expected change in WSL of $-0.002 \mathrm{~m}$ and $-0.004 \mathrm{~m}$ for pan and cone bathymetries respectively, both of which are below the pressure transducer sensors' $0.005 \mathrm{~m}$ resolution.

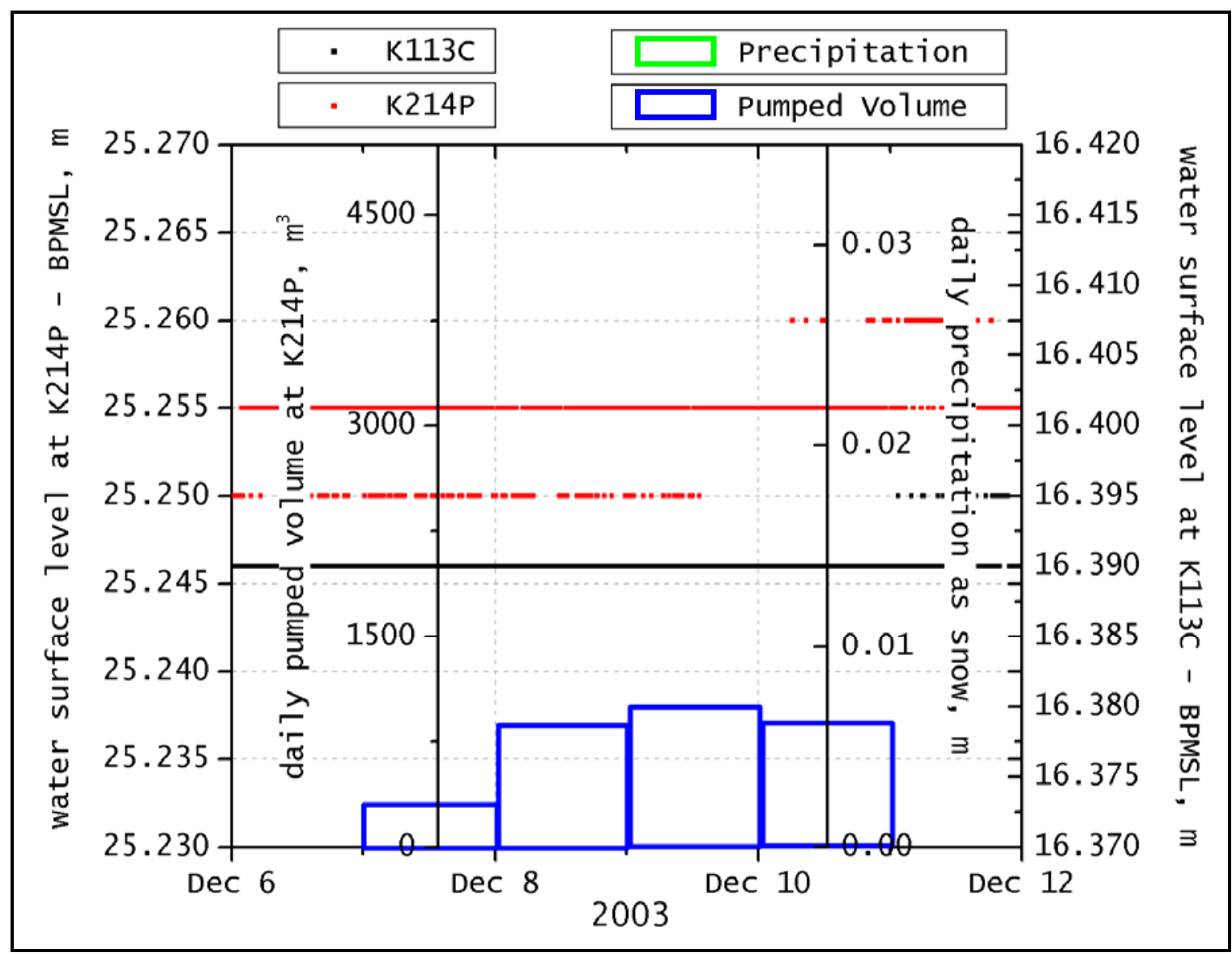

Figure 74. Water surface level at pumped lake K214P during pumping activity December 7-10, 2003 compared to WSL at control lake K113C.

In Figure 75 , control lake $\mathrm{K} 113 \mathrm{C}$ shows an increase of $+0.010 \mathrm{~m}$ while pumped lake K209P only shows an increase of $+0.005 \mathrm{~m}$. The $-0.005 \mathrm{~m}$ difference at K209P is due to the cumulative water withdrawal or $6597.3 \mathrm{~m}^{3}$ during the time period. The expected change in WSL from $6597.3 \mathrm{~m}^{3}$ of water withdrawal is $-0.005 \mathrm{~m}$ and $-0.014 \mathrm{~m}$ based on pan and cone bathymetries respectively. Thus, the water withdrawal at K209P shows the detected response due to pumping agreeably meeting the expected response to pumping. Further, the expectation of WSL in early winter favors a pan bathymetry as previously summarized. 


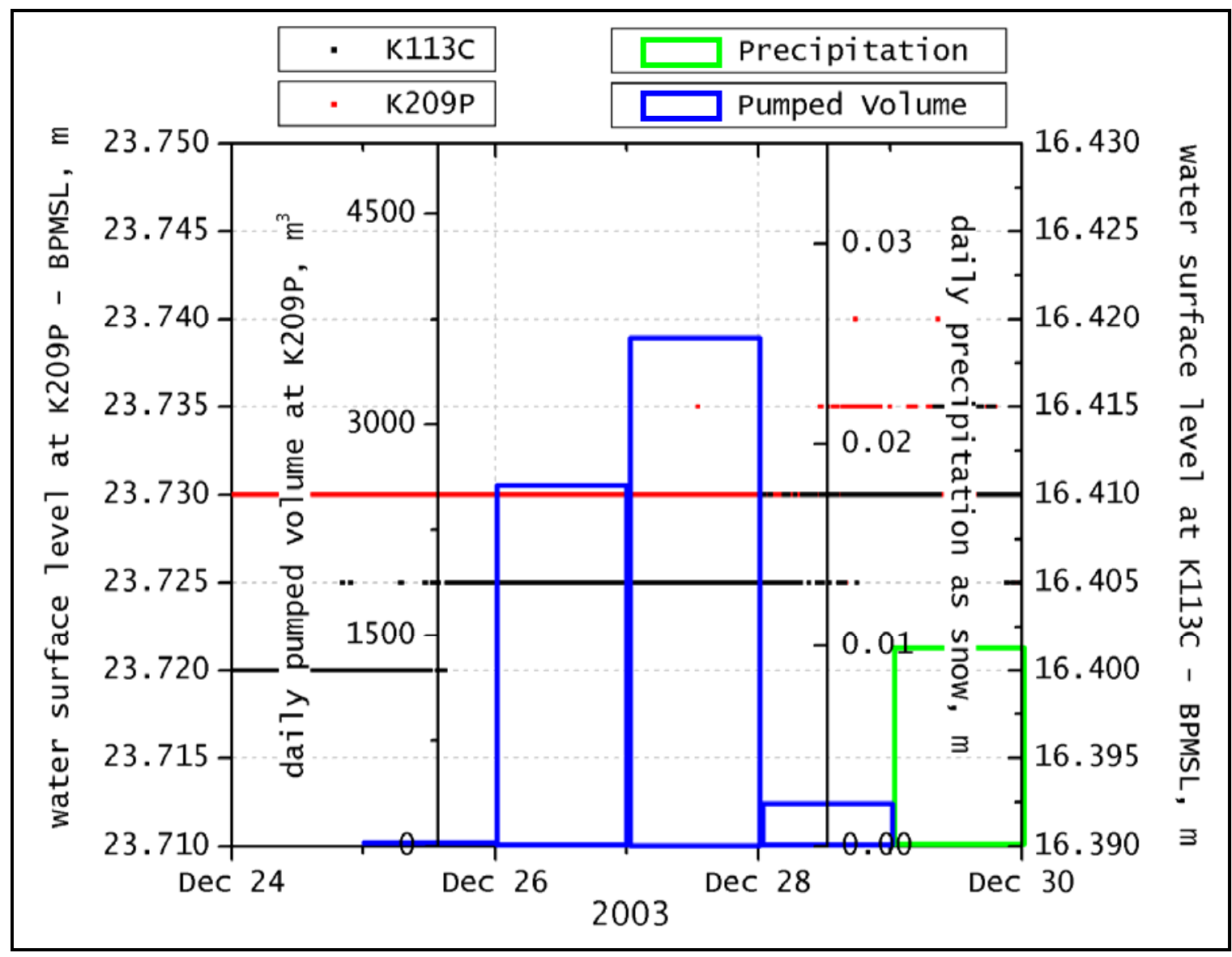

Figure 75. Water surface level at lake K209P during pumping activity December 25-28, 2003 compared to WSL at control lake K113C. Daily precipitation values are taken from the Wyoming Snow Gauge at Betty Pingo.

Figure 75 shows both control and pumped lake responding to the $+0.010 \mathrm{~m}$ precipitation input detected at the Wyoming Snow Gauge at Betty Pingo as WSL at both lakes increases +0.005. Thereafter, both lakes see a corresponding decline in WSL, which is unexpected. The expected change in water surface level at K209P in response to the $6668.9 \mathrm{~m}^{3}$ water withdrawal is -0.005 $\mathrm{m}$ based on a pan bathymetry and $-0.015 \mathrm{~m}$ based on a cone bathymetry. K209P does show the expected decrease of $-0.010 \mathrm{~m}$ after the pumping event, but a $-0.010 \mathrm{~m}$ decrease is also seen at K113C. Discrepancies such as this would have benefited from second instrumented control lake as was planned, but was not operational. 


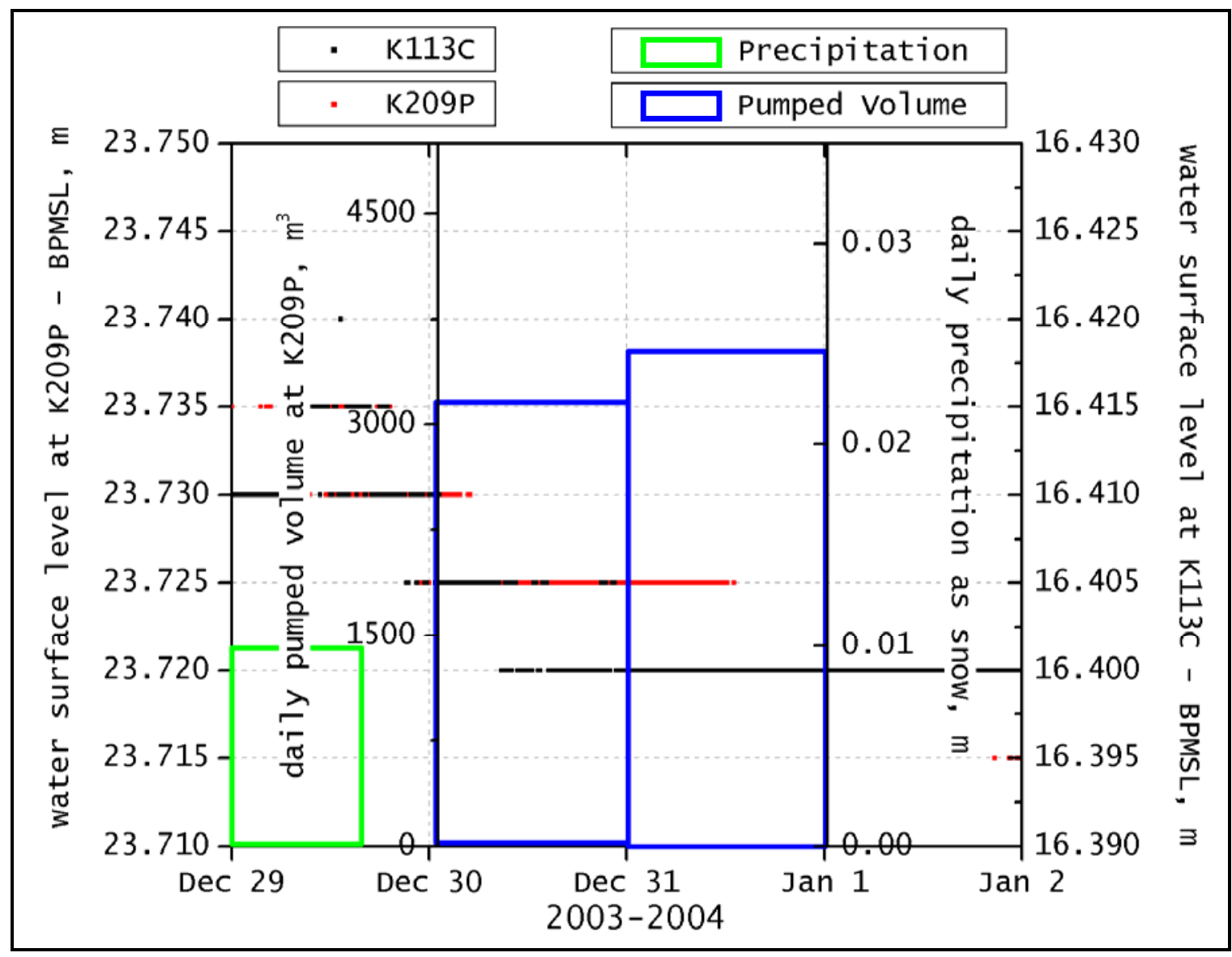

Figure 76. Water surface level measurements at pumped lake K209P during pumping activity December 30-31, 2003 compared to control lake K113C. Daily precipitation values are taken from the Wyoming Snow Gauge at Betty Pingo.

Figure 76 shows the expected response to pumping of K209P with WSL decreasing by -0.015 $\mathrm{m}$ while $\mathrm{K} 113 \mathrm{C}$ remains generally steady with the lack of any precipitation input. The expected cumulative change in water surface level at K209P in response to the $7731.4 \mathrm{~m}^{3}$ water withdrawal is $-0.006 \mathrm{~m}$ based on a pan bathymetry and $-0.018 \mathrm{~m}$ based on a cone bathymetry. 


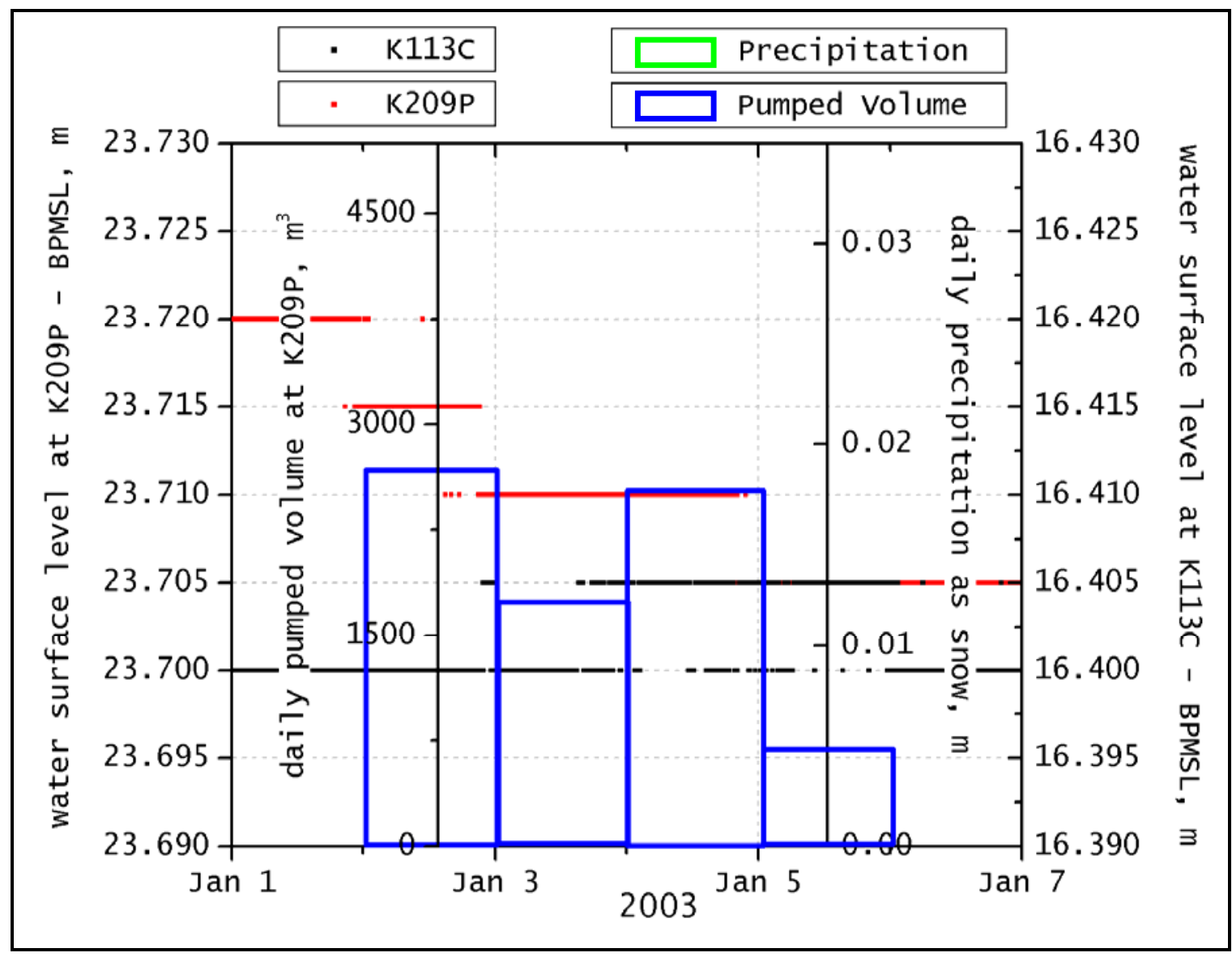

Figure 77. Water surface level measurements at lake K209P during pumping activity January 2-5, 2004 compared to control lake K113C January 2-5, 2004. Daily precipitation values are taken from the Wyoming Snow Gauge at Betty Pingo.

In Figure 78, sustained and heavy pumping activity January 11-22, 2003 provides an excellent opportunity to view responses to pumping. The expected cumulative change to the $16,588.2 \mathrm{~m}^{3}$ water withdrawal is $-0.012 \mathrm{~m}$ based on a pan bathymetry and $-0.044 \mathrm{~m}$ based on a cone bathymetry. K209P shows a decrease of $-0.020 \mathrm{~m}$, which agrees well with the expected WSL change. K113C shows a steady baseline during this period and exhibits good control. 


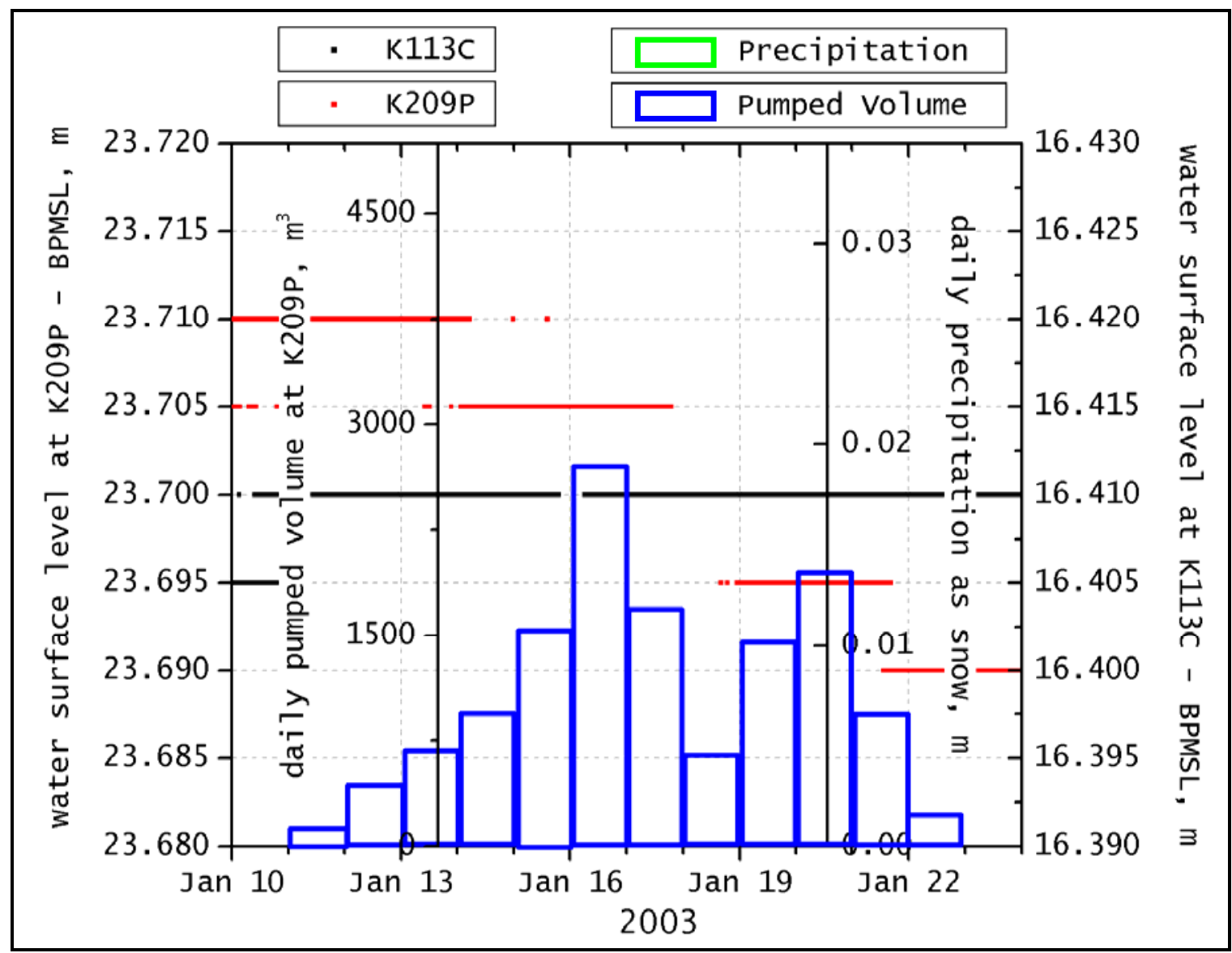

Figure 78. Water surface level measurements at lake K209P during pumping activity January 11-22, 2004 compared to control lake K113C January 11-22, 2004. There was no measured precipitation during this period.

\subsection{Specific Conductance}

Specific conductance (SC) in arctic lakes is driven by the ice exclusion process during the winter freezing. As the ice grows throughout the freezing season, salts are rejected from the ice into the remaining water below the ice. The ice exclusion process is remarkably efficient as most impurities are excluded during the phase change. It is assumed that the entire mass of solutes within the ice generated is rejected into the under-ice water (Smith, 1999).

In shallow tundra lakes, the results of ice exclusion are magnified due to the small volumes of water remaining under the relatively large volumes of ice towards the end of winter. The expected result is that lakes with shallower bathymetries will see a faster rise in SC than those lakes with deeper bathymetries. This expectation was shown to be true for the winter 20022003 data collection period - February 2003 to May 2003 - with K113C, the deepest lake with a maximum depth of $2.3 \mathrm{~m}$, showing lower SC at the end of winter than the shallower lakes K203C, K209P and K214P with maximum depths of 1.88, 1.86 and $1.75 \mathrm{~m}$ respectively. Solute exclusion during freezing is not the only process that affects SC, so it is not surprising that there 
is not an exact correlation between lake depths and SC. The other major factors influencing SC is the sediment chemistry and the related local geology.

Figure 79, Figure 80 , Figure 81 and Figure 82 show SC measurements throughout the 20022003 and 2003-2004 winters at the study lakes. Manual measurements taken during site visits are also given to verify continuous readings in the figures and in Appendix I. The likely source of measurement difference is the vertical differences in concentrations in the water column. Although continuous measurements and manual measurements were collected in close proximity $(\sim 10-15 \mathrm{~m})$, lateral differences in concentrations in SC could arise due to sampling difficulty that occurs when drilling through thick ice into the shallow water below the ice. It was not possible to confirm that the bottom sediments were not slightly disturbed during drilling, which would increase SC measurements. Therefore, late winter manual measurements are likely higher due to inadvertent agitation of the sediments during sampling. Figure 83 and Figure 84 compare the SC of each study lake during the 2002-2003 and 2003-2004 winters. The specific conductance increases over winter due to solute exclusion from the growing ice matrix. Lakes with smaller under-ice volumes will have a relatively larger increase in SC. Each lake may also have different summer and winter variations in SC due to differences in lake bottom sediments and variations in soil types in the lake watershed.

Notable in the continuous measurements are the 2003-2004 winter readings at lake K209P (Figure 81). SC displays a large exponential increase later in the winter and then goes offline March 21, 2004. The measurements are an observation of minimal under-ice water volume with higher salinity and then ice growth, eventually intersecting the SC sensors.

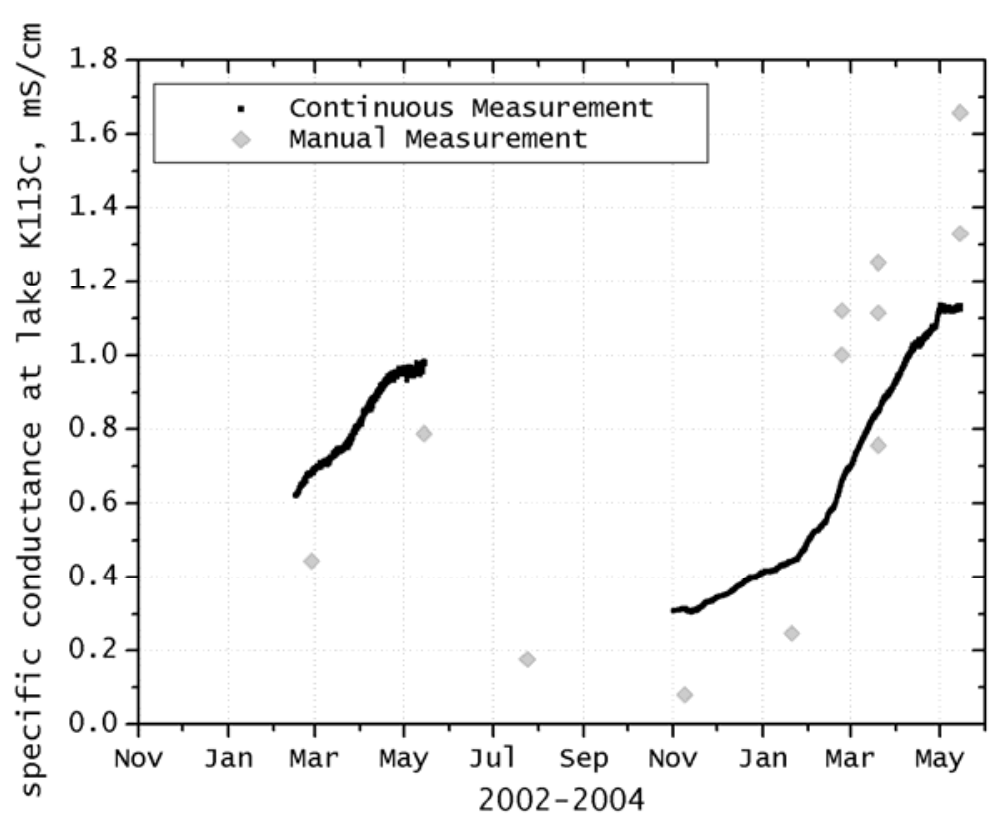

Figure 79. SC measurements at control lake K113C. 


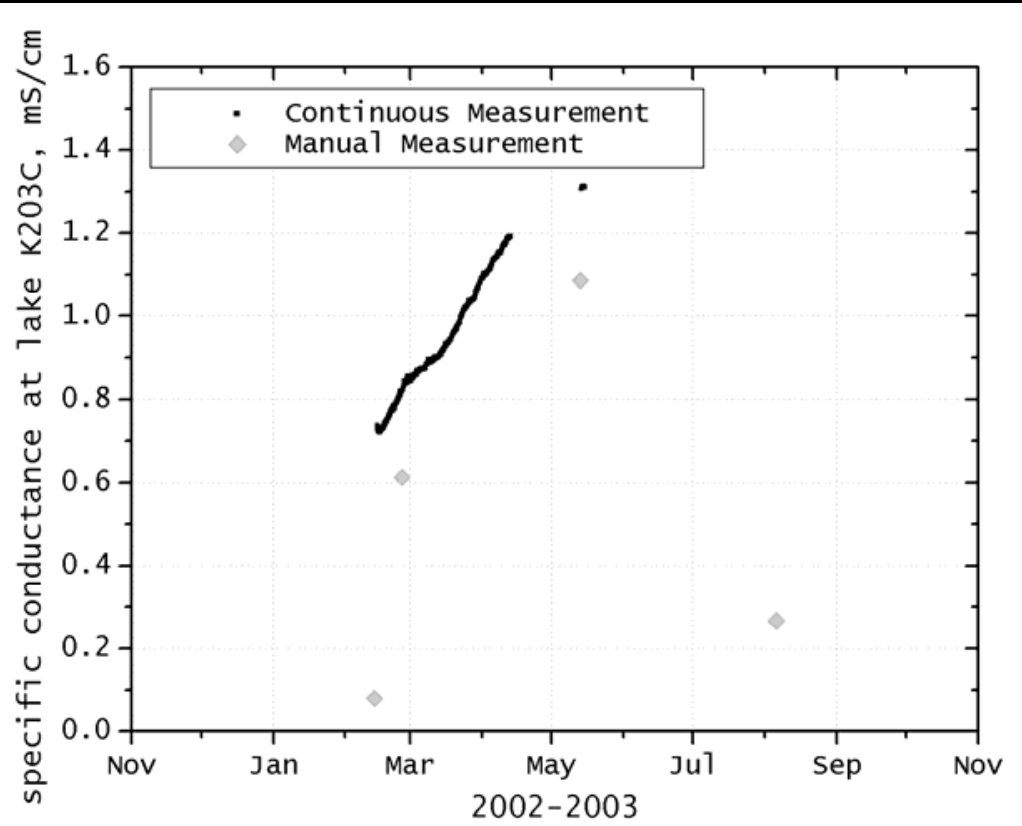

Figure 80. SC measurements at control lake K203C.

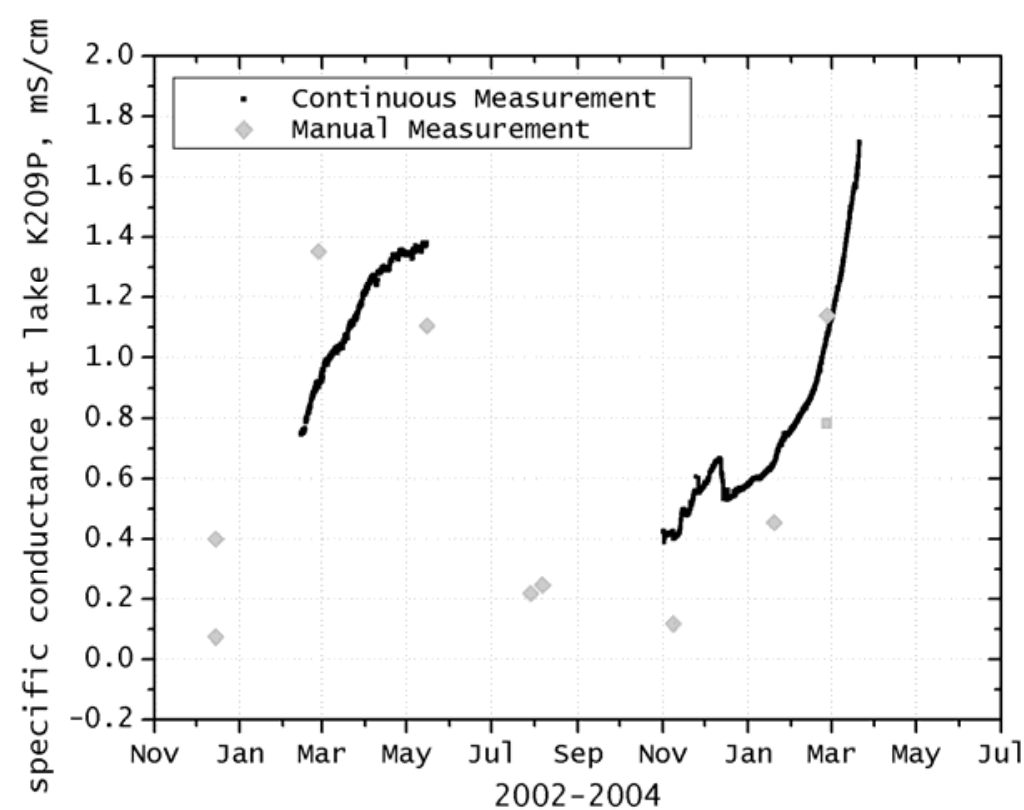

Figure 81. SC measurements at pumped lake K209P. 


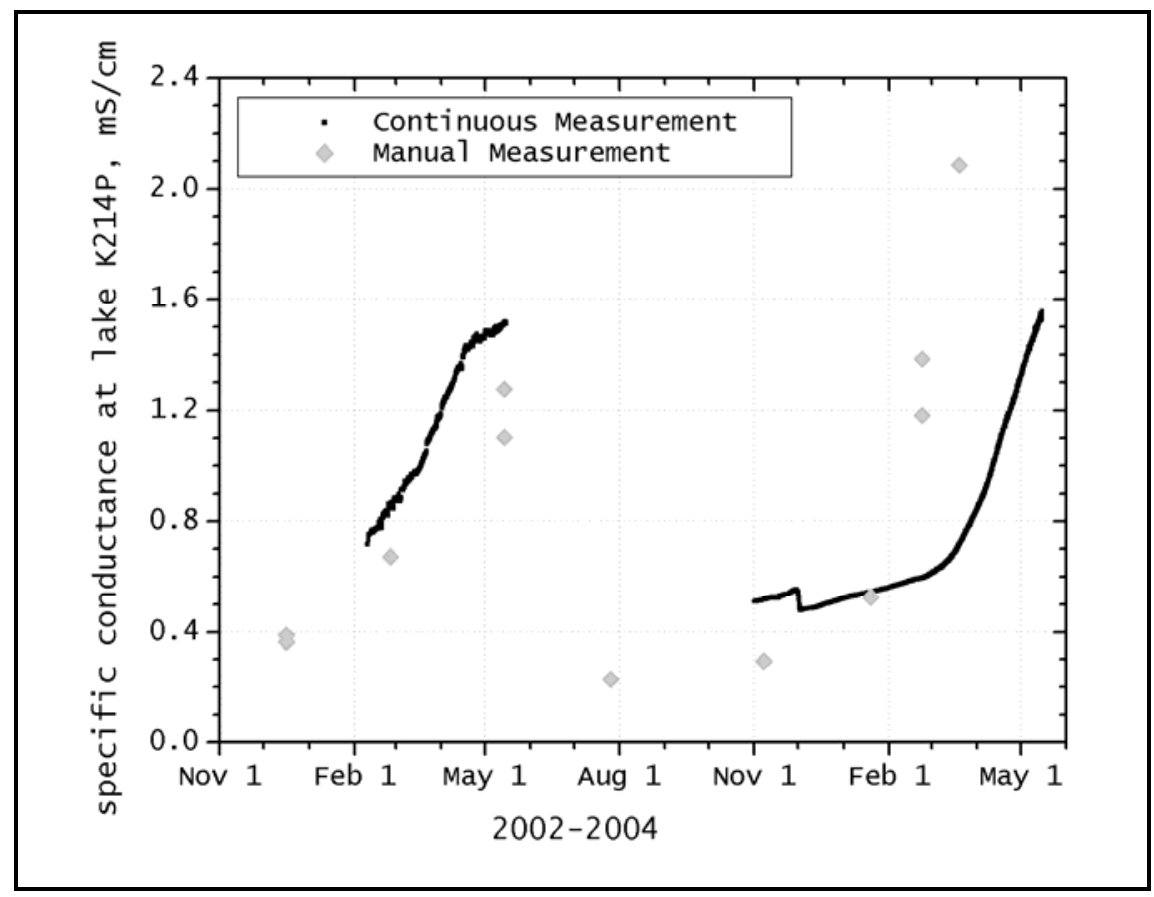

Figure 82. SC measurements at pumped lake K214P.

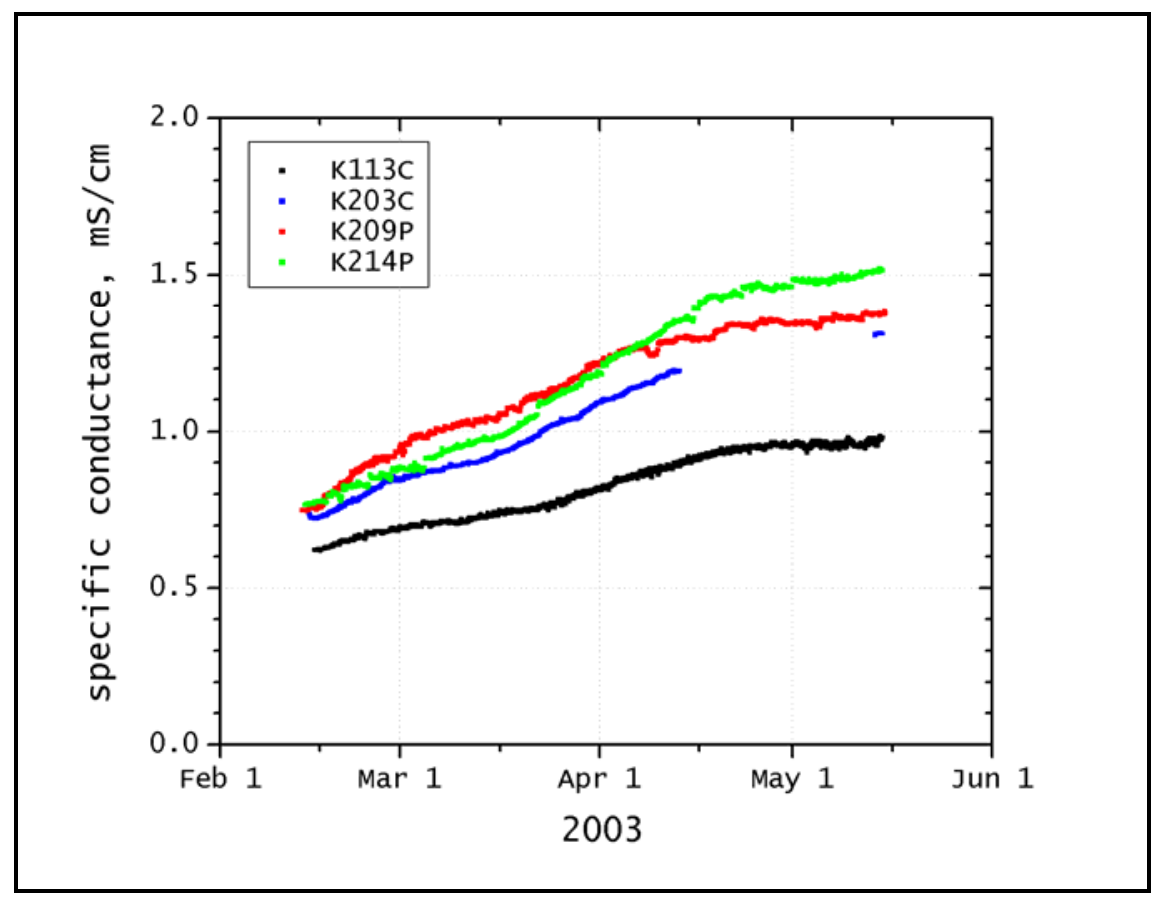

Figure 83. Comparison of SC at study lakes throughout 2002-2003. 


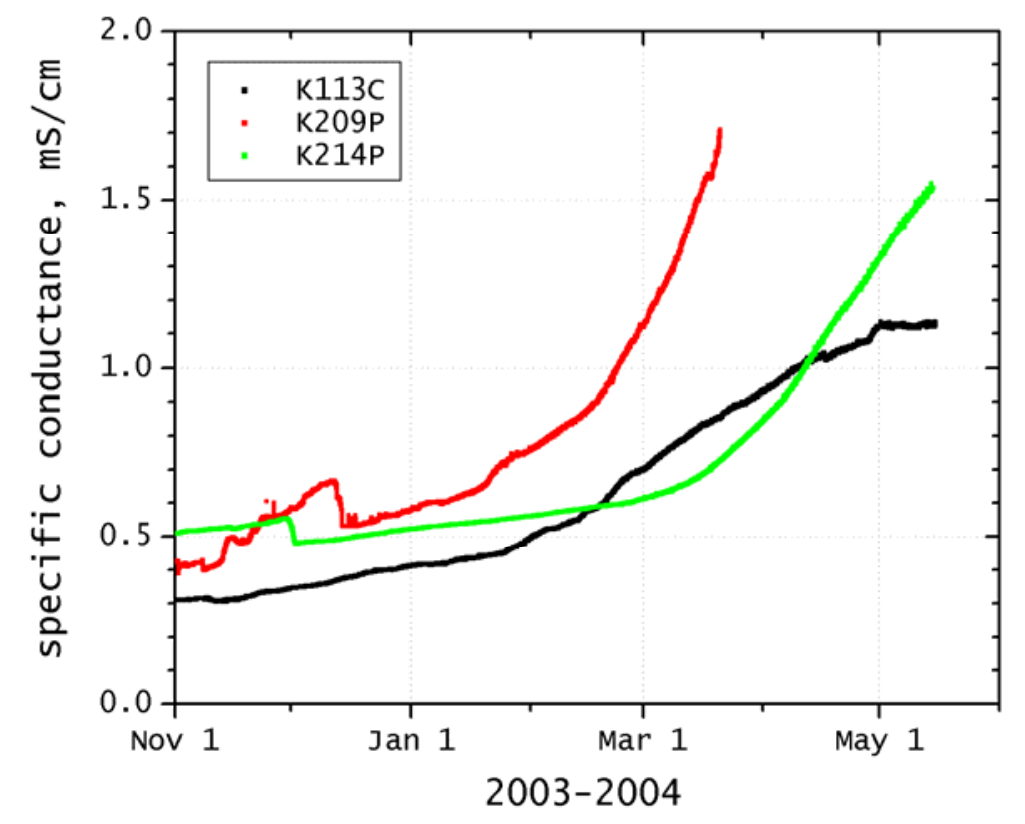

Figure 84. Comparison of SC at study lakes throughout winter 2003-2004 data collection period.

Another interesting SC feature is seen at pumped lakes K209P and K214P when SC sees a sudden drop over about a 36-hr period in mid-December 2004 and early-December 2004 respectively. This observation is unexpected since the sensor is under ice and should show an increasing trend from the solutes excluded from the growing ice. It is unlikely the drop is a result of pumping since no pumping had yet occurred for the 2003-2004 winter.

An important question to address, similar to whether tundra lakes are hydrologically recharged by spring meltwater, are tundra lakes chemically reset by spring meltwater? If the chemistry of tundra lakes is affected by pumping, then cumulative impacts to chemistry would occur if not chemically reset each spring. Figure 85, Figure 86 and Figure 87 show the response in SC at the study lakes to the introduction of meltwater in the spring of 2005 . The sudden decrease in conductivity indicates mixing of snowmelt runoff with the higher conductivity lake water below the ice. 
K113 Spring Snowmelt 2005

Conductance, Temperature, and Water Level

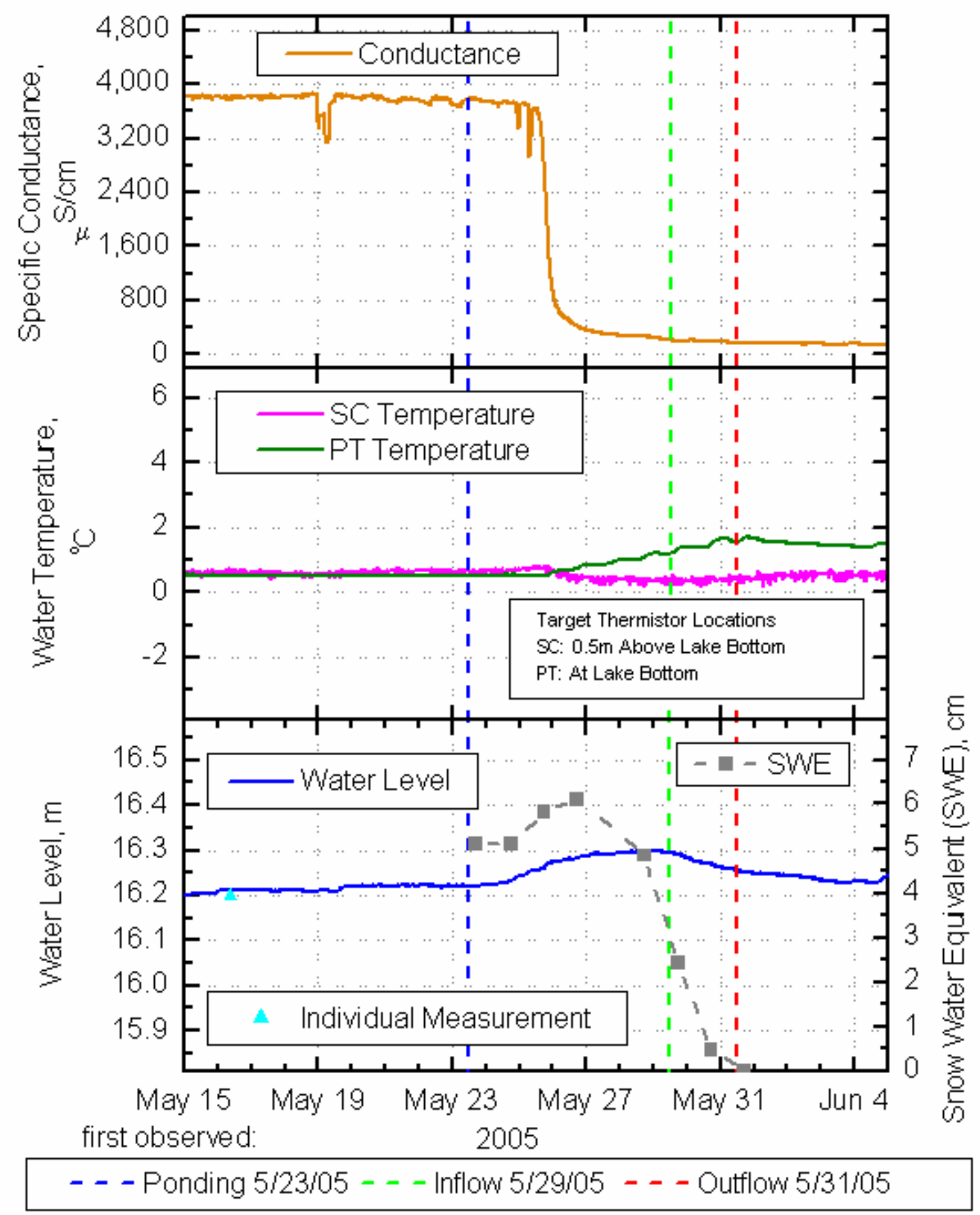

Figure 85. Spring 2005 chemistry and snow water equivalent during ablation at K113C. 


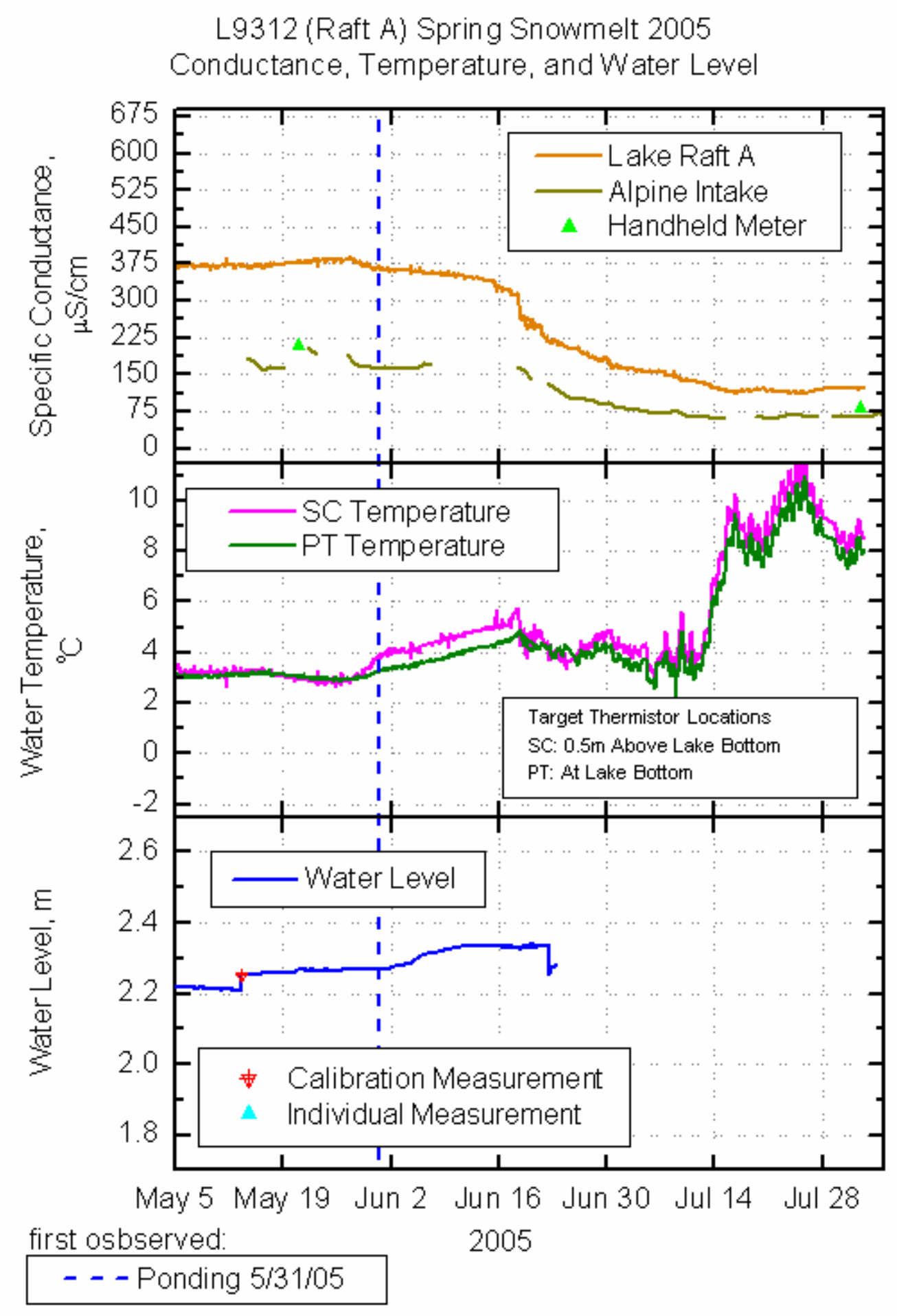

Figure 86. Spring 2005 chemistry and snow water equivalent during ablation at L9312P. 


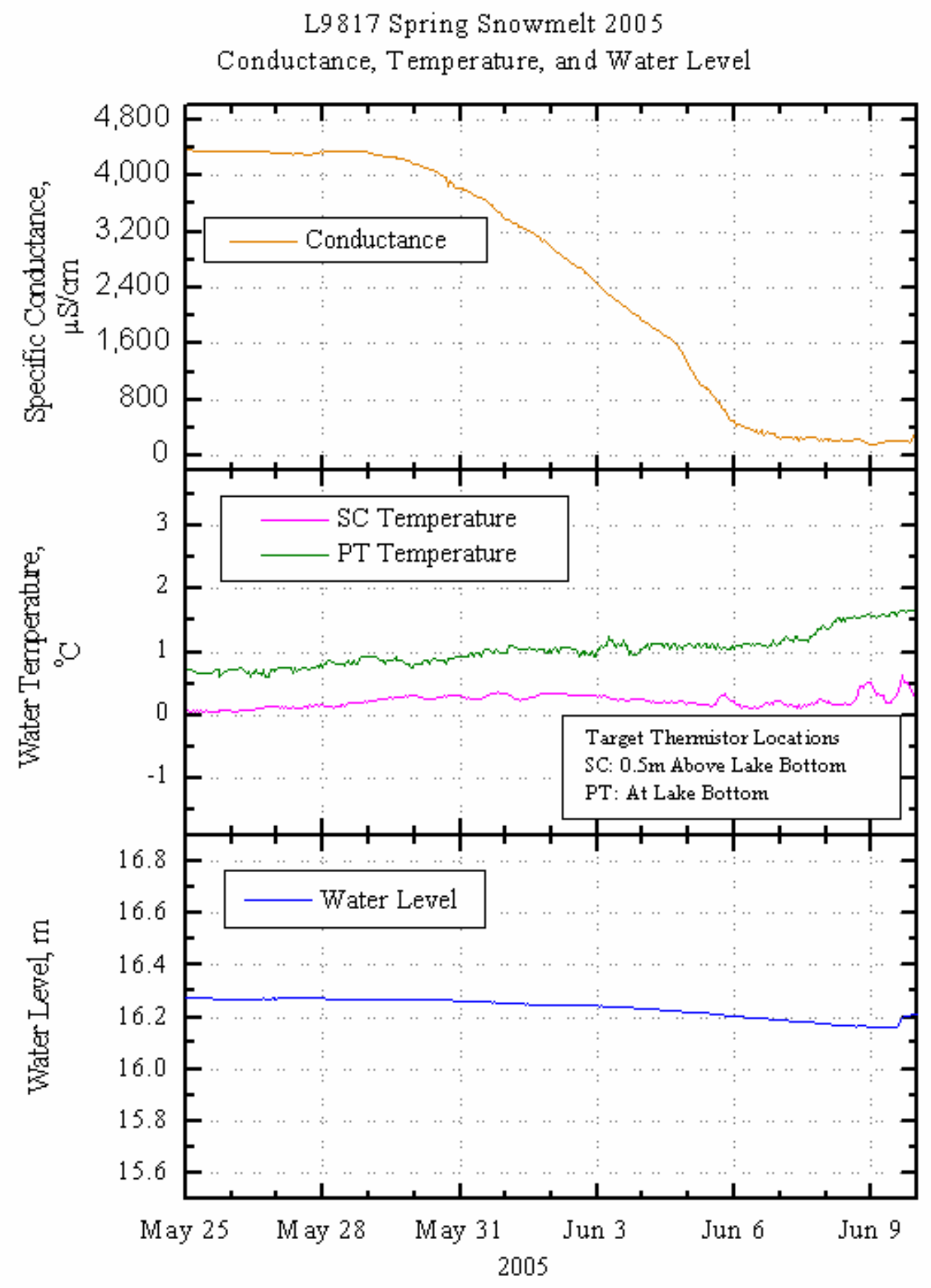

Figure 87. Spring 2005 chemistry and snow water equivalent at L9817P.

The drop in SC at the study lakes in late-May and early-June shows the input from meltwater runoff. The decline in the lake SC is documented until the beginning of July when the 
instrumented stations broke free of the ice and moved to shore by strong winds when the ice broke up. After July, the lakes show a gradual increase of SC due to summer evaporation.

Figure 85, Figure 86 and Figure 87 provide some evidence that the study lakes, both pumped and control, may be chemically reset by spring meltwater. As meltwater enters the lake in early stage of snowmelt, the hydrostatic surface slowly increases. Mass exchange has not yet taken place at the raft location. The ice around the edge of the lake is frozen to the bottom, so water accumulates on top of this ice, while the ice in the middle is free to rise as water percolates beneath the ice. The water level and ice surface rises about the central ice elevation creating the moat around the edge of the lake. As accumulation of water in the lake increases to the point of outflow, the floating ice surface becomes stable and water levels increase as the lake reaches an overfull state. The ice surface is at a higher elevation now compared to freeze-up conditions, when the formation of ice usually occurs at lower water levels. As water is flowing out of the lake, it will melt through discharge points, resulting in a lowering of the lake water table. As the lake ice is becomes ungrounded, the raft drifts into shallow water, possible moving around the lake resulting in erratic relative water levels due to vertical movements of the pressure transducer over pond bottom or in response to tangled cables.

Figure 88, Figure 89, Figure 90, Figure 91 and Figure 92 compare SC at control and pumped lakes during selected periods of heavier pumping. Daily water withdrawal volumes are illustrated in the figures. Although there appears to be some correlation of increasing SC near pumping events, the trend is inconsistent overall. More precise records of exact pumping times and durations would benefit future analyses. It is important to note, the greatest increase noted during a pumping event was $008 \mathrm{~ms} / \mathrm{cm}$ (Figure 89), which is about $6 \%$ of the total change that occurred over the winter.

Figure 88 presents SC measurements at lake K214P during pumping activity December 7-10, 2003 compared to control lake K113C. Both lakes show the similar trend of increasing SC due to growing ice and solute exclusion as expected. 


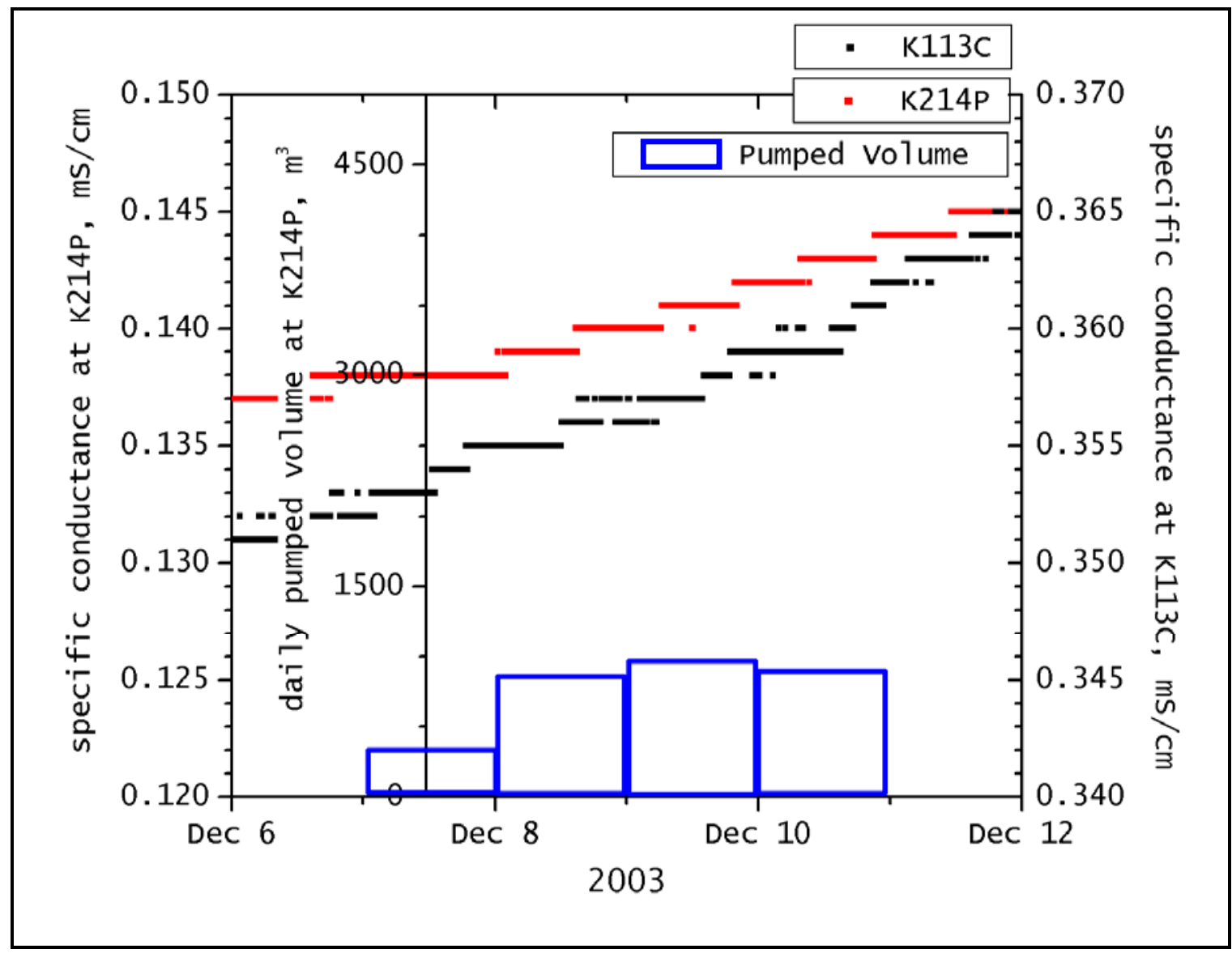

Figure 88. SC measurements at lake K214P during pumping activity December 7-10, 2003 compared to control lake K113C.

Figure 89, which details SC measurements at lake K209P during pumping activity December $25-28,2003$, displays variable increases and decreases in SC measurements. These fluctuations may be a response of SC to pumping, but because the increases and decreases are within the variance of the SC sensor they cannot be treated as significant. The fluctuations in SC are generally within $+/-2 \%$ of the values which is within the sensors' $5 \%$ accuracy tolerance. Thus, some of the rapid increases and decreases in SC may be due to the accuracy tolerance of the sensor, not pumping activity. 


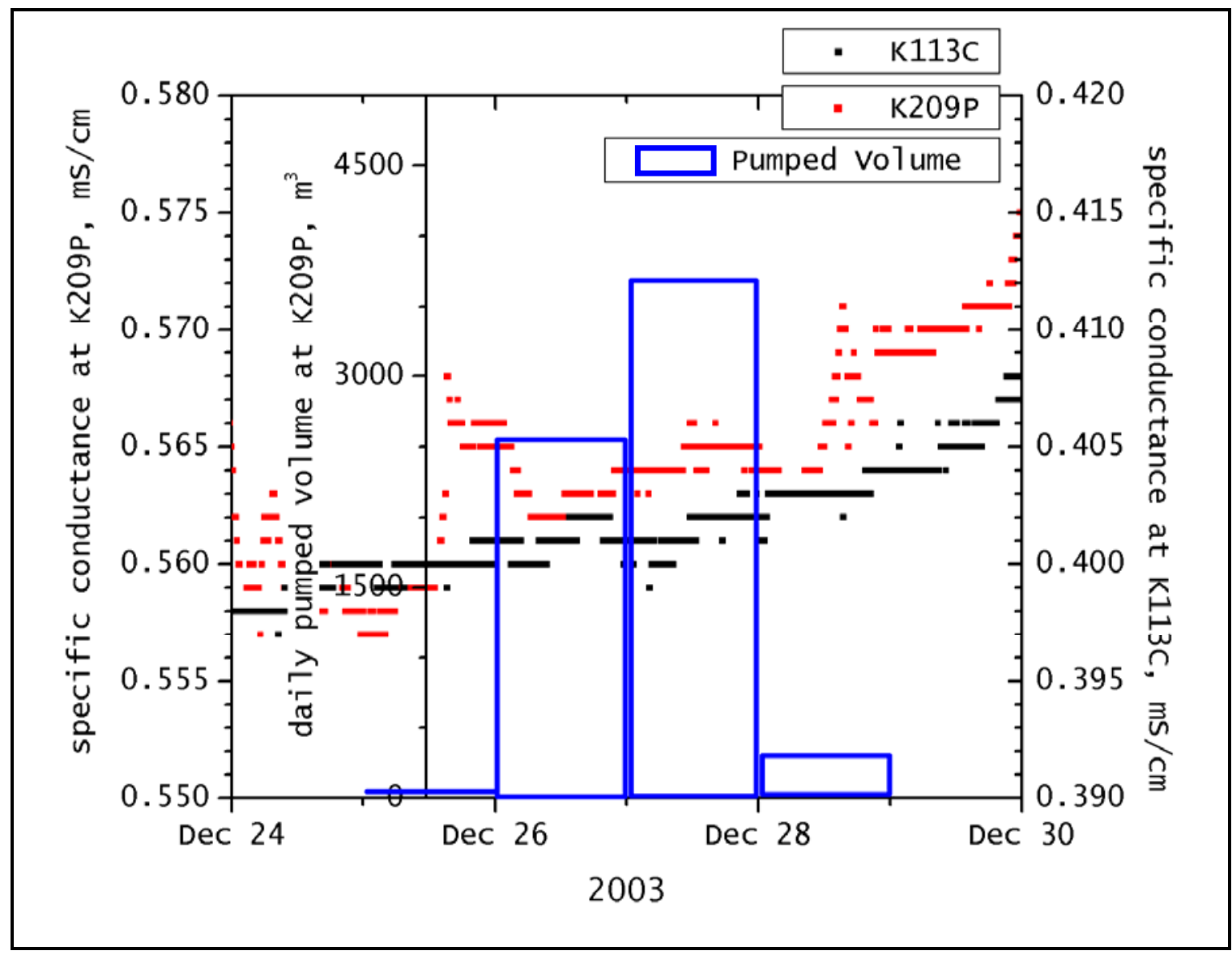

Figure 89. SC measurements at lake K209P during pumping activity December 25-28, 2003 compared to control lake K113C.

Figure 90 presents SC measurements at lake K209P during heavy pumping activity on December 30-31, 2003 compared to control lake K113C. A slight increase during both days of pumping is apparent in this plot. The magnitude of the pulses is usually small, but the timing appears to be related to pumping activity. 


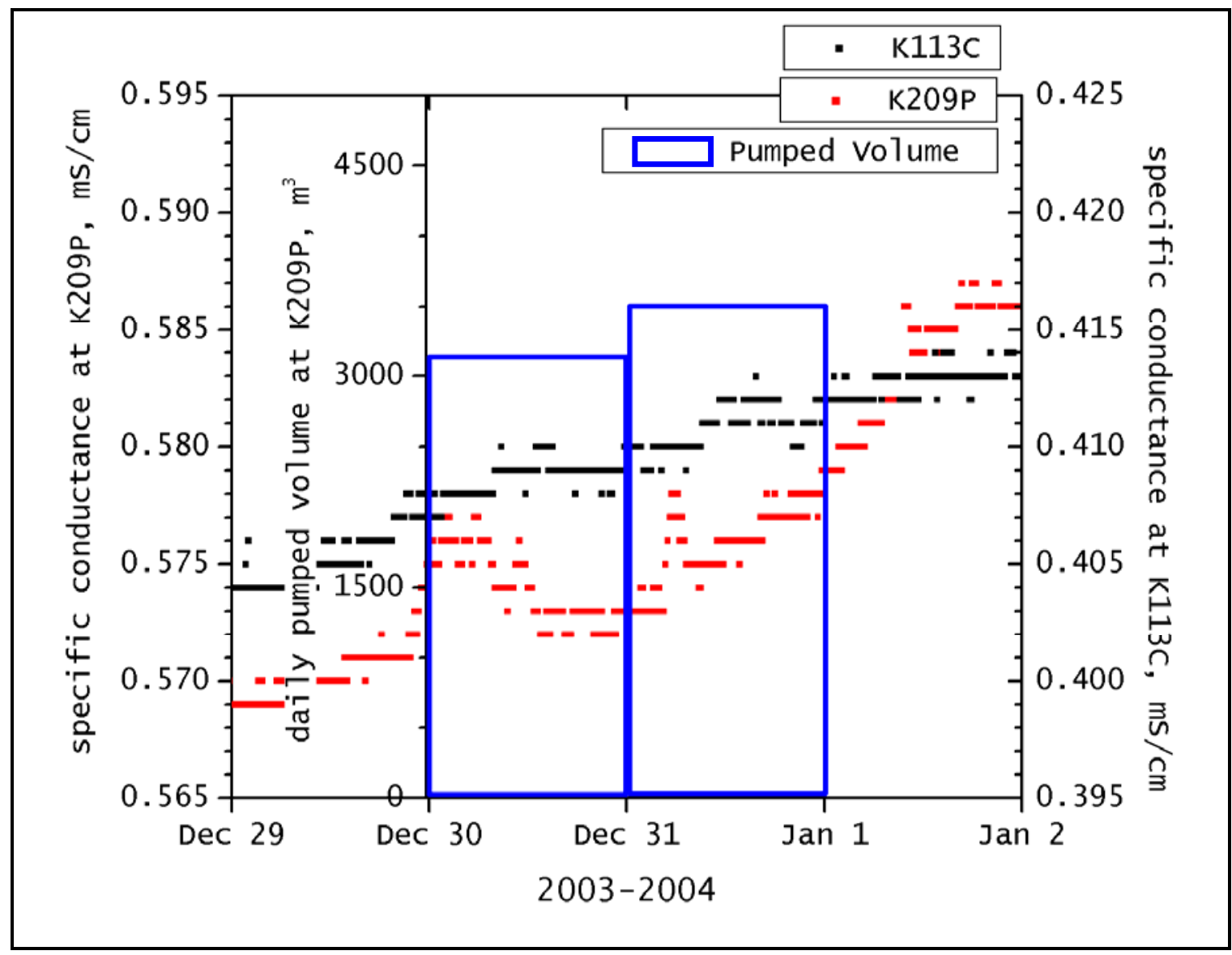

Figure 90. SC measurements at lake K209P during pumping activity December 30-31, 2003 compared to control lake K113C.

Figure 91 shows SC measurements at lake K209P during pumping activity January 2-5, 2004 compared to control lake K113C. Fluctuations such as those in Figure 89 and Figure 90 are not seen in Figure 91. Generally, K209P begins to rise in SC at a greater rate than K113C during the examined time period. This is probably due to the shallower bathymetry at K209P. A more detailed understanding of lake bathymetry is essential for future analyses to qualify if differences can be attributed to pumping or simply bathymetric differences. 


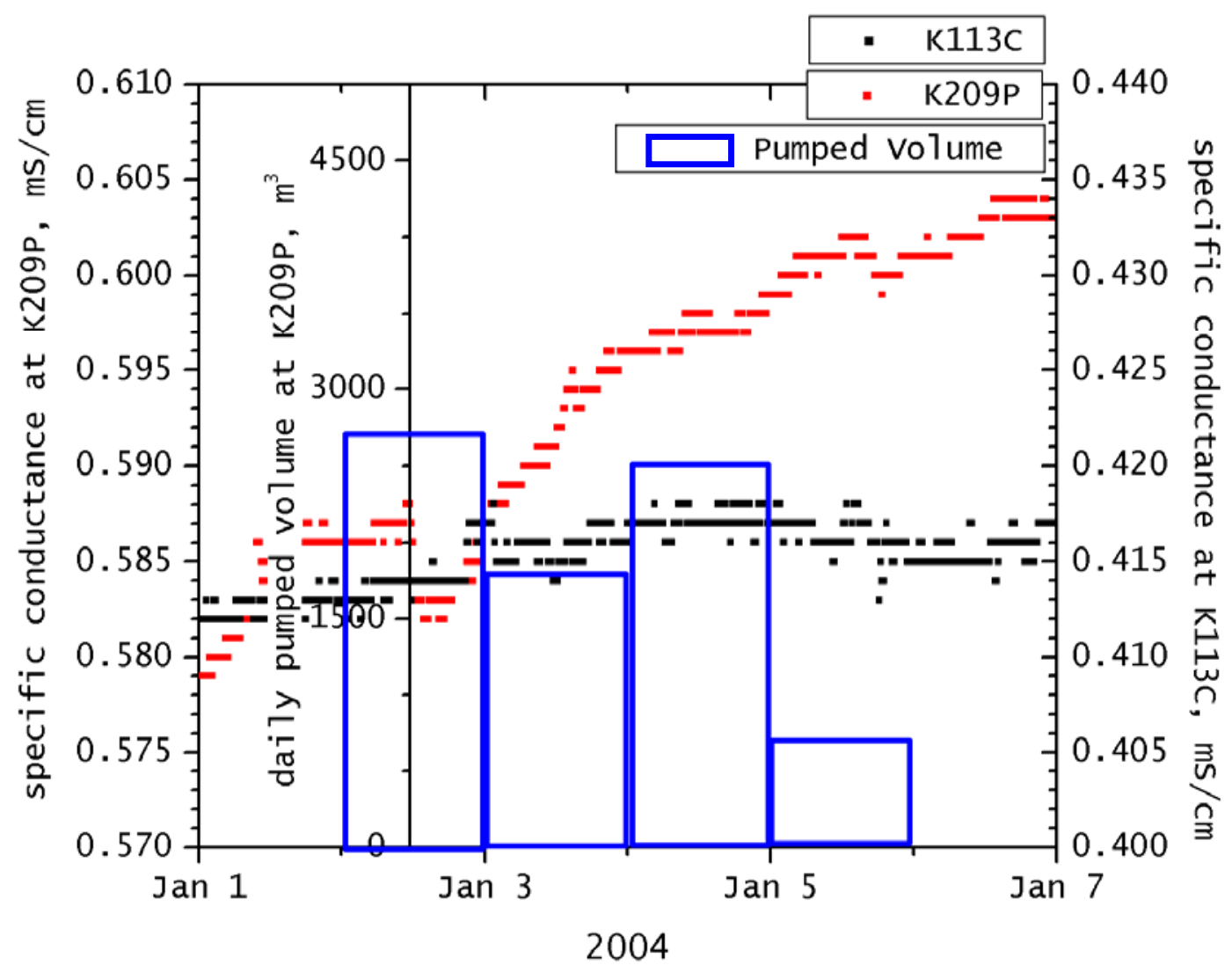

Figure 91. SC measurements at lake K209P during pumping activity January 2-5, 2004 compared to control lake K113C.

The heavy pumping activity at K209P from January 11-22, 2004 (Figure 92) is a good opportunity to view potential effects due to pumping. K209P shows a marked increase about $0.080 \mathrm{mS} / \mathrm{cm}$ while K113C shows no increase. This may be a result of K209P's shallower bathymetry and/or, possibly, the heavier pumping activity at K209P may have perturbed bottom sediments. Since these slight increases are usually followed by a decrease of a similar magnitude, this explanation seems plausible. 


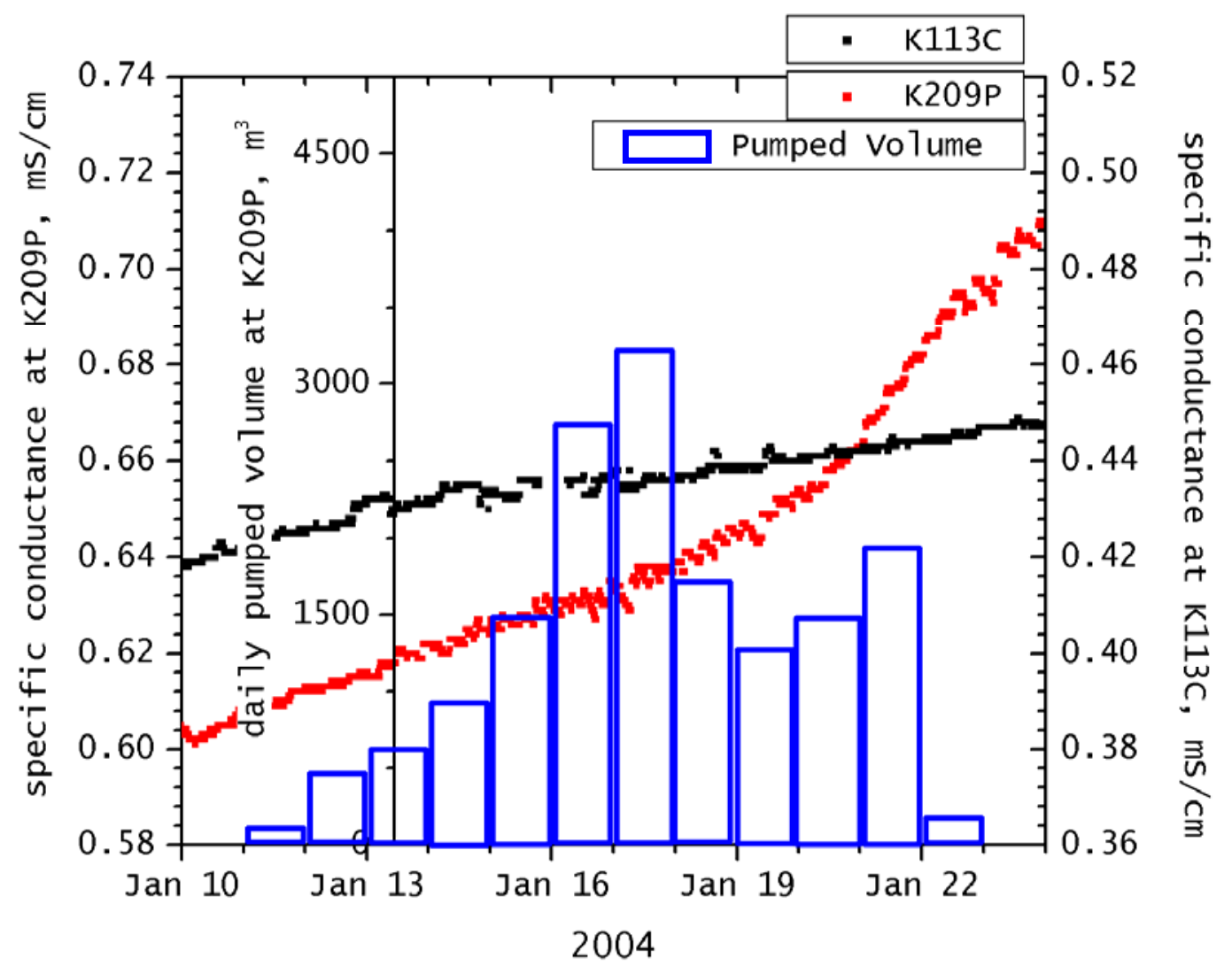

Figure 92. Averaged SC measurements at lake K209P during pumping activity January 11-22, 2004 compared to control lake K113C.

\section{$11.5 \quad$ Temperature}

Water temperature was measured by paired thermistor sensors in a vertical profile at 15 or 30 $\mathrm{cm}$ increments at the study lakes. Thermistors near the top of the ice show a good correlation to ambient air temperature as expected due to conduction through the ice. Lower thermistors, located in liquid water and near the sediment interface, remain above $0^{\circ} \mathrm{C}$ as expected. In the subsequent figures, thermistors are referenced to a lake bottom datum then reduced to a measured distance above bottom sediment (ABS).

Investigation of lake temperature was undertaken because pumping might disrupt the conventional thermal structure of the lake by mixing the under-ice water due to pumping agitation. In deep lakes, the lower under-ice water stratifies from 0 to $4^{\circ} \mathrm{C}$ from below the ice to the bottom. Thus, the lower thermal profile shows the deepest water near $4^{\circ} \mathrm{C}$ since it is the densest. Also, the pumping activity occurred some distance from the instrumented station, creating another challenge to observe any potential disturbance.

Thermal profiles of the study lakes at one-month intervals after installation in the winter of 2003 are presented in Figure 93, Figure 94, Figure 95, and Figure 96. Thermal profiles from 
February 2003 - May 2003 are impacted by the sustained cold weather, below $-40^{\circ} \mathrm{C}$, lasting into late February. Beginning in April, temperatures warm and the ice gradually warms, rots and is nearly isothermal by the end of the freezing season in mid-June.

Accurate thermal profiles were not available during the 2003-2004 winter because the strong summer winds moved the rafts, tangling and disorienting the vertical thermistor sensor string. In-situ temperatures were also collected to verify online readings. These onsite temperature measurements are presented in Appendix I. Generally, pumped and control lakes show similar thermal profiles and no effect from pumping activity was observed.

Figure 93 shows 2002-2003 winter thermal profiles at one-month intervals at K113C. K113C shows an isothermal profile throughout the winter between $0.0-1.0^{\circ} \mathrm{C}$ with the warmer and denser water nearer the pond bottom.

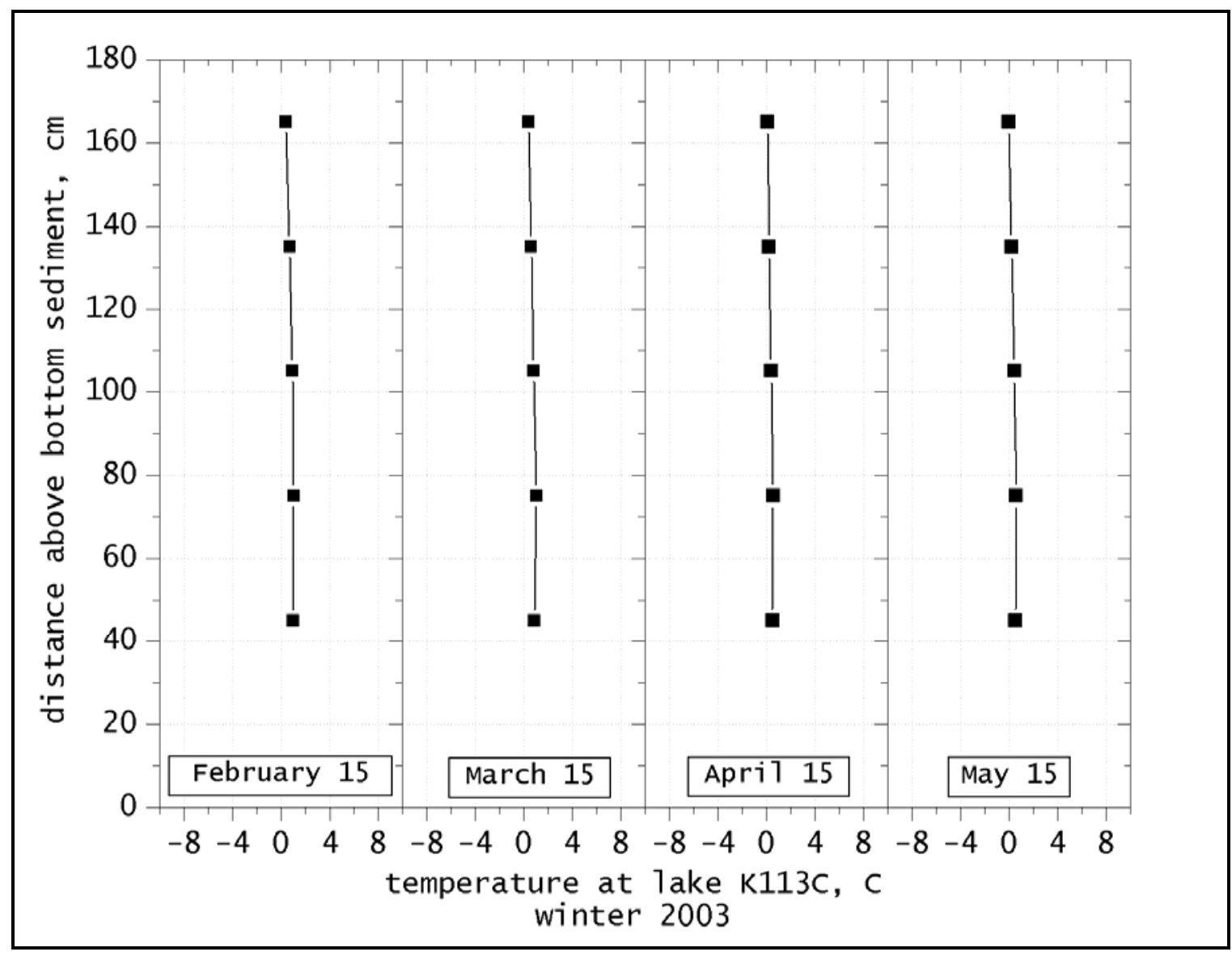

Figure 93. Thermal profiles at control lake K113C during the winter 2002-2003 data collection period.

Figure 94 presents thermal profiles at lake K203C. The profile is nearly isothermal, but some effect from ambient air temperature is seen in the upper thermistor $(155 \mathrm{~cm}$ ABS) in March and April as the uppermost thermistors became frozen in the ice. The lower thermistors $(15,45,75$ $\mathrm{cm} A B S$ ) remain unfrozen but are very close to $0.0^{\circ} \mathrm{C}$. 


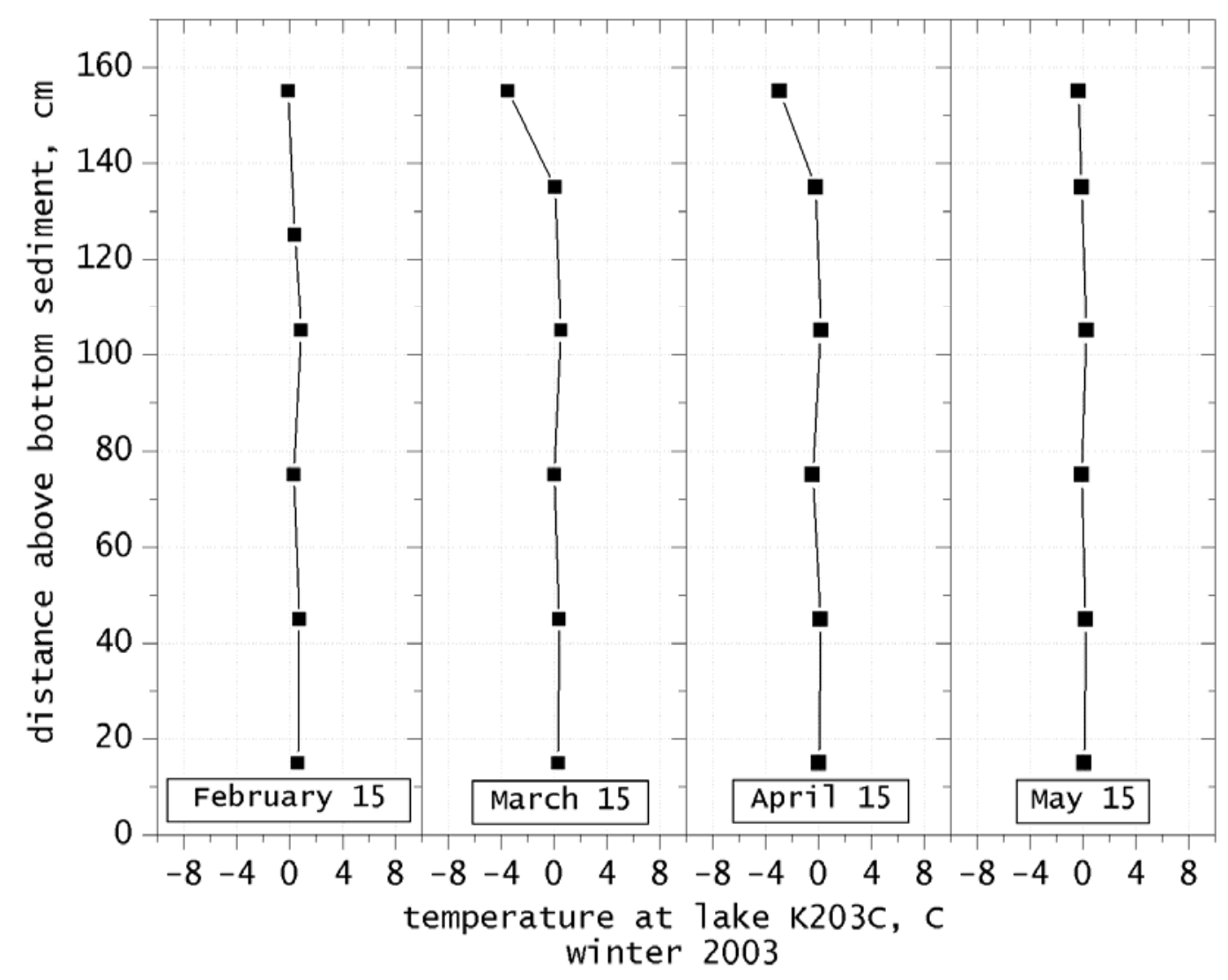

Figure 94. Thermal profiles at control lake K203C during the winter 2002-2003 data collection period.

Figure 95 shows the expected thermal profile for lake K209P. The upper thermistors are affected by the ambient air temperature. Since the coldest temperatures occurred in February, the upper profile warms from February on. Although the thermal profile at pumped lake K209P deviates from the control lakes, this is primarily due to lake depth as the top of the thermistor string was frozen in ice in the shallower lakes. 


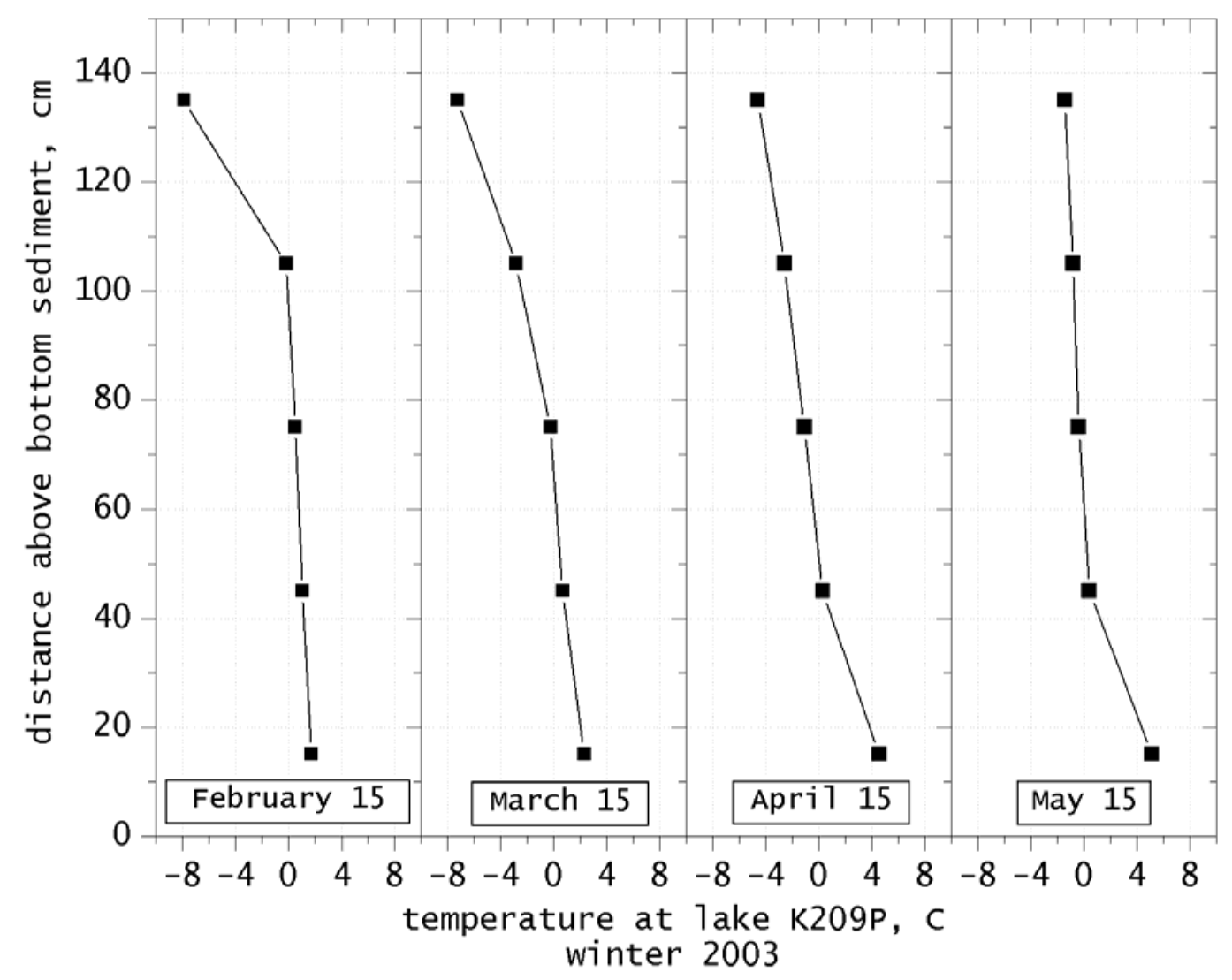

Figure 95. Thermal profiles at pumped lake K209P during the winter 2002-2003 data collection period.

Similar to K209P in Figure 95, K214P shows the expected thermal profile for a tundra lake progressing towards spring in Figure 96. No effect from pumping was observed. 


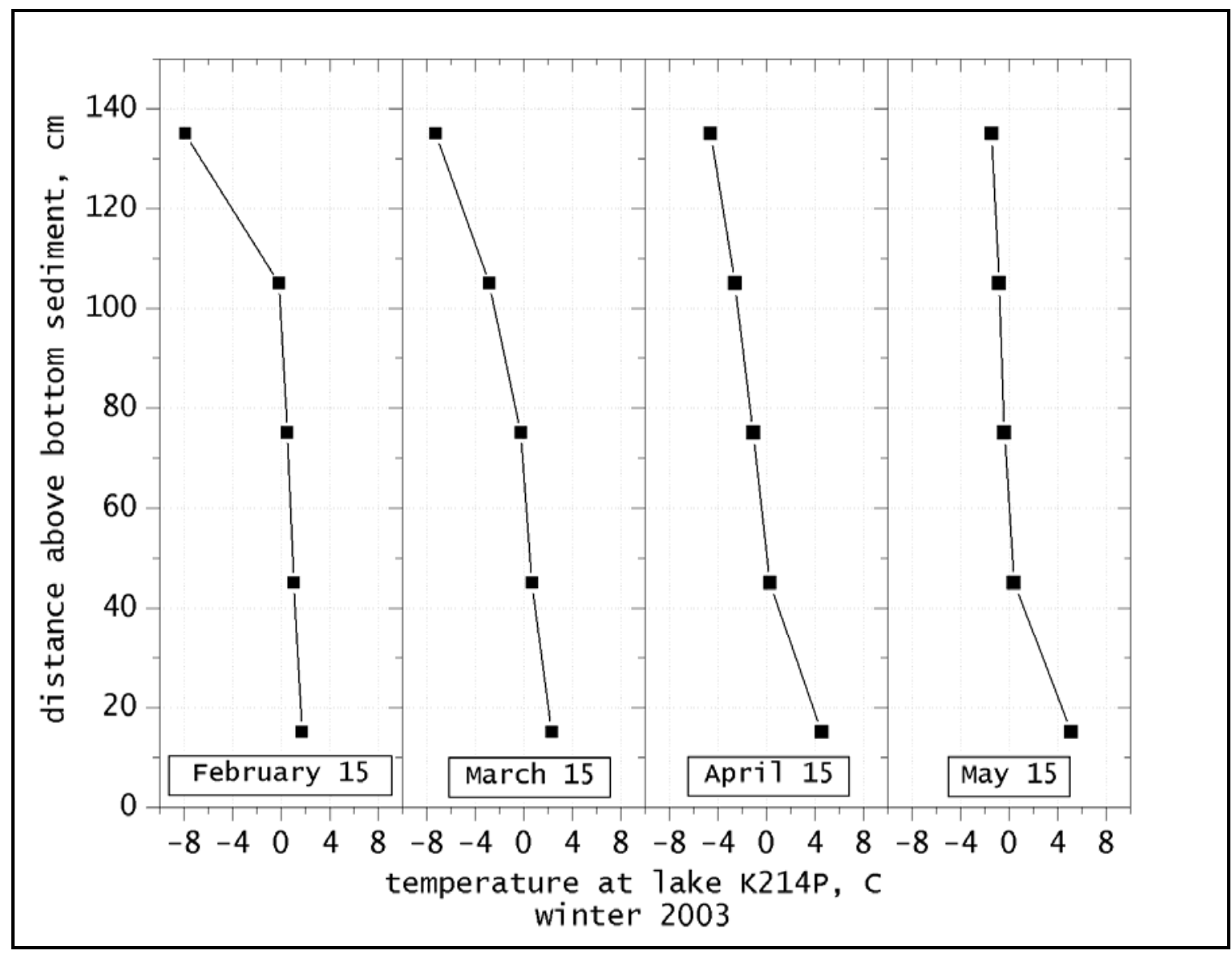

Figure 96. Thermal profiles at pumped lake K214P during the winter 2002-2003 data collection period.

\subsection{Dissolved Oxygen}

Dissolved oxygen (DO) is a difficult variable to accurately measure in any freshwater system and the challenge is compounded when measuring under-ice concentrations in cold and shallow tundra lakes. Due to the cold temperature and limited under-ice volumes for operation, many of the DO sensors malfunctioned on installation. However, some DO data were obtained and are presented to provide some insight into winter $\mathrm{O}_{2}$ dynamics. It is not possible to characterize pumping effects from these data. Dissolved oxygen measurements through the winter are expected to show a gradual depletion in the water column. The depletion is a result of biological oxygen demand and chemical oxidation. Most of the uptake occurs near the sediment interface. In-situ measurements of DO were taken on sampling visits, but were affected by aerating the water column during augering.

Figure 97 and Figure 98 present dissolved oxygen measurements obtained for the control lakes in winter. An initial look at the data shows several rapid increases and decreases in DO concentration. It is difficult to explain the substantial increases in dissolved oxygen in midwinter. These increases may be due to the ice fracturing and introducing atmospheric oxygen into the under-ice water or may be related to oxygen exclusion during freezing. Thereafter, the concentrations gradually deplete as expected. Unfortunately, no accurate DO data were 
obtained from pumped lakes K209P and K214P so little can be said about effects from pumping. It is critically important to understand the mechanisms controlling the changes in DO and further study is warranted. Improved methods of measuring in situ DO must be developed to ensure accurate assessment of these processes.

Figure 97 shows dissolved oxygen measurements at lake K113C during the 2003-2004 winter. Oxygen concentrations under ice in early November are near 30\% saturation, but then increase due to auguring onsite near the instrumented station on November 7, 2003. It is not obvious why the DO continued to increase for several days after augering. After this noted increase, a gradual depletion of oxygen in the water column is observed until the lake becomes anoxic in April. Later onsite augering (February 19, 2004; March 23, 2004; May 14, 2004) was not detected by the DO sensor.

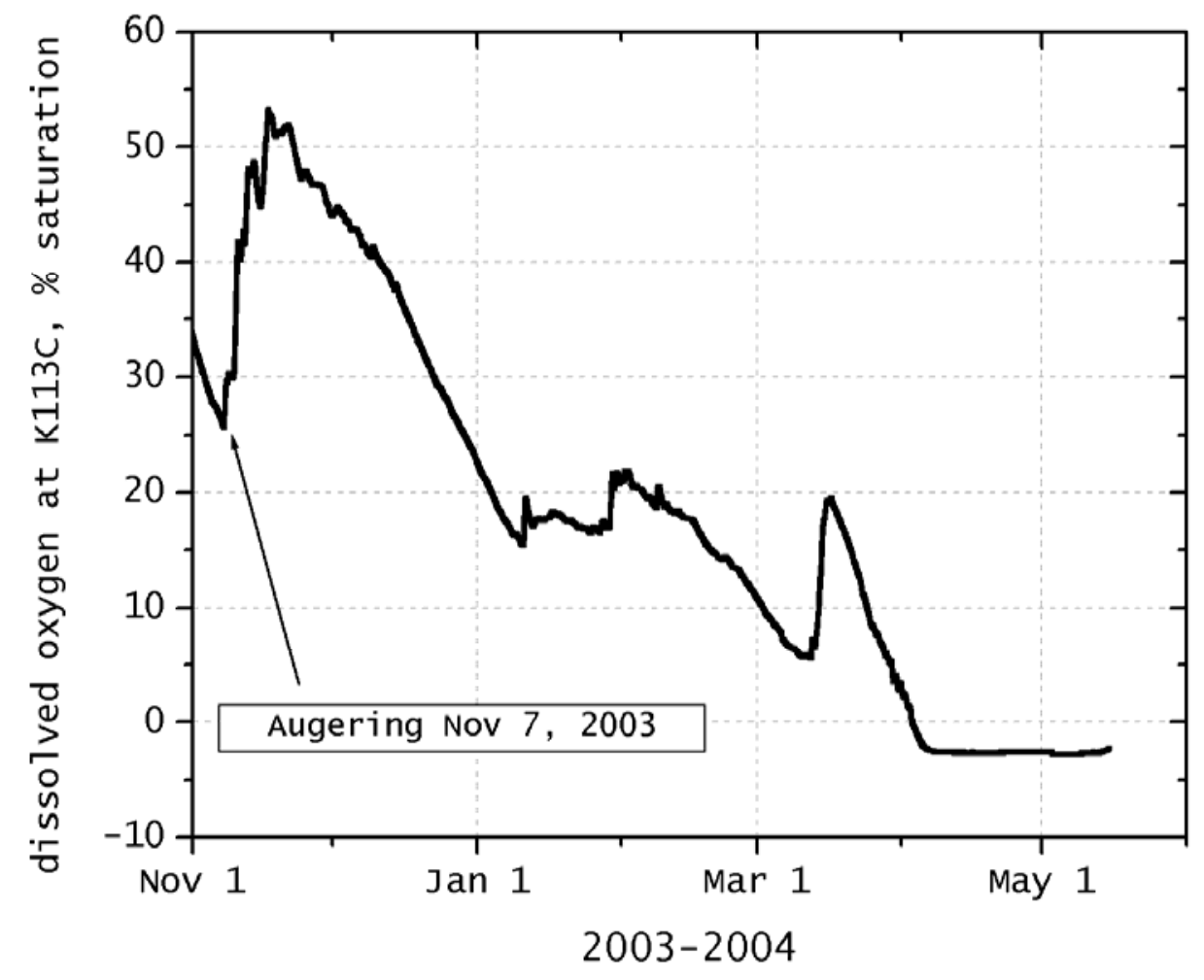

Figure 97. Dissolved oxygen at control lake K113C during 2003-2004 winter data collection.

Dissolved oxygen measurements at lake K203C for the 2002-2003 winter are presented in Figure 80 . K203C shows the expected gradual depletion of under-ice DO to anoxic concentrations in April or May. 


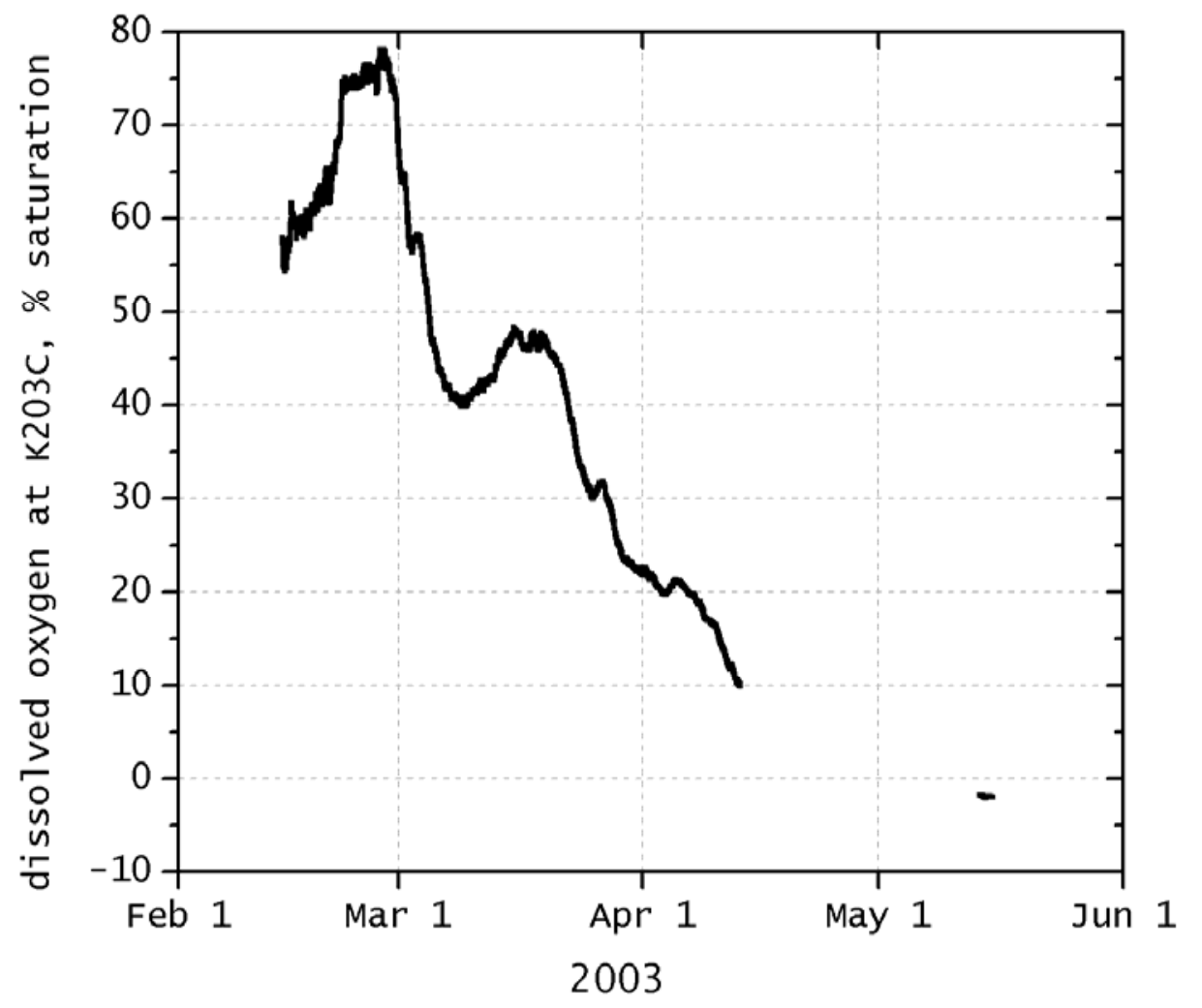

Figure 98. Dissolved oxygen at control lake K203C during 2002-2003 winter data collection. Gap in data due to a lack of telemetry with station.

\subsection{Water Quality Chemistry}

Under-ice concentrations of ions, nutrients, metals and carbon are analyzed for differences observed due to pumping. All ions, nutrients, metals and carbon examined are excluded by ice growth and consequently display an increase in concentration similar to the impact of freezing on specific conductance (see Figure 83 and Figure 84). Consequently, maximum concentrations are observed at the end of the freezing season in May when the ice has reached its maximum thickness. Both pumped and control lakes show this trend of ice exclusion. In other words, nutrient (nitrogen as nitrite and nitrate and ortho-phosphate), metal (calcium, iron, magnesium, potassium and sodium) and carbon (total and dissolved organic carbon) concentrations were not significantly affected by winter water withdrawal.

Measurements of water quality variables are presented in Figure 99 to Figure 109. The chemistry data can be found in Appendix K through $\mathrm{M}$. Dotted lines are presented as a pathway to follow from one data point to another for each lake. Three water quality variables were also tested in the laboratory, but found to be below the lower detection limit at both pumped and control lakes. Ortho-phosphate, nitrogen as nitrite and total iron, were consistently below their respective lower detection limits of $0.01 \mathrm{ppm}, 0.005 \mathrm{ppm}$ and $0.1 \mathrm{ppm}$ (Figure 105). 
Manual measurements by handheld meters for $\mathrm{pH}$ are also given as a single point reading. An important note is that the May 2004 data point at K214P was likely affected by an amount of sediment in the water sample due to the limited under-ice water volume at winter's end.

Figure 99 shows measurements of alkalinity during the study period. Alkalinity is expected to increase with ice exclusion of solutes as hydroxide, carbonate and bicarbonate are rejected into the unfrozen water. The study lakes show the expected response in water quality variables, especially in the 2003-2004 winter where prominent peaking of alkalinity occurs in May 2004 when the ice has nearly reached its maximum thickness.

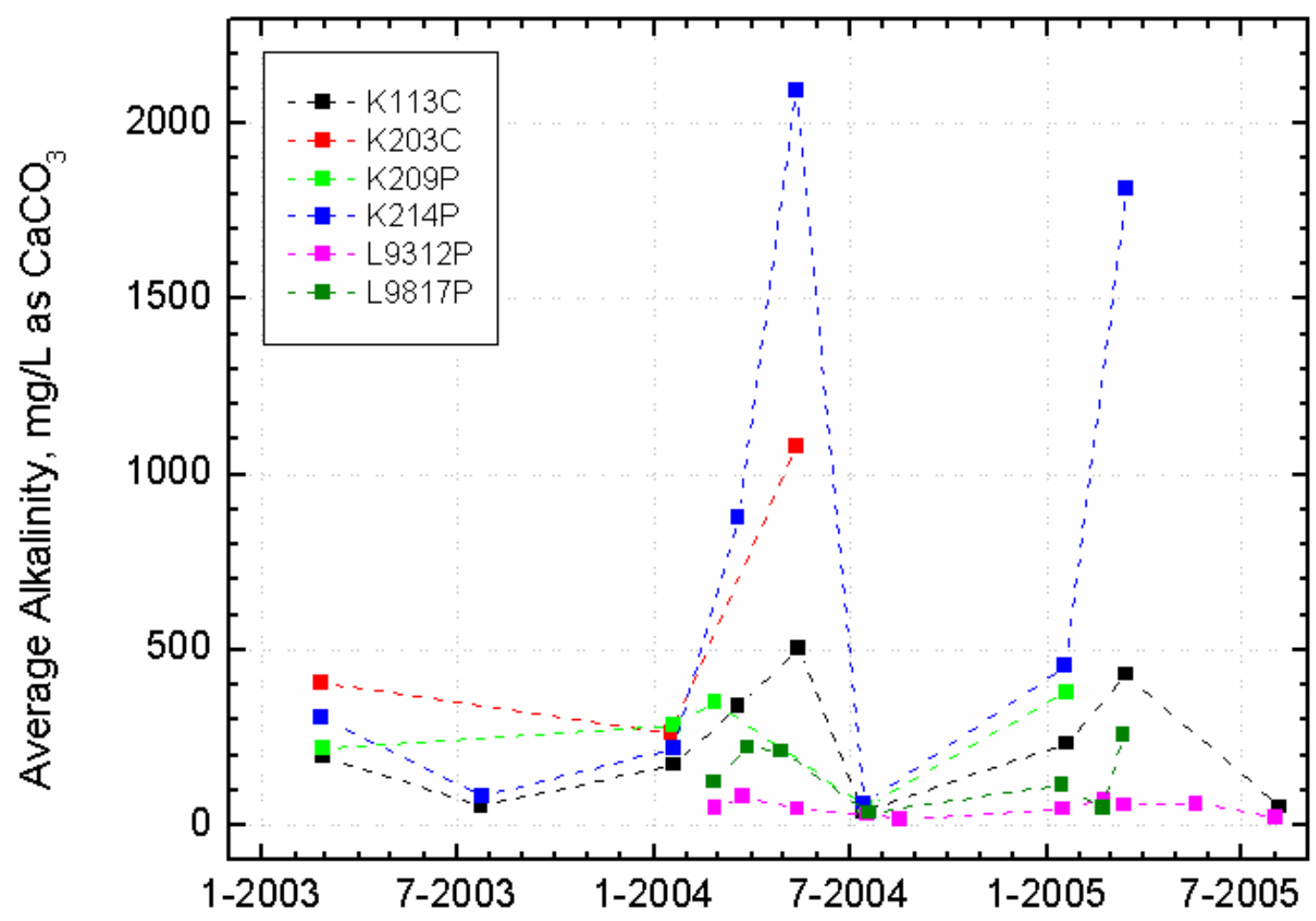

Figure 99. Average alkalinity as $\mathrm{CaCO} 3$ at study lakes.

Figure 83 Figure 100 shows measurements of $\mathrm{pH}$ from 2002-2004. Measurements of $\mathrm{pH}$ are expected to decrease through the winter with ice growth and the accumulation of $\mathrm{CO}_{2}$ beneath the ice. Thus, lower pH occurs in May 2003 and May 2004 for all study lakes. In August 2003, $\mathrm{K} 214 \mathrm{P}$ and $\mathrm{K} 113 \mathrm{C}$ are within the more conventional $6.0-8.0+\mathrm{pH}$ range as expected with sufficient alkalinity acting as a buffer to acid where K209P and K203C fall into an unexpected range of $\mathrm{pH}=5.0-5.5$. After the ice decays, $\mathrm{K} 214 \mathrm{P}$ and $\mathrm{K} 113 \mathrm{C}$ then increase back to a more basic $\mathrm{pH}$ as expected since overland flow on the tundra picks up alkaline organic matter and delivers it into the lake water. However, K209P and K203C again show acidic pH values within the 5.0-5.5 range despite the input. It would be possible that K209P and K203C might have a 
more acidic terrestrial input, but the proximity of K203C and K214P makes this hypothesis unlikely.

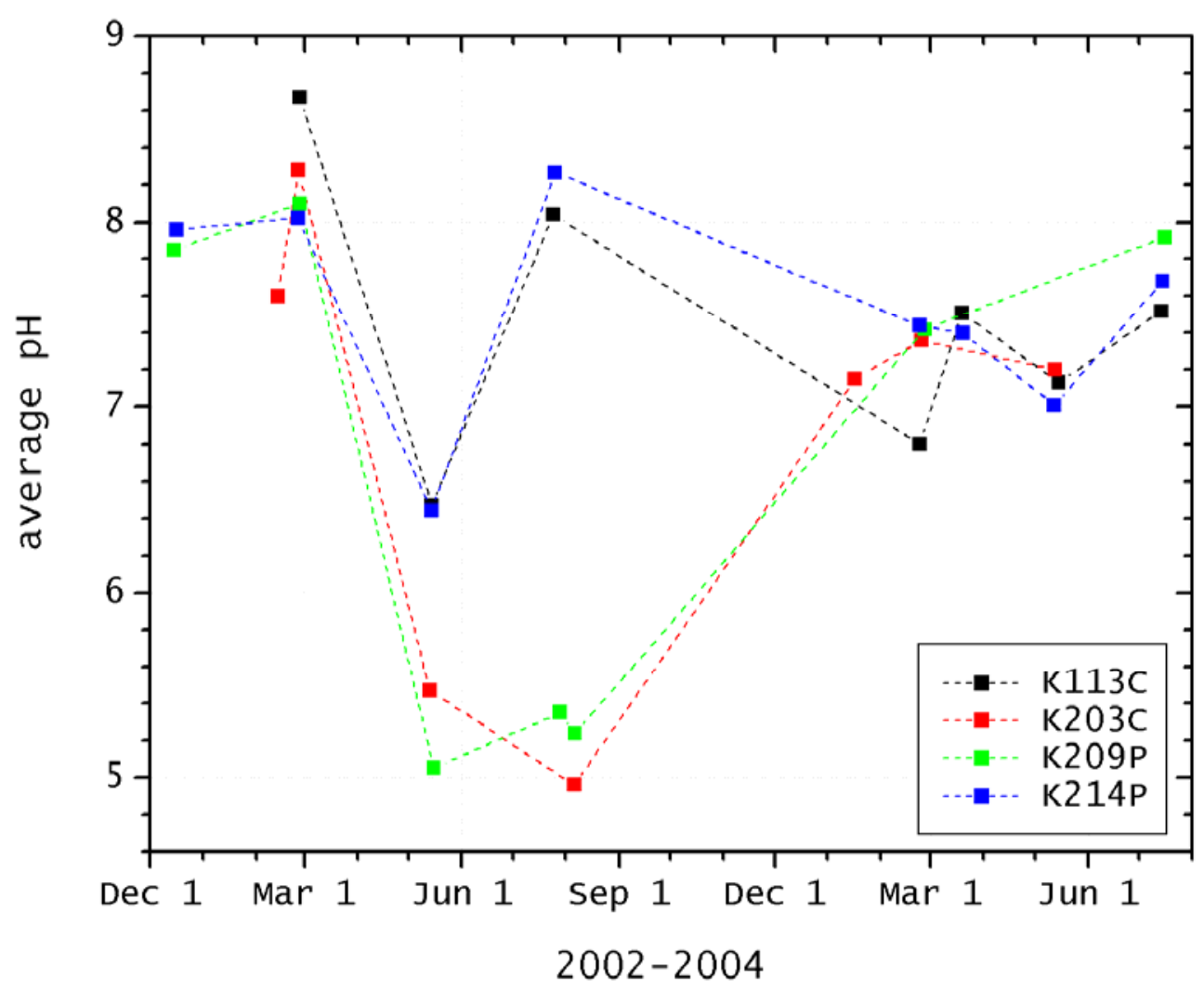

Figure 100. In situ measurements of $\mathrm{pH}$ at study lakes.

Figure 101 shows turbidity measurements taken at all the study lakes during the study period. Turbidity is also affected by the ice exclusion process. Thus, at high ratios of ice volume to water volume, the water is also expected to be more turbid. Turbidity values in May 2004, at maximum ice growth, meet the expectation with the highest turbidity values. Three turbidity values must be qualified in Figure 101: the high value for K209P in February 2003 was likely a result of disruption of the bottom sediment from the auger causing an artificially high turbidity value as were the two high values at K203C and K214P in May 2004. 


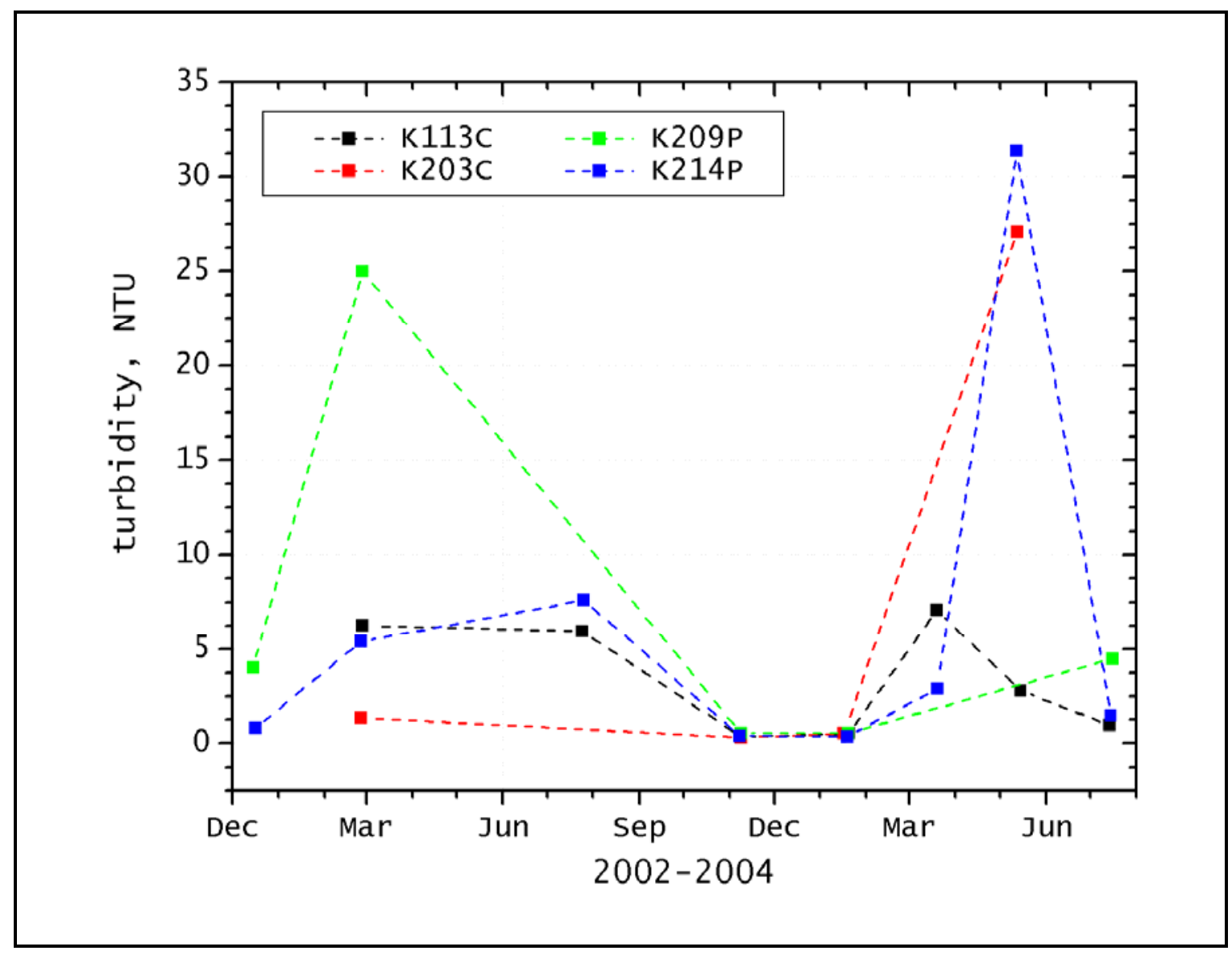

Figure 101. In situ measurements of turbidity at study lakes.

Figure 102 and Figure 103 show organic carbon concentrations in the study lakes. By comparing the water samples' total carbon concentrations to dissolved carbon concentrations, it is apparent that most organic carbon is present in a dissolved form. Trends in organic carbon also follow the ice exclusion process. 


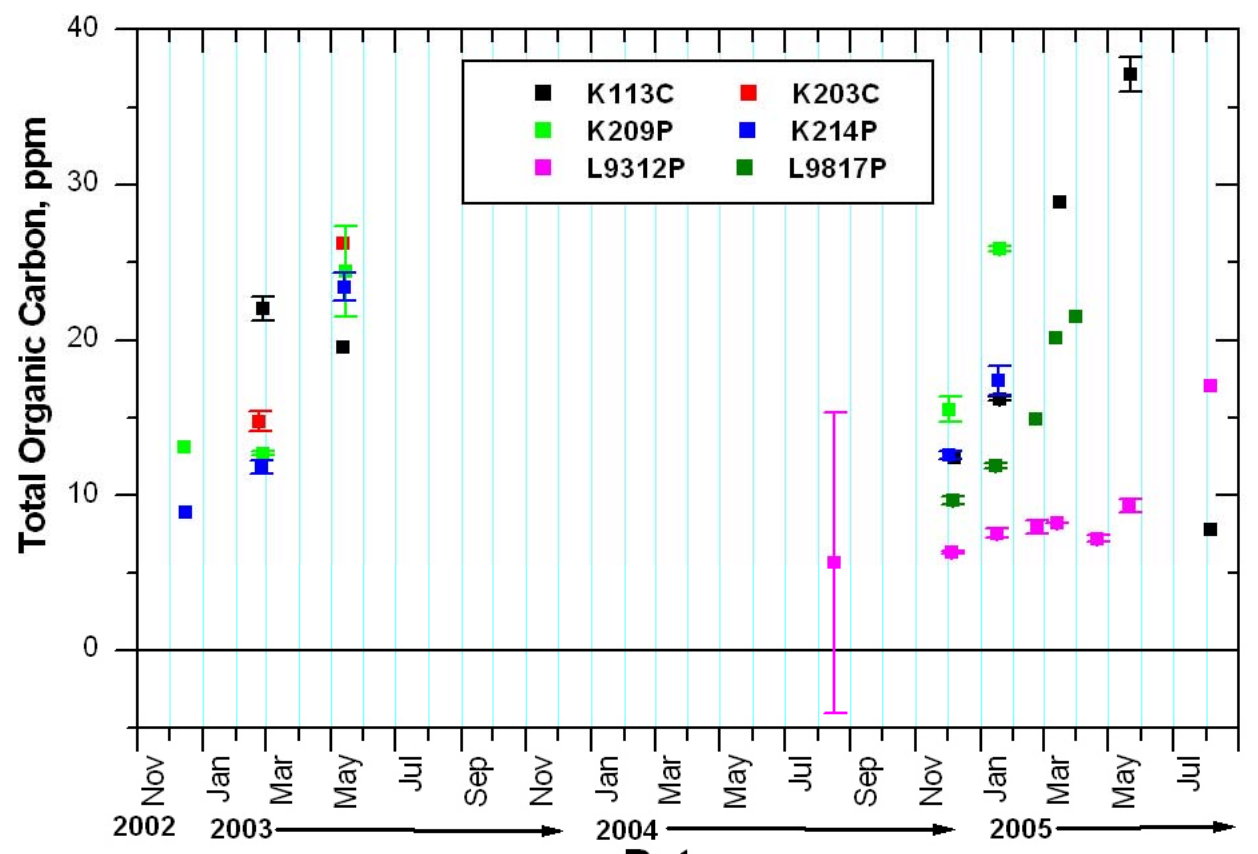

Date

Note: Error Bars on Data Points represent +/- one Standard Deviation where multiple concentration readings were available.

Lab Detection Limit $=2.5 \mathrm{ppm}$

Figure 102. Total organic carbon concentrations at the study lakes. 


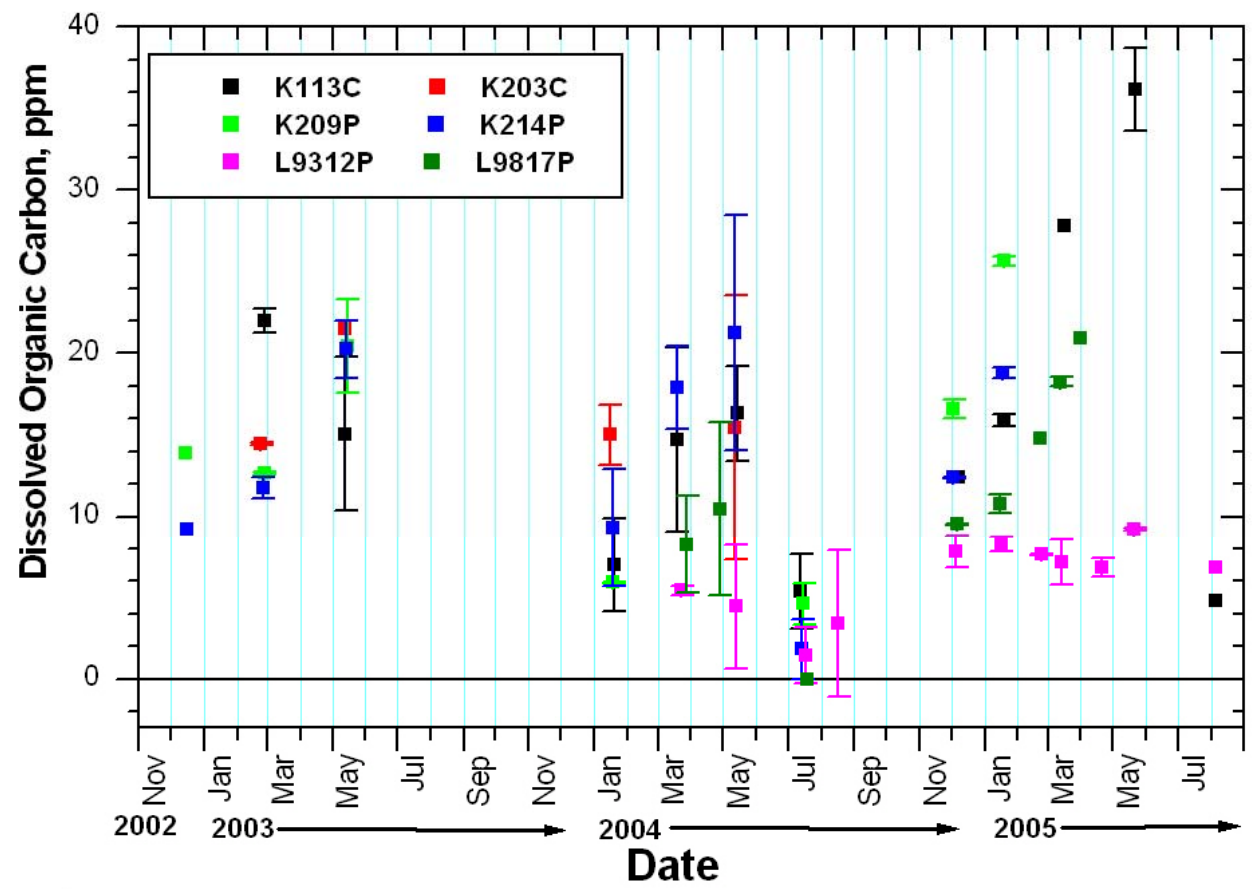

Note: Error Bars on Data Points represent +/- one Standard Deviation where multiple concentration readings were available. Outliers rejected if $Q>Q 95 \%$. Lab Detection Limit $=2.5 \mathrm{ppm}$

Figure 103. Dissolved organic carbon concentrations at the study lakes.

Figure 104 and Figure 105 shows nitrate concentrations during the study period. Nitrate is an important nutrient in the tundra lake ecosystem. The other minor nutrients, nitrite and orthophosphate, were consistently below lower detection limits in the laboratory. It is expected that more nitrate than nitrite exists in the system, as nitrite concentrations are less than $0.1 \mathrm{mg} / \mathrm{L}$ in typical surface waters. Phosphorous is the limiting nutrient for tundra lakes and is therefore the results are not surprising. 


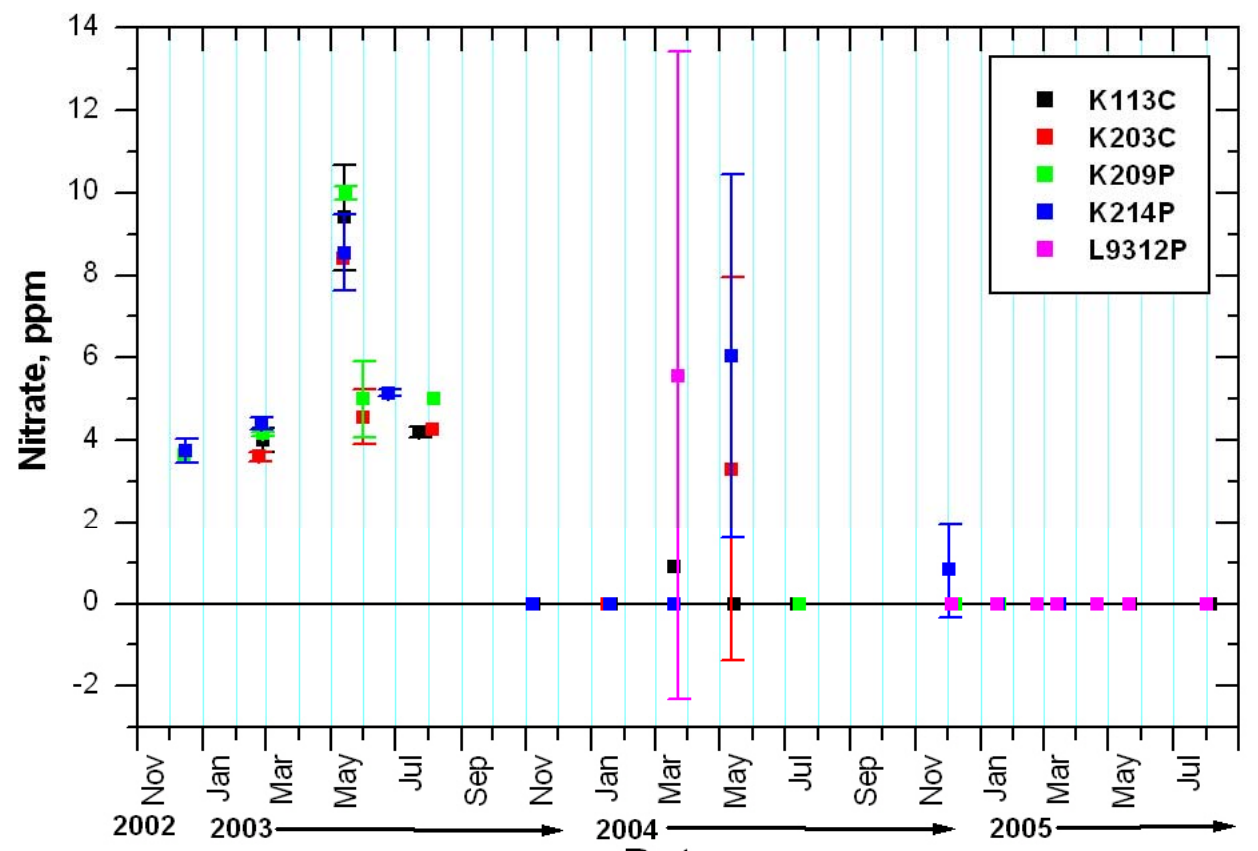

Date

Note: L9817 reported no nitrate concentrations above lab detection limit. Detection Level= $0.625 \mathrm{ppm}$

Note: Error Bars on Data Points represent +/- one Standard Deviation where multiple concentration readings were available. Outliers rejected if $Q>Q 95 \%$.

Figure 104. Nitrogen as nitrate concentrations at the study lakes. 


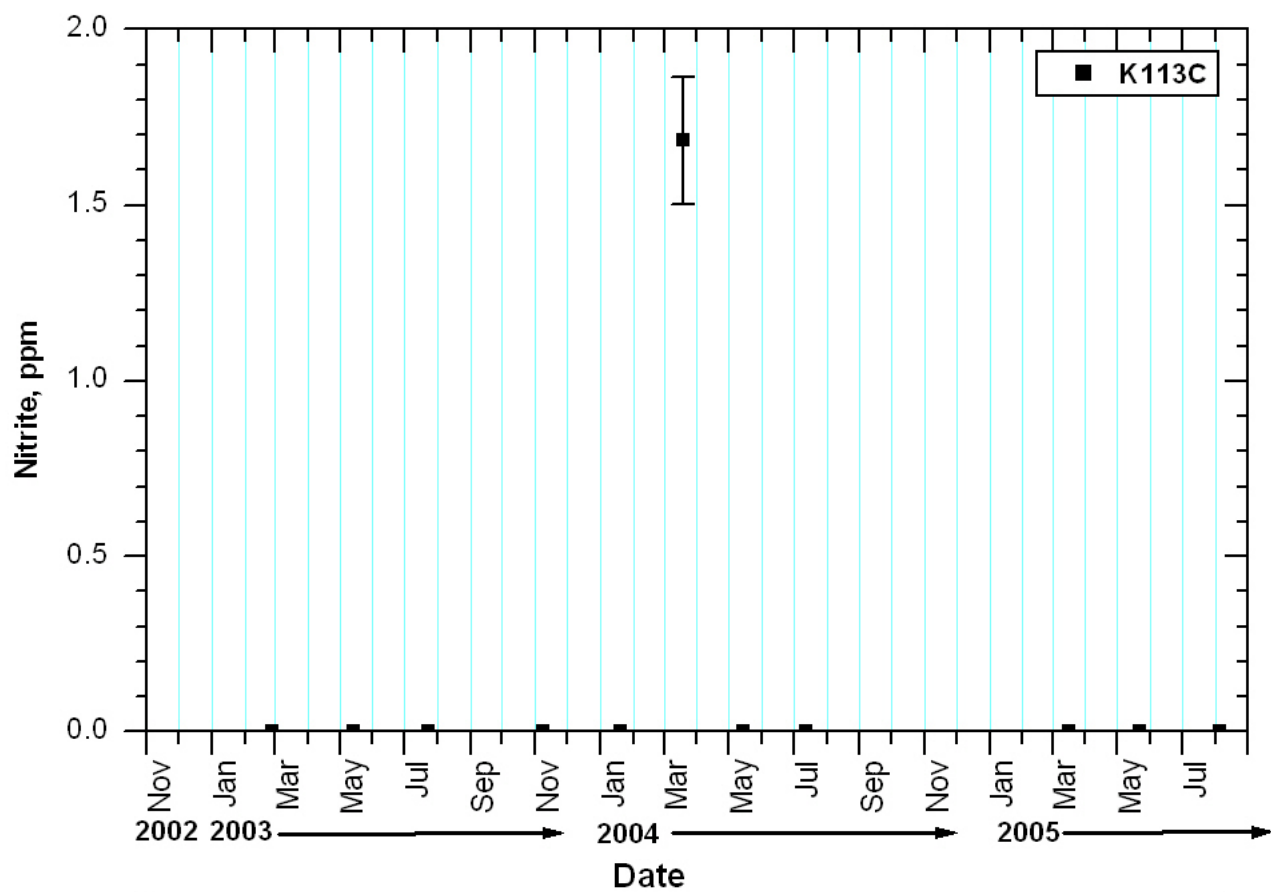

Note: Error Bars on Data Points represent +/- one Standard Deviation where multiple concentration readings were available

Note: K203C, K209P, K214P, L9312P and L9817P reported no nitrite concentrations above lab detection limit. $L D L=0.625 \mathrm{ppm}$.

Figure 105. Nitrogen as nitrite concentrations at the study lakes.

Figure 106 to Figure 109 present measurements of metals at the study lakes. All metals analyzed show no significance difference at a 95\% confidence interval between pumped and control lakes. Iron analyses at pumped and control lakes were consistently below the $0.25 \mathrm{mg} / \mathrm{l}$ detection limit.

The measurement from mid-May 2004 is less certain than the 2002-2003 winter data since the K214P sample likely contained sediment and K209P could not be sampled due to complete freezing. Lakes are dominated by a calcium and bicarbonate ions. All study lakes generally show predominance in cation concentrations as follows: $\mathrm{Ca}++>\mathrm{Mg}++>=\mathrm{Na}+>=\mathrm{K}+$. This relationship is as expected for tundra lakes. 


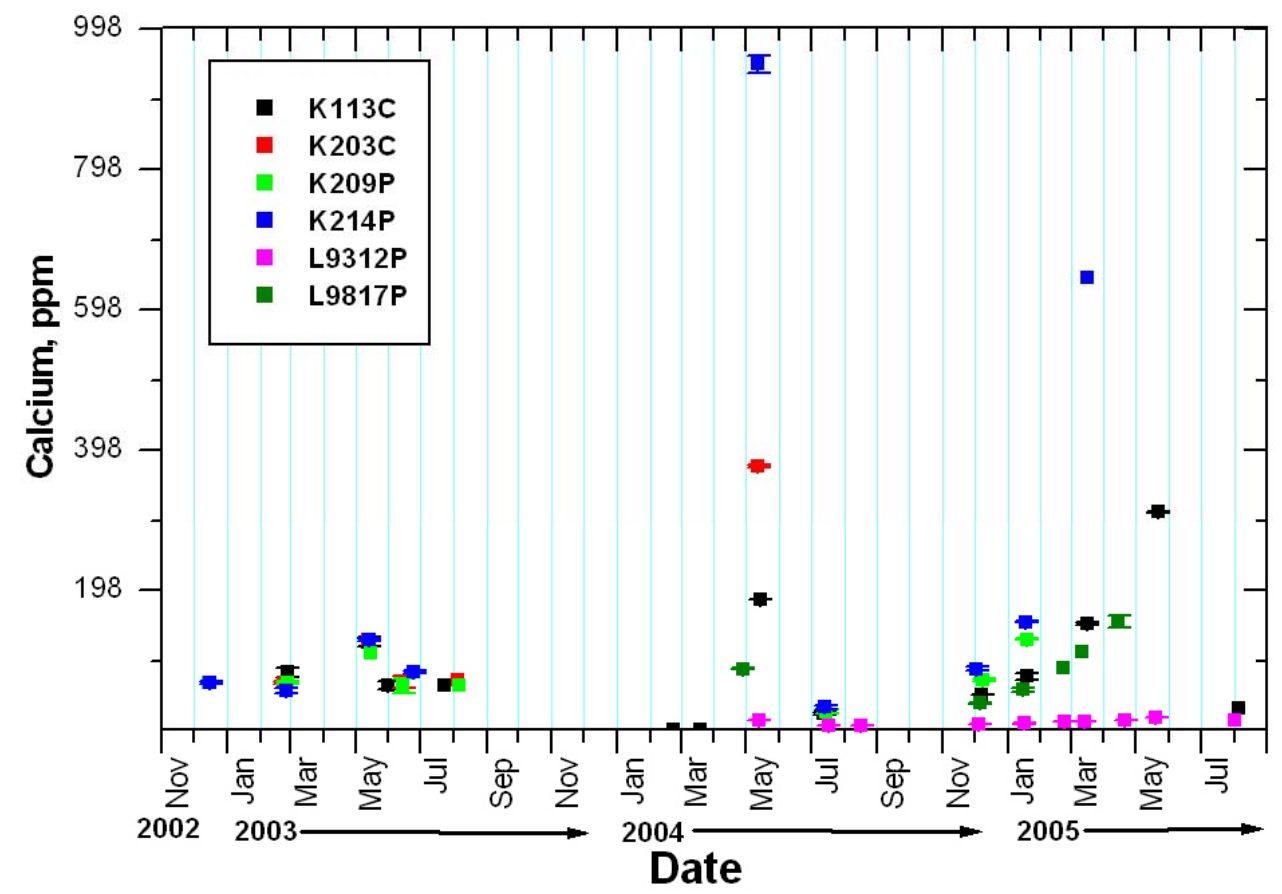

Note: Error Bars on Data Points represent +/- one Standard Deviation where multiple concentration readings were available

Figure 106. Calcium concentrations at the study lakes. 


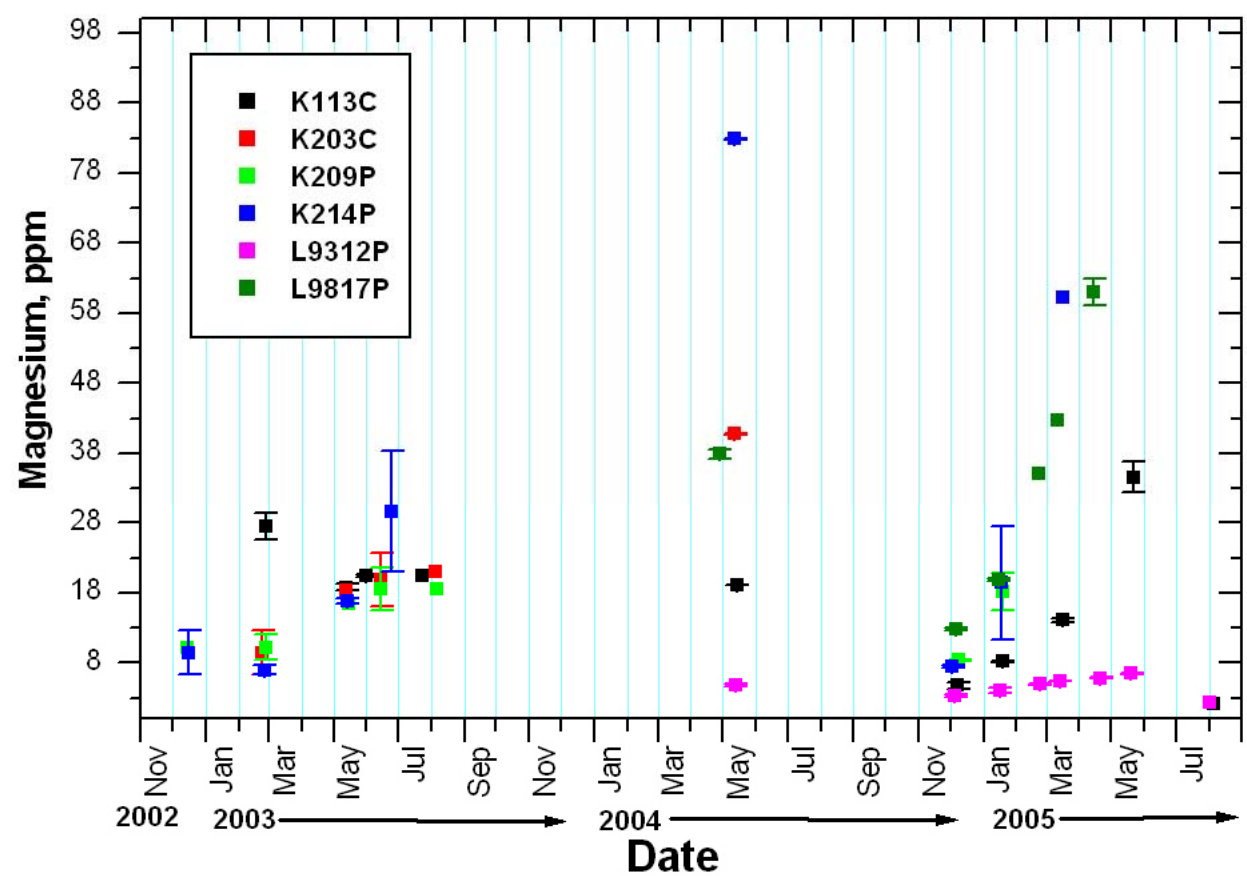

Note: Error Bars on Data Points represent +/- one Standard Deviation where multiple concentration readings were available

Figure 107. Magnesium concentrations at the study lakes. 


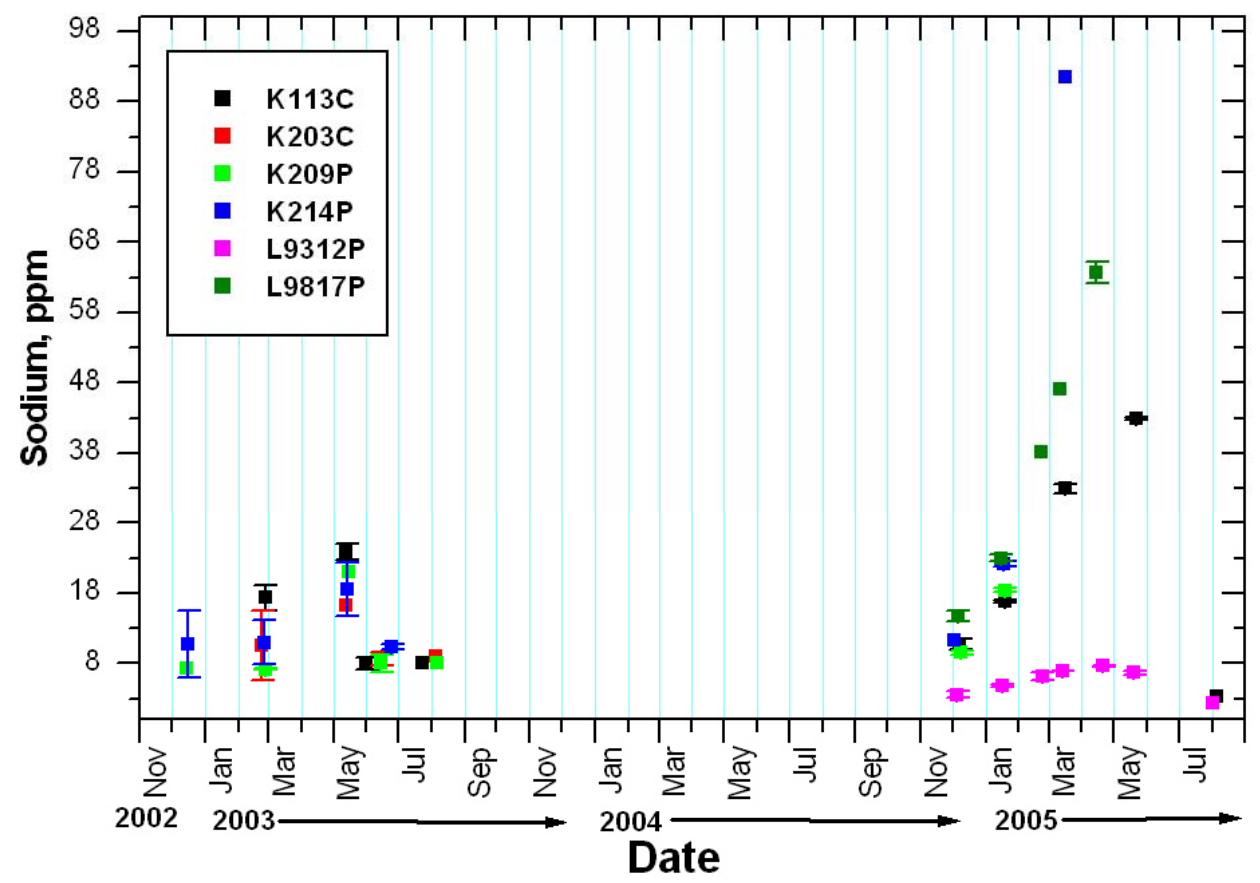

Note: Error Bars on Data Points represent +/- one Standard Deviation where multiple concentration readings were available

Figure 108. Sodium concentrations at the study lakes. 


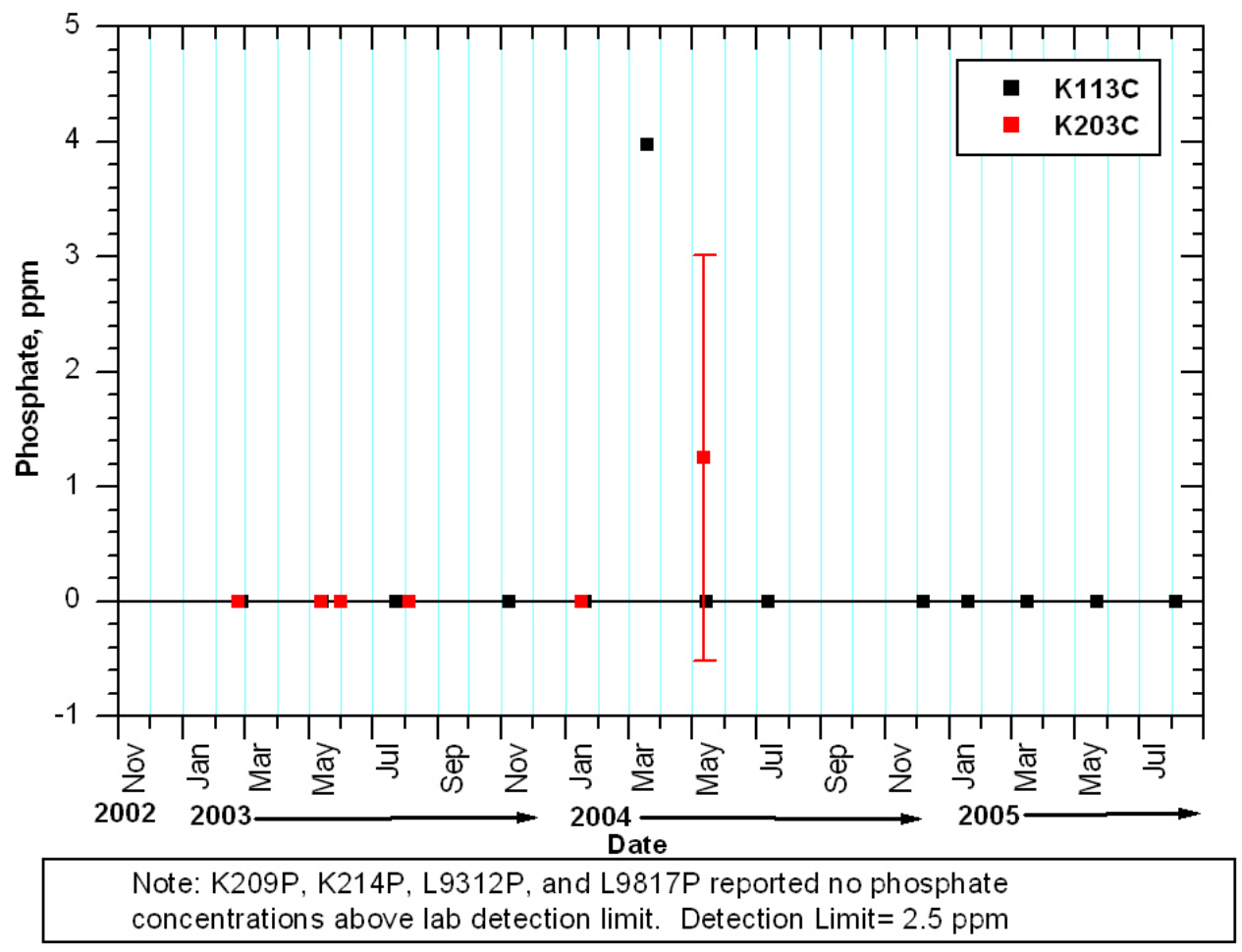

Note: Error Bars on Data Points represent +/- one Standard Deviation where multiple concentration readings were available.

Figure 109. Phosphate concentrations at the study lakes.

\section{CONCLUSIONS AND RECOMMENDATIONS}

Tundra lakes on the North Slope of Alaska were monitored between September 2002 and August 2005 to determine the effects of winter water withdrawals for ice road construction and facility or field operations. Physical and chemical parameters were measured for pumped and control lakes. Four lakes in the Kuparuk operations area were included in the study. Lakes K113C and K203C were unpumped control lakes, and lakes K209P and K214P were pumped lakes. An early winter storm in October 2003 overturned the data collection raft at K203C, and all raft components were recovered in January 2004. Instrumentation was not reinstalled at this site. In early 2004, two additional pumped lakes were added in the Alpine Field Area. Lake L9312 serves as one of the facility water-supply lakes for Alpine, and lake L9817 was used for ice road construction and maintenance. Two research rafts were installed at L9312 to observe potential differences across a study lake.

The lake recharge was monitored during spring snowmelt. Lakes K209P, K214P, and K113C all showed complete recharge during the snowmelt periods in 2003, 2004 and 2005 based on visual observations. Lake L9312 was completely recharged by the Colville River bank overflow during 2004 springmelt. In 2005, the Colville did not overflow its banks and recharge the lake. 
The contributions of snowmelt and summer precipitation runoff from the L9312 watershed did recharge the lake by fall freeze-up. A clear definition of lake-full conditions is not in practice and would help in evaluation of lake water-use studies. It is recommended that this be based on outlet elevation, which can be referenced to a local datum when needed. L9817 is more remote and not road accessible, thus leading to less frequent observations. During September 2005, its small outlet stream was flowing, indicating lake-full conditions going into winter.

$\checkmark$ Recommended actions include continuation of hydrologic surveys at lake K113C, L9817 and L9312. Lake water use from K214 is not high enough to support further application for water use investigations. K209 is too shallow and does not represent a good overwintering fish-habitat lake.

$\mathrm{K} 113 \mathrm{C}$ is a non-pumped lake, easily accessible and useful for background comparisons with past data. It is also representative of lakes in the Kuparuk field area. L9312 is used for facility operations and is pumped year-round. It has a small watershed and the potential for annual recharge from the Colville River. It helps represent natural lakes in river floodplain deposits. L9817 was used strictly for ice-road construction and was extensively monitored during the 2004-05 winter period. L9817 was not pumped in winter 2005-06. Additional comparison years, without pumping, will help verify the natural lake chemistry characteristics and the presence or absence of effects due to pumping.

Lake water-level decreases in response to pumping were detected and matched reasonably well with calculated values of water-level changes. Snow loading atop lake ice impacts lake water-level measurements, but was adequately quantified to give acceptable resolution compared to small changes in lake water levels due to pumping. Many lakes have less snow cover than adjacent tundra, due to wind erosion and redistribution of snow. This impacts the assessment of snow loading on lakes from standard snowfall measurements. Extensive measurements of snow loading effects are not recommended for regulatory compliance, but would be useful in developing a general relationship with snow depth monitoring sites.

$\checkmark$ We recommend uniform reporting and archiving standards for lake water use data (monthly use volumes) to help with future evaluation of water use practices and future efforts to verify the lack of, or presence of cumulative effects. This would include the development of lake water use METADATA standards covering issues such as lake volume determination methods, supporting data, lake depth information, assumed ice thicknesses, and permitted volume determinations. This will significantly contribute to the state of knowledge and understanding of tundra lakes and water use issues. This increased understanding should reduce risks associated with water use for both facility purposes and natural ecosystems. It will also help evaluate the ongoing potential effects of changing climate and baseline conditions.

$\checkmark$ The permitting of lake water usage currently falls under the Alaska Department of Natural Resources, Division of Water and the Division of Habitat. Historically, two different permit periods have been used. Annual permit periods (January 1 to December 31 ) have been used for temporary water use permits and water right allocations. Fish Habitat permits have been typically issued on a "water year" basis, which is typically from October to the following September. The water year management approach corresponds better with the natural hydrologic cycle for tundra lakes. Adopting a uniform permitting period based on the water year, with a focus on appropriate recharge time periods would reduce risks to both water users and simplify the water management process. 
$\checkmark$ We recommend separate reporting and permitting of land-fast ice (ice that is completely frozen to the lake sediments) removal from lakes. This is currently reported and permitted as part of the under-ice pumped water. The current industry practice is to take ice from ice-grounded locations. The primary management issue with surface ice removal is the determination of the equivalent water volume replacement during spring breakup. In addition, the removal of surface ice from grounded areas should not decrease the amount of under-ice water volume, available for over-wintering fish habitat. The archiving of actual water volumes withdrawn from under lakes will help evaluate lake chemistry changes during winter months and to quantify the importance of spring snowmelt runoff for replacing removed lake ice and water.

$\checkmark$ It is also recommended that more descriptive bathymetry of each individual permitted lake be generated to enable more exact quantification of water and ice volumes during annual hydrologic cycles. In addition, we recommend that bathymetry data, including end results and base data, be reported and made available in standard formats to improve the understanding of lake hydrologic and water-use applications.

Lake chemistry changes during winter periods are dominated by ice-formation processes in shallow lakes. Specific conductance and ion concentrations were shown to increase throughout the winter due to solute exclusion processes. Measurements of specific conductance through spring breakup showed that the under-ice water is diluted by fresh, low specific-conductance meltwater, which essentially resets the lakes' chemistry going into summer. Thus, pumped lakes probably do not incur any cumulative changes in chemistry potentially generated by winter water withdrawals.

$\checkmark$ Understanding vertical chemistry differences in the water column and lateral chemistry differences across the lake would be beneficial for future studies and defining water management objectives. These differences can have a significant effect on regulatory management practices. Dissolved oxygen is particularly important to characterize so that predictive "end-of-winter" modeling tools and practical field auditing practices can be developed.

Temperatures in the water column were similar between pumped and control lakes and thermal profiles at pumped lakes were consistent with cold, shallow arctic lakes. Predominant windmixing in shallow lakes prevails over the typical lake turnover events due to temperature-density relationships. Deeper lakes and reservoirs may experience lake-turnover events on a biannual basis. Water quality variables were not observed to change during pumping. Nitrate, calcium, magnesium, potassium, sodium and organic carbon concentrations were shown to positively correlate with specific conductance.

Sensors need regular maintenance to function well, and vertical surveys indicate a range in dissolved oxygen concentrations with depth. Single-location measurements have a lower utility; however, risks due to sensors freezing in the ice make this approach impractical with current sensor technology.

The gradual depletion of dissolved oxygen observed at the control lakes meets expectations of under-ice oxygen dynamics. Rigorous field measurements displayed vertical differences in DO concentration, with the highest levels found just below the ice and lowest just above lake bottoms. L9312 was observed to maintain high DO levels throughout winter months. The marked differences in vertical profiles clearly indicate that sampling technique is critically important in quantifying dissolved oxygen concentrations, and that lakes in different soil associations may have different dissolved-oxygen consumption rates. 
$\checkmark$ The use of new optical fluorescence sensor technology for measuring dissolved oxygen during winter months should be considered.

$\checkmark$ Developing a more robust measurement technique for continuously monitoring dissolved oxygen is recommended for future studies.

$\checkmark$ Understanding the mechanisms responsible for vertical differences in the water column and lateral differences across lakes is recommended.

$\checkmark$ Continuous measurements of dissolved oxygen were unfortunately not always of usable quality due to technical limitations and extreme conditions experienced in shallow lakes. Other concurrent studies indicate that these sensors need to have cleaning and verification on a monthly basis. We do not recommend such measurements until marked improvements in the technology are introduced.

$\checkmark$ Expanded studies related to natural DO depletion in arctic lakes and their geomorphologic characteristics to help identify regions with naturally low late-winter levels of DO is recommended

Lakes and adjacent water bodies can be connected through taliks (unfrozen ground). The use of GPR methods is effective at identifying very shallow taliks. Resistivity methods are more effective at talik identification for larger lakes and river systems. Isotope analysis can also help identify water source information. Both of these methods can be used together, but should always be incorporated with standard water-level surveys. The combined approach will provide better evaluations of risks associated with water use on adjacent water bodies.

In conclusion, physical and chemical parameters were similar between pumped and control lakes for the range of water use observed during the 2002-2003, 2003-2004 and 2004-2005 winters. All lakes were completely recharged by spring snowmelt, with the exception of L9312 during the spring of 2005. L9312 was partially recharged during spring snowmelt and summer 2005 precipitation. This lake was potentially completely recharged, based on the assumptions used in defining a full lake level. In many cases, overfull conditions are measured and used to represent a full lake volume. All lakes were essentially chemically reset by the spring meltwater. Thus, at the observed water withdrawal volumes for these ice road construction seasons, current pumping practices appear sustainable for tundra lakes. It is recommended for further study to encourage greater water withdrawal to at least the maximum regulatory $30 \%$ under-ice volume to define at what level of pumping measurable physical and chemical changes may be distinguished. 


\section{BIBLIOGRAPHY}

Adams, W. P., 1981, Snow and Ice on Lakes in Handbook of Snow: Principles, Processes, Management and Use, edited by D.M. Gray and D.H. Male. Pergamon Press, Elmsford, NY. pp.437-474.

Alexander, V., Stanley, D.W., Daley, R.J., and McRoy, C.P., 1980, Primary Producers in Limnology of Tundra Ponds, edited by J.E. Hobbie. Strousdsburg, PA, Dowden, Hutchinson \& Ross.

Baker, Michael, Jr. [MBJ], 2002, Kuparuk 2002 lake monitoring and recharge study. Prepared for ConocoPhillips by Michael Baker Jr., Inc. 25288-MGJ-DOC-003.

Belzile, C., Gibson, J.A.E., and Vincent, W.F., 2002, Colored Dissolved Organic Matter and Dissolved Organic Carbon Exclusion from Lake Ice: Implications for Irradiance Transmission and Carbon Cycling. Journal of Limnology and Oceanography 47(5): 1283-1293.

Bendock, T.N. and Burr, J., 1985, Freshwater Fish Distributions in the Central Arctic Coastal Plain. Alaska Department of Fish and Game, Sport Fish Division, Fairbanks, AK.

Benning, J., and Yang, D., 2005, Adjustment of daily precipitation data at Barrow and Nome Alaska for 1995-2001, Arctic, Antarctic and Alpine Research 12(4): 413-432.

Bettis, P., 2006, Personal Communication, October 2, 2006, Alaska Department of Natural Resources.

Billings W. D. and Peterson, K.M., 1980, Vegetational Change and Ice-Wedge Polygons through the Thaw-Lake Cycle in Arctic Alaska. Arctic and Alpine Research 12(4): 413-432.

Black, R.F., and Barksdale, W.F., 1949, Oriented Lakes of Northern Alaska. Journal of Geology 57: 105-118.

Bowling, L.C., Kane, D.L., Gieck, R.E., Hinzman, L.D., and Lettenmaier, D.P., 2003, The Role of Surface Storage in a Low-Gradient Arctic Watershed. Water Resources 39(4): 1087.

Boyd, W.L., 1959, Limnology of Selected Arctic Lakes in Relation to Water Supply Problems. Ecology 40(1): 49-54.

Brewer, M.C., 1958, The Thermal Regime of an Arctic Lake. Transactions of the American Geophysical Union 39: 278-284.

Britton, M.E., 1957, Vegetation of the Arctic tundra in Arctic Biology, edited by H.P. Hansen. Oregon State University Press. Corvallis, Oregon.

Carson, C.E. and Hussey, K.M., 1962, The Oriented Lakes of Arctic Alaska. Journal of Geology 70: 417-439.

Clark, I.D., and Fritz P., 1997, Environmental Isotopes in Hydrogeology. Lewis Publishers. Boca Raton, New York. 
Cowardin, L.M., Carter, V., Golet, F.C., and LaRoe, E.T., 1979, Classification of wetlands and deep water habitats of the United States. U.S. Fish and Wildlife Service, 103 pp.

CPAI [ConocoPhillips Alaska, Inc.], 2004, CPAI Health, Safety, Environment and Training (HEST) Water Use Database, Monthly Water Use Report, 4/15/04 Data Retrieval.

Ellis, C.R. and Stefan, H.G., 1989, Oxygen Demand in Ice Covered lakes as it pertains to Winter Aeration. American Water Resources Association 33(6): 1363-1374.

Everett, K.R., Marion, G.M., and Kane, D.L., 1989, Seasonal geochemistry of an Arctic tundra drainage basin. HolArctic Ecology 12: 279-289.

Everett, K.R. and Parkinson, R.J., 1977, Soil and Landform Associations, Prudhoe Bay Area, Alaska. Arctic and Alpine Research 9: 1-19.

Gonfiantini, R., 1986, Environmental Isotopes in Lake Studies in Handbook of Environmental Isotope Geochemistry, vol.2, The Terrestrial Environment, edited by Fritz and Fontes, B. Elsevier, Amsterdam, The Netherlands. Pp113-168.

Guyer, S., Keating, B., and Payne, J., 2006, The Impact and Recovery of Ice Roads and Ice Pads on Tundra Ecosystems, National Petroleum Reserve, Alaska (NPR-A). Alaska Section, American Water Resources Association, Annual Meeting, abstract.

Hablett, T.R., 1979, Fish Inventories Conducted within the National Petroleum Reserve on the North Slope, Alaska, 1977-78. Alaska Department of Fish and Game, Sport Fish Division, Fairbanks, AK.

Hall, J.V., Frayer, W.E., and Wilen, B.O., 1994, Status of Alaskan Wetlands. US. Fish and Wildlife Service, Alaska Region. Anchorage, Alaska.

Hamilton, P.B., Gajewski, K., Atkinson, D.E., and Lean, D.R.S., 2001, Physical and Chemical Limnology of 204 Lakes from the Canadian Arctic Archipelago. Hydrobiologia 457: 133-148.

Harada, K., and Yoshikawa, K., 1996, Permafrost Age and Thickness near Adventfjorden, Spitsbergen. Polar Geography, 20 (4), 267-281.

Hinkel, K.M., and Brown, J., 2000, Circumpolar Active Layer Monitoring, University of Cincinnati, http://www.geography.uc.edu/ kenhinke/CALM/sites.html.

Hinzman, L.D., Goering, D.J., and Kane, D.L., 1998, A Distributed Thermal Model for Calculating Soil Temperature Profiles and Depth of Thaw in Permafrost Regions. Journal of Geophysical Research. Vol. 103 (D22):28, 975-992.

Hinzman, L.D., Robinson, D.W., and Kane, D.L. 1998, A Biogeochemical Survey of an Arctic Coastal Wetland. Seventh International Conference on Permafrost. Yellowknife, Canada. June 1998. pp 459-463.

Hobbie, J.E., 1973, Arctic Limnology: a Review in Alaskan Arctic Tundra, edited by M.E. Britton. Arctic Institute of North America Technical Paper 25. Sauls Lithograph Company, Inc., Washington, DC. 
Hobbie, J.E., ed., 1980, Introduction and Site Description. in Limnology of Tundra Ponds. Strousdsburg, PA, Dowden, Hutchinson \& Ross.

Hobbie, J.E., Traaen, T., Rublee, P., Reed, J.P, Miller, M.C., and Fenchel, T., 1980, Decomposers, Bacteria, and Microbenthos in Limnology of Tundra Ponds, edited by J.E. Hobbie. Strousdsburg, PA, Dowden, Hutchinson \& Ross.

Hopkins, D.M., 1949, Thaw Lakes and Thaw Sinks in the Imuruk Lake Area, Seward Peninsula, Alaska. Journal of Geology 57: 119-131.

Huntington, H.P., 2001, Arctic Flora and Fauna: Status and Conservation. Edita Plc, Helsinki. 163-181.

Hussey, K.M. and Michelson, R.W., 1966, Tundra Relief Features Near Point Barrow, Alaska. Arctic 19: 162-184.

Iglauer, E., 1974, Denison’s Ice Road. Vancouver, British Columbia, Douglas \& Mclntyre. $237 p$.

Jeffries, M.O., Morris, K., and Liston, G.E., 1996, A Method to Determine Lake Depth and Water Availability on the North Slope of Alaska with Spaceborne Imaging Radar and Numerical Ice Growth Modeling. Arctic 49: 367-374.

Johnson, S., and Truett, J., 2000, The Natural History of an Arctic Oil Field: Development and the Biota. San Diego, Academic Press.

Jorgenson, M.T., Pullman, E.R., and Shur, Y., 2002, Geomorphology of the Northeast Planning Area of the National Petroleum Reserve - Alaska, 2001. A report for Phillips Alaska, Inc.

Kane, D.L., Gieck, R.E., Kitover, D.C., Hinzman, L.D., McNamara, J.P., and Yang, D., 2004, Hydrological cycle on the North Slope of Alaska in Northern Research Basins Water Balance, Kane, D.L., and Yang, D. (Eds.), IAHS Publication 290, pp 224-266.

Kane, D.L., Hinzman, L.D., McNamara, J.P., Zhang, Z., and Benson, C.S., 2000, An Overview of a Nested Watershed Study in Arctic Alaska. Nordic Hydrology 31: 245-266.

Kane, D.L. and Hinzman, L.D. (2004), Climate data from the North Slope Hydrology Research project. University of Alaska Fairbanks, Water and Environmental Research Center. URL: http://www.uaf.edu/water/projects/NorthSlope/coastal_plain/betty/betty.html/ Fairbanks, Alaska, variously paged, data retrieved: July 15, 2004.

Lachenbruch, A.H, 1963, Contraction Theory of Ice-Wedge Polygons: A

Qualitative Discussion in Proceedings 11-15 of the November 1963 Lafeyette, Indiana:

Permafrost International Conference. National Academy of Sciences. National Research Council, Washington, D.C. 1287: 63-71.

Lauruhn, J.A., 2001, North Slope Basin 2001-2002 Lake Locations. Map. ConocoPhillips File No. 01081004B02.

Majoube, M., 1971, Fractionnement en oxygene-18 et en deuterium entre l'eau et sa vapor. Jour. Chemi. Physics. 197: 1423-1436. 
Mendez, J., Hinzman, L.D., and Kane, D.L., 1998, Evapotranspiration from a Wetland Complex on the Arctic Coastal Plain of Alaska. Nordic Hydrology 29(4): 303-320.

Michel, B., 1971, Winter Regime of Rivers and Lakes. Cold Regions Science and Engineering, Hanover, NH. CRREL Monograph III-B1a.

Miller, M.C., Prentki, R.T., and Barsdate, R.J., 1980, Physics in Limnology of Tundra Ponds, edited by J.E. Hobbie. Strousdsburg, PA, Dowden, Hutchinson \& Ross.

Moulton, L., 1998, Lakes Sampled for Fish in and near the Colville River Delta, Alaska 19791998. Prepared by MJM Research for ARCO Alaska, Inc.

Morris, B., 2003, Personal Communication, October 8, 2003, Data retrieval from ADF\&G database.

Olsson, P.Q., Hinzman, L.D., Sturm, M., Liston, G.E., and Kane, D.L., 2002, Surface Climate and Snow-Weather Relationships of the Kuparuk Basin on Alaska's Arctic Slope. Cold Regions Research and Engineering Laboratory. Technical Report ERDC/CRREL TR-02-10.

Osterkamp, T.E., Peterson, J.K., and Collet, T.S., 1985, Permafrost thickness in the Oliktok Point, Prudhoe Bay, and Mikkelson Bay area of Alaska. Cold Regions Science and Technology 11: 99-105.

Pielou, E.C., 1994, A Naturalist's Guide to the Arctic, The University of Chicago Press, Chicago, IL, 101-190.

Pounder, E.R., 1969, Strength and Growth Rates of Sea Ice. Ice Seminar, Canadian Institute of Mining and Metallurgy. 10: 73-76.

Prentki, R.T., Miller, M.C., Barsdate, R.J., Alexander, V., Kelley, J., and Coyne, P., 1980, Chemistry in Limnology of Tundra Ponds, edited by J.E. Hobbie. Strousdsburg, PA, Dowden, Hutchinson \& Ross.

Rantz, S.E., et al., 1982, Measurement and Computation of Streamflow: Measurement of Stage and Discharge. USGS Water Supply Paper 2175, p284.

Rawlinson, S.E., 1986, Surficial-Geologic map of the Beechey point B-4 Quadrangle, Alaska. Report of Investigations 86-12. State of Alaska Geological \& Geophysical surveys.

Rawlinson, S.E., 1990, Surficial Geology and Morphology of the Alaskan central Arctic Coastal Plain. Public data file 90-27. Alaska Division of Geological and Geophysical Surveys.

Robinson, D.W., 1995, Biogeochemical Survey of an Arctic Coastal Wetland, Masters Thesis, University of Alaska.

Rodhe, J., 1949, The Ionic Composition of Lake Waters. Verh. Int. Ver. Limnology 10: 377-386.

Rovansek, R.J., 1994, The Hydrology and Jurisdictional Status of a Wetland Complex on the Alaskan Arctic Coastal Plain, Masters Thesis, University of Alaska. 
Rovansek, R.J., Kane, D.L., Hinzman, L.D., 1993, Improving Estimates of Snowpack Water Equivalent using Double Sampling. Eastern Snow Conference, Quebec Canada.

Rovansek, R.J., Hinzman, L.D., and Kane, D.L., 1996, Hydrology of a Tundra Wetland Complex on the Alaskan Arctic Coastal Plain. Arctic and Alpine Research 28(3): 311-317.

Sellman, P.V., Brown, J., Lewellen, R.I., McKim, H., and Merry, C., 1975, The Classification and Geomorphic Implications of Thaw Lakes on the Arctic Coastal Plain, Alaska. CRREL Research Report 344.

Sierszen, M.E., McDonald, M.E., and Jensen, D.A., 2003, Benthos as the Basis for Arctic Food Webs. Aquatic Ecology 37: 437-445.

Smith, D.W., 1999, Cold Regions Utilities Monograph. ASCE.

Sturm and Liston, 2003, The Snow Cover on Lakes of the Arctic Coastal Plain of Alaska, USA. CRREL Report.

Truett, J. and Johnson, S., 2000, The Natural History of an Arctic Oil Field: Development and the Biota. Academic Press, San Diego, CA.

Walker, H.J., 1973, Morphology of the North Slope in Alaskan Arctic Tundra. Arctic Institute of North America Technical Paper 25. Sauls Lithograph Company, Inc., Washington, DC.

Walker, D.A., Everett, K.R., Webber, P.J., and Brown, J., 1980, Geobotanical Atlas of the Prudhoe Bay Region, Alaska, US Army CRREL Report 80-14.

Welch, H. E. and Bergmann, M.A., 1985, Water Circulation in Small Arctic Lakes in Winter. Canadian Journal of Fisheries Aquatic Science 42: 506-520.

Western Regional Climate Center, 2004, Climate data for Kuparuk station 505136-9. Desert Research Institute. URL: http://www.wrcc.dri.edu/ Reno, Nevada. Variously paged, data retrieved: July 20, 2004.

Wetzel, R.G., 2001, Limnology: Lake and River Ecosystems. Academic Press. San Diego, CA.

Yoshikawa, K., Romanovsky, V., Duxbury, N., Brown, J., and Tsapin, A., 2004, The Use of Geophysical Methods to Discriminate between Brine Layers and Freshwater Taliks in Permafrost Regions. Jour. Glaciology and Geocryology, vol.26, 301-309.

Yoshikawa, K., Hinzman, L.D., 2003, Shrinking Thermokarst Ponds and Groundwater Dynamics in Discontinuous Permafrost near Council, Alaska. Permafrost Periglac. Process 14: 151-160. DOI:10.1002/pp.451.

Zhang, T. and M. O. Jeffries, 2000, Modeling Interdecadal Variations of Lake-Ice Thickness and Sensitivity to Climatic Change in Northernmost Alaska. Annals of Glaciology 31: 339-347. 


\section{APPENDIX A: SCHEDULE OF METER USE AND CALIBRATION DATES}

The following table reports the meters that were used during field sampling and the calibration dates for each lake sampled. These data were collected during the Phase 1 portion of the North Slope Lakes project.

Table A-1. Sampling events, meter use and calibration, and study lake information. 
Table A-1. Sampling events, meter use and calibration, and study lake information.

\begin{tabular}{|c|c|c|c|}
\hline Sampling Event & Meter(s) Utilized [Serial No.] & Calibration Date & Lakes Sampled \\
\hline \multirow[t]{2}{*}{ mid-December 2002} & YSI 650 [02J0038] & $12 / 12 / 2002$ & K209 \\
\hline & YSI 30 [00B0064] & $12 / 13 / 2002$ & K214 \\
\hline early-February 2003 & YSI 650 [02J0038] & $2 / 8 / 2003$ & K203 \\
\hline \multirow[t]{4}{*}{ late-February 2003} & Lakewood [16693] & $2 / 24 / 2003$ & K113 \\
\hline & Hach Sension 1 [0314030] & $2 / 25 / 2003$ & K203 \\
\hline & & & K209 \\
\hline & & & K214 \\
\hline \multirow{5}{*}{ mid-May 2003} & & & \\
\hline & YSI 650 [02J0038] & $5 / 13 / 2003$ & K113 \\
\hline & YSI 30 [00B0064] & $5 / 13 / 2003$ & K203 \\
\hline & & & K209 \\
\hline & & & K214 \\
\hline \multirow{3}{*}{ late-July 2003} & YSI 650 [02J0038] & $7 / 23 / 2003$ & K113 \\
\hline & & & K209 \\
\hline & & & K214 \\
\hline \multirow[t]{2}{*}{ early-August 2003} & YSI 650 [02J0038] & $8 / 3 / 2003$ & K203 \\
\hline & & & K209 \\
\hline \multirow[t]{4}{*}{ early-November 2003} & YSI 30 [00B0064] & $11 / 7 / 2003$ & K113 \\
\hline & & & K203 \\
\hline & & & K209 \\
\hline & & & K214 \\
\hline \multirow[t]{4}{*}{ mid-January 2004} & Hydrolab MiniSonde [34067] & $1 / 11 / 2004$ & K113 \\
\hline & YSI 30 [00B0064] & $1 / 12 / 2004$ & K203 \\
\hline & & & K209 \\
\hline & & & K214 \\
\hline \multirow[t]{4}{*}{ late-February 2004} & Hannah 991300 [185786] & $2 / 22 / 2004$ & K113 \\
\hline & Hach Senslon 1 [3197143] & $2 / 22 / 2004$ & K203 \\
\hline & Hach Senslon 5 [3287130] & $2 / 22 / 2004$ & K209 \\
\hline & & & K214 \\
\hline \multirow{4}{*}{ late-March 2004} & Hannah 991300 [185786] & $3 / 19 / 2004$ & K113 \\
\hline & Hach Senslon 1 [3197143] & $3 / 19 / 2004$ & K214 \\
\hline & Hach Senslon 5 [3287130] & $3 / 19 / 2004$ & \\
\hline & YSI 30 [00B0064] & $3 / 19 / 2004$ & \\
\hline & & & \\
\hline \multirow[t]{4}{*}{ mid-May 2004} & Hydrolab Quanta [01865] & $5 / 6 / 2004$ & K113 \\
\hline & Hydrolab DataSonde 4a [41423] & $5 / 7 / 2004$ & K203 \\
\hline & Hannah 8733 & $5 / 13 / 2004$ & K214 \\
\hline & Thermo Orion [016243] & $5 / 13 / 2004$ & \\
\hline
\end{tabular}




\section{APPENDIX B: RECORD OF PRESSURE TRANSDUCER CALIBRATIONS AND WATER SURFACE ELEVATION SURVEYS}

The following tables report the pressure transducer calibrations and water surface elevation surveys from each sampling trip. These data were collected during the Phase 1 portion of the North Slope Lakes project.

Table B-1. Study lake K113 water-surface elevation surveys and associated pressure transducer calibration information.

Table B-2. Study lake K203 water-surface elevation surveys and associated pressure transducer calibration information.

Table B-3. Study lake K209 water-surface elevation surveys and associated pressure transducer calibration information.

Table B-4. Study lake K214 water-surface elevation surveys and associated pressure transducer calibration information. 
Table B-1. Study lake K113 water-surface elevation surveys and associated pressure transducer calibration information.

\begin{tabular}{|c|c|c|c|c|c|c|}
\hline \multicolumn{7}{|l|}{ K113C PT1 } \\
\hline Date & PT S/N & $\begin{array}{l}\text { WSL - } \\
\text { BPMSL, } \\
\text { m }\end{array}$ & Voltage & $\begin{array}{l}\text { PT slope, } \\
\mathrm{m} / \mathrm{mV}\end{array}$ & $\begin{array}{c}\text { PT } \\
\text { offset, } m\end{array}$ & Notes \\
\hline 2/14/03 17:00 & GWS5B148 & 16.23 & 1.784 & 0.807 & - & $\begin{array}{c}\text { WSL } \\
\text { backcalculated } \\
\text { from } 5 / 15 / 03 \\
\text { survey }\end{array}$ \\
\hline 5/9/03 12:00 & GWS5B148 & 16.24 & 1.791 & 0.807 & 14.79 & $\begin{array}{c}\text { Lounsbury Inc. } \\
\text { survey }\end{array}$ \\
\hline 7/24/03 13:00 & GWS5B148 & 16.21 & 1.379 & 0.807 & 15.09 & $\begin{array}{l}\text { UAF/GWS } \\
\text { survey at north } \\
\text { side of lake }\end{array}$ \\
\hline \multicolumn{7}{|l|}{ K113C РT2 } \\
\hline Date & PT S/N & $\begin{array}{l}\text { WSL - } \\
\text { BPMSL, } \\
\text { m }\end{array}$ & Voltage & $\begin{array}{l}\text { PT slope, } \\
\mathrm{m} / \mathrm{mV}\end{array}$ & $\begin{array}{c}\text { PT } \\
\text { offset, } m\end{array}$ & Notes \\
\hline 2/14/03 17:00 & GWS5B131 & 16.24 & 1.835 & 0.798 & - & $\begin{array}{c}\text { WSL } \\
\text { backcalculated } \\
\text { from } 5 / 15 / 03 \\
\text { survey }\end{array}$ \\
\hline 5/9/03 12:00 & GWS5B131 & 16.24 & 1.839 & 0.798 & 14.77 & $\begin{array}{c}\text { Lounsbury Inc. } \\
\text { survey }\end{array}$ \\
\hline 7/24/03 13:00 & GWS5B131 & 16.21 & 1.413 & 0.798 & 15.08 & $\begin{array}{l}\text { UAF/GWS } \\
\text { survey at north } \\
\text { side of lake }\end{array}$ \\
\hline
\end{tabular}


Table B-2. Study lake K203 water-surface elevation surveys and associated pressure transducer calibration information.

\begin{tabular}{|c|c|c|c|c|c|c|}
\hline \multicolumn{7}{|l|}{ K203C РT1 } \\
\hline Date & PT S/N & $\begin{array}{l}\text { WSL - } \\
\text { BPMSL, } \\
\text { m }\end{array}$ & Voltage & $\begin{array}{l}\text { PT slope, } \\
\mathrm{m} / \mathrm{mV}\end{array}$ & $\begin{array}{c}\text { PT } \\
\text { offset, } m\end{array}$ & Notes \\
\hline 2/13/03 20:00 & GWS5B146 & 25.29 & 1.2 & 0.827 & - & $\begin{array}{c}\text { WSL } \\
\text { backcalculated } \\
\text { from } 5 / 15 / 03 \\
\text { survey }\end{array}$ \\
\hline $5 / 12 / 03$ 20:00 & GWS5B146 & 25.36 & 1.288 & 0.827 & 24.30 & $\begin{array}{l}\text { Lounsbury Inc. } \\
\text { survey }\end{array}$ \\
\hline 8/6/03 0:00 & GWS5B146 & 25.32 & 1.023 & 0.827 & 24.48 & $\begin{array}{l}\text { UAF/GWS } \\
\text { survey at west } \\
\text { side of lake }\end{array}$ \\
\hline \multicolumn{7}{|l|}{ К203C РT2 } \\
\hline Date & PT S/N & $\begin{array}{l}\text { WSL - } \\
\text { BPMSL, } \\
\text { m }\end{array}$ & Voltage & $\begin{array}{l}\text { PT slope, } \\
\mathrm{m} / \mathrm{mV}\end{array}$ & $\begin{array}{c}\text { PT } \\
\text { offset, m }\end{array}$ & Notes \\
\hline 2/13/03 20:00 & GWS5B128 & 25.29 & 1.354 & 0.808 & - & $\begin{array}{c}\text { WSL } \\
\text { backcalculated } \\
\text { from } 5 / 15 / 03 \\
\text { survey }\end{array}$ \\
\hline $5 / 12 / 0320: 00$ & GWS5B128 & 25.36 & 1.45 & 0.808 & 24.19 & $\begin{array}{l}\text { Lounsbury Inc. } \\
\text { survey }\end{array}$ \\
\hline 8/6/03 0:00 & GWS5B128 & 25.32 & 1.413 & 0.808 & 24.40 & $\begin{array}{l}\text { UAF/GWS } \\
\text { survey at west } \\
\text { side of lake }\end{array}$ \\
\hline
\end{tabular}


Table B-3. Study lake K209 water-surface elevation surveys and associated pressure transducer calibration information.

\begin{tabular}{|c|c|c|c|c|c|c|}
\hline \multicolumn{7}{|l|}{ K209P PT1 } \\
\hline Date & PT S/N & WSL (m) & $\begin{array}{c}\text { CR10x } \\
\text { measurement } \\
\text { (V) }\end{array}$ & $\begin{array}{c}\text { PT } \\
\text { calibration } \\
\text { slope }(\mathrm{V} / \mathrm{m})\end{array}$ & $\begin{array}{l}\text { PT } \\
\text { offset } \\
\text { (m) }\end{array}$ & Notes \\
\hline 2/12/03 19:00 & GWS5B118 & 23.64 & 1.332 & 0.835 & - & $\begin{array}{c}\text { WSL } \\
\text { backcalculated } \\
\text { from } 5 / 15 / 03 \\
\text { survey }\end{array}$ \\
\hline $5 / 15 / 03$ 11:45 & GWS5B118 & 23.67 & 1.361 & 0.835 & 22.53 & $\begin{array}{c}\text { Lounsbury Inc. } \\
\text { survey }\end{array}$ \\
\hline 8/6/03 14:30 & GWS5B118 & 23.68 & 0.77 & 0.835 & 23.04 & $\begin{array}{l}\text { UAF/GWS } \\
\text { survey at north } \\
\text { side of lake }\end{array}$ \\
\hline 12/4/03 15:00 & GWS5B275 & 23.73 & 1.159 & 0.821 & 22.77 & $\begin{array}{c}\text { new PT, } \\
\text { UAF/GWS } \\
\text { survey at north } \\
\text { side of lake }\end{array}$ \\
\hline \multicolumn{7}{|l|}{ K209P РT2 } \\
\hline Date & PT S/N & WSL (m) & $\begin{array}{c}\text { CR10x } \\
\text { measurement } \\
\text { (V) }\end{array}$ & $\begin{array}{c}\text { PT } \\
\text { calibration } \\
\text { slope }(\mathrm{V} / \mathrm{m})\end{array}$ & $\begin{array}{l}\text { PT } \\
\text { offset } \\
\text { (m) }\end{array}$ & Notes \\
\hline 2/12/03 19:00 & GWS5B209 & 23.66 & 1.878 & 0.794 & - & $\begin{array}{c}\text { WSL } \\
\text { backcalculated } \\
\text { from } 5 / 15 / 03 \\
\text { survey }\end{array}$ \\
\hline $5 / 15 / 0311: 45$ & GWS5B209 & 23.67 & 1.885 & 0.794 & 22.17 & $\begin{array}{l}\text { Lounsbury Inc. } \\
\text { survey }\end{array}$ \\
\hline 8/6/03 14:30 & GWS5B268 & 23.68 & 0.748 & 0.819 & 23.07 & $\begin{array}{c}\text { new PT, } \\
\text { UAF/GWS } \\
\text { survey at north } \\
\text { side of lake }\end{array}$ \\
\hline $12 / 4 / 0315: 00$ & GWS5B276 & 23.73 & 1.158 & 0.811 & 22.79 & $\begin{array}{c}\text { new PT, } \\
\text { UAF/GWS } \\
\text { survey at north } \\
\text { side of lake }\end{array}$ \\
\hline
\end{tabular}


Table B-4. Study lake K214 water-surface elevation surveys and associated pressure transducer calibration information.

\begin{tabular}{|c|c|c|c|c|c|c|}
\hline \multicolumn{7}{|c|}{ K214P PT1 } \\
\hline Date & PT S/N & WSL (m) & $\begin{array}{c}\text { CR10x } \\
\text { measurement } \\
\text { (V) }\end{array}$ & $\begin{array}{l}\text { PT calibration } \\
\text { slope }(\mathrm{m} / \mathrm{V})\end{array}$ & $\begin{array}{l}\text { PT offset } \\
\text { (m) }\end{array}$ & Notes \\
\hline $\begin{array}{l}2 / 8 / 03 \\
22: 00\end{array}$ & GWS5B130 & 24.85 & 1.187 & 0.828 & - & $\begin{array}{c}\text { WSL } \\
\text { backcalculated } \\
\text { from } 5 / 15 / 03 \\
\text { survey }\end{array}$ \\
\hline $\begin{array}{l}5 / 8 / 03 \\
15: 00\end{array}$ & GWS5B130 & 24.85 & 1.184 & 0.828 & 23.87 & $\begin{array}{c}\text { Lounsbury Inc. } \\
\text { survey }\end{array}$ \\
\hline $\begin{array}{c}7 / 28 / 03 \\
8: 00\end{array}$ & GWS5B130 & 24.82 & 0.6 & 0.828 & 24.33 & $\begin{array}{l}\text { UAF/GWS } \\
\text { survey at west } \\
\text { side of lake }\end{array}$ \\
\hline $\begin{array}{l}12 / 3 / 04 \\
20: 00\end{array}$ & GWS5B278 & & 1.134 & 0.808 & & $\begin{array}{l}\text { new PT, no } \\
\text { survey }\end{array}$ \\
\hline \multicolumn{7}{|c|}{ K214P РT2 } \\
\hline Date & PT S/N & WSL (m) & $\begin{array}{c}\text { CR10x } \\
\text { measurement } \\
\text { (V) }\end{array}$ & $\begin{array}{l}\text { PT calibration } \\
\text { slope }(\mathrm{m} / \mathrm{V})\end{array}$ & $\begin{array}{l}\text { PT offset } \\
\text { (m) }\end{array}$ & Notes \\
\hline $\begin{array}{l}2 / 8 / 03 \\
22: 00\end{array}$ & GWS5B229 & 24.55 & 1.835 & 0.822 & - & $\begin{array}{c}\text { WSL } \\
\text { backcalculated } \\
\text { from } 5 / 15 / 03 \\
\text { survey }\end{array}$ \\
\hline $\begin{array}{l}5 / 8 / 03 \\
15: 00\end{array}$ & GWS5B229 & 24.85 & 1.839 & 0.822 & 23.59 & $\begin{array}{l}\text { Lounsbury Inc. } \\
\text { survey }\end{array}$ \\
\hline $\begin{array}{l}7 / 28 / 03 \\
8: 00\end{array}$ & GWS5B269 & 24.82 & 1.413 & 0.833 & 23.84 & $\begin{array}{c}\text { new PT, } \\
\text { UAF/GWS } \\
\text { survey at west } \\
\text { side of lake }\end{array}$ \\
\hline $\begin{array}{c}12 / 3 / 04 \\
20: 00\end{array}$ & GWS5B277 & & 1.131 & 0.809 & & $\begin{array}{c}\text { new PT, no } \\
\text { survey }\end{array}$ \\
\hline
\end{tabular}




\section{APPENDIX C: SENSOR CHANGE-OUT LOGS}

The following table reports the logged sensor replacements at each study lake location. These data were collected during the Phase 1 portion of the North Slope Lakes project.

Table C-1. Study lake sensor change-out log information. 
Table C-1. Study lake sensor change-out log information.

\begin{tabular}{|c|c|c|c|c|c|}
\hline \multirow{2}{*}{ Date } & \multirow{2}{*}{ Lake } & \multicolumn{2}{|c|}{ Sensor 1 Change } & \multicolumn{2}{|c|}{ Sensor 2 Change } \\
\hline & & From & To & From & To \\
\hline $2 / 8 / 2003$ & K214P & initial install & DO1 = 14209 & initial install & $\mathrm{DO} 2=014206$ \\
\hline $2 / 8 / 2003$ & K214P & initial install & SC1 = 3544 & initial install & $\mathrm{SC} 2=3541$ \\
\hline $2 / 8 / 2003$ & K214P & initial install & PT1 = GWS5B130 & initial install & PT2 = GWS5B229 \\
\hline $2 / 8 / 2003$ & K214P & initial install & \multicolumn{3}{|c|}{ TS \#1 @ 0.0, 0.5, 1.5, 2.5, 3.5, $5.0 \mathrm{ft}$ abs } \\
\hline $2 / 12 / 2003$ & K209P & initial install & DO1 = 014214 & initial install & $\mathrm{DO} 2=014208$ \\
\hline $2 / 12 / 2003$ & K209P & initial install & SC1 = 3552 & initial install & SC2 $=3553$ \\
\hline $2 / 12 / 2003$ & K209P & initial install & PT1 = GWS5B118 & initial install & PT2 = GWS5B209 \\
\hline $2 / 12 / 2003$ & K209P & initial install & \multicolumn{3}{|c|}{ TS \#1 @ 0.0, 0.5, 1.5, 2.5, 3.5, $4.5 \mathrm{ft}$ abs } \\
\hline $2 / 13 / 2003$ & K203C & initial install & DO1 = 014217 & initial install & $\mathrm{DO} 2=014213$ \\
\hline $2 / 13 / 2003$ & K203C & initial install & SC1 $=3616$ & initial install & SC2 $=3617$ \\
\hline $2 / 13 / 2003$ & K203C & initial install & PT1 = GWS5B146 & initial install & PT2 = GWS5B128 \\
\hline $2 / 13 / 2003$ & K203C & initial install & \multicolumn{3}{|c|}{ TS \#1 @ 0.0, 0.5, 1.5, 2.5, 3.5, $5.5 \mathrm{ft}$ abs } \\
\hline $2 / 14 / 2003$ & K113C & initial install & DO1 = 014207 & initial install & $\mathrm{DO} 2=014215$ \\
\hline $2 / 14 / 2003$ & $\mathrm{~K} 113 \mathrm{C}$ & initial install & SC1 = 3555 & initial install & SC2 $=3559$ \\
\hline $2 / 14 / 2003$ & $\mathrm{~K} 113 \mathrm{C}$ & initial install & PT1 = GWS5B148 & initial install & PT2 = GWS5B131 \\
\hline $2 / 14 / 2003$ & $\mathrm{~K} 113 \mathrm{C}$ & initial install & \multicolumn{3}{|c|}{ TS \#1 @ 0.0, 0.5, 1.5, 2.5, 3.5, 7.0 ft abs } \\
\hline $7 / 23 / 2003$ & K113C & DO1 = 014207 & $\mathrm{DO} 1=014210$ & DO2 removed & \\
\hline $7 / 25 / 2003$ & K214P & & & PT2 = GWS5B229 & PT2 = GWS5B269 \\
\hline $7 / 25 / 2003$ & K214P & SC1 $=3544$ & SC1 $=3540$ & & \\
\hline $7 / 25 / 2003$ & K214P & DO1 = 14209 & DO1 = 014212 & DO2 removed & \\
\hline $7 / 26 / 2003$ & K203C & DO1 removed & & DO2 removed & \\
\hline $7 / 26 / 2003$ & K203C & \multicolumn{2}{|c|}{ TS \#1 @ 0.0, $2.5 \mathrm{ft}$ abs } & \multicolumn{2}{|c|}{ TS \#2@ 0.0, $2.5 \mathrm{ft}$ abs } \\
\hline $7 / 28 / 2003$ & K209P & DO1 = 014214 & $\mathrm{DO} 1=014216$ & DO2 removed & \\
\hline $7 / 28 / 2003$ & K209P & & & PT2 = GWS5B209 & PT2 = GWS5B268 \\
\hline $12 / 3 / 2003$ & K214P & PT1 = GWS5B130 & PT1 = GWS5B278 & PT2 = GWS5B229 & PT2 = GWS5B277 \\
\hline $12 / 4 / 2003$ & K209P & PT1 = GWS5B118 & PT1 = GWS5B275 & PT2 = GWS5B268 & PT2 = GWS5B276 \\
\hline
\end{tabular}




\section{APPENDIX D: SELECTED WATER WITHDRAWAL RECORDS AND EXPECTED CHANGES IN WATER SURFACE LEVEL}

The following tables report the water withdrawal records and the expected immediate and cumulative changes in water surface level based on pan bathymetry. Data was provided by ConocoPhillips Alaska Inc. These data were collected during the Phase 1 portion of the North Slope Lakes project.

Table D-1. Study lake K214 2002-2003 selected daily winter season pumping records and expected changes in water-surface levels (WSL), and cumulative changes in WSL. Table D-2. Study lake K214 2003-2004 selected daily winter season pumping records and expected changes in water-surface levels (WSL), and cumulative changes in WSL. Table D-3. Study lake K214 2003-2004 winter season pumping records and expected changes in water-surface levels (WSL), and cumulative changes in WSL.

Table D-4. Study lake K209 2002-2003 selected daily winter season pumping records and expected changes in water-surface levels (WSL), and cumulative changes in WSL. Table D-5. Study lake K209 2003-2004 selected daily winter season pumping records and expected changes in water-surface levels (WSL), and cumulative changes in WSL. Table D-6. Study lake K209 2003-2004 winter season pumping records and expected changes in water-surface levels (WSL), and cumulative changes in WSL. 
Table D-1. Study lake K214 2002-2003 selected daily winter season pumping records and expected changes in water-surface levels (WSL), and cumulative changes in WSL.

\begin{tabular}{|c|c|c|c|c|c|}
\hline \multicolumn{6}{|c|}{ Lake K214: 2002-2003 Winter Pumping Season } \\
\hline Date & $\begin{array}{c}\text { Daily } \\
\text { Volume } \mathrm{m}^{\wedge} 3\end{array}$ & $\begin{array}{c}\text { Monthly } \\
\text { Volume, m^3 }\end{array}$ & $\begin{array}{c}\text { Cumulative } \\
\text { Volume, } m^{\wedge} 3\end{array}$ & $\begin{array}{c}\text { Expected } \\
\text { immediate } \\
\text { change in } \\
\text { WSL, } \mathbf{m} \\
\end{array}$ & $\begin{array}{c}\text { Expected } \\
\text { cumulative } \\
\text { change in } \\
\text { WSL, m } \\
\end{array}$ \\
\hline $10 / 19 / 2002$ & 95.39 & - & 95.39 & 0.0000 & -0.00005 \\
\hline $10 / 20 / 2002$ & 71.54 & - & 166.94 & 0.0000 & -0.00008 \\
\hline $10 / 22 / 2002$ & 715.44 & 882.38 & 882.38 & -0.0003 & -0.00042 \\
\hline $12 / 21 / 2002$ & 258.35 & - & 1140.73 & -0.0001 & -0.00054 \\
\hline $12 / 22 / 2002$ & 349.77 & - & 1490.51 & -0.0002 & -0.00071 \\
\hline $12 / 23 / 2002$ & 481.73 & - & 1972.24 & -0.0002 & -0.00094 \\
\hline $12 / 24 / 2002$ & 491.27 & - & 2463.51 & -0.0002 & -0.00117 \\
\hline $12 / 25 / 2002$ & 378.39 & 1959.52 & 2841.90 & -0.0002 & -0.00135 \\
\hline 1/9/2003 & 24.98 & - & 2866.88 & 0.0000 & -0.00136 \\
\hline $1 / 10 / 2003$ & 49.97 & - & 2916.85 & 0.0000 & -0.00139 \\
\hline $1 / 11 / 2003$ & 101.45 & - & 3018.30 & 0.0000 & -0.00143 \\
\hline $1 / 12 / 2003$ & 126.81 & 303.21 & 3145.11 & -0.0001 & -0.00149 \\
\hline $4 / 30 / 2003$ & 842.63 & 842.63 & 3987.74 & -0.0004 & -0.00189 \\
\hline
\end{tabular}

Table D-2. Study lake K214 2003-2004 selected daily winter season pumping records and expected changes in water-surface levels (WSL), and cumulative changes in WSL.

\begin{tabular}{|cccccc|}
\hline \multicolumn{7}{|l}{ Lake K214: 2003-2004 Winter Pumping Season } & & \\
Date & $\begin{array}{c}\text { Daily } \\
\text { Volume, } \\
\mathbf{m}^{\wedge 3}\end{array}$ & $\begin{array}{c}\text { Monthly } \\
\text { Volume, } \\
\mathbf{m}^{\wedge} \mathbf{3}\end{array}$ & $\begin{array}{c}\text { Cumulative } \\
\text { Volume, } \mathbf{m}^{\wedge 3}\end{array}$ & $\begin{array}{c}\text { Expected } \\
\text { immediate } \\
\text { change in } \\
\text { WSL, } \mathbf{m}\end{array}$ & $\begin{array}{c}\text { Expected } \\
\text { cumulative } \\
\text { change in } \\
\text { WSL, } \mathbf{m}\end{array}$ \\
\hline \hline $12 / 7 / 2003$ & 349.77 & - & 349.77 & -0.0002 & -0.0002 \\
$12 / 8 / 2003$ & 906.22 & - & 1256.00 & -0.0006 & -0.0008 \\
$12 / 9 / 2003$ & 997.64 & - & 2253.64 & -0.0011 & -0.0018 \\
$12 / 10 / 2003$ & 902.25 & - & 3155.89 & -0.0015 & -0.0033 \\
$1 / 31 / 2004$ & - & 2539.50 & 5695.38 & -0.0027 & -0.0060 \\
$2 / 29 / 2004$ & - & 79.49 & 5774.88 & -0.0027 & -0.0088 \\
\hline
\end{tabular}


Table D-3. Study lake K214 2003-2004 winter season pumping records and expected changes in water-surface levels (WSL), and cumulative changes in WSL.

\begin{tabular}{|c|c|c|c|}
\hline \multicolumn{2}{|c}{ Lake K214P: 2003-2004 Winter Pumping Season } \\
Time Period & $\begin{array}{c}\text { Water } \\
\text { withdrawal } \\
\text { volume, } \mathbf{~ m}^{\mathbf{3}}\end{array}$ & $\begin{array}{c}\text { Expected } \\
\text { immediate } \\
\text { change in WSL, } \\
\mathbf{m}\end{array}$ & $\begin{array}{c}\text { Expected } \\
\text { cumulative } \\
\text { change in WSL, } \\
\mathbf{m}\end{array}$ \\
\hline \hline $12 / 7 / 2003-12 / 10 / 2003$ & $3,155.89$ & -0.004 & -0.004 \\
\hline $1 / 1 / 2004-1 / 31 / 2004$ & $2,539.50$ & -0.004 & -0.008 \\
\hline $2 / 1 / 2004-2 / 29 / 2004$ & 77.49 & 0.000 & -0.008 \\
\hline
\end{tabular}

Table D-4. Study lake K209 2002-2003 selected daily winter season pumping records and expected changes in water-surface levels (WSL), and cumulative changes in WSL.

\begin{tabular}{|cccccc|}
\hline \multicolumn{7}{|c}{ Lake K209P: } & $\begin{array}{c}\text { 2002-2003 Winter Pumping Season } \\
\text { Daily } \\
\text { Volume, } \\
\mathbf{m}^{\wedge 3}\end{array}$ & $\begin{array}{c}\text { Monthly } \\
\text { Volume, } \\
\mathbf{m}^{\wedge 3}\end{array}$ & $\begin{array}{c}\text { Cumulative } \\
\text { Volume, } \mathbf{m}^{\wedge 3} \mathbf{3}\end{array}$ & $\begin{array}{c}\text { Expected } \\
\text { immediate } \\
\text { change in } \\
\text { WSL, m }\end{array}$ & $\begin{array}{c}\text { Expected } \\
\text { cumulative } \\
\text { change in } \\
\text { WSL, m }\end{array}$ \\
\hline \hline $1 / 20 / 2003$ & 209.86 & - & 209.86 & -0.0001 & -0.0001 \\
$1 / 21 / 2003$ & 756.78 & - & 966.64 & -0.0005 & -0.0007 \\
$1 / 22 / 2003$ & 2287.82 & - & 3254.46 & -0.0016 & -0.0023 \\
$1 / 23 / 2003$ & 2763.19 & - & 6017.65 & -0.0020 & -0.0043 \\
$1 / 24 / 2003$ & 3001.67 & - & 9019.32 & -0.0021 & -0.0064 \\
$1 / 25 / 2003$ & 3462.73 & - & 12482.05 & -0.0025 & -0.0089 \\
$1 / 26 / 2003$ & 2928.54 & - & 15410.59 & -0.0021 & -0.0110 \\
$1 / 27 / 2003$ & 2517.44 & - & 17928.03 & -0.0018 & -0.0128 \\
$1 / 28 / 2003$ & 3885.32 & - & 21813.35 & -0.0028 & -0.0155 \\
$1 / 29 / 2003$ & 3240.15 & - & 25053.50 & -0.0023 & -0.0178 \\
$1 / 30 / 2003$ & 596.20 & - & 25649.70 & -0.0004 & -0.0183 \\
$2 / 7 / 2003$ & 107.32 & - & 25757.02 & -0.0001 & -0.0183 \\
$2 / 12 / 2003$ & 410.19 & - & 26167.21 & -0.0003 & -0.0186 \\
$2 / 13 / 2003$ & 581.10 & - & 26748.30 & -0.0004 & -0.0190 \\
$2 / 14 / 2003$ & 178.86 & - & 26927.16 & -0.0001 & -0.0192 \\
$2 / 15 / 2003$ & 35.77 & - & 26962.93 & 0.0000 & -0.0192 \\
\hline
\end{tabular}


Table D-5. Study lake K209 2003-2004 selected daily winter season pumping records and expected changes in water-surface levels (WSL), and cumulative changes in WSL.

\begin{tabular}{|c|c|c|c|c|c|}
\hline \multicolumn{6}{|c|}{ Lake K209: 2003-2004 Winter Pumping Season } \\
\hline Date & $\begin{array}{c}\text { Daily } \\
\text { Volume, } \\
\mathrm{m}^{\wedge} 3\end{array}$ & $\begin{array}{c}\text { Monthly } \\
\text { Volume, } \\
\mathrm{m}^{\wedge} 3\end{array}$ & $\begin{array}{l}\text { Cumulative } \\
\text { Volume, } m^{\wedge} 3\end{array}$ & $\begin{array}{c}\text { Expected } \\
\text { immediate } \\
\text { change in } \\
\text { WSL, } m\end{array}$ & $\begin{array}{l}\text { Expected } \\
\text { cumulative } \\
\text { change in } \\
\text { WSL, } m\end{array}$ \\
\hline $12 / 25 / 2003$ & 31.80 & - & 31.80 & 0.0000 & 0.0000 \\
\hline $12 / 26 / 2003$ & 2566.05 & - & 2597.84 & -0.0018 & -0.0018 \\
\hline $12 / 27 / 2003$ & 3663.69 & - & 6261.54 & -0.0026 & -0.0045 \\
\hline $12 / 28 / 2003$ & 335.78 & - & 6597.32 & -0.0002 & -0.0047 \\
\hline $12 / 30 / 2003$ & 3161.45 & - & 9758.77 & -0.0023 & -0.0069 \\
\hline $12 / 31 / 2003$ & 3507.41 & - & 13266.18 & -0.0025 & -0.0094 \\
\hline $1 / 2 / 2004$ & 2711.84 & - & 15978.01 & -0.0019 & -0.0114 \\
\hline $1 / 3 / 2004$ & 1780.65 & - & 17758.67 & -0.0013 & -0.0126 \\
\hline $1 / 4 / 2004$ & 2509.92 & - & 20268.59 & -0.0018 & -0.0144 \\
\hline $1 / 5 / 2004$ & 728.95 & - & 20997.55 & -0.0005 & -0.0150 \\
\hline $1 / 11 / 2004$ & 133.55 & - & 21131.09 & -0.0001 & -0.0150 \\
\hline $1 / 12 / 2004$ & 489.68 & - & 21620.77 & -0.0003 & -0.0154 \\
\hline $1 / 13 / 2004$ & 673.31 & - & 22294.08 & -0.0005 & -0.0159 \\
\hline $1 / 14 / 2004$ & 984.92 & - & 23279.01 & -0.0007 & -0.0166 \\
\hline $1 / 15 / 2004$ & 1546.94 & - & 24825.95 & -0.0011 & -0.0177 \\
\hline $1 / 16 / 2004$ & 2746.50 & - & 27572.44 & -0.0020 & -0.0196 \\
\hline $1 / 17 / 2004$ & 3241.74 & - & 30814.19 & -0.0023 & -0.0219 \\
\hline $1 / 18 / 2004$ & 1775.41 & - & 32589.59 & -0.0013 & -0.0232 \\
\hline $1 / 19 / 2004$ & 1339.46 & - & 33929.06 & -0.0010 & -0.0242 \\
\hline $1 / 20 / 2004$ & 1510.37 & - & 35439.43 & -0.0011 & -0.0252 \\
\hline $1 / 21 / 2004$ & 1947.59 & - & 37387.02 & -0.0014 & -0.0266 \\
\hline $1 / 22 / 2004$ & 198.73 & - & 37585.75 & -0.0001 & -0.0268 \\
\hline $2 / 5 / 2004$ & 186.81 & - & 37772.56 & -0.0001 & -0.0269 \\
\hline $2 / 6 / 2004$ & 246.43 & - & 38018.99 & -0.0002 & -0.0271 \\
\hline $2 / 14 / 2004$ & 194.76 & - & 38213.75 & -0.0001 & -0.0272 \\
\hline $2 / 17 / 2004$ & 202.71 & - & 38416.46 & -0.0001 & -0.0274 \\
\hline $2 / 18 / 2004$ & 321.95 & - & 38738.41 & -0.0002 & -0.0276 \\
\hline $2 / 18 / 2004$ & 405.42 & - & 39143.82 & -0.0003 & -0.0279 \\
\hline $2 / 19 / 2004$ & 727.36 & - & 39871.19 & -0.0005 & -0.0284 \\
\hline $2 / 20 / 2004$ & 357.72 & - & 40228.91 & -0.0003 & -0.0286 \\
\hline $2 / 21 / 2004$ & 393.49 & - & 40622.40 & -0.0003 & -0.0289 \\
\hline $2 / 24 / 2004$ & 314.00 & - & 40936.40 & -0.0002 & -0.0292 \\
\hline $2 / 25 / 2004$ & 214.63 & - & 41151.03 & -0.0002 & -0.0293 \\
\hline $2 / 26 / 2004$ & 282.20 & - & 41433.23 & -0.0002 & -0.0295 \\
\hline $2 / 27 / 2004$ & 353.75 & - & 41786.98 & -0.0003 & -0.0298 \\
\hline $2 / 28 / 2004$ & 504.78 & - & 42291.76 & -0.0004 & -0.0301 \\
\hline $3 / 5 / 2004$ & 472.99 & - & 42764.75 & -0.0003 & -0.0305 \\
\hline $3 / 6 / 2004$ & 655.82 & - & 43420.57 & -0.0005 & -0.0309 \\
\hline $3 / 7 / 2004$ & 290.15 & - & 43710.72 & -0.0002 & -0.0311 \\
\hline
\end{tabular}


Table D-6. Study lake K209 2003-2004 winter season pumping records and expected changes in water-surface levels (WSL), and cumulative changes in WSL.

\begin{tabular}{|c|c|c|c|}
\hline Lake K209: 2003-2004 Winter Pumping Season & $\begin{array}{c}\text { Water } \\
\text { withdrawal } \\
\text { volume, } \mathbf{m}^{\mathbf{3}}\end{array}$ & $\begin{array}{c}\text { Expected } \\
\text { immediate } \\
\text { change in WSL, } \\
\mathbf{m}\end{array}$ & $\begin{array}{c}\text { Expected } \\
\text { cumulative } \\
\text { change in WSL, } \\
\mathbf{m}\end{array}$ \\
\hline \hline $12 / 25 / 2003-12 / 28 / 2003$ & $6,587.32$ & -0.014 & -0.014 \\
\hline $12 / 30 / 2003-12 / 31 / 2003$ & $6,668.86$ & -0.015 & -0.029 \\
\hline $1 / 2 / 2004-1 / 5 / 2004$ & $7,731.37$ & -0.018 & -0.048 \\
\hline $1 / 11 / 2004-1 / 22 / 2004$ & $16,588.21$ & -0.044 & -0.091 \\
\hline $2 / 17 / 2004-2 / 21 / 2004$ & $2,408.65$ & -0.013 & -0.105 \\
\hline $2 / 24 / 2004-2 / 28 / 2004$ & $1,669.36$ & -0.011 & -0.116 \\
\hline $3 / 5 / 2004-3 / 7 / 2004$ & $1,418.96$ & -0.012 & -0.128 \\
\hline
\end{tabular}


APPENDIX E: STUDY LAKE INLET AND OUTLET COORDINATES AND SELECTED FIELD PHOTOGRAPHS.

The following tables report the coordinates of the inlets and outlets of sampled lakes after snowmelt. These data were collected during the Phase 1 portion of the North Slope Lakes project. This appendix also includes photographs of selected lake outlets. Photographs were taken by Braden Galloway.

Table E-1. Selected study lake outlet and inlet locations.

Figure E-1. Photograph of outlets 1 and 2 at study lake K113C.

Figure E-2. Photograph of outlet 2 at study lake K214P.

Figure E-3. Photograph of outlet 3 at study lake K214P.

Figure E-4. Photograph of outlet 2 at study lake K209P.

Figure E-5. Photograph of outlet 1 at study lake L9312P.

Figure E-6. Photograph of outlet 1 at study lake L9817P. 
Table E-1. Selected study lake outlet and inlet locations.

\begin{tabular}{|c|c|c|}
\hline \multicolumn{3}{|l|}{ Lake K214 } \\
\hline & Latitude (WGS 84) & Longitude (WGS 84) \\
\hline Inlet 1 & $7017.590 \mathrm{~N}$ & $14956.204 \mathrm{~W}$ \\
\hline Inlet & $7017.430 \mathrm{~N}$ & $14955.121 \mathrm{~W}$ \\
\hline \multicolumn{3}{|l|}{ Inlet } \\
\hline Outlet 1 & $7017.991 \mathrm{~N}$ & 14954.953 W \\
\hline Outlet 2 & $7018.015 \mathrm{~N}$ & $14955.129 \mathrm{~W}$ \\
\hline Outlet 3 & $7017.915 \mathrm{~N}$ & $14955.799 \mathrm{~W}$ \\
\hline Outlet & $7017.983 \mathrm{~N}$ & $14954.872 \mathrm{~W}$ \\
\hline Outlet & $7016.943 \mathrm{~N}$ & $14955.014 \mathrm{~W}$ \\
\hline \multicolumn{3}{|l|}{ Lake K113 } \\
\hline & Latitude (WGS 84) & Longitude (WGS 84) \\
\hline Inlet 1 & $7019.074 \mathrm{~N}$ & $14919.452 \mathrm{~W}$ \\
\hline Inlet 2 & $7019.107 \mathrm{~N}$ & $14919.172 \mathrm{~W}$ \\
\hline Inlet 3 & $7019.080 \mathrm{~N}$ & $14919.044 \mathrm{~W}$ \\
\hline Outlet $1 \& 2$ & $7019.174 \mathrm{~N}$ & $14918.748 \mathrm{~W}$ \\
\hline \multicolumn{3}{|l|}{ Lake K209 } \\
\hline & Latitude (WGS 84) & Longitude (WGS 84) \\
\hline Inlet 1 & $7013.970 \mathrm{~N}$ & $15020.428 \mathrm{~W}$ \\
\hline Inlet 2 & $7014.005 \mathrm{~N}$ & $15020.414 \mathrm{~W}$ \\
\hline Inlet 3 & $7014.146 \mathrm{~N}$ & $15020.516 \mathrm{~W}$ \\
\hline Outlet 1 & $7014.195 \mathrm{~N}$ & $15021.149 \mathrm{~W}$ \\
\hline Outlet 2 & $7014.149 \mathrm{~N}$ & $15021.608 \mathrm{~W}$ \\
\hline Outlet 3 & $7014.092 \mathrm{~N}$ & $15021.668 \mathrm{~W}$ \\
\hline
\end{tabular}




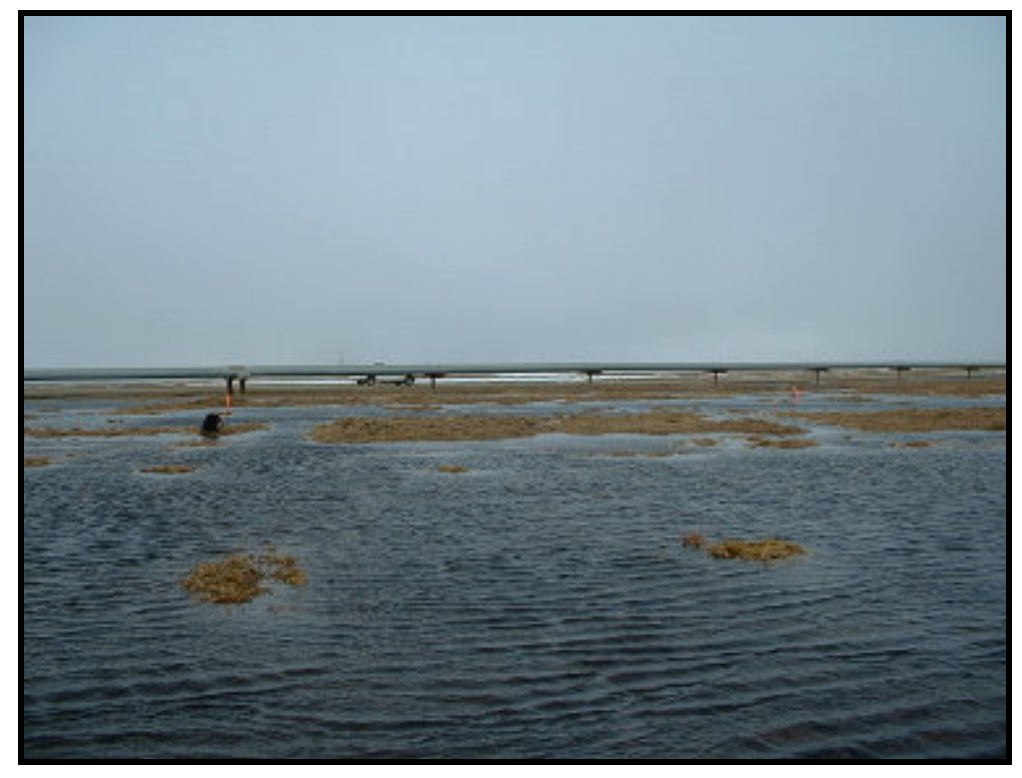

Figure E-1. Photograph of outlets 1 and 2 at study lake K113C.

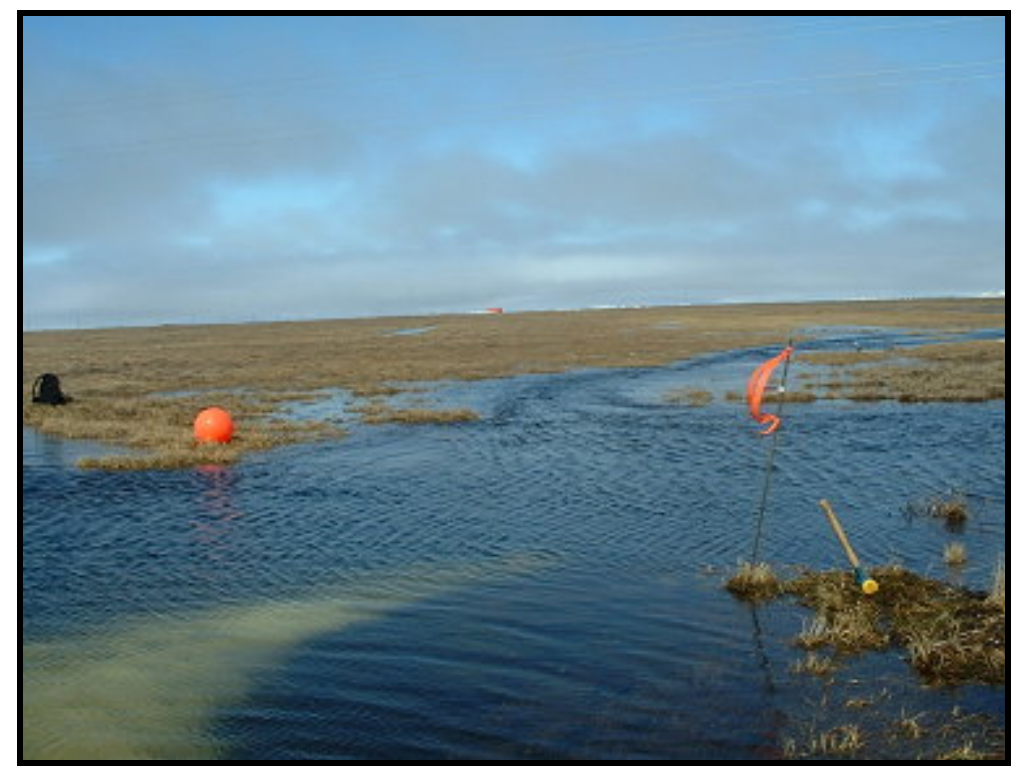

Figure E-2. Photograph of outlet 2 at study lake K214P. 


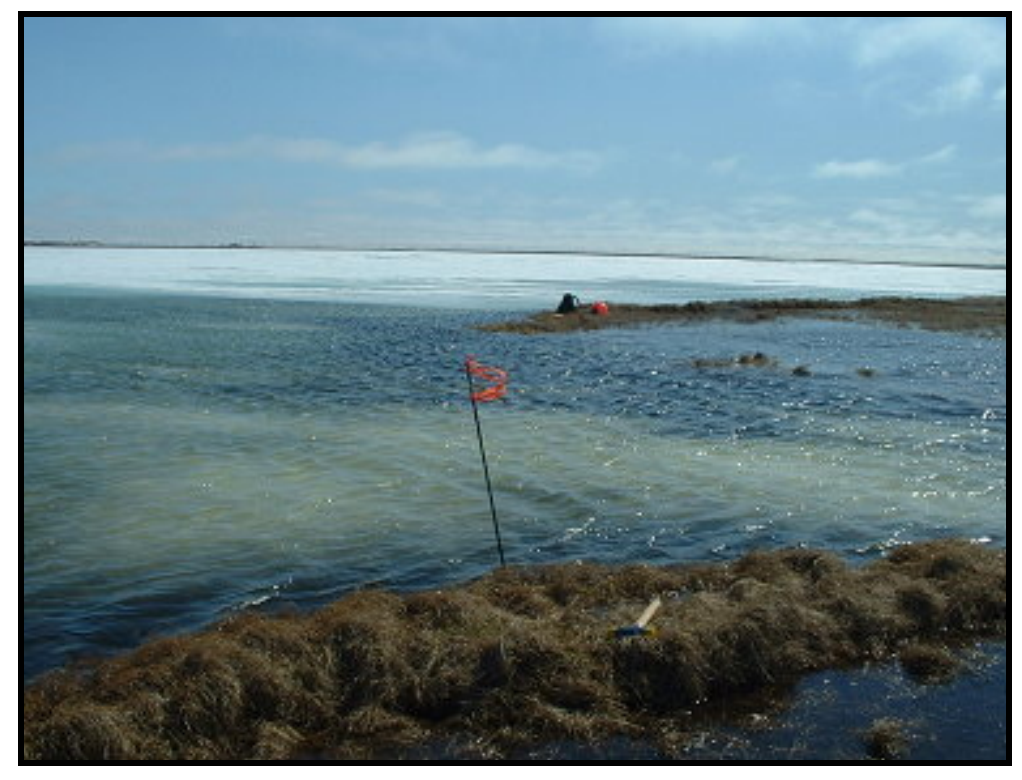

Figure E-3. Photograph of outlet 3 at study lake K214P.

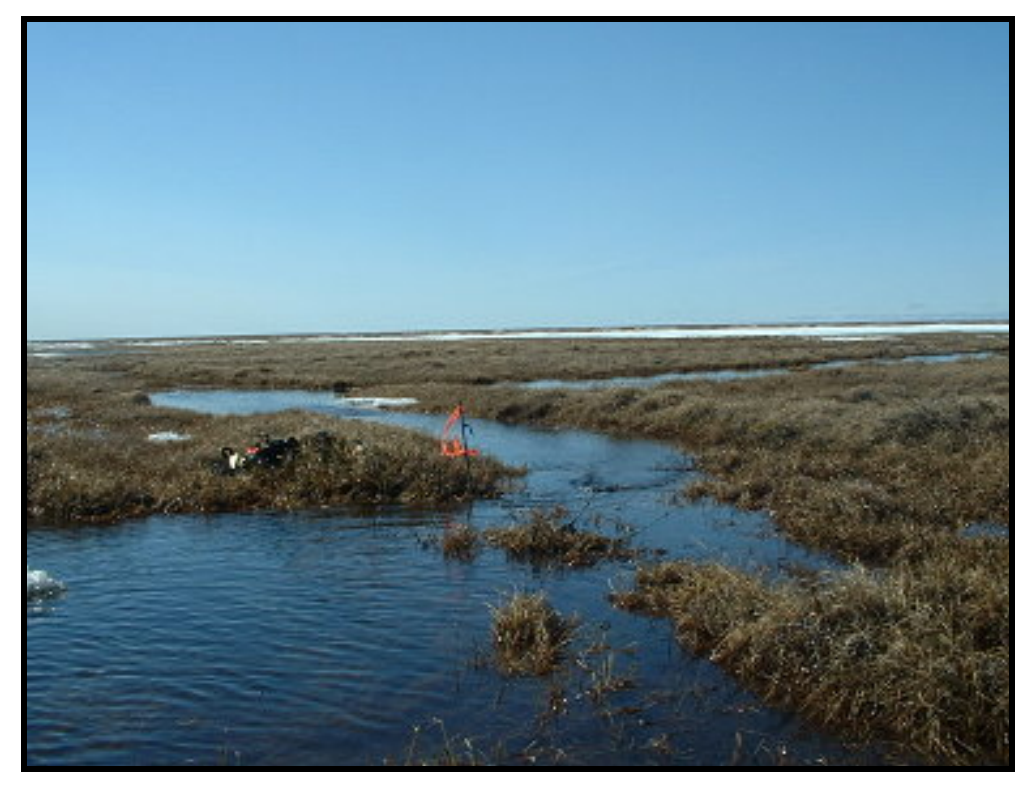

Figure E-4. Photograph of outlet 2 at study lake K209P. 


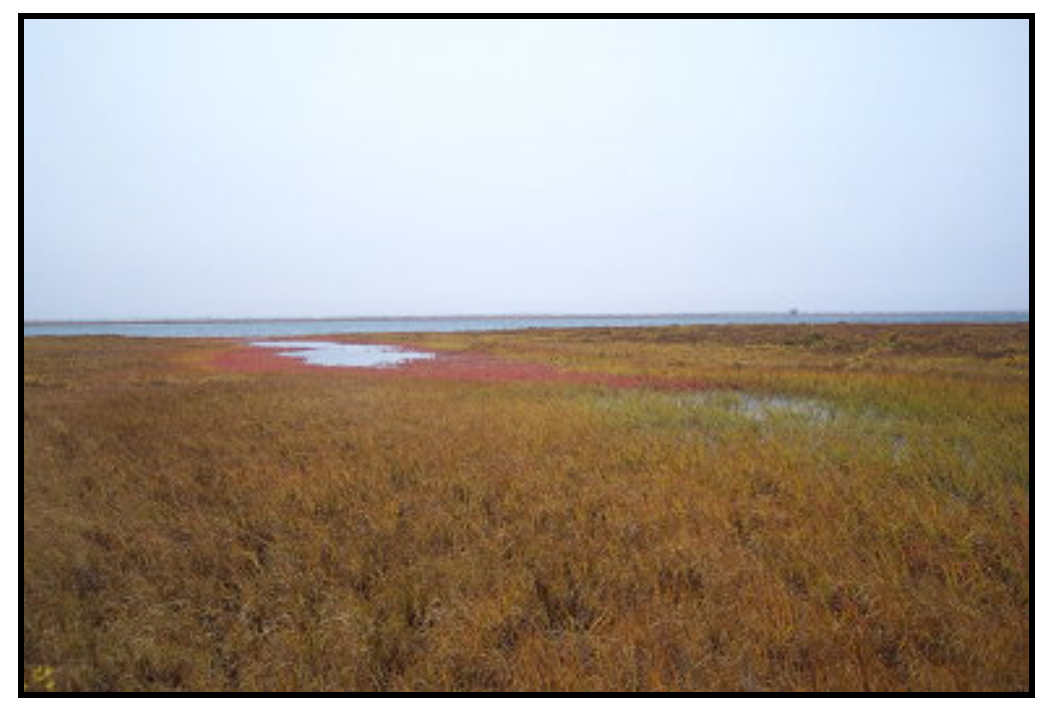

Figure E-5. Photograph of outlet 1 at study lake L9312P.

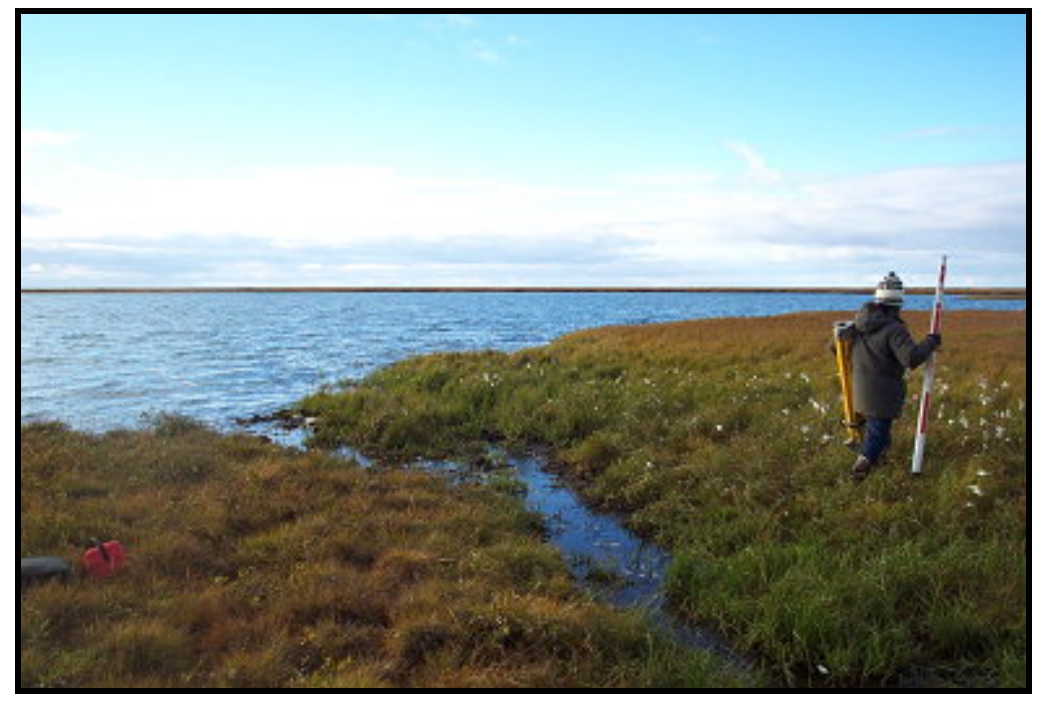

Figure E-6. Photograph of outlet 1 at study lake L9817P. 


\section{APPENDIX F: AERIAL PHOTOS OF STUDY LAKES}

The following figures include aerial photos of selected study lakes. Aerial photography provided by ConocoPhillips Alaska, Inc. These data were collected during the Phase 1 portion of the North Slope Lakes project.

Figure F-1. Aerial photo of study lake K113C. Figure F-2. Aerial photo of study lake K214P.

Figure F-3. Aerial photo of study lake K209P.

Figure F-4. Aerial photo of study lake L9312P.

Figure F-5. Aerial photo of study lake L9817P. 


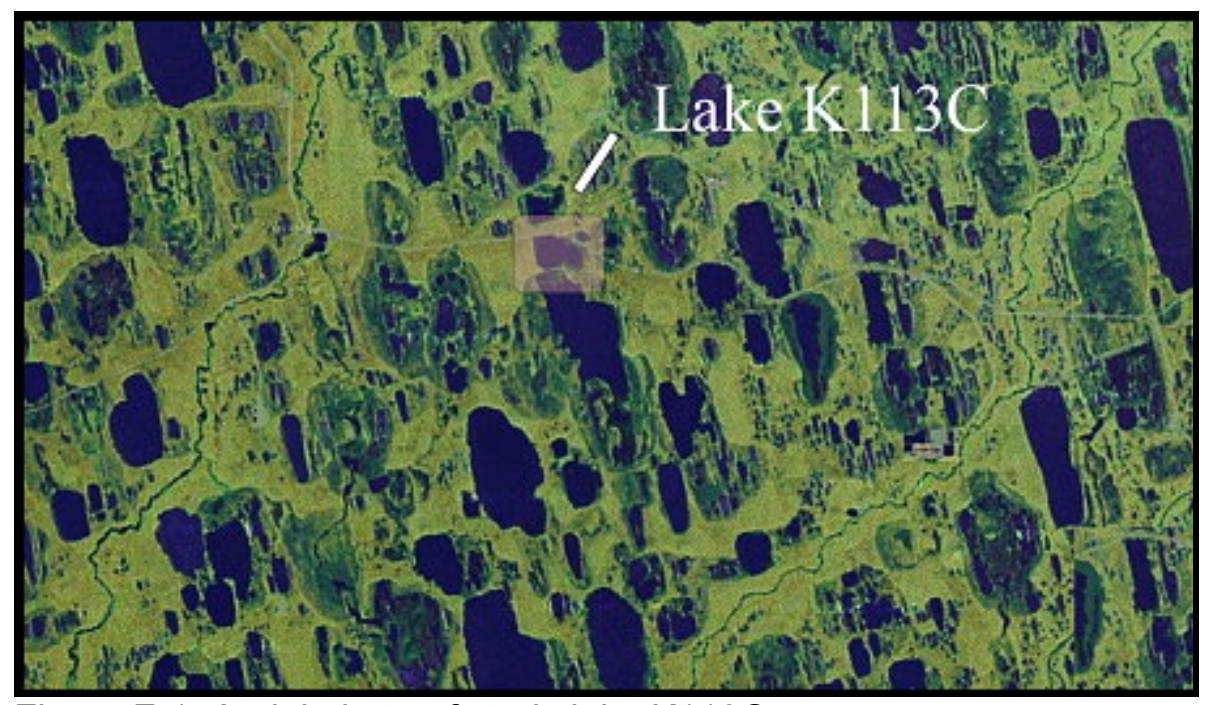

Figure F-1. Aerial photo of study lake K113C.

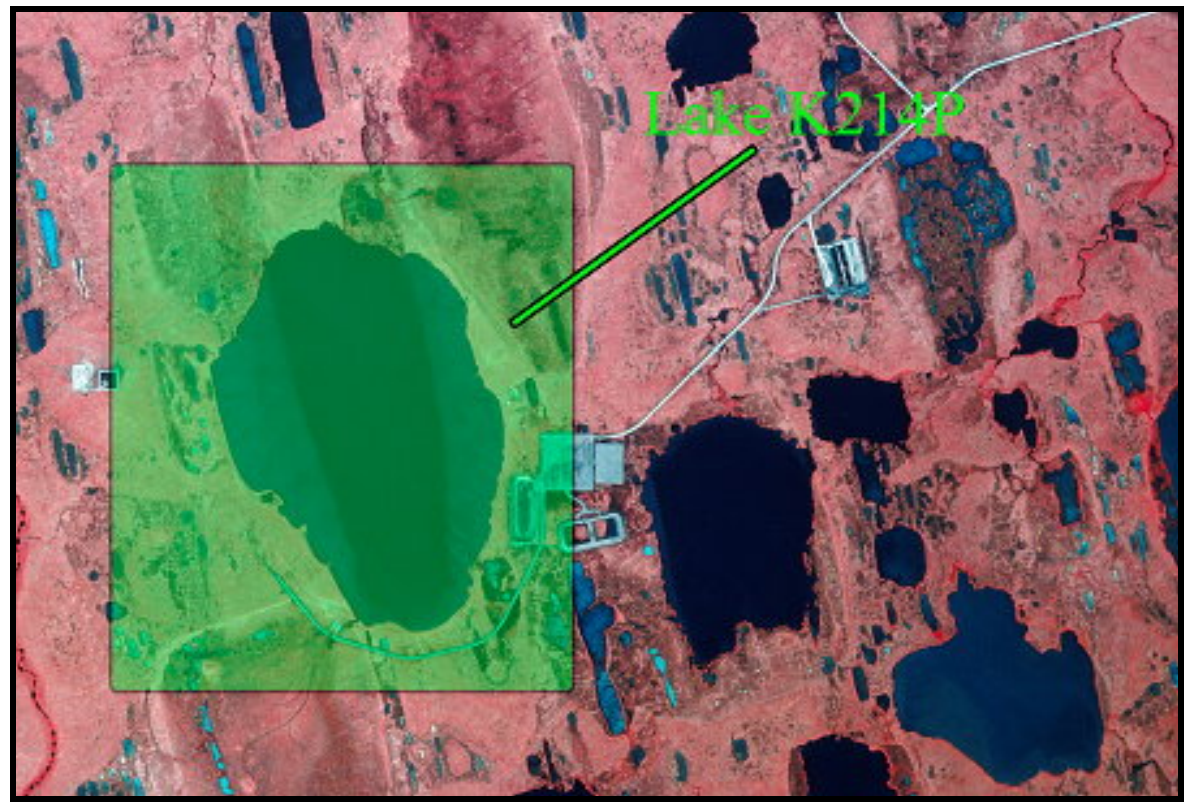

Figure F-2. Aerial photo of study lake K214P. 


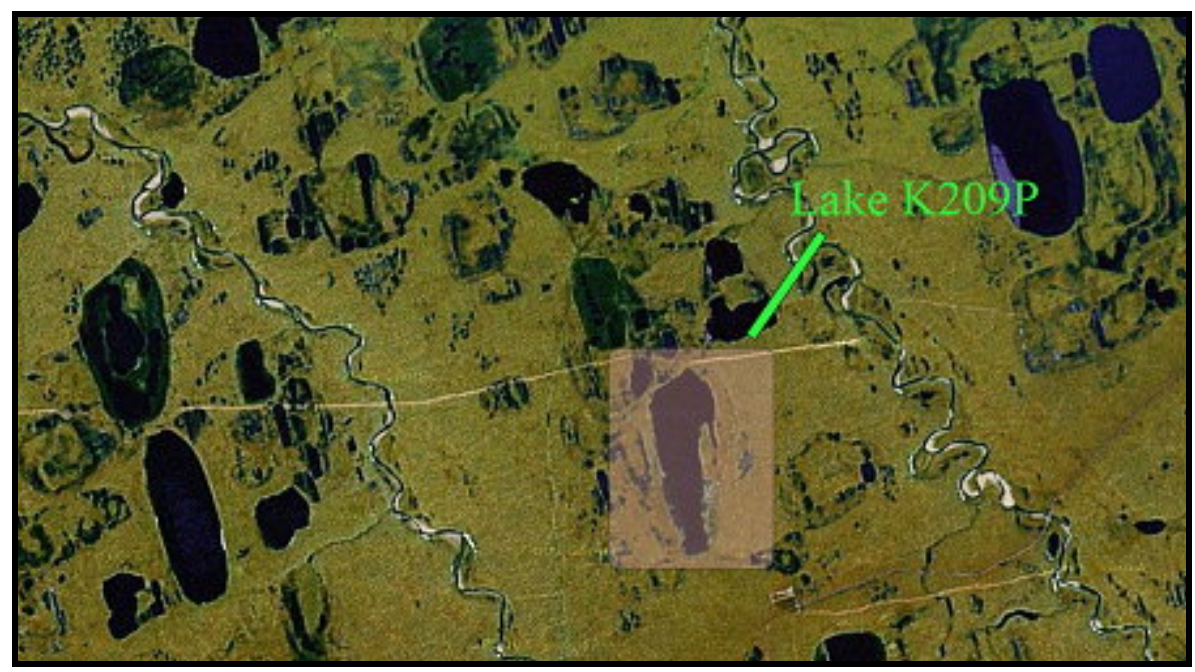

Figure F-3. Aerial photo of study lake K209P.

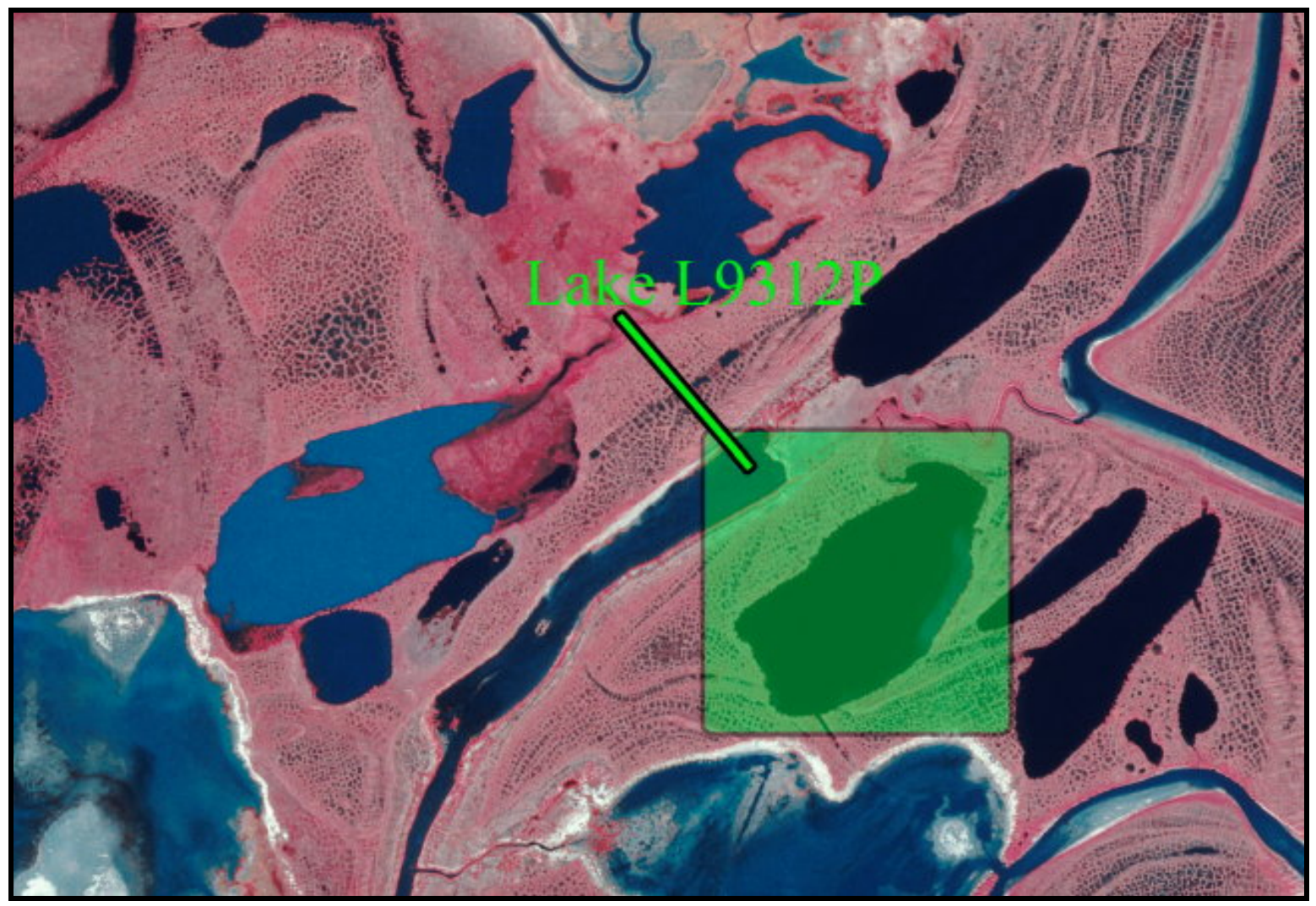

Figure F-4. Aerial photo of study lake L9312P. 


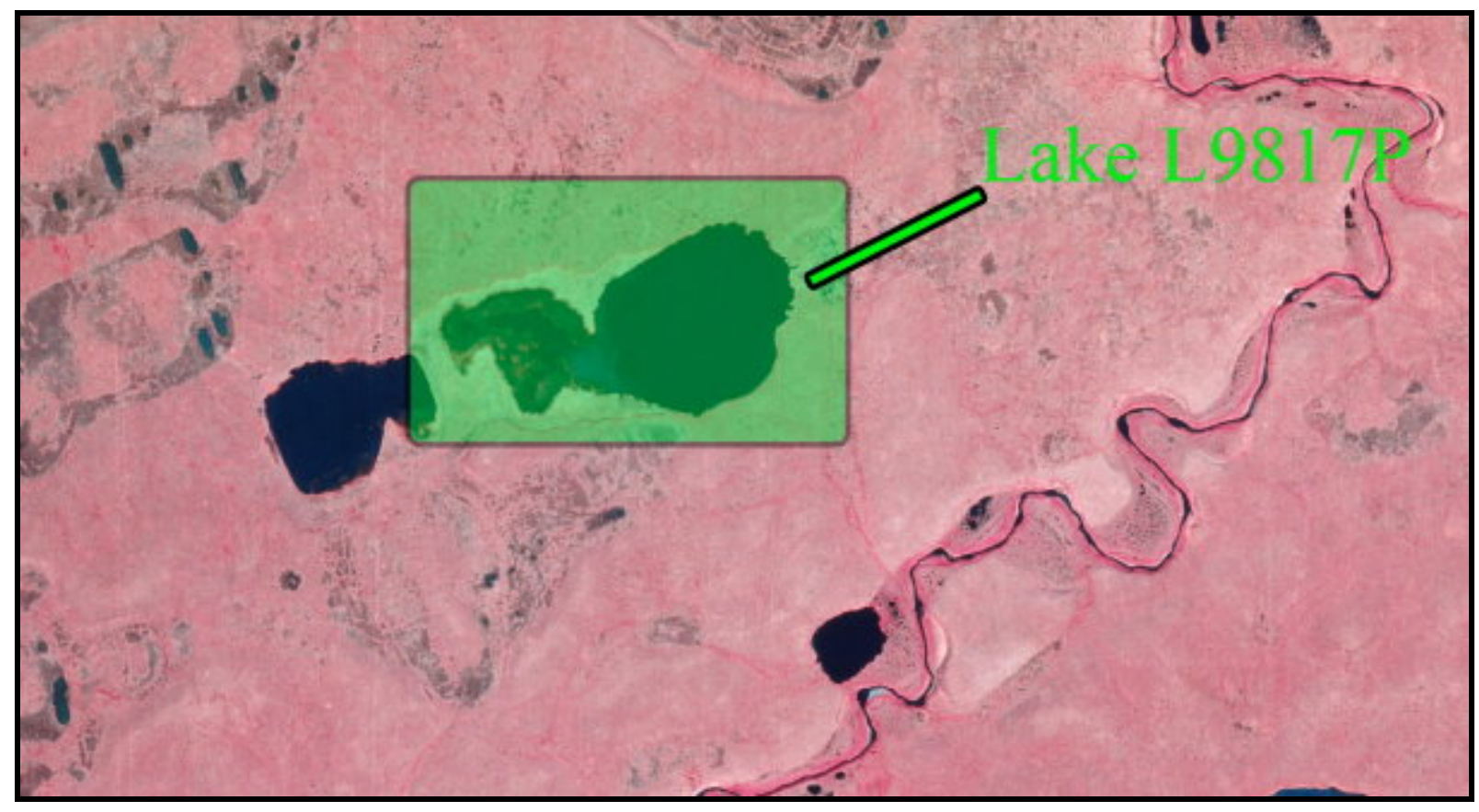

Figure F-5. Aerial photo of study lake L9817P. 


\section{APPENDIX G: AVERAGE SNOW WATER EQUIVALENCE FOR STUDY LAKE BASINS AND RELATED AND SNOW ABLATION DATA.}

The following tables report average Snow-Water Equivalent (SWE) data for study lake basins and snow ablation data collected during spring snowmelt periods. These data were collected during the Phase 1 portion of the North Slope Lakes project. SWE data is used to determine how much winter precipitation is available for spring snowmelt.

Table G-1. Average snowpack SWE within lake basins before 2003 spring melt.

Table G-2. Average snowpack SWE within lake basins before 2004 spring melt.

Table G-3. Average snowpack SWE within lake basins before 2005 spring melt.

Table G-4. Historical pre-melt snow water equivalence at WERC Betty Pingo Meteorological Station.

Table G-5. Snow ablation at K113C Index Site during 2003 spring melt. Snow survey site is 100 $\mathrm{m}$ north of the Spine Rd and melt was be premature due to road dust and decreased albedo of snowpack.

Table G-6. Snow ablation at Betty Pingo meteorological station during 2003 spring melt. Table G-7. Snow ablation at Betty Pingo meteorological station during 2004 spring melt.

Table G-8. Snow ablation at K113C Index Site during 2004 spring melt. Snow survey site is 100 $\mathrm{m}$ north of the Spine Rd and melt was be premature due to road dust and decreased albedo of snowpack.

Table G-9. Snow ablation at Betty Pingo meteorological station during 2005 spring melt.

Table G-10. Snow ablation at K113C Index Site during 2005 spring melt. Snow survey site is $100 \mathrm{~m}$ north of the Spine Rd and melt was be premature due to road dust and decreased albedo of snowpack. 
Table G-1. Average snowpack SWE within lake basins before 2003 spring melt.

\begin{tabular}{|c|c|}
\hline Lake Basin & Average SWE, cm \\
\hline \hline K113C & 10.33 \\
\hline K203C & 10.36 \\
\hline K209P & 9.76 \\
\hline K214P & 8.30 \\
\hline
\end{tabular}

Table G-2. Average snowpack SWE within lake basins before 2004 spring melt.

\begin{tabular}{|c|c|}
\hline Lake Basin & Average SWE, cm \\
\hline \hline K113C & 7.06 \\
\hline K214P & 9.98 \\
\hline K209P & 11.27 \\
\hline
\end{tabular}

Table G-3. Average snowpack SWE within lake basins before 2005 spring melt.

\begin{tabular}{|c|c|}
\hline Lake Basin & Average SWE, cm \\
\hline \hline K113C & 6.27 \\
\hline K214P & 6.77 \\
\hline K209P & 7.50 \\
\hline L9312P & 5.24 \\
\hline L9817P & 5.02 \\
\hline
\end{tabular}

Table G-4. Historical pre-melt snow water equivalence at WERC Betty Pingo Meteorological Station.

\begin{tabular}{|c|c|c|}
\hline Year & SWE, cm & Date of Measurement \\
\hline \hline 1996 & 5.8 & $19-$ May \\
\hline 1997 & 12.9 & $19-$ May \\
\hline 1999 & 9.3 & $15-$ May \\
\hline 2000 & 8.2 & $20-$ May \\
\hline 2001 & 8.3 & $21-$ May \\
\hline 2002 & 7.6 & $20-$ May \\
\hline 2003 & 10.9 & $17-$ May \\
\hline 2004 & 8.1 & 19-May \\
\hline 2005 & 7.1 & $28-$ April \\
\hline
\end{tabular}


Table G-5. Snow ablation at K113C Index Site during 2003 spring melt. Snow survey site is 100 $\mathrm{m}$ north of the Spine Rd and melt was be premature due to road dust and decreased albedo of snowpack.

\begin{tabular}{|c|c|}
\hline Date & SWE, cm \\
\hline \hline $5 / 16 / 200312: 00$ & 11.50 \\
\hline $5 / 17 / 200312: 00$ & 11.51 \\
\hline $5 / 18 / 200314: 30$ & 10.04 \\
\hline $5 / 19 / 20039: 00$ & 8.84 \\
\hline $5 / 20 / 200313: 00$ & 9.57 \\
\hline $5 / 21 / 200317: 00$ & 8.34 \\
\hline $5 / 22 / 200313: 00$ & 11.73 \\
\hline $5 / 23 / 200311: 00$ & 12.95 \\
\hline $5 / 24 / 200313: 00$ & 10.14 \\
\hline $5 / 26 / 200319: 30$ & 9.16 \\
\hline $5 / 27 / 200314: 00$ & 8.99 \\
\hline $5 / 28 / 200310: 00$ & 7.26 \\
\hline $5 / 29 / 200310: 30$ & 7.49 \\
\hline $5 / 30 / 200312: 00$ & 3.01 \\
\hline $5 / 31 / 200312: 00$ & 0 \\
\hline
\end{tabular}

Table G-6. Snow ablation at Betty Pingo meteorological station during 2003 spring melt.

\begin{tabular}{|c|c|}
\hline Date & SWE, cm \\
\hline \hline 17-May-03 & 10.93 \\
\hline 18-May-03 & 10.03 \\
\hline 19-May-03 & 11.52 \\
\hline 20-May-03 & 12.74 \\
\hline $21-$ May-03 & 12.64 \\
\hline $22-$ May-03 & 12.67 \\
\hline 23-May-03 & 11.26 \\
\hline 24-May-03 & 9.50 \\
\hline 26-May-03 & 11.07 \\
\hline 27-May-03 & 11.77 \\
\hline 28-May-03 & 11.76 \\
\hline 29-May-03 & 11.49 \\
\hline 30-May-03 & 9.81 \\
\hline 31-May-03 & 10.05 \\
\hline 1-Jun-03 & 8.93 \\
\hline 2-Jun-03 & 7.15 \\
\hline 3-Jun-03 & 6.53 \\
\hline 4-Jun-03 & 0 \\
\hline
\end{tabular}


Table G-7. Snow ablation at Betty Pingo meteorological station during 2004 spring melt.

\begin{tabular}{|c|c|}
\hline Date & SWE, cm \\
\hline \hline 19-May-04 & 8.1 \\
\hline 24-May-04 & 2.7 \\
\hline 29-May-04 & 1.9 \\
\hline 31-May-04 & 2.6 \\
\hline 2-Jun-04 & 1.9 \\
\hline 3-Jun-04 & 1.3 \\
\hline 4-Jun-04 & 1.1 \\
\hline 5-Jun-04 & 0.5 \\
\hline 6-Jun-04 & 0 \\
\hline
\end{tabular}

Table G-8. Snow ablation at K113C Index Site during 2004 spring melt. Snow survey site is 100 $\mathrm{m}$ north of the Spine Rd and melt was be premature due to dusting and decreased albedo of snowpack.

\begin{tabular}{|c|c|}
\hline Date & Avg SWE, $\mathbf{~ c m}$ \\
\hline \hline 20-May-04 & 5.4 \\
\hline 21-May-04 & 5.5 \\
\hline 24-May-04 & 4.2 \\
\hline 26-May-04 & 2.9 \\
\hline 28-May-04 & 1.8 \\
\hline 31-May-04 & 0.7 \\
\hline 2-Jun-04 & 0 \\
\hline
\end{tabular}

Table G-9. Snow ablation at Betty Pingo meteorological station during 2005 spring melt.

\begin{tabular}{|c|c|}
\hline Date & SWE, $\mathbf{~ m ~}$ \\
\hline \hline 28-Apr-05 & 7.1 \\
\hline 18-May-05 & 7.0 \\
\hline 20-May-05 & 9.5 \\
\hline 26-May-05 & 10.8 \\
\hline 30-May-05 & 5.5 \\
\hline 31-May-05 & 4.4 \\
\hline 1-Jun-05 & 4.2 \\
\hline 3-Jun-05 & 3.8 \\
\hline 4-Jun-05 & 2.4 \\
\hline 5-Jun-05 & 1.1 \\
\hline 6-Jun-05 & 0.2 \\
\hline
\end{tabular}


Table G-10. Snow ablation at K113C Index Site during 2005 spring melt. Snow survey site is $100 \mathrm{~m}$ north of the Spine Rd and melt was be premature due to road dust and decreased albedo of snowpack.

\begin{tabular}{|c|c|}
\hline Date & Avg SWE, cm \\
\hline \hline 16-May-05 & 6.1 \\
\hline 17-May-05 & 7.8 \\
\hline 18-May-05 & 4.9 \\
\hline 19-May-05 & 5.5 \\
\hline $22-M a y-05$ & 7.9 \\
\hline $23-M a y-05$ & 5.1 \\
\hline $24-M a y-05$ & 5.1 \\
\hline 25-May-05 & 5.8 \\
\hline 26-May-05 & 6.1 \\
\hline 28-May-05 & 4.8 \\
\hline 29-May-05 & 2.4 \\
\hline 30-May-05 & 0.5 \\
\hline 31-May-05 & 0.0 \\
\hline
\end{tabular}


APPENDIX H: SNOW-WATER EQUIVALENCE DATA AND SNOW TRANSECT LOCATIONS.

The following tables report the location and results of snow survey transects to measure SnowWater Equivalent (SWE). These data were collected during the Phase 1 portion of the North Slope Lakes project. SWE data is used to determine how much winter precipitation is available for spring snowmelt. 


\begin{tabular}{|c|c|c|c|c|}
\hline \multicolumn{5}{|c|}{ Lake K113C (surveyed 5/14/03) } \\
\hline $\begin{array}{c}\text { Snow Survey } \\
\text { ID }\end{array}$ & $\begin{array}{c}\text { Average } \\
\text { Depth, cm }\end{array}$ & SWE & $\begin{array}{c}\text { Latitude (WGS } \\
\text { 84) }\end{array}$ & $\begin{array}{c}\text { Longitude (WGS } \\
\text { 84) }\end{array}$ \\
\hline SS1 & 23.24 & 5.49 & $7019^{\prime} 24.4^{\prime \prime} \mathrm{N}$ & 149 19' 33.9" W \\
\hline SS2 & 34.12 & 9.59 & $7018^{\prime} 38.5^{\prime \prime} \mathrm{N}$ & 149 19' 00.8" W \\
\hline SS3 & 37.50 & 10.28 & $7018^{\prime} 38.1 " \mathrm{~N}$ & 14920 ' 19.7" W \\
\hline SS4 & 51.46 & 15.95 & $7018^{\prime} 49.2^{\prime \prime} \mathrm{N}$ & 149 22' 39.7" W \\
\hline \multicolumn{5}{|c|}{ Lake K214P (surveyed 5/14/03) } \\
\hline $\begin{array}{c}\text { Snow Survey } \\
\text { ID }\end{array}$ & $\begin{array}{c}\text { Average } \\
\text { Depth, } \mathrm{cm}\end{array}$ & SWE & $\begin{array}{c}\text { Latitude (WGS } \\
\text { 84) }\end{array}$ & $\begin{array}{c}\text { Longitude (WGS } \\
\text { 84) }\end{array}$ \\
\hline SS5 & 27.96 & 5.23 & $7018.968 ' \mathrm{~N}$ & $14956.410^{\prime} \mathrm{W}$ \\
\hline SS1 & 22.54 & 4.98 & $7017^{\prime} 28.8^{\prime \prime}$ & $14955^{\prime} 02.8 "$ \\
\hline SS2 & 50.06 & 11.91 & $7016^{\prime} 24.7^{\prime \prime} \mathrm{N}$ & 149 51' 34.4" W \\
\hline SS3 & 54.42 & 13.22 & $7016^{\prime} 09.1^{\prime \prime} \mathrm{N}$ & 149 55' 15.8" W \\
\hline SS4 & 29.25 & 6.14 & $7017.138^{\prime} \mathrm{N}$ & 14956.534 ' W \\
\hline \multicolumn{5}{|c|}{ Lake K209P (surveyed 5/15/03) } \\
\hline $\begin{array}{c}\text { Snow Survey } \\
\text { ID }\end{array}$ & $\begin{array}{c}\text { Average } \\
\text { Depth, } \mathrm{cm}\end{array}$ & SWE & $\begin{array}{c}\text { Latitude (WGS } \\
\text { 84) }\end{array}$ & $\begin{array}{c}\text { Longitude (WGS } \\
\text { 84) }\end{array}$ \\
\hline SS5 & 24.44 & 4.84 & 7011 ' 27.1" N & $15019^{\prime} 13.8 " \mathrm{~W}$ \\
\hline SS1 & 29.70 & 9.42 & $7023^{\prime} 40.1^{\prime \prime}$ & 149 49' 05.4" \\
\hline SS2 & 40.74 & 10.14 & 70 12' 30.1" & 15021 ' 05.3" \\
\hline SS4 & 58.74 & 16.98 & $7013^{\prime} 45.7^{\prime \prime} \mathrm{N}$ & $15019^{\prime} 33.2^{\prime \prime} \mathrm{W}$ \\
\hline SS3 & 36.62 & 8.61 & $7013^{\prime} 07.6 " \mathrm{~N}$ & 150 23' 11.9" W \\
\hline \multicolumn{5}{|c|}{ Lake K203C (surveyed 5/18/03) } \\
\hline $\begin{array}{c}\text { Snow Survey } \\
\text { ID }\end{array}$ & $\begin{array}{c}\text { Average } \\
\text { Depth, cm }\end{array}$ & SWE & $\begin{array}{c}\text { Latitude (NAD } \\
\text { 27) }\end{array}$ & $\begin{array}{l}\text { Longitude (NAD } \\
27)\end{array}$ \\
\hline SS1 & 39.34 & 13.81 & $7017^{\prime} 07.6^{\prime \prime}$ & $14951^{\prime} 39.5 "$ \\
\hline SS2 & 32.66 & 8.88 & 7018 '06.2" & $14951 ' 25.0 "$ \\
\hline SS3 & 38.68 & 11.18 & 7016.926 & 14953.526 \\
\hline SS4 & 24.18 & 7.57 & $7016.941^{\prime}$ & $14948.247^{\prime}$ \\
\hline
\end{tabular}




\begin{tabular}{|c|c|c|c|c|}
\hline \multicolumn{5}{|c|}{ Lake K113C (surveyed 5/20/04) } \\
\hline $\begin{array}{c}\text { Snow Survey } \\
\text { ID }\end{array}$ & $\begin{array}{c}\text { Average } \\
\text { Depth, cm }\end{array}$ & SWE & $\begin{array}{c}\text { Latitude (WGS } \\
\text { 84) }\end{array}$ & Longitude (WGS 84) \\
\hline SS1 & 13.80 & 5.45 & $7019 ' 24.4 " \mathrm{~N}$ & 149 19' 33.9" W \\
\hline SS4 & 19.50 & 7.00 & $7018^{\prime} 49.2^{\prime \prime} \mathrm{N}$ & 149 22' 39.7" W \\
\hline SS3 & 14.00 & 5.80 & $7018^{\prime} 38.1^{\prime \prime} \mathrm{N}$ & 14920 ' 19.7" W \\
\hline SS2 & 16.90 & 10.00 & $7018^{\prime} 38.5^{\prime \prime} \mathrm{N}$ & 149 19' 00.8" W \\
\hline \multicolumn{5}{|c|}{ Lake K214P (surveyed 5/21/04) } \\
\hline $\begin{array}{c}\text { Snow Survey } \\
\text { ID }\end{array}$ & $\begin{array}{c}\text { Average } \\
\text { Depth, cm }\end{array}$ & SWE & $\begin{array}{c}\text { Latitude (WGS } \\
\text { 84) }\end{array}$ & Longitude (WGS 84) \\
\hline SS5 & 16.40 & 8.10 & $7018.968 ' \mathrm{~N}$ & $14956.410^{\prime} \mathrm{W}$ \\
\hline SS2 & 23.00 & 9.50 & $7016^{\prime} 24.7^{\prime \prime} \mathrm{N}$ & 149 51' 34.4" W \\
\hline SS3 & 20.60 & 8.40 & $7016^{\prime} 09.1^{\prime \prime} \mathrm{N}$ & 149 55' 15.8" W \\
\hline SS4 & 36.10 & 13.90 & $7017.138 \mathrm{~N}$ & $14956.534^{\prime} \mathrm{W}$ \\
\hline \multicolumn{5}{|c|}{ Lake K209P (surveyed 5/21/04) } \\
\hline $\begin{array}{c}\text { Snow Survey } \\
\text { ID }\end{array}$ & $\begin{array}{c}\text { Average } \\
\text { Depth, cm }\end{array}$ & SWE & $\begin{array}{c}\text { Latitude (WGS } \\
\text { 84) }\end{array}$ & Longitude (WGS 84) \\
\hline SS5 & 38.10 & 13.00 & 7011 ' $27.1 " \mathrm{~N}$ & $15019^{\prime} 13.8 " \mathrm{~W}$ \\
\hline SS4 & 28.10 & 8.30 & $7013^{\prime} 45.7 " \mathrm{~N}$ & 15019 '33.2" W \\
\hline SS3 & 31.70 & 12.50 & $7013^{\prime} 07.6 " \mathrm{~N}$ & 150 23' 11.9" W \\
\hline
\end{tabular}




\begin{tabular}{|c|c|c|c|c|}
\hline \multicolumn{5}{|c|}{ Lake K113C (surveyed 5/16/05) } \\
\hline $\begin{array}{c}\text { Snow Survey } \\
\text { ID }\end{array}$ & $\begin{array}{c}\text { Average } \\
\text { Depth, cm }\end{array}$ & SWE & $\begin{array}{l}\text { Latitude (WGS } \\
\text { 84) }\end{array}$ & Longitude (WGS 84) \\
\hline $\mathrm{K} 113$ & 12.70 & 2.34 & $7019.1966^{\prime} \mathrm{N}$ & 149 19.293’ W \\
\hline K113-SS1 & 34.52 & 6.56 & $7019.218^{\prime} \mathrm{N}$ & 149 18.948' W \\
\hline K113-SS2 & 37.08 & 9.12 & $7018.6688^{\prime} \mathrm{N}$ & 14918.831 ' W \\
\hline K113-SS3 & 36.50 & 7.08 & $7018.569^{\prime} \mathrm{N}$ & 149 20.369' W \\
\hline \multicolumn{5}{|c|}{ Lake K214P (surveyed 5/21/05) } \\
\hline $\begin{array}{c}\text { Snow Survey } \\
\text { ID }\end{array}$ & $\begin{array}{c}\text { Average } \\
\text { Depth, cm }\end{array}$ & SWE & $\begin{array}{c}\text { Latitude (WGS } \\
\text { 84) }\end{array}$ & Longitude (WGS 84) \\
\hline K214-SS6 & 17.44 & 5.91 & $7017.537^{\prime} \mathrm{N}$ & 149 55.133' W \\
\hline K214-SS7 & 29.09 & 6.66 & $7017.194^{\prime} \mathrm{N}$ & 149 55.723' W \\
\hline K214-SS8 & 32.54 & 7.75 & $7017.889^{\prime} \mathrm{N}$ & $14955.937^{\prime} \mathrm{W}$ \\
\hline \multicolumn{5}{|c|}{ Lake K209P (surveyed 5/16/05) } \\
\hline $\begin{array}{c}\text { Snow Survey } \\
\text { ID }\end{array}$ & $\begin{array}{c}\text { Average } \\
\text { Depth, } \mathbf{c m}\end{array}$ & SWE & $\begin{array}{c}\text { Latitude (WGS } \\
84 \text { ) }\end{array}$ & Longitude (WGS 84) \\
\hline K209-SS6 & 16.18 & 5.08 & $7014.128^{\prime} \mathrm{N}$ & $15021.237^{\prime} \mathrm{W}$ \\
\hline K209-SS4 & 32.80 & 8.00 & $7013.783^{\prime} \mathrm{N}$ & $15019.065^{\prime} \mathrm{W}$ \\
\hline K209-SS7 & 38.30 & 9.61 & $7014.305^{\prime} \mathrm{N}$ & 15022.122 ' W \\
\hline K209-SS8 & 28.26 & 7.29 & $7012.760^{\prime} \mathrm{N}$ & 15019.920 ' W \\
\hline \multicolumn{5}{|c|}{ Lake L9312P (surveyed 5/13/05) } \\
\hline $\begin{array}{c}\text { Snow Survey } \\
\text { ID }\end{array}$ & $\begin{array}{l}\text { Average } \\
\text { Depth, cm }\end{array}$ & SWE & $\begin{array}{l}\text { Latitude (WGS } \\
84)\end{array}$ & Longitude (WGS 84) \\
\hline L9312-SS5 & 6.18 & 2.02 & 7020.016 ' N & $15057.081^{\prime} \mathrm{W}$ \\
\hline L9312-SS6 & 26.74 & 7.70 & $7019.756^{\prime} \mathrm{N}$ & $15057.907{ }^{\prime} \mathrm{W}$ \\
\hline L9312-SS7 & 27.48 & 7.45 & $7019.753^{\prime} \mathrm{N}$ & 150 55.244' W \\
\hline L9312-SS8 & 27.78 & 3.78 & $7020.121^{\prime} \mathrm{N}$ & $15055.217^{\prime} \mathrm{W}$ \\
\hline \multicolumn{5}{|c|}{ Lake L9817P (surveyed 5/14/05) } \\
\hline $\begin{array}{c}\text { Snow Survey } \\
\text { ID }\end{array}$ & $\begin{array}{l}\text { Average } \\
\text { Depth, cm }\end{array}$ & SWE & $\begin{array}{l}\text { Latitude (WGS } \\
\text { 84) }\end{array}$ & Longitude (WGS 84) \\
\hline L9817-SS1 & 7.96 & 2.38 & 70 14.062' N & $15120.1600^{\prime} \mathrm{W}$ \\
\hline L9817-SS2 & 27.92 & 5.72 & $7014.165^{\prime} \mathrm{N}$ & 151 19.469' W \\
\hline L9817-SS3 & 22.46 & 5.12 & $7013.797^{\prime} \mathrm{N}$ & $15121.322^{\prime} \mathrm{W}$ \\
\hline L9817-SS4 & 32.54 & 6.87 & 7014.142 ' N & $15120.884^{\prime} \mathrm{W}$ \\
\hline
\end{tabular}




\section{APPENDIX I: WATER QUALITY PARAMETERS AT STATION LOCATIONS}

The following tables report the water-quality parameters measured in-situ at various depths in each of the sample lakes. The depths were normally half the distance between the bottom of lake ice and the lake bottom. These samples were collected during the Phase 1 portion of the North Slope Lakes project. Data collection methods changed during this season to sample profiles at most locations. Exceptions would include summer samples taken near shore during ice-free conditions. 


\begin{tabular}{|c|c|c|}
\hline Lake & Date & $\begin{array}{c}\text { Specific Conductance, } \\
\text { mS/cm }\end{array}$ \\
\hline \hline K113C & $2 / 26 / 0318: 00$ & 444 \\
\hline K113C & $5 / 14 / 0315: 00$ & 788 \\
\hline K113C & $7 / 24 / 039: 00$ & 177 \\
\hline K113C & $11 / 8 / 0317: 15$ & 134 \\
\hline K113C & $1 / 20 / 0412: 00$ & 247 \\
\hline K113C & $2 / 23 / 0420: 00$ & 1,120 \\
\hline K113C & $3 / 19 / 0413: 35$ & 1,251 \\
\hline K113C & $5 / 14 / 0420: 00$ & 1,330 \\
\hline & & 79 \\
\hline K203C & $2 / 13 / 0313: 30$ & 612 \\
\hline K203C & $2 / 25 / 0312: 30$ & 1,086 \\
\hline K203C & $5 / 13 / 0312: 00$ & 267 \\
\hline K203C & $8 / 5 / 0321: 30$ & 781 \\
\hline K203C & $1 / 16 / 0415: 45$ & 1,137 \\
\hline K203C & $2 / 24 / 0412: 45$ & 2,362 \\
\hline K203C & $5 / 12 / 0414: 00$ & \\
\hline & & 400 \\
\hline K209P & $12 / 14 / 0218: 00$ & 1,354 \\
\hline K209P & $2 / 26 / 0312: 00$ & 1,106 \\
\hline K209P & $5 / 15 / 0314: 30$ & 217 \\
\hline K209P & $7 / 28 / 0314: 30$ & 246 \\
\hline K209P & $8 / 6 / 0312: 00$ & 117 \\
\hline K209P & $11 / 8 / 0311: 00$ & 454 \\
\hline K209P & $1 / 19 / 0413: 30$ & 1,140 \\
\hline K209P & $2 / 26 / 0416: 30$ & 363 \\
\hline & & 672 \\
\hline K214P & $12 / 16 / 0210: 00$ & 1,103 \\
\hline K214P & $2 / 25 / 0315: 00$ & 227 \\
\hline K214P & $5 / 14 / 0310: 00$ & 294 \\
\hline K214P & $7 / 25 / 0315: 00$ & 526 \\
\hline K214P & $11 / 7 / 0316: 00$ & 1,384 \\
\hline K214P & $1 / 19 / 0412: 00$ & 2,462 \\
\hline K214P & $2 / 23 / 0413: 00$ & 4,073 \\
\hline K214P & $3 / 19 / 0415: 45$ & \\
\hline K214P & $5 / 12 / 048: 30$ & \\
\hline & & \\
\hline
\end{tabular}




\begin{tabular}{|c|c|c|}
\hline Lake & Date & Temperature, C \\
\hline K113C & $2 / 26 / 03$ 18:00 & 0.1 \\
\hline K113C & 5/14/03 15:00 & 0.7 \\
\hline K113C & 7/24/03 9:00 & 14.9 \\
\hline K113C & 11/8/03 17:15 & 0.9 \\
\hline K113C & 1/20/04 0:00 & 1.0 \\
\hline K113C & $2 / 23 / 0420: 00$ & 7.9 \\
\hline K113C & 3/19/04 13:35 & 0.7 \\
\hline K113C & 5/14/04 20:00 & 0.0 \\
\hline K203C & 2/13/03 13:30 & 0.5 \\
\hline K203C & $2 / 25 / 03 \quad 12: 30$ & 0.1 \\
\hline K203C & $5 / 13 / 0312: 00$ & 0.3 \\
\hline K203C & 8/5/03 21:30 & 7.8 \\
\hline K203C & $11 / 8 / 0315: 00$ & 0.4 \\
\hline K203C & $1 / 16 / 04 \quad 15: 45$ & 0.0 \\
\hline K203C & 2/24/04 12:45 & 0.8 \\
\hline K203C & 5/12/04 14:00 & 0.0 \\
\hline K209P & $12 / 14 / 0218: 00$ & 0.9 \\
\hline K209P & $2 / 26 / 0312: 00$ & 0.1 \\
\hline K209P & $5 / 15 / 03$ 14:30 & 0.1 \\
\hline K209P & $7 / 28 / 03$ 14:30 & 5.4 \\
\hline K209P & 8/6/03 0:00 & 7.6 \\
\hline K209P & 11/8/03 11:00 & 0.6 \\
\hline K209P & 1/19/04 13:30 & 0.3 \\
\hline K209P & $2 / 26 / 04$ 16:30 & 1.1 \\
\hline K214P & $12 / 16 / 02$ 10:00 & 0.9 \\
\hline K214P & $2 / 25 / 03$ 15:00 & 1.8 \\
\hline K214P & $5 / 14 / 0310: 00$ & 0.4 \\
\hline K214P & $7 / 25 / 03$ 15:00 & 12.5 \\
\hline K214P & 11/7/03 16:00 & 0.9 \\
\hline K214P & 1/19/04 0:00 & 0.1 \\
\hline K214P & 2/23/04 13:00 & 0.5 \\
\hline K214P & 3/19/04 15:45 & 1.4 \\
\hline K214P & $5 / 12 / 048: 30$ & 0.0 \\
\hline
\end{tabular}




\begin{tabular}{|l|c|c|c|}
\hline Lake & Date & $\begin{array}{c}\text { Alkalinity, } \\
\text { mg/L as } \\
\text { CaCO3 }\end{array}$ & $\begin{array}{c}\text { Turbidity, } \\
\text { NTU }\end{array}$ \\
\hline \hline K113C & $2 / 26 / 0318: 00$ & 194.8 & 6.26 \\
\hline K113C & $5 / 14 / 0315: 00$ & & \\
\hline K113C & $7 / 24 / 039: 00$ & 54.8 & 5.98 \\
\hline K113C & $11 / 8 / 0317: 15$ & & 0.33 \\
\hline K113C & $1 / 20 / 040: 00$ & 172.4 & 0.53 \\
\hline K113C & $2 / 23 / 0420: 00$ & & \\
\hline K113C & $3 / 19 / 0413: 35$ & 340.0 & 7.09 \\
\hline K113C & $5 / 14 / 0420: 00$ & 504.0 & 2.81 \\
\hline K113C & $1 / 19 / 05$ & 233 & \\
\hline K113C & $1 / 19 / 05$ & 233 & \\
\hline K113C & $3 / 16 / 05$ & 430 & \\
\hline K113C & $8 / 5 / 05$ & 53 & \\
\hline & & & \\
\hline K203C & $2 / 13 / 0313: 30$ & & \\
\hline K203C & $2 / 25 / 0312: 30$ & 406.5 & 1.35 \\
\hline K203C & $5 / 13 / 0312: 00$ & & \\
\hline K203C & $8 / 5 / 0321: 30$ & & \\
\hline K203C & $11 / 8 / 0315: 00$ & & 0.32 \\
\hline K203C & $1 / 16 / 0415: 45$ & 262.5 & 0.53 \\
\hline K203C & $2 / 24 / 0412: 45$ & & \\
\hline K203C & $5 / 12 / 0414: 00$ & 1081.0 & 27.10 \\
\hline & & & \\
\hline K209P & $12 / 14 / 0218: 00$ & & 4.04 \\
\hline K209P & $2 / 26 / 0312: 00$ & 218.5 & 25.01 \\
\hline K209P & $5 / 15 / 0314: 30$ & & \\
\hline K209P & $7 / 28 / 0314: 30$ & & \\
\hline K209P & $8 / 6 / 030: 00$ & & \\
\hline K209P & $11 / 8 / 0311: 00$ & & \\
\hline K209P & $1 / 19 / 0413: 30$ & 284.4 & 0.51 \\
\hline K209P & $2 / 26 / 0416: 30$ & 350.0 & \\
\hline K209P & $1 / 19 / 05$ & 380 & \\
\hline K209P & $1 / 19 / 05$ & 380 & \\
\hline & & & \\
\hline K214P & $12 / 16 / 0210: 00$ & & \\
\hline K214P & $2 / 25 / 0315: 00$ & 308.3 & \\
\hline K214P & $5 / 14 / 0310: 00$ & & \\
\hline K214P & $7 / 25 / 0315: 00$ & 82.8 & \\
\hline K214P & $11 / 7 / 0316: 00$ & & \\
\hline K214P & $1 / 19 / 040: 00$ & 219.6 & \\
\hline K214P & $2 / 23 / 0413: 00$ & & \\
\hline K214P & $3 / 19 / 0415: 45$ & 884.0 & \\
\hline K214P & $5 / 12 / 048: 30$ & 2147.0 & \\
\hline K214P & $1 / 18 / 05$ & 457 & \\
\hline K214P & $1 / 18 / 05$ & 452 & \\
\hline & & & \\
\hline
\end{tabular}




\begin{tabular}{|c|c|c|l|}
\hline & & & \\
\hline L9312P & $1 / 16 / 05$ & 48 & \\
\hline L9312P & $1 / 15 / 05$ & 45 & \\
\hline L9312P & $2 / 23 / 05$ & 73.6 & \\
\hline L9312P & $2 / 23 / 05$ & 72.4 & \\
\hline L9312P & $3 / 14 / 05$ & 57.6 & \\
\hline L9312P & $3 / 14 / 05$ & 57.2 & \\
\hline L9312P & $5 / 20 / 05$ & 62 & \\
\hline L9312P & $8 / 2 / 05$ & 22 & \\
\hline & & & \\
\hline L9817P & $1 / 15 / 05$ & 114 & \\
\hline L9817P & $1 / 15 / 05$ & 118 & \\
\hline L9817P & $2 / 22 / 05$ & 51.9 & \\
\hline L9817P & $3 / 13 / 05$ & 258 & \\
\hline
\end{tabular}




\begin{tabular}{|c|c|c|}
\hline Lake & DateTime (AST) & $\mathbf{p H}$ \\
\hline \hline K113C & $2 / 26 / 0318: 00$ & 8.67 \\
\hline K113C & $5 / 14 / 0315: 00$ & 6.47 \\
\hline K113C & $7 / 24 / 039: 00$ & 8.04 \\
\hline K113C & $2 / 23 / 0420: 00$ & 6.16 \\
\hline K113C & $3 / 19 / 0413: 35$ & 7.64 \\
\hline K113C & $5 / 14 / 0420: 00$ & 7.21 \\
\hline & & \\
\hline K203C & $2 / 13 / 0313: 30$ & 7.60 \\
\hline K203C & $2 / 25 / 0312: 30$ & 8.28 \\
\hline K203C & $5 / 13 / 0312: 00$ & 5.47 \\
\hline K203C & $8 / 5 / 0321: 30$ & 4.96 \\
\hline K203C & $1 / 16 / 0415: 45$ & 7.15 \\
\hline K203C & $2 / 24 / 0412: 45$ & 7.37 \\
\hline K203C & $5 / 12 / 0414: 00$ & 6.95 \\
\hline & & \\
\hline K209P & $12 / 14 / 0218: 00$ & 7.85 \\
\hline K209P & $2 / 26 / 0312: 00$ & 8.10 \\
\hline K209P & $5 / 15 / 0314: 30$ & 5.05 \\
\hline K209P & $7 / 28 / 0314: 30$ & 5.35 \\
\hline K209P & $8 / 6 / 030: 00$ & 5.24 \\
\hline K209P & $2 / 26 / 0416: 30$ & 7.45 \\
\hline & & \\
\hline K214P & $12 / 16 / 0210: 00$ & 7.96 \\
\hline K214P & $2 / 25 / 0315: 00$ & 8.02 \\
\hline K214P & $5 / 14 / 0310: 00$ & 6.44 \\
\hline K214P & $7 / 25 / 0315: 00$ & 8.27 \\
\hline K214P & $2 / 23 / 0413: 00$ & 7.41 \\
\hline K214P & $3 / 19 / 0415: 45$ & 7.45 \\
\hline K214P & $5 / 12 / 048: 30$ & 7.44 \\
\hline & & \\
\hline
\end{tabular}




\section{APPENDIX J: WINTER 2004 - 2005 WATER-QUALITY DATA}

The following tables report the water-quality data measured in-situ at various depths in each of the sample lakes. These samples were collected during the Phase 1 portion of the North Slope Lakes project. Data collection methods changed during this season to sample profiles at most locations. Exceptions would include summer samples taken near shore during ice-free conditions.

Table J-1. K113C winter 2004 - 2005 water-quality data. Table J-2. K209P winter 2004 - 2005 water-quality data. Table J-3. K214P winter 2004 - 2005 water-quality data. Table J-4. L9312P winter 2004 - 2005 water-quality data. Table J-5. L9817P winter 2004 - 2005 water-quality data. 
Table J-1. K113C winter 2004 - 2005 water-quality data.

\begin{tabular}{|c|c|c|c|c|c|c|c|}
\hline K113 & $12 / 8 / 2004$ 17:00 & & & & & & \\
\hline $\begin{array}{c}\text { Height } \\
\text { Above } \\
\text { Bottom }\end{array}$ & Sampling Elevation & $\mathrm{pH}$ & $\begin{array}{c}\mathrm{DO} \\
(\mathrm{mg} / \mathrm{L})\end{array}$ & $\begin{array}{l}\text { Temp } \\
\text { ( C ) }\end{array}$ & $\begin{array}{l}\text { Conductivity } \\
\text { (uS/cm) }\end{array}$ & $\begin{array}{c}\text { Specific } \\
\text { Conductance } \\
\text { (uS/cm) }\end{array}$ & $\begin{array}{c}\text { Turbidity } \\
\text { (NTU) }\end{array}$ \\
\hline 3.85 & 50.67 & 7.02 & 14.87 & 0.0 & 31.4 & 59.9 & -0.2 \\
\hline 2.85 & 49.67 & - & 15.14 & 0.4 & 48.6 & 91.6 & 0.2 \\
\hline 1.85 & 48.67 & 7.02 & 16.30 & 0.9 & 209.7 & 388.0 & 1.0 \\
\hline 0.85 & 47.67 & 7.02 & 17.46 & 1.3 & 215.7 & 394.5 & 1.9 \\
\hline 0 & 46.82 & 7.02 & 13.00 & 1.5 & 224.2 & 406.4 & 10.8 \\
\hline
\end{tabular}

\begin{tabular}{|c|c|c|c|c|c|c|c|}
\hline $\begin{array}{c}\text { K113 } \\
\begin{array}{c}\text { Height } \\
\text { Above } \\
\text { Bottom }\end{array}\end{array}$ & SamplingElevation & $\mathrm{pH}$ & $\begin{array}{c}\mathrm{DO} \\
(\mathrm{mg} / \mathrm{L})\end{array}$ & $\begin{array}{c}\text { Temp } \\
(\mathrm{C})\end{array}$ & $\begin{array}{c}\text { Conductivity } \\
\text { (uS/cm) }\end{array}$ & $\begin{array}{c}\text { Specific } \\
\text { Conductance } \\
\text { (uS/cm) }\end{array}$ & $\begin{array}{c}\text { Turbidity } \\
\text { (NTU) }\end{array}$ \\
\hline 1.8 & 48.19 & - & 9.38 & 0.3 & 327.8 & 620.6 & 0.5 \\
\hline 0.8 & 47.19 & - & 8.96 & 0.5 & 331.8 & 624.7 & 0.3 \\
\hline
\end{tabular}

\begin{tabular}{|c|c|c|c|c|c|c|c|}
\hline K113 & $3 / 16 / 200517: 29$ & & & & \\
\hline $\begin{array}{c}\text { Height Above } \\
\text { Bottom }\end{array}$ & SamplingElevation & $\mathrm{pH}$ & $\begin{array}{c}\text { DO } \\
(\mathrm{mg} / \mathrm{L})\end{array}$ & $\begin{array}{c}\text { Temp } \\
(\mathrm{C})\end{array}$ & $\begin{array}{c}\text { Conductivity } \\
\text { (uS/cm) }\end{array}$ & $\begin{array}{c}\text { Specific } \\
\text { Conductance } \\
\text { (uS/cm) }\end{array}$ & $\begin{array}{c}\text { Turbidity } \\
\text { (NTU) }\end{array}$ \\
\hline 1.65 & - & 7.07 & 1.32 & 0.47 & 1039 & 1955 & 2.6 \\
\hline 0.65 & - & 7.08 & 1.18 & 0.27 & 1117 & 2117 & 2.7 \\
\hline
\end{tabular}

\begin{tabular}{|c|c|c|c|c|c|c|c|}
\hline $\begin{array}{c}\text { K113 } \\
\begin{array}{c}\text { Height } \\
\text { Above } \\
\text { Bottom }\end{array}\end{array}$ & SamplingElevation & $\mathrm{pH}$ & $\begin{array}{c}\mathrm{DO} \\
(\mathrm{mg} / \mathrm{L})\end{array}$ & $\begin{array}{c}\text { Temp } \\
(\mathrm{C})\end{array}$ & $\begin{array}{c}\text { Conductivity } \\
\text { (uS/cm) }\end{array}$ & $\begin{array}{c}\text { Specific } \\
\text { Conductance } \\
\text { (uS/cm) }\end{array}$ & $\begin{array}{c}\text { Turbidity } \\
\text { (NTU) }\end{array}$ \\
\hline 1.2 & 51.99 & - & 8.92 & 0.3 & 318.4 & 603.0 & 0.7 \\
\hline
\end{tabular}

\begin{tabular}{|c|r|l|l|l|l|l|c|}
\hline K113 & $5 / 22 / 200516: 20$ & & & & & \\
\hline $\begin{array}{c}\text { Height } \\
\text { Above } \\
\text { Bottom }\end{array}$ & SamplingElevation & $\mathrm{pH}$ & $\begin{array}{c}\text { DO } \\
(\mathrm{mg} / \mathrm{L})\end{array}$ & $\begin{array}{c}\text { Temp } \\
(\mathrm{C})\end{array}$ & $\begin{array}{c}\text { Conductivity } \\
(\mathrm{uS} / \mathrm{cm})\end{array}$ & $\begin{array}{c}\text { Specific } \\
\text { Conductance } \\
\text { (uS/cm) }\end{array}$ & $\begin{array}{c}\text { Turbidity } \\
\text { (NTU) }\end{array}$ \\
\hline 0.0 & 46.66 & 6.96 & 6.7 & 0.35 & 920.4 & 1739.3 & - \\
\hline
\end{tabular}

\begin{tabular}{|c|c|c|c|c|c|c|c|}
\hline K113 & $8 / 5 / 200510: 35$ & & & & \\
\hline $\begin{array}{c}\text { Height Above } \\
\text { Bottom }\end{array}$ & SamplingElevation & $\mathrm{pH}$ & $\begin{array}{c}\text { DO } \\
(\mathrm{mg} / \mathrm{L})\end{array}$ & $\begin{array}{c}\text { Temp } \\
(\mathrm{C})\end{array}$ & $\begin{array}{c}\text { Conductivity } \\
(\mathrm{uS} / \mathrm{cm})\end{array}$ & $\begin{array}{c}\text { Specific } \\
\text { Conductance } \\
\text { (uS/cm) }\end{array}$ & $\begin{array}{c}\text { Turbidity } \\
\text { (NTU) }\end{array}$ \\
\hline 1 & 51.9 & 8.22 & 11.52 & 11.33 & 152.1 & 205.8 & 1.2 \\
\hline
\end{tabular}

\begin{tabular}{|c|c|c|c|c|c|c|c|}
\hline K113 & $8 / 5 / 200510: 39$ & & & & \\
\hline $\begin{array}{c}\text { Height Above } \\
\text { Bottom }\end{array}$ & SamplingElevation & $\mathrm{pH}$ & $\begin{array}{c}\text { DO } \\
(\mathrm{mg} / \mathrm{L})\end{array}$ & $\begin{array}{c}\text { Temp } \\
(\mathrm{C})\end{array}$ & $\begin{array}{c}\text { Conductivity } \\
\text { (uS/cm) }\end{array}$ & $\begin{array}{c}\text { Specific } \\
\text { Conductance } \\
\text { (uS/cm) }\end{array}$ & $\begin{array}{c}\text { Turbidity } \\
\text { (NTU) }\end{array}$ \\
\hline 1 & 51.9 & 8.26 & 11.48 & 11.31 & 151.8 & 205.5 & 1 \\
\hline
\end{tabular}




\begin{tabular}{|c|c|c|c|c|c|c|c|}
\hline K113 & $8 / 5 / 200510: 45$ & & & & \\
\hline $\begin{array}{c}\text { Height Above } \\
\text { Bottom }\end{array}$ & SamplingElevation & $\mathrm{pH}$ & $\begin{array}{c}\text { DO } \\
(\mathrm{mg} / \mathrm{L})\end{array}$ & $\begin{array}{c}\text { Temp } \\
(\mathrm{C})\end{array}$ & $\begin{array}{c}\text { Conductivity } \\
(\mathrm{uS} / \mathrm{cm})\end{array}$ & $\begin{array}{c}\text { Specific } \\
\text { Conductance } \\
\text { (uS/cm) }\end{array}$ & $\begin{array}{c}\text { Turbidity } \\
\text { (NTU) }\end{array}$ \\
\hline 1 & 51.9 & 8.27 & 11.49 & 11.33 & 151.9 & 205.6 & 1.5 \\
\hline
\end{tabular}

\begin{tabular}{|c|r|r|c|c|c|c|c|}
\hline K113 & $8 / 5 / 200512: 35$ & & & & \\
\hline $\begin{array}{c}\text { Height Above } \\
\text { Bottom }\end{array}$ & SamplingElevation & $\mathrm{pH}$ & $\begin{array}{c}\text { DO } \\
(\mathrm{mg} / \mathrm{L})\end{array}$ & $\begin{array}{c}\text { Temp } \\
\text { ( C })\end{array}$ & $\begin{array}{c}\text { Conductivity } \\
\text { (uS/cm) }\end{array}$ & $\begin{array}{c}\text { Specific } \\
\text { Conductance } \\
\text { (uS/cm) }\end{array}$ & $\begin{array}{c}\text { Turbidity } \\
\text { (NTU) }\end{array}$ \\
\hline 1 & 51.9 & - & - & 11.9 & 122.8 & 163.8 & - \\
\hline
\end{tabular}

\begin{tabular}{|c|c|c|c|c|c|c|c|}
\hline K113 & $8 / 5 / 200512: 41$ & & & & \\
\hline $\begin{array}{c}\text { Height Above } \\
\text { Bottom }\end{array}$ & SamplingElevation & $\mathrm{pH}$ & $\begin{array}{c}\text { DO } \\
(\mathrm{mg} / \mathrm{L})\end{array}$ & $\begin{array}{c}\text { Temp } \\
(\mathrm{C})\end{array}$ & $\begin{array}{c}\text { Conductivity } \\
\text { (uS/cm) }\end{array}$ & $\begin{array}{c}\text { Specific } \\
\text { Conductance } \\
\text { (uS/cm) }\end{array}$ & $\begin{array}{c}\text { Turbidity } \\
\text { (NTU) }\end{array}$ \\
\hline 1 & 51.9 & 8.23 & 11.38 & 11.62 & 152.9 & 205.4 & 4 \\
\hline
\end{tabular}

\begin{tabular}{|c|r|l|l|l|l|c|c|}
\hline K113 & $8 / 5 / 200512: 44$ & & & & & \\
\hline $\begin{array}{c}\text { Height Above } \\
\text { Bottom }\end{array}$ & SamplingElevation & $\mathrm{pH}$ & $\begin{array}{c}\text { DO } \\
(\mathrm{mg} / \mathrm{L})\end{array}$ & $\begin{array}{c}\text { Temp } \\
(\mathrm{C})\end{array}$ & $\begin{array}{c}\text { Conductivity } \\
\text { (uS/cm) }\end{array}$ & $\begin{array}{c}\text { Specific } \\
\text { Conductance } \\
\text { (uS/cm) }\end{array}$ & $\begin{array}{c}\text { Turbidity } \\
\text { (NTU) }\end{array}$ \\
\hline 1 & 51.9 & 7.82 & - & 11.7 & 138.1 & 185.1 & 8.6 \\
\hline
\end{tabular}

Table J-2. K209P winter 2004 - 2005 water-quality data.

\begin{tabular}{|c|c|c|c|c|c|c|c|}
\hline K209 & 12/9/2004 13:00 & & & & & & \\
\hline $\begin{array}{l}\text { Height } \\
\text { Above } \\
\text { Bottom }\end{array}$ & $\begin{array}{l}\text { Sampling } \\
\text { Elevation }\end{array}$ & $\mathrm{pH}$ & $\begin{array}{c}\mathrm{DO} \\
(\mathrm{mg} / \mathrm{L})\end{array}$ & $\begin{array}{l}\text { Temp } \\
\text { ( C ) }\end{array}$ & $\begin{array}{l}\text { Conductivity } \\
\text { (uS/cm) }\end{array}$ & $\begin{array}{c}\text { Specific } \\
\text { Conductance } \\
\text { (uS/cm) }\end{array}$ & $\begin{array}{c}\text { Turbidity } \\
\text { (NTU) }\end{array}$ \\
\hline 3.2 & 74.73 & 7.92 & 14.39 & 0.0 & 284.6 & 544.5 & 0.4 \\
\hline 2.2 & 73.73 & 7.80 & 14.32 & 0.6 & 277.1 & 519.9 & 0.3 \\
\hline 1.2 & 72.73 & 7.59 & 14.5 & 1.0 & 286.1 & 528.6 & 1.0 \\
\hline 0.2 & 71.73 & 7.48 & 14.5 & 1.2 & 314.8 & 578.2 & 3.5 \\
\hline
\end{tabular}

\begin{tabular}{|c|c|c|c|c|c|c|c|}
\hline K209 & $1 / 19 / 200513: 29$ & & & & \\
$\begin{array}{c}\text { Height } \\
\text { Above } \\
\text { Bottom }\end{array}$ & $\begin{array}{c}\text { Sampling } \\
\text { Elevation }\end{array}$ & $\mathrm{pH}$ & $\begin{array}{c}\text { DO } \\
(\mathrm{mg} / \mathrm{L})\end{array}$ & $\begin{array}{c}\text { Temp } \\
(\mathrm{C})\end{array}$ & $\begin{array}{c}\text { Conductivity } \\
\text { (uS/cm) }\end{array}$ & $\begin{array}{c}\text { Specific } \\
\text { Conductance } \\
\text { (uS/cm) }\end{array}$ & $\begin{array}{c}\text { Turbidity } \\
\text { (NTU) }\end{array}$ \\
\hline 1 & 72.58 & - & 7.2 & 0.3 & 519.9 & 984.6 & 2.2 \\
\hline 0.5 & 72.08 & - & 7.16 & 0.2 & 512.8 & 973.3 & 1.8 \\
\hline
\end{tabular}

\begin{tabular}{|c|c|c|c|c|c|c|c|}
\hline K209 & $1 / 19 / 200513: 44$ & & & & \\
\hline $\begin{array}{c}\text { Height } \\
\text { Above } \\
\text { Bottom }\end{array}$ & $\begin{array}{c}\text { Sampling } \\
\text { Elevation }\end{array}$ & $\mathrm{pH}$ & $\begin{array}{c}\text { DO } \\
(\mathrm{mg} / \mathrm{L})\end{array}$ & $\begin{array}{c}\text { Temp } \\
(\mathrm{C})\end{array}$ & $\begin{array}{c}\text { Conductivity } \\
\text { (uS/cm) }\end{array}$ & $\begin{array}{c}\text { Specific } \\
\text { Conductance } \\
\text { (uS/cm) }\end{array}$ & $\begin{array}{c}\text { Turbidity } \\
\text { (NTU) }\end{array}$ \\
\hline 0.5 & 72.58 & - & 8.33 & 0.1 & 528.5 & 1008.2 & 2.7 \\
\hline
\end{tabular}




\begin{tabular}{|c|c|c|c|c|c|c|c|}
\hline K209 & $\mathbf{5 / 2 2 / 2 0 0 5}$ & & & & & \\
\hline $\begin{array}{c}\text { Height } \\
\text { Above } \\
\text { Bottom }\end{array}$ & $\begin{array}{c}\text { Sampling } \\
\text { Elevation }\end{array}$ & $\mathrm{pH}$ & $\begin{array}{c}\text { DO } \\
(\mathrm{mg} / \mathrm{L})\end{array}$ & $\begin{array}{c}\text { Temp } \\
\text { ( C })\end{array}$ & $\begin{array}{c}\text { Conductivity } \\
\text { (uS/cm) }\end{array}$ & $\begin{array}{c}\text { Specific } \\
\text { Conductance } \\
\text { (uS/cm) }\end{array}$ & $\begin{array}{c}\text { Turbidity } \\
\text { (NTU) }\end{array}$ \\
\hline Lake frozen to the bottom & & & & & \\
\hline
\end{tabular}

Table J-3. K214P winter 2004 - 2005 water-quality data.

\begin{tabular}{|c|c|c|c|c|c|c|c|}
\hline \multirow{3}{*}{$\begin{array}{l}\text { Troll } \\
\text { K214 } \\
\text { Height } \\
\text { Above } \\
\text { Bottom }\end{array}$} & \multirow{3}{*}{$\begin{array}{c}\text { 12/3/2004 14:51 } \\
\text { Sampling } \\
\text { Elevation }\end{array}$} & \multirow[b]{3}{*}{$\mathrm{pH}$} & \multicolumn{3}{|c|}{\begin{tabular}{|l|l} 
Position: & \\
\end{tabular}} & \multirow[b]{3}{*}{$\begin{array}{c}\text { Specific } \\
\text { Conductance } \\
\text { (uS } / \mathrm{cm})\end{array}$} & \multirow[b]{3}{*}{$\begin{array}{c}\text { Turbidity } \\
\text { (NTU) }\end{array}$} \\
\hline & & & \multirow[b]{2}{*}{$\begin{array}{c}\mathrm{N} 70.534 \\
\mathrm{DO} \\
(\mathrm{mg} / \mathrm{L})\end{array}$} & \multicolumn{2}{|c|}{ W149 54.88} & & \\
\hline & & & & $\begin{array}{l}\text { Temp } \\
\text { ( C ) }\end{array}$ & $\begin{array}{l}\text { Conductivity } \\
\text { (uS/cm) }\end{array}$ & & \\
\hline 2.75 & 78.91 & 7.9 & 10.37 & 0.3 & 311.8 & 589.8 & 1.2 \\
\hline 0.75 & 76.91 & 7.6 & 8.02 & 1.5 & 315.4 & 572.1 & 2.4 \\
\hline-0.75 & 75.41 & 7.7 & 2.63 & 2.0 & 380.8 & 680.3 & 24.9 \\
\hline
\end{tabular}

\begin{tabular}{|c|c|c|c|c|c|c|c|}
\hline Hach & & \multicolumn{2}{|c|}{ Position: } & & \\
\hline K214 & $12 / 3 / 200414: 55$ & & N70.534 & W149 54.88 & & \\
\hline $\begin{array}{c}\text { Height } \\
\text { Above } \\
\text { Bottom }\end{array}$ & $\begin{array}{c}\text { Sampling } \\
\text { Elevation }\end{array}$ & $\mathrm{pH}$ & $\begin{array}{c}\text { DO } \\
(\mathrm{mg} / \mathrm{L})\end{array}$ & $\begin{array}{c}\text { Temp } \\
(\mathrm{C})\end{array}$ & $\begin{array}{c}\text { Conductivity } \\
\text { (uS/cm) }\end{array}$ & $\begin{array}{c}\text { Specific } \\
\text { Conductance } \\
\text { (uS/cm) }\end{array}$ & $\begin{array}{c}\text { Turbidity } \\
\text { (NTU) }\end{array}$ \\
\hline 2.75 & 78.91 & - & 13.10 & 0.5 & - & - & - \\
\hline 0.75 & 76.91 & - & 11.40 & 1.6 & - & - & - \\
\hline-0.75 & 75.41 & - & 0.26 & 2.3 & - & - & - \\
\hline
\end{tabular}

\begin{tabular}{|c|c|c|c|c|c|c|c|}
\hline Troll & & & Pos & & & & \\
\hline K214 & $1 / 18 / 200517: 10$ & & N70 17.53 & 14954. & & & \\
\hline $\begin{array}{c}\text { Height } \\
\text { Above } \\
\text { Bottom }\end{array}$ & $\begin{array}{l}\text { Sampling } \\
\text { Elevation }\end{array}$ & $\mathrm{pH}$ & $\begin{array}{c}\mathrm{DO} \\
(\mathrm{mg} / \mathrm{L})\end{array}$ & $\begin{array}{l}\text { Temp } \\
\text { ( C ) }\end{array}$ & $\begin{array}{l}\text { Conductivity } \\
\text { (uS/cm) }\end{array}$ & $\begin{array}{c}\text { Specific } \\
\text { Conductance } \\
\text { (uS } / \mathrm{cm})\end{array}$ & $\begin{array}{c}\text { Turbidity } \\
\text { (NTU) }\end{array}$ \\
\hline 1.4 & 73.35 & - & 6.08 & 0.3 & 565.1 & 1071.7 & -0.1 \\
\hline 0.4 & 72.35 & - & 6.19 & 0.4 & 567.8 & 1069.9 & -0.1 \\
\hline-0.1 & 71.85 & - & 5.06 & 0.5 & 567.9 & 1068.5 & - \\
\hline
\end{tabular}

\begin{tabular}{|c|c|c|c|c|c|c|c|}
\hline K214 & $1 / 18 / 200517: 25$ & & & & & \\
\hline $\begin{array}{c}\text { Height } \\
\text { Above } \\
\text { Bottom }\end{array}$ & $\begin{array}{c}\text { Sampling } \\
\text { Elevation }\end{array}$ & $\mathrm{pH}$ & $\begin{array}{c}\text { DO } \\
(\mathrm{mg} / \mathrm{L})\end{array}$ & $\begin{array}{c}\text { Temp } \\
(\mathrm{C})\end{array}$ & $\begin{array}{c}\text { Conductivity } \\
\text { (uS/cm) }\end{array}$ & $\begin{array}{c}\text { Specific } \\
\text { Conductance } \\
\text { (uS/cm) }\end{array}$ & $\begin{array}{c}\text { Turbidity } \\
\text { (NTU) }\end{array}$ \\
\hline 1.4 & $\mathbf{7 3 . 3 5}$ & 7.41 & 5.12 & -0.1 & 580 & 1114.1 & - \\
\hline 0.4 & $\mathbf{7 2 . 3 5}$ & 7.4 & 3.36 & -0.1 & 575.4 & 1103.7 & - \\
\hline-0.1 & $\mathbf{7 1 . 8 5}$ & 7.34 & 4.81 & 0.1 & 666.1 & 1272.0 & - \\
\hline
\end{tabular}

\begin{tabular}{|c|c|c|c|c|c|c|c|}
\hline Troll & & & & & \\
\hline K214 & $3 / 16 / 200511: 17$ & & & & & \\
\hline $\begin{array}{c}\text { Height } \\
\text { Above } \\
\text { Bottom }\end{array}$ & $\begin{array}{c}\text { Sampling } \\
\text { Elevation }\end{array}$ & $\mathrm{pH}$ & $\begin{array}{c}\text { DO } \\
(\mathrm{mg} / \mathrm{L})\end{array}$ & $\begin{array}{c}\text { Temp } \\
(\mathrm{C})\end{array}$ & $\begin{array}{c}\text { Conductivity } \\
\text { (uS/cm) }\end{array}$ & $\begin{array}{c}\text { Specific } \\
\text { Conductance } \\
\text { (uS/cm) }\end{array}$ & $\begin{array}{c}\text { Turbidity } \\
\text { (NTU) }\end{array}$ \\
\hline 0.25 & 76.10 & 7.08 & 0.56 & 0.1 & 5580 & 10648 & - \\
\hline
\end{tabular}


Table J-4. L9312P winter 2004 - 2005 water-quality data.

\begin{tabular}{|c|c|c|c|c|c|c|c|}
\hline Hach LDO & & & L9312A & & & & \\
\hline L9312- Hole \#1 & 12/5/2004 10:45 & & & & & & \\
\hline $\begin{array}{r}\text { Height } \\
\text { Above } \\
\text { Bottom }\end{array}$ & Sampling Elevation & $\mathrm{pH}$ & $\begin{array}{c}\mathrm{DO} \\
(\mathrm{mg} / \mathrm{L})\end{array}$ & $\begin{array}{l}\text { Temp } \\
\text { ( C ) }\end{array}$ & $\begin{array}{l}\text { Conductivity } \\
\text { (uS } / \mathrm{cm})\end{array}$ & $\begin{array}{c}\text { Conductance } \\
\text { (uS } / \mathrm{cm})\end{array}$ & $\begin{array}{c}\text { Turbidity } \\
\text { (NTU) }\end{array}$ \\
\hline 0.25 & 4.53 & - & 14.30 & 0.5 & - & - & - \\
\hline
\end{tabular}

\begin{tabular}{|c|c|c|c|c|c|c|c|}
\hline Troll & & & & & & & \\
\hline L9312- Hole \#1 & 12/5/2004 10:47 & & & & & & \\
\hline $\begin{array}{c}\text { Height } \\
\text { Above } \\
\text { Bottom }\end{array}$ & Sampling Elevation & $\mathrm{pH}$ & $\begin{array}{c}\mathrm{DO} \\
(\mathrm{mg} / \mathrm{L})\end{array}$ & $\begin{array}{l}\text { Temp } \\
\text { ( C ) }\end{array}$ & $\begin{array}{c}\text { Conductivity } \\
\text { (uS } / \mathrm{cm})\end{array}$ & $\begin{array}{l}\text { Conductance } \\
\text { (uS } / \mathrm{cm})\end{array}$ & $\begin{array}{c}\text { Turbidity } \\
\text { (NTU) }\end{array}$ \\
\hline 0.25 & -2.97 & 6.87 & - & 0.4 & 66.2 & 124.9 & 8.8 \\
\hline
\end{tabular}

\begin{tabular}{|c|c|c|c|c|c|c|c|}
\hline \multicolumn{8}{|l|}{ Troll } \\
\hline L9312 - Hole \#3 & $12 / 5 / 200411: 34$ & & & & & & \\
\hline $\begin{array}{l}\text { Height } \\
\text { Above } \\
\text { Bottom }\end{array}$ & $\begin{array}{l}\text { Sampling } \\
\text { Elevation }\end{array}$ & $\mathrm{pH}$ & $\begin{array}{c}\mathrm{DO} \\
(\mathrm{mg} / \mathrm{L})\end{array}$ & $\begin{array}{l}\text { Temp } \\
\text { ( C ) }\end{array}$ & $\begin{array}{l}\text { Conductivity } \\
\text { (uS } / \mathrm{cm})\end{array}$ & $\begin{array}{l}\text { Conductance } \\
\text { (uS } / \mathrm{cm})\end{array}$ & $\begin{array}{c}\text { Turbidity } \\
\text { (NTU) }\end{array}$ \\
\hline 3.50 & 3.70 & 7.14 & - & 0.1 & 62.9 & 119.9 & 2.8 \\
\hline 2.33 & 2.53 & 7.10 & - & 0.8 & 62.7 & 116.6 & 3.6 \\
\hline 1.33 & 1.53 & 7.03 & - & 1.1 & 62.3 & 114.7 & 4.5 \\
\hline 0.33 & 0.53 & 6.91 & - & 1.2 & 64.8 & 118.9 & 4.9 \\
\hline
\end{tabular}

\begin{tabular}{|c|c|c|c|c|c|c|c|}
\hline \multicolumn{8}{|l|}{ Hach LDO } \\
\hline L9312A - Hole \#3 & $12 / 5 / 200411: 35$ & & & & & & \\
\hline $\begin{array}{c}\text { Height } \\
\text { Above } \\
\text { Bottom }\end{array}$ & $\begin{array}{l}\text { Sampling } \\
\text { Elevation }\end{array}$ & $\mathrm{pH}$ & $\begin{array}{c}\mathrm{DO} \\
(\mathrm{mg} / \mathrm{L})\end{array}$ & $\begin{array}{l}\text { Temp } \\
\text { ( C ) }\end{array}$ & $\begin{array}{l}\text { Conductivity } \\
\text { (uS/cm) }\end{array}$ & $\begin{array}{c}\text { Conductance } \\
\text { (uS } / \mathrm{cm})\end{array}$ & $\begin{array}{c}\text { Turbidity } \\
\text { (NTU) }\end{array}$ \\
\hline 3.50 & 3.70 & - & 17.50 & 0.3 & - & - & - \\
\hline 2.33 & 2.53 & - & 16.00 & 1.0 & - & - & - \\
\hline 1.33 & 1.53 & - & 15.90 & 1.4 & - & - & - \\
\hline 0.33 & 0.53 & - & 15.90 & 1.6 & - & - & - \\
\hline
\end{tabular}

\begin{tabular}{|c|c|c|c|c|c|c|c|}
\hline $\begin{array}{c}\text { L9312 - Hole \#4(2) } \\
\begin{array}{c}\text { Height } \\
\text { Above } \\
\text { Bottom }\end{array}\end{array} \quad \begin{array}{c}\text { Sampling } \\
\text { Elevation }\end{array}$ & $\mathrm{pH}$ & $\begin{array}{c}\mathrm{DO} \\
(\mathrm{mg} / \mathrm{L})\end{array}$ & $\begin{array}{c}\text { Temp } \\
(\mathrm{C})\end{array}$ & $\begin{array}{c}\text { Conductivity } \\
\text { (uS/cm) }\end{array}$ & $\begin{array}{c}\text { Conductance } \\
\text { (uS/cm) }\end{array}$ & $\begin{array}{c}\text { Turbidity } \\
\text { (NTU) }\end{array}$ \\
\hline 5.5 & 3.78 & 7.35 & - & 0.5 & 53.0 & 99.6 & 2.9 \\
\hline 4.25 & 2.53 & 7.35 & - & 0.9 & 52.9 & 97.8 & 3.4 \\
\hline 3.25 & 1.53 & 7.35 & - & 1.3 & 52.7 & 96.2 & 3.8 \\
\hline 2.25 & 0.53 & 7.34 & - & 1.6 & 52.7 & 95.3 & 4.1 \\
\hline
\end{tabular}

\begin{tabular}{|c|c|c|c|c|c|c|c|}
\hline \multicolumn{8}{|l|}{ Hach LDO } \\
\hline L9312 - Hole \#4 & $12 / 5 / 200412: 37$ & & & & & & \\
\hline $\begin{array}{c}\text { Height } \\
\text { Above } \\
\text { Bottom }\end{array}$ & $\begin{array}{l}\text { Sampling } \\
\text { Elevation }\end{array}$ & $\mathrm{pH}$ & $\begin{array}{c}\mathrm{DO} \\
(\mathrm{mg} / \mathrm{L})\end{array}$ & $\begin{array}{c}\text { Temp } \\
\text { ( C ) }\end{array}$ & $\begin{array}{c}\text { Conductivity } \\
\text { (uS/cm) }\end{array}$ & $\begin{array}{c}\text { Conductance } \\
\text { (uS/cm) }\end{array}$ & $\begin{array}{c}\text { Turbidity } \\
\text { (NTU) }\end{array}$ \\
\hline 4.25 & 2.57 & - & 17.10 & 0.8 & - & - & - \\
\hline 3.25 & 1.57 & - & 16.60 & 1.2 & - & - & - \\
\hline 2.25 & 0.57 & - & 16.60 & 2.0 & - & - & - \\
\hline 1.25 & -0.43 & - & 16.70 & 2.5 & - & - & - \\
\hline
\end{tabular}




\begin{tabular}{|c|c|c|c|c|c|c|c|}
\hline Troll & 12/5/2004 17:00 & & & & \\
\hline $\begin{array}{c}\text { L9312-2 } \\
\begin{array}{c}\text { Height } \\
\text { Above }\end{array}\end{array}$ & $\begin{array}{c}\text { Sampling } \\
\text { Elevation }\end{array}$ & $\mathrm{pH}$ & $\begin{array}{c}\mathrm{DO} \\
(\mathrm{mg} / \mathrm{L})\end{array}$ & $\begin{array}{c}\text { Temp } \\
(\mathrm{C})\end{array}$ & $\begin{array}{c}\text { Conductivity } \\
\text { (uS/cm) }\end{array}$ & $\begin{array}{c}\text { Conductance } \\
\text { (uS/cm) }\end{array}$ & $\begin{array}{c}\text { Turbidity } \\
\text { (NTU) }\end{array}$ \\
\hline 7 & 0.53 & 7.48 & - & 0.1 & 49.8 & 95.1 & 0.9 \\
\hline 5.42 & 2.11 & 7.48 & - & 1.0 & 50.7 & 93.6 & 1.2 \\
\hline 4.42 & 3.11 & 7.48 & - & 1.3 & 50.8 & 92.8 & 1.3 \\
\hline 3.42 & 4.11 & 7.45 & - & 1.7 & 50.7 & 91.3 & 1.5 \\
\hline 2.42 & 5.11 & 7.41 & - & 2.0 & 50.7 & 90.4 & 1.7 \\
\hline 1.42 & 6.11 & 7.37 & - & 2.2 & 50.4 & 89.3 & 1.8 \\
\hline 0.42 & 7.11 & 7.08 & - & 2.5 & 49.2 & 86.3 & 1.7 \\
\hline
\end{tabular}

\begin{tabular}{|c|c|c|c|c|c|c|c|}
\hline \multicolumn{8}{|l|}{ Troll } \\
\hline L9312-6 & $12 / 5 / 200417: 45$ & & & & & & \\
\hline $\begin{array}{c}\text { Height } \\
\text { Above } \\
\text { Bottom }\end{array}$ & $\begin{array}{l}\text { Sampling } \\
\text { Elevation }\end{array}$ & $\mathrm{pH}$ & $\begin{array}{c}\mathrm{DO} \\
(\mathrm{mg} / \mathrm{L})\end{array}$ & $\begin{array}{l}\text { Temp } \\
\text { ( C ) }\end{array}$ & $\begin{array}{l}\text { Conductivity } \\
\text { (uS } / \mathrm{cm})\end{array}$ & $\begin{array}{c}\text { Conductance } \\
\text { (uS } / \mathrm{cm})\end{array}$ & $\begin{array}{c}\text { Turbidity } \\
\text { (NTU) }\end{array}$ \\
\hline- & 3.86 & 7.43 & - & 0.5 & 56.1 & 105.2 & 3.6 \\
\hline- & 2.53 & 7.46 & - & 1.0 & 53.2 & 98.3 & 3.5 \\
\hline- & 1.53 & 7.43 & - & 1.3 & 52.6 & 96.1 & 3.9 \\
\hline- & 0.53 & 7.41 & - & 1.6 & 52.4 & 94.7 & 4.0 \\
\hline- & -0.47 & 7.37 & - & 1.9 & 52.0 & 93.1 & 4.0 \\
\hline- & -1.47 & 7.20 & - & 2.1 & 51.7 & 91.9 & 4.0 \\
\hline- & -2.47 & 6.91 & - & 2.3 & 57.9 & 102.4 & 4.5 \\
\hline
\end{tabular}

\begin{tabular}{|c|c|c|c|c|c|c|c|}
\hline Hach LDO & & & & & & & \\
\hline L9312- Hole \#6 & $12 / 5 / 2004$ 18:13 & & & & & & \\
\hline $\begin{array}{c}\text { Height } \\
\text { Above } \\
\text { Bottom }\end{array}$ & Sampling Elevation & $\mathrm{pH}$ & $\begin{array}{c}\mathrm{DO} \\
(\mathrm{mg} / \mathrm{L})\end{array}$ & $\begin{array}{l}\text { Temp } \\
\text { ( C ) }\end{array}$ & $\begin{array}{l}\text { Conductivity } \\
\text { (uS/cm) }\end{array}$ & $\begin{array}{c}\text { Conductance } \\
\text { (uS } / \mathrm{cm})\end{array}$ & $\begin{array}{c}\text { Turbidity } \\
\text { (NTU) }\end{array}$ \\
\hline 0.75 & -2.47 & - & 14.70 & 2.7 & - & - & - \\
\hline
\end{tabular}

\begin{tabular}{|c|c|c|c|c|c|c|c|}
\hline Troll & & & & \multicolumn{2}{|c|}{ Position: } & & \\
\hline L9312B (Raft) & 12/5/2004 18:44 & & & N70 19.961 & W150 56.755 & & \\
\hline $\begin{array}{l}\text { Height } \\
\text { Above } \\
\text { Bottom }\end{array}$ & Sampling Elevation & $\mathrm{pH}$ & $\begin{array}{c}\mathrm{DO} \\
(\mathrm{mg} / \mathrm{L})\end{array}$ & $\begin{array}{l}\text { Temp } \\
\text { ( C ) }\end{array}$ & $\begin{array}{l}\text { Conductivity } \\
\text { (uS } / \mathrm{cm})\end{array}$ & $\begin{array}{c}\text { Conductance } \\
\text { (uS } / \mathrm{cm})\end{array}$ & $\begin{array}{c}\text { Turbidity } \\
\text { (NTU) }\end{array}$ \\
\hline 7.25 & 4.03 & 7.51 & - & 0.5 & 53.04 & 99.6 & 6.8 \\
\hline 5.75 & 2.53 & 7.49 & - & 1.1 & 51.21 & 94.3 & 4.1 \\
\hline 4.75 & 1.53 & 7.47 & - & 1.5 & 50.59 & 91.9 & 4.3 \\
\hline
\end{tabular}

\begin{tabular}{|c|c|c|c|c|c|c|c|}
\hline \multicolumn{8}{|l|}{ Hach LDO } \\
\hline L9312B - Hole \#2 & $12 / 5 / 200418: 44$ & & & & & & \\
\hline $\begin{array}{l}\text { Height } \\
\text { Above } \\
\text { Bottom }\end{array}$ & $\begin{array}{l}\text { Sampling } \\
\text { Elevation }\end{array}$ & $\mathrm{pH}$ & $\begin{array}{c}\mathrm{DO} \\
(\mathrm{mg} / \mathrm{L})\end{array}$ & $\begin{array}{l}\text { Temp } \\
\text { ( C ) }\end{array}$ & $\begin{array}{l}\text { Conductivity } \\
\text { (uS/cm) }\end{array}$ & $\begin{array}{c}\text { Conductance } \\
\text { (uS/cm) }\end{array}$ & $\begin{array}{c}\text { Turbidity } \\
\text { (NTU) }\end{array}$ \\
\hline 5.75 & 2.53 & - & 17.80 & 0.0 & - & - & - \\
\hline 4.75 & 1.53 & - & 17.70 & 0.2 & - & - & - \\
\hline
\end{tabular}




\begin{tabular}{|c|c|c|c|c|c|c|c|}
\hline Troll & & & & Po & sition: & & \\
\hline L9312 & 12/5/2004 19:15 & & L9312 A & N70 20.017 & W150 56.401 & & \\
\hline $\begin{array}{c}\text { Height } \\
\text { Above } \\
\text { Bottom }\end{array}$ & $\begin{array}{l}\text { Sampling } \\
\text { Elevation }\end{array}$ & $\mathrm{pH}$ & $\begin{array}{c}\mathrm{DO} \\
(\mathrm{mg} / \mathrm{L})\end{array}$ & $\begin{array}{l}\text { Temp } \\
\text { ( C ) }\end{array}$ & $\begin{array}{c}\text { Conductivity } \\
\text { (uS/cm) }\end{array}$ & $\begin{array}{c}\text { Conductance } \\
(\mathrm{uS} / \mathrm{cm})\end{array}$ & $\begin{array}{c}\text { Turbidity } \\
\text { (NTU) }\end{array}$ \\
\hline 6.5 & 4.03 & 7.53 & - & 0.5 & 52.19 & 98.1 & 5.9 \\
\hline 5 & 2.53 & 7.52 & - & 0.9 & 51.61 & 95.6 & 6.2 \\
\hline 4 & 1.53 & 7.51 & - & 1.3 & 51.61 & 94.2 & 6.3 \\
\hline 3 & 0.53 & 7.5 & - & 1.6 & 51.71 & 93.5 & 6.3 \\
\hline 2 & -0.47 & 7.45 & - & 1.9 & 51.39 & 92.1 & 6.3 \\
\hline 1 & -1.47 & 7.23 & - & 2.1 & 51.62 & 91.9 & 6.2 \\
\hline 0 & -2.47 & 6.94 & - & 2.3 & 64.01 & 113.1 & 7.8 \\
\hline
\end{tabular}

\begin{tabular}{|c|c|c|c|c|c|c|c|}
\hline \multicolumn{8}{|l|}{ Troll } \\
\hline L9312A & $12 / 5 / 200419: 26$ & & & & & & \\
\hline $\begin{array}{c}\text { Height } \\
\text { Above } \\
\text { Bottom }\end{array}$ & $\begin{array}{l}\text { Sampling } \\
\text { Elevation }\end{array}$ & $\mathrm{pH}$ & $\begin{array}{c}\mathrm{DO} \\
(\mathrm{mg} / \mathrm{L})\end{array}$ & $\begin{array}{l}\text { Temp } \\
\text { ( C ) }\end{array}$ & $\begin{array}{l}\text { Conductivity } \\
\text { (uS } / \mathrm{cm})\end{array}$ & $\begin{array}{l}\text { Conductance } \\
\text { (uS/cm) }\end{array}$ & $\begin{array}{c}\text { Turbidity } \\
\text { (NTU) }\end{array}$ \\
\hline 6.5 & 4.03 & 7.53 & - & 0.5 & 52.2 & 98.1 & 5.9 \\
\hline 5 & 2.53 & 7.52 & - & 0.9 & 51.6 & 95.6 & 6.2 \\
\hline 4 & 1.53 & 7.51 & - & 1.3 & 51.6 & 94.2 & 6.3 \\
\hline 3 & 0.53 & 7.50 & - & 1.6 & 51.7 & 93.5 & 6.3 \\
\hline 2 & -0.47 & 7.45 & - & 1.9 & 51.4 & 92.1 & 6.3 \\
\hline 1 & -1.47 & 7.23 & - & 2.1 & 51.6 & 91.9 & 6.2 \\
\hline 0 & -2.47 & 6.94 & - & 2.3 & 64.0 & 113.1 & 7.8 \\
\hline
\end{tabular}

\begin{tabular}{|c|c|c|c|c|c|c|c|}
\hline Hydrolab Quanta & & & & & \\
\hline $\begin{array}{c}\text { L9312A1- Trial1 } \\
\text { Height }\end{array}$ & $1 / 16 / 200514: 00$ & & & & & \\
\hline $\begin{array}{c}\text { Above } \\
\text { Bottom }\end{array}$ & Sampling Elevation & $\mathrm{pH}$ & $\begin{array}{c}\mathrm{DO} \\
(\mathrm{mg} / \mathrm{L})\end{array}$ & $\begin{array}{c}\text { Temp } \\
(\mathrm{C})\end{array}$ & $\begin{array}{c}\text { Conductivity } \\
\text { (uS/cm) }\end{array}$ & $\begin{array}{c}\text { Conductance } \\
\text { (uS/cm) }\end{array}$ & $\begin{array}{c}\text { Turbidity } \\
(\mathrm{NTU})\end{array}$ \\
\hline 4.95 & 2.53 & 7.08 & 14.34 & 0.1 & - & 126.0 & - \\
\hline 2.95 & 0.53 & 6.96 & 14.10 & 0.9 & - & 122.0 & - \\
\hline 0.95 & -1.47 & 6.55 & 10.50 & 1.4 & - & 134.0 & - \\
\hline
\end{tabular}

\begin{tabular}{|c|c|c|c|c|c|c|c|}
\hline Hydrolab Quanta & & & & & & & \\
\hline L9312A1- Trial2 & $1 / 16 / 200514: 00$ & & & & & & \\
\hline $\begin{array}{c}\text { Height } \\
\text { Above } \\
\text { Bottom }\end{array}$ & Sampling Elevation & $\mathrm{pH}$ & $\begin{array}{c}\mathrm{DO} \\
(\mathrm{mg} / \mathrm{L})\end{array}$ & $\begin{array}{l}\text { Temp } \\
\text { ( C ) }\end{array}$ & $\begin{array}{l}\text { Conductivity } \\
\text { (uS } / \mathrm{cm})\end{array}$ & $\begin{array}{c}\text { Conductance } \\
\text { (uS } / \mathrm{cm})\end{array}$ & $\begin{array}{c}\text { Turbidity } \\
\text { (NTU) }\end{array}$ \\
\hline 4.95 & 2.53 & 6.85 & 14.27 & 0.1 & - & 125.0 & - \\
\hline 2.95 & 0.53 & 6.87 & 14.13 & 0.9 & - & 121.0 & - \\
\hline 0.95 & -1.47 & 6.48 & 9.80 & 1.4 & - & 129.0 & - \\
\hline
\end{tabular}

\begin{tabular}{|c|c|c|c|c|c|c|c|}
\hline Hydrolab Quanta & & & & & & & \\
\hline L9312B2 - Trial1 & $1 / 16 / 200514: 00$ & & & & & & \\
\hline $\begin{array}{l}\text { Height } \\
\text { Above } \\
\text { Bottom }\end{array}$ & Sampling Elevation & $\mathrm{pH}$ & $\begin{array}{c}\mathrm{DO} \\
(\mathrm{mg} / \mathrm{L})\end{array}$ & $\begin{array}{l}\text { Temp } \\
\text { ( C ) }\end{array}$ & $\begin{array}{l}\text { Conductivity } \\
\text { (uS } / \mathrm{cm})\end{array}$ & $\begin{array}{l}\text { Conductance } \\
\text { (uS/cm) }\end{array}$ & $\begin{array}{c}\text { Turbidity } \\
\text { (NTU) }\end{array}$ \\
\hline 6.05 & 3.63 & 6.86 & 14.41 & 0.2 & - & 119.0 & - \\
\hline 3.05 & 0.63 & 6.86 & 14.20 & 1.3 & - & 115.0 & - \\
\hline 1.05 & -1.37 & 6.54 & 6.24 & 1.8 & - & 121.0 & - \\
\hline
\end{tabular}




\begin{tabular}{|c|c|c|c|c|c|c|c|}
\hline Hydrolab Quanta & & & & & & & \\
\hline L9312B2 - Trial2 & $1 / 16 / 200514: 00$ & & & & & & \\
\hline $\begin{array}{c}\text { Height } \\
\text { Above } \\
\text { Bottom }\end{array}$ & Sampling Elevation & $\mathrm{pH}$ & $\begin{array}{c}\mathrm{DO} \\
(\mathrm{mg} / \mathrm{L})\end{array}$ & $\begin{array}{c}\text { Temp } \\
\text { ( C ) }\end{array}$ & $\begin{array}{l}\text { Conductivity } \\
\text { (uS/cm) }\end{array}$ & $\begin{array}{c}\text { Conductance } \\
\text { (uS/cm) }\end{array}$ & $\begin{array}{c}\text { Turbidity } \\
\text { (NTU) }\end{array}$ \\
\hline 6.05 & 3.63 & - & 14.50 & 0.2 & - & 119.0 & - \\
\hline 3.05 & 0.63 & - & 13.90 & 1.2 & - & 116.0 & - \\
\hline 1.05 & -1.37 & - & 6.49 & 1.8 & - & 121.0 & - \\
\hline
\end{tabular}

\begin{tabular}{|c|c|c|c|c|c|c|c|}
\hline Hydrolab Quanta & & & & & & & \\
\hline L9312B2 - Trial3 & $1 / 16 / 200514: 00$ & & & & & & \\
\hline $\begin{array}{l}\text { Height } \\
\text { Above } \\
\text { Bottom }\end{array}$ & Sampling Elevation & $\mathrm{pH}$ & $\begin{array}{c}\mathrm{DO} \\
(\mathrm{mg} / \mathrm{L})\end{array}$ & $\begin{array}{l}\text { Temp } \\
\text { ( C ) }\end{array}$ & $\begin{array}{l}\text { Conductivity } \\
\text { (uS } / \mathrm{cm})\end{array}$ & $\begin{array}{c}\text { Conductance } \\
\text { (uS } / \mathrm{cm})\end{array}$ & $\begin{array}{c}\text { Turbidity } \\
\text { (NTU) }\end{array}$ \\
\hline 6.05 & 3.63 & 6.81 & 13.70 & 0.4 & - & 118.0 & - \\
\hline 3.05 & 0.63 & 6.83 & 13.90 & 1.3 & - & 115.0 & - \\
\hline 1.05 & -1.37 & 6.59 & 4.00 & 1.8 & - & 121.0 & - \\
\hline
\end{tabular}

\begin{tabular}{|c|c|c|c|c|c|c|c|}
\hline \multicolumn{8}{|l|}{ Hach LDO } \\
\hline L9312B2 - Trial1 & $1 / 16 / 200514: 00$ & & & & & & \\
\hline $\begin{array}{c}\text { Height } \\
\text { Above } \\
\text { Bottom }\end{array}$ & Sampling Elevation & $\mathrm{pH}$ & $\begin{array}{c}\mathrm{DO} \\
(\mathrm{mg} / \mathrm{L})\end{array}$ & $\begin{array}{c}\text { Temp } \\
\text { ( C ) }\end{array}$ & $\begin{array}{l}\text { Conductivity } \\
\text { (uS/cm) }\end{array}$ & $\begin{array}{l}\text { Conductance } \\
\text { (uS/cm) }\end{array}$ & $\begin{array}{c}\text { Turbidity } \\
\text { (NTU) }\end{array}$ \\
\hline 6.05 & 3.63 & - & 18.70 & 0.5 & - & - & - \\
\hline 3.05 & 0.63 & - & 18.60 & 1.0 & - & - & - \\
\hline 1.05 & -1.37 & - & 9.22 & 1.8 & - & - & - \\
\hline
\end{tabular}

\begin{tabular}{|c|c|c|c|c|c|c|c|}
\hline \\
\hline L9312B2 - Trial2 & 1/16/2005 14:00 & & & & & & \\
\hline $\begin{array}{c}\text { Height } \\
\text { Above } \\
\text { Bottom }\end{array}$ & Sampling Elevation & $\mathrm{pH}$ & $\begin{array}{c}\mathrm{DO} \\
(\mathrm{mg} / \mathrm{L})\end{array}$ & $\begin{array}{l}\text { Temp } \\
\text { ( C ) }\end{array}$ & $\begin{array}{l}\text { Conductivity } \\
\text { (uS/cm) }\end{array}$ & $\begin{array}{c}\text { Conductance } \\
\text { (uS/cm) }\end{array}$ & $\begin{array}{c}\text { Turbidity } \\
\text { (NTU) }\end{array}$ \\
\hline 6.05 & 3.63 & - & 18.60 & 0.2 & - & - & - \\
\hline 3.05 & 0.63 & - & 18.60 & 0.8 & - & - & - \\
\hline 1.05 & -1.37 & - & 13.20 & 1.8 & - & - & - \\
\hline
\end{tabular}

\begin{tabular}{|c|c|c|c|c|c|c|c|}
\hline Hach LDO & & & & & & & \\
\hline L9312B2 - Trial3 & 1/16/2005 14:00 & & & & & & \\
\hline $\begin{array}{l}\text { Height } \\
\text { Above } \\
\text { Bottom }\end{array}$ & Sampling Elevation & $\mathrm{pH}$ & $\begin{array}{c}\mathrm{DO} \\
(\mathrm{mg} / \mathrm{L})\end{array}$ & $\begin{array}{l}\text { Temp } \\
\text { ( C ) }\end{array}$ & $\begin{array}{l}\text { Conductivity } \\
\text { (uS } / \mathrm{cm})\end{array}$ & $\begin{array}{c}\text { Conductance } \\
\text { (uS } / \mathrm{cm})\end{array}$ & $\begin{array}{c}\text { Turbidity } \\
\text { (NTU) }\end{array}$ \\
\hline 6.05 & 3.63 & - & 18.60 & 0.2 & - & - & - \\
\hline 3.05 & 0.63 & - & - & 0.9 & - & - & - \\
\hline 1.05 & -1.37 & - & - & - & - & - & - \\
\hline
\end{tabular}

\begin{tabular}{|c|c|c|c|c|c|c|c|}
\hline Troll & & & & & \\
\hline $\begin{array}{c}\text { L9312B3 - Trial1 } \\
\begin{array}{c}\text { Height } \\
\text { Above } \\
\text { Bottom }\end{array}\end{array}$ & Sampling Elevation & $\mathrm{pH}$ & $\begin{array}{c}\mathrm{DO} \\
(\mathrm{mg} / \mathrm{L})\end{array}$ & $\begin{array}{c}\text { Temp } \\
(\mathrm{C})\end{array}$ & $\begin{array}{c}\text { Conductivity } \\
(\mathrm{uS} / \mathrm{cm})\end{array}$ & $\begin{array}{c}\text { Conductance } \\
(\mathrm{uS} / \mathrm{cm})\end{array}$ & $\begin{array}{c}\text { Turbidity } \\
(\mathrm{NTU})\end{array}$ \\
\hline 6.05 & 3.63 & - & 16.03 & 0.6 & 79.05 & - & -0.3 \\
\hline 3.05 & 0.63 & - & 17.06 & 1.5 & 78.22 & - & -0.1 \\
\hline 1.05 & -1.37 & - & 7.29 & 2.4 & 79.91 & - & 1.3 \\
\hline
\end{tabular}




\begin{tabular}{|c|c|c|c|c|c|c|c|}
\hline \begin{tabular}{|l|l|l|} 
Troll \\
L9312B3 - Trial2
\end{tabular} & $1 / 16 / 200514: 00$ & & & & & \\
\hline $\begin{array}{c}\text { Height } \\
\text { Above } \\
\text { Bottom }\end{array}$ & Sampling Elevation & $\mathrm{pH}$ & $\begin{array}{c}\mathrm{DO} \\
(\mathrm{mg} / \mathrm{L})\end{array}$ & $\begin{array}{c}\text { Temp } \\
(\mathrm{C})\end{array}$ & $\begin{array}{c}\text { Conductivity } \\
(\mathrm{uS} / \mathrm{cm})\end{array}$ & $\begin{array}{c}\text { Conductance } \\
(\mathrm{uS} / \mathrm{cm})\end{array}$ & $\begin{array}{c}\text { Turbidity } \\
(\mathrm{NTU})\end{array}$ \\
\hline 6.05 & 3.63 & - & 12.19 & 0.8 & 79.02 & - & -0.1 \\
\hline 3.05 & 0.63 & - & 14.79 & 1.5 & 78.59 & - & 0.1 \\
\hline 1.05 & -1.37 & - & 7.48 & 2.4 & 80.41 & - & 1.8 \\
\hline
\end{tabular}

\begin{tabular}{|c|c|c|c|c|c|c|c|}
\hline \multicolumn{8}{|l|}{ Troll } \\
\hline L9312B3 - Trial3 & 1/16/2005 14:00 & & & & & & \\
\hline $\begin{array}{l}\text { Height } \\
\text { Above } \\
\text { Bottom }\end{array}$ & Sampling Elevation & $\mathrm{pH}$ & $\begin{array}{c}\mathrm{DO} \\
(\mathrm{mg} / \mathrm{L})\end{array}$ & $\begin{array}{l}\text { Temp } \\
\text { ( C ) }\end{array}$ & $\begin{array}{c}\text { Conductivity } \\
\text { (uS } / \mathrm{cm})\end{array}$ & $\begin{array}{l}\text { Conductance } \\
\text { (uS } / \mathrm{cm})\end{array}$ & $\begin{array}{c}\text { Turbidity } \\
\text { (NTU) }\end{array}$ \\
\hline 6.05 & 3.63 & - & 13.64 & 0.7 & 79.62 & - & 0.7 \\
\hline 3.05 & 0.63 & - & 15.74 & 1.6 & 77.12 & - & 1.3 \\
\hline 1.05 & -1.37 & - & 4.06 & 2.5 & 80.6 & - & - \\
\hline
\end{tabular}

\begin{tabular}{|c|c|c|c|c|c|c|c|}
\hline Hydrolab Datasonde & & & & & \\
\hline $\begin{array}{c}\text { L9312B- Trial1 } \\
\text { Height }\end{array}$ & $1 / 16 / 200515: 30$ & & & & & \\
$\begin{array}{c}\text { Above } \\
\text { Bottom }\end{array}$ & Sampling Elevation & $\mathrm{pH}$ & $\begin{array}{c}\mathrm{DO} \\
(\mathrm{mg} / \mathrm{L})\end{array}$ & $\begin{array}{c}\text { Temp } \\
(\mathrm{C})\end{array}$ & $\begin{array}{c}\text { Conductivity } \\
\text { (uS/cm) }\end{array}$ & $\begin{array}{c}\text { Conductance } \\
\text { (uS/cm) }\end{array}$ & $\begin{array}{c}\text { Turbidity } \\
\text { (NTU) }\end{array}$ \\
\hline 6.05 & 3.63 & 7.45 & 17.28 & 0.7 & 90.6 & 169.0 & - \\
\hline 3.05 & 0.63 & 7.45 & 15.18 & 1.9 & 87.0 & 155.8 & - \\
\hline 1.05 & -1.37 & 7.45 & 2.30 & 2.3 & 91.1 & 160.8 & - \\
\hline
\end{tabular}

\begin{tabular}{|c|c|c|c|c|c|c|c|}
\hline Hydrolab Datasonde & & & & & & & \\
\hline L9312B- Trial2 & $1 / 16 / 2005$ 15:30 & & & & & & \\
\hline $\begin{array}{c}\text { Height } \\
\text { Above } \\
\text { Bottom }\end{array}$ & Sampling Elevation & $\mathrm{pH}$ & $\begin{array}{c}\mathrm{DO} \\
(\mathrm{mg} / \mathrm{L})\end{array}$ & $\begin{array}{l}\text { Temp } \\
\text { ( C ) }\end{array}$ & $\begin{array}{l}\text { Conductivity } \\
\text { (uS } / \mathrm{cm})\end{array}$ & $\begin{array}{c}\text { Conductance } \\
\text { (uS } / \mathrm{cm})\end{array}$ & $\begin{array}{c}\text { Turbidity } \\
\text { (NTU) }\end{array}$ \\
\hline 6.05 & 3.63 & 7.39 & 17.28 & 0.7 & 90.6 & 169.0 & - \\
\hline 3.05 & 0.63 & 7.43 & 15.18 & 1.9 & 87 & 155.8 & - \\
\hline 1.05 & -1.37 & 7.46 & 5.55 & 2.3 & 91.1 & 160.8 & - \\
\hline
\end{tabular}

\begin{tabular}{|c|c|c|c|c|c|c|c|}
\hline Hydrolab Datasonde & & & & & \\
\hline $\begin{array}{c}\text { L9312B- Trial3 } \\
\text { Height }\end{array}$ & $1 / 16 / 200515: 30$ & & & & & \\
\hline $\begin{array}{c}\text { Above } \\
\text { Bottom }\end{array}$ & Sampling Elevation & $\mathrm{pH}$ & $\begin{array}{c}\mathrm{DO} \\
(\mathrm{mg} / \mathrm{L})\end{array}$ & $\begin{array}{c}\text { Temp } \\
(\mathrm{C})\end{array}$ & $\begin{array}{c}\text { Conductivity } \\
\text { (uS/cm) }\end{array}$ & $\begin{array}{c}\text { Conductance } \\
\text { (uS/cm) }\end{array}$ & $\begin{array}{c}\text { Turbidity } \\
\text { (NTU) }\end{array}$ \\
\hline 6.05 & 3.63 & 7.41 & 15.3 & 0.7 & 91.3 & 170.4 & - \\
\hline 3.05 & 0.63 & 7.46 & 16.8 & 1.6 & 88.6 & 160.4 & - \\
\hline 1.05 & -1.37 & 7.49 & 7.41 & 2.2 & 91.6 & 162.1 & - \\
\hline
\end{tabular}

\begin{tabular}{|c|c|c|c|c|c|c|c|}
\hline Hydrolab Datasonde & & & & & & & \\
\hline L9312A2 - Trial1 & 1/16/2005 17:20 & & & & & & \\
\hline $\begin{array}{c}\text { Height } \\
\text { Above } \\
\text { Bottom }\end{array}$ & Sampling Elevation & $\mathrm{pH}$ & $\begin{array}{c}\mathrm{DO} \\
(\mathrm{mg} / \mathrm{L})\end{array}$ & $\begin{array}{l}\text { Temp } \\
\text { ( C ) }\end{array}$ & $\begin{array}{l}\text { Conductivity } \\
\text { (uS } / \mathrm{cm})\end{array}$ & $\begin{array}{c}\text { Conductance } \\
\text { (uS } / \mathrm{cm})\end{array}$ & $\begin{array}{c}\text { Turbidity } \\
\text { (NTU) }\end{array}$ \\
\hline 6.05 & 3.63 & 7.52 & 15.93 & 0.7 & 96.8 & 181.0 & - \\
\hline 3.05 & 0.63 & 7.49 & 16.83 & 1.4 & 95.2 & 173.1 & - \\
\hline 1.05 & -1.37 & 7.53 & 13.54 & 1.7 & 102.1 & 184.2 & - \\
\hline
\end{tabular}




\begin{tabular}{|c|c|c|c|c|c|c|c|}
\hline Hydrolab Datasonde & & & & & \\
\hline $\begin{array}{c}\text { L9312A2 - Trial2 } \\
\text { Height }\end{array}$ & $1 / 16 / 200517: 38$ & & & & & \\
\hline $\begin{array}{c}\text { Above } \\
\text { Bottom }\end{array}$ & Sampling Elevation & $\mathrm{pH}$ & $\begin{array}{c}\mathrm{DO} \\
(\mathrm{mg} / \mathrm{L})\end{array}$ & $\begin{array}{c}\text { Temp } \\
(\mathrm{C})\end{array}$ & $\begin{array}{c}\text { Conductivity } \\
(\mathrm{uS} / \mathrm{cm})\end{array}$ & $\begin{array}{c}\text { Conductance } \\
\text { (uS/cm) }\end{array}$ & $\begin{array}{c}\text { Turbidity } \\
(\mathrm{NTU})\end{array}$ \\
\hline 6.05 & 3.63 & 7.48 & 16.36 & 0.6 & 98.2 & 184.0 & - \\
\hline 3.05 & 0.63 & 7.54 & 17.31 & 1.3 & 96 & 175.3 & - \\
\hline 1.05 & -1.37 & 7.57 & 12.51 & 1.7 & 102 & 183.9 & - \\
\hline
\end{tabular}

\begin{tabular}{|c|c|c|c|c|c|c|c|}
\hline Hydrolab Datasonde & & & & & \\
\hline $\begin{array}{c}\text { L9312A2 - Trial3 } \\
\text { Height }\end{array}$ & $1 / 16 / 200518: 05$ & & & & & \\
\hline $\begin{array}{c}\text { Above } \\
\text { Bottom }\end{array}$ & Sampling Elevation & $\mathrm{pH}$ & $\begin{array}{c}\mathrm{DO} \\
(\mathrm{mg} / \mathrm{L})\end{array}$ & $\begin{array}{c}\text { Temp } \\
(\mathrm{C})\end{array}$ & $\begin{array}{c}\text { Conductivity } \\
\text { (uS/cm) }\end{array}$ & $\begin{array}{c}\text { Conductance } \\
\text { (uS/cm) }\end{array}$ & $\begin{array}{c}\text { Turbidity } \\
(\mathrm{NTU})\end{array}$ \\
\hline 6.05 & 3.63 & 7.52 & 16.53 & 0.6 & 97.2 & 182.0 & - \\
\hline 3.05 & 0.63 & 7.55 & 17.14 & 1.4 & 94.6 & 172.0 & - \\
\hline 1.05 & -1.37 & 7.6 & 16.63 & 1.7 & 100.4 & 181.2 & - \\
\hline
\end{tabular}

\begin{tabular}{|c|c|c|c|c|c|c|c|}
\hline Troll & & & & & & & \\
\hline L9312A - Trial1 & 1/16/2005 18:12 & & & & & & \\
\hline $\begin{array}{l}\text { Height } \\
\text { Above } \\
\text { Bottom }\end{array}$ & Sampling Elevation & $\mathrm{pH}$ & $\begin{array}{c}\mathrm{DO} \\
(\mathrm{mg} / \mathrm{L})\end{array}$ & $\begin{array}{l}\text { Temp } \\
\text { ( C ) }\end{array}$ & $\begin{array}{l}\text { Conductivity } \\
\text { (uS } / \mathrm{cm})\end{array}$ & $\begin{array}{c}\text { Conductance } \\
\text { (uS } / \mathrm{cm})\end{array}$ & $\begin{array}{c}\text { Turbidity } \\
\text { (NTU) }\end{array}$ \\
\hline 4.95 & 2.53 & - & 13.22 & 0.1 & 78.97 & 150.8 & -0.4 \\
\hline 2.95 & 0.53 & - & 13.80 & 0.4 & 78.76 & 148.6 & -0.4 \\
\hline 0.95 & -1.47 & - & 13.76 & 1.8 & 83.38 & 149.8 & 0.8 \\
\hline
\end{tabular}

\begin{tabular}{|c|c|c|c|c|c|c|c|}
\hline Troll & & & & & \\
\hline $\begin{array}{c}\text { L9312A - Trial2 } \\
\text { Height }\end{array}$ & $1 / 16 / 200518: 25$ & & & & & \\
\hline $\begin{array}{c}\text { Above } \\
\text { Bottom }\end{array}$ & Sampling Elevation & $\mathrm{pH}$ & $\begin{array}{c}\mathrm{DO} \\
(\mathrm{mg} / \mathrm{L})\end{array}$ & $\begin{array}{c}\text { Temp } \\
(\mathrm{C})\end{array}$ & $\begin{array}{c}\text { Conductivity } \\
\text { (uS/cm) }\end{array}$ & $\begin{array}{c}\text { Conductance } \\
\text { (uS/cm) }\end{array}$ & $\begin{array}{c}\text { Turbidity } \\
(\mathrm{NTU})\end{array}$ \\
\hline 4.95 & 2.53 & - & 17.18 & 0.6 & 82.1 & 153.8 & -0.1 \\
\hline 2.95 & 0.53 & - & 17.53 & 1.5 & 81.23 & 147.2 & 0.3 \\
\hline 0.95 & -1.47 & - & 15.37 & 1.9 & 84.69 & 151.8 & 1.5 \\
\hline
\end{tabular}

\begin{tabular}{|c|c|c|c|c|c|c|c|}
\hline Troll & & & & & & & \\
\hline L9312A - Trial3 & 1/16/2005 18:38 & & & & & & \\
\hline $\begin{array}{l}\text { Height } \\
\text { Above } \\
\text { Bottom }\end{array}$ & Sampling Elevation & $\mathrm{pH}$ & $\begin{array}{c}\mathrm{DO} \\
(\mathrm{mg} / \mathrm{L})\end{array}$ & $\begin{array}{l}\text { Temp } \\
\text { ( C ) }\end{array}$ & $\begin{array}{l}\text { Conductivity } \\
\text { (uS } / \mathrm{cm})\end{array}$ & $\begin{array}{c}\text { Conductance } \\
\text { (uS } / \mathrm{cm})\end{array}$ & $\begin{array}{c}\text { Turbidity } \\
\text { (NTU) }\end{array}$ \\
\hline 4.95 & 2.53 & - & 16.15 & 0.7 & 81.19 & 151.5 & 0 \\
\hline 2.95 & 0.53 & - & 16.89 & 1.3 & 80.62 & 147.4 & 0 \\
\hline 0.95 & -1.47 & - & 15.49 & 1.9 & 84.16 & 150.9 & 1 \\
\hline
\end{tabular}




\begin{tabular}{|c|c|c|c|c|c|c|c|}
\hline \multicolumn{8}{|l|}{ Troll } \\
\hline L9312A-4 (raft) & 2/23/2005 13:40 & & & & & & \\
\hline $\begin{array}{r}\text { Height } \\
\text { Above } \\
\text { Bottom }\end{array}$ & Sampling Elevation & $\mathrm{pH}$ & $\begin{array}{c}\mathrm{DO} \\
(\mathrm{mg} / \mathrm{L})\end{array}$ & $\begin{array}{c}\text { Temp } \\
\text { ( C ) }\end{array}$ & $\begin{array}{l}\text { Conductivity } \\
\text { (uS/cm) }\end{array}$ & $\begin{array}{c}\text { Conductance } \\
\text { (uS/cm) }\end{array}$ & $\begin{array}{c}\text { Turbidity } \\
\text { (NTU) }\end{array}$ \\
\hline- & 2.53 & 7.10 & 16.02 & 0.2 & 87.9 & 166.9 & 0.3 \\
\hline- & 1.53 & 7.08 & 16.26 & 1.0 & 86.9 & 160.5 & 4.3 \\
\hline- & 0.53 & 7.06 & - & 1.3 & 87.8 & 160.5 & 5.9 \\
\hline- & -0.47 & 6.97 & - & 1.5 & 88.9 & 161.2 & 2.0 \\
\hline- & -1.47 & 6.79 & - & 1.7 & 92.2 & 166.0 & 1.2 \\
\hline- & -2.47 & 6.66 & 4.26 & 1.9 & 95.7 & 171.1 & - \\
\hline- & -1.47 & 6.84 & 9.39 & 1.8 & 91.4 & 164.1 & 2.8 \\
\hline- & -0.47 & 6.99 & 12.61 & 1.6 & 89.2 & 161.1 & 0.8 \\
\hline- & -1.47 & 7.08 & 14.20 & 1.3 & 87.2 & 159.1 & 0.1 \\
\hline
\end{tabular}

\begin{tabular}{|c|c|c|c|c|c|c|c|}
\hline Troll & & & & & & & \\
\hline L9312- 3 & 2/23/2005 13:40 & & & & & & \\
\hline $\begin{array}{l}\text { Height } \\
\text { Above } \\
\text { Bottom }\end{array}$ & Sampling Elevation & $\mathrm{pH}$ & $\begin{array}{c}\mathrm{DO} \\
(\mathrm{mg} / \mathrm{L})\end{array}$ & $\begin{array}{l}\text { Temp } \\
\text { ( C ) }\end{array}$ & $\begin{array}{l}\text { Conductivity } \\
\text { (uS } / \mathrm{cm})\end{array}$ & $\begin{array}{l}\text { Conductance } \\
\text { (uS } / \mathrm{cm})\end{array}$ & $\begin{array}{c}\text { Turbidity } \\
\text { (NTU) }\end{array}$ \\
\hline 5.90 & 2.53 & 7.16 & 16.57 & 0.3 & 87.8 & 166.4 & 3.9 \\
\hline 4.90 & 1.53 & 7.16 & 16.70 & 0.9 & 86.5 & 160.5 & 1.5 \\
\hline 3.90 & 0.53 & 7.13 & 16.63 & 1.5 & 85.8 & 155.8 & 0.9 \\
\hline 2.90 & -0.47 & 7.02 & 16.33 & 1.8 & 86.5 & 155.3 & 0.7 \\
\hline 1.90 & -1.47 & 6.75 & 8.55 & 2.1 & 90.6 & 161.2 & 1.5 \\
\hline 0.90 & -2.47 & 6.70 & 5.98 & 2.2 & 97.6 & 172.9 & 2.5 \\
\hline
\end{tabular}

\begin{tabular}{|c|c|c|c|c|c|c|c|}
\hline Troll & & & & & \\
\hline $\begin{array}{c}\text { L9312- 2 } \\
\text { Height }\end{array}$ & $2 / 23 / 200513: 40$ & & & & & \\
\hline $\begin{array}{c}\text { Above } \\
\text { Bottom }\end{array}$ & Sampling Elevation & $\mathrm{pH}$ & $\begin{array}{c}\mathrm{DO} \\
(\mathrm{mg} / \mathrm{L})\end{array}$ & $\begin{array}{c}\text { Temp } \\
(\mathrm{C})\end{array}$ & $\begin{array}{c}\text { Conductivity } \\
\text { (uS/cm) }\end{array}$ & $\begin{array}{c}\text { Conductance } \\
\text { (uS/cm) }\end{array}$ & $\begin{array}{c}\text { Turbidity } \\
(\mathrm{NTU})\end{array}$ \\
\hline 5.80 & 2.46 & 7.10 & 16.08 & 0.2 & 91.1 & 172.9 & 0.5 \\
\hline 4.80 & 1.46 & 7.05 & 16.12 & 0.8 & 91.6 & 170.1 & 0.8 \\
\hline 3.80 & 0.46 & 7.01 & 16.34 & 1.3 & 92.9 & 169.5 & 2.3 \\
\hline 2.80 & -0.54 & 6.83 & 13.97 & 1.7 & 94.7 & 170.8 & 5.9 \\
\hline 1.80 & -1.54 & 6.67 & 6.31 & 2.0 & 92.1 & 164.2 & 1.8 \\
\hline 0.80 & -2.54 & 6.66 & 4.19 & 2.1 & 96.3 & 171.1 & 11.5 \\
\hline
\end{tabular}

\begin{tabular}{|c|c|c|c|c|c|c|c|}
\hline Troll & & & & & \\
\hline $\begin{array}{c}\text { L9312- } 1 \\
\begin{array}{c}\text { Height } \\
\text { Above } \\
\text { Bottom }\end{array}\end{array}$ & Sampling Elevation & $\mathrm{pH}$ & $\begin{array}{c}\mathrm{DO} \\
(\mathrm{mg} / \mathrm{L})\end{array}$ & $\begin{array}{c}\text { Temp } \\
(\mathrm{C})\end{array}$ & $\begin{array}{c}\text { Conductivity } \\
\text { (uS/cm) }\end{array}$ & $\begin{array}{c}\text { Conductance } \\
\text { (uS/cm) }\end{array}$ & $\begin{array}{c}\text { Turbidity } \\
(\mathrm{NTU})\end{array}$ \\
\hline 1.50 & 2.46 & 6.67 & 10.23 & 0.3 & 105.3 & 199.6 & 1.1 \\
\hline 0.50 & -2.84 & 6.65 & 10.31 & 0.5 & 106.3 & 200.0 & 1.8 \\
\hline
\end{tabular}

\begin{tabular}{|c|c|c|c|c|c|c|c|}
\hline Troll & & & & & \\
\hline $\begin{array}{c}\text { L9312- Raft SH } \\
\begin{array}{c}\text { Height } \\
\text { Above } \\
\text { Bottom }\end{array}\end{array}$ & Sampling Elevation & $\mathrm{pH}$ & $\begin{array}{c}\mathrm{DO} \\
(\mathrm{mg} / \mathrm{L})\end{array}$ & $\begin{array}{c}\text { Temp } \\
(\mathrm{C})\end{array}$ & $\begin{array}{c}\text { Conductivity } \\
\text { (uS/cm) }\end{array}$ & $\begin{array}{c}\text { Conductance } \\
\text { (uS/cm) }\end{array}$ & $\begin{array}{c}\text { Turbidity } \\
(\mathrm{NTU})\end{array}$ \\
\hline 1.05 & 1.43 & 6.46 & 7.77 & 0.6 & 134.5 & 251.5 & 2.0 \\
\hline 0.05 & 0.43 & 6.45 & 7.42 & 1.0 & 135.7 & 250.3 & 8.1 \\
\hline
\end{tabular}




\begin{tabular}{|c|c|c|c|c|c|c|c|}
\hline Troll & & & & & \\
\hline $\begin{array}{c}\text { L9312- Raft MP } \\
\begin{array}{c}\text { Height } \\
\text { Above } \\
\text { Bottom }\end{array}\end{array}$ & Sampling Elevation & $\mathrm{pH}$ & $\begin{array}{c}\mathrm{DO} \\
(\mathrm{mg} / \mathrm{L})\end{array}$ & $\begin{array}{c}\text { Temp } \\
(\mathrm{C})\end{array}$ & $\begin{array}{c}\text { Conductivity } \\
\text { (uS/cm) }\end{array}$ & $\begin{array}{c}\text { Conductance } \\
\text { (uS/cm) }\end{array}$ & $\begin{array}{c}\text { Turbidity } \\
\text { (NTU) }\end{array}$ \\
\hline 4.95 & 1.43 & 6.76 & 12.45 & - & 120.5 & - & 3.1 \\
\hline 3.95 & 0.43 & 6.73 & 13.01 & 1.4 & 120.4 & 219.3 & 4.7 \\
\hline 2.95 & -0.57 & 6.70 & 12.83 & 1.8 & 120.3 & 216.0 & 7.9 \\
\hline 1.95 & -1.57 & 6.70 & 12.85 & 2.1 & 120.3 & 213.5 & 14.9 \\
\hline 1.45 & -2.07 & 6.50 & 7.60 & 2.6 & 127.8 & 223.7 & 8.8 \\
\hline 0.95 & -2.57 & 6.49 & 5.37 & 2.6 & 134.3 & 234.7 & - \\
\hline
\end{tabular}

\begin{tabular}{|c|c|c|c|c|c|c|c|}
\hline Troll & & & & & & & \\
\hline L9312- Raft A & $3 / 14 / 2005$ 12:04 & & & & & & \\
\hline $\begin{array}{l}\text { Height } \\
\text { Above } \\
\text { Bottom }\end{array}$ & Sampling Elevation & $\mathrm{pH}$ & $\begin{array}{c}\mathrm{DO} \\
(\mathrm{mg} / \mathrm{L})\end{array}$ & $\begin{array}{l}\text { Temp } \\
\text { ( C ) }\end{array}$ & $\begin{array}{l}\text { Conductivity } \\
\text { (uS/cm) }\end{array}$ & $\begin{array}{c}\text { Conductance } \\
\text { (uS } / \mathrm{cm})\end{array}$ & $\begin{array}{c}\text { Turbidity } \\
\text { (NTU) }\end{array}$ \\
\hline 4.15 & 1.43 & 6.88 & 14.40 & 0.8 & 118.9 & 221.2 & 3.9 \\
\hline 3.15 & 0.43 & 6.83 & 14.15 & 1.6 & 117.4 & 212.0 & 8.0 \\
\hline 2.15 & -0.57 & 6.72 & 13.75 & 2.0 & 119.4 & 212.7 & 19.4 \\
\hline 1.15 & -1.57 & 6.42 & 12.13 & 2.4 & 122 & 214.9 & 21.5 \\
\hline 0.65 & -2.07 & 6.26 & 10.69 & 2.4 & 122.3 & 215.2 & 20.5 \\
\hline 0.15 & -2.57 & 6.25 & 8.37 & 2.4 & 125.4 & 220.4 & 19.0 \\
\hline
\end{tabular}

\begin{tabular}{|c|c|c|c|c|c|c|c|}
\hline Troll & & & & & & & \\
\hline L9312- Raft B & $3 / 14 / 2005$ 12:04 & & & & & & \\
\hline $\begin{array}{r}\text { Height } \\
\text { Above } \\
\text { Bottom }\end{array}$ & Sampling Elevation & $\mathrm{pH}$ & $\begin{array}{c}\mathrm{DO} \\
(\mathrm{mg} / \mathrm{L})\end{array}$ & $\begin{array}{l}\text { Temp } \\
\text { ( C ) }\end{array}$ & $\begin{array}{l}\text { Conductivity } \\
\text { (uS/cm) }\end{array}$ & $\begin{array}{c}\text { Conductance } \\
\text { (uS } / \mathrm{cm})\end{array}$ & $\begin{array}{c}\text { Turbidity } \\
\text { (NTU) }\end{array}$ \\
\hline 6.15 & 2.43 & 6.65 & 13.48 & 0.2 & 121.4 & 230.7 & 3.5 \\
\hline 5.15 & 1.43 & 6.68 & 13.48 & 0.7 & 121.1 & 225.7 & 5.6 \\
\hline 4.15 & 0.43 & 6.59 & 12.66 & 1.5 & 121.8 & 221.0 & 9.7 \\
\hline 3.15 & -0.57 & 6.45 & 11.70 & 2.0 & 120.9 & 215.7 & 12.3 \\
\hline 2.15 & -1.57 & 6.20 & 4.13 & 2.2 & 119.1 & 210.7 & 6.3 \\
\hline 1.15 & -2.57 & 6.15 & 3.50 & 2.3 & 125.8 & 221.9 & 3.1 \\
\hline 0.15 & -3.57 & 6.16 & 3.23 & 2.3 & 128 & 225.8 & - \\
\hline
\end{tabular}

\begin{tabular}{|c|c|c|c|c|c|c|c|}
\hline Troll & & & & & & & \\
\hline L9312 - Survey Hole & 4/21/2005 11:16 & & & & & & \\
\hline $\begin{array}{l}\text { Height } \\
\text { Above } \\
\text { Bottom }\end{array}$ & Sampling Elevation & $\mathrm{pH}$ & $\begin{array}{c}\mathrm{DO} \\
(\mathrm{mg} / \mathrm{L})\end{array}$ & $\begin{array}{l}\text { Temp } \\
\text { ( C ) }\end{array}$ & $\begin{array}{l}\text { Conductivity } \\
\text { (uS } / \mathrm{cm})\end{array}$ & $\begin{array}{l}\text { Conductance } \\
\text { (uS } / \mathrm{cm})\end{array}$ & $\begin{array}{c}\text { Turbidity } \\
\text { (NTU) }\end{array}$ \\
\hline 0.5 & -0.63 & 6.38 & 6.26 & 2.1 & 136.3 & 242.3 & 4 \\
\hline 0.5 & -0.63 & 6.36 & 6.24 & 2.1 & 136.4 & 242.4 & 4.4 \\
\hline 0.0 & -1.13 & 6.31 & 6.02 & 2.2 & 136.9 & 242.2 & 6.2 \\
\hline 0.0 & -1.13 & 6.34 & 5.95 & 2.3 & 137.1 & 242.5 & 6.1 \\
\hline
\end{tabular}

\begin{tabular}{|c|c|c|c|c|c|c|c|}
\hline Hach LDO & & & & & & & \\
\hline L9312 - Survey Hole & 4/21/2005 11:16 & & & & & & \\
\hline $\begin{array}{c}\text { Height } \\
\text { Above } \\
\text { Bottom }\end{array}$ & Sampling Elevation & $\mathrm{pH}$ & $\begin{array}{c}\mathrm{DO} \\
(\mathrm{mg} / \mathrm{L})\end{array}$ & $\begin{array}{l}\text { Temp } \\
\text { ( C ) }\end{array}$ & $\begin{array}{l}\text { Conductivity } \\
\text { (uS/cm) }\end{array}$ & $\begin{array}{l}\text { Conductance } \\
\text { (uS/cm) }\end{array}$ & $\begin{array}{c}\text { Turbidity } \\
\text { (NTU) }\end{array}$ \\
\hline 0.5 & -0.63 & - & 6.20 & 2.3 & - & - & - \\
\hline 0.5 & -0.63 & - & 6.20 & 2.3 & - & - & - \\
\hline 0.0 & -1.13 & - & 6.10 & 2.4 & - & - & - \\
\hline 0.0 & -1.13 & - & 6.00 & 2.4 & - & - & - \\
\hline
\end{tabular}




\begin{tabular}{|c|c|c|c|c|c|c|c|}
\hline $\begin{array}{c}\text { Troll } \\
\text { L9312B }\end{array}$ & 4/21/2005 11:44 & & & & \\
\hline $\begin{array}{c}\text { Height } \\
\text { Above } \\
\text { Bottom }\end{array}$ & Sampling Elevation & $\mathrm{pH}$ & $\begin{array}{c}\mathrm{DO} \\
(\mathrm{mg} / \mathrm{L})\end{array}$ & $\begin{array}{c}\text { Temp } \\
(\mathrm{C})\end{array}$ & $\begin{array}{c}\text { Conductivity } \\
\text { (uS/cm) }\end{array}$ & $\begin{array}{c}\text { Conductance } \\
\text { (uS/cm) }\end{array}$ & $\begin{array}{c}\text { Turbidity } \\
(\mathrm{NTU})\end{array}$ \\
\hline 4.7 & 1.37 & 6.56 & 11.08 & 0.4 & 123.1 & 232.5 & 3.4 \\
\hline 4.7 & 1.37 & 6.54 & 11.07 & 0.3 & 123.0 & 232.5 & 3.5 \\
\hline 3.7 & 0.37 & 6.54 & 11.21 & 1.2 & 121.9 & 223.2 & 3.7 \\
\hline 3.7 & 0.37 & 6.55 & 11.26 & 1.6 & 122.7 & 222.2 & 3.4 \\
\hline 2.7 & -0.63 & 6.64 & 10.88 & 2.5 & 125.4 & 220.1 & 0.8 \\
\hline 2.7 & -0.63 & 6.59 & 10.81 & 2.4 & 125.1 & 219.8 & 2.1 \\
\hline 1.7 & -1.63 & 6.51 & 10.60 & 2.8 & 127.8 & 221.8 & 2.5 \\
\hline 1.7 & -1.63 & 6.46 & 10.57 & 2.9 & 128.0 & 221.9 & 3.6 \\
\hline 0.7 & -2.63 & 6.38 & 9.20 & 3.0 & 133.4 & 230.0 & 5.5 \\
\hline 0.7 & -2.63 & 6.41 & 8.94 & 3.0 & 133.7 & 230.5 & 4.1 \\
\hline 0.7 & -2.63 & 6.38 & 8.77 & 3.0 & 133.8 & 230.6 & 4.1 \\
\hline 0.7 & -2.63 & 6.43 & 8.63 & 3.0 & 133.7 & 230.4 & 3.6 \\
\hline 0.2 & -3.13 & 6.33 & 8.00 & 3.0 & 133.9 & 230.6 & 5.4 \\
\hline 0.2 & -3.13 & 6.34 & 7.84 & 3.1 & 134.2 & 231.1 & 5.4 \\
\hline 0.2 & -3.13 & 6.34 & 7.72 & 3.1 & 135.1 & 232.6 & 6.0 \\
\hline
\end{tabular}

\begin{tabular}{|c|c|c|c|c|c|c|c|}
\hline \multicolumn{8}{|l|}{ Hach LDO } \\
\hline L9312B & $4 / 21 / 200511: 44$ & & & & & & \\
\hline $\begin{array}{c}\text { Height } \\
\text { Above } \\
\text { Bottom }\end{array}$ & Sampling Elevation & $\mathrm{pH}$ & $\begin{array}{c}\mathrm{DO} \\
(\mathrm{mg} / \mathrm{L})\end{array}$ & $\begin{array}{l}\text { Temp } \\
\text { ( C ) }\end{array}$ & $\begin{array}{l}\text { Conductivity } \\
\text { (uS } / \mathrm{cm})\end{array}$ & $\begin{array}{c}\text { Conductance } \\
\text { (uS } / \mathrm{cm})\end{array}$ & $\begin{array}{c}\text { Turbidity } \\
\text { (NTU) }\end{array}$ \\
\hline 4.7 & 1.37 & - & 10.70 & 0.3 & - & - & - \\
\hline 4.7 & 1.37 & - & 10.60 & 0.4 & - & - & - \\
\hline 3.7 & 0.37 & - & 10.50 & 1.6 & - & - & - \\
\hline 3.7 & 0.37 & - & 10.10 & 2.0 & - & - & - \\
\hline 2.7 & -0.63 & - & 9.50 & 2.6 & - & - & - \\
\hline 2.7 & -0.63 & - & 9.40 & 2.6 & - & - & - \\
\hline 1.7 & -1.63 & - & 9.50 & 3.0 & - & - & - \\
\hline 1.7 & -1.63 & - & 9.40 & 3.1 & - & - & - \\
\hline 0.7 & -2.63 & - & 7.30 & 3.1 & - & - & - \\
\hline 0.7 & -2.63 & - & 7.00 & 3.2 & - & - & - \\
\hline 0.7 & -2.63 & - & 6.80 & 3.2 & - & - & - \\
\hline 0.7 & -2.63 & - & 6.70 & 3.1 & - & - & - \\
\hline 0.2 & -3.13 & - & 6.10 & 3.1 & - & - & - \\
\hline 0.2 & -3.13 & - & 5.70 & 3.1 & - & - & - \\
\hline 0.2 & -3.13 & - & 5.50 & 3.1 & - & - & - \\
\hline
\end{tabular}




\begin{tabular}{|c|c|c|c|c|c|c|c|}
\hline \multicolumn{8}{|l|}{ Troll } \\
\hline L9312 - Mid Point & $4 / 21 / 200512: 42$ & & & & & & \\
\hline $\begin{array}{c}\text { Height } \\
\text { Above } \\
\text { Bottom }\end{array}$ & Sampling Elevation & $\mathrm{pH}$ & $\begin{array}{c}\mathrm{DO} \\
(\mathrm{mg} / \mathrm{L})\end{array}$ & $\begin{array}{l}\text { Temp } \\
\text { ( C ) }\end{array}$ & $\begin{array}{l}\text { Conductivity } \\
\text { (uS/cm) }\end{array}$ & $\begin{array}{l}\text { Conductance } \\
\text { (uS/cm) }\end{array}$ & $\begin{array}{c}\text { Turbidity } \\
\text { (NTU) }\end{array}$ \\
\hline 4.7 & 1.37 & 6.72 & 15.50 & 0.5 & 132.6 & 249.7 & 1.5 \\
\hline 4.7 & 1.37 & 6.75 & 15.42 & 0.5 & 132.5 & 249.4 & 1.5 \\
\hline 3.7 & 0.37 & 6.73 & 15.80 & 1.1 & 129.7 & 239.0 & 1.8 \\
\hline 3.7 & 0.37 & 6.71 & 15.85 & 1.5 & 129.8 & 235.6 & 1.6 \\
\hline 3.7 & 0.37 & 6.72 & 15.82 & 1.6 & 129.5 & 234.6 & 1.6 \\
\hline 2.7 & -0.63 & 6.7 & 15.95 & 2.1 & 130.5 & 231.7 & 2.1 \\
\hline 2.7 & -0.63 & 6.69 & 15.81 & 2.4 & 131.1 & 231.1 & 2.4 \\
\hline 2.7 & -0.63 & 6.7 & 15.73 & 2.4 & 131.2 & 230.9 & 2.6 \\
\hline 1.7 & -1.63 & 6.68 & 16.07 & 2.9 & 132.3 & 229.2 & 2.8 \\
\hline 1.7 & -1.63 & 6.65 & 16.08 & 2.9 & 132.6 & 229.5 & 3.8 \\
\hline 0.7 & -2.63 & 6.66 & 16.12 & 3.3 & 134.2 & 229.0 & 3.4 \\
\hline 0.7 & -2.63 & 6.64 & 16.00 & 3.3 & 134.5 & 229.7 & 4.1 \\
\hline 0.2 & -3.13 & 6.56 & 15.65 & 3.4 & 134.9 & 229.9 & 4.9 \\
\hline 0.2 & -3.13 & 6.58 & 15.51 & 3.4 & 135.1 & 230.1 & 4.1 \\
\hline
\end{tabular}

\begin{tabular}{|c|c|c|c|c|c|c|c|}
\hline \multicolumn{8}{|l|}{ Hach LDO } \\
\hline L9312 - Mid Point & $4 / 21 / 200512: 42$ & & & & & & \\
\hline $\begin{array}{c}\text { Height } \\
\text { Above } \\
\text { Bottom }\end{array}$ & Sampling Elevation & $\mathrm{pH}$ & $\begin{array}{c}\mathrm{DO} \\
(\mathrm{mg} / \mathrm{L})\end{array}$ & $\begin{array}{l}\text { Temp } \\
\text { ( C ) }\end{array}$ & $\begin{array}{l}\text { Conductivity } \\
\text { (uS/cm) }\end{array}$ & $\begin{array}{l}\text { Conductance } \\
\text { (uS/cm) }\end{array}$ & $\begin{array}{c}\text { Turbidity } \\
\text { (NTU) }\end{array}$ \\
\hline 4.7 & 1.37 & - & 14.30 & 0.5 & - & - & - \\
\hline 4.7 & 1.37 & - & 14.20 & 0.6 & - & - & - \\
\hline 3.7 & 0.37 & - & 14.10 & 1.6 & - & - & - \\
\hline 3.7 & 0.37 & - & 13.70 & 1.9 & - & - & - \\
\hline 3.7 & 0.37 & - & 13.70 & 1.9 & - & - & - \\
\hline 2.7 & -0.63 & - & 13.80 & 2.5 & - & - & - \\
\hline 2.7 & -0.63 & - & 13.60 & 2.6 & - & - & - \\
\hline 2.7 & -0.63 & - & 13.60 & 2.7 & - & - & - \\
\hline 1.7 & -1.63 & - & 14.00 & 3.1 & - & - & - \\
\hline 1.7 & -1.63 & - & 13.90 & 3.2 & - & - & - \\
\hline 0.7 & -2.63 & - & 13.60 & 3.5 & - & - & - \\
\hline 0.7 & -2.63 & - & 13.40 & 3.5 & - & - & - \\
\hline 0.2 & -3.13 & - & 13.20 & 3.6 & - & - & - \\
\hline 0.2 & -3.13 & - & 13.10 & 3.6 & - & - & - \\
\hline
\end{tabular}

\begin{tabular}{|c|c|c|c|c|c|c|c|}
\hline Troll & & & & & \\
\hline $\begin{array}{c}\text { L9312A } \\
\text { Height } \\
\text { Above } \\
\text { Bottom }\end{array}$ & Sampling Elevation & $\mathrm{pH}$ & $\begin{array}{c}\text { DO } \\
(\mathrm{mg} / \mathrm{L})\end{array}$ & $\begin{array}{c}\text { Temp } \\
(\mathrm{C})\end{array}$ & $\begin{array}{c}\text { Conductivity } \\
(\mathrm{uS} / \mathrm{cm})\end{array}$ & $\begin{array}{c}\text { Conductance } \\
(\mathrm{uS} / \mathrm{cm})\end{array}$ & $\begin{array}{c}\text { Turbidity } \\
(\mathrm{NTU})\end{array}$ \\
\hline 4 & 1.37 & 6.67 & 13.59 & 0.3 & 127.5 & 241.1 & 1.7 \\
\hline 4 & 1.37 & 6.61 & 13.60 & 0.3 & 127.6 & 241.5 & 3.3 \\
\hline 3 & 0.37 & 6.58 & 13.68 & 1.4 & 126.5 & 230.6 & 3.8 \\
\hline 3 & 0.37 & 6.59 & 13.67 & 1.3 & 126.8 & 231.6 & 4.0 \\
\hline 3 & 0.37 & 6.58 & 13.63 & 1.6 & 127.2 & 230.2 & 4.3 \\
\hline 2 & -0.63 & 6.56 & 13.39 & 2.1 & 127.6 & 226.7 & 4.4 \\
\hline 2 & -0.63 & 6.59 & 13.33 & 2.2 & 128.1 & 227.0 & 4.4 \\
\hline 1 & -1.63 & 6.46 & 12.72 & 2.8 & 129.9 & 225.4 & 5.2 \\
\hline 1 & -1.63 & 6.50 & 12.60 & 2.8 & 129.8 & 225.3 & 4.9 \\
\hline 0 & -2.63 & 6.49 & 11.65 & 3.1 & 133.4 & 229.5 & 12.0 \\
\hline 0 & -2.63 & 6.46 & 11.54 & 3.1 & 134.4 & 231.1 & 14.3 \\
\hline
\end{tabular}




\begin{tabular}{|c|c|c|c|c|c|c|c|}
\hline \multicolumn{8}{|l|}{ Hach LDO } \\
\hline L9312A & $4 / 21 / 200514: 08$ & & & & & & \\
\hline $\begin{array}{c}\text { Height } \\
\text { Above } \\
\text { Bottom }\end{array}$ & Sampling Elevation & $\mathrm{pH}$ & $\begin{array}{c}\mathrm{DO} \\
(\mathrm{mg} / \mathrm{L})\end{array}$ & $\begin{array}{l}\text { Temp } \\
\text { ( C ) }\end{array}$ & $\begin{array}{l}\text { Conductivity } \\
\text { (uS } / \mathrm{cm})\end{array}$ & $\begin{array}{c}\text { Conductance } \\
\text { (uS } / \mathrm{cm})\end{array}$ & $\begin{array}{c}\text { Turbidity } \\
\text { (NTU) }\end{array}$ \\
\hline 4 & 1.37 & - & 12.80 & 0.6 & - & - & - \\
\hline 4 & 1.37 & - & 12.70 & 0.6 & - & - & - \\
\hline 3 & 0.37 & - & 12.70 & 1.5 & - & - & - \\
\hline 3 & 0.37 & - & 12.40 & 1.7 & - & - & - \\
\hline 3 & 0.37 & - & 12.20 & 1.9 & - & - & - \\
\hline 2 & -0.63 & - & 11.80 & 2.5 & - & - & - \\
\hline 2 & -0.63 & - & 11.60 & 2.6 & - & - & - \\
\hline 1 & -1.63 & - & 11.20 & 3.1 & - & - & - \\
\hline 1 & -1.63 & - & 11.00 & 3.2 & - & - & - \\
\hline 0 & -2.63 & - & 0.40 & 3.3 & - & - & - \\
\hline 0 & -2.63 & - & 0.20 & 3.3 & - & - & - \\
\hline
\end{tabular}

\begin{tabular}{|c|c|c|c|c|c|c|c|}
\hline \multicolumn{1}{|l|}{$\begin{array}{l}\text { Troll } \\
\text { L9312B }\end{array}$} & $5 / 20 / 200517: 00$ & & & & & \\
\hline $\begin{array}{c}\text { Height } \\
\text { Above } \\
\text { Bottom }\end{array}$ & Sampling Elevation & $\mathrm{pH}$ & $\begin{array}{c}\mathrm{DO} \\
(\mathrm{mg} / \mathrm{L})\end{array}$ & $\begin{array}{c}\text { Temp } \\
(\mathrm{C})\end{array}$ & $\begin{array}{c}\text { Conductivity } \\
\text { (uS/cm) }\end{array}$ & $\begin{array}{c}\text { Conductance } \\
\text { (uS/cm) }\end{array}$ & $\begin{array}{c}\text { Turbidity } \\
(\mathrm{NTU})\end{array}$ \\
\hline 3.83 & 0.39 & 5.1 & 11.95 & 2.1 & 116.8 & - & -3.1 \\
\hline 2.83 & -0.61 & 6.26 & 10.89 & 3.1 & 119.3 & - & -3 \\
\hline 1.8 & -1.61 & 6.06 & 10.66 & 3.4 & 122.1 & - & -3.4 \\
\hline 0.8 & -2.61 & 6.06 & 10.71 & 3.4 & 122.7 & - & -3.5 \\
\hline
\end{tabular}

\begin{tabular}{|c|c|c|c|c|c|c|c|}
\hline \multicolumn{1}{|l|}{$\begin{array}{l}\text { Troll } \\
\text { L9312A A }\end{array}$} & 5/20/2005 17:00 & & & & & \\
\hline $\begin{array}{c}\text { Height } \\
\text { Above } \\
\text { Bottom }\end{array}$ & Sampling Elevation & $\mathrm{pH}$ & $\begin{array}{c}\text { DO } \\
(\mathrm{mg} / \mathrm{L})\end{array}$ & $\begin{array}{c}\text { Temp } \\
(\mathrm{C})\end{array}$ & $\begin{array}{c}\text { Conductivity } \\
(\mathrm{uS} / \mathrm{cm})\end{array}$ & $\begin{array}{c}\text { Conductance } \\
(\mathrm{uS} / \mathrm{cm})\end{array}$ & $\begin{array}{c}\text { Turbidity } \\
(\mathrm{NTU})\end{array}$ \\
\hline 3.08 & 0.39 & 6.86 & 16.01 & 2.3 & 119.8 & - & -3.5 \\
\hline 2.08 & -0.61 & 6.7 & 14.73 & 3.2 & 121.8 & - & -3.6 \\
\hline 1.1 & -1.61 & 6.62 & 12.71 & 3.4 & 122.6 & - & -2.6 \\
\hline
\end{tabular}

\begin{tabular}{|c|c|c|c|c|c|c|c|}
\hline \multicolumn{8}{|l|}{ Troll } \\
\hline L9312 -3 (SH) & $5 / 20 / 200517: 00$ & & & & & & \\
\hline $\begin{array}{c}\text { Height } \\
\text { Above } \\
\text { Bottom }\end{array}$ & Sampling Elevation & $\mathrm{pH}$ & $\begin{array}{c}\mathrm{DO} \\
(\mathrm{mg} / \mathrm{L})\end{array}$ & $\begin{array}{l}\text { Temp } \\
\text { ( C ) }\end{array}$ & $\begin{array}{l}\text { Conductivity } \\
\text { (uS } / \mathrm{cm})\end{array}$ & $\begin{array}{l}\text { Conductance } \\
\text { (uS/cm) }\end{array}$ & $\begin{array}{c}\text { Turbidity } \\
\text { (NTU) }\end{array}$ \\
\hline 0.3 & 1.39 & 6.63 & 7.96 & 0.2 & 114.7 & - & 2.4 \\
\hline
\end{tabular}

\begin{tabular}{|c|c|c|c|c|c|c|c|}
\hline Troll & & & & & & & \\
\hline L9312 -2 & $5 / 20 / 2005$ 17:00 & & & & & & \\
\hline $\begin{array}{c}\text { Height } \\
\text { Above } \\
\text { Bottom }\end{array}$ & Sampling Elevation & $\mathrm{pH}$ & $\begin{array}{c}\mathrm{DO} \\
(\mathrm{mg} / \mathrm{L})\end{array}$ & $\begin{array}{l}\text { Temp } \\
\text { ( C ) }\end{array}$ & $\begin{array}{l}\text { Conductivity } \\
\text { (uS } / \mathrm{cm})\end{array}$ & $\begin{array}{c}\text { Conductance } \\
\text { (uS } / \mathrm{cm})\end{array}$ & $\begin{array}{c}\text { Turbidity } \\
\text { (NTU) }\end{array}$ \\
\hline 3.25 & 0.39 & 6.82 & 12.75 & 2.3 & 119.1 & - & -3.6 \\
\hline 2.25 & -0.61 & 6.8 & 11.62 & 2.9 & 121.6 & - & -3.3 \\
\hline 1.3 & -1.61 & 6.81 & 11.53 & 3.3 & 123.6 & - & -2.8 \\
\hline
\end{tabular}




\begin{tabular}{|c|c|c|c|c|c|c|c|}
\hline Troll & & & & & & & \\
\hline L9312 -1 (MP) & 5/20/2005 17:00 & & & & & & \\
\hline $\begin{array}{r}\text { Height } \\
\text { Above } \\
\text { Bottom }\end{array}$ & Sampling Elevation & $\mathrm{pH}$ & $\begin{array}{c}\mathrm{DO} \\
(\mathrm{mg} / \mathrm{L})\end{array}$ & $\begin{array}{l}\text { Temp } \\
\text { ( C ) }\end{array}$ & $\begin{array}{l}\text { Conductivity } \\
\text { (uS/cm) }\end{array}$ & $\begin{array}{c}\text { Conductance } \\
\text { (uS } / \mathrm{cm})\end{array}$ & $\begin{array}{c}\text { Turbidity } \\
\text { (NTU) }\end{array}$ \\
\hline 3.67 & 0.39 & 6.71 & 12.79 & 1.8 & 115.6 & - & -4.2 \\
\hline 2.67 & -0.61 & 6.7 & 12.22 & 2.8 & 119.9 & - & -4.2 \\
\hline 1.7 & -1.61 & 6.75 & 13.36 & 3.5 & 124.1 & - & -4.1 \\
\hline
\end{tabular}

\begin{tabular}{|c|c|c|c|c|c|c|c|}
\hline Troll & & & & & & & \\
\hline L9312 & $8 / 2 / 2005$ 14:31 & & & & & & \\
\hline $\begin{array}{c}\text { Height } \\
\text { Above } \\
\text { Bottom }\end{array}$ & Sampling Elevation & $\mathrm{pH}$ & $\begin{array}{c}\mathrm{DO} \\
(\mathrm{mg} / \mathrm{L})\end{array}$ & $\begin{array}{l}\text { Temp } \\
\text { ( C ) }\end{array}$ & $\begin{array}{l}\text { Conductivity } \\
\text { (uS/cm) }\end{array}$ & $\begin{array}{l}\text { Conductance } \\
\text { (uS } / \mathrm{cm})\end{array}$ & $\begin{array}{c}\text { Turbidity } \\
\text { (NTU) }\end{array}$ \\
\hline 1 & 6.84 & 7.77 & 11.00 & 9.0 & 56.75 & 81.8 & - \\
\hline 1 & 6.84 & 7.59 & 11.00 & 9.5 & 57.42 & 81.6 & - \\
\hline
\end{tabular}

Table J-5. L9817P winter 2004 - 2005 water-quality data.

\begin{tabular}{|c|c|c|c|c|c|c|c|}
\hline Troll & \multicolumn{2}{|c|}{ L9817 } & & \multicolumn{2}{|c|}{ Position: } \\
\hline $\begin{array}{c}\text { L9817 } \\
\begin{array}{c}\text { Height } \\
\text { Bottom }\end{array}\end{array}$ & $\begin{array}{c}\text { Sampling } \\
\text { Elevation }\end{array}$ & $\mathrm{pH}$ & $\begin{array}{c}\mathrm{DO} \\
(\mathrm{mg} / \mathrm{L})\end{array}$ & $\begin{array}{c}\text { Temp } \\
(\mathrm{C})\end{array}$ & $\begin{array}{c}\text { Conductivity } \\
\text { (uS/cm) }\end{array}$ & $\begin{array}{c}\text { Conductance } \\
\text { (uS/cm) }\end{array}$ & $\begin{array}{c}\text { Turbidity } \\
\text { (NTU) }\end{array}$ \\
\hline 7 & 51.88 & 7.02 & 11.77 & 0.2 & 244.8 & 464.4 & 0.4 \\
\hline 6 & 50.88 & 7.02 & - & 1.0 & 248.1 & 457.6 & 0.4 \\
\hline 5 & 49.88 & 7.02 & - & 1.3 & 249.3 & 454.8 & 0.5 \\
\hline 4 & 48.88 & 7.02 & 11.65 & 1.8 & 253.7 & 456.0 & 0.7 \\
\hline 3 & 47.88 & 7.02 & 12.14 & 2.1 & 261.6 & 465.8 & 1.4 \\
\hline 2 & 46.88 & 7.02 & - & 2.4 & 278.2 & 488.8 & 2.3 \\
\hline 1 & 45.88 & 7.02 & 0.28 & 2.7 & 349.6 & 610.0 & - \\
\hline
\end{tabular}

\begin{tabular}{|c|c|c|c|c|c|c|c|}
\hline \multicolumn{2}{|c|}{ Hydrolab Quanta } & & \multirow[b]{2}{*}{ L9817 } & & \multicolumn{2}{|c|}{ Position: } & \\
\hline L9817 & $12 / 6 / 200417: 00$ & & & & N70 14.090 & W151 19.929 & \\
\hline $\begin{array}{c}\text { Height } \\
\text { Above } \\
\text { Bottom }\end{array}$ & $\begin{array}{l}\text { Sampling } \\
\text { Elevation }\end{array}$ & $\mathrm{pH}$ & $\begin{array}{c}\mathrm{DO} \\
(\mathrm{mg} / \mathrm{L})\end{array}$ & $\begin{array}{l}\text { Temp } \\
\text { ( C ) }\end{array}$ & $\begin{array}{l}\text { Conductivity } \\
\text { (uS } / \mathrm{cm})\end{array}$ & $\begin{array}{l}\text { Conductance } \\
\text { (uS/cm) }\end{array}$ & $\begin{array}{c}\text { Turbidity } \\
\text { (NTU) }\end{array}$ \\
\hline 6.2 & 49.88 & 7.66 & 14.79 & 0.4 & - & 413 & - \\
\hline 5.2 & 48.88 & 7.64 & - & 1.1 & - & 407 & - \\
\hline 4.2 & 47.88 & 7.67 & 14.71 & 1.6 & - & 407 & - \\
\hline 3.2 & 46.88 & 7.71 & - & 1.8 & - & 412 & - \\
\hline 2.2 & 45.88 & 7.64 & - & 2.1 & - & 422 & - \\
\hline 1.2 & 44.88 & 7.64 & 5.41 & 2.4 & - & 466 & - \\
\hline
\end{tabular}

\begin{tabular}{|c|c|c|c|c|c|c|c|}
\hline \multicolumn{2}{|c|}{ Hydrolab Quanta } & & & & \multicolumn{2}{|c|}{ Position: } & \multirow[b]{3}{*}{$\begin{array}{c}\text { Turbidity } \\
\text { (NTU) }\end{array}$} \\
\hline L9817 & $1 / 15 / 200512: 00$ & & \multicolumn{2}{|c|}{ L9817 - Repeat of hole \#1 } & N70 14.09 & W151 19.929 & \\
\hline $\begin{array}{l}\text { Above } \\
\text { Bottom }\end{array}$ & $\begin{array}{l}\text { Sampling } \\
\text { Elevation }\end{array}$ & $\mathrm{pH}$ & $\begin{array}{c}\mathrm{DO} \\
(\mathrm{mg} / \mathrm{L})\end{array}$ & $\begin{array}{l}\text { Temp } \\
\text { ( C ) }\end{array}$ & $\begin{array}{l}\text { Conductivity } \\
\text { (uS } / \mathrm{cm})\end{array}$ & $\begin{array}{c}\text { Conductance } \\
\text { (uS } / \mathrm{cm})\end{array}$ & \\
\hline 4.9 & 49.37 & 7.18 & 10.18 & -0.4 & - & 649 & - \\
\hline 3.9 & 48.37 & 7.09 & 10.01 & 0.0 & - & 646 & - \\
\hline 2.9 & 47.37 & 7.07 & 8.04 & 0.5 & - & 644 & - \\
\hline 1.9 & 46.37 & 7.00 & 6.94 & 0.8 & - & 638 & - \\
\hline 0.9 & 45.37 & 7.05 & 3.8 & 1.2 & - & 640 & - \\
\hline 0.4 & 44.87 & 7.40 & 3.36 & 1.4 & - & 691 & - \\
\hline
\end{tabular}




\begin{tabular}{|c|c|c|c|c|c|c|c|}
\hline \multicolumn{2}{|c|}{ Hydrolab Datasonde } & & \multirow[b]{2}{*}{ L9817 } & & \multicolumn{2}{|c|}{ Position: } & \\
\hline L9817 & 1/15/2005 12:00 & & & & N70 14.090 & W151 19.929 & \\
\hline $\begin{array}{c}\text { Height } \\
\text { Above } \\
\text { Bottom }\end{array}$ & $\begin{array}{l}\text { Sampling } \\
\text { Elevation }\end{array}$ & $\mathrm{pH}$ & $\begin{array}{c}\mathrm{DO} \\
(\mathrm{mg} / \mathrm{L})\end{array}$ & $\begin{array}{c}\text { Temp } \\
\text { ( C ) }\end{array}$ & $\begin{array}{l}\text { Conductivity } \\
\text { (uS } / \mathrm{cm})\end{array}$ & $\begin{array}{c}\text { Conductance } \\
\text { (uS/cm) }\end{array}$ & $\begin{array}{c}\text { Turbidity } \\
\text { (NTU) }\end{array}$ \\
\hline 4.9 & 49.37 & 6.26 & 10.47 & 0.5 & - & 520.4 & 0.3 \\
\hline 3.9 & 48.37 & 6.38 & 9.56 & 0.8 & - & 520.1 & 0.3 \\
\hline 2.9 & 47.37 & 6.42 & 7.05 & 1.4 & - & 516.7 & 0.3 \\
\hline 1.9 & 46.37 & 6.53 & 5.71 & 1.6 & - & 519.5 & 0.3 \\
\hline
\end{tabular}

\begin{tabular}{|c|c|c|c|c|c|c|c|}
\hline \multicolumn{2}{|c|}{ Hydrolab Quanta } & & \multirow[b]{2}{*}{ L9817 - Hole \#4 } & & \multicolumn{2}{|c|}{ Position: } & \\
\hline L9817 & $1 / 15 / 200512: 00$ & & & & N70 14.011 & W151 19.484 & \\
\hline $\begin{array}{l}\text { Height } \\
\text { Above } \\
\text { Bottom }\end{array}$ & $\begin{array}{l}\text { Sampling } \\
\text { Elevation }\end{array}$ & $\mathrm{pH}$ & $\begin{array}{c}\mathrm{DO} \\
(\mathrm{mg} / \mathrm{L})\end{array}$ & $\begin{array}{l}\text { Temp } \\
\text { ( C ) }\end{array}$ & $\begin{array}{l}\text { Conductivity } \\
\text { (uS } / \mathrm{cm})\end{array}$ & $\begin{array}{c}\text { Conductance } \\
\text { (uS } / \mathrm{cm})\end{array}$ & $\begin{array}{c}\text { Turbidity } \\
\text { (NTU) }\end{array}$ \\
\hline 2.1 & 49.37 & 7.88 & 5.30 & 0.5 & 392.4 & 738.9 & 2.5 \\
\hline 1.1 & 48.37 & 8.16 & 4.92 & 0.1 & 380.3 & 724.9 & 2.0 \\
\hline 0.6 & 47.87 & 8.15 & 4.82 & 0.5 & 379.8 & 714.1 & 9.2 \\
\hline
\end{tabular}

\begin{tabular}{|c|c|c|c|c|c|c|c|}
\hline \multirow{2}{*}{$\begin{array}{l}\text { Troll } \\
\text { L9817 }\end{array}$} & \multirow[b]{2}{*}{ 1/15/2005 15:00 } & & & & \multicolumn{2}{|c|}{ Position: } & \multirow[b]{3}{*}{$\begin{array}{l}\text { Turbidity } \\
\text { (NTU) }\end{array}$} \\
\hline & & & \multicolumn{2}{|c|}{ L9817 - Hole \#2 (Repeat) } & N70 14.071 & W151 19.873 & \\
\hline $\begin{array}{l}\text { Above } \\
\text { Bottom }\end{array}$ & $\begin{array}{l}\text { Sampling } \\
\text { Elevation }\end{array}$ & $\mathrm{pH}$ & $\begin{array}{c}\mathrm{DO} \\
(\mathrm{mg} / \mathrm{L})\end{array}$ & $\begin{array}{l}\text { Temp } \\
\text { ( C ) }\end{array}$ & $\begin{array}{l}\text { Conductivity } \\
\text { (uS/cm) }\end{array}$ & $\begin{array}{l}\text { Conductance } \\
\text { (uS/cm) }\end{array}$ & \\
\hline 3.9 & 49.37 & - & 9.08 & 0.1 & 381.2 & 727.2 & 0.6 \\
\hline 2.9 & 48.37 & - & 8.83 & 0.2 & 381.3 & 724.5 & 0.5 \\
\hline 1.9 & 47.37 & - & 8.63 & 0.5 & 380.6 & 714.8 & 0.5 \\
\hline 0.9 & 46.37 & - & 8.35 & 1.0 & 383.4 & 708.7 & 0.6 \\
\hline
\end{tabular}

\begin{tabular}{|c|c|c|c|c|c|c|c|}
\hline \multicolumn{2}{|c|}{ Hydrolab Quanta } & & & & \multicolumn{2}{|c|}{ Position: } & \\
\hline L9817 & $1 / 15 / 200515: 00$ & & L9817 - Hole \#2 & & N70 14.071 & W151 19.873 & \\
\hline $\begin{array}{c}\text { Height } \\
\text { Above } \\
\text { Bottom }\end{array}$ & $\begin{array}{l}\text { Sampling } \\
\text { Elevation }\end{array}$ & $\mathrm{pH}$ & $\begin{array}{c}\mathrm{DO} \\
(\mathrm{mg} / \mathrm{L})\end{array}$ & $\begin{array}{l}\text { Temp } \\
\text { ( C ) }\end{array}$ & $\begin{array}{l}\text { Conductivity } \\
\text { (uS } / \mathrm{cm})\end{array}$ & $\begin{array}{l}\text { Conductance } \\
\text { (uS/cm) }\end{array}$ & $\begin{array}{l}\text { Turbidity } \\
\text { (NTU) }\end{array}$ \\
\hline 3.9 & 49.37 & 5.41 & 11.35 & 0.0 & - & 554.9 & 0.4 \\
\hline 2.9 & 48.37 & 5.43 & 10.62 & 0.4 & - & 547.6 & 0.4 \\
\hline 1.9 & 47.37 & 5.44 & 10.04 & 0.9 & - & 546.8 & 0.3 \\
\hline 0.9 & 46.37 & 5.46 & 9.80 & 1.2 & - & 544.9 & 0.3 \\
\hline
\end{tabular}

\begin{tabular}{|c|c|c|c|c|c|c|c|}
\hline \multicolumn{2}{|c|}{ Hydrolab Quanta } & & \multirow[b]{2}{*}{ L9817 - Hole \#9 } & & \multicolumn{2}{|c|}{ Position: } & \\
\hline L9817 & $1 / 15 / 200516: 40$ & & & & [No Coords] & & \\
\hline $\begin{array}{l}\text { Height } \\
\text { Above } \\
\text { Bottom }\end{array}$ & $\begin{array}{l}\text { Sampling } \\
\text { Elevation }\end{array}$ & $\mathrm{pH}$ & $\begin{array}{c}\mathrm{DO} \\
(\mathrm{mg} / \mathrm{L})\end{array}$ & $\begin{array}{l}\text { Temp } \\
\text { ( C ) }\end{array}$ & $\begin{array}{l}\text { Conductivity } \\
\text { (uS } / \mathrm{cm})\end{array}$ & $\begin{array}{l}\text { Conductance } \\
\text { (uS } / \mathrm{cm})\end{array}$ & $\begin{array}{c}\text { Turbidity } \\
\text { (NTU) }\end{array}$ \\
\hline 2.2 & 49.37 & 6.98 & 9.11 & -0.3 & - & 635 & - \\
\hline 1.2 & 48.37 & 6.96 & 9.09 & 0.3 & - & 630 & - \\
\hline 0.7 & 47.87 & 6.96 & 8.99 & 0.4 & - & 627 & - \\
\hline
\end{tabular}




\begin{tabular}{|c|c|c|c|c|c|c|c|}
\hline \multicolumn{2}{|c|}{ Hydrolab Quanta } & & \multirow[b]{2}{*}{ L9817 - Hole \#8 } & & \multicolumn{2}{|c|}{ Position: } & \\
\hline L9817 & 1/15/2005 16:40 & & & & [No Coords] & & \\
\hline $\begin{array}{c}\text { Height } \\
\text { Above } \\
\text { Bottom }\end{array}$ & $\begin{array}{l}\text { Sampling } \\
\text { Elevation }\end{array}$ & $\mathrm{pH}$ & $\begin{array}{c}\mathrm{DO} \\
(\mathrm{mg} / \mathrm{L})\end{array}$ & $\begin{array}{l}\text { Temp } \\
\text { ( C ) }\end{array}$ & $\begin{array}{l}\text { Conductivity } \\
\text { (uS/cm) }\end{array}$ & $\begin{array}{c}\text { Conductance } \\
\text { (uS/cm) }\end{array}$ & $\begin{array}{c}\text { Turbidity } \\
\text { (NTU) }\end{array}$ \\
\hline 3.2 & 49.37 & 7.23 & 8.53 & -0.4 & - & 666 & - \\
\hline 2.2 & 48.37 & 7.12 & 8.32 & 0.0 & - & 663 & - \\
\hline 1.2 & 47.37 & 7.06 & 8.15 & 0.4 & - & 660 & - \\
\hline 0.7 & 46.87 & 7.02 & 8.11 & 0.7 & - & 658 & - \\
\hline 0.2 & 46.37 & 6.98 & 8.04 & 0.7 & - & 656 & - \\
\hline
\end{tabular}

\begin{tabular}{|c|c|c|c|c|c|c|c|}
\hline \multicolumn{2}{|c|}{ Hyrdolab Quanta } & & \multirow[b]{2}{*}{ L9817 - Hole \#4 } & & \multicolumn{2}{|c|}{ Position: } & \\
\hline L9817 & 1/15/2005 16:40 & & & & [No Coords] & & \\
\hline $\begin{array}{c}\text { Height } \\
\text { Above } \\
\text { Bottom }\end{array}$ & $\begin{array}{l}\text { Sampling } \\
\text { Elevation }\end{array}$ & $\mathrm{pH}$ & $\begin{array}{c}\mathrm{DO} \\
(\mathrm{mg} / \mathrm{L})\end{array}$ & $\begin{array}{l}\text { Temp } \\
\text { ( C ) }\end{array}$ & $\begin{array}{l}\text { Conductivity } \\
\text { (uS/cm) }\end{array}$ & $\begin{array}{l}\text { Conductance } \\
\text { (uS } / \mathrm{cm})\end{array}$ & $\begin{array}{c}\text { Turbidity } \\
\text { (NTU) }\end{array}$ \\
\hline 2.1 & 49.37 & 7.88 & 5.30 & 0.5 & 392.4 & 738.9 & - \\
\hline 1.1 & 48.37 & 8.16 & 4.92 & 0.1 & 380.3 & 724.9 & - \\
\hline 0.6 & 47.87 & 8.15 & 4.82 & 0.5 & 379.8 & 714.1 & - \\
\hline
\end{tabular}

\begin{tabular}{|c|c|c|c|c|c|c|c|}
\hline \multicolumn{2}{|c|}{ Hydrolab Quanta } & & & & \multicolumn{2}{|c|}{ Position: } & \multirow[b]{3}{*}{$\begin{array}{c}\text { Turbidity } \\
\text { (NTU) }\end{array}$} \\
\hline L9817 & $1 / 15 / 200516: 40$ & & \multicolumn{2}{|c|}{ L9817 - Hole \#3 (repeat) } & N70 14.052 & W151 19.833 & \\
\hline $\begin{array}{l}\text { Above } \\
\text { Bottom }\end{array}$ & $\begin{array}{l}\text { Sampling } \\
\text { Elevation }\end{array}$ & $\mathrm{pH}$ & $\begin{array}{c}\mathrm{DO} \\
(\mathrm{mg} / \mathrm{L})\end{array}$ & $\begin{array}{l}\text { Temp } \\
\text { ( C ) }\end{array}$ & $\begin{array}{l}\text { Conductivity } \\
\text { (uS } / \mathrm{cm})\end{array}$ & $\begin{array}{l}\text { Conductance } \\
\text { (uS } / \mathrm{cm})\end{array}$ & \\
\hline 4.9 & 49.37 & 6.96 & 10.45 & -0.3 & - & 672 & - \\
\hline 3.9 & 48.37 & 6.83 & 10.29 & 0.0 & - & 670 & - \\
\hline 2.9 & 47.37 & 6.83 & 9.65 & 0.3 & - & 667 & - \\
\hline 1.9 & 46.37 & 6.83 & 9.01 & 0.7 & - & 665 & - \\
\hline
\end{tabular}

\begin{tabular}{|c|c|c|c|c|c|c|c|}
\hline Troll & & & & & \multicolumn{2}{|c|}{ Position: } & \\
\hline L9817 & 1/15/2005 16:40 & & L9817 - hole \#3 & & N70 14.052 & W151 19.833 & \\
\hline $\begin{array}{l}\text { Height } \\
\text { Above } \\
\text { Bottom }\end{array}$ & $\begin{array}{l}\text { Sampling } \\
\text { Elevation }\end{array}$ & $\mathrm{pH}$ & $\begin{array}{c}\mathrm{DO} \\
(\mathrm{mg} / \mathrm{L})\end{array}$ & $\begin{array}{l}\text { Temp } \\
\text { ( C ) }\end{array}$ & $\begin{array}{c}\text { Conductivity } \\
\text { (uS } / \mathrm{cm})\end{array}$ & $\begin{array}{c}\text { Conductance } \\
\text { (uS } / \mathrm{cm})\end{array}$ & $\begin{array}{c}\text { Turbidity } \\
\text { (NTU) }\end{array}$ \\
\hline 4.9 & 49.37 & 7.44 & 8.84 & 0.7 & 386.8 & 722.3 & 1.3 \\
\hline 3.9 & 48.37 & 6.85 & 8.9 & 0.4 & 376.6 & 710.9 & 0.5 \\
\hline 2.9 & 47.37 & 7.24 & 8.78 & 0.7 & 367.3 & 685.9 & 0.5 \\
\hline 1.9 & 46.37 & 6.57 & 8.63 & 1.0 & 378.9 & 699.1 & 0.6 \\
\hline 0.9 & 45.37 & 6.7 & 8.23 & 1.4 & 382.3 & 695.1 & 1.2 \\
\hline
\end{tabular}

\begin{tabular}{|c|c|c|c|c|c|c|c|}
\hline \multicolumn{2}{|c|}{ Hydrolab Datasonde } & & \multirow{2}{*}{$\begin{array}{l}\text { (Ice to } 3.6 \text { HAB) } \\
\text { L9817 }\end{array}$} & & \multicolumn{2}{|c|}{ Position: } & \\
\hline L9817 & $2 / 22 / 200511: 34$ & & & & N70 14.073 & W151 20.118 & \\
\hline $\begin{array}{l}\text { Height } \\
\text { Above } \\
\text { Bottom }\end{array}$ & $\begin{array}{l}\text { Sampling } \\
\text { Elevation }\end{array}$ & $\mathrm{pH}$ & $\begin{array}{c}\mathrm{DO} \\
(\mathrm{mg} / \mathrm{L})\end{array}$ & $\begin{array}{l}\text { Temp } \\
\text { ( C ) }\end{array}$ & $\begin{array}{l}\text { Conductivity } \\
\text { (uS } / \mathrm{cm})\end{array}$ & $\begin{array}{l}\text { Conductance } \\
\text { (uS/cm) }\end{array}$ & $\begin{array}{c}\text { Turbidity } \\
\text { (NTU) }\end{array}$ \\
\hline 6.5 & 51.15 & 6.78 & 3.79 & -0.7 & - & 1045.0 & - \\
\hline 5.5 & 50.15 & 6.81 & 3.70 & -0.7 & - & 1040.0 & - \\
\hline 4.5 & 49.15 & 6.78 & 3.68 & -0.7 & - & 1080.0 & - \\
\hline 3.5 & 48.15 & 6.79 & 3.69 & -0.5 & - & 1013.0 & - \\
\hline 2.5 & 47.15 & 6.78 & 3.70 & -0.2 & - & 1008.0 & - \\
\hline 1.5 & 46.15 & 6.79 & 3.43 & 0.3 & - & 1019.0 & - \\
\hline 0.5 & 45.15 & 6.84 & 0.47 & 0.7 & - & 1096.0 & - \\
\hline
\end{tabular}




\begin{tabular}{|c|c|c|c|c|c|c|c|}
\hline Troll & & & (Ice to $3.6 \mathrm{HAB}$ ) & & & sition: & \\
\hline L9817 & $2 / 22 / 200511: 34$ & & L9817 & & N70 14.073 & W151 20.118 & \\
\hline $\begin{array}{l}\text { Height } \\
\text { Above } \\
\text { Bottom }\end{array}$ & $\begin{array}{l}\text { Sampling } \\
\text { Elevation }\end{array}$ & $\mathrm{pH}$ & $\begin{array}{c}\mathrm{DO} \\
(\mathrm{mg} / \mathrm{L})\end{array}$ & $\begin{array}{l}\text { Temp } \\
\text { ( C ) }\end{array}$ & $\begin{array}{l}\text { Conductivity } \\
\text { (uS } / \mathrm{cm})\end{array}$ & $\begin{array}{c}\text { Conductance } \\
\text { (uS/cm) }\end{array}$ & $\begin{array}{c}\text { Turbidity } \\
\text { (NTU) }\end{array}$ \\
\hline 6.5 & 51.15 & 6.69 & 2.68 & 0.3 & 543.6 & 1028.7 & 2.5 \\
\hline 5.5 & 50.15 & 6.74 & 2.39 & 0.2 & 539.3 & 1024.3 & 2.5 \\
\hline 4.5 & 49.15 & 6.77 & 2.18 & 0.1 & 532.4 & 1013.8 & 2.5 \\
\hline 3.5 & 48.15 & 6.79 & 2.05 & 0.1 & 530.9 & 1011.3 & 3.2 \\
\hline 2.5 & 47.15 & 6.82 & 2.06 & 0.3 & 533.1 & 1007.8 & 3.3 \\
\hline 1.5 & 46.15 & 6.81 & 1.8 & 0.7 & 538.2 & 1004.3 & 5 \\
\hline 0.5 & 45.15 & 6.83 & 0.45 & 1.0 & 550.8 & 1016.3 & 15.3 \\
\hline
\end{tabular}

\begin{tabular}{|c|c|c|c|c|c|c|c|}
\hline Troll & & & (Ice to $1.5 \mathrm{HAB}$ ) & & & sition: & \\
\hline L9817 & 2/22/2005 14:19 & & L9817 & & N70 13.997 & W151 19.999 & \\
\hline $\begin{array}{l}\text { Height } \\
\text { Above } \\
\text { Bottom }\end{array}$ & $\begin{array}{l}\text { Sampling } \\
\text { Elevation }\end{array}$ & $\mathrm{pH}$ & $\begin{array}{c}\mathrm{DO} \\
(\mathrm{mg} / \mathrm{L})\end{array}$ & $\begin{array}{l}\text { Temp } \\
\text { ( C ) }\end{array}$ & $\begin{array}{l}\text { Conductivity } \\
\text { (uS } / \mathrm{cm})\end{array}$ & $\begin{array}{l}\text { Conductance } \\
\text { (uS } / \mathrm{cm})\end{array}$ & $\begin{array}{c}\text { Turbidity } \\
\text { (NTU) }\end{array}$ \\
\hline 3.8 & 51.15 & 6.85 & 5.48 & 0.1 & 275.6 & 526.3 & 6.2 \\
\hline 2.8 & 50.15 & 6.8 & 4.77 & 0.1 & 263.4 & 502.8 & 6.1 \\
\hline 1.8 & 49.15 & 6.77 & 4.29 & 0.1 & 257.2 & 491.2 & 7.1 \\
\hline 0.8 & 48.15 & 6.75 & 3.57 & 0.1 & 486.6 & 928.9 & 6.4 \\
\hline-0.2 & 47.15 & 6.77 & 2.17 & 0.1 & 483.6 & 923.2 & 47.2 \\
\hline
\end{tabular}

\begin{tabular}{|c|c|c|c|c|c|c|c|}
\hline Troll & & & & & & sition: & \\
\hline L9817 & 2/22/2005 15:19 & & L9817 & & N70 14.1 & W151 20.365 & \\
\hline $\begin{array}{c}\text { Height } \\
\text { Above } \\
\text { Bottom }\end{array}$ & $\begin{array}{l}\text { Sampling } \\
\text { Elevation }\end{array}$ & $\mathrm{pH}$ & $\begin{array}{c}\mathrm{DO} \\
(\mathrm{mg} / \mathrm{L})\end{array}$ & $\begin{array}{l}\text { Temp } \\
\text { ( C ) }\end{array}$ & $\begin{array}{l}\text { Conductivity } \\
\text { (uS } / \mathrm{cm})\end{array}$ & $\begin{array}{l}\text { Conductance } \\
\text { (uS/cm) }\end{array}$ & $\begin{array}{c}\text { Turbidity } \\
\text { (NTU) }\end{array}$ \\
\hline 1.4 & 47.15 & 6.86 & 10.04 & 0.4 & 413.1 & 778.9 & 4.8 \\
\hline 0.4 & 46.15 & 6.82 & 9.9 & 0.8 & 544.3 & 1010.7 & 13.6 \\
\hline 1.4 & 47.15 & 6.87 & 2.26 & 0.7 & 520.9 & 971.4 & 4.2 \\
\hline 0.4 & 46.15 & 6.85 & 1.7 & 1.1 & 531.7 & 978.6 & 12.6 \\
\hline
\end{tabular}

\begin{tabular}{|c|c|c|c|c|c|c|c|}
\hline Troll & & & & & \multicolumn{2}{|c|}{ Position: } & \\
\hline L9817 & $2 / 22 / 200515: 48$ & & L9817 & & N70 14.048 & W151 20.070 & \\
\hline $\begin{array}{c}\text { Height } \\
\text { Above } \\
\text { Bottom }\end{array}$ & $\begin{array}{l}\text { Sampling } \\
\text { Elevation }\end{array}$ & $\mathrm{pH}$ & $\begin{array}{c}\mathrm{DO} \\
(\mathrm{mg} / \mathrm{L})\end{array}$ & $\begin{array}{l}\text { Temp } \\
\text { ( C ) }\end{array}$ & $\begin{array}{l}\text { Conductivity } \\
\text { (uS/cm) }\end{array}$ & $\begin{array}{l}\text { Conductance } \\
\text { (uS/cm) }\end{array}$ & $\begin{array}{c}\text { Turbidity } \\
\text { (NTU) }\end{array}$ \\
\hline 1.6 & 47.15 & 6.88 & 6.77 & 0.1 & 570 & 1086.5 & 2.3 \\
\hline 1.6 & 47.15 & 6.87 & 4.07 & 0.3 & 573.5 & 1086.9 & 1.5 \\
\hline 0.6 & 46.15 & 6.85 & 2.8 & 0.4 & 567.5 & 1069.3 & 1.9 \\
\hline
\end{tabular}

\begin{tabular}{|c|c|c|c|c|c|c|c|}
\hline \multirow{2}{*}{$\begin{array}{l}\text { Troll } \\
\text { L9817 }\end{array}$} & \multirow[b]{2}{*}{$2 / 22 / 2005$ 16:18 } & & \multirow[b]{2}{*}{ L9817 } & & \multicolumn{2}{|c|}{ Position: } & \\
\hline & & & & & N70 14.030 & W151 20.029 & \\
\hline $\begin{array}{l}\text { Height } \\
\text { Above } \\
\text { Bottom }\end{array}$ & $\begin{array}{l}\text { Sampling } \\
\text { Elevation }\end{array}$ & $\mathrm{pH}$ & $\begin{array}{c}\mathrm{DO} \\
(\mathrm{mg} / \mathrm{L})\end{array}$ & $\begin{array}{l}\text { Temp } \\
\text { ( C ) }\end{array}$ & $\begin{array}{l}\text { Conductivity } \\
\text { (uS } / \mathrm{cm})\end{array}$ & $\begin{array}{l}\text { Conductance } \\
\text { (uS } / \mathrm{cm})\end{array}$ & $\begin{array}{c}\text { Turbidity } \\
\text { (NTU) }\end{array}$ \\
\hline 3.8 & 48.15 & 6.88 & 3.3 & 0.2 & 548.2 & 1041.9 & 3.2 \\
\hline 2.8 & 47.15 & 6.87 & 2.28 & 0.3 & 542.9 & 1028.5 & 3.4 \\
\hline 1.8 & 46.15 & 6.83 & 2.09 & 0.5 & 544.3 & 1022.3 & 3.2 \\
\hline 0.8 & 45.15 & 6.83 & 0.82 & 0.7 & 566.4 & 1056.2 & 3.7 \\
\hline
\end{tabular}




\begin{tabular}{|c|c|c|c|c|c|c|c|}
\hline Troll & & & & & \multicolumn{2}{|c|}{ Position: } & \\
\hline L9817 & 2/22/2005 16:37 & & L9817 & & N70 14.080 & W151 20.223 & \\
\hline $\begin{array}{c}\text { Height } \\
\text { Above } \\
\text { Bottom }\end{array}$ & $\begin{array}{l}\text { Sampling } \\
\text { Elevation }\end{array}$ & $\mathrm{pH}$ & $\begin{array}{c}\mathrm{DO} \\
(\mathrm{mg} / \mathrm{L})\end{array}$ & $\begin{array}{l}\text { Temp } \\
\text { ( C ) }\end{array}$ & $\begin{array}{l}\text { Conductivity } \\
\text { (uS/cm) }\end{array}$ & $\begin{array}{c}\text { Conductance } \\
\text { (uS/cm) }\end{array}$ & $\begin{array}{c}\text { Turbidity } \\
\text { (NTU) }\end{array}$ \\
\hline 2.2 & 50.95 & 6.89 & 2.42 & 0.3 & 532.3 & 1008.8 & 2.9 \\
\hline 1.2 & 49.95 & 6.88 & 2.19 & 0.6 & 536.1 & 1002.6 & 4.2 \\
\hline 0.2 & 48.95 & 6.81 & 1.45 & 0.8 & 551.9 & 1025.9 & 7.6 \\
\hline
\end{tabular}

\begin{tabular}{|l|c|c|c|c|c|c|c|}
\hline Troll & & & & \multicolumn{2}{|c|}{ Position: } \\
\hline L9817 & $3 / 13 / 200510: 56$ & & L9817 Hole 8 & & N70 14.018 & W151 19.805 & \\
\hline $\begin{array}{c}\text { Height } \\
\text { Above }\end{array}$ & Sampling & & DO & Temp & $\begin{array}{c}\text { Conductivity } \\
\text { (uS/cm) }\end{array}$ & $\begin{array}{c}\text { Conductance } \\
\text { (uS/cm) }\end{array}$ & $\begin{array}{c}\text { Turbidity } \\
\text { (NTU) }\end{array}$ \\
\hline 1.35 & 47.01 & 6.78 & 0.59 & 0.3 & 1543 & 2926.4 & 9.1 \\
\hline 0.35 & 46.01 & 6.78 & 0.38 & 0.5 & 1652 & 3107.2 & - \\
\hline
\end{tabular}

\begin{tabular}{|c|c|c|c|c|c|c|c|}
\hline Troll & & & & \multicolumn{2}{|c|}{ Position: } \\
\hline L9817 & $3 / 13 / 200511: 27$ & & L9817 Hole 11 (PH) & & N70 14.113 & W151 20.168 & \\
\hline $\begin{array}{c}\text { Height } \\
\text { Above } \\
\text { Bottom }\end{array}$ & $\begin{array}{c}\text { Sampling } \\
\text { Elevation }\end{array}$ & $\mathrm{pH}$ & $\begin{array}{c}\mathrm{DO} \\
(\mathrm{mg} / \mathrm{L})\end{array}$ & $\begin{array}{c}\text { Temp } \\
(\mathrm{C})\end{array}$ & $\begin{array}{c}\text { Conductivity } \\
\text { (uS/cm) }\end{array}$ & $\begin{array}{c}\text { Conductance } \\
\text { (uS/cm) }\end{array}$ & $\begin{array}{c}\text { Turbidity } \\
\text { (NTU) }\end{array}$ \\
\hline 0.95 & 47.01 & 6.74 & 0.52 & 0.8 & 1274 & 2365.6 & 13.1 \\
\hline-0.05 & 46.01 & 6.76 & 0.12 & 0.7 & 1385 & 2585.5 & - \\
\hline
\end{tabular}

\begin{tabular}{|c|c|c|c|c|c|c|c|}
\hline Troll & & & & & \multicolumn{2}{|c|}{ Position: } & \\
\hline L9817 & 3/13/2005 11:27 & & L9817 Hole 12 (A) & & N70 14.101 & W151 20.027 & \\
\hline $\begin{array}{c}\text { Height } \\
\text { Above } \\
\text { Bottom }\end{array}$ & $\begin{array}{l}\text { Sampling } \\
\text { Elevation }\end{array}$ & $\mathrm{pH}$ & $\begin{array}{c}\mathrm{DO} \\
(\mathrm{mg} / \mathrm{L})\end{array}$ & $\begin{array}{l}\text { Temp } \\
\text { ( C ) }\end{array}$ & $\begin{array}{l}\text { Conductivity } \\
\text { (uS } / \mathrm{cm})\end{array}$ & $\begin{array}{l}\text { Conductance } \\
\text { (uS/cm) }\end{array}$ & $\begin{array}{c}\text { Turbidity } \\
\text { (NTU) }\end{array}$ \\
\hline 2.35 & 47.01 & 6.76 & 0.66 & 0.2 & 1700 & 3226.5 & 6 \\
\hline 1.35 & 46.01 & 6.77 & 0.59 & 0.5 & 1726 & 3248.7 & 8.3 \\
\hline 0.35 & 45.01 & 6.82 & 0.34 & 0.7 & 1996 & 3722.1 & - \\
\hline
\end{tabular}

\begin{tabular}{|c|c|c|c|c|c|c|c|}
\hline Troll & & & & & & sition: & \\
\hline L9817 & 3/13/2005 13:27 & & L9817 Hole 13 & & N70 14.103 & W151 19.88 & \\
\hline $\begin{array}{c}\text { Height } \\
\text { Above } \\
\text { Bottom }\end{array}$ & $\begin{array}{l}\text { Sampling } \\
\text { Elevation }\end{array}$ & $\mathrm{pH}$ & $\begin{array}{c}\mathrm{DO} \\
(\mathrm{mg} / \mathrm{L})\end{array}$ & $\begin{array}{l}\text { Temp } \\
\text { ( C ) }\end{array}$ & $\begin{array}{l}\text { Conductivity } \\
\text { (uS } / \mathrm{cm})\end{array}$ & $\begin{array}{l}\text { Conductance } \\
\text { (uS/cm) }\end{array}$ & $\begin{array}{c}\text { Turbidity } \\
\text { (NTU) }\end{array}$ \\
\hline 2.45 & 47.01 & 6.78 & 0.32 & 0.3 & 1470 & 2778.9 & 16.5 \\
\hline 1.45 & 46.01 & 6.75 & 0.26 & 0.4 & 1616 & 3050.4 & 11.7 \\
\hline 0.45 & 45.01 & 6.73 & 0.26 & 0.5 & 1801 & 3385.0 & - \\
\hline
\end{tabular}

\begin{tabular}{|l|c|c|c|c|c|c|c|}
\hline Troll & & & & \multicolumn{2}{|c|}{ Position: } \\
\hline L9817 & $3 / 13 / 200511: 44$ & & L9817 Hole 2 & & N70 14.071 & W151 19.870 & \\
\hline $\begin{array}{c}\text { Height } \\
\text { Above }\end{array}$ & Sampling & & DO & Temp & Conductivity & Conductance \\
Bottom & Elevation & $\mathrm{pH}$ & $\begin{array}{c}\text { ( } \mathrm{mg} / \mathrm{L}) \\
\text { (uS/cm) }\end{array}$ & $\begin{array}{c}\text { Turbidity } \\
\text { (NTU) }\end{array}$ \\
\hline 1.8 & 47.01 & 6.72 & 0.65 & 0.6 & 1093 & 2048.4 & 6.7 \\
\hline 0.8 & 46.01 & 6.73 & 0.44 & 0.6 & 1212 & 2273.9 & 9.2 \\
\hline
\end{tabular}




\begin{tabular}{|c|c|c|c|c|c|c|c|}
\hline Troll & & & & & \multicolumn{2}{|c|}{ Position: } & \\
\hline L9817 & $3 / 13 / 2005$ 12:12 & & L9817 Hole 3 & & N70 14.029 & W151 19.792 & \\
\hline $\begin{array}{c}\text { Height } \\
\text { Above } \\
\text { Bottom }\end{array}$ & $\begin{array}{l}\text { Sampling } \\
\text { Elevation }\end{array}$ & $\mathrm{pH}$ & $\begin{array}{c}\mathrm{DO} \\
(\mathrm{mg} / \mathrm{L})\end{array}$ & $\begin{array}{l}\text { Temp } \\
\text { ( C ) }\end{array}$ & $\begin{array}{l}\text { Conductivity } \\
\text { (uS/cm) }\end{array}$ & $\begin{array}{l}\text { Conductance } \\
\text { (uS/cm) }\end{array}$ & $\begin{array}{c}\text { Turbidity } \\
\text { (NTU) }\end{array}$ \\
\hline 3.1 & 47.01 & 6.72 & 0.4 & 0.2 & 1352 & 2568.8 & 10.1 \\
\hline 2.1 & 46.01 & 6.72 & 0.17 & 0.5 & 1372 & 2580.6 & 12.1 \\
\hline 1.1 & 45.01 & 6.74 & 0.11 & 0.7 & 1449 & 2705.9 & 11.4 \\
\hline 1.1 & 45.01 & 6.75 & 0.31 & 0.7 & 1499 & 2800.3 & 9.6 \\
\hline
\end{tabular}

\begin{tabular}{|l|c|c|c|c|c|c|c|}
\hline Troll & & & & \multicolumn{2}{|c|}{ Position: } \\
\hline L9817 & $3 / 13 / 200512: 51$ & & L9817 Hole 4 & & N70 14.018 & W151 19.805 & \\
\hline $\begin{array}{c}\text { Height } \\
\text { Above } \\
\text { Bottom }\end{array}$ & $\begin{array}{c}\text { Sampling } \\
\text { Elevation }\end{array}$ & $\mathrm{pH}$ & $\begin{array}{c}\text { DO } \\
\text { (mg/L) }\end{array}$ & $\begin{array}{c}\text { Temp } \\
(\mathrm{C})\end{array}$ & $\begin{array}{c}\text { Conductivity } \\
\text { (uS/cm) }\end{array}$ & $\begin{array}{c}\text { Conductance } \\
\text { (uS/cm) }\end{array}$ & $\begin{array}{c}\text { Turbidity } \\
\text { (NTU) }\end{array}$ \\
\hline 0.6 & 48.01 & 6.81 & 0.38 & 0.3 & 1472 & 2791.7 & 7.9 \\
\hline
\end{tabular}

\begin{tabular}{|l|c|c|c|c|c|c|c|}
\hline Troll & & & & \multicolumn{2}{|c|}{ Position: } \\
\hline $\begin{array}{c}\text { L9817 } \\
\text { Height }\end{array}$ & $3 / 13 / 200512: 51$ & & L9817 Hole 9 & & N70 14.042 & W151 20.158 & \\
$\begin{array}{c}\text { Above } \\
\text { Bottom }\end{array}$ & $\begin{array}{c}\text { Sampling } \\
\text { Elevation }\end{array}$ & $\mathrm{pH}$ & $\begin{array}{c}\text { DO } \\
(\mathrm{mg} / \mathrm{L})\end{array}$ & $\begin{array}{c}\text { Temp } \\
(\mathrm{C})\end{array}$ & $\begin{array}{c}\text { Conductivity } \\
\text { (uS/cm) }\end{array}$ & $\begin{array}{c}\text { Conductance } \\
\text { (uS/cm) }\end{array}$ & $\begin{array}{c}\text { Turbidity } \\
\text { (NTU) }\end{array}$ \\
\hline 0 & 47.01 & 6.71 & 0.54 & 0.2 & 1284 & 2443.1 & - \\
\hline
\end{tabular}

\begin{tabular}{|c|c|c|c|c|c|c|c|}
\hline Troll & & & & & \multicolumn{2}{|c|}{ Position: } & \\
\hline L9817 & $3 / 13 / 2005$ 18:27 & & L9817 Hole 1 & & N70 14.09 & W151 19.929 & \\
\hline $\begin{array}{c}\text { Height } \\
\text { Above } \\
\text { Bottom }\end{array}$ & $\begin{array}{l}\text { Sampling } \\
\text { Elevation }\end{array}$ & $\mathrm{pH}$ & $\begin{array}{c}\mathrm{DO} \\
(\mathrm{mg} / \mathrm{L})\end{array}$ & $\begin{array}{l}\text { Temp } \\
\text { ( C ) }\end{array}$ & $\begin{array}{l}\text { Conductivity } \\
\text { (uS } / \mathrm{cm})\end{array}$ & $\begin{array}{l}\text { Conductance } \\
\text { (uS } / \mathrm{cm})\end{array}$ & $\begin{array}{c}\text { Turbidity } \\
\text { (NTU) }\end{array}$ \\
\hline 2.4 & 47.01 & 6.68 & 0.42 & 0.3 & 897 & 1697.5 & 8.4 \\
\hline 1.4 & 46.01 & 6.66 & 0.23 & 0.5 & 916.4 & 1720.5 & 10.4 \\
\hline 0.4 & 45.01 & 6.78 & 0.19 & 0.9 & 973.7 & 1806.7 & 34.7 \\
\hline
\end{tabular}

\begin{tabular}{|c|c|c|c|c|c|c|c|}
\hline Troll & & & & & & sition: & \\
\hline L9817 & 3/13/2005 18:39 & & L9817 Hole 14 & & N70 14.114 & W151 19.835 & \\
\hline $\begin{array}{c}\text { Height } \\
\text { Above } \\
\text { Bottom }\end{array}$ & $\begin{array}{l}\text { Sampling } \\
\text { Elevation }\end{array}$ & $\mathrm{pH}$ & $\begin{array}{c}\mathrm{DO} \\
(\mathrm{mg} / \mathrm{L})\end{array}$ & $\begin{array}{l}\text { Temp } \\
\text { ( C ) }\end{array}$ & $\begin{array}{l}\text { Conductivity } \\
\text { (uS } / \mathrm{cm})\end{array}$ & $\begin{array}{l}\text { Conductance } \\
\text { (uS } / \mathrm{cm})\end{array}$ & $\begin{array}{c}\text { Turbidity } \\
\text { (NTU) }\end{array}$ \\
\hline 2.5 & 47.06 & 6.74 & 0.43 & 0.5 & 977 & 1837 & 9.9 \\
\hline 1.5 & 46.06 & 6.72 & 0.42 & 0.5 & 1030 & 1939 & 7.1 \\
\hline 0.5 & 45.06 & 6.8 & 0.31 & 0.7 & 1061 & 1979 & 12.5 \\
\hline-0.5 & 44.06 & 7.08 & 0.19 & 0.9 & 1063 & 1970 & - \\
\hline
\end{tabular}




\section{APPENDIX K: ANION CONCENTRATIONS}

The following tables report the anion concentrations as determined by from WERC laboratory analysis of water samples collected at study lakes. These samples were collected during the Phase 1 portion of the North Slope Lakes project. Most samples represent a collection point halfway between the bottom of ice and the lake bottom. Exceptions would include summer samples taken near shore during ice-free conditions.

Table K-1. Measured anion concentrations at lake K113C. Table K-2. Measured anion concentrations at lake K203C Table K-3. Measured anion concentrations at lake K209P. Table K-4. Measured anion concentrations at lake K214P. Table K-5. Measured anion concentrations at lake L9312P. Table K-6. Measured anion concentrations at lake L9817P. 
Table K-1. Measured anion concentrations at lake K113C. Idl= lower than detection level. Lab detection level for nitrite and nitrate $=0.625 \mathrm{ppm}$, phosphate $=2.5 \mathrm{ppm}$. Standard deviations are given where multiple concentration readings were available.

\begin{tabular}{|c|c|c|c|c|c|c|c|c|c|}
\hline \multirow[b]{2}{*}{ Date } & \multicolumn{3}{|c|}{ Nitrite - $\left(\mathrm{NO}_{2}^{-}\right) \mathrm{ppm}$} & \multicolumn{3}{|c|}{ Nitrate - $\left(\mathrm{NO}_{3}^{-}\right) \mathrm{ppm}$} & \multicolumn{3}{|c|}{ Phosphate - $\left(\mathrm{PO}_{4}{ }^{3-}\right) \mathrm{ppm}$} \\
\hline & Mean & $\begin{array}{l}\text { Std. } \\
\text { Dev. }\end{array}$ & Samples & Mean & $\begin{array}{l}\text { Std. } \\
\text { Dev. }\end{array}$ & Samples & Mean & $\begin{array}{l}\text { Std. } \\
\text { Dev. }\end{array}$ & Samples \\
\hline $2 / 26 / 2003$ & $\mathrm{ldl}$ & - & 2 & 4.000 & 0.28 & 2 & Idl & - & 2 \\
\hline $5 / 14 / 2003$ & Idl & - & 2 & 9.400 & 1.27 & 2 & Idl & - & 2 \\
\hline $7 / 24 / 2003$ & Idl & - & 2 & 4.200 & 0.14 & 2 & Idl & - & 2 \\
\hline $11 / 8 / 2003$ & Idl & - & 1 & Idl & - & 1 & Idl & - & 1 \\
\hline $1 / 20 / 2004$ & Idl & - & 1 & Idl & - & 1 & Idl & - & 1 \\
\hline $3 / 19 / 2004$ & 1.683 & 0.18 & 2 & 0.910 & - & 1 & 3.970 & - & 1 \\
\hline $5 / 14 / 2004$ & Idl & - & 2 & Idl & - & 1 & Idl & - & 2 \\
\hline $7 / 13 / 2004$ & Idl & - & 1 & Idl & - & 1 & Idl & - & 1 \\
\hline $12 / 8 / 2004$ & - & - & - & Idl & - & 2 & Idl & - & 2 \\
\hline $1 / 19 / 2005$ & - & - & - & Idl & - & 2 & Idl & - & 2 \\
\hline $3 / 16 / 2005$ & Idl & & & Idl & & & Idl & & \\
\hline $5 / 22 / 2005$ & Idl & - & 2 & Idl & - & 2 & Idl & - & 2 \\
\hline $8 / 5 / 2005$ & Idl & - & 2 & Idl & - & 2 & Idl & - & 2 \\
\hline
\end{tabular}

Table K-2. Measured anion concentrations at lake K203C. Idl= lower than detection level. Lab detection level for nitrite and nitrate $=0.625 \mathrm{ppm}$, phosphate $=2.5 \mathrm{ppm}$. Standard deviations are given where multiple concentration readings were available.

\begin{tabular}{|c|c|c|c|c|c|c|c|c|c|}
\hline \multirow[b]{2}{*}{ Date } & \multicolumn{3}{|c|}{ Nitrite - $\left(\mathrm{NO}_{2}^{-}\right) \mathrm{ppm}$} & \multicolumn{3}{|c|}{ Nitrate - $\left(\mathrm{NO}_{3}^{-}\right) \mathrm{ppm}$} & \multicolumn{3}{|c|}{ Phosphate - $\left(\mathrm{PO}_{4}^{3-}\right) \mathrm{ppm}$} \\
\hline & Mean & $\begin{array}{l}\text { Std. } \\
\text { Dev. }\end{array}$ & Samples & Mean & $\begin{array}{l}\text { Std. } \\
\text { Dev. }\end{array}$ & Samples & Mean & $\begin{array}{l}\text { Std. } \\
\text { Dev. }\end{array}$ & Samples \\
\hline $2 / 23 / 2003$ & Idl & - & 3 & 3.600 & 0.10 & 3 & Idl & - & 3 \\
\hline $5 / 13 / 2003$ & Idl & - & 1 & 8.400 & - & 1 & Idl & - & 1 \\
\hline $6 / 1 / 2003$ & Idl & - & 3 & 4.567 & 0.65 & 3 & Idl & - & 3 \\
\hline $8 / 5 / 2003$ & Idl & - & 1 & 4.250 & - & 1 & Idl & - & 1 \\
\hline $1 / 16 / 2004$ & Idl & - & 1 & Idl & - & 1 & Idl & - & 1 \\
\hline $5 / 12 / 2004$ & Idl & - & 2 & 3.290 & 4.65 & 2 & 1.250 & 1.77 & 2 \\
\hline
\end{tabular}


Table K-3. Measured anion concentrations at lake K209P. Idl= lower than detection level. Lab detection level for nitrite and nitrate $=0.625 \mathrm{ppm}$, phosphate $=2.5 \mathrm{ppm}$. Standard deviations are given where multiple concentration readings were available.

\begin{tabular}{|c|c|c|c|c|c|c|c|c|c|}
\hline \multirow[b]{2}{*}{ Date } & \multicolumn{3}{|c|}{ Nitrite - $\left(\mathrm{NO}_{2}^{-}\right) \mathrm{ppm}$} & \multicolumn{3}{|c|}{ Nitrate - $\left(\mathrm{NO}_{3}^{-}\right) \mathrm{ppm}$} & \multicolumn{3}{|c|}{ Phosphate - $\left(\mathrm{PO}_{4}{ }^{3-}\right) \mathrm{ppm}$} \\
\hline & Mean & $\begin{array}{l}\text { Std. } \\
\text { Dev. }\end{array}$ & Samples & Mean & $\begin{array}{l}\text { Std. } \\
\text { Dev. }\end{array}$ & Samples & Mean & $\begin{array}{l}\text { Std. } \\
\text { Dev. }\end{array}$ & Samples \\
\hline $\begin{array}{c}12 / 14 / 200 \\
2\end{array}$ & Idl & - & 1 & 3.640 & - & 1 & Idl & - & 1 \\
\hline $2 / 26 / 2003$ & Idl & - & 3 & 4.150 & 0.05 & 3 & Idl & - & 1 \\
\hline $5 / 15 / 2003$ & Idl & - & 3 & $\begin{array}{c}10.00 \\
0\end{array}$ & 0.17 & 3 & Idl & - & 3 \\
\hline $6 / 1 / 2003$ & Idl & - & 3 & 5.000 & 0.92 & 3 & Idl & - & 3 \\
\hline $8 / 6 / 2003$ & Idl & - & 1 & 5.000 & - & 1 & Idl & - & 1 \\
\hline $7 / 15 / 2004$ & Idl & - & 2 & Idl & - & 2 & Idl & - & 2 \\
\hline $12 / 9 / 2004$ & Idl & - & 2 & Idl & - & 2 & Idl & - & 2 \\
\hline $1 / 19 / 2005$ & Idl & - & 2 & Idl & - & 2 & Idl & - & 2 \\
\hline
\end{tabular}

Table K-4. Measured anion concentrations at lake K214P. Idl= lower than detection level. Lab detection level for nitrite and nitrate $=0.625 \mathrm{ppm}$, phosphate $=2.5 \mathrm{ppm}$. Standard deviations are given where multiple concentration readings were available.

\begin{tabular}{|c|c|c|c|c|c|c|c|c|c|}
\hline \multirow[b]{2}{*}{ Date } & \multicolumn{3}{|c|}{ Nitrite - $\left(\mathrm{NO}_{2}^{-}\right) \mathrm{ppm}$} & \multicolumn{3}{|c|}{ Nitrate - $\left(\mathrm{NO}_{3}^{-}\right) \mathrm{ppm}$} & \multicolumn{3}{|c|}{ Phosphate - $\left(\mathrm{PO}_{4}{ }^{3-}\right) \mathrm{ppm}$} \\
\hline & Mean & $\begin{array}{l}\text { Std. } \\
\text { Dev. }\end{array}$ & Samples & Mean & $\begin{array}{l}\text { Std. } \\
\text { Dev. }\end{array}$ & Samples & Mean & $\begin{array}{l}\text { Std. } \\
\text { Dev. }\end{array}$ & Samples \\
\hline $\begin{array}{c}12 / 16 / 200 \\
2\end{array}$ & $|d|$ & - & 2 & 3.745 & 0.29 & 2 & Idl & - & 2 \\
\hline $2 / 25 / 2003$ & Idl & - & 2 & 4.400 & 0.14 & 2 & Idl & - & 2 \\
\hline $5 / 14 / 2003$ & Idl & - & 2 & 8.550 & 0.92 & 2 & Idl & - & 2 \\
\hline $6 / 25 / 2003$ & Idl & - & 2 & 5.150 & 0.07 & 2 & Idl & - & 2 \\
\hline $11 / 7 / 2003$ & Idl & - & 2 & Idl & - & 2 & Idl & - & 2 \\
\hline $1 / 19 / 2004$ & Idl & - & 2 & Idl & - & 2 & Idl & - & 2 \\
\hline $3 / 19 / 2004$ & Idl & - & 2 & Idl & - & 2 & Idl & - & 2 \\
\hline $5 / 12 / 2004$ & Idl & - & 3 & 6.030 & 4.41 & 3 & Idl & - & 5 \\
\hline $12 / 3 / 2004$ & - & - & - & 0.815 & 1.15 & 2 & Idl & - & 2 \\
\hline $1 / 18 / 2005$ & - & - & - & Idl & - & 2 & Idl & - & 2 \\
\hline $3 / 16 / 2005$ & Idl & - & 2 & Idl & - & 2 & Idl & - & 2 \\
\hline
\end{tabular}


Table K-5. Measured anion concentrations at lake L9312P. Idl= lower than detection level. Lab detection level for nitrite and nitrate $=0.625 \mathrm{ppm}$, phosphate $=2.5 \mathrm{ppm}$. Standard deviations are given where multiple concentration readings were available.

\begin{tabular}{|c|c|c|c|c|c|c|c|c|c|}
\hline \multirow[b]{2}{*}{ Date } & \multicolumn{3}{|c|}{ Nitrite - $\left(\mathrm{NO}_{2}^{-}\right) \mathrm{ppm}$} & \multicolumn{3}{|c|}{ Nitrate - $\left(\mathrm{NO}_{3}^{-}\right) \mathrm{ppm}$} & \multicolumn{3}{|c|}{ Phosphate - $\left(\mathrm{PO}_{4}{ }^{3-}\right) \mathrm{ppm}$} \\
\hline & Mean & $\begin{array}{l}\text { Std. } \\
\text { Dev. }\end{array}$ & Samples & Mean & $\begin{array}{l}\text { Std. } \\
\text { Dev. }\end{array}$ & Samples & Mean & $\begin{array}{l}\text { Std. } \\
\text { Dev. }\end{array}$ & Samples \\
\hline $3 / 23 / 2004$ & Idl & - & 1 & 5.565 & 7.87 & 2 & Idl & - & 1 \\
\hline $5 / 13 / 2004$ & - & - & - & - & - & - & Idl & - & 2 \\
\hline $12 / 5 / 2004$ & - & - & - & Idl & - & 1 & Idl & - & 1 \\
\hline $1 / 16 / 2005$ & - & - & - & Idl & - & - & Idl & - & - \\
\hline $2 / 23 / 2005$ & Idl & - & 5 & Idl & - & 5 & Idl & - & 5 \\
\hline $3 / 14 / 2005$ & Idl & - & 2 & Idl & - & 2 & Idl & - & 2 \\
\hline $4 / 21 / 2005$ & Idl & - & 2 & Idl & - & 2 & Idl & - & 2 \\
\hline $5 / 21 / 2005$ & Idl & - & 2 & Idl & - & 2 & Idl & - & 2 \\
\hline $8 / 2 / 2005$ & Idl & - & 2 & Idl & - & 2 & Idl & - & 2 \\
\hline
\end{tabular}

Table K-6. Measured anion concentrations at lake L9817P. Idl= lower than detection level. Lab detection level for nitrite and nitrate $=0.625 \mathrm{ppm}$, phosphate $=2.5 \mathrm{ppm}$. Standard deviations are given where multiple concentration readings were available.

\begin{tabular}{|c|c|c|c|c|c|c|c|c|c|}
\hline \multirow[b]{2}{*}{ Date } & \multicolumn{3}{|c|}{ Nitrite - $\left(\mathrm{NO}_{2}^{-}\right) \mathrm{ppm}$} & \multicolumn{3}{|c|}{ Nitrate $-\left(\mathrm{NO}_{3}{ }^{-}\right) \mathrm{ppm}$} & \multicolumn{3}{|c|}{ Phosphate - $\left(\mathrm{PO}_{4}{ }^{3-}\right) \mathrm{ppm}$} \\
\hline & Mean & $\begin{array}{l}\text { Std. } \\
\text { Dev. }\end{array}$ & Samples & Mean & $\begin{array}{l}\text { Std. } \\
\text { Dev. }\end{array}$ & Samples & Mean & $\begin{array}{l}\text { Std. } \\
\text { Dev. }\end{array}$ & Samples \\
\hline $3 / 28 / 2004$ & Idl & - & 1 & Idl & - & 1 & Idl & - & 1 \\
\hline $4 / 28 / 2004$ & - & - & - & - & - & - & Idl & - & 3 \\
\hline $7 / 19 / 2004$ & Idl & - & 2 & Idl & - & 2 & Idl & - & 2 \\
\hline $12 / 6 / 2004$ & - & - & - & - & - & - & ldl & - & 2 \\
\hline $1 / 15 / 2005$ & - & - & - & - & - & - & Idl & - & 2 \\
\hline $2 / 22 / 2005$ & Idl & - & 2 & Idl & - & 2 & Idl & - & 2 \\
\hline $3 / 13 / 2005$ & Idl & - & 2 & Idl & - & 2 & Idl & - & 2 \\
\hline $4 / 1 / 2005$ & Idl & - & 2 & Idl & - & 2 & Idl & - & 2 \\
\hline
\end{tabular}




\section{APPENDIX L: DISSOLVED AND TOTAL CARBON CONCENTRATIONS}

The following tables report the dissolved and total carbon concentrations as determined by from WERC laboratory analysis of water samples collected at study lakes. These samples were collected during the Phase 1 portion of the North Slope Lakes project. Most samples represent a collection point halfway between the bottom of ice and the lake bottom. Exceptions would include summer samples taken near shore during ice-free conditions.

Table L-1. Measured dissolved and total carbon concentrations at lake K113C. Table L-2. Measured dissolved and total carbon concentrations at lake K203C. Table L-3. Measured dissolved and total carbon concentrations at lake K209P. Table L-4. Measured dissolved and total carbon concentrations at lake K214P. Table L-5. Measured dissolved and total carbon concentrations at lake L9312P. Table L-6. Measured dissolved and total carbon concentrations at lake L9817P. 
Table L-1. Measured dissolved and total carbon concentrations at lake K113C. Standard deviations are given where multiple concentration readings were available.

\begin{tabular}{|c|c|c|c|c|c|c|c|}
\hline \multirow{2}{*}{ Date } & \multirow{2}{*}{ Sample ID } & \multicolumn{3}{|c|}{$\begin{array}{c}\text { Dissolved Organic Carbon } \\
\text { (ppm) }\end{array}$} & \multicolumn{3}{|c|}{ Total Organic Carbon (ppm) } \\
\hline & & Mean & $\begin{array}{l}\text { Std. } \\
\text { Dev. }\end{array}$ & Samples & Mean & $\begin{array}{l}\text { Std. } \\
\text { Dev. }\end{array}$ & Samples \\
\hline $2 / 26 / 2003$ & K113 & 22.00 & 0.71 & 2 & 22.05 & 0.78 & 2 \\
\hline $5 / 13 / 2003$ & K113 & 15.08 & 4.70 & 2 & 19.50 & - & 1 \\
\hline $1 / 20 / 2004$ & K113 & 7.01 & 2.88 & 4 & - & - & - \\
\hline $3 / 19 / 2004$ & K113 & 14.71 & 5.67 & 4 & - & - & - \\
\hline $5 / 14 / 2004$ & K113 & 16.32 & 2.93 & 6 & - & - & - \\
\hline $7 / 13 / 2004$ & K113 & 5.41 & 2.29 & 7 & - & - & - \\
\hline $12 / 8 / 2004$ & K113-(Raft) & 12.41 & - & 1 & 12.41 & - & 1 \\
\hline $1 / 19 / 2005$ & $\mathrm{~K} 113$ & 15.90 & 0.37 & 2 & 16.22 & 0.12 & 2 \\
\hline $3 / 16 / 2005$ & K113-(Raft) & 27.85 & - & 1 & 28.84 & - & 1 \\
\hline $5 / 22 / 2005$ & $\mathrm{~K} 113$ & 36.18 & 2.53 & 2 & 37.12 & 1.13 & 2 \\
\hline $8 / 5 / 2005$ & K113-(Shore) & 4.80 & - & 1 & 7.80 & - & 1 \\
\hline
\end{tabular}

Table L-2. Measured dissolved and total carbon concentrations at lake K203C. Standard deviations are given where multiple concentration readings were available.

\begin{tabular}{|c|c|c|c|c|c|c|c|}
\hline \multirow{2}{*}{ Date } & \multirow{2}{*}{ Sample ID } & \multicolumn{3}{|c|}{$\begin{array}{c}\text { Dissolved Organic Carbon } \\
\text { (ppm) } \\
\text { Std. }\end{array}$} & \multicolumn{3}{c|}{ Total Organic Carbon (ppm) } \\
& & Mean & Dev. & Samples & Mean & \multicolumn{2}{c|}{ Std. } \\
Dev. & Samples \\
\hline $2 / 23 / 2003$ & $\mathrm{~K} 203$ & 14.45 & 0.07 & 2 & 14.75 & 0.64 & 2 \\
\hline $5 / 13 / 2003$ & $\mathrm{~K} 203$ & 21.50 & - & 1 & 26.20 & - & 1 \\
\hline $1 / 16 / 2004$ & $\mathrm{~K} 203$ & 15.01 & 1.84 & 3 & - & - & - \\
\hline $5 / 12 / 2004$ & $\mathrm{~K} 203$ & 15.43 & 8.12 & 3 & - & - & - \\
\hline
\end{tabular}

Table L-3. Measured dissolved and total carbon concentrations at lake K209P. Standard deviations are given where multiple concentration readings were available.

\begin{tabular}{|c|c|c|c|c|c|c|c|}
\hline \multirow{2}{*}{ Date } & \multirow{2}{*}{ Sample ID } & \multicolumn{3}{|c|}{$\begin{array}{l}\text { Dissolved Organic Carbon } \\
(\text { (ppm) }\end{array}$} & \multicolumn{3}{|c|}{ Total Organic Carbon (ppm) } \\
\hline & & Mean & $\begin{array}{l}\text { Std. } \\
\text { Dev. }\end{array}$ & Samples & Mean & $\begin{array}{l}\text { Std. } \\
\text { Dev. }\end{array}$ & Samples \\
\hline $\begin{array}{c}12 / 14 / 200 \\
2\end{array}$ & K209 & 13.90 & - & 1 & 13.10 & - & 1 \\
\hline $2 / 26 / 2003$ & K209 & 12.65 & 0.07 & 2 & 12.70 & 0.14 & 2 \\
\hline $5 / 15 / 2003$ & K209 & 20.45 & 2.90 & 2 & 24.45 & 2.90 & 2 \\
\hline $12 / 3 / 2004$ & K209 & 16.58 & 0.56 & 2 & 15.55 & 0.84 & 2 \\
\hline $1 / 19 / 2004$ & K209 & 5.92 & 0.03 & 3 & - & - & - \\
\hline $7 / 15 / 2004$ & K209 & 4.61 & 1.26 & 5 & - & - & - \\
\hline $1 / 19 / 2005$ & K209 & 25.66 & 0.28 & 2 & 25.88 & 0.14 & 2 \\
\hline
\end{tabular}


Table L-4. Measured dissolved and total carbon concentrations at lake K214P. Standard deviations are given where multiple concentration readings were available.

\begin{tabular}{|c|c|c|c|c|c|c|c|}
\hline \multirow{2}{*}{ Date } & \multirow{2}{*}{ Sample ID } & \multicolumn{3}{|c|}{$\begin{array}{c}\text { Dissolved Organic Carbon } \\
(\mathrm{ppm})\end{array}$} & \multicolumn{3}{|c|}{ Total Organic Carbon (ppm) } \\
\hline & & Mean & $\begin{array}{l}\text { Std. } \\
\text { Dev. }\end{array}$ & Samples & Mean & $\begin{array}{l}\text { Std. } \\
\text { Dev. }\end{array}$ & Samples \\
\hline $\begin{array}{c}12 / 16 / 200 \\
2\end{array}$ & $\mathrm{~K} 214$ & 9.20 & - & 1 & 8.90 & - & 1 \\
\hline $2 / 25 / 2003$ & K214 & 11.75 & 0.64 & 2 & 11.80 & 0.42 & 2 \\
\hline $5 / 14 / 2003$ & K214 & 20.25 & 1.75 & 3 & 23.40 & 0.90 & 3 \\
\hline $1 / 19 / 2004$ & K214 & 9.30 & 3.58 & 4 & - & - & - \\
\hline $3 / 19 / 2004$ & K214 & 17.93 & 2.55 & 2 & - & - & - \\
\hline $5 / 12 / 2004$ & K214 & 21.24 & 7.22 & 6 & - & - & - \\
\hline $7 / 14 / 2004$ & K214 & 1.84 & 1.85 & 7 & - & - & - \\
\hline $12 / 3 / 2004$ & K214 & 12.38 & 0.06 & 2 & 12.59 & 0.29 & 2 \\
\hline $1 / 18 / 2005$ & K214 & 18.80 & 0.33 & 2 & 17.38 & 0.97 & 2 \\
\hline
\end{tabular}

Table L-5. Measured dissolved and total carbon concentrations at lake L9312P. Standard deviations are given where multiple concentration readings were available.

\begin{tabular}{|c|c|c|c|c|c|c|c|}
\hline \multirow{2}{*}{ Date } & \multirow{2}{*}{ Sample ID } & \multicolumn{3}{|c|}{$\begin{array}{l}\text { Dissolved Organic Carbon } \\
(\mathrm{ppm})\end{array}$} & \multicolumn{3}{|c|}{$\begin{array}{c}\text { Total Organic Carbon } \\
\text { (ppm) }\end{array}$} \\
\hline & & Mean & $\begin{array}{l}\text { Std. } \\
\text { Dev. }\end{array}$ & Samples & Mean & $\begin{array}{l}\text { Std. } \\
\text { Dev. }\end{array}$ & Samples \\
\hline $3 / 23 / 2004$ & L9312 & 5.42 & 0.31 & 3 & & & \\
\hline $5 / 13 / 2004$ & L9312 & 4.45 & 3.83 & 4 & & & \\
\hline $7 / 17 / 2004$ & L9312 & 1.45 & 1.74 & 4 & & & \\
\hline $8 / 17 / 2004$ & L9312 & 3.43 & 4.49 & 7 & 5.64 & 9.67 & 5 \\
\hline $12 / 5 / 2004$ & L9312 & 7.81 & 0.99 & 2 & 6.33 & 0.08 & 2 \\
\hline $1 / 16 / 2005$ & L9312 & 8.31 & 0.44 & 2 & 7.55 & 0.30 & 2 \\
\hline $2 / 23 / 2005$ & L9312 & 7.64 & 0.06 & 2 & 7.97 & 0.42 & 2 \\
\hline $3 / 14 / 2005$ & L9312 & 7.18 & 1.41 & 2 & 8.22 & 0.04 & 2 \\
\hline $4 / 21 / 2005$ & L9312 & 6.84 & 0.56 & 2 & 7.22 & 0.19 & 2 \\
\hline $5 / 21 / 2005$ & L9312 & 9.24 & 0.09 & 2 & 9.33 & 0.42 & 2 \\
\hline $8 / 5 / 2005$ & L9312 (Shore) & 6.88 & - & 1 & 17.07 & - & 1 \\
\hline
\end{tabular}


Table L-6. Measured dissolved and total carbon concentrations at lake L9817P. Standard deviations are given where multiple concentration readings were available.

\begin{tabular}{|c|c|c|c|c|c|c|c|}
\hline \multirow{2}{*}{ Date } & \multirow{2}{*}{ Sample ID } & \multicolumn{3}{|c|}{$\begin{array}{l}\text { Dissolved Organic Carbon } \\
(\text { (ppm) }\end{array}$} & \multicolumn{3}{|c|}{ Total Organic Carbon (ppm) } \\
\hline & & Mean & $\begin{array}{l}\text { Std. } \\
\text { Dev. }\end{array}$ & Samples & Mean & $\begin{array}{l}\text { Std. } \\
\text { Dev. }\end{array}$ & Samples \\
\hline $3 / 28 / 2004$ & L9817 & 8.27 & 3.00 & 4 & - & - & - \\
\hline $4 / 28 / 2004$ & L9817 & 10.46 & 5.29 & 2 & - & - & - \\
\hline $7 / 19 / 2004$ & L9817 & Idl & - & 8 & - & - & - \\
\hline $12 / 6 / 2004$ & L9817 & 9.52 & 0.04 & 2 & 9.70 & 0.26 & 2 \\
\hline $1 / 15 / 2005$ & L9817 & 10.77 & 0.55 & 2 & 11.88 & 0.18 & 2 \\
\hline $2 / 22 / 2005$ & 9817 & 14.79 & - & 1 & 14.88 & - & 1 \\
\hline $3 / 13 / 2005$ & L9817 & 18.27 & 0.27 & 2 & 20.10 & - & 1 \\
\hline 4/1/2005 & 9817 & 20.91 & - & 1 & 21.51 & - & 1 \\
\hline
\end{tabular}




\section{APPENDIX M: METAL CONCENTRATIONS}

The following tables report the metal concentrations as determined by from WERC laboratory analysis of water samples collected at study lakes. These samples were collected during the Phase 1 portion of the North Slope Lakes project. Most samples represent a collection point halfway between the bottom of ice and the lake bottom. Exceptions would include summer samples taken near shore during ice-free conditions.

Table M-1. Measured metal concentrations at lake K113C. Table M-2. Measured metal concentrations at lake K203C. Table M-3. Measured metal concentrations at lake K209P. Table M-4. Measured metal concentrations at lake K214P. Table M-5. Measured metal concentrations at lake L9312P. Table M-6. Measured metal concentrations at lake L9817P. 
Table M-1. Measured metal concentrations at lake K113C. Standard deviations are given where multiple concentration readings were available.

\begin{tabular}{|c|c|c|c|c|c|c|c|c|c|}
\hline \multirow[b]{2}{*}{ Date } & \multicolumn{3}{|c|}{ Sodium - (Na) ppm } & \multicolumn{3}{|c|}{ Calcium - (Ca) ppm } & \multicolumn{3}{|c|}{ Magnesium - (Mg) ppm } \\
\hline & Mean & Std. Dev. & Samples & Mean & $\begin{array}{l}\text { Std. } \\
\text { Dev. }\end{array}$ & Samples & Mean & $\begin{array}{l}\text { Std. } \\
\text { Dev. }\end{array}$ & Samples \\
\hline $\begin{array}{l}2 / 26 / 200 \\
3\end{array}$ & 17.30 & 1.80 & 3 & 81.97 & 6.58 & 3 & 27.47 & 1.86 & 3 \\
\hline $6 / 1 / 2003$ & 8.00 & 0.86 & 2 & 63.23 & 6.15 & 2 & 20.46 & 0.16 & 2 \\
\hline $\begin{array}{l}5 / 13 / 200 \\
3\end{array}$ & 23.85 & 1.10 & 3 & 125.10 & 7.42 & 3 & 18.78 & 0.46 & 3 \\
\hline $\begin{array}{l}7 / 24 / 200 \\
3\end{array}$ & 8.00 & - & 1 & 63.23 & - & 1 & 20.46 & - & 1 \\
\hline $\begin{array}{l}2 / 23 / 200 \\
4\end{array}$ & - & - & - & 0.01 & - & 1 & - & - & - \\
\hline $\begin{array}{l}3 / 19 / 200 \\
4\end{array}$ & - & - & - & 0.07 & - & 1 & - & - & - \\
\hline $\begin{array}{l}5 / 14 / 200 \\
4\end{array}$ & - & - & - & 185.05 & 0.02 & 2 & 19.05 & 0.04 & 2 \\
\hline $\begin{array}{l}7 / 13 / 200 \\
4\end{array}$ & - & - & - & 22.79 & 1.64 & 4 & - & - & - \\
\hline $\begin{array}{l}12 / 8 / 200 \\
4\end{array}$ & 10.78 & 0.74 & 2 & 49.80 & 0.51 & 2 & 4.79 & 0.46 & 2 \\
\hline $\begin{array}{l}1 / 19 / 200 \\
5\end{array}$ & 16.85 & 0.21 & 2 & 76.16 & 4.58 & 2 & 8.22 & 0.08 & 2 \\
\hline $\begin{array}{l}3 / 16 / 200 \\
5\end{array}$ & 32.93 & 0.69 & 2 & 150.36 & 1.75 & 2 & 14.06 & 0.28 & 2 \\
\hline $\begin{array}{l}5 / 22 / 200 \\
5\end{array}$ & 42.90 & 0.28 & 2 & 310.40 & 0.57 & 2 & 34.59 & 2.22 & 2 \\
\hline $8 / 5 / 2005$ & 3.36 & - & 1 & 30.46 & & 1 & 2.14 & - & 1 \\
\hline
\end{tabular}

Table M-2. Measured metal concentrations at lake K203C. Standard deviations are given where multiple concentration readings were available.

\begin{tabular}{|l|l|c|c|c|c|c|c|c|c|}
\hline \multirow{2}{*}{ Date } & \multicolumn{3}{|c|}{ Sodium - (Na) ppm } & \multicolumn{3}{c|}{ Calcium - (Ca) ppm } & \multicolumn{3}{c|}{ Magnesium - (Mg) ppm } \\
\cline { 2 - 10 } & Mean & Std. Dev. & Samples & Mean & $\begin{array}{c}\text { Std. } \\
\text { Dev. }\end{array}$ & Samples & Mean & Std. Dev. & Samples \\
\hline $\begin{array}{l}2 / 23 / 200 \\
3\end{array}$ & 10.55 & 4.95 & 3 & 67.20 & 1.50 & 3 & & 3.45 & 3 \\
\hline $\begin{array}{l}5 / 13 / 200 \\
3\end{array}$ & 16.20 & - & 1 & 128.30 & - & 1 & & - & 1 \\
\hline Jun-03 & 8.61 & 0.90 & 3 & 68.49 & 8.93 & 3 & 19.89 & 3.83 & 3 \\
\hline $8 / 5 / 2003$ & 8.92 & - & 1 & 70.70 & - & 1 & 21.03 & - & 1 \\
\hline $\begin{array}{l}5 / 12 / 200 \\
4\end{array}$ & - & - & - & 375.57 & 2.20 & 2 & 40.72 & 0.13 & 2 \\
\hline
\end{tabular}

Table M-3. Measured metal concentrations at lake K209P. Standard deviations are given where multiple concentration readings were available.

\begin{tabular}{|c|c|c|c|c|c|c|c|c|c|}
\hline \multirow{3}{*}{ Date } & \multicolumn{3}{|c|}{ Sodium - (Na) $\mathrm{ppm}$} & \multicolumn{3}{c|}{ Calcium - (Ca) $\mathrm{ppm}$} & \multicolumn{3}{c|}{ Magnesium - (Mg) ppm } \\
\cline { 2 - 8 } & & & & $\begin{array}{c}\text { Std. } \\
\text { Dev. }\end{array}$ & Samples & Mean & Std. Dev. & Samples \\
\hline
\end{tabular}




\begin{tabular}{|l|l|l|l|l|l|l|l|l|l|}
$12 / 14 / 200$ & 7.24 & & & 66.99 & & & 10.09 & & 1 \\
\hline $2 / 26 / 2003$ & 7.15 & 0.05 & 3 & 67.00 & 1.90 & 3 & 10.22 & 1.77 & 3 \\
\hline $5 / 15 / 2003$ & 21 & - & 1 & 0 & - & 1 & 16.50 & - & 1 \\
\hline Jun-03 & 7.96 & 1.32 & 3 & 62.70 & 10.03 & 3 & 18.50 & 3.07 & 3 \\
\hline $8 / 6 / 2003$ & 7.96 & - & 1 & 62.70 & & 1 & 18.50 & - & 1 \\
\hline $7 / 15 / 2004$ & - & - & - & 25.36 & 2.94 & 3 & - & - & - \\
\hline $12 / 9 / 2004$ & 9.48 & 0.25 & 2 & 71.04 & 1.81 & 2 & 8.37 & 0.14 & 2 \\
\hline $1 / 19 / 2005$ & 18.38 & 0.32 & 2 & 6 & 0.54 & 2 & 18.16 & 2.70 & 2 \\
\hline
\end{tabular}


Table M-4. Measured metal concentrations at lake K214P. Standard deviations are given where multiple concentration readings were available.

\begin{tabular}{|c|c|c|c|c|c|c|c|c|c|}
\hline \multirow[b]{2}{*}{ Date } & \multicolumn{3}{|c|}{ Sodium - $(\mathrm{Na})^{\mathrm{ppm}}$} & \multicolumn{3}{|c|}{ Calcium - (Ca) ppm } & \multicolumn{3}{|c|}{ Magnesium - (Mg) ppm } \\
\hline & Mean & $\begin{array}{l}\text { Std. } \\
\text { Dev. }\end{array}$ & Samples & Mean & Std. Dev. & Samples & Mean & $\begin{array}{l}\text { Std. } \\
\text { Dev. }\end{array}$ & Samples \\
\hline $\begin{array}{l}12 / 16 / 200 \\
2\end{array}$ & 10.68 & 4.82 & 3 & 67.17 & 1.49 & 3 & 9.44 & 3.13 & 3 \\
\hline $2 / 25 / 2003$ & 11.00 & 3.10 & 3 & 55.50 & 3.10 & 3 & 7.00 & 0.70 & 3 \\
\hline $5 / 14 / 2003$ & 18.60 & 3.80 & 3 & $\begin{array}{l}127.6 \\
0\end{array}$ & 2.00 & 3 & 16.85 & 0.35 & 3 \\
\hline $6 / 25 / 2003$ & 10.32 & 0.34 & 2 & 82.50 & 2.15 & 2 & 29.62 & 8.62 & 2 \\
\hline $5 / 12 / 2004$ & - & - & - & $\begin{array}{l}948.2 \\
2\end{array}$ & 11.56 & 2 & 82.87 & 0.12 & 2 \\
\hline $7 / 14 / 2004$ & - & - & - & 31.97 & 3.36 & 3 & - & - & - \\
\hline $12 / 3 / 2004$ & 11.28 & - & 2 & 86.94 & 2.12 & 2 & 7.53 & 0.19 & 2 \\
\hline $1 / 18 / 2005$ & 22.08 & 0.39 & 2 & $\begin{array}{l}153.8 \\
0\end{array}$ & 1.58 & 2 & 19.41 & 8.03 & 2 \\
\hline $3 / 16 / 2005$ & 91.48 & - & 1 & $\begin{array}{l}645.0 \\
0\end{array}$ & - & 1 & 60.27 & - & 1 \\
\hline
\end{tabular}

Table M-5. Measured metal concentrations at lake L9312P. Standard deviations are given where multiple concentration readings were available.

\begin{tabular}{|c|c|c|c|c|c|c|c|c|c|}
\hline \multirow{2}{*}{ Date } & \multicolumn{3}{|c|}{ Sodium - (Na) ppm } & \multicolumn{3}{c|}{ Calcium - (Ca) ppm } & \multicolumn{3}{c|}{ Magnesium - (Mg) ppm } \\
\cline { 2 - 10 } & Mean & $\begin{array}{c}\text { Std. } \\
\text { Dev. }\end{array}$ & Samples & Mean & Std. Dev. & Samples & Mean & $\begin{array}{c}\text { Std. } \\
\text { Dev. }\end{array}$ & Samples \\
\hline $5 / 13 / 2004$ & - & - & - & 13.84 & 0.31 & 2 & 4.84 & 0.14 & 2 \\
\hline $7 / 17 / 2004$ & - & - & - & 6.02 & 0.12 & 6 & - & - & - \\
\hline $8 / 17 / 2004$ & - & - & - & 6.30 & 0.02 & 4 & - & - & - \\
\hline $12 / 5 / 2004$ & 3.50 & 0.49 & 2 & 7.76 & 0.47 & 2 & 3.27 & 0.19 & 2 \\
\hline $1 / 16 / 2005$ & 4.84 & 0.16 & 2 & 9.88 & 0.88 & 2 & 4.00 & 0.42 & 2 \\
\hline $2 / 23 / 2005$ & 6.15 & 0.64 & 2 & 11.45 & 0.23 & 2 & 4.91 & 0.04 & 2 \\
\hline $3 / 14 / 2005$ & 6.85 & 0.01 & 2 & 12.29 & 0.20 & 2 & 5.33 & 0.02 & 2 \\
\hline $4 / 21 / 2005$ & 7.62 & 0.14 & 2 & 12.95 & 0.07 & 2 & 5.79 & 0.12 & 2 \\
\hline $5 / 20 / 2005$ & 6.66 & 0.34 & 2 & 17.21 & 0.13 & 2 & 6.43 & 0.01 & 2 \\
\hline $8 / 2 / 2005$ & 2.32 & - & 1 & 13.50 & - & 1 & 2.25 & - & 1 \\
\hline
\end{tabular}

Table M-6. Measured metal concentrations at lake L9817P. Standard deviations are given where multiple concentration readings were available.

\begin{tabular}{|c|c|c|c|c|c|c|c|c|c|}
\hline \multirow{2}{*}{ Date } & \multicolumn{3}{|c|}{ Sodium - (Na) ppm } & \multicolumn{3}{c|}{ Calcium - (Ca) ppm } & \multicolumn{3}{c|}{ Magnesium - (Mg) ppm } \\
\cline { 2 - 11 } & Mean & $\begin{array}{c}\text { Std. } \\
\text { Dev. }\end{array}$ & Samples & Mean & Std. Dev. & Samples & Mean & Std. Dev. & Samples \\
\hline $4 / 28 / 2004$ & - & - & - & 86.38 & 0.78 & 3 & 37.91 & 0.67 & 3 \\
\hline $7 / 19 / 2004$ & - & - & - & - & - & - & - & - & - \\
\hline $12 / 6 / 2004$ & 14.75 & 0.71 & 2 & 37.82 & 0.42 & 2 & 12.75 & 0.16 & 2 \\
\hline $1 / 15 / 2005$ & 23.00 & 0.42 & 2 & 56.72 & 2.21 & 2 & 19.86 & 0.18 & 2 \\
\hline $2 / 22 / 2005$ & 38.10 & - & 1 & 87.88 & - & 1 & 35.06 & - & 1 \\
\hline $3 / 12 / 2005$ & 47.06 & - & 1 & 110.9 & - & 1 & 42.67 & - & 1 \\
\hline
\end{tabular}




\begin{tabular}{|l|l|l|l|l|l|l|l|l|l|} 
& & & & 6 & & & \\
\hline Apr-05 & 63.69 & 1.48 & 2 & $\begin{array}{l}153.9 \\
0\end{array}$ & 8.34 & 2 & 61.01 & 1.94 & 2 \\
\hline
\end{tabular}




\section{APPENDIX N: KUPARUK DEADARM ISOTOPE AND WATER CHEMISTRY}

The following tables report the isotope and water chemistry at the Kuparuk Deadarm Reservoirs. Tundra ponds, river water and concurrent precipitation were sampled for stable isotope analysis at the Water and Environmental Research Center, University of Alaska Fairbanks. The samples were sealed until laboratory analysis.

Table N-1. Measured isotope and water chemistry. 
Table N-1. Measured isotope and water chemistry.

\begin{tabular}{|c|c|c|c|c|}
\hline $08 / 20 / 04$ & Conductivity & Location & $\mathbf{H}$ & 0 \\
\hline Deadarm Kuparuk & 116 & cell\#1 & -142.51 & -18.68 \\
\hline Deadarm Kuparuk & 116 & cell\#1 & -141.82 & -18.42 \\
\hline Deadarm Kuparuk & 116 & cell\#1 & -142.47 & -18.56 \\
\hline Deadarm Kuparuk & 102 & cell\#2 & -144.06 & -18.84 \\
\hline Deadarm Kuparuk & 102 & cell\#2 & -144.82 & -18.89 \\
\hline Deadarm Kuparuk & 102 & cell\#2 & -145.04 & -18.82 \\
\hline Deadarm Kuparuk & 106 & cell\#3 & -142.55 & -18.64 \\
\hline Deadarm Kuparuk & 106 & cell\#3 & -142.46 & -18.58 \\
\hline Deadarm Kuparuk & 106 & cell\#3 & -143.48 & -18.57 \\
\hline Deadarm Kuparuk & 97.8 & cell\#4 & -148.66 & -19.23 \\
\hline Deadarm Kuparuk & 97.8 & cell\#4 & -149.40 & -19.47 \\
\hline Deadarm Kuparuk & 97.8 & cell\#4 & -149.19 & -19.57 \\
\hline Deadarm Kuparuk & 88.5 & cell\#5 & -150.53 & -19.42 \\
\hline Deadarm Kuparuk & 88.5 & cell\#5 & -149.81 & -19.55 \\
\hline Deadarm Kuparuk & 88.5 & cell\#5 & -150.11 & -19.45 \\
\hline \multirow[t]{2}{*}{$\begin{array}{l}\text { Kuparuk river east } \\
\text { channel }\end{array}$} & 104 & KUPRiver & -139.55 & -18.66 \\
\hline & 104 & KUPRiver & -138.96 & -18.43 \\
\hline \multirow[t]{5}{*}{ pond near dead arm } & 253 & $\begin{array}{l}\text { pond near dead } \\
\text { arm }\end{array}$ & -100.80 & -13.35 \\
\hline & 253 & & -101.26 & -12.64 \\
\hline & & & -97.75 & -10.76 \\
\hline & & & -98.64 & -10.63 \\
\hline & & & -96.96 & -10.27 \\
\hline \multirow[t]{5}{*}{ pond near dead arm } & 333 & $\begin{array}{l}\text { pond near dead } \\
\text { arm }\end{array}$ & -86.37 & -12.18 \\
\hline & 333 & & -93.70 & -11.26 \\
\hline & & & -93.22 & -10.38 \\
\hline & & & -92.51 & -10.22 \\
\hline & & & -92.14 & -9.83 \\
\hline
\end{tabular}

